UNIVERSIDADE DE SÃO PAULO

INSTITUTO DE GEOCIÊNCIAS

AS ROCHAS ALCALINAS DE CANANÉIA, LITORAL SUL DO ESTADO DE SÃO PAULO: ESTUDOS MINERALÓGICOS, GEOQUÍMICOS E ISOTÓPICOS

Fernando Pelegrini Spinelli

Orientador: Prof. Dr. Celso de Barros Gomes

TESE DE DOUTORADO

Programa de Pós-Graduação em Mineralogia e Petrologia

SÃO PAULO

2007 
Ficha catalográfica preparada pelo Serviço de Biblioteca e Documentação do Instituto de Geociências da Universidade de São Paulo

Spinelli, Fernando Pelegrini

As rochas alcalinas de Cananéia, litoral sul do Estado de São Paulo: estudos mineralógicos, geoquímicos e isotópicos/ Fernando Pelegrini Spinelli. - São Paulo, 2007.

xili, $139 \mathrm{f}$. : 64 il.

Tese (Doutorado) : IGc/USP

Orient.: Gomes, Celso de Barros

1. Cananéia (SP): Rochas alcalinas 2. Petrografia 3. Mineralogia química 4. Geoquímica dos minerais 5. Geoquímica das rochas 6. Geoquímica isotópica I. Título 
ÍNDICE DAS FIGURAS $\quad$ iii

ÍNDICE DAS FOTOS viii

ÍNDICE DAS FOTOMICROGRAFIAS $\quad$ x

ÍNDICE DAS TABELAS Xii

AGRADECIMENTOS 2

RESUMO

$\begin{array}{lc}\text { ABSTRACT } & 6\end{array}$

1. INTRODUÇÃO

1.1. Vias de acesso 10

2. MÉTODOS DE TRABALHO 12

2.1. Atividades de campo 12

2.2. Petrografia 12

2.3. Preparação das amostras $\quad 12$

2.4. Geoquímica 13

2.4.1. Análise química de minerais

2.4.2. Análise química de rochas

2.5. Tratamentos dos dados $\quad 14$

2.6. Geocronologia e dados de isotopia $\quad 15$

2.6.1. Método $\mathrm{Rb} / \mathrm{Sr} \quad 15$

2.6.2. Método $\mathrm{Sm} / \mathrm{Nd}$

2.6.3. Método $\mathrm{Ar} / \mathrm{Ar} \quad 16$

3. GEOLOGIA REGIONAL 17

3.1. Grupo Açungui 19

3.2. Planície Costeira Cananéia-Iguape 19

4. GEOLOGIA LOCAL 22

5. PETROGRAFIA 28

5.1. Álcali feldspato sienitos $\quad 31$

5.2. Quartzo-álcali feldspato sienitos $\quad 34$

5.3. Quartzo-álcali feldspato sienitos porfiríticos de matriz fina $\quad 37$

5.4. Microssienitos com textura em mosaico 39

5.5. Microssienitos porfiríticos com textura traquítica 40

5.6. Seqüência de cristalização

6. QUÍMICA MINERAL $\quad 43$

6.1. Feldspatos 43

6.2. Clinopiroxênios $\quad 50$

6.3. Anfibólios $\quad 57$ 
$\begin{array}{ll}\text { 6.4. Biotitas } & 67\end{array}$

$\begin{array}{ll}\text { 6.5. Olivinas } & 73\end{array}$

6.6. Apatitas
6

$\begin{array}{ll}\text { 6.7. Ilmenitas e magnetitas } & 78\end{array}$

$\begin{array}{ll}\text { 7. GEOQUÍMICA } & 84\end{array}$

8. GEOCRONOLOGIA

8.1. Método $\mathrm{Rb} / \mathrm{Sr} \quad 95$

$\begin{array}{ll}\text { 8.2. Método } \mathrm{K} / \mathrm{Ar} & 97\end{array}$

$\begin{array}{ll}\text { 8.3. Método } \mathrm{Ar} / \mathrm{Ar} & 97\end{array}$

$\begin{array}{lr}\text { 8.4. Outras considerações } & 101\end{array}$

9. GEOQUÍMICA ISOTÓPICA 102

9.1. Isótopos de Sr e Nd 102

$\begin{array}{lr}\text { 9.2. Contaminação crustal } & 106\end{array}$

10. PETROGÊNESE 110

$\begin{array}{lr}\text { 10.1. Magma parental } & 110\end{array}$

10.2. Condições e seqüência de cristalização 111

$\begin{array}{lr}\text { 10.3. Cristalização fracionada } & 115\end{array}$

$\begin{array}{lr}\text { 10.4. Fonte do magmatismo } & 116\end{array}$

11. CORRELAÇÃO GEOLÓGICA 121

11.1. As ocorrências da Província do Arco de Ponta Grossa 121

11.2. As ocorrências da Província da Serra do Mar 123

11.3. A ocorrência de Ponta do Morro, MT 125

12. CONSIDERAÇÕES FINAIS 127

$\begin{array}{lr}\text { 12.1. Seqüência cronológica } & 127\end{array}$

$\begin{array}{lr}\text { 12.2. Conclusões } & 128\end{array}$

13. REFERÊNCIAS BIBLIOGRÁFICAS 131 


\section{ÍNDICE DAS FIGURAS}

Figura 1. Províncias alcalinas da região centro-sudeste da Plataforma Brasileira e suas relações com os principais regimes estruturais (cf. Riccomini et al., 2005). 1) Bacia do Paraná Ordoviciano Superior ao Cretáceo Inferior; 2) lavas toleíticas - Cretáceo Inferior; 3) Bacia Bauru - Cretáceo Superior; 4) bacias marinhas marginais; 5) ocorrências alcalinas; 6) idades de rochas alcalinas (losango, Permo-Triássico; quadrado, Cretáceo Inferior; triângulo, Cretáceo Superior; círculo, Paleoceno); 7) eixos de arcos principais (AX, Alto Xingu; SV, São Vicente; BJ, Bom Jardim; PG, Ponta Grossa; RG, Rio Grande; PP, Ponta Porã); 8) Sinclinal de Torres; 9) zonas de falhas (Rifts: MR, Mercedes; RM, Rio das Mortes; MG Moirão; SR, Santa Rosa; AR, Assunção; Lineamentos: TB, Transbrasiliano; AP, Alto Paranaíba; MJ, Moji-Guaçu; CF, Cabo Frio; RT, Rio Tietê; SL, São Carlos-Leme; PR, Paranapanema; PI, Piedade; GP, Guapiara; JC, Jerônimo-Curiúva; RA, Rio Alonzo; PQ, Rio Piquiri; AM, Santa Lúcia-Aiguá-Merin).

Figura 2. Mapa de localização com as vias de acesso à área de estudo. Extraído e modificado do Guia 4 Rodas 2003.

Figura 3. Mapa geológico do litoral sul do Estado de São Paulo, com destaque para as intrusões da llha de Cananéia (Morro de São João) e da llha Comprida (Morrete). Parcialmente modificado de IPT (1981), escala original 1:500.000.

Figura 4. Mapa de localização com os pontos de amostragem das intrusões de Cananéia e Morrete, separadas pelo "Mar de Cananéia". Amostras de diques estão representadas por um quadrado vermelho. Escala original 1:10.000 (IGC, 1989).

Figura 5. A) Falhas (círculos máximos) e estrias (pontos) presentes no Morro de São João. As abreviações indicam o movimento relativo entre os blocos: ns, normal com componente sinistral; sn, sinistral com componente normal; rd, reversa com componente dextral; rs, reversa com componente sinistral; sr, sinistral com componente reversa; dn, dextral com componente normal. B) Pólos de juntas do maciço. Rede de Schimidt-Lambert, semi-esfera inferior. Extraído de Riccomini (1995).

Figura 6. Modelo proposto por Riccomini (1995) para o maciço de Cananéia: A) extensão NE$\mathrm{SW}$, com a intrusão dos diques de traquito (t) de direção NW-SE; B) extensão NW-SE e compressão NE-SW, com a colocação do dique de lamprófiro (I) e fraturamento nos diques de traquito (f).

Figura 7. Diagrama ternário de classificação de rochas ígneas (QAP) segundo Streckeisen (1976). Os campos 1 e 2 indicados no detalhe correspondem, respectivamente, a quartzo-álcali feldspato sienitos e álcali feldspato sienitos. Os números plotados no diagrama referem-se às amostras da Tabela 1. As intrusivas do Morro de São João estão representadas por círculos azuis (- quartzo-álcali feldspato sienitos) e losangos roxos ( álcali feldspato sienitos), enquanto que as hipoabissais por quadrados vermelhos ( $\square$ microssienitos); já as intrusivas do Morrete estão indicadas por círculos verdes (@ quartzo-álcali feldspato sienitos).

Figura 8. Variação composicional dos feldspatos alcalinos (A, C, D, E, F) e plagioclásios (B), expressa em proporções moleculares de Ab-Or-An para as rochas de Cananéia. Legenda: lilás, azul e vermelho: Morro de São João; verde: Morrete; álcali feldspato sienitos: $(\diamond)$ centro, $(\diamond)$ borda, $(\diamond)$ região intermediária; quartzo-álcali feldspato sienitos: $(\bullet)$ centro, $(0)$ borda, $(\bullet)$ região intermediária; quartzo-álcali feldspato sienitos porfiríticos: (๑) centro, (O) borda, (0) região intermediária; microssienitos com textura em mosaico e microssienitos porfiríticos com textura traquítica: $(\square)$ centro, $(\square)$ borda e $(\square)$ região intermediária.

Figura 9. Diagrama de classificação para clinopiroxênios segundo Morimoto (1990), onde $\mathrm{Q}=\mathrm{Ca}+\mathrm{Mg}+\mathrm{Fe}^{2+}$ e $\mathrm{J}=2 \mathrm{Na}$. Símbolos como na Figura 8.

Figura 10. A) Diagrama ternário de classificação Wo-En-Fs (Morimoto, 1990), onde $\mathrm{Wo}=100 \mathrm{Ca} /\left(\mathrm{Ca}+\mathrm{Mg}+\mathrm{Fe}^{2+}+\mathrm{Fe}^{3+}+\mathrm{Mn}+\mathrm{Na}\right), \quad \mathrm{En}=100 \mathrm{Mg} /\left(\mathrm{Ca}+\mathrm{Mg}+\mathrm{Fe}^{2+}+\mathrm{Fe}^{3+}+\mathrm{Mn}+\mathrm{Na}\right) \quad$ e $\mathrm{Fs}=100\left(\mathrm{Fe}^{2+}+\mathrm{Fe}^{3+}+\mathrm{Mn}\right) /\left(\mathrm{Ca}+\mathrm{Mg}+\mathrm{Fe}^{2+}+\mathrm{Fe}^{3+}+\mathrm{Mn}+\mathrm{Na}\right)$. B) Diagrama ternário de classificação WEF-Jd-Ae (Morimoto, 1990), onde WEF=(wollastonita, enstatita e ferrossilita), $\mathrm{Jd}=\left(\mathrm{NaAlSi}_{2} \mathrm{O}_{6}\right)$ e $\mathrm{Ae}=\left(\mathrm{NaFe}^{3+} \mathrm{Si}_{2} \mathrm{O}_{6}\right)$. Símbolos como na Figura 8.

Figura 11. A) Distribuição dos clinopiroxênios das rochas de Cananéia no diagrama ternário Na-Mg$\mathrm{Fe}^{*}$ [onde $\left.\mathrm{Fe}^{*}=\mathrm{Fe}^{2+}+\mathrm{Mn}+\left(\mathrm{Fe}^{3+}-\mathrm{Na}\right)\right]$. B) Tendências composicionais de clinopiroxênios em diversos complexos alcalinos: 1. llimaussaq, Groenlândia (Larsen, 1976); 2. South Qôroq, Groenlândia 
(Stephenson, 1972); 3. Tunas (Gomes et al., 1987); 4. Tanguá-Rio Bonito-Itaúna-Morro de São João (Valença, 1980); 5. Illha de Vitória (Motoki, 1986); 6. Ponta do Morro (Sousa, 1997); 7. Ilha de Búzios a) área central e b) área periférica (Alves, 1996); 8. Ilha Monte de Trigo (Enrich, 2000); 9. Itatiaia; 10. São Sebastião; 11. Passa Quatro (Enrich et al., 2005). Símbolos como na Figura 8.

Figura 12. Diagramas de variação composicional dos clinopiroxênios das rochas de Cananéia; $\mathrm{mg} \#=\mathrm{Mg} /\left(\mathrm{Mg}+\mathrm{Fe}^{2+}\right)$. Símbolos como na Figura 8.

Figura 13. Diagramas classificatórios segundo Leake (1997) para anfibólios cálcicos (A e B) e cálcico-sódicos (C e D) das rochas de Cananéia. Símbolos como na Figura 8.

Figura 14. Diagrama classificatório segundo Leake (1997) para anfibólios sódicos das rochas de Cananéia. Símbolos como na Figura 8.

Figura 15. A) Diagrama ternário Ca-Mg-Fe* (onde $\mathrm{Fe}^{*}=\mathrm{Fe}^{3+}+\mathrm{Fe}^{2+}+\mathrm{Mn}$ ); B) Corte do diagrama triangular K-Ca-Na mostrando a evolução composicional dos anfibólios das rochas de Cananéia. Símbolos como na Figura 8

Figura 16. Diagrama ternário $(\mathrm{Na}+\mathrm{K})-\mathrm{Mg}-\left(\mathrm{Fe}^{2+}+\mathrm{Mn}\right)$ comparando as variações composicionais de anfibólios e clinopiroxênios das rochas de Cananéia. Campos para os clinopiroxênios do Morro de São João: lilás - álcali feldspato sienitos; azul - quartzo-álcali feldspato sienitos; rosa: - microssienitos. Símbolos como na Figura 8.

Figura 17. Diagrama $\mathrm{Si}_{T}+\mathrm{Na}_{B}+\mathrm{Na}_{A}+\mathrm{K}_{\mathrm{A}}$ vs. $\mathrm{Al}_{T}+\mathrm{Ca}_{C}+\mathrm{Ca}_{B}$ mostrando a variação composicional dos anfibólios das rochas de Cananéia. Símbolos como na Figura 8.

Figura 18. Diagramas de variação composicional dos anfibólios das rochas de Cananéia. Símbolos como na Figura 8.

Figura 19. Diagrama Al-Mg- $\left(\mathrm{Fe}^{2+}+\mathrm{Fe}^{3+}\right)$ de classificação de biotitas para as rochas de Cananéia. Símbolos como na Figura 8.

Figura 20. Diagramas de variação relacionando o índice $\mathrm{mg \#}\left(\mathrm{Mg} / \mathrm{Mg}+\mathrm{Fe}^{2+}\right)$ das biotitas com os diferentes cátions presentes na estrutura desses minerais. Símbolos como na Figura 8.

Figura 21. Projeção das biotitas das rochas de Cananéia no diagrama ternário $M g-\left(\mathrm{A}^{\mathrm{IIV}}+\mathrm{Ti}\right)-$ $\left(\mathrm{Fe}^{2+}+\mathrm{Mn}\right)$. Símbolos como na Figura 8.

Figura 22. Projeção das biotitas das rochas de Cananéia nos diagramas ternários $\mathrm{Al}-\mathrm{Mg}-\mathrm{Fe}^{2+}$ (A) e K-Mg-Fe ${ }^{2+}$ (B). Símbolos como na Figura 8.

Figura 23. Diagrama $\mathrm{Fe}^{2+}$ vs. $\mathrm{Mg}$ indicativa da principal substituição do sítio octaédrico nas biotitas das rochas de Cananéia. Símbolos como na Figura 8.

Figura 24. A) Diagrama Ti vs. $\square^{\mathrm{VI}}$ mostrando as substituições acopladas com a entrada de Ti no sítio octaédrico. B) Diagrama Ti vs. $\mathrm{Al}^{\mathrm{lV}}+\mathrm{Fe}^{3+}$ evidenciando as substituições causadas pela entrada de Ti no sítio octaédrico. Símbolos como na Figura 8.

Figura 25. Diagrama $\left(\mathrm{Mg}+\mathrm{Fe}^{2+}\right)$ vs. $\left(\mathrm{Ti}+\square^{\mathrm{Vl}}\right)$ mostrando as substituições dos cátions no sítio octaédrico. Símbolos como na Figura 8.

Figura 26. Diagrama de classificação de olivinas para as rochas de Cananéia. Símbolos como na Figura 8.

Figura 27. Diagrama $\mathrm{La}_{2} \mathrm{O}_{3}+\mathrm{Ce}_{2} \mathrm{O}_{3}+\mathrm{Sm}_{2} \mathrm{O}_{3}+\mathrm{Y}_{2} \mathrm{O}_{3}$ vs. $\mathrm{F}$ mostrando a variação composicional das apatitas das rochas de Cananéia. Símbolos como na Figura 8.

Figura 28. Diagramas de variação composicional de apatitas das rochas de Cananéia. Símbolos como na Figura 8.

Figura 29. Diagramas de variação composicional de apatitas das rochas de Cananéia. Símbolos como na Figura 8.

Figura 30. Diagrama $\mathrm{FeO}-\mathrm{TiO}_{2}-\mathrm{Fe}_{2} \mathrm{O}_{3}$ de Buddington e Lindsley (1964), modificado por Haggerty (1976), para ilmenitas e magnetitas das rochas de Cananéia. Símbolos como na Figura 8. 
Figura 31. Diagramas relacionando $\mathrm{FeO}_{\mathrm{T}}$ vs. $\mathrm{TiO}_{2}, \mathrm{Al}_{2} \mathrm{O}_{3}, \mathrm{MnO}$ e $\mathrm{MgO}$ para ilmenitas e magnetitas. Em A e B, o campo ocupado pelas análises de ilmenitas encontra-se expandido para facilitar a visualização. Símbolos como na Figura 8.

Figura 32. Diagrama classificatório para o índice de alcalinidade das rochas de Cananéia segundo os campos definidos por Comin-Chiaramonti e Gomes (1996). Símbolos como na Figura 7.

Figura 33. Diagrama R1-R2 (R1=4Si-11(Na+K)-2(Fe+Ti); R2=6Ca-2Mg+Al; cf. De La Roche et al., 1980; De La Roche, 1986) para as rochas de Cananéia. Símbolos como na Figura 7.

Figura 34. Diagrama TAS (cf. LeMaitre et al., 2003). para as rochas de Cananéia. O campo de cor cinza no diagrama está subdividido conforme a tabela. Abreviações: ol=olivina normativa e $q=Q /(Q+o r+a b+a n)$ normativos X100. Símbolos como na Figura 7.

Figura 35. Diagramas relacionando os elementos maiores com a concentração de sílica para as rochas de Cananéia. Símbolos como na Figura 7.

Figura 36. Diagramas relacionando os elementos menores com a concentração de sílica para as rochas de Cananéia. Símbolos como na Figura 7.

Figura 37. Diagramas relacionando os elementos menores com a concentração de sílica para as rochas de Cananéia. Símbolos como na Figura 7.

Figura 38. Diagramas do tipo spider para elementos incompatíveis normalizados para o manto primitivo (McDonough e Sun, 1995). O gráfico $A$ contém os pontos referentes às rochas intrusivas do Morro de São João e do Morrete; já o B reúne os microssienitos do Morro de São João, ao lado dos campos relativos às variedades intrusivas. Símbolos como na Figura 7.

Figura 39. Diagramas de elementos Terras Raras normalizados para os condritos (McDonough e Sun, 1995). O gráfico A contém os pontos referentes às variedades intrusivas do Morro de São João; já o $B$ reúne os campos de distribuição dessas rochas e os pontos relativos às hipoabissais do Morro de São João. Símbolos como na Figura 7.

Figura 40. Diagramas $\mathrm{SiO}_{2}$ vs. $(\mathrm{La} / \mathrm{Sm})_{\mathrm{N}},(\mathrm{La} / \mathrm{Yb})_{\mathrm{N}},(\mathrm{Gd} / \mathrm{Yb})_{\mathrm{N}}$ e $\left(\mathrm{Eu} / \mathrm{Eu}^{*}\right)_{\mathrm{N}}$. Elementos normalizados segundo o Condrito C1 de McDonough e Sun (1995). Símbolos como na Figura 7.

Figura 41. Idades $\mathrm{Rb} / \mathrm{Sr}$ em rocha total $(\mathrm{A})$ e em concentrados minerais $(\mathrm{B})$ para as rochas de Cananéia.

Figura 42. Diagrama ${ }^{87} \mathrm{Rb} /{ }^{86} \mathrm{Sr}$ vs. ${ }^{87} \mathrm{Sr} /{ }^{86} \mathrm{Sr}$ para as rochas de Cananéia.

Figura 43. A-C) Diagramas de extração de argônio por aquecimento em etapas de biotitas da amostra 7 mostrando idades platôs e integradas. D) Ideograma de densidade de probabilidade dos resultados dos diagramas A-C define uma boa distribuição.

Figura 44. A-C) Diagramas de extração de argônio por aquecimento em etapas de biotitas da amostra 29 mostrando idades platôs e integradas. D) Ideograma de densidade de probabilidade dos resultados dos diagramas A-C define uma boa distribuição.

Figura 45. A-C) Diagramas de extração de argônio por aquecimento em etapas de biotitas da amostra 36 mostrando idades platôs e integradas. D) Ideograma de densidade de probabilidade dos resultados dos diagramas A-C define dois picos de distribuição.

Figura 46. A-C) Diagramas de extração de argônio por aquecimento em etapas de biotitas da amostra 9A mostrando idades platôs e integradas. D) Ideograma de densidade de probabilidade dos resultados dos diagramas $\mathrm{A}-\mathrm{C}$ define uma boa distribuição.

Figura 47. Diagrama $\varepsilon S r$ vs. $\varepsilon N d$ para as rochas de Cananéia. Abreviações: PAEP, Província Paraná-Angola-Etendeka, H-Ti e L-Ti, alto e baixo Ti; APG, Arco de Ponta Grossa; SdM, Serra do Mar; APIP, Alto Paranaíba; SC, Anitápolis e Lages; TR, Ilhas Trindade e Martin Vaz; ITG, Ilhas Inaccessible, Tristan e Gough; MAR, Dorsal Meso-Atlântica; DM, EMI, EMII e HIMU, respectivamente, manto empobrecido, mantos enriquecidos e manto de alto $\mu$ (alto ${ }^{238} \mathrm{U} /{ }^{204} \mathrm{~Pb}$ ). Fonte de dados: Ruberti et al. (2005 e referências) e Enrich et al. (2005 e referências). Símbolos como na Figura 7. 
Figura 48. Diagrama $T_{D M}$ vs. $\varepsilon N d$ (DePaolo, 1988) para as rochas de Cananéia (azul). Abreviações: SdM, Serra do Mar; APG, Arco de Ponta Grossa; DM, manto empobrecido Valor de $T_{\mathrm{DM}}$ : calculado de acordo com a idade modelo relativa ao manto empobrecido (83,6 ma), ${ }^{143} \mathrm{Nd} /{ }^{144} \mathrm{Nd}=0,513114 \mathrm{e}^{147} \mathrm{Sm} /{ }^{144} \mathrm{Nd}=0,222$; (Faure, 1986).

Figura 49. Distribuição de idades $T_{D M}(\mathrm{Ga})$ das rochas alcalinas de Cananéia (1) e Paraguai Oriental (2, Província do Alto do Paraguai; 3, Província do Rio Apa; 4, Província de Amambay; 6, Província Central-Sapucai; 7, Província de Assunção; 8, Província de Misiones). Basaltos toleíticos: 5, Carayó; 9, Encarnación. A linha em vermelho representa toleítos com baixo teor em Ti. Dados de Comin-Chiaramonti e Gomes (2005) e Comin-Chiaramonti et al. (2007a).

Figura 50. A) Diagrama reunindo razão inicial ${ }^{87} \mathrm{Sr} /{ }^{86} \mathrm{Sr}\left(\mathrm{R}_{0}\right)$ e $\mathrm{Sr}(\mathrm{ppm})$ (cf. DePaolo, 1988). A curva em negrito mostra a linha de mistura simples entre a crosta e o manto; a seta indica um trend negativo para as rochas de Cananéia. B) Diagrama reunindo razão inicial ${ }^{87} \mathrm{Sr} /{ }^{86} \mathrm{Sr}\left(\mathrm{R}_{0}\right) \mathrm{e}$ $10^{3} / \mathrm{Sr}$, com a seta sugerindo um trend positivo para as rochas de Cananéia. Símbolos como na Figura 7.

Figura 51. Diagrama de razão inicial ${ }^{87} \mathrm{Sr} /{ }^{86} \mathrm{Sr}\left(\mathrm{R}_{0}\right)$ vs. $\mathrm{SiO}_{2}$ (\% peso) para as rochas de Cananéia e de ocorrências associadas aos Alinhamentos de Guapiara (A) e de São JerônimoCuriúva (B) no Arco de Ponta Grossa. Dos diagramas constam também a tendência das rochas de Cananéia e os vetores (setas tracejadas em vermelho) indicativos de cristalização fracionada (FC) em sistema fechado. Extraído de Ruberti et al. (2005). Símbolos como na Figura.

Figura 52. Dados de $\varepsilon N d$ e $1 / \mathrm{Nd}$ para as rochas de Cananéia. Diagrama extraído de Stevenson et al. (1997) mostrando o comportamento dos processos de cristalização fracionada (FC), assimilação-cristalização fracionada (AFC) e de mistura de magmas para as rochas alcalinas do complexo de llímaussaq, na Groenlândia.

Figura 53. Diagrama $\mathrm{SiO}_{2}$ vs. $\mathrm{La} / \mathrm{Ce}(\mathrm{A})$ e $\mathrm{SiO}_{2}$ vs. $\mathrm{Ba} / \mathrm{Rb}(\mathrm{B})$ para as rochas de Cananéia.

Figura 54. Diagrama $\mathrm{SiO}_{2}$ vs. $\mathrm{P}_{2} \mathrm{O}_{5}$ para as rochas de Cananéia mostrando as curvas de saturação em $\mathrm{P}_{2} \mathrm{O}_{5}$ para temperaturas de $800^{\circ} \mathrm{C}, 950^{\circ} \mathrm{C}$ e $1080^{\circ} \mathrm{C}$ (Watson e Harrison, 1984). Símbolos como na Figura 7.

Figura 55. Diagrama $\mathrm{T}^{\circ} \mathrm{C}$ vs. $\log _{10} \mathrm{fO}_{2}$ (Andersen e Lindsley, 1988) para os pares magnetita e ilmenita das rochas de Cananéia. Buffers: HM, hematita-magnetita; NNO, níquel-óxido de níquel; QFM, quartzo-faialita-magnetita; MW, magnetita-wüstita. Valores de $\mathrm{fO}_{2}$ e $\mathrm{T}^{\circ} \mathrm{C}$ obtidos pelo programa ILMAT (Lepage, 2003).

Figura 56. A) Diagrama Q-Ab-Or normativo para as rochas de Cananéia. B) Diagrama An-AbOr normativo mostrando as curvas de solvus (linha LSK; K, ponto consoluto) para feldspatos e a linha cotética plagioclásio-feldspato alcalino ( $\mathrm{PAL} ; \mathrm{C}$, ponto mínimo) para o sistema insaturado com pressão de $\mathrm{H}_{2} \mathrm{O}=0,1$ (Nevkvasil, 1990 apud Janasi, 1992). Símbolos como na Figura 7.

Figura 57. Diagrama normativo nefelina-quartzo-kalsilita para as rochas de Cananéia no sistema petrogenético residual de Hamilton e MacKenzie (1965) para uma pressão de água de 1 kbar. Mínimos: $\mathrm{m}_{1}$, riolítico; $\mathrm{m}_{2}$, magma inicial; $\mathrm{m}_{3}$, fonolítico.

Figura 58. Diagramas de elementos incompatíveis (A) e Terras Raras (B), normalizados, respectivamente, para o manto primitivo (Sun e McDonough, 1989) e condritos (Boynton, 1984), para as rochas alcalinas de Tunas. Dados extraídos de Ruberti et al. (2005).

Figura 59. Diagramas de elementos incompatíveis, normalizados para o manto primitivo (McDonough e Sun, 1995) para as rochas alcalinas intrusivas (A) e hipoabissais (B) das llhas de Vitória, Monte de Trigo, Búzios e São Sebastião. Dados extraídos de Motoki (1986) para Vitória, de Alves (1996) para Búzios e de Enrich (2005) e Enrich et al. (2005) para Monte de Trigo e São Sebastião.

Figura 60. Diagramas de elementos Terras Raras, normalizados para os condritos (McDonough e Sun, 1995), para as rochas alcalinas intrusivas (A) e hipoabissais (B) das llhas de Monte de Trigo e São Sebastião. Dados extraídos de Enrich (2005) e Enrich et al. (2005). 
Figura 61. Diagramas de elementos incompatíveis, normalizados para o manto primitivo (McDonough e Sun, 1995), para as rochas alcalinas intrusivas (A) e hipoabissais (B) de Itatiaia, Morro Redondo e Passa Quatro. Dados extraídos de Brotzu et al. (1989) e Enrich et al. (2005).

Figura 62. Diagramas de elementos Terras Raras, normalizados para condritos (McDonough e Sun, 1995). Para as rochas alcalinas intrusivas (A) e hipoabissais (B) de Itatiaia, Morro Redondo e Passa Quatro. Dados extraídos de Brotzu et al. (1989) e Enrich et al. (2005).

Figura 63. Diagramas de elementos incompatíveis, normalizados para o manto primitivo (McDonough e Sun, 1995), das rochas intrusivas (A) e de diques (B) do Ponta do Morro. Dados extraídos de Sousa (1997).

Figura 64. Blocos diagramas esquemáticos da evolução magmática de Cananéia; sem escala. 1 e 2 - início da intrusão do magma alcalino e assimilação de material crustal; 3 desenvolvimento da Superfície Japi no Senoniano com extensão NE-SW e intrusão dos diques de direção NW-SE; 4 - avanço da erosão na Superfície Japi no Paleozóico/Eoceno com extensão NW-SE e intrusão dos diques de direção NE-SW; 5 - estágio atual da Planície Costeira Cananéia-Iguape. 


\section{ÍNDICE DAS FOTOS}

Foto 1. Vista parcial da Planície Costeira Cananéia-Iguape observada do Mirante do Cristo, no Morro de Iguape.

Foto 2. Depósito arenoso da Formação Cananéia aflorante na llha Comprida.

Foto 3. Depósito arenoso da Formação Cananéia localizado na Estrada do Quaternário, na llha de Cananéia.

Foto 4. Vista geral do Morro de São João e do porto de Cananéia. Ao fundo, à direita, vê-se a Ilha do Cardoso, constituída basicamente por rochas pré-cambrianas.

Foto 5. Vista geral do Morrete, com o pequeno arcadouro, ponto de embarque/desembarque do ferry-boat, ocupando o centro da fotografia.

Foto 6. Vista do canal conhecido como "Mar de Cananéia", que separa as duas ocorrências alcalinas: Morro de São João, à direita; Morrete, à esquerda. Ao fundo, à direita da fotografia, aparece parte da llha do Cardoso.

Foto 7. Detalhe da vegetação cerrada cobrindo o Morro de São João e que termina abruptamente nos blocos costeiros.

Foto 8. Matacões de dimensões métricas em uma clareira formada pela atividade de extração de palmito. Porção $E$ do morro próxima à área costeira.

Foto 9. Bloco com alteração esferoidal e coberto por líquen.

Foto 10. Matacões expostos ao longo da área costeira.

Foto 11. Amostra de granulação muito fina referente à amostra 19 (Morro de São João).

Foto 12. Amostra de granulação muito fina referente à amostra 9B (Morro de São João).

Foto 13. Dique de espessura decimétrica, constituído por rocha traquítica de coloração escura cortando a encaixante sienítica. Região costeira. Direção do dique: N40W/subvertical. Amostra $9 B$.

Foto 14. Dique traquítico penetrando a encaixante sienítica de coloração mais rosada. Região costeira, bloco deslocado. Amostra 9B.

Foto 15. Veio centimétrico de rocha afanítica penetrando a encaixante sienítica aflorante próximo à área costeira. Direção do veio: N35W/subvertical. Amostra 12.

Foto 16. Mesmo veio da foto anterior.

Foto 17. Veio e fragmentos de rocha afanítica, de coloração acinzentada, no interior da massa sienítica.

Foto 18. Fragmento irregular de rocha afanítica, de coloração cinza, no interior da massa sienítica.

Foto 19. Fragmento decimétrico de rocha afanítica, de coloração rosada, no interior da massa sienítica.

Foto 20. Rochas do corpo satélite do Morrete aflorando como matacões de dimensões métricas, e formando pequena gruta.

Foto 21. Dique de rocha afanítica cortando as rochas sieníticas do Morrete; ambas as litologias encontram-se totalmente alteradas por intemperismo. Direção do dique: N48E/subvertical.

Foto 22. Veio de caráter pegmatóide, de espessura centimétrica, cortando a encaixante sienítica. Direção do veio N60W/subvertical.

Foto 23. Textura pegmatóide das rochas de Cananéia, com os cristais de feldspato alcalino atingindo dimensões de até $2 \mathrm{~cm}$. 
Foto 24. Veio pegmatóide de espessura decimétrica na encaixante sienítica, localizado na área costeira; ambas as litologias estão alteradas intempericamente.

Foto 25. Veios pegmatóides de natureza dominantemente feldspática, com raros minerais ferromagnesianos, penetrando o material sienítico de coloração mais escura.

Foto 26. Microssienito com veio pegmatóide de espessura centimétrica. Amostra referente à amostra 30 (Morro de São João).

Foto 27. Amostra de rocha da fácies porfirítica referente à amostra 53 (porção $E$ do corpo do Morrete).

Foto 28. Concentração de minerais ferromagnesianos, de forma irregular (schlieren de constituição), no interior das rochas intrusivas do Morrete.

Foto 29. Concentração de minerais ferromagnesianos na forma de veios (schlieren de injeção) cortando a massa sienítica. 


\section{ÍNDICE DAS FOTOMICROGRAFIAS}

Fotomicrografia 1. Álcali feldspato sienito: estrutura mesopertítica no cristal do centro. À direita, observa-se cristal de feldspato com as fases micropertítica, sódica e potássica. Polarizadores cruzados. Amostra 39B.

Fotomicrografia 2. Álcali feldspato sienito: aglomerado de plagioclásio substituído parcialmente pelo processo de desmisturação. Polarizadores cruzados. Amostra 32A.

Fotomicrografia 3. Álcali feldspato sienito: cristal de plagioclásio, no interior do feldspato alcalino, contendo inclusões de vários minerais (clinopiroxênio, anfibólio e biotita). Polarizadores cruzados. Amostra 32B

Fotomicrografia 4. Álcali feldspato sienito: textura zonada, com a magnesiohornblenda (hbl) envolvendo o clinopiroxênio (cpx), que ocupa as partes centrais dos cristais; opacos e apatita (ap) idiomórfica aparecem na forma de inclusões. Polarizadores paralelos. Amostra 28A.

Fotomicrografia 5. Álcali feldspato sienito: Magnesiohornblenda substituindo o clinopiroxênio, ao lado de biotita associada às fraturas e bordas dos cristais. opacos e apatita ocorrem como inclusões. Nota-se também a presença de lamelas de opacos nos planos da clivagem da biotita. Polarizadores paralelos. Amostra 32B.

Fotomicrografia 6. Álcali feldspato sienito: pseudomorfo de olivina no interior do clinopiroxênio com borda associada de magnesiohornblenda. Nota-se também a biotita associada às clivagens do anfibólio. Polarizadores paralelos. Amostra 32B.

Fotomicrografia 7. Álcali feldspato sienito: pseudomorfo de olivina substituído por iddingsita(?) com bordas de magnesiohornblenda (verde oliva escuro) e biotita (vermelho-acastanhado escuro). Polarizadores paralelos. Amostra 32B.

Fotomicrografia 8. Álcali feldspato sienito: quartzo (qtz) intersticial, de aspecto límpido, associado a magnesiohornblenda (hbl). Polarizadores paralelos. Amostra 33A.

Fotomicrografia 9. Quartzo-álcali feldspato sienito: textura fanerítica média, inequigranular com cristais de katoforita com textura poiquilítica (à direita), olivina substituída por iddingsita(?) e quartzo intersticial de aspecto límpido. Polarizadores paralelos. Amostra 34.

Fotomicrografia 10. Quartzo-álcali feldspato sienito: feldspato alcalino com as fases pertítica (esquerda superior), sódica (turva) e potássica (límpida) e cristal idiomórfico zonado (centro). Polarizadores cruzados. Amostra 41.

Fotomicrografia 11. Quartzo-álcali feldspato sienito: feldspato alcalino apresentando geminação do periclínio associada à da albita. Inclusão de zircão (birrefringência azul) e titanita no feldspato mostrando as fases pertítica e potássica. Polarizadores cruzados. Amostra 15A.

Fotomicrografia 12. Quartzo-álcali feldspato sienito: feldspato alcalino com intercrescimento de quartzo. Feição observada somente em amostras de rochas do Morrete. Polarizadores cruzados. Amostra 41.

Fotomicrografia 13. Quartzo-álcali feldspato sienito: feldspato alcalino com estruturas de exsolução (fases pertítica, sódica-límpida e potássica-turva). O quartzo ocorre preenchendo espaços intergranulares. Polarizadores cruzados. Amostra 41.

Fotomicrografia 14. Quartzo-álcali feldspato sienito: magnesiohornblenda (hbl) associada às bordas do clinopiroxênio (cpx). Polarizadores cruzados. Amostra $1 B$.

Fotomicrografia 15. Quartzo-álcali feldspato sienito: olivina (olv) substituída por clinopiroxênio (cpx) com bordas de magnesiohornblenda (hbl) e biotita (bio). Polarizadores paralelos. Amostra 35.

Fotomicrografia 16. Quartzo-álcali feldspato sienito: cristal de katoforita com grãos de clinopiroxênio no centro e biotita associada às suas bordas. Na biotita, nota-se halo pleocróico causado pela inclusão de zircão. Polarizadores paralelos. Amostra 1B. 
Fotomicrografia 17. Quartzo-álcali feldspato sienito: olivina com magnesiohornblenda e biotita associada às bordas e fraturas do cristal. Polarizadores paralelos. Amostra 15A.

Fotomicrografia 18. Quartzo-álcali feldspato sienito porfirítico de matriz fina: fenocristal de feldspato alcalino zonado com porções pertíticas e homogêneas. Os fenocristais menores são totalmente mesopertíticos. Polarizadores cruzados. Amostra 53.

Fotomicrografia 19. Quartzo-álcali feldspato sienito porfirítico de matriz fina: fenocristal de feldspato alcalino zonado apresentando fase mesopertita no centro e sódica na borda do cristal. No canto direito superior, observam-se cristais de feldspato com borda pertítica e centro mais homogêneo (fase sódica). Polarizadores cruzados. Amostra 53.

Fotomicrografia 20. Quartzo-álcali feldspato sienito porfirítico: agregado de ilmenita com biotita nas bordas. Polarizadores paralelos. Amostra 50.

Fotomicrografia 21. Microssienito com textura em mosaico: feldspato alcalino, quartzo e clinopiroxênio representam as principais fases minerais presentes. Polarizadores cruzados. Amostra 19.

Fotomicrografia 22. Microssienito com textura em mosaico: cristais de feldspato alcalino, clinopiroxênio e quartzo dispostos seguindo discreta orientação; vê-se também raro megacristal de feldspato alcalino. Polarizadores cruzados. Amostra 12.

Fotomicrografia 23. Microssienito com textura em mosaico: feldspato alcalino com microestrutura de exsolução (cristais mais claros da fase sódica), clinopiroxênio (cpx) como grãos hipidiomórficos isolados e presentes na borda de cristal de olivina (olv). O quartzo é intergranular e apresenta aspecto mais límpido. Polarizadores paralelos. Amostra 18.

Fotomicrografia 24. Microssienito com textura em mosaico: feldspato alcalino apresentando microestruturas de intercrescimento pertítico (fases pertítica, sódica e potássica), clinopiroxênio hipidiomórfico, além de quartzo e opacos intersticiais. Polarizadores paralelos. Amostra 37.

Fotomicrografia 25. Microssienito com textura traquítica porfirítica: matriz formada por cristais de feldspato alcalino e clinopiroxênio prismáticos ligeiramente orientados, caracterizando uma textura de fluxo. Próximo ao fenocristal de feldspato, a matriz apresenta-se pouco orientada. Polarizadores paralelos. Amostra 9B.

Fotomicrografia 26. Microssienito com textura traquítica porfiritica: matriz composta por cristais de feldspato alcalino e ripas de clinopiroxênio. A matriz assume orientação diversa quando em contato com o fenocristal de feldspato alcalino. Este apresenta borda pertítica e núcleo homogêneo. Polarizadores cruzados. Amostra 9B.

Fotomicrografia 27. Microssienito com textura traquítica porfirítica: feldspato alcalino e clinopiroxênio prismático formando a matriz. No centro, fenocristal de plagioclásio xenomórfico bordejado por albita, inclusão de clinopiroxênio e alterações secundárias. Polarizadores cruzados. Amostra 18.

Fotomicrografia 28. Microssienito com textura traquítica porfirítica: cristais prismáticos de clinopiroxênio. À esquerda, observa-se uma porção mais límpida constituída por quartzo com inclusões de clinopiroxênio. Polarizadores paralelos. Amostra 18. 


\section{ÍNDICE DAS TABELAS}

Tabela 1. Contagem modal de amostras representativas das rochas alcalinas de Cananéia. Os valores são expressos em \%; espaçamento $0,02 \mathrm{~mm}$ e média de 2.300 pontos. Legenda: Morro de São João - hipoabissais: 1 (12), 2 (18), 4 (37), 5 (19) e 6 (9B); intrusivas: amostras 7 (2) a 32 (29). Morrete - intrusivas: $33(40)$ a $36(51 A)$. Abreviações: Qs: quartzo-álcali feldspato sienito; As: álcali feldspato sienito, $m S$ : microssienito com textura em mosaico; Tq: microssienito porfirítico com textura traquítica (nomenclatura cf. Streckeisen, 1976).

Tabela 2. Composição química de feldspatos alcalinos e plagioclásios dos álcali feldspato sienitos do Morro de São João. Abreviações: c, b, i, respectivamente, centro, borda e região intermediária dos cristais; $p$, pertita; h, hospedeiro; lam, lamela hóspede; incl, inclusão; pl, plagioclásio; f, fenocristal; m, matriz; v, veio. n.d., não detectado.

Tabela 3. Composição química de feldspatos alcalinos e plagioclásios dos quartzo-álcali feldspato sienitos do Morro de São João. Abreviações como na Tabela 2.

Tabela 4. Composição química de feldspatos alcalinos e plagioclásios dos quartzo-álcali feldspato sienitos porfiríticos do Morrete. Abreviações como na Tabela 2.

Tabela 5. Composição química de feldspatos alcalinos dos microssienitos com textura em mosaico $(37,19)$ e dos microssienitos porfiríticos com textura traquítica $(30)$ do Morro de São João. Abreviações como na Tabela 2.

Tabela 6. Composição química de clinopiroxênios dos álcali feldspato sienitos do Morro de São João. Abreviações: c, b, i, respectivamente, centro, borda e região intermediária dos cristais. Classificação: Di, diopsídio; Hd, hedenbergita; Au, augita; Ea, egirina-augita; mg\# = $\mathrm{Mg} /(\mathrm{Mg}+\mathrm{Fe})$; n.d., não detectado.

Tabela 7. Composição química de clinopiroxênios dos quartzo-álcali feldspato sienitos do Morro de São João. Abreviações e classificação como na Tabela 6.

Tabela 8. Composição química de clinopiroxênios dos microssienitos com textura em mosaico $(37,19)$ e dos microssienitos porfiríticos com textura traquítica $(30)$ do Morro de São João. Abreviações e classificação como na Tabela 6.

Tabela 9. Composição química de anfibólios dos álcali feldspato sienitos do Morro de São João. Abreviações: c, b, i, respectivamente, centro, borda e região intermediária dos cristais. Classificação: Ed, edenita; FEd, ferro-edenita; MHas, magnesiohastingsita; MHbl, magnesiohornblenda; FHbl, ferrohornblenda; Rct, richterita; FRct, ferrorrichterita; Ktf, katoforita; MKtf, magnesiokatoforita; Tmt, taramita; Win, winchita; FWin, ferrowinchita; fBar, ferribarroisita; FBar, ferrobarroisita; fFBar, ferri-ferrobarroisita; Avd, arfvedsonita. Fórmula estrutural calculada assumindo $(\mathrm{OH}, \mathrm{F}, \mathrm{Cl})=2,00$ a.f.u.; $\mathrm{mg} \#=\mathrm{Mg} /(\mathrm{Mg}+\mathrm{Fe})$.

Tabela 10. Composição química de anfibólios dos quartzo-álcali feldspato sienitos do Morro de São João. Abreviações e classificação como na Tabela 9.

Tabela 11. Composição química de anfibólios dos quartzo-álcali feldspato sienitos porfiríticos do Morrete. Abreviações e classificação como na Tabela 9.

Tabela 12. Composição química de anfibólios dos microssienitos porfiríticos com textura traquítica do Morro de São João. Abreviações e classificação como na Tabela 9.

Tabela 13. Composição química de biotitas dos álcali feldspato sienitos do Morro de São João. Abreviações: c, b, i, respectivamente, centro, borda e região intermediária dos cristais. Proporção de $\mathrm{H}_{2} \mathrm{O}$ na fórmula estrutural estimada em 4,00 a.f.u.; $\mathrm{mg} \#=\mathrm{Mg} /(\mathrm{Mg}+\mathrm{Fe})$; n.d., não detectado.

Tabela 14. Composição química de biotitas dos quartzo-álcali feldspato sienitos do Morro de São João $(1 A, 22 B, 15 A)$ e dos quartzo-álcali feldspato sienitos porfiríticos do Morrete $(50,40)$. Abreviações como na Tabela 13.

Tabela 15. Composição química de olivinas dos quartzo-álcali feldspato sienitos do Morro de São João. Abreviações: c, b, i, respectivamente, centro, borda e região intermediária dos cristais; n.d., não determinado. 
Tabela 16. Composição química de apatitas dos álcali feldspato sienitos do Morro de São João. Abreviações: c, b, respectivamente, centro e borda dos cristais; n.d., não determinado.

Tabela 17. Composição química de apatitas dos quartzo-álcali feldspato sienitos do Morro de São João. Abreviações como na Tabela 16.

Tabela 18. Composição química de apatitas dos quartzo-álcali feldspato sienitos $(9 A)$ e dos microssienitos com textura em mosaico (37) do Morro de São João. Abreviações como na Tabela 16.

Tabela 19. Composição química de ilmenitas (ilm) e magnetitas (mt) dos álcali feldspato sienitos do Morro de São João. Abreviações: c, b, respectivamente, centro e borda dos cristais; lam: lamela. Classificação: Gkl, geikielita; Ilm, ilmenita; Hem, hematita; Crm, cromita; Her, hercinita; Mt, magnetita; Spi, espinélio; Usp, ulvöespinélio; n.d., não determinado. Cálculo de $\mathrm{fO}_{2}$ e $\mathrm{T}^{\circ} \mathrm{C}$.

Tabela 20. Composição química de ilmenitas (ilm) e magnetitas (mt) dos quartzo-álcali feldspato sienitos do Morro de São João. Abreviações e classificação como na Tabela 19.

Tabela 21. Composição química de ilmenitas (ilm) e magnetitas (mt) dos quartzo-álcali feldspato sienitos do Morrete. Abreviações e classificação como na Tabela 19.

Tabela 22. Composição química de ilmenitas (ilm) e magnetitas (mt) dos microssienitos com textura em mosaico do Morro de São João. Abreviações e classificação como na Tabela 19.

Tabela 23. Análises químicas de elementos maiores (\%) e traços (ppm), juntamente com os valores para a norma CIPW, R1-R2 (cf. De La Roche, 1986; De La Roche et al., 1980); mg\# $\left[(\mathrm{Mg} / \mathrm{Mg}+\mathrm{Fe})\right.$ assumindo $\left.\mathrm{Fe}^{3+} / \mathrm{Fe}^{2+}=0,18\right]$; índice agpaítico (I.A. $=\mathrm{Na}_{2} \mathrm{O}+\mathrm{K}_{2} \mathrm{O} / \mathrm{Al}_{2} \mathrm{O}_{3}$; proporção molecular, cf. Sørensen, 1960); índice de cor (I.C.); índice de diferenciação (I.D. $=\mathrm{Q}+\mathrm{Or}+\mathrm{Ab}+\mathrm{Ne}+\mathrm{Ks}+\mathrm{Lc}$; cf. Thornton e Tuttle, 1960) e razões entre elementos incompatíveis e Terras Raras para as rochas de Cananéia. Outras abreviações: n.d., não detectado; não analisado, em branco.

Tabela 24. Composições isotópicas de $\mathrm{Sr}$ e $\mathrm{Nd}$ e concentrações em ppm de $\mathrm{Rb}, \mathrm{Sr}, \mathrm{Sm}$ e Nd para as rochas alcalinas de Cananéia. Razão inicial $\left(\mathrm{R}_{0}\right){ }^{87} \mathrm{Sr} /{ }^{86} \mathrm{Sr}$ e ${ }^{143} \mathrm{Nd} /{ }^{144} \mathrm{Nd}$ calculado para 83,6 Ma. $\left({ }^{*}\right)$ :dados de $\mathrm{Rb}$ e Sr extraídos de Spinelli (2000). ${ }^{143} \mathrm{Nd} /{ }^{144} \mathrm{Nd}=0,51344, \mathrm{Sm} / \mathrm{Nd}=0,222$ (Michard et al., 1985), ${ }^{147} \mathrm{Sm} /{ }^{144} \mathrm{Nd}_{\mathrm{CHUR}}=0,1967$ Faure, (1986).

Tabela 25. Síntese dos dados analíticos de ${ }^{40} \mathrm{Ar} /{ }^{39} \mathrm{Ar}$ para as rochas de Cananéia. 
Para meus pais, Luiz Silvério e Regina Célia, família e amigos. 


\section{AGRADECIMENTOS}

Durante a etapa da pós-graduação, confirmei que é impossível concluir um trabalho sozinho. Esta tese contou com a colaboração, auxílio e apoio de instituições, de profissionais, de familiares e de amigos. Na conclusão do doutorado, quero expressar os meus mais sinceros agradecimentos a todos que contribuíram para a finalização da minha tese.

Em primeiro lugar, agradeço ao Prof. Dr. Celso de Barros Gomes pela dedicação, apoio, compreensão e paciência durante 8 anos, desde o período do último ano da graduação até hoje. Sou muito grato pela sua orientação exemplar; mesmo ocupado, principalmente como Chefe de Gabinete do Reitor, sempre dedicou atenção ao meu trabalho e às minhas ansiedades.

Agradeço à Fundação de Amparo à Pesquisa do Estado de São Paulo pela assistência financeira através do Processo 01/10743-3, referente ao "Magmatismo alcalino na Plataforma Sul-Americana: implicações petrogenéticas e geodinâmicas", coordenados pelo Prof. Dr. Celso de Barros Gomes e ao Conselho Nacional de Desenvolvimento Científico e Tecnológico (CNPq) pela concessão da bolsa de pesquisa durante a realização desta tese.

Agradeço ao Prof. Dr. Victor Velázquez Fernandez que acompanhou o meu trabalho, mesmo antes do ingresso no Curso de Pós-graduação do IG/USP, e me ajudou nos trabalhos de campo e nas interpretações dos dados.

Meus agradecimentos pelo trabalho de arte final de Anna Letícia Acquaviva que contou com a sua paciência e experiência na diagramação da tese. Muito obrigado!

Agradeço ao Prof. Dr. Piero Comin-Chiaramonti e ao Prof. Dr. Paolo Censi ambos da Universidade de Trieste, Itália, pela obtenção dos dados geoquímicos; ao Prof. Dr. Gergely Szabó e a Sra. Angélica Morente, pelo auxílio durante as atividades realizadas no Laboratório de Óptica do Departamento de Mineralogia e Geotectônica; ao Prof. Dr. Sílvio R. F. Vlach, Prof. Dr. Excelso Ruberti e ao Sr Marcos Mansueto, pela assistência nas atividades durante a obtenção dos dados de química mineral no Laboratório de Microscopia Eletrônica do Departamento de Mineralogia e Geotectônica.

Sou grato também aos colegas de Programa Adriana Alves, Frederico Vilalva, Gaston Eduardo Enrich Rojas, Lucelene Martins, Marcelo Barbosa, Paulo César Corrêa da Costa, Rogério G. Azzone e a todos os colegas de pós-graduação do Departamento de Mineralogia e Geotectônica e Silvia Cremones, Paula Amaral, Sibele Ezaki do Departamento de Geologia Sedimentar e Ambiental.

Meus agradecimentos ao Prof. Dr. José B. Madureira Filho, Prof. Dr. Daniel Atêncio, Prof. Dr. Darcy Pedro Svizero, Prof. Dr. Fábio Dias, Prof. Dr. Francisco Rubens Alves, Prof. Dr. Rainer A. S. Güttler, Prof. Dr. Cláudio Riccomini, Prof. Dr. Colombo Tassinari, Prof. Dr. Marcos Egydio da Silva, Prof. Dr. Oswaldo Siga Júnior, Prof. Dr. Ian McReath e Prof. Dr. Wilson Texeira pela companhia, convívio, ajudas e discussões durante o período da pós graduação.

Agradeço ás Secretárias do Departamento de Mineralogia e Geotectônica, as Sras. Valéria Cristina Santos e Sônia Gomes C. Vieira; às funcionárias da Biblioteca Sras. Brenda Mascarenhas, Érica do Nascimento e Maria Aparecida Ayello; os funcionários das Secções de Pós-Graduação Sras. Ana Paula Cabanal e Magali F. Rizzo e ao Sr. Tadeu Gaggiano; ao Sr. José Paulo e as Sras. Sandra Andrade e Marinês do Laboratório de Química; os funcionários do Setor de Laminação, Srs. Cláudio Hopp, Paulo Roberto Molinaro, Paulo Augusto Morgato, Luiz Cláudio Nogueira. 
Agradeço também aos funcionários da Gráfica, ao Srs. Claudionor Barbosa, Edmir de Oliveira e Henrique Martins responsáveis pela encadernação dos volumes finais dessa tese.

Importantíssimo lembrar-se do infinito apoio e ajuda da minha amiga, e futura colega de profissão, Rachel Prochoroff. Ela me ajudou com precisos momentos de descontração, de companheirismo, atenção e papos úteis e inúteis, pelas inúmeras palavras de apoio e incentivo, pelo auxilio na correção do texto e claro, pela revisão do abstract. Obrigado pela sua preciosa amizade!

Meus eternos agradecimentos às amizades de maior estima; muito obrigado às amigas: Luciana Rodrigues Caparroz, Janaína Trindade C. Silva, Fernanda Nishiyama da Silva, Patrícia Braga T. lezzi, Monalisa Horvath, Alethéa Ernandes M. Sallun, Tânia Jacobson e lede Terezinha Zolinger, que mesmo à distância me incentivava e ajudava com suas experiências. Agradeço também aos grandes amigos Deyna Pinho e Sérgio Bueno pelas discussões proveitosas, suporte, convívio, empréstimo e transporte dos materiais de impressão, além da ajuda e soluções oferecidas nas etapas de finalização da impressão. Aos amigos Liuska Sandim T. Lima, Cirsyano Sandim da Silveira, Kamila Rapini, Rochely K. Paludetto e Gisele Múfalo que sempre participaram dessa minha jornada. Os meus sinceros agradecimentos a todos vocês!

Por fim, em muito especial, agradeço aos meus queridos pais, Luiz Silvério e Regina Célia, que são os meus grandes exemplos, sempre me estimulando e apoiando com enorme dedicação e experiência de vida. Obrigado a toda minha família que presenciou essa etapa.

A todos os profissionais e amigos, que de uma forma ou de outra colaboraram neste trabalho e que por descuido não tenham sido mencionados, apresento os meus mais sinceros agradecimentos. 


\section{RESUMO}

A ocorrência alcalina de Cananéia, SE do Brasil, situada na parte meridional da ilha homônima, é uma intrusão subcircular com área de $1,8 \mathrm{~km}^{2}$ (Morro de São João) e $137 \mathrm{~m}$ de altura. Um corpo satélite (Morrete) de menor dimensão e petrografia similar é encontrado na adjacente llha Comprida.

Geomorfologicamente, ela está inserida na Planície Costeira Cananéia-Iguape. Apresenta-se coberta por sedimentos quaternários e tem como encaixante rochas do embasamento cristalino (Grupo Açungui), que afloram a alguns quilômetros de distância, já no continente. Quanto ao condicionamento tectônico, a exemplo dos complexos alcalino-carbonatíticos vizinhos de Jacupiranga, Juquiá e Pariquera-Açu, a intrusão está relacionada ao Lineamento de Guapiara, uma das principais feições estruturais associadas ao Arco de Ponta Grossa.

A ocorrência é constituída exclusivamente por rochas de natureza sienítica, com álcali feldspato sienitos e quartzo-álcali feldspato sienitos representando os tipos litológicos principais, além de microssienitos na forma de pequenos diques e veios. Do ponto de vista mineralógico, essas rochas contêm feldspato alcalino (mesopertita) como fase mais abundante. A mesopertita é do tipo dominantemente hipersolvus, em geral presente junto às litologias mais evoluídas. Plagioclásio tem ocorrência restrita e quartzo é o segundo mineral félsico em importância. Clinopiroxênio e anfibólio, com ampla variação composicional, correspondem às fases máficas mais comuns, aparecendo subordinadamente biotita e olivina. Os principais acessórios incluem apatita, titanita, opacos e zircão.

As condições de cristalização apontam para temperaturas de formação em torno de $950^{\circ} \mathrm{C}$ para os álcali feldspato sienitos e ao redor de $800^{\circ} \mathrm{C}$ para os quartzo-álcali feldspato sienitos, associadas, respectivamente, a um ambiente levemente oxidado e menos oxidado sob baixa pressão ( $<1 \mathrm{kbar}$ ).

Dados geoquímicos atestam o caráter saturado a supersaturado em $\mathrm{SiO}_{2}$ das rochas de Cananéia, a afinidade potássica e o seu alto grau de evolução. Os diagramas multielementares reunindo elementos maiores e traços com a concentração de sílica são indicativos de que processos de cristalização fracionada exerceram papel importante na sua formação. A distribuição normalizada dos elementos incompatíveis mostra anomalias negativas pronunciadas em $\mathrm{Sr}, \mathrm{P}$ e Ti e subordinadas em Ba. $\mathrm{Zr}$ e Nd exibem visíveis anomalias positivas, estas menos evidentes para o La, Y e Ba. Em geral, o comportamento é comparável àquele observado em outras ocorrências alcalinas brasileiras do Cretáceo Superior, contendo essencialmente rochas evoluídas.

A distribuição normalizada dos padrões de ETR indica alta concentração desses elementos e fracionamento das TRL em relação às TRP. A forte anomalia negativa registrada para o Eu poderia ser devida a processo de remoção de feldspato ou a possível assimilação de material granítico da encaixante.

Determinações radiométricas pelo método $\mathrm{Ar} / \mathrm{Ar}$ realizadas em concentrados de biotita mostram uma idade de $83,6,9 \pm 0,9$ Ma para as rochas sieníticas, similar à obtida a partir de uma isócrona interna de Rb-Sr, apresentando valor de $83,5 \pm 2,2$ Ma e razão inicial ${ }^{87} \mathrm{Sr} /{ }^{86} \mathrm{Sr}$ de 0,70686 .

As razões iniciais ${ }^{87} \mathrm{Sr}^{86} \mathrm{Sr}_{(83,6 \mathrm{Ma})}\left(\mathrm{R}_{0}\right)$ variam entre 0,7065 e 0,70700 para os litotipos menos diferenciados e entre 0,70538 e 0,70777 para os mais evoluídos. As razões elevadas das rochas de Cananéia, em geral superiores a 0,706, indicam claramente que processos de assimilação e contaminação crustal participaram da sua formação, como sugerido no gráfico $\mathrm{R}_{0}$ versus $\mathrm{SiO}_{2}$, com os valores mais altos correspondendo às variedades com maior quantidade em sílica, e no diagrama 
normativo nefelina-quartzo-kalsilita (sistema petrogenético residual).

Estudos isotópicos ( $\mathrm{Sr}-\mathrm{Nd}$ ) e comparações com outras ocorrências alcalinas do SE do Brasil sugerem que as rochas de Cananéia provavelmente se desenvolveram a partir de um magma parental de natureza basanítica. Acredita-se, ainda, que a sua formação tenha envolvido a ação de processos de enriquecimento metassomático do manto ocorridos no Proterozóico, além de contado com a contribuição de fontes do tipo HIMU e EMI.

Cálculos para a idade modelo $\left(T_{D M}\right)$ apresentam valores muito superiores aos disponíveis para outras ocorrências da região sudeste, exceção feita aos dois complexos de Santa Catarina (Anitápolis e Lages). A idade média obtida ( $1400 \pm 200 \mathrm{Ma})$ é, por sua vez, apenas comparável àquela relativa às ocorrências alcalinas potássicas da borda ocidental da Bacia do Paraná, em território paraguaio (1500 $\pm 200 \mathrm{Ma})$.

Estudo comparativo com outras ocorrências alcalinas brasileiras formadas quase que exclusivamente de litologias sieníticas permite reconhecer similaridades entre as rochas de Cananéia e aquelas de alguns maciços da Província da Serra do Mar (Serra da Mantiqueira: Itatiaia, Passa Quatro e Morro Redondo; ilhas oceânicas: Vitória, Monte de Trigo, Búzios e São Sebastião), da Província do Arco de Ponta Grossa (Tunas) e da intrusão de Ponta do Morro, no Mato Grosso, particularmente quanto às características geoquímicas (comportamento dos elementos incompatíveis e Terras Raras) e idade (Cretáceo Superior). 


\section{ABSTRACT}

The alkaline occurrence of Cananéia, SE Brazil, lying in the southern part of the homonymous island, is a subcircular intrusion $1.8 \mathrm{~km}^{2}$ in area (Morro de São João) and $137 \mathrm{~m}$ high. A small and petrographically similar satellite body (Morrete) is found in the adjacent llha Comprida.

Geomorphologically, it belongs to the Cananéia-Iguape Coast Plain. It is covered by Quaternary sediments and is enclosed into the crystalline basement (Grupo Açungui), which outcrops some kilometers away, in the continental area. Regarding tectonical control, together the neighboring alkaline-carbonatitic complexes of Jacupiranga, Juquiá and Pariquera-Açu, the intrusion is related to the Guapiara Lineament - one of the major structural features associated with the Ponta Grossa Arch.

The occurrence is constituted exclusively by syenitic rocks, with alkali feldspar syenites and quartz-alkali feldspar syenites representing the main lithologies, besides microsyenites as small dikes and veins. From the mineralogical point of view, these rocks have alkaline feldspar (mesoperthite) as the major abundant phase. The mesoperthite belongs to the hypersolvus type, being in general present in the more evolved rock types. Plagioclase is scarce and quartz corresponds to the second felsic mineral in importance. Clinopyroxene and amphibole widely variable in composition are the most common mafic phases whereas biotite and olivine occur subordinately. Main accessory minerals include apatite, titanite, opaques and zircon.

The crystallization conditions point to formation temperatures around $950^{\circ} \mathrm{C}$ for the alkali-feldspar syenites and $800^{\circ} \mathrm{C}$ for the quartz-alkali feldspar syenites, associated with a slightly oxidized environment and a less oxidized one under low pressure ( $<1 \mathrm{kbar}$ ), respectively.

Geochemical data confirm the saturated to oversaturated in $\mathrm{SiO}_{2}$ nature of the Cananéia rocks, the potassic affinity and their high degree of evolution. The multielemental diagrams relating major and trace element contents against silica concentration indicate that fractional crystallization processes have played an important role on its formation. The normalized distribution of the incompatible elements show pronounced negative anomalies in $\mathrm{Sr}, \mathrm{P}$ and $\mathrm{Ti}$ and subordinate in $\mathrm{Ba} . \mathrm{Zr}$ and $\mathrm{Nd}$ display visible positive spikes, which are less evident in $\mathrm{La}, \mathrm{Y}$ and $\mathrm{Ba}$. In general, the behavior is quite comparable to that recognized for other Late Cretaceous Brazilian alkaline occurrences, mainly consisting of evolved rocks.

The normalized distribution of the REE patterns point to their high concentration and to the enrichment of LREE in relation to HREE. The strong Eu negative anomaly could be due to feldspar removal process or to a possible assimilation of granitic material from the country rocks.

$\mathrm{Ar} / \mathrm{Ar}$ radiometric determinations carried out on biotite separates provide an age of $83.6 \pm 0.9 \mathrm{Ma}$ for the syenitic rocks, which is similar to that given by an internal $\mathrm{Rb}-\mathrm{Sr}$ isochronous, showing a value of 83.5 $\pm 2.2 \mathrm{Ma}$ and ${ }^{87} \mathrm{Sr} /{ }^{86} \mathrm{Sr}$ initial ratio of 0.70686 .

The ${ }^{87} \mathrm{Sr}^{86} \mathrm{Sr}_{(83,6 \mathrm{Ma})}$ initial ratios $\left(\mathrm{R}_{0}\right)$ vary between 0.7065 and 0.70700 for the less differentiated lithotypes and between 0.70538 e 0.70777 for the most evolved ones. The high values of the Cananéia rocks, in general over 0.706 , clearly indicate that assimilation and crustal contamination processes have participated of its formation, as it is suggested in the $\mathrm{R}_{0}$ versus $\mathrm{SiO}_{2}$ graph, where the highest values correspond to the varieties having the largest amounts of silica, and in the normative nepheline-quartz-kalsilite diagram (petrogenetical residual system).

Isotopical studies (Sr-Nd) and comparison with other alkaline occurrences of SE Brazil suggest 
that the Cananéia rocks probably developed from a parental magma of basanitic nature. Also, it is believed that its formation has involved metasomatic enrichment processes of the mantle occurred in Proterozoic times as well as the contribution of HIMU and EMI source types.

Model age $\left(T_{D M}\right)$ calculations give values higher than those available for other alkaline occurrences of the southern region, except for the two Santa Catarina complexes (Anitápolis and Lages). The average age $(1400 \pm 200 \mathrm{Ma})$ is only comparable to that shown by the alkaline potassic occurrences from the western side of the Paraná Basin, in Paraguayan territory (1500 $\pm 200 \mathrm{Ma}$ ).

Comparative study with other Brazilian alkaline occurrences almost exclusively formed of syenitic lithologies allows recognize similarities between the Cananéia rocks and those of some massives of the Serra do Mar (Serra da Mantiqueira: Itatiaia, Passa Quatro e Morro Redondo; oceanic islands: Vitória, Monte de Trigo, Búzios e São Sebastião) and Ponta Grossa Arch (Tunas) Provinces and of the Ponta do Morro intrusion in the Mato Grosso State, especially regarding geochemical characteristics (behavior of incompatible and Rare Earth elements) and age (Late Cretaceous). 


\section{INTRODUÇÃO}

Desde a década dos 40 (Leinz, 1940; Freitas, 1947), as rochas alcalinas brasileiras vêm sendo alvo de grande interesse, que se estende até os nossos dias. Devido às suas particularidades, fruto da grande diversidade mineralógico-petrográfica e complexidade química, elas têm despertado, ao longo dos anos, a atenção de numerosos pesquisadores, principalmente, dos petrógrafos. Nesse período de tempo, foram muitos os trabalhos sobre o tema produzidos pelo núcleo geológico da Universidade de São Paulo, grande parte deles na forma de teses de doutoramento.

Uma primeira idéia sobre o muito até então realizado é oferecida nos artigos de revisão de Ulbrich e Gomes (1981) e, posteriormente, de Gomes et al. (1990), o último tratando especificamente das rochas carbonatíticas. Mais recentemente, as informações disponíveis foram compiladas nas contribuições, ainda de caráter revisional, de Morbidelli et al. (1995) e Gomes et al. (1996). De maneira geral, a ênfase estava quase que inteiramente centrada nas ocorrências alcalinas encontradas em território nacional. Contudo, a partir de meados da década passada, deu-se também o envolvimento desse grupo de pesquisa com aquelas presentes em território paraguaio (Velázquez, 1992, 1996). Um dos trabalhos mais abrangentes dessa fase é o livro de Comin-Chiaramonti e Gomes (1996), reunindo dados mineralógicos, petrográficos, geoquímicos e paleomagnéticos sobre as últimas rochas, bem como trazendo análise comparativa sobre as variedades presentes nos dois países. Outra importante fonte de informações é o volume produzido há pouco tempo por CominChiaramonti e Gomes (2005), que focaliza o magmatismo alcalino mesozóico-cenozóico na Plataforma Brasileira.

As rochas alcalinas, ocorrendo principalmente nas porções periféricas da Bacia do Paraná, apresentam grande variação, que se reflete, em se tratando dos corpos brasileiros, nos seus seguintes aspectos: modo de ocorrência, reconhecendo-se desde formas intrusivas (complexos anelares, stocks), hipoabissais (diques, diques radiais e anelares, veios) e vulcânicas (lavas, plugs); quimismo, passando de tipos extremos ultrabásicos a ácidos; área de exposição, variando de poucos metros a centenas de quilômetros quadrados, com o principal complexo brasileiro, o de Poços de Caldas, cobrindo superfície superior a $800 \mathrm{~km}^{2}$; cronologia, estendendo-se desde o Permo-Triássico (240-250 Ma) até o Eoceno ( 50 Ma).

Adicionalmente, mencione-se que as rochas alcalinas, sobretudo os carbonatitos, constituem-se em fontes comercialmente exploráveis de bauxita, nióbio, fosfato, tório e vermiculita, além de potenciais em terras raras e titânio. No momento, encontram-se em atividade produtiva as ocorrências de Lages, SC (extração de bauxita), Araxá, Tapira e Salitre, MG (fosfato, nióbio), Catalão I, GO (fosfato, vermiculita, terras raras) e Jacupiranga, SP (fosfato e calcário). Poços de Caldas (MG) teve suas atividades encerradas desde 1998. A ocorrência de Itataia, CE, é um importante depósito de urânio, porém, a sua produção depende de ações administrativas e, principalmente, de avanços tecnológicos. O trabalho de Biondi (2005) reúne as principais associações de rochas alcalinas brasileiras contendo depósitos minerais: complexos alcalinos miaskíticos; complexos alcalinos agpaíticos (urânio, zircão, molibdênio, terras raras e fluorita); complexos kimberlíticos; complexos lamproíticos, lamprofíricos e ultrapotássicos; complexos máfico-ultramáficos do tipo Alasca (níquel); associações peralcalinas de granitos+sienitos+gabro; e "episienitos" e albititos metassomáticos formados em zonas de cisalhamento (urânio). 
Rochas alcalinas fanerozóicas estão presentes em diversos pontos do território nacional, ainda que sejam mais abundantes junto às regiões centro-sudeste (Fig. 1). Elas são mais freqüentes nas áreas continentais, mas também podem ser encontradas em algumas ilhas continentais costeiras (p.e. Búzios, Monte de Trigo, São Sebastião, Vitória, no litoral do Estado de São Paulo).

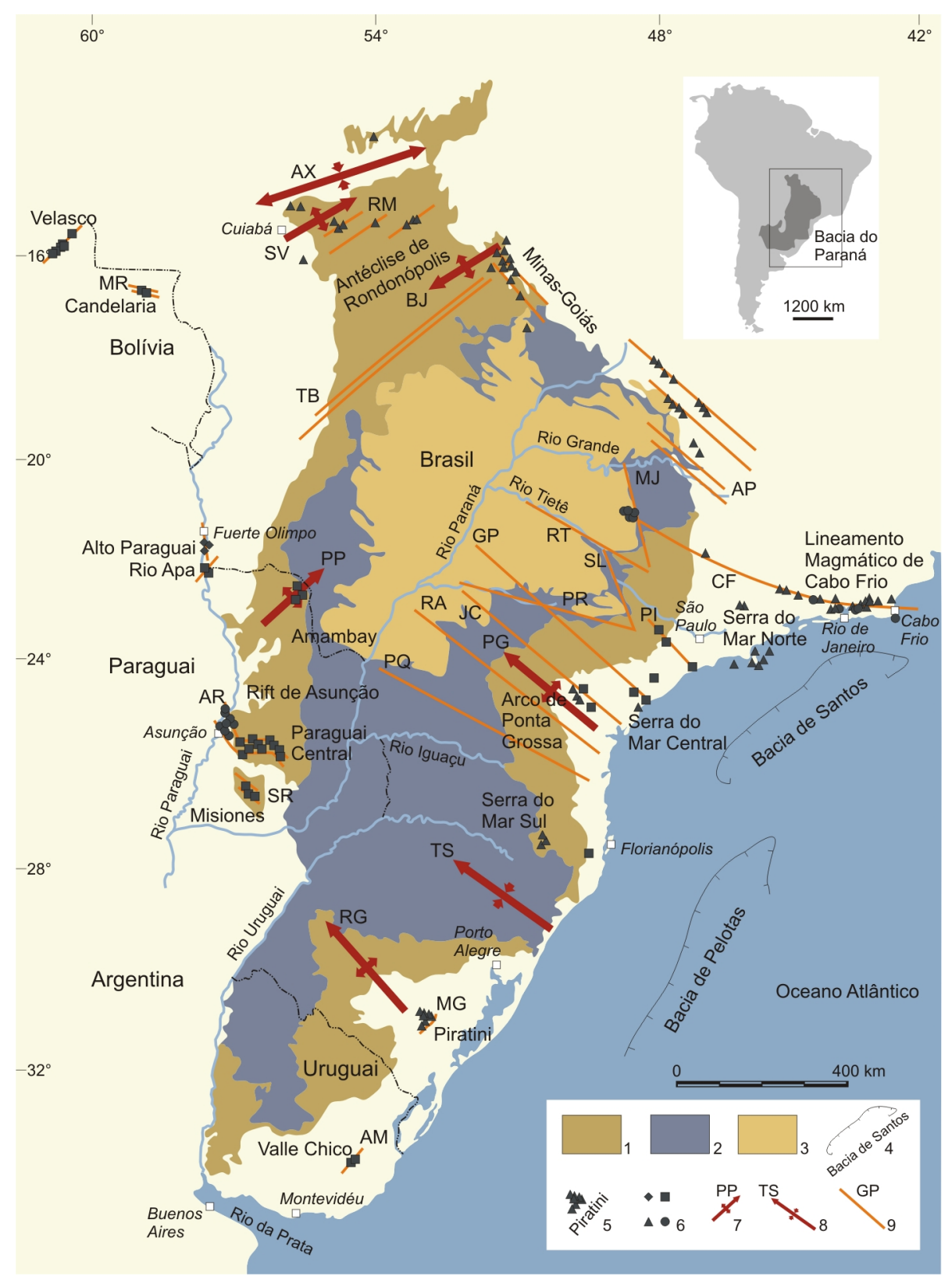

Figura 1. Províncias alcalinas da região centro-sudeste da Plataforma Brasileira e suas relações com os principais regimes estruturais (cf. Riccomini et al., 2005). 1) Bacia do Paraná - Ordoviciano Superior ao Cretáceo Inferior; 2) lavas toleíticas Cretáceo Inferior; 3) Bacia Bauru - Cretáceo Superior; 4) bacias marinhas marginais; 5) ocorrências alcalinas; 6) idades de rochas alcalinas (losango, Permo-Triássico; quadrado, Cretáceo Inferior; triângulo, Cretáceo Superior; círculo, Paleoceno); 7) eixos de arcos principais (AX, Alto Xingu; SV, São Vicente; BJ, Bom Jardim; PG, Ponta Grossa; RG, Rio Grande; PP, Ponta Porã); 8) Sinclinal de Torres; 9) zonas de falhas (Rifts: MR, Mercedes; RM, Rio das Mortes; MG Moirão; SR, Santa Rosa; AR, Assunção; Lineamentos: TB, Transbrasiliano; AP, Alto Paranaíba; MJ, Moji-Guaçu; CF, Cabo Frio; RT, Rio Tietê; SL, São Carlos-Leme; PR, Paranapanema; PI, Piedade; GP, Guapiara; JC, Jerônimo-Curiúva; RA, Rio Alonzo; PQ, Rio Piquiri; AM, Santa Lúcia-Aiguá-Merin). 
Com base principalmente em evidências tectônicas, Almeida (1983) procurou agrupar as numerosas ocorrências conhecidas, incluídas aqui aquelas dos países vizinhos, em diversas províncias: Piratini, Santa Catarina, Arco de Ponta Grossa, Ipanema, Poços de Caldas, Alto Paranaíba, Rio Verde-Iporá, Serra do Mar, Mariscala (Uruguai), Paraguai Oriental, Candelaria e Velasco (as duas últimas na Bolívia). Ainda segundo esse autor, as ocorrências brasileiras podem, por sua vez, ser reunidas em dois grandes conjuntos: 1) bordas da Bacia do Paraná e 2) cinturão litorâneo São Paulo-Rio de Janeiro.

Um novo esquema de classificação das províncias alcalinas, a partir de seu condicionamento tectônico, é proposto por Riccomini et al. (2005) (Fig. 1). Os autores agrupam o magmatismo alcalino da região centro-sudeste da Plataforma Brasileira em quinze províncias: Alto Paraguai, Arco de Ponta Grossa, Valle Chico, Misiones, Paraguai Central, Amambay e Rio Apa, todas localizadas na borda da Bacia do Paraná; Antéclise de Rondonópolis e Minas-Goiás, na borda da Bacia Bauru; Serra do Mar e Piratini adjacentes, respectivamente, à Bacia de Santos e de Pelotas; Assunção, relacionada à evolução cenozóica do sistema de rift homônimo; Lineamento Magmático de Cabo Frio, relacionando eventos magmáticos ao longo dessa zona estrutural; e Velasco e Candelaria junto à porção oriental da Bolívia, no Cráton Amazônico.

Desde meados dos 80 , as rochas alcalinas situadas nas bordas da Bacia do Paraná têm sido investigadas de forma sistemática do ponto de vista petrológico e geoquímico, sobretudo no âmbito de projetos temáticos apoiados financeiramente pela Fapesp ("Magmatismo básico-alcalino da Bacia do Paraná", Proc. 90/3692-7, e "Petrologia e geoquímica das rochas alcalinas", Proc. 97/01210-4, ambos já encerrados; "Magmatismo alcalino na Plataforma Sul-Americana: implicações petrogenéticas e geodinâmicas", Proc. 01/10714-3, em andamento).

\subsection{Vias de acesso}

Partindo de São Paulo, o acesso à intrusão de Cananéia, distante aproximadamente $259 \mathrm{~km}$, é feito a partir da rodovia Régis Bittencourt (BR-116), em direção ao sul do país, até a cidade de

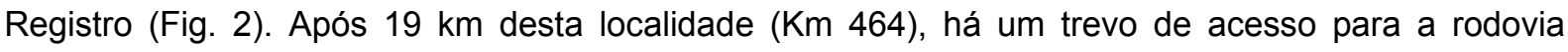
Pariquera-Açu-Cananéia (SP-226). Nessa estrada, percorridos $16 \mathrm{~km}$ de Pariquera-Açu, chega-se a uma bifurcação oferecendo duas alternativas para atravessar o "Mar de Cubatão": uma por meio de balsa e a outra, mais usada, cruzando-se a ponte do rio Aroeira. Deste último ponto, chega-se à cidade de Cananéia num percurso de $26 \mathrm{~km}$.

A intrusão do Morrete, de menor extensão, localiza-se na vizinha llha Comprida. O acesso ao corpo é realizado por meio de balsa (ferry-boat) partindo da zona central da cidade. Feita a travessia, pega-se a estrada de terra para Boqueirão Sul e, cerca de $600 \mathrm{~m}$ adiante, toma-se a primeira via à direita, que passa ao lado do pequeno morro (ver Fig. 4 mais adiante). 


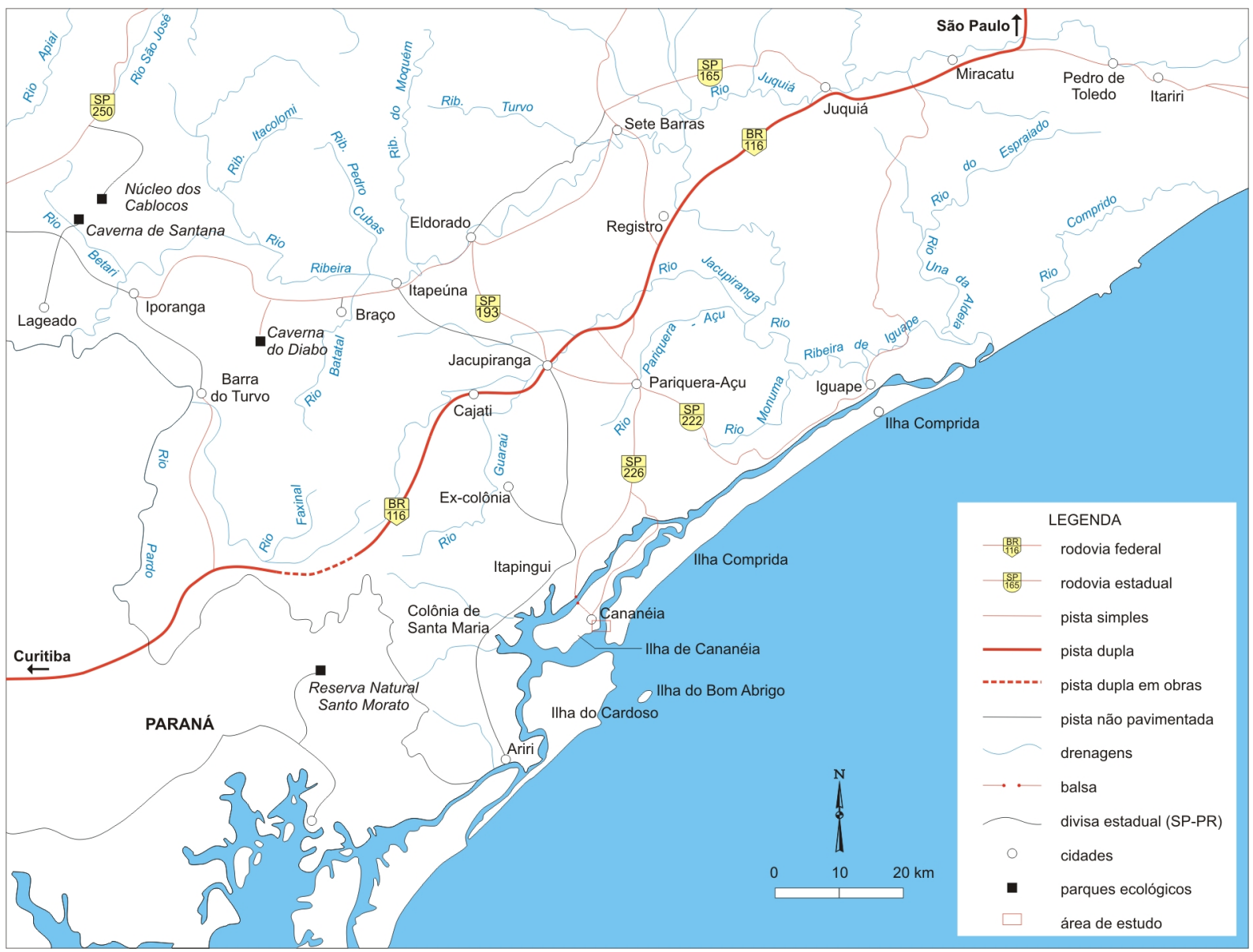

Figura 2. Mapa de localização com as vias de acesso à área de estudo. Extraído e modificado do Guia 4 Rodas 2003. 


\section{MÉTODOS DE TRABALHO}

\subsection{Atividades de campo}

Para as atividades de campo, foram empregados mapas topográficos na escala aproximada de 1:5.000 e 1:7.500, que permitiram a locação dos pontos examinados, o registro das observações geológicas e a correspondente coleta de amostras representativas dos corpos. Os trabalhos de campo tiveram início em fevereiro de 2000 com o Prof. Cláudio Riccomini; nas etapas seguintes, contaram com a participação dos Profs. Celso de Barros Gomes, Victor Velázquez Fernandez e da então pós-graduanda lede Terezinha Zolinger. Junto à região costeira, recorreu-se a uma pequena lancha pertencente à unidade básica de Cananéia do Instituto Oceanográfico da USP, como forma de facilitar o acesso aos matacões, que constituem a feição dominante por toda a orla do lado do canal.

\subsection{Petrografia}

Um total de 47 amostras representativas das alcalinas de Cananéia foi examinado e agrupado com base nas suas características macroscópicas (textura, granulação e mineralogia). Para cada grupo petrográfico, foram selecionados os tipos mais significativos e, ao final, confeccionadas 40 lâminas delgadas para fins de estudos microscópicos preliminares. Desse total, 36 foram objeto de trabalhos de microscopia petrográfica de detalhe, empregando-se aparelho de fabricação Olympus, modelo BX40, acoplado com luz refletida para análise de opacos.

Para as estimativas modais, com contagens de pontos superiores a 2.300 pontos, utilizou-se microscópio da marca Zeiss, modelo Axioplan, acoplado com charriot, e contador elétrico marca J. Smith \& Son. Um segundo microscópio da mesma marca e modelo, com charriot próprio e contador manual da marca Clay-Adams, foi também usado para idêntico propósito.

O objetivo nessa etapa de trabalho foi reconhecer as feições ópticas e os diferentes aspectos texturais exibidos pelos minerais, recorrendo-se, para tanto, aos manuais de referência de Tröger (1979), Williams et al. (1982), Bard (1986), Mackenzie et al. (1993) e Deer et al. (1992). Para os estudos descritivos e de classificação dos tipos petrográficos, foram empregados os trabalhos de Streckeisen (1976) e Gillespie e Styles (1997).

As fotomicrografias foram obtidas com auxílio de estereomicroscópio modelo SZH10 e microscópio modelo BX50, ambos da marca Olympus, acoplados com objetivas de aumento de 2,5 a 100 X e câmara fotográfica Olympus.

\subsection{Preparação das amostras}

Esta programação foi desenvolvida no Laboratório de Tratamento de Amostras (LTA) do Departamento de Mineralogia e Geotectônica do Instituto de Geociências. Os trabalhos visando à determinação da química global e isotópica das rochas envolveram a fragmentação do material com prensa, britador de mandíbulas e moagem com moinho de anéis, e sua posterior micronização por meio do Micronising Mill, tipo H2A.

Com vistas à determinação da idade radiométrica pelo método $\mathrm{Rb} / \mathrm{Sr}$, as amostras foram trabalhadas em três frações granulométricas distintas: 60 mesh $(0,25 \mathrm{~mm})$ para a preparação de pó para análise de rocha total; entre 60 e 80 mesh $(0,25$ e 0,18 mm) e 100 mesh $(0,15 \mathrm{~mm})$, respectivamente, para a obtenção de concentrados minerais de biotita, feldspato alcalino e 
clinopiroxênio+anfibólio. Para a concentração desses minerais, foram empregadas também técnicas complementares, como o separador eletromagnético Frantz e a mesa vibratória.

Para a determinação de idade pelo método Ar/Ar, foram selecionados grãos de biotita, com dimensões entre 0,2 a 1,6 mm, procedentes de quatro amostras distintas.

\subsection{Geoquímica}

\subsubsection{Análise química de minerais}

Das 36 amostras escolhidas previamente, 21 foram escolhidas para programação analítica com a microssonda. O estudo microscópico, que levou em consideração as características ópticas das fases minerais de interesse (p.e. presença de zoneamento, lamelas de exsolução, corrosão, inclusões, etc.), foi de grande importância para a seleção prévia dos pontos a serem objeto de análise.

As determinações foram efetuadas no Laboratório de Microssonda do Instituto de Geociências, empregando-se instrumental de fabricação Jeol, modelo JXA-8600, equipado com cinco espectrômetros acoplados com os seguintes pares de cristais: TAP/STE, TAP/PET, LIF/PET, PET/LIF e LIF/PET. O equipamento encontra-se automatizado com um sistema Voyager 3.6.1 da Noran Instruments. As determinações foram feitas em secções delgadas polidas, metalizadas a vácuo com uma película de carbono ( $25 \mathrm{~nm}$ ) em um operador Auto 206 de fabricação Edwards.

As condições analíticas de rotina adotadas nos trabalhos foram de $15 \mathrm{kV}$ para o potencial de aceleração e de $20 \pm 0,1 \mathrm{n} \AA$ para a corrente do feixe eletrônico. O diâmetro do feixe variou entre 5 a 10 $\mu \mathrm{m}$ para os feldspatos e entre 1 e $5 \mu \mathrm{m}$ para as fases opacas; para os minerais máficos foi de $5 \mu \mathrm{m}$. O tempo máximo de integração das contagens foi de 20 " para a maioria dos elementos, de 10 " para os mais voláteis $(\mathrm{Na}, \mathrm{K}, \mathrm{F}, \mathrm{Cl})$ e de 30 a 50" para os menores e traços. As correções para o efeito matriz (número atômico, absorção de massa e fluorescência secundária) foram conduzidas com o programa de uso interno do laboratório (Proza). Os erros totais máximos estimados para os resultados são de 1 a $2 \%$ para os elementos maiores, $5 \%$ para os menores e superiores a $10 \%$ para os traços (>1\% em peso do elemento).

A exatidão dos resultados obtidos, que varia com a concentração do determinado elemento presente em cada fase mineral investigada, aponta para erros em torno de $3 \%$ para os elementos maiores e $5 \%$ para os menores. Quanto à reprodutibilidade (precisão), refletindo por excelência as condições operacionais, os erros são de aproximadamente $1 \%$.

Uma técnica muito empregada na rotina do laboratório consiste na marcação prévia das coordenadas dos pontos de interesse analítico na secção. Isto é feito num microscópio Zeiss acoplado com platina eletrônica Zeiss Standard, de modo a facilitar o trabalho de localização dos pontos.

Com objetivo de avaliar o grau de homogeneidade do mineral, foram realizadas rotineiramente leituras de pontos nas bordas e nos centros dos cristais, sendo os resultados apresentados na forma de tabelas e diagramas.

As principais fases minerais investigadas foram feldspatos, clinopiroxênios, anfibólios, biotitas e olivinas, além dos acessórios opacos e apatita. No total, foram analisados 160 pontos em feldspatos, 82 em clinopiroxênios, 121 em anfibólios, 55 em biotitas, 9 em olivinas, 144 em opacos (98 em ilmenitas e 46 em titanomagnetitas) e 64 em apatitas, visando à caracterização de possíveis variações composicionais presentes em cada um desses minerais para os elementos maiores, menores e traços. 


\subsubsection{Análise química de rochas}

Trinta e seis amostras foram objeto de determinação da composição química global e 11 da isotópica, sendo elas provenientes tanto do Morro de São João como do Morrete.

A dosagem dos elementos se deu por fluorescência de raios $X$ e teve lugar nos laboratórios do Departamento de Ciências da Terra da Universidade de Trieste, Itália, empregando-se pastilhas prensadas e equipamento de fabricação Philips, modelo PW-1400. A exatidão dos resultados é, respectivamente, superior a $2 \%$ e $10 \%$ para os elementos maiores e menores, e a metodologia utilizada foi a descrita em Bellieni et al. (1983).

Do total acima de amostras, 13 delas foram também analisadas para os Elementos Terras Raras. O trabalho foi realizado pelo Dr. Paolo Censi no Laboratório do Instituto de Mineralogia, Petrologia e Geoquímica da Universidade de Palermo, Itália, empregando-se metodologia preconizada por Casetta et al. (1990).

\subsection{Tratamentos dos dados}

Os dados de química global e mineral são apresentados na forma de porcentagem em peso (\%) dos óxidos, bem como expressos em proporções catiônicas, fórmulas estruturais, componentes moleculares ou mesmo diagramas de variação química, usando-se para este último propósito os programas MINPET 2.02 (Richard, 1995), Corew Draw ${ }^{\circledR}$, Microsoft Word ${ }^{\circledR}$ e Excel ${ }^{\circledR}$ (Office 2000) e Isoplot/Ex (Ludwig, 1999).

O cálculo da fórmula estrutural seguiu as recomendações de Deer et al. (1992), sendo os feldspatos calculados na base de 32 átomos de oxigênio; os clinopiroxênios de 6 átomos de oxigênio; os anfibólios de 24 átomos de oxigênio, assumindo-se para a estimativa da $\mathrm{H}_{2} \mathrm{O}$ presente $(\mathrm{OH}, \mathrm{F}$, $\mathrm{Cl})=2,0$ a.f.u. (átomos por fórmula unitária); as biotitas de 22 átomos de oxigênio, assumindo-se para a estimativa da $\mathrm{H}_{2} \mathrm{O}$ presente $(\mathrm{OH}, \mathrm{F}, \mathrm{Cl})=4,0$ (a.f.u.); as olivinas de 4 átomos de oxigênio; as ilmenitas de 6 átomos de oxigênio; as titanomagnetitas de 32 átomos de oxigênio; já as apatitas foram calculadas na base em 26 átomos de oxigênio, assumindo-se $(\mathrm{OH}, \mathrm{F}, \mathrm{Cl})=2,0$ (a.f.u.).

Assumiu-se também que o Fe nas olivinas encontra-se na forma de $\mathrm{Fe}^{2+}$; nas biotitas, ele se apresenta como $\mathrm{Fe}^{2+}$ e $\mathrm{Fe}^{3+}$. A proporção estimada para completar a deficiência no sítio tetraédrico desses últimos minerais é atribuída ao $\mathrm{Fe}^{3+}$, com o restante do $\mathrm{Fe}$ calculado como $\mathrm{Fe}^{2+}$. Nos feldspatos, o $\mathrm{Fe}$ presente foi assumido como sendo $\mathrm{Fe}^{3+}$. Para os clinopiroxênios, a proporção $\mathrm{Fe}^{3+} / \mathrm{Fe}^{2+}$ foi calculada a partir da fórmula de Droop (1987), definida por $\mathrm{F}=2 \mathrm{X}(1-\mathrm{T} / \mathrm{S})$, onde $\mathrm{F}$ é o número de íons $\mathrm{Fe}^{3+}$ presentes por $\mathrm{X}$ átomos de oxigênio na fórmula do mineral; $T$ é o número ideal de cátions por unidade de fórmula e $S$ o total de cátions observados por $X$ átomos de oxigênio. Esse cálculo somente pode ser empregado obedecidas às seguintes premissas: presença de ferro como único elemento exibindo valências diferentes, presença de oxigênio como único ânion e inexistência de sítios estruturais vagos ou com proporção de elemento não analisado. Nos anfibólios, a estimativa de $\mathrm{Fe}^{2+} / \mathrm{Fe}^{3+}$ foi feita respeitando-se os limites estequiométricos, e seguindo os procedimentos sugeridos por Schumacher (1997). A quantidade de $\mathrm{Fe}^{3+}$ em análises de anfibólios por microssonda é baseada nos limites estequiométricos de uma distribuição ideal que considera a soma das cargas positivas e negativas igual a 46. Para os opacos (ilmenita e titanomagnetita), a distribuição de $\mathrm{Fe}^{2+} \mathrm{e}$ $\mathrm{Fe}^{3+}$ se deu em conformidade com o método de Carmichael (1974).

Para o cálculo da fórmula química geral dos clinopiroxênios foram seguidas as recomendações 
de Morimoto (1990). Essa fórmula é expressa como $M 2 \mathrm{M}_{2} \mathrm{~T}_{2} \mathrm{O}_{6}$, onde $\mathrm{M} 2$ corresponde aos cátions de coordenação octaédrica, geralmente distorcida; M1 aos cátions de coordenação octaédrica regular; e T aos cátions de coordenação tetraédrica. A distribuição dos componentes moleculares segundo os membros finais obedeceu à metodologia proposta por Cawthorn e Collerson (1974), em que eles são calculados na seguinte ordem: Jd, jadeíta $\left(\mathrm{NaAlSi}_{2} \mathrm{O}_{6}\right)$; $\mathrm{Ae}$, egirina $\left(\mathrm{Na}, \mathrm{K}, \mathrm{Fe}^{3+}, \mathrm{Cr}_{,}, \mathrm{Si}_{2} \mathrm{O}_{6}\right) ; \mathrm{Es}$, essenita $\left(\mathrm{CaFe}^{3+} \mathrm{Al}^{\mathrm{IV}} \mathrm{SiO}_{6}\right)$; CaTiTS, cálcio-titano-tschermakita $\left(\mathrm{CaAl}{ }^{\mathrm{VI}} \mathrm{Al}^{\mathrm{IV}} \mathrm{SiO}_{6}\right)$; CaTS, cálcio-tschermakita, Wo, wollastonita $\left(\mathrm{Ca}_{2} \mathrm{Si}_{2} \mathrm{O}_{6}\right)$; En, enstatita $\left(\mathrm{Mg}_{2} \mathrm{Si}_{2} \mathrm{O}_{6}\right)$ e $\mathrm{Fs}$, ferrossilita $\left(\mathrm{Fe}^{2+}{ }_{2} \mathrm{Si}_{2} \mathrm{O}_{6}\right)$. Alguns autores questionam o cálculo do componente Jd antes de Ae, que resulta na impossibilidade da coexistência das moléculas Ae e CaTS.

Essa classificação segue as recomendações da International Mineralogical Association (IMA) (Morimoto, 1990), inclusive quanto ao emprego dos adjetivos modificadores para expressar as quantidades de cátions pouco comuns nesses minerais.

As composições representativas dos anfibólios foram calculadas com base nas recomendações de Leake (1997), respeitando a seguinte fórmula teórica: $\mathrm{A}_{0-1} \mathrm{~B}_{2} \mathrm{C}_{5} \mathrm{~T}_{8} \mathrm{O}_{22}(\mathrm{OH}, \mathrm{F}, \mathrm{Cl})_{2}$, onde:

A: 0 a 1 sítio por fórmula unitária;

B: 2 sítios M4 por fórmula unitária;

C: 5 sítios compostos por 2 M1, 2 M2 e 1 M3 por fórmula unitária;

T: 8 sítios em 2 grupos de 4;

$(\mathrm{OH}, \mathrm{F}, \mathrm{Cl}): 2$ sítios por fórmula unitária.

Tendo em vista que a quantidade de $\mathrm{H}_{2} \mathrm{O}$ foi estimada assumindo-se o valor de $(\mathrm{OH}, \mathrm{F}, \mathrm{Cl})=2,00$ a.f.u., o cálculo da fórmula estrutural se deu na base de $24(\mathrm{O}, \mathrm{OH}, \mathrm{F}, \mathrm{Cl})$.

Dessa forma, os limites de Si $\leq 8$ e $\Sigma$ até Ca $\leq 15$ e $\Sigma$ até $K \leq 16$ permitem chegar a um valor mínimo para a estimativa de $\mathrm{Fe}^{3+}$, enquanto que os limites $\Sigma$ até $\mathrm{Al} \geq 8$, de $\mathrm{Mn} \geq 13$ e $\Sigma$ até $\mathrm{Na} \geq 15$ possibilitam determinar o valor máximo de $\mathrm{Fe}^{3+}$. No presente trabalho, optou-se pelo emprego do método em que os cátions são ajustados num total de 13, excluindo-se $\mathrm{Ca}$, Na e K.

Os procedimentos para a distribuição catiônica das biotitas seguiram as recomendações da IMA (Rieder, 1999). Sendo assim, a fórmula geral para esses minerais é expressa como: $I M_{2-3} \square_{0-1} T_{4} O_{11} A_{2}$, onde I é ocupado por $\mathrm{K}, \mathrm{Na}$ ou $\mathrm{Ca}$, podendo conter também $\mathrm{Ba}, \mathrm{Rb}, \mathrm{Cs}, \mathrm{NH}_{4} ; \mathrm{M}$ é preenchido por $\mathrm{Li}$, $\mathrm{Fe}^{2+}$ ou $\mathrm{Fe}^{3+}, \mathrm{Mg}, \mathrm{Al}$ ou Ti, ou ainda $\mathrm{Mn}^{2+}$ ou $\mathrm{Mn}^{3+}, \mathrm{Zn}, \mathrm{Cr}$ e V; $\square$ é uma vacância; T é ocupado por $\mathrm{Si}$, $\mathrm{Al}$ ou $\mathrm{Fe}^{3+}$, e ainda por Be ou B; A é preenchido por $\mathrm{OH}, \mathrm{F}, \mathrm{Cl}, \mathrm{O}$ (oxi-micas) e $\mathrm{S}$.

Como informado acima, a fórmula estrutural das biotitas foi calculada na base de 22 cargas positivas (equivalente a 11 oxigênios) e a $\mathrm{H}_{2} \mathrm{O}$ estimada considerando 4,00 a.f.u. de $\mathrm{OH}, \mathrm{F}, \mathrm{Cl}, \mathrm{O}, \mathrm{S}$.

\subsection{Geocronologia e dados de isotopia}

De um total de 11 amostras selecionadas, 7 foram preparadas para análise pelo método $\mathrm{Rb} / \mathrm{Sr} \mathrm{e}$ $\mathrm{Sm} / \mathrm{Nd}$, e 4 pelo método $\mathrm{Ar} / \mathrm{Ar}$, visando à obtenção da idade radiométrica das rochas do maciço.

\subsubsection{Método $\mathrm{Rb} / \mathrm{Sr}$}

Os dados de Rb/Sr foram obtidos no Laboratório de Geocronologia da Universidade de Brasília, sob a coordenação do Prof. Márcio Pimentel. Os procedimentos de preparação incluíram ataque químico e separação dos elementos em coluna de troca iônica. A determinação das razões isotópicas foi feita por meio de espectrômetro de massa de marca Finnigan, modelo MAT-262, com sete 
coletores e contador de íons, e os cálculos efetuados de acordo com Faure (1986) e DePaolo (1988).

As constantes empregadas para as razões isotópicas e das idades foram aquelas indicadas por Steiger e Jäger (1977): ${ }^{86} \mathrm{Sr} /{ }^{87} \mathrm{Sr}=0,1194 ; \quad \mathrm{LRb}=1,42 \times 10^{-11} / \mathrm{ano} ;{ }^{87} \mathrm{Rb} /{ }^{86} \mathrm{Sr}=\mathrm{Rb} / \mathrm{Sr}{ }^{\star} 2,89362$. Nos diagramas isocrônicos, calculou-se a variância média quadrática ponderada MSWD, que fornece o grau de colinearidade das amostras analisadas. Os erros foram estimados levando-se em consideração o desvio dos pontos em relação à melhor reta calculada. As idades modelos, assim como os valores para $\varepsilon S r$, foram calculados com relação ao manto empobrecido (DM), seguindo os procedimentos propostos por DePaolo (1988).

\subsubsection{Método $\mathrm{Sm} / \mathrm{Nd}$}

As análises foram executadas no Centro de Pesquisas Geocronológicas (CPGeo) do Instituto de Geociências, obedecendo a rotina descrita nos trabalhos de Sato (1998), Kawashita et al. (1991) e Sato et al. (1995), que incluem dosagens de spikes nas amostras, digestão química, separação dos elementos, eluição e preparação e calibração de colunas de troca catiônica, deposição de Sm e Nd, medidas espectrométricas e cálculos de diluição e concentração isotópica. A determinação da concentração de $\mathrm{Sm}$ e $\mathrm{Nd}$ e de suas razões isotópicas foi feita por meio de espectrômetro de massa de fonte sólida marca Finnigan, modelo MAT-262.

As idades modelo e também o parâmetro $\varepsilon N d$ foram calculados em relação ao manto empobrecido (DM), em conformidade com as recomendações de DePaolo (1988). As constantes empregadas para o cálculo das razões isotópicas foram as seguintes: ${ }^{143} \mathrm{Nd} /{ }^{144} \mathrm{Nd}=0,513114$ (CHUR); $\lambda_{\mathrm{Sm}}=6,54 \times 10^{-12}$ ano; ${ }^{147} \mathrm{Sm} /{ }^{144} \mathrm{Nd}=\left(0,6047^{\star} \mathrm{Sm}\right) / \mathrm{Nd}$.

\subsubsection{Método $\mathrm{Ar} / \mathrm{Ar}$}

Os dados de $\mathrm{Ar} / \mathrm{Ar}$ foram também obtidos no CPGeo, seguindo rotina preconizada por Vasconcelos et al. (2002). Com a finalidade de evitar contaminação, os grãos extraídos de biotita foram lavados com água e acetona, e secos sob luz infravermelha.

Para as determinações analíticas, os concentrados de biotita foram montados em disco de alumínio, adicionados de spike (sanidina da localidade de Fish Canyon, de idade conhecida) e bombardeados, durante quarenta horas, no reator nuclear de fluxo integrado de nêutrons (IEA-R1) do Instituto de Pesquisas Nucleares.

Após a fase de radiação, três grãos de cada amostra foram escolhidos para a extração do argônio pelo método de fusão de etapas. As análises foram executadas por meio de aquecimento a laser em sistema de ultra-alto vácuo, acoplado a um espectrômetro de massa MAP-215-50, do CPGeo.

Para a interpretação dos dados foi utilizado o conceito de temperatura de fechamento, que representa o momento em que a velocidade de difusão do argônio no sistema torna-se nula. A temperatura de fechamento considerada para os grãos de biotita foi entre 300 e $350^{\circ} \mathrm{C}$ (Faure, 1986; Villa, 1998). 


\section{GEOLOGIA REGIONAL}

A área investigada pertence à Planície Costeira Cananéia-Iguape (Fig. 3), litoral sul do Estado de São Paulo, e acha-se coberta em grande parte por sedimentos quaternários arenosos, homogêneos, compostos de areias finas muito bem selecionadas, que variam de continentais, na base, a de influência marinha, no topo. Esses depósitos, que também formam um pequeno conjunto de ilhas, estão assentados sobre um embasamento cristalino de idade pré-cambriana relacionado ao Grupo Açungui (Relatório Projeto Sudelpa 1975 apud Tessler, 1982). Esta unidade consiste basicamente em rochas metamórficas (filitos, mica xistos, gnaisses) recortadas por intrusões graníticas. Na região de Cananéia, esse embasamento aparece exposto, no continente, ao longo da estrada Pariquera-AçuCananéia, nas imediações da ponte do rio Aroeira, que cruza o canal de Cubatão; na parte oceânica, junto às ilhas do Bom Abrigo e Cardoso, esta última um pouco mais distante da cidade de Cananéia. Cortando todo esse conjunto, afloram rochas alcalinas mesozóicas, tendo como principais ocorrências o Morro de São João (Ilha de Cananéia) e Morrete (llha Comprida). Presentemente, essas duas ocorrências estão separadas pelo "Mar de Cananéia" (Fig. 3A). Essas intrusões são interpretadas como associadas tectonicamente ao Alinhamento de Guapiara, pertencente à feição estrutural do Arco de Ponta Grossa, e, como conseqüência, enquadradas na província alcalina homônima. Mais recentemente, Riccomini et al. (2005) propuseram a sua inclusão na Província da Serra do Mar, mais precisamente junto ao seu segmento central, situado dentro da área geográfica do Arco de Ponta Grossa (Fig. 1).

O Arco de Ponta Grossa é uma grande estrutura soerguida com orientação principal NW, na qual se distinguem quatro grandes falhamentos desenvolvidos subparalelamente a essa direção e associados a uma única fase tectônica ocorrida nos primórdios do Cretáceo (Ferreira, 1982a, b; Almeida, 1983). Essa atividade tectônica levou à formação de fraturamentos e falhamentos normais, bem como de arqueamentos regionais e horsts dômicos (Vieira, 1973). Juntamente com o surgimento dos padrões de fraturamento, originaram-se as vias de acesso para o magmatismo basáltico, que teve seu clímax de intensidade em torno de $130 \mathrm{Ma}$ (Piccirillo e Melfi, 1988). Levantamentos aeromagnetométricos realizados (Ferreira, 1982a, b) possibilitaram reconhecer a importância desses falhamentos.

Na descrição de Ferreira (1982a), o Alinhamento de Guapiara demarcaria o limite norte do Arco de Ponta Grossa. Este se estende por, pelo menos, $600 \mathrm{~km}$ e apresenta largura variável de 20 a 100 $\mathrm{km}$, além de atingir a região litorânea na altura da cidade de lguape, em São Paulo. Na sua porção mais interna, são definidos dois alinhamentos subparalelos, São Jerônimo-Curiúva, junto ao lado norte, e Rio Alonzo, junto à parte sul. Delimitando a parte sul da estrutura, tem-se o Alinhamento do Rio Piquiri (Fig. 1). Almeida (1982), além de reconhecer os quatro alinhamentos principais, propôs ainda, com base em levantamentos executados por sensoriamento remoto, um quinto, o Alinhamento de Ivaí, marcando o limite sul da grande estrutura.

No Arco de Ponta Grossa estão localizados diversos corpos alcalinos de variadas formas e dimensões, com o maior deles correspondendo ao complexo de Jacupiranga $\left(65 \mathrm{~km}^{2}\right)$. Os dados geológicos e geofísicos obtidos por vários autores (Almeida, 1983 entre outros) evidenciam que as intrusões próximas à região central dessa importante feição estrutural estão intimamente condicionadas às grandes zonas de falhas e fraturamentos tracionais de orientação NW, que também serviram de acesso ao magma toleítico. 


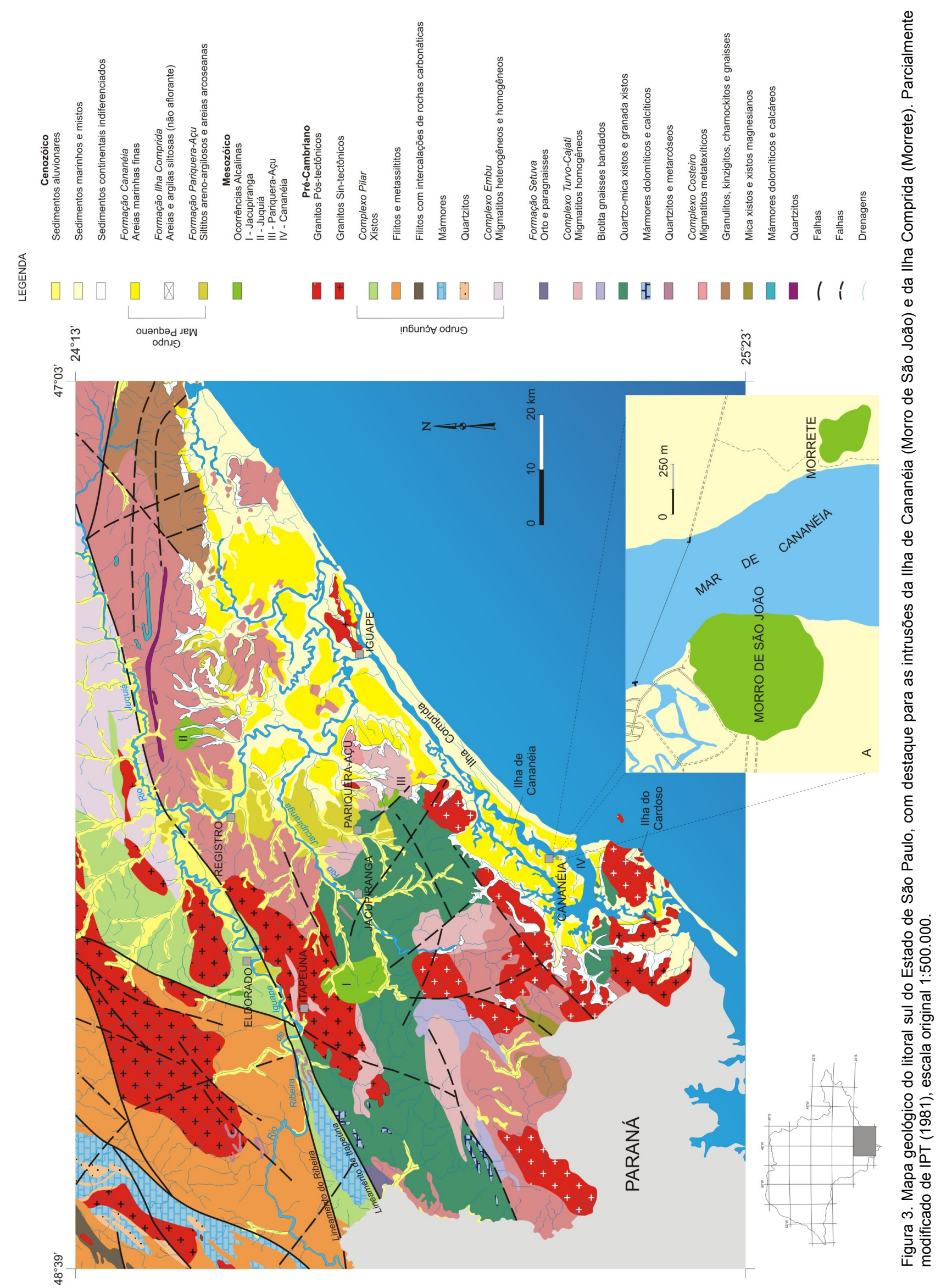




\subsection{Grupo Açungui}

O embasamento da região investigada é formado pelo Grupo Açungui, que se constitui na mais extensa faixa unidade do Pré-Cambriano paulista. Sua forma é alongada e se estende pelos estados do Paraná até o do Rio de Janeiro e Espírito Santo. No Estado de São Paulo, está presente na sua porção SE e encontra-se delimitado, ao sul, pela Falha de Cubatão e Lineamento de Além Paraíba e, ao norte, pelas falhas de Taxaquara, Monteiro Lobato e Jundiuvira (Hasui et al., 1981).

O Grupo Açungui foi dividido em dois conjuntos litológicos (cf. Hasui e Sadowski, 1976), a fim de se evitar a conotação de um empilhamento temporal. Assim, esses autores distinguiram o conjunto de rochas metassedimentares como Complexo Pilar, e o de rochas migmatíticas e gnaisses migmatíticos como Complexo Embu.

O Complexo Pilar é dominantemente formado de rochas xistosas (quartzo-mica xistos, biotitaquartzo xistos, granada-biotita xistos, xistos grafitosos, clorita xistos, sericita-biotita xistos, talco xistos, magnetita xistos e calcoxistos) com intercalações de filitos, metassiltitos, quartzitos, mármores e calcoxistos (Hasui et al., 1981). Essas rochas afloram na região de São Paulo, Moji das Cruzes, Cubatão e Embu-Guaçu, em áreas adjacentes aos falhamentos de Jundiuvira, Taxaquara, Monteiro Lobato e Cubatão, bem como em manchas isoladas em meio ao Complexo Embu, na porção leste do Estado de São Paulo (Hasui et al., 1981). Datações K/Ar indicam para essas rochas uma idade de $675 \pm 41 \mathrm{Ma}$ (Silva et al., 1981).

Por sua vez, o Complexo Embu é composto de rochas migmatíticas homogêneas oftálmicas, nebulíticas e facoidais (Hasui et al., 1981). Nota-se ainda a presença de núcleos paleossomáticos de dimensões variáveis (metabasitos irregulares) e também de natureza quartzítica e calcossilicática. Estudos radiométricos revelaram para elas uma idade em torno de 640 Ma (Schobbenhaus Filho, 1979 apud Hasui et al., 1981).

\subsection{Planície Costeira Cananéia-Iguape}

O litoral sul do Estado de São Paulo é coberto pela Planície Costeira Cananéia-Iguape (Foto 1), demarcada pela linha estrutural de Itatins, a NW do Complexo Cristalino da Serra do Mar, e pela Ilha do Cardoso, a SW (Suguio e Tessler, 1992).

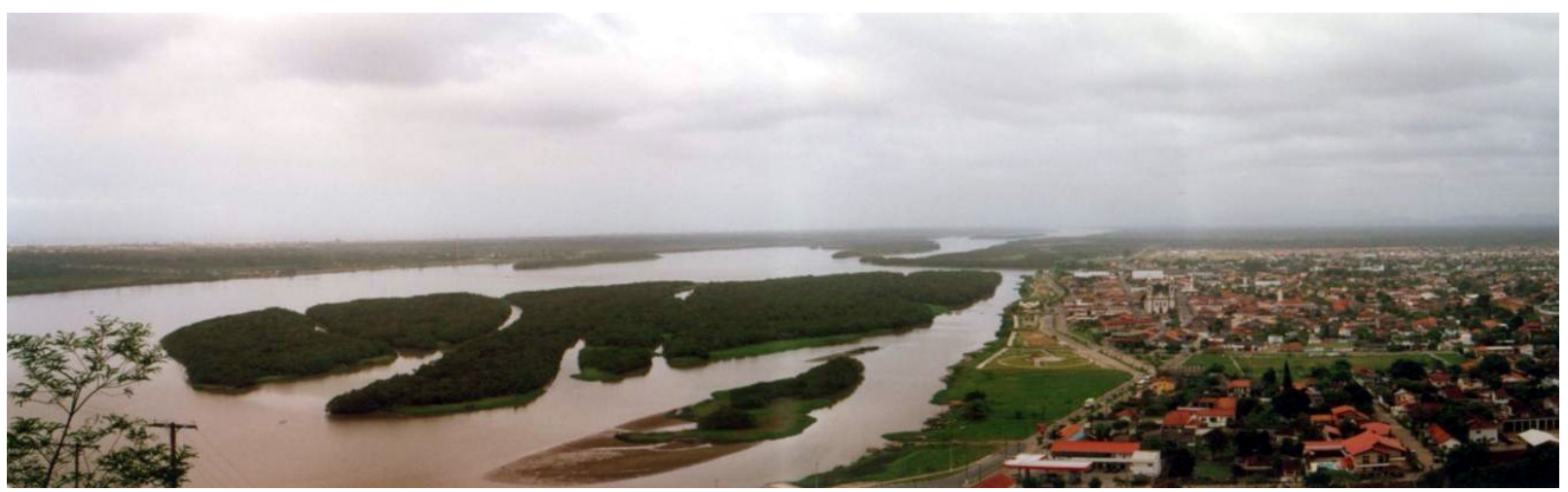

Foto 1. Vista parcial da Planície Costeira Cananéia-Iguape observada do Mirante do Cristo, no Morro de Iguape.

Ela possui a forma de um extenso arco, com aproximadamente $40 \mathrm{~km}$ de extensão e $130 \mathrm{~km}$ de largura, estendendo-se por uma área total de $2.500 \mathrm{~km}^{2}$ (cf. Suguio e Tessler, 1992) e acha-se delimitada por rochas do embasamento cristalino que avançam no oceano.

A hidrografia da região é composta por rios de alto gradiente, a montante, e muito suaves na sua 
foz, junto à planície. Estes últimos sofrem influências marinhas que podem se estender a alguns quilômetros da foz. A relação entre os rios e as oscilações das marés contribuiu para a formação dos ambientes de sedimentação atuais, para a influência da salinidade e para os processos hidrodinâmicos na região (Souza, 1995).

Com base nas interpretações granulométricas e mineralógicas e do conteúdo de fósseis em testemunhos de sondagens, executadas pelo antigo Instituto Geográfico e Geológico em 1971, a seqüência estratigráfica da planície foi estabelecida por Petri e Suguio $(1971,1973)$ e Suguio e Petri (1973), que subdividiram o pacote sedimentar em quatro seqüências.

A Seqüência I, denominada de Formação Pariquera-Açu (Silveira, 1950, 1952, apud Melo, 1990; Bigarella e Mousinho, 1965; Petri e Suguio, 1971, 1973; Suguio e Petri, 1973; Suguio e Martin, 1978; Poçano, 1981), reúne sedimentos continentais compostos por areias e areias conglomeráticas com níveis argilosos e dispostos na base de coluna sedimentar sobreposta ao embasamento. Sua espessura máxima chega a $118 \mathrm{~m}$ de profundidade (Souza, 1995). Estudos palinológicos revelaram uma idade pós-pliocênica e pré-holocênica, situada no limite plio-pleistoceno (Sundaram e Suguio, 1983).

A Formação Ilha Comprida, que corresponde às Seqüências II e III de Petri e Suguio (1971, 1973) e Suguio e Petri (1973), é composta de dois pacotes principais. O inferior (Seqüência II) é constituído por argilas sílticas ricas em diatomáceas e pobres em foraminíferos, com o ambiente deposicional associado a águas salobras, como sugerido pela presença de diatomáceas, e de natureza marinho transicional, devido aos raros foraminíferos. O superior (Seqüência III) é formado de areias sílticas com abundante presença de foraminíferos, confirmando, assim, a sua origem marinha. Segundo Petri e Suguio (1971), essa formação possui caráter de transgressão marinha. Datações de radiocarbono e correlações estratigráficas levaram Suguio e Petri (1973) a atribuir para o conjunto uma idade quaternária.

A Formação Cananéia, Seqüência IV de Petri e Suguio $(1971,1973)$ e de Suguio e Petri (1973), consiste essencialmente em areias finas bem selecionadas e friáveis (Fotos 2 e 3). Esta unidade possui pequena espessura, de 20 a $30 \mathrm{~m}$, e ampla distribuição na planície (Souza, 1995), com os sedimentos contribuindo para a formação de praias modernas e dunas, bem como do material de fundos de rios e lagos. A origem dessas areias é marinha, como indicado pela presença de tubos fósseis de idade quaternária.

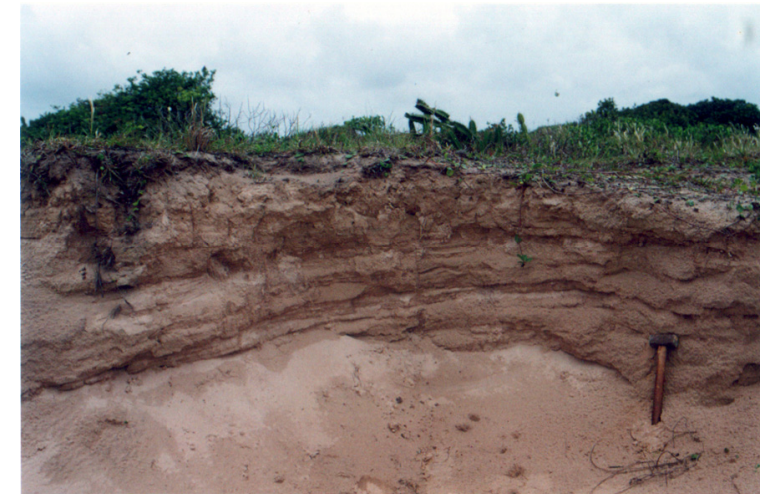

Foto 2. Depósito arenoso da Formação Cananéia aflorante na Ilha Comprida.

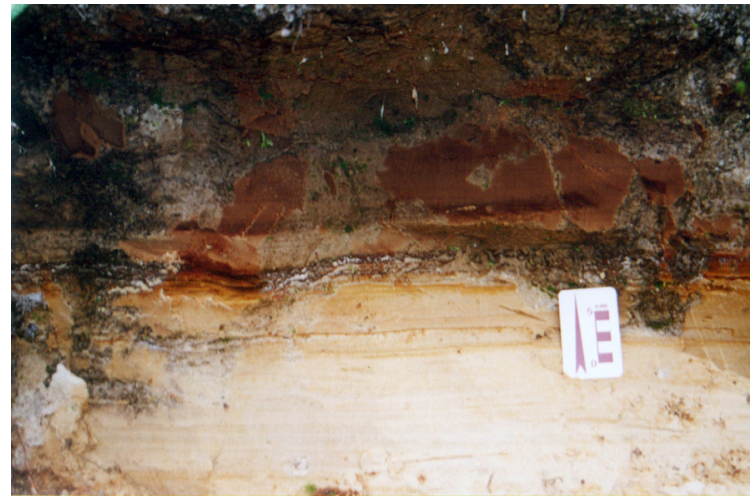

Foto 3. Depósito arenoso da Formação Cananéia localizado na Estrada do Quaternário, na llha de Cananéia. 
Suguio e Petri (1973), Bigarella e Mousinho (1965) e Melo (1990) correlacionaram a Seqüência I à Formação Pariquera-Açu, de origem continental. Suguio e Petri (1973) e Suguio e Martin (1978) redefiniram a Formação Cananéia, que passaria a englobar as Seqüências II e III e envolver todo o pacote de sedimentos transgressivos. Por outro lado, Poçano (1981) reuniu as quatro seqüências no Grupo Mar Pequeno, abrangendo as Formações Pariquera-Açu (origem continental basal), Ilha Comprida (intermediária) e Cananéia (marinha). Segundo Melo (1990), a Formação Pariquera-Açu representaria um episódio de sedimentação mais antigo com as Formações llha Comprida e Cananéia repousando sobre ela, uma vez que tratam de episódios recentes de transgressão e regressão distintos do anterior.

Quanto à sua origem, a Planície Costeira Cananéia-Iguape teria sido um golfo vinculado ao processo de recuo da Serra do Mar em direção ao interior, como proposto por Besnard (1950, apud Tessler, 1982) com base em evidências geomorfológicas. Por sua vez, Suguio e Martin (1978), Martin e Suguio (1978) e Suguio e Tessler (1992) elaboraram um modelo evolutivo a partir de correlações espaciais e temporais extraídas da estratigrafia local para o litoral entre a llha do Cardoso e o Morro da Juréia, que engloba a área de interesse deste trabalho. $O$ desenvolvimento proposto para essa porção da planície é dividido em cinco etapas: a principal marcada pela transgressão Cananéia; a segunda pela regressão e deposição de cordões litorâneos; a seguinte pela erosão parcial dos depósitos marinhos; a quarta pela transgressão Santos (Holoceno) e a última pela regressão em direção ao nível atual. Souza et al. (1996) propuseram para a evolução da planície um modelo de sistemas de falhas, comumente de comportamento normal, com basculamento de blocos para NW, relacionados com reativações cenozóicas e configurando o Gráben de Cananéia. 


\section{GEOLOGIA LOCAL}

As principais ocorrências de rochas ígneas de natureza alcalina e idade mesozóica que cortam o embasamento cristalino regional são as do Morro de São João (Foto 4), na porção meridional da llha de Cananéia, e do Morrete (Foto 5), na adjacente Ilha Comprida, distante aproximadamente $920 \mathrm{~m}$, a SE, da intrusão anterior (Fig. 4). Em realidade, essas ocorrências deveriam fazer parte de um corpo maior, agora seccionado pelo canal conhecido como "Mar de Cananéia" (Foto 6).

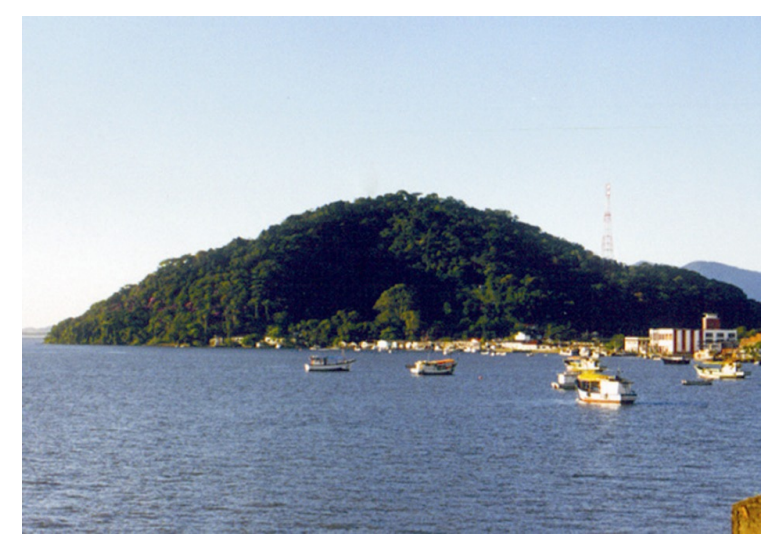

Foto 4. Vista geral do Morro de São João e do porto de Cananéia. Ao fundo, à direita, vê-se a llha do Cardoso, constituída basicamente por rochas pré-cambrianas.

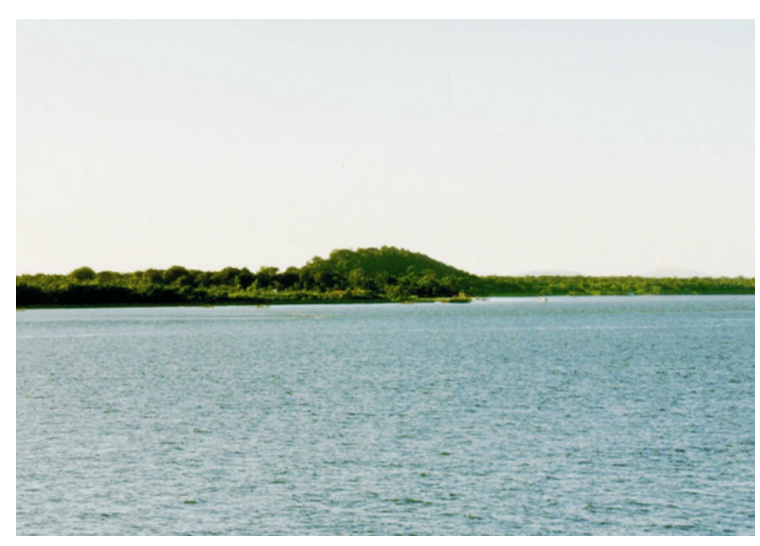

Foto 5. Vista geral do Morrete, com o pequeno arcadouro, ponto de embarque/desembarque do ferry-boat, ocupando o centro da fotografia.

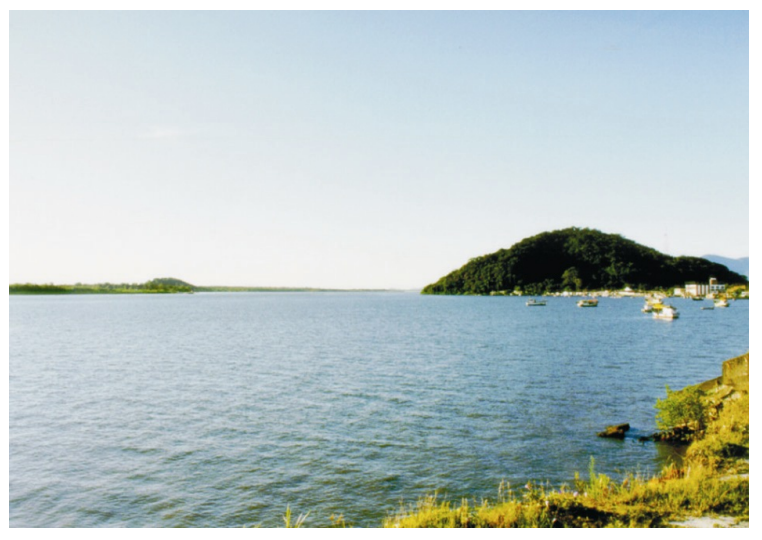

Foto 6. Vista do canal conhecido como "Mar de Cananéia", que separa as duas ocorrências alcalinas: Morro de São João, à direita; Morrete, à esquerda. Ao fundo, à direita da fotografia, aparece parte da llha do Cardoso.

O canal que separa as duas intrusões foi investigado por Suguio et al. (1987), por meio de perfilagens geofísicas, que comprovaram a existência da "Laje do Argolão", uma superfície de rocha contínua no canal lagunar interligando o Morro de São João (Ilha de Cananéia) com o do Morrete (Ilha Comprida).

A intrusão do Morro de São João corresponde a um stock de forma subcircular, cobrindo área de $1,8 \mathrm{~km}^{2}$. Seu eixo principal, orientado ligeiramente para NE, possui $800 \mathrm{~m}$ de comprimento, com o corpo alcalino atingindo a cota máxima de $137 \mathrm{~m}$. Ele encontra-se coberto por densa vegetação (Foto 7) e tem como principais elementos geográficos de delimitação, a E, o canal, e a W, uma estrada de terra que, circundando parcialmente o morro, leva à empresa de congelados Golfinho Azul. Os trabaIhos de amostragem foram efetuados junto à borda oriental do maciço, onde as rochas afloram comumente como matacões de dimensões métricas (Fotos 8 e 9), muitos deles exibindo esfoliação esferoidal (Foto 9). Na área costeira, os blocos estão mais expostos devido aos processos de 
abrasão (Foto 10), o mesmo não ocorrendo na região central, de acesso mais difícil e carente de exposições.

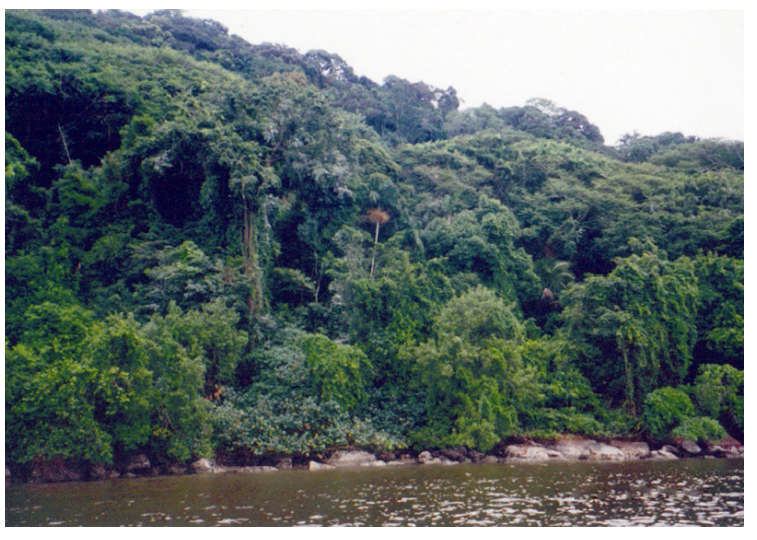

Foto 7. Detalhe da vegetação cerrada cobrindo o Morro de São João e que termina abruptamente nos blocos costeiros.

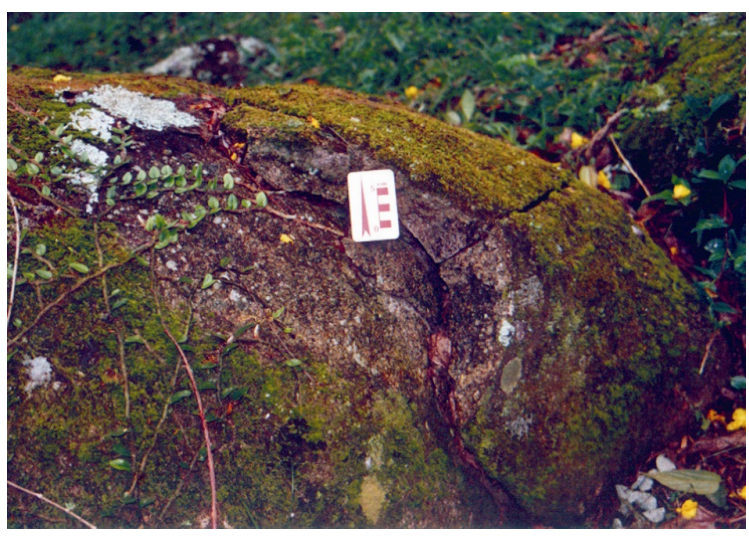

Foto 9. Bloco com alteração esferoidal e coberto por líquen.

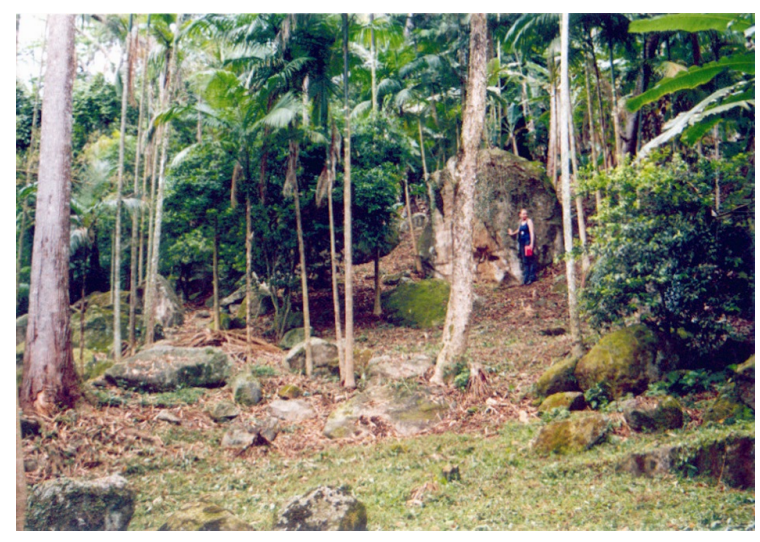

Foto 8. Matacões de dimensões métricas em uma clareira formada pela atividade de extração de palmito. Porção E do morro próxima à área costeira.

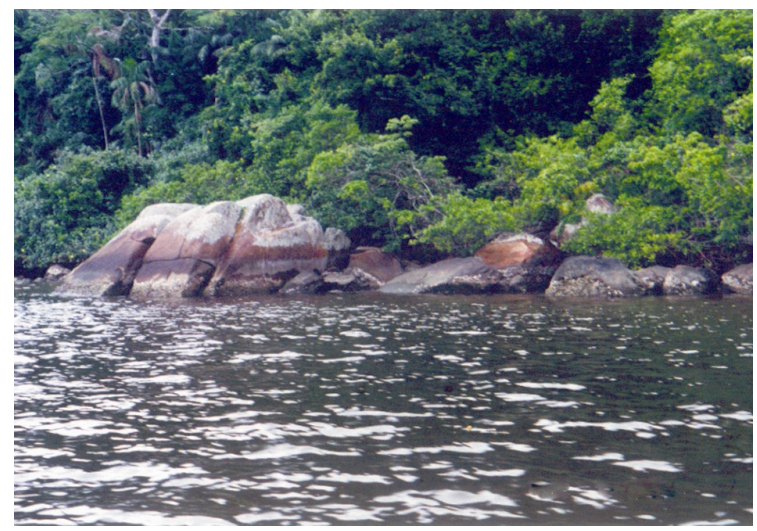

Foto 10. Matacões expostos ao longo da área costeira.

A intrusão é constituída predominantemente por rochas faneríticas de natureza sienítica, porém, variedades de granulação fina (microssienitos) (Fotos 11 e 12) ou afaníticas (traquitos) aparecem na forma de pequenos diques (Fotos 13 e 14) ou mesmo de veios de espessura centimétrica (Fotos $15 \mathrm{e}$ 16), em especial na região $E$ e NW do maciço.

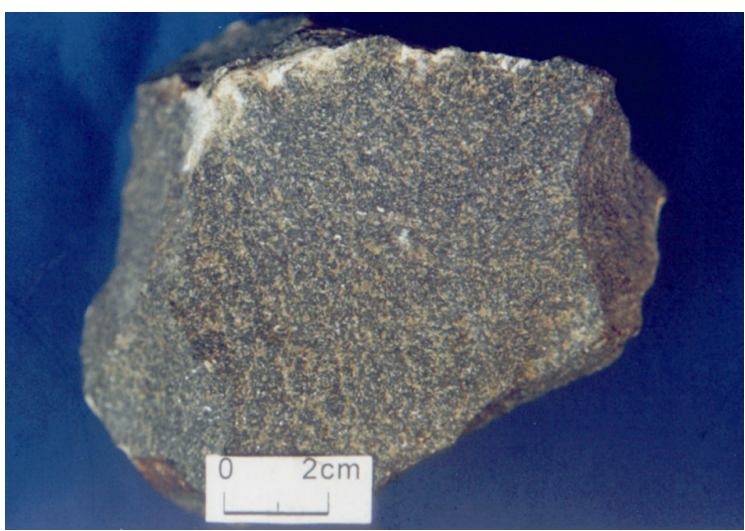

Foto 11. Amostra de granulação muito fina referente à amostra 19 (Morro de São João).

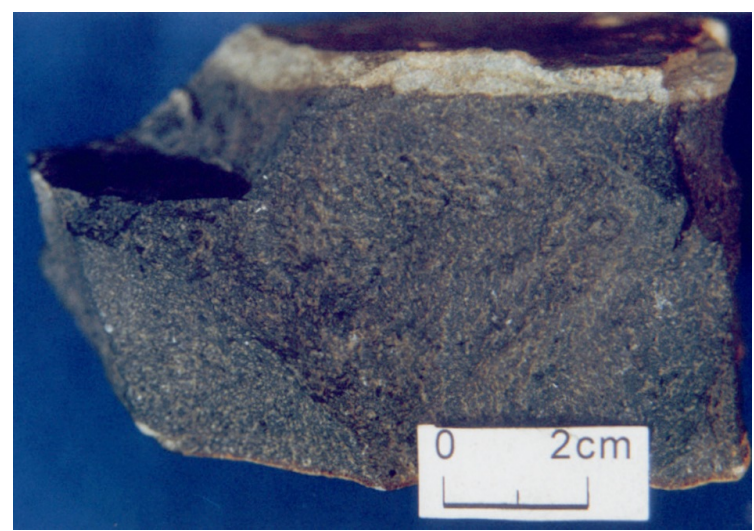

Foto 12. Amostra de granulação muito fina referente à amostra 9B (Morro de São João). 


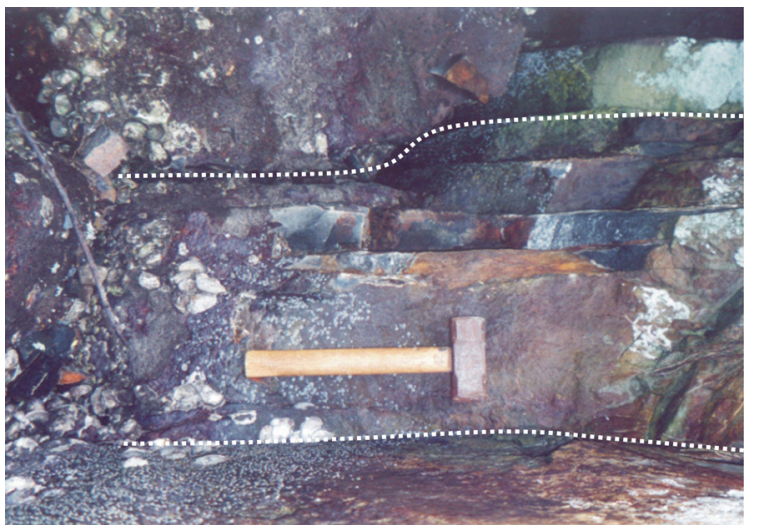

Foto 13. Dique de espessura decimétrica, constituído por rocha traquítica de coloração escura cortando a encaixante sienítica. Região costeira. Direção do dique: N40W/subvertical. Amostra 9B.

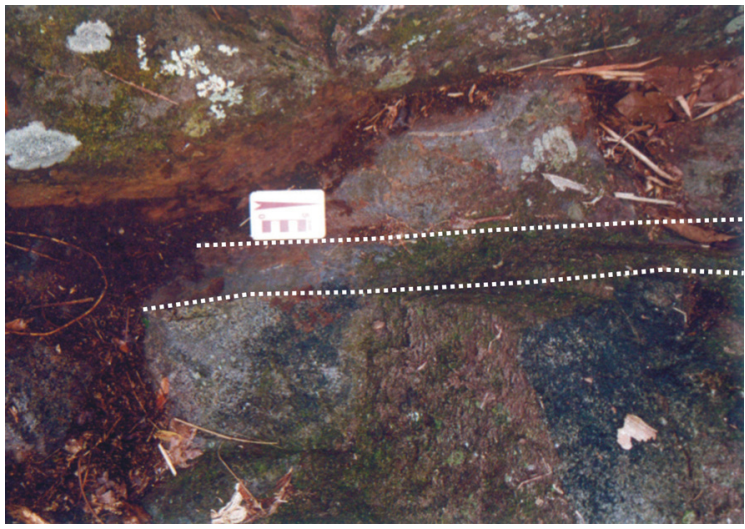

Foto 15. Veio centimétrico de rocha afanítica penetrando a encaixante sienítica aflorante próximo à área costeira. Direção do veio: N35W/subvertical. Amostra 12.

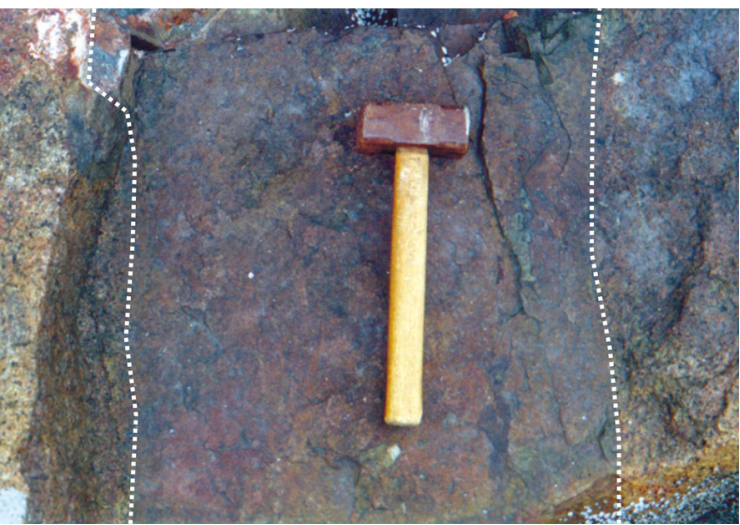

Foto 14. Dique traquítico penetrando a encaixante sienítica de coloração mais rosada. Região costeira, bloco deslocado. Amostra 9B.

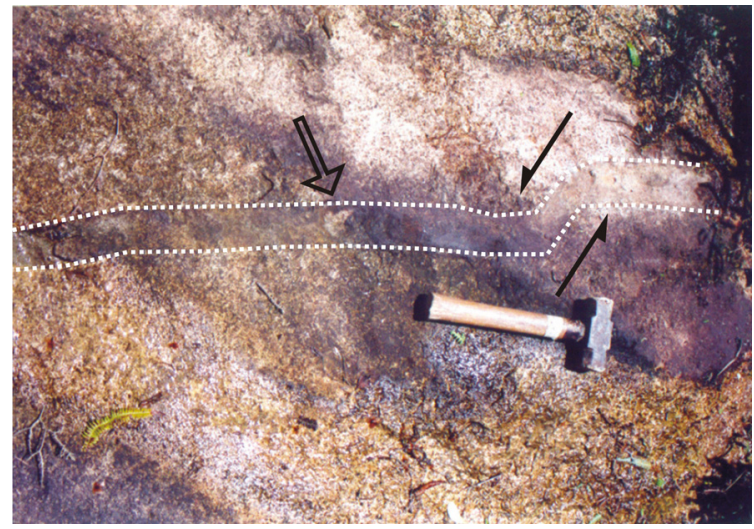

Foto 16. Mesmo veio da foto anterior.

Como observado por Freitas (1947), o contato dos diques é muito irregular com interpenetração de uma rocha na outra, ora reconhecendo-se fragmentos de sienito dentro do tipo litológico mais fino (Foto 16), ora a presença de inclusões deste último na encaixante sienítica (Fotos 17, 18 e 19), sugerindo, assim, a existência de mais de uma geração de diques.

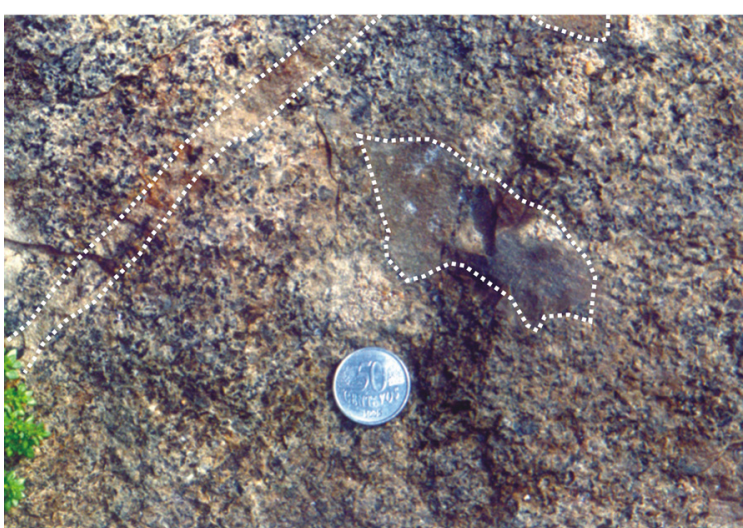

Foto 17. Veio e fragmentos de rocha afanítica, de coloração acinzentada, no interior da massa sienítica.

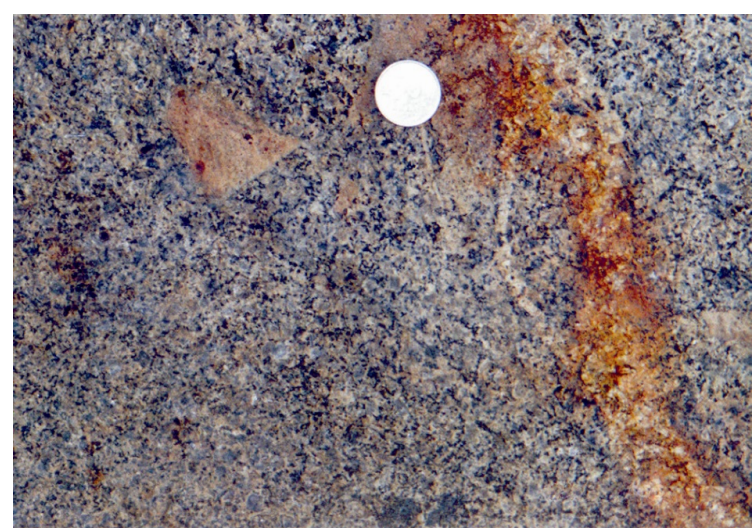

Foto 18. Fragmento irregular de rocha afanítica, de coloração cinza, no interior da massa sienítica. 


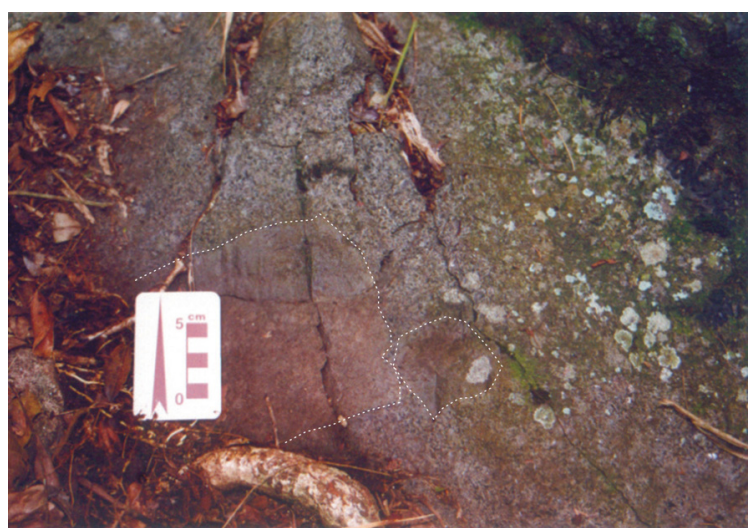

Foto 19. Fragmento decimétrico de rocha afanítica, de coloração rosada, no interior da massa sienítica.

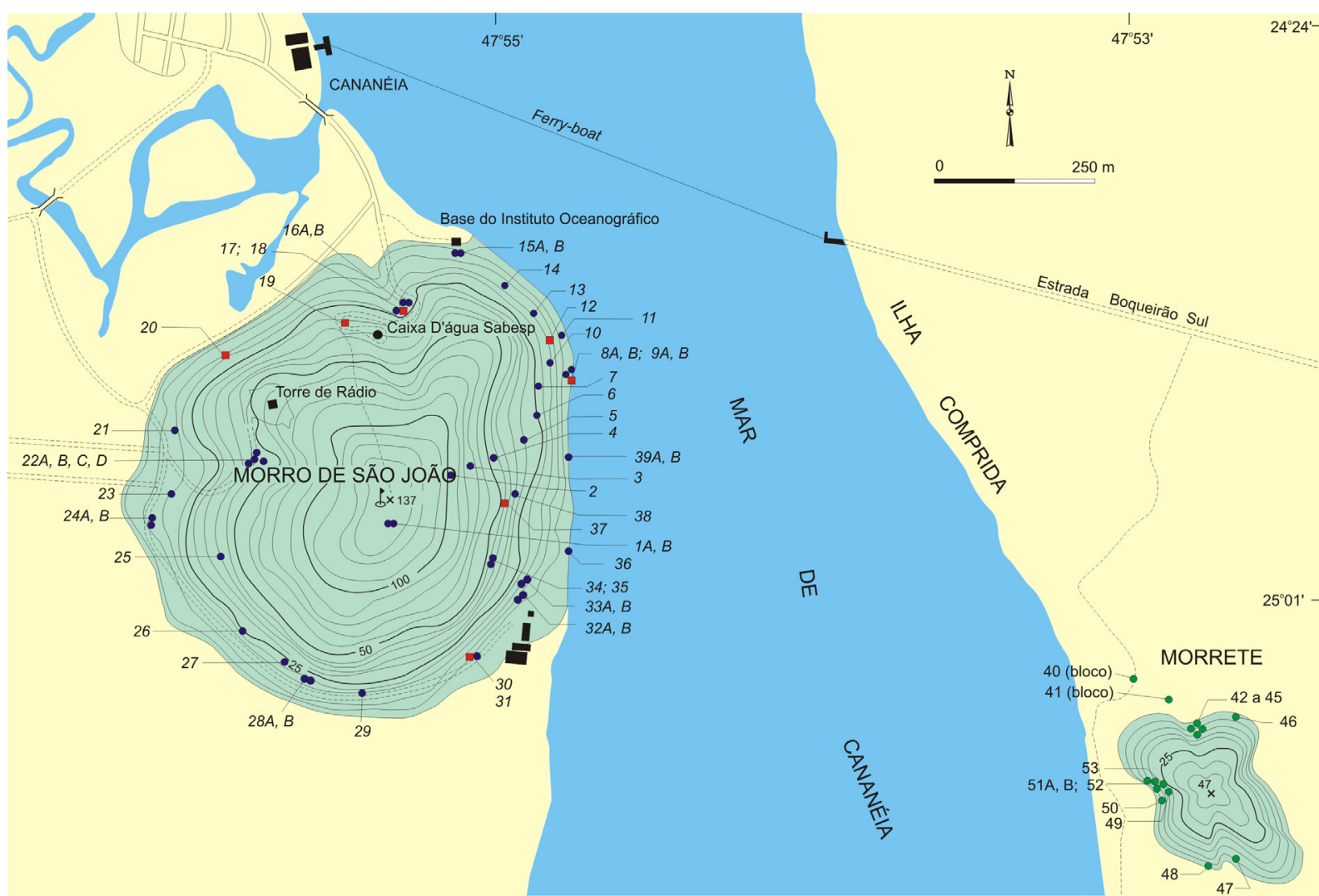

Figura 4. Mapa de localização com os pontos de amostragem das intrusões de Cananéia e Morrete, separadas pelo "Mar de Cananéia". Amostras de diques estão representadas por um quadrado vermelho. Escala original 1:10.000 (IGC, 1989).

O corpo satélite do Morrete, na Ilha Comprida (Fig. 4), corresponde também a um stock, porém, de dimensões mais modestas, com área de $0,4 \mathrm{~km}^{2}$. Sua forma é elíptica, com o eixo principal, de aproximadamente $410 \mathrm{~m}$, orientado na direção NW. Alcança cota máxima de apenas $47 \mathrm{~m}$, mas é de difícil acesso em razão da cobertura vegetal. Os afloramentos estão muito alterados e localizam-se principalmente nas bordas do morro, com as rochas formando matacões de dimensões métricas (Foto 20). Predominam ali tipos intrusivos com características gerais muito similares às do corpo principal. Da mesma maneira, são também cortados por variedades de granulação mais fina ou mesmo afaníticas, na forma de pequenos diques (Foto 21), ou ainda por variedades de granulação grossa, na forma de pequenos veios de espessura centimétrica (Foto 22).

As juntas reconhecidas no Morro de São João e Morrete são subverticais e definem duas famílias, uma de direção WNW e a outra orientada segundo NNE (Figs. 5A, B). Segundo Riccomini (1995), o padrão estrutural do maciço de Cananéia aponta para a vigência de duas fases distintas de 
deformação: a primeira, de extensão NE-SW e idade cretácea superior (ligada à extensão do Alinhamento de Guapiara); a segunda, com orientação NW-SE, caráter transcorrente sinistral de direção E-W e idade paleogênica (relacionada à reativação de antigas zonas de cisalhamento do Rift Continental do Sudeste do Brasil) (Fig. 6).

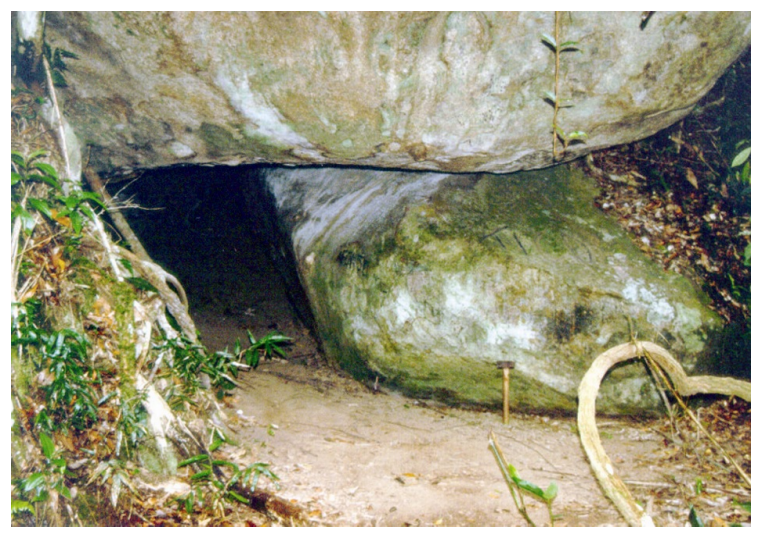

Foto 20. Rochas do corpo satélite do Morrete aflorando como matacões de dimensões métricas, e formando pequena gruta.

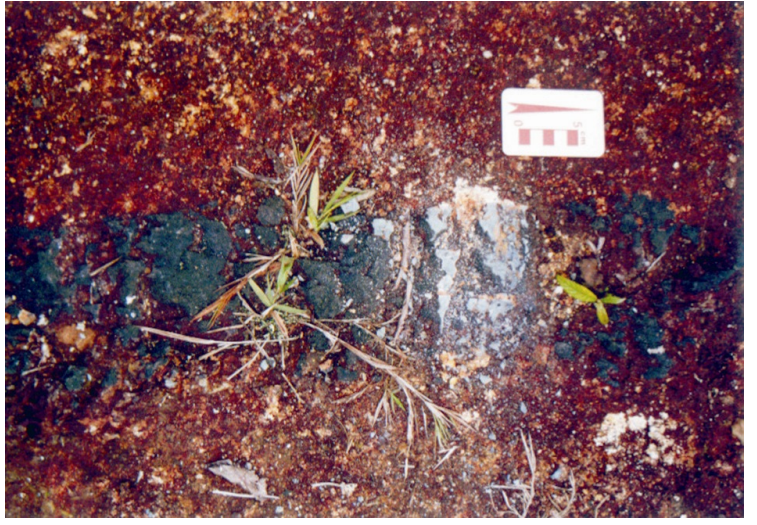

Foto 21. Dique de rocha afanítica cortando as rochas sieníticas do Morrete; ambas as litologias encontram-se totalmente alteradas por intemperismo. Direção do dique: N48E/subvertical.

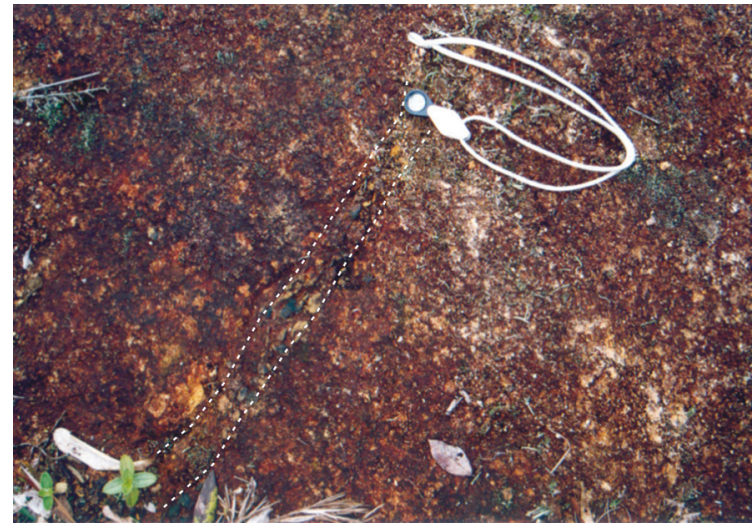

Foto 22. Veio de caráter pegmatóide, de espessura centimétrica, cortando a encaixante sienítica. Direção do veio N60W/subvertical. 

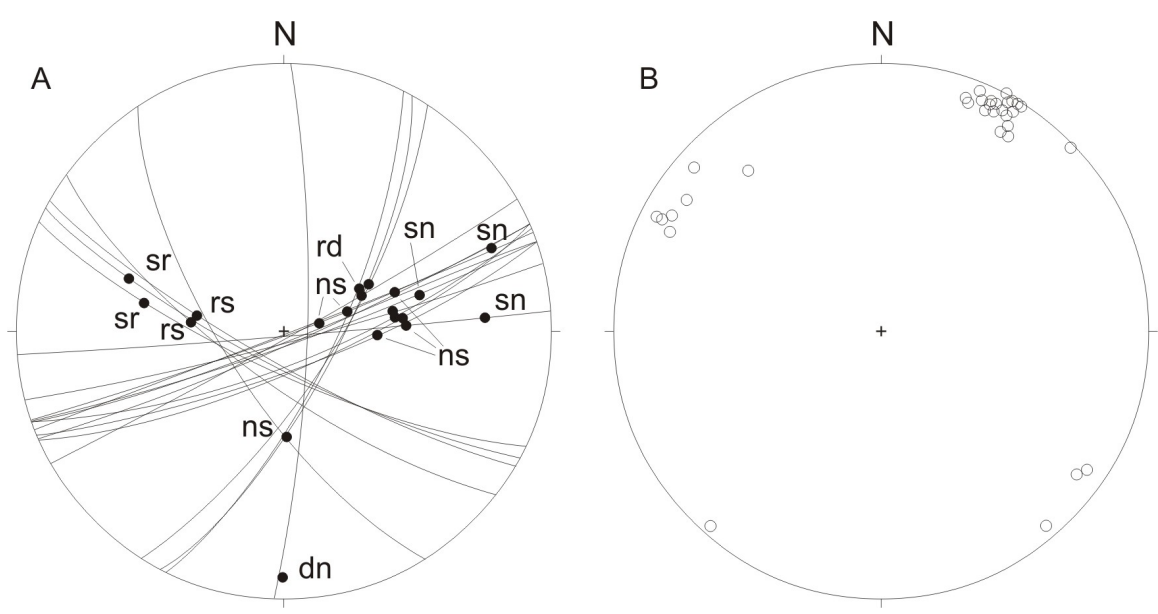

Figura 5. A) Falhas (círculos máximos) e estrias (pontos) presentes no Morro de São João. As abreviações indicam o movimento relativo entre os blocos: ns, normal com componente sinistral; sn, sinistral com componente normal; rd, reversa com componente dextral; rs, reversa com componente sinistral; sr, sinistral com componente reversa; dn, dextral com componente normal. B) Pólos de juntas do maciço. Rede de Schimidt-Lambert, semi-esfera inferior. Extraído de Riccomini (1995).

\section{A - Senoniano}

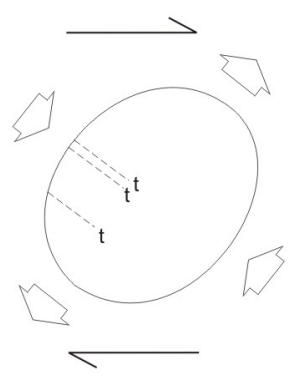

extensão NE-SW

\section{B - Paleoceno/Eoceno}

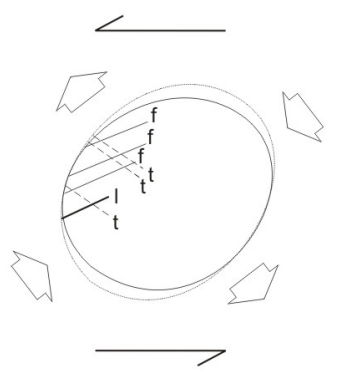

extensão NW-SE

Figura 6. Modelo proposto por Riccomini (1995) para o maciço de Cananéia: A) extensão NE-SW, com a intrusão dos diques de traquito (t) de direção NW-SE; B) extensão NW-SE e compressão NE-SW, com a colocação do dique de lamprófiro (I) e fraturamento nos diques de traquito (f). 


\section{PETROGRAFIA}

As rochas de Cananéia são constituídas essencialmente por litotipos saturados a supersaturados de composição sienítica. Os dados da Tabela 1 contêm determinações modais de 35 amostras do Morro de São João, representativas de um total de 47 lâminas delgadas estudadas. No diagrama de classificação QAP de Streckeisen (1976) da Figura 7, verifica-se que essas rochas correspondem, exclusivamente, a álcali feldspato sienitos e quartzo-álcali feldspato sienitos.

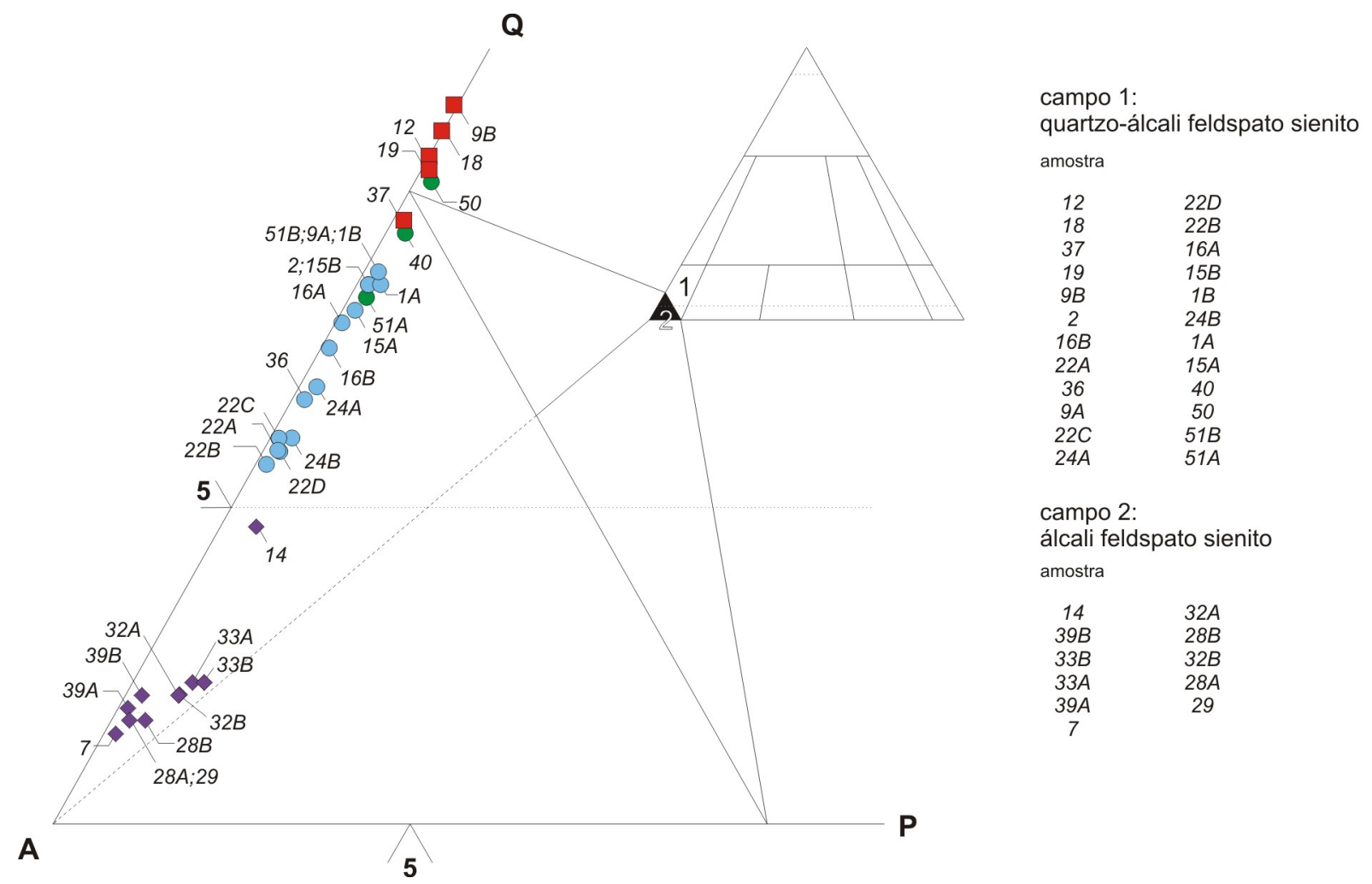

Figura 7. Diagrama ternário de classificação de rochas ígneas (QAP) segundo Streckeisen (1976). Os campos 1 e 2 indicados no detalhe correspondem, respectivamente, a quartzo-álcali feldspato sienitos e álcali feldspato sienitos. Os números plotados no diagrama referem-se às amostras da Tabela 1. As intrusivas do Morro de São João estão representadas por círculos azuis ( quartzo-álcali feldspato sienitos) e losangos roxos ( $\bullet$ álcali feldspato sienitos), enquanto que as hipoabissais por quadrados vermelhos ( $\square$ microssienitos); já as intrusivas do Morrete estão indicadas por círculos verdes (0 quartzo-álcali feldspato sienitos).

As rochas são leucocráticas, com índice de coloração variando de 4 a 22, porém, abaixo de 10 , na quase totalidade das amostras constantes da Tabela 1. Texturalmente, as variedades intrusivas são faneríticas de granulação média a grossa, assumindo ocasionalmente caráter pegmatóide (Foto 23) nas amostras encontradas nas porções $E$ e $W$ da intrusão ou então naquelas presentes na forma de veios (Fotos 24, 25 e 26); em algumas amostras a textura é tipicamente porfirítica, com fenocristais de feldspato alcalino (Foto 27). A coloração é na maioria das vezes acinzentada, tendo como tonalidades extremas o cinza claro e o escuro. Mais comumente esta última tonalidade é aparente, não refletindo necessariamente uma maior riqueza em minerais ferromagnesianos, mas, sim, decorre da granulometria e da presença de micro inclusões máficas no feldspato alcalino, bem como do intemperismo afetando o mineral. O grau de alteração é variável, com as rochas de coloração mais clara mostrando-se em geral mais intemperizadas. Particularmente, as rochas do Morrete encontram-se em estágio avançado de alteração. 


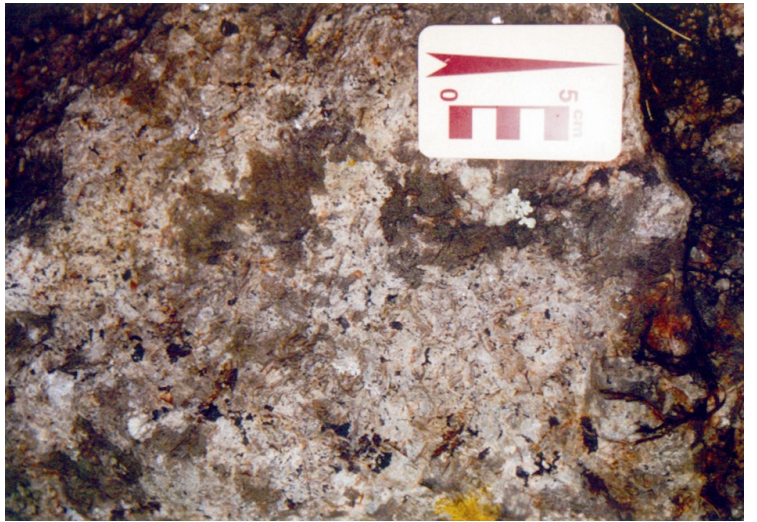

Foto 23. Textura pegmatóide das rochas de Cananéia, com os cristais de feldspato alcalino atingindo dimensões de até 2 $\mathrm{cm}$.

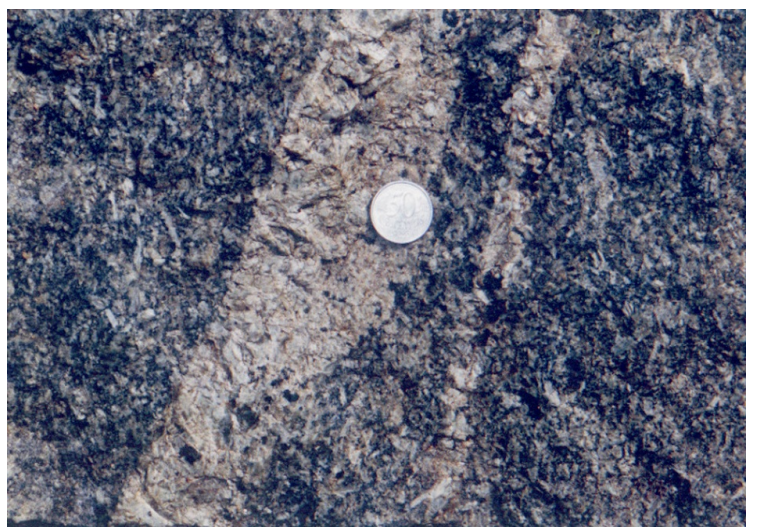

Foto 25. Veios pegmatóides de natureza dominantemente feldspática, com raros minerais ferromagnesianos, penetrando o material sienítico de coloração mais escura.

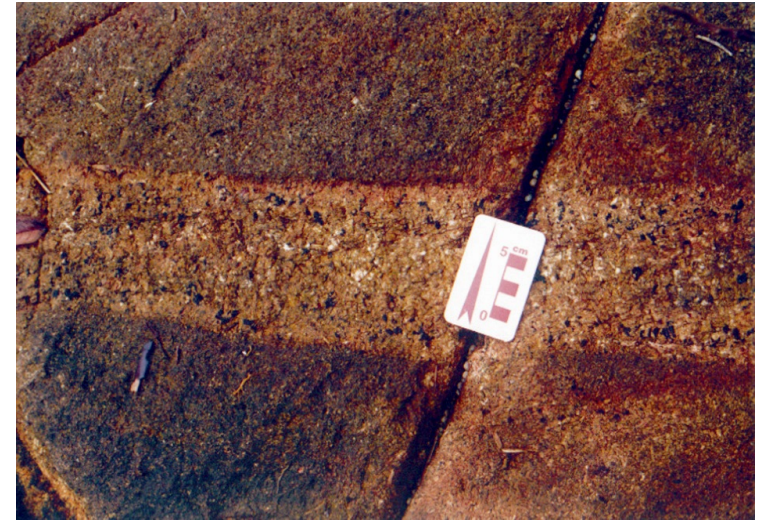

Foto 24. Veio pegmatóide de espessura decimétrica na encaixante sienítica, localizado na área costeira; ambas as litologias estão alteradas intempericamente.

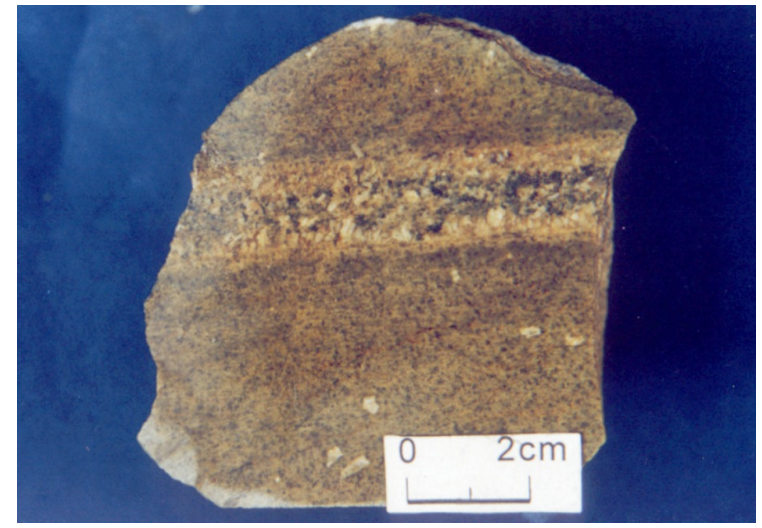

Foto 26. Microssienito com veio pegmatóide de espessura centimétrica. Amostra referente à amostra 30 (Morro de São João).

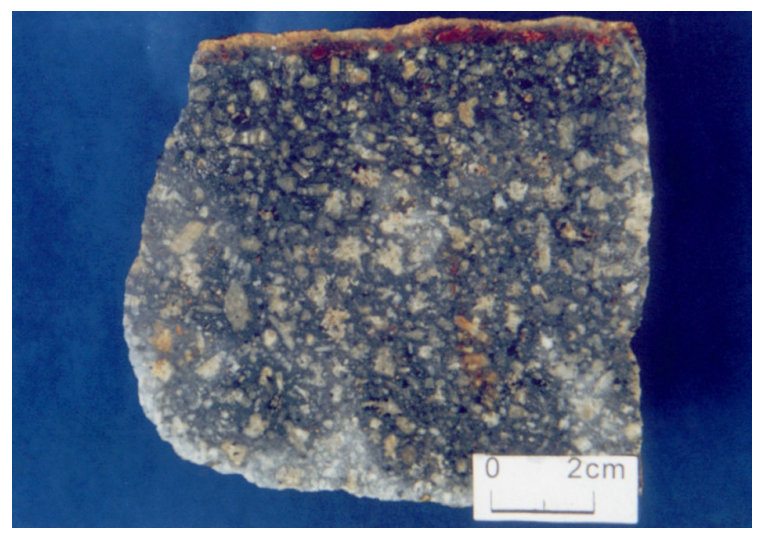

Foto 27. Amostra de rocha da fácies porfirítica referente à amostra 53 (porção E do corpo do Morrete).

Junto à litologia sienítica, reconhece-se também a presença de pequenas manchas de granulação fina a muito fina, ricas em minerais ferromagnesianos, interpretadas como representando schlieren de constituição (Foto 28) e/ou de injeção (Foto 29). Essas estruturas parecem indicativas de um processo de assimilação de rochas máficas pelo magma original, levando à modificação da sua composição. Ou, alternativamente, poderiam resultar da ação intensa da assimilação da rocha encaixante, produzindo segregações de níveis ricos em minerais máficos, dispersos ou se dispondo concordantemente ao fluxo magmático. 


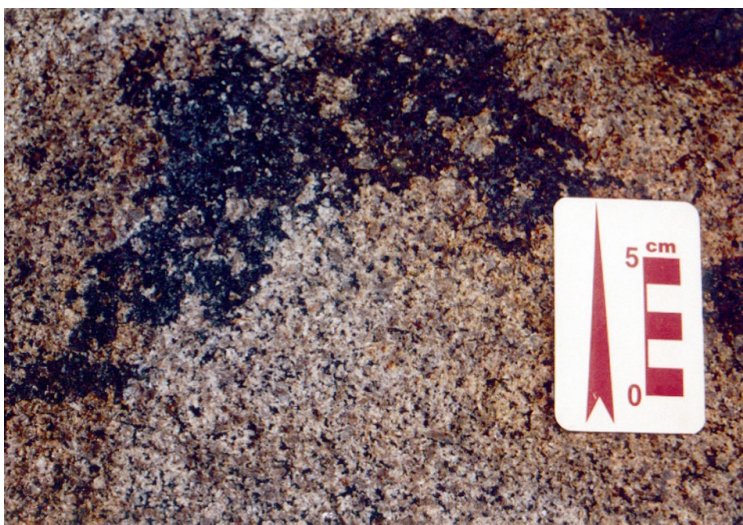

Foto 28. Concentração de minerais ferromagnesianos, de forma irregular (schlieren de constituição), no interior das rochas intrusivas do Morrete.

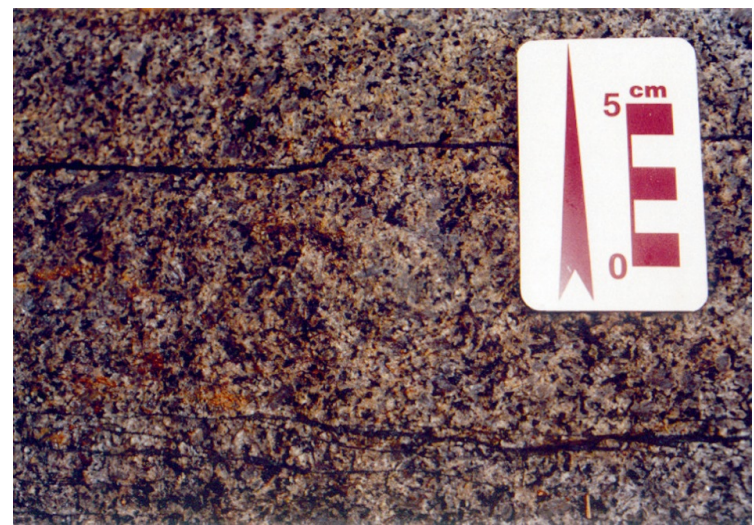

Foto 29. Concentração de minerais ferromagnesianos na forma de veios (schlieren de injeção) cortando a massa sienítica.

Tabela 1. Contagem modal de amostras representativas das rochas alcalinas de Cananéia. Os valores são expressos em \%; espaçamento 0,02 mm e média de 2.300 pontos. Legenda: Morro de São João - hipoabissais: 1 (12), 2 (18), 4 (37), 5 (19) e 6 (9B); intrusivas: amostras 7 (2) a 32 (29). Morrete - intrusivas: 33 (40) a 36 (51A). Abreviações: Qs: quartzo-álcali feldspato sienito; As: álcali feldspato sienito, $m S$ : microssienito com textura em mosaico; Tq: microssienito porfirítico com textura traquítica (nomenclatura cf. Streckeisen, 1976).

\begin{tabular}{|c|c|c|c|c|c|c|c|c|c|c|c|c|}
\hline & 1 & 2 & 4 & 5 & 6 & 7 & 8 & 9 & 10 & 11 & 12 & 13 \\
\hline Amostra & 12 & 18 & 37 & 19 & $9 B$ & 2 & $16 B$ & $22 A$ & 36 & $9 a$ & $22 C$ & $24 A$ \\
\hline $\begin{array}{l}\text { Feldsp. alcalino } \\
\text { Plagioclásio }\end{array}$ & 76,7 & 73,2 & 82,9 & 77,6 & 75,3 & 69,7 & 71,9 & 71,6 & 71,4 & 72,1 & 71,4 & 70,9 \\
\hline Quartzo & 4,6 & 4,3 & 4,7 & 4,8 & 3,8 & 6,9 & 6,1 & 4,7 & 5,4 & 7,0 & 4,8 & 5,5 \\
\hline Olivina & 0,9 & & & 0,6 & & 0,7 & 0,7 & 0,7 & 0,7 & 0,9 & 0,6 & 0,7 \\
\hline Clinopiroxênio & 15,9 & 21,1 & 9,0 & 15,2 & 19,3 & 5,1 & 4,8 & 5,2 & 5,2 & 4,7 & 5,1 & 5,3 \\
\hline Anfibólio & & & & & & 7,9 & 7,3 & 7,8 & 7,9 & 7,3 & 7,9 & 7,7 \\
\hline Biotita & & & & & & 8,0 & 7,5 & 7,9 & 8,1 & 7,3 & 8,2 & 7,9 \\
\hline Apatita & & & & & & 0,2 & 0,2 & 0,2 & 0,2 & 0,3 & 0,2 & 0,2 \\
\hline Titanita & & & & & & $<0,1$ & $<0,1$ & $<0,1$ & $<0,1$ & $<0,1$ & $<0,1$ & $<0,1$ \\
\hline Zircão & & & & & & $<0,1$ & $<0,1$ & $<0,1$ & $<0,1$ & $<0,1$ & $<0,1$ & $<0,1$ \\
\hline Opacos & 1,9 & 1,5 & 3,4 & 1,8 & 1,6 & 1,5 & 1,5 & 1,9 & 1,2 & 0,4 & 1,9 & 1,7 \\
\hline \multirow{2}{*}{ Nome da rocha } & $\mathrm{mS}$ & $\mathrm{Tq}$ & $\mathrm{mS}$ & $\mathrm{mS}$ & $\mathrm{Tq}$ & Qs & Qs & Qs & Qs & Qs & Qs & Qs \\
\hline & 14 & 15 & 16 & 17 & 18 & 19 & 20 & 21 & 22 & 23 & 24 & 25 \\
\hline Amostra & $22 D$ & $22 B$ & $16 A$ & $15 B$ & $1 B$ & $24 B$ & 14 & $39 B$ & $33 B$ & $1 A$ & $33 A$ & $39 A$ \\
\hline Feldsp. alcalino & 71,1 & 71,7 & 71,3 & 70,7 & 70,4 & 71,5 & 69,6 & 73,3 & 75,1 & 70,4 & 75,7 & 73,5 \\
\hline Plagioclásio & & & & & & & 0,8 & & 0,5 & & 0,5 & \\
\hline Quartzo & 4,6 & 4,5 & 6,3 & 6,8 & 6,7 & 4,9 & 3,1 & 1,7 & 1,9 & 6,9 & 1,7 & 1,6 \\
\hline Olivina & 0,8 & 0,7 & 0,7 & 0,8 & 0,9 & 0,7 & & 0,1 & & 0,8 & & 0,1 \\
\hline Clinopiroxênio & 5,1 & 5,1 & 4,9 & 4,8 & 4,9 & 5,3 & 3,8 & 3,5 & 2,7 & 4,9 & 2,6 & 3,6 \\
\hline Anfibólio & 8,0 & 7,8 & 7,5 & 7,3 & 7,5 & 7,6 & 9,8 & 11,6 & 10,4 & 7,6 & 9,9 & 11,4 \\
\hline Biotita & 8,2 & 8,1 & 7,7 & 7,5 & 7,6 & 7,9 & 10,9 & 6,9 & 6,7 & 7,5 & 6,7 & 6,8 \\
\hline Apatita & 0,2 & 0,2 & 0,3 & 0,3 & 0,2 & 0,3 & 0,3 & 0,9 & 0,9 & 0,1 & 1,0 & 0,9 \\
\hline Titanita & $<0,1$ & $<0,1$ & $<0,1$ & $<0,1$ & $<0,1$ & $<0,1$ & $<0,1$ & & $<0,1$ & $<0,1$ & & \\
\hline Zircão & & & $<0,1$ & $<0,1$ & $<0,1$ & $<0,1$ & $<0,1$ & & & & $<0,1$ & \\
\hline Opacos & 2,0 & 1,8 & 1,4 & 1,6 & 1,7 & 1,8 & 1,6 & 2,1 & 1,9 & 1,8 & 1,9 & 2,2 \\
\hline \multirow[t]{2}{*}{ Nome da rocha } & Qs & Qs & Qs & Qs & Qs & Qs & As & As & As & Qs & As & As \\
\hline & & 26 & 27 & 28 & 29 & 30 & 31 & 32 & 33 & 34 & 35 & 36 \\
\hline Amostra & & 7 & $32 A$ & $28 B$ & $32 B$ & $28 A$ & $15 A$ & 29 & 40 & 50 & $51 B$ & $51 A$ \\
\hline Feldsp. alcalino & & 74,2 & 75,5 & 75,8 & 75,6 & 75,5 & 71,1 & 73,7 & 70,5 & 71,0 & 69,6 & 70 \\
\hline Plagioclásio & & & 0,6 & 0,1 & 0,6 & 0,1 & & & & & & \\
\hline Quartzo & & 1,3 & 2 & 1,5 & 1,8 & 1,5 & 6,5 & 1,4 & 9,5 & 9,1 & 9,9 & 9,7 \\
\hline Olivina & & & & & & & 1 & & 0,6 & 0,6 & 0,7 & 0,6 \\
\hline Clinopiroxênio & & 3,8 & 2,8 & 3,2 & 2,7 & 3,5 & 5,2 & 3,9 & $<0,1$ & $<0,1$ & $<0,1$ & $<0,1$ \\
\hline Anfibólio & & 11,2 & 10,5 & 10,5 & 10,6 & 10,5 & 7,9 & 11,2 & 10,5 & 10,6 & 10,5 & 10,4 \\
\hline Biotita & & 8,6 & 7,8 & 8,1 & 7,8 & 8,1 & 8,1 & 8,8 & 8,8 & 7,9 & 9,4 & 9,1 \\
\hline Apatita & & 0,9 & 0,8 & 0,8 & 0,9 & 0,8 & 0,3 & 1 & 0,2 & 0,3 & 0,2 & 0,2 \\
\hline Titanita & & $<0,1$ & $<0,1$ & $<0,1$ & $<0,1$ & & $<0,1$ & & $<0,1$ & $<0,1$ & $<0,1$ & $<0,1$ \\
\hline Zircão & & & & $<0,1$ & & & $<0,1$ & & $<0,1$ & $<0,1$ & $<0,1$ & $<0,1$ \\
\hline Opacos & & 2,2 & 2,1 & 2,0 & 2,1 & 2,1 & 2,0 & 2,2 & 2,1 & 1,8 & 1,6 & 1,5 \\
\hline Nome da rocha & & As & As & As & As & As & Qs & As & Qs & Qs & Qs & Qs \\
\hline
\end{tabular}




\section{1. Álcali feldspato sienitos}

São rochas de estrutura maciça, faneríticas, e coloração cinza a cinza-esverdeada. Ao microscópio, exibem textura inequigranular, hipidiomórfica a xenomórfica e granulação variável de média $(1,2$ a 2,0 $\mathrm{mm})$ a grossa $(2,7$ a 4,0 mm). Mineralogicamente, elas contêm feldspato alcalino, clinopiroxênio, anfibólio, biotita, quartzo, além de raros pseudomorfos de olivina; opacos e apatita constituem os principais acessórios.

Feldspato alcalino é o mineral mais abundante e ocorre como cristais hipidiomórficos a xenomórficos, com dimensões médias variando de 1,4 a 1,8 mm; ocasionalmente, esses cristais podem atingir até 4,0 mm. Geminação do tipo Carlsbad é comum. Os grãos exibem contato irregular a difuso e inclusões idiomórficas de clinopiroxênio, anfibólio, biotita, opacos e apatita. Outras feições observadas incluem alteração para minerais argilosos e fraturas preenchidas por sericita e carbonatos.

O feldspato alcalino apresenta mesopertitas de textura complexa, típicas de rochas sieníticas, formadas por processos de exsolução. Três fases são distinguíveis: micropertítica a mesopertítica, sódica e potássica (Fotomicrografia 1), com as duas últimas dominantes e formando porções irregulares.

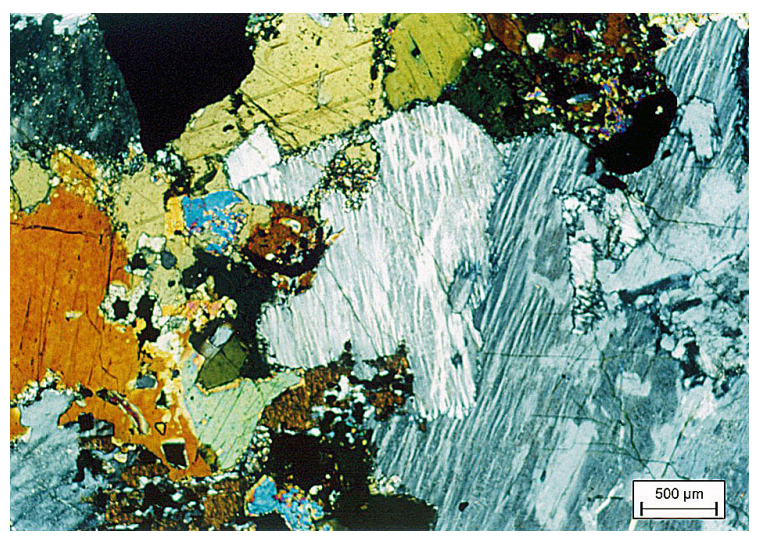

Fotomicrografia 1. Álcali feldspato sienito: estrutura mesopertítica no cristal do centro. À direita, observa-se cristal de feldspato com as fases micropertítica, sódica e potássica. Polarizadores cruzados. Amostra 39B.

A fase micropertítica a mesopertítica é caracterizada por um padrão de exsolução diferente, presente no mesmo cristal, onde se distinguem micropertitas de lamelas sódicas muito finas $(<2 \mu \mathrm{m})$ a quase imperceptíveis (braid pertitas), visíveis apenas com aumento máximo, associadas a mesopertitas com lamelas de até $10 \mu \mathrm{m}$ de largura. Em algumas amostras podem ser reconhecidos efeitos de schiller, como resultado da presença de intercrescimentos criptopertíticos a micropertíticos. As lamelas finas estão desenvolvidas em maior número junto às bordas dos grãos, ainda que ocorram também no seu interior. A disposição das lamelas de exsolução nas bordas dos cristais está condicionada ao aparecimento de zonas de fraqueza induzidas pela contração diferencial durante o processo de resfriamento. $O$ aumento da freqüência das lamelas possibilita a identificação de outras maiores e mais sinuosas, na forma de barras e interligadas, que se distribuem aleatoriamente no interior do mineral.

As fases sódica e potássica são produtos de dissolução, deposição e desmisturação total dos componentes alcalinos $\mathrm{Ab}-\mathrm{Or}$ e formam patch pertitas, com porções irregulares e interpenetradas, dando ao feldspato um aspecto manchado. As lamelas estão dispostas preferencialmente nas bordas dos cristais. A separação das porções mais ricas em sódio ou em potássio se dá na forma de inclusões irregulares, dispostas em geral segundo planos bem definidos do cristal (paralelos ao eixo cristalográfico "b"). A fase sódica ocupa na maior parte das vezes o interior dos cristais, mostra-se 
límpida e, em alguns casos, pode apresentar geminação polissintética. Por outro lado, a fase potássica é turva, mais rica em inclusões e está presente nas porções mais externas do mineral.

O plagioclásio é idiomórfico, com o eixo principal dos cristais possuindo até $2,2 \mathrm{~mm}$ de comprimento; no geral, predominam grãos com 0,3 a $0,9 \mathrm{~mm}$. O mineral ocorre também como manchas no interior dos cristais de feldspato pertítico, o que parece sugerir uma formação a partir da desmisturação parcial dos componentes Ab-Or (Fotomicrografia 2) ou então resultante da comtribuição de magma mais básico. Ele contém inclusões de clinopiroxênio, anfibólio e de biotita, além de exibir evidências de alteração secundária (saussuritização e caolinização) (Fotomicrografia 3).

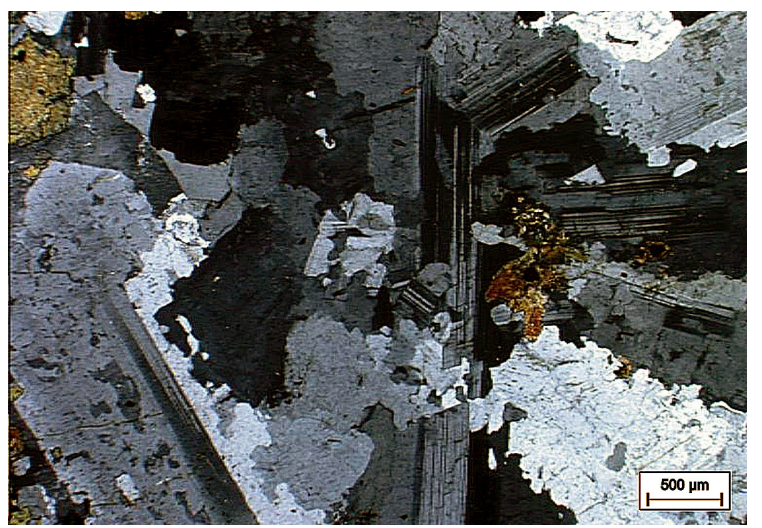

Fotomicrografia 2. Álcali feldspato sienito: aglomerado de plagioclásio substituído parcialmente pelo processo de desmisturação. Polarizadores cruzados. Amostra $32 A$.

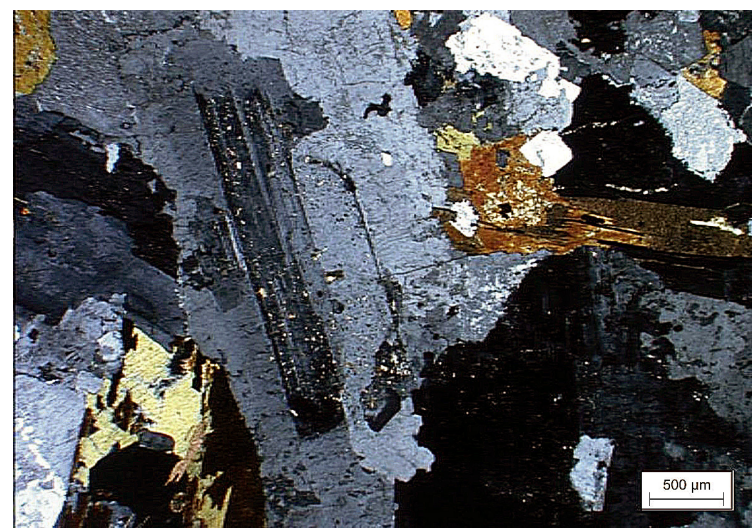

Fotomicrografia 3. Álcali feldspato sienito: cristal de plagioclásio, no interior do feldspato alcalino, contendo inclusões de vários minerais (clinopiroxênio, anfibólio e biotita). Polarizadores cruzados. Amostra 32B

O grupo dos minerais máficos é representado por clinopiroxênio, anfibólio, biotita e opacos, ocorrendo em íntima associação. O clinopiroxênio é uma hedenbergita (cf. Morimoto, 1990), com pleocroísmo em $Z=$ verde pálido, $Y=$ verde-amarelado pálido e $X=$ verde-azulado claro. $\mathrm{Na}$ microssonda, verifica-se que os grãos são em sua maioria homogêneos, ainda que possam exibir bordas de cor verde mais intenso, indicativas de sua transformação para augita. A augita é incolor a

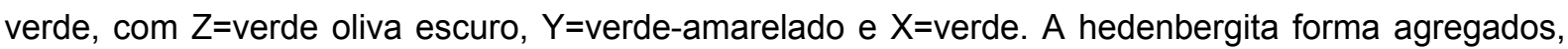
que não ultrapassam 0,7 mm de comprimento (Fotomicrografias 4 e 5), no interior do anfibólio, mas pode estar também presente na forma de cristais isolados preenchendo espaços intersticiais. Opacos e apatita idiomórficos estão inclusos nesse mineral.

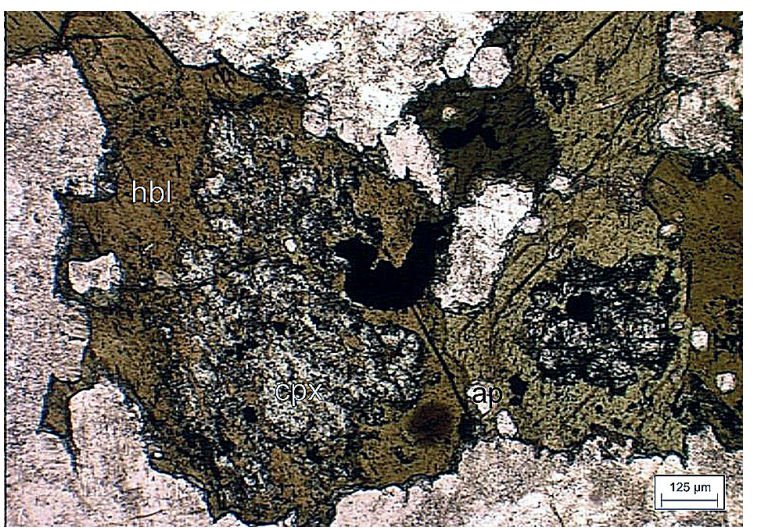

Fotomicrografia 4. Álcali feldspato sienito: textura zonada, com a magnesiohornblenda ( $\mathrm{hbl}$ ) envolvendo o clinopiroxênio (cpx), que ocupa as partes centrais dos cristais; opacos e apatita (ap) idiomórfica aparecem na forma de inclusões. Polarizadores paralelos. Amostra 28A.

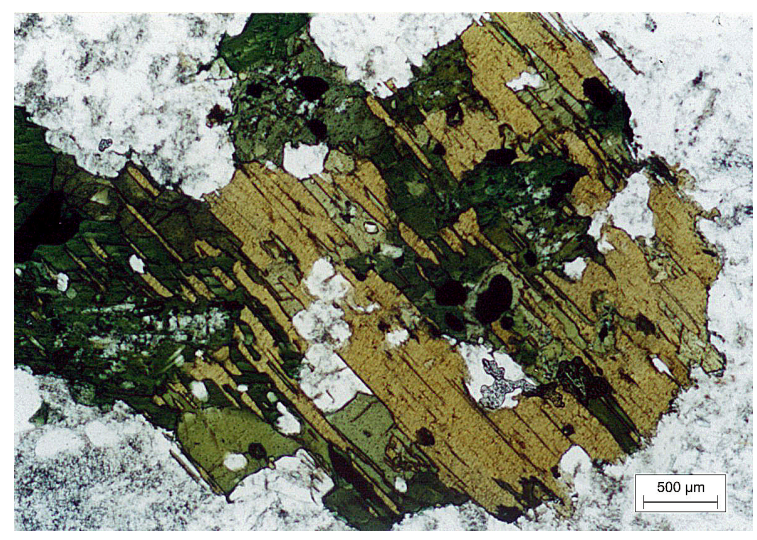

Fotomicrografia 5. Álcali feldspato sienito: Magnesiohornblenda substituindo o clinopiroxênio, ao lado de biotita associada às fraturas e bordas dos cristais. opacos e apatita ocorrem como inclusões. Nota-se também a presença de lamelas de opacos nos planos da clivagem da biotita. Polarizadores paralelos. Amostra 32B. 
O anfibólio é hipidiomórfico a xenomórfico e de tamanho variável, 0,4 a 1,4 mm, raramente formando grãos superiores a 4,0 mm. O mineral possui contatos retilíneos a irregulares e bordas associadas com biotita e opacos (Fotomicrografia 5). Tem ocorrência isolada, quando preenche vazios intergranulares, ou mais comumente encontra-se associado às porções periféricas dos cristais de hedenbergita, chegando mesmo a englobar por completo esse mineral. É tipicamente um produto de transformação do clinopiroxênio, substituindo-o parcial ou totalmente. Na microssonda, verifica-se que o anfibólio (cf. Leake, 1997) é uma magnesiohornblenda, com núcleo de composição edenítica e bordas mais ricas em ferrohornblenda. Em alguns cristais, o núcleo é formado por barroisita enriquecida ou não em ferro. A magnesiohornblenda é pleocróica, com $Z=v e r d e$ oliva a verdeacastanhado escuro, $Y=$ verde-acastanhado e $X=$ marrom-esverdeado.

A biotita é hipidiomórfica, com o tamanho dos grãos variando de 0,7 a 1,8 mm, ocasionalmente chegando a $3,3 \mathrm{~mm}$. O pleocroísmo mostra $Z=v e r d e$ castanho a vermelho-acastanhado escuro, $\mathrm{Y}=$ verde-amarelado a laranja-acastanhado e $\mathrm{X}=$ verde-acastanhado a laranja-amarelado. $\mathrm{O}$ mineral ocorre associado às bordas de grãos de anfibólio, bem como aparece na forma de lamelas inclusas no seu interior, seguindo ou não os seus planos de clivagem (Fotomicrografias 5 e 6). Associa-se ainda aos opacos, que se concentram nas bordas dos seus grãos ou ao longo dos planos de clivagem. Anfibólio e apatita estão presentes como inclusões.

Em algumas amostras desse litotipo reconhece-se também a presença de pseudomorfos de olivina, agora representada por um mineral de coloração amarelada (iddingsita?), com dimensões de 0,5 a 3,0 mm, associado comumente com anfibólio e biotita (Fotomicrografias 6 e 7).

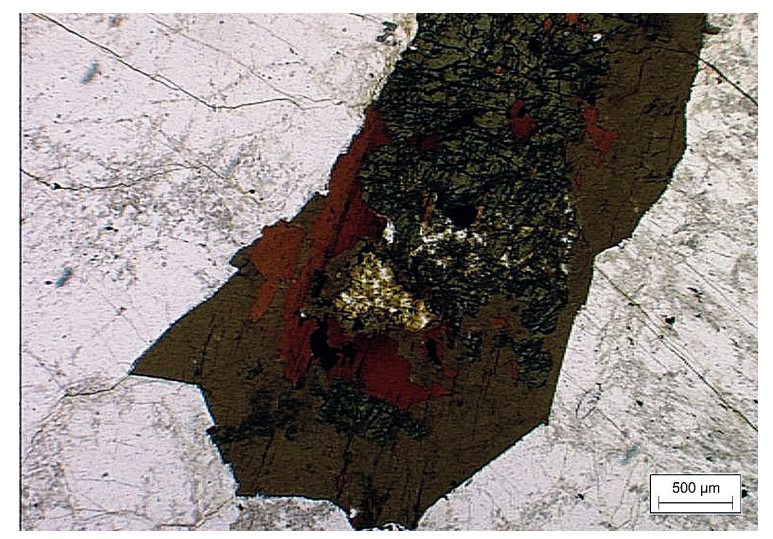

Fotomicrografia 6. Álcali feldspato sienito: pseudomorfo de olivina no interior do clinopiroxênio com borda associada de magnesiohornblenda. Nota-se também a biotita associada às clivagens do anfibólio. Polarizadores paralelos. Amostra 32B.

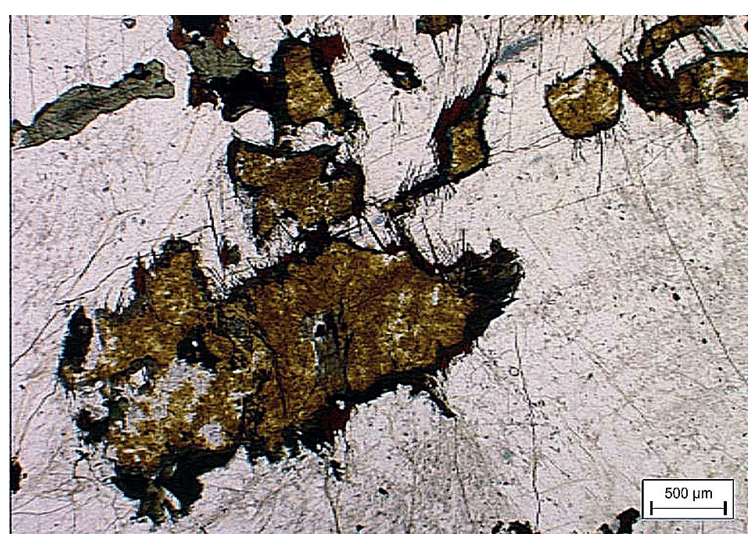

Fotomicrografia 7. Álcali feldspato sienito: pseudomorfo de olivina substituído por iddingsita(?) com bordas de magnesiohornblenda (verde oliva escuro) e biotita (vermelho-acastanhado escuro). Polarizadores paralelos. Amostra 32B.

O quartzo, sempre em pequena quantidade, é xenomórfico, com as dimensões dos grãos variando entre 0,4 e $0,9 \mathrm{~mm}$. O mineral possui bordas retilíneas a irregulares e ocorre preenchendo vazios intergranulares, além de freqüentemente associado ao anfibólio. As suas inclusões mais comuns são de anfibólio, biotita e apatita idiomórfica. É de fácil identificação devido ao seu aspecto mais límpido (Fotomicrografia 8).

Os opacos correspondem a titanomagnetita com lamelas exsolvidas de ilmenita. Apresentam-se como cristais idiomórficos ou xenomórficos, quando associados às clivagens da biotita. Ocorrem na forma de inclusões em feldspato e clinopiroxênio e parecem pertencer a duas gerações distintas. 


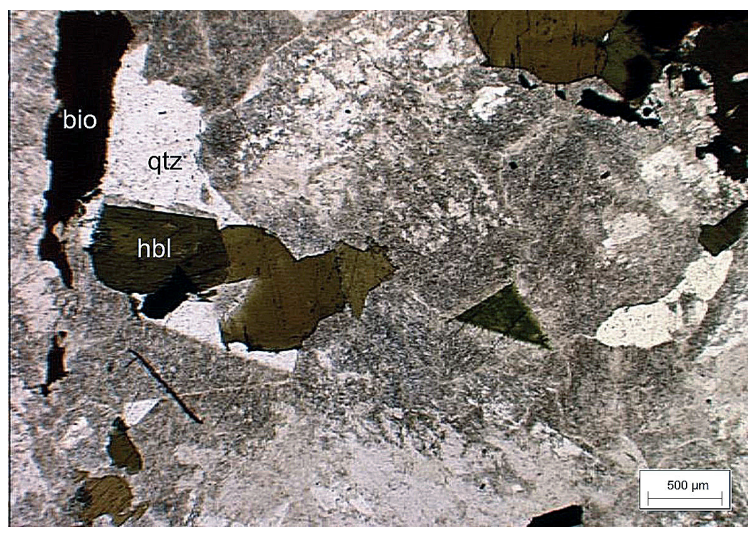

Fotomicrografia 8. Álcali feldspato sienito: quartzo (qtz) intersticial, de aspecto límpido, associado a magnesiohornblenda (hbl). Polarizadores paralelos. Amostra 33A.

\subsection{Quartzo-álcali feldspato sienitos}

Este litotipo é formado por rochas de estrutura maciça e, microscopicamente, de textura fanerítica inequigranular, hipidiomórfica a xenomórfica, e de granulação média (1,2 a 1,8 $\mathrm{mm})$ a grossa $(2,5$ a $5,7 \mathrm{~mm})$, podendo assumir localmente caráter pegmatóide $(>1,5 \mathrm{~cm})$. É de coloração cinza a cinzaesverdeado, além de composto de feldspato alcalino, clinopiroxênio, anfibólio, biotita, quartzo, olivina e acessórios (opacos, apatita, titanita e zircão) (Fotomicrografia 9).

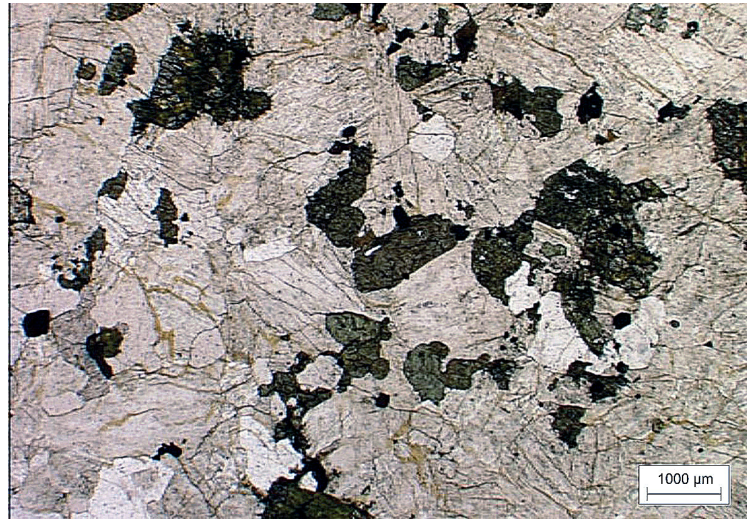

Fotomicrografia 9. Quartzo-álcali feldspato sienito: textura fanerítica média, inequigranular com cristais de katoforita com textura poiquilítica (à direita), olivina substituída por iddingsita(?) e quartzo intersticial de aspecto límpido. Polarizadores paralelos. Amostra 34.

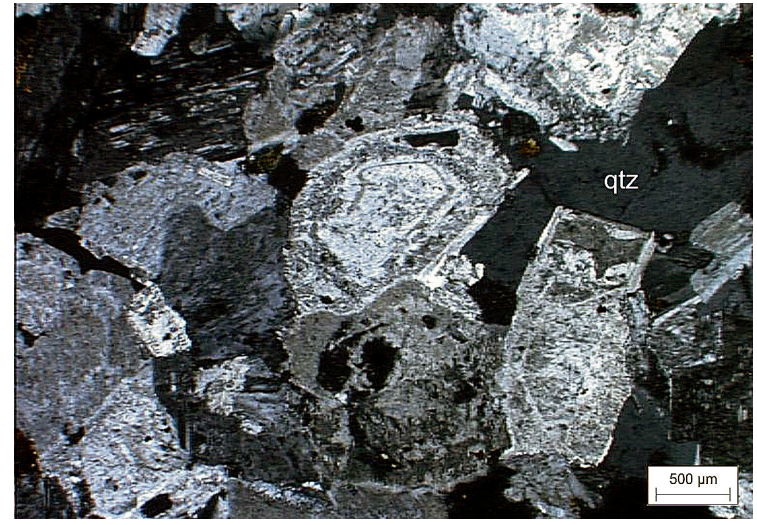

Fotomicrografia 10. Quartzo-álcali feldspato sienito: feldspato alcalino com as fases pertítica (esquerda superior), sódica (turva) e potássica (límpida) e cristal idiomórfico zonado (centro). Polarizadores cruzados. Amostra 41

O feldspato alcalino é o principal constituinte dessas rochas e forma cristais irregulares, por vezes tabulares, com dimensões entre 0,6 e 5,0 mm ou mesmo superiores a 2,0 cm, no caso dos tipos pegmatíticos. Em geral, o mineral acha-se geminado segundo a lei de Carlsbad, observando-se ainda ocasionalmente cristais zonados com geminação do periclínio e albita (Fotomicrografias 10 e 11). As bordas de alguns cristais podem exibir uma textura eutética a proto-eutética, caracterizada pela cristalização simultânea com quartzo (Fotomicrografia 12). Esta feição é reconhecida tão somente em algumas amostras de rochas do Morrete. Os grãos apresentam contato irregular a difuso e inclusões idiomórficas de minerais máficos, opacos apatita, zircão e titanita. Algumas vezes mostram também evidências de alteração secundária para minerais argilosos (caolinita), além de fraturas preenchidas por sericita e carbonatos. 


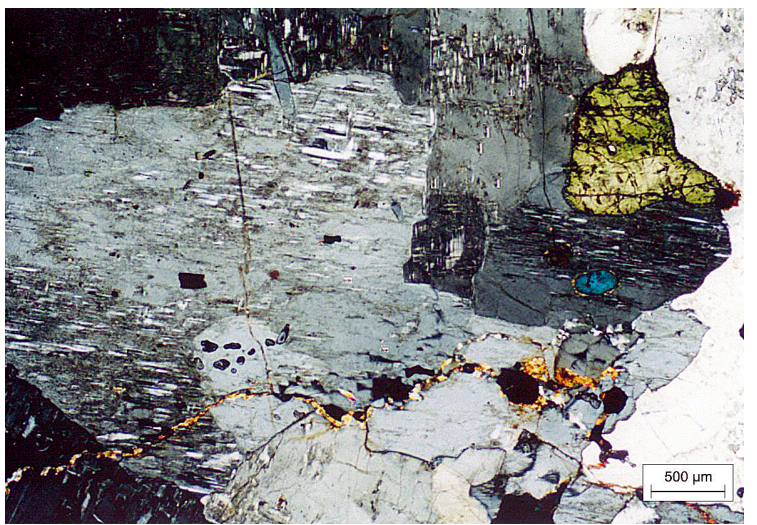

Fotomicrografia 11. Quartzo-álcali feldspato sienito: feldspato alcalino apresentando geminação do periclínio associada à da albita. Inclusão de zircão (birrefringência azul) e titanita no feldspato mostrando as fases pertítica e potássica. Polarizadores cruzados. Amostra 15A.

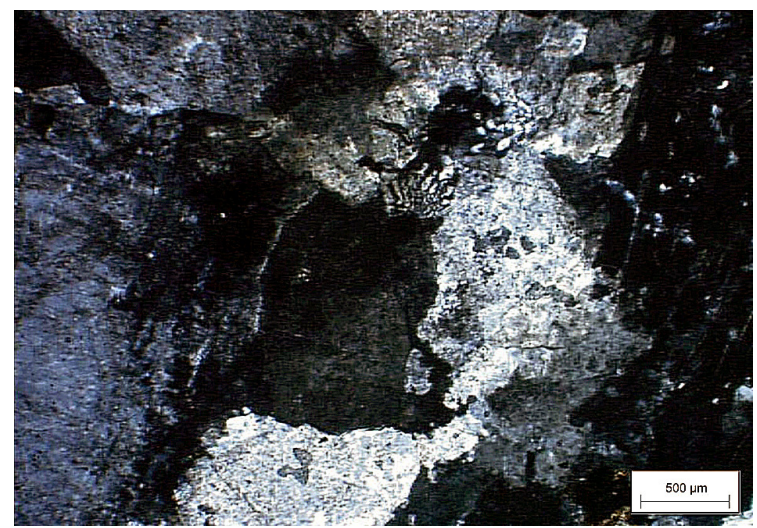

Fotomicrografia 12. Quartzo-álcali feldspato sienito: feldspato alcalino com intercrescimento de quartzo. Feição observada somente em amostras de rochas do Morrete. Polarizadores cruzados. Amostra 41.

O processo de exsolução é muito semelhante ao descrito anteriormente para o caso dos álcali feldspato sienitos, sendo também distinguíveis as fases pertítica, sódica e potássica. A primeira fase é constituída por lamelas sódicas muito finas $(<2 \mu \mathrm{m})$ a finas $(10 \mu \mathrm{m})$, geralmente dispersas ao longo das bordas do hospedeiro potássico (Fotomicrografia 13). As demais formam porções irregulares e interpenetradas, dando ao mineral um aspecto manchado (patch pertitas). A fase potássica localizase nas bordas dos grãos, enquanto que a sódica mais junto à sua parte central e, ao contrário da anterior, tem aparência turva.

Dentre os minerais máficos destaca-se o clinopiroxênio, que ocorre como cristais inequigranulares, em geral hipidiomórficos, e parcialmente alterados. Está sempre presente no interior do anfibólio, mas, por vezes, pode aparecer de forma isolada (Fotomicrografia 14). Na microssonda, verifica-se que ele é dominantemente de composição hedenbergítica a augítica. Em geral, os grãos são homogêneos, porém, alguns deles exibem zoneamento do tipo gradacional, com o núcleo composto de augita e as bordas de egirina-augita. Os primeiros são identificados pelo pleocroísmo de coloração verde oliva a verde-amarelado a acastanhado em $Z$, verde-amarelado em $Y$ e verde a verde-azulado pálido em X; já o tipo mais rico no componente egirina-augita possui coloração verde a verde-azulado pálido em $Z$, verde-amarelado pálido em $\mathrm{Y}$ e verde-azulado a amarelado em $\mathrm{X}$. $\mathrm{O}$ clinopiroxênio contém apatita e opacos como inclusões, além de áreas com feldspato.

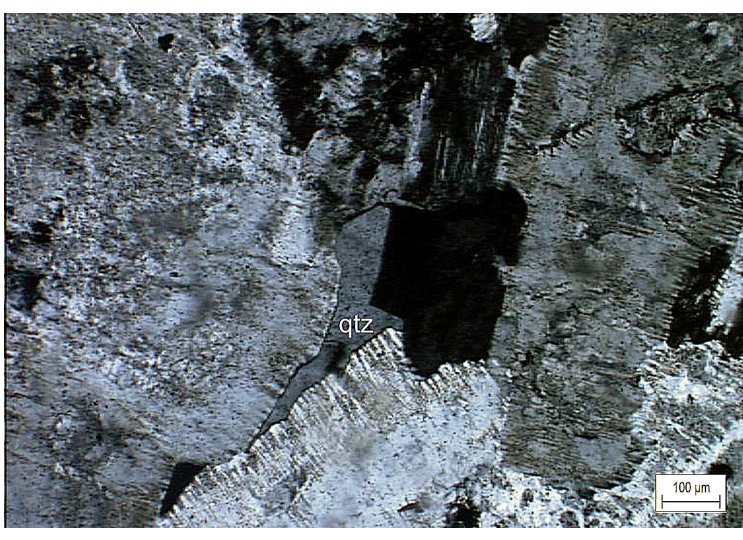

Fotomicrografia 13. Quartzo-álcali feldspato sienito: feldspato alcalino com estruturas de exsolução (fases pertítica, sódicalímpida e potássica-turva). O quartzo ocorre preenchendo espaços intergranulares. Polarizadores cruzados. Amostra 41.

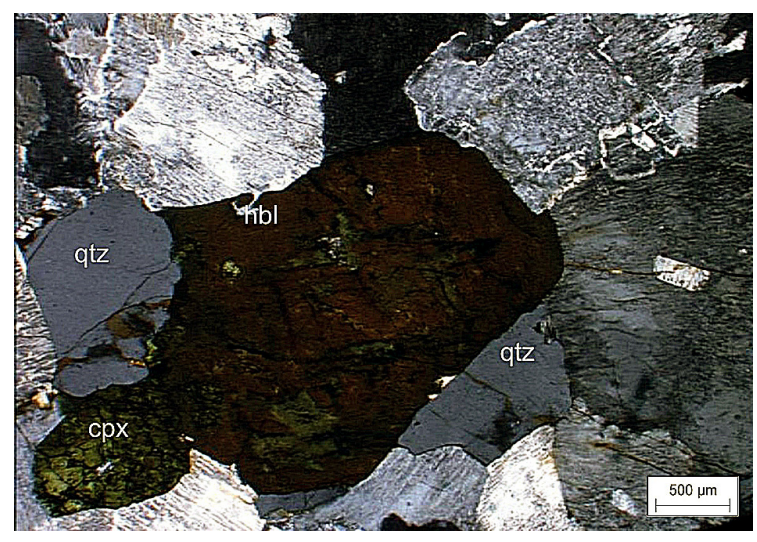

Fotomicrografia 14. Quartzo-álcali feldspato sienito: magnesiohornblenda (hbl) associada às bordas do clinopiroxênio (cpx). Polarizadores cruzados. Amostra 1B.

O anfibólio representa a fase máfica mais abundante. Em geral, o mineral é xenomórfico, 
associado às bordas dos cristais de clinopiroxênio e mostra textura zonada ou de emulsão; mais raramente acha-se em contato com as porções mais periféricas e fraturas da olivina (Fotomicrografia 15). Por vezes, forma grãos isolados, com tamanho médio de $1,0 \mathrm{~mm}$, que podem alcançar até 3,0 $\mathrm{mm}$. Na microssonda, ele é identificado como katoforita, com núcleos de composição richterítica, edenítica e taramítica enriquecidos em ferro (cf. Leake, 1997). Opticamente, apresenta pleocroísmo de coloração marrom-esverdeado, verde-acastanhado escuro e verde oliva pálido, respectivamente, em Z, Y e X. Nas rochas do Morrete, a katoforita é mais magnesiana, com os núcleos dos cristais formados por ferrowinchita e as bordas por ferrobarroisita.

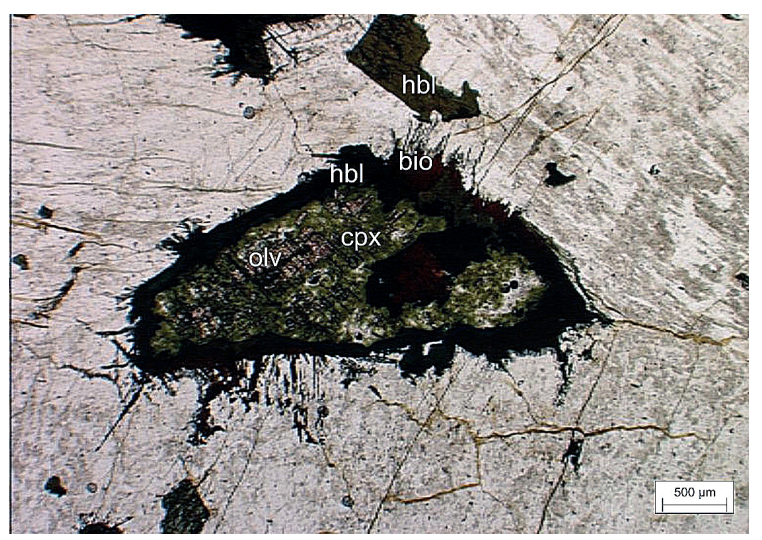

Fotomicrografia 15. Quartzo-álcali feldspato sienito: olivina (olv) substituída por clinopiroxênio (cpx) com bordas de magnesiohornblenda (hbl) e biotita (bio). Polarizadores paralelos. Amostra 35.

A biotita aparece como placas de ocorrência isolada ou então associada às bordas e fraturas de anfibólio e olivina; ocasionalmente, forma uma coroa nos opacos. Exibe pleocroísmo de coloração laranja claro a intenso, laranja-acastanhado a verde-acastanhado e marrom-avermelhado, respectivamente, em Z, Y e X. Comumente, contém inclusões de opacos, apatita e zircão (Fotomicrografia 16). A olivina está presente em pequena concentração. Ocorre na forma de cristais arredondados hipidiomórficos, com granulação de $0,4 \mathrm{~mm}$, muitas vezes alterados para iddingsita(?) ou parcial a totalmente substituídos por clinopiroxênio e anfibólio (Fotomicrografias 15 e 17).

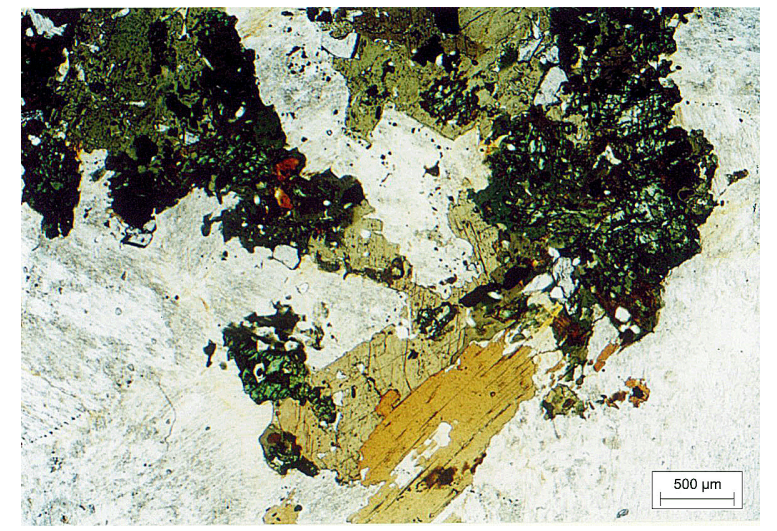

Fotomicrografia 16. Quartzo-álcali feldspato sienito: cristal de katoforita com grãos de clinopiroxênio no centro e biotita associada às suas bordas. Na biotita, nota-se halo pleocróico causado pela inclusão de zircão. Polarizadores paralelos. Amostra 1B.

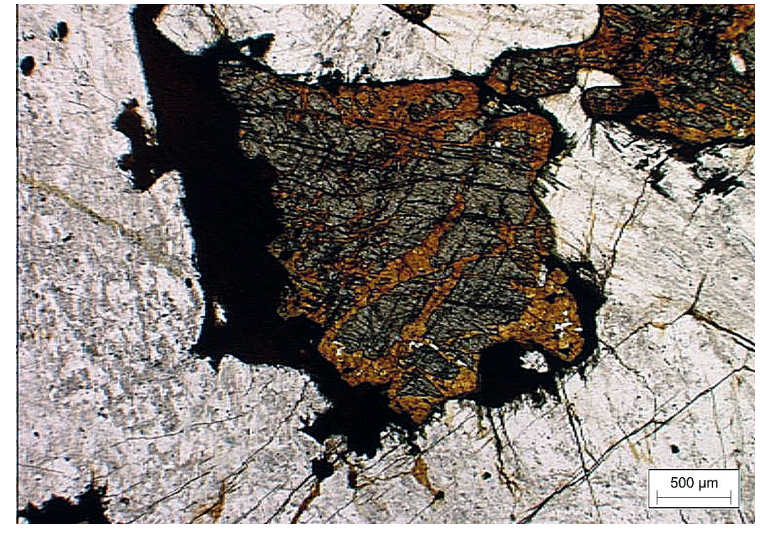

Fotomicrografia 17. Quartzo-álcali feldspato sienito: olivina com magnesiohornblenda e biotita associada às bordas e fraturas do cristal. Polarizadores paralelos. Amostra 15A.

O quartzo é xenomórfico e ocupa vazios intergranulares, além de conter inclusões de máficos e de opacos. Aparece intercrescido com o feldspato alcalino (Fotomicrografia 12) e associado às bordas de anfibólio (Fotomicrografia 14). Apatita é sempre idiomórfica, de hábito prismático, e dimensões não superiores a $0,4 \mathrm{~mm}$. Aparece na forma de pequenas inclusões nos minerais 
principais, mas também está presente como grãos isolados.

Ainda na condição de acessórios distinguem-se opacos (titanomagnetita e ilmenita), titanita e zircão. Eles mostram tendência ao idiomorfismo e constituem grãos isolados ou então aparecem associados a outros minerais, notadamente as fases máficas acima. Lamelas finíssimas de ilmenita são comuns na titanomagnetita, mas registra-se também em alguns casos a presença de cristais homogêneos de ilmenita.

\subsection{Quartzo-álcali feldspato sienitos porfiríticos de matriz fina}

Este litotipo é formado por rochas de estrutura maciça, textura porfirítica, e matriz fanerítica fina em mosaico; a cor é cinza a cinza-esverdeado. Ao microscópio, essas rochas exibem também textura traquítica, com a matriz de granulação variável, 0,1 a $0,3 \mathrm{~mm}$, mostrando-se orientada face à disposição dos cristais tabulares de feldspato. Anfibólio é o principal máfico, biotita ocorre raramente, enquanto que clinopiroxênio e olivina não foram identificados. Opacos, titanita, zircão e apatita são as fases acessórias.

Os fenocristais de feldspato alcalino são idiomórficos, alongados com o eixo principal entre 0,7 a $1,0 \mathrm{~mm}$ e razão comprimento/largura média de 6:1. A maioria dos cristais exibe intercrescimento micropertítico, que ora ocupa toda a extensão do cristal, ora limita-se apenas às suas bordas ou ainda concentra-se nas partes centrais. Estas últimas áreas, quando analisadas com objetiva de maior aumento, permitem reconhecer microlamelas de distribuição regular. Por outro lado, apenas os fenocristais menores apresentam textura mesopertítica na quase totalidade do grão (Fotomicrografias 18 e 19). Os fenocristais possuem geminação do tipo Carlsbad, bem como se mostram zonados com inclusões de anfibólio, biotita e opacos. Alteram-se secundariamente em argilominerais e têm suas fraturas preenchidas por sericita, caolinita e carbonatos.

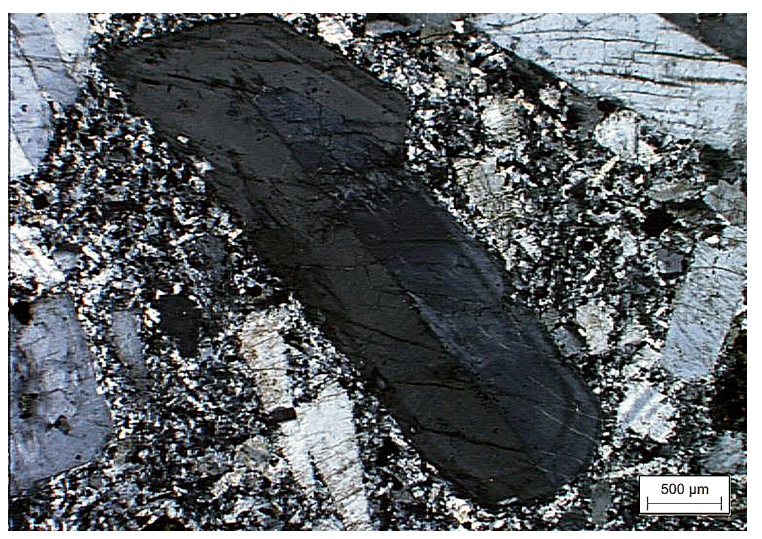

Fotomicrografia 18. Quartzo-álcali feldspato sienito porfirítico de matriz fina: fenocristal de feldspato alcalino zonado com porções pertíticas e homogêneas. Os fenocristais menores são totalmente mesopertíticos. Polarizadores cruzados. Amostra 53.

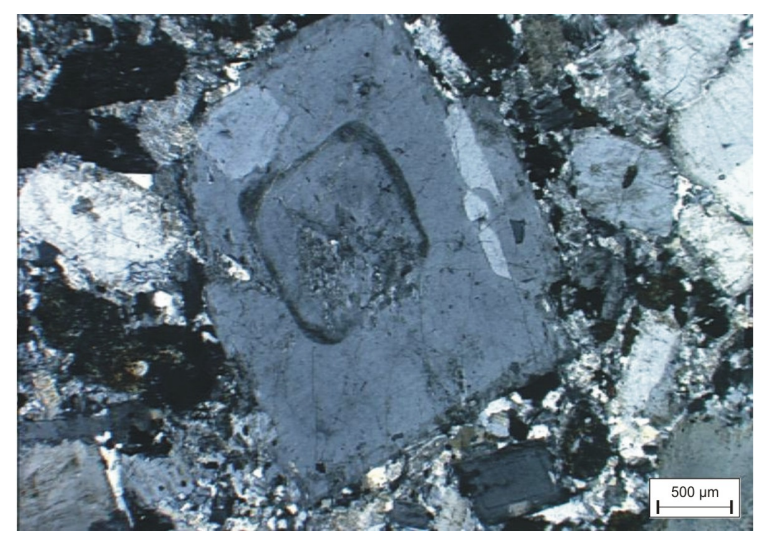

Fotomicrografia 19. Quartzo-álcali feldspato sienito porfirítico de matriz fina: fenocristal de feldspato alcalino zonado apresentando fase mesopertita no centro e sódica na borda do cristal. No canto direito superior, observam-se cristais de feldspato com borda pertítica e centro mais homogêneo (fase sódica). Polarizadores cruzados. Amostra 53.

O feldspato da matriz é hipidiomórfico a xenomórfico, com cristais mostrando comprimento variado, de 0,1 a 0,3 $\mathrm{mm}$, que alcança ocasionalmente 0,4 $\mathrm{mm}$. Exibe bordas serrilhadas e, mais raramente, encontra-se geminado segundo a lei de Carlsbad. Tem como inclusões anfibólio, biotita e opacos. Por vezes, aparece sericitizado e caolinizado.

O anfibólio é a fase máfica mais abundante. Em geral, o mineral está presente como cristais 
hipidiomórficos e xenomórficos que se dispõem em agregados intersticiais. Por vezes, forma grãos isolados, com tamanho médio de 0,5 $\mathrm{mm}$, que podem chegar até $3,0 \mathrm{~mm}$. Na microssonda, observase que a fase corresponde a uma magnesiokatoforita, podendo conter núcleos formados por ferrowinchita e bordas por ferrobarroisita. Opticamente, exibe pleocroísmo de coloração marromesverdeado, verde-acastanhado escuro e verde oliva pálido, respectivamente, em Z, Y e X.

A biotita é rara e aparece na forma de grãos irregulares ou placóides, de ocorrência isolada, associados às bordas do anfibólio e dos opacos, ou então como inclusões nos minerais principais. Apresenta pleocroísmo de coloração laranja claro, laranja-acastanhado a verde-acastanhado e marrom-avermelhado, respectivamente, em Z, Y e X.

O quartzo é xenomórfico, de tamanho inferior a 0,2 mm, e ocorre preenchendo espaços intersticiais da matriz. Os opacos são idiomórficos e estão presentes na forma de agregados, como inclusões nos constituintes principais ou ainda concentrados junto às bordas de cristais de anfibólio. Muitas vezes os agregados estão circundados por grãos de biotita (Fotomicrografia 20). A fase dominante é uma titanomagnetita, com finas lamelas de ilmenita; este último mineral aparece também como cristais de composição homogênea.

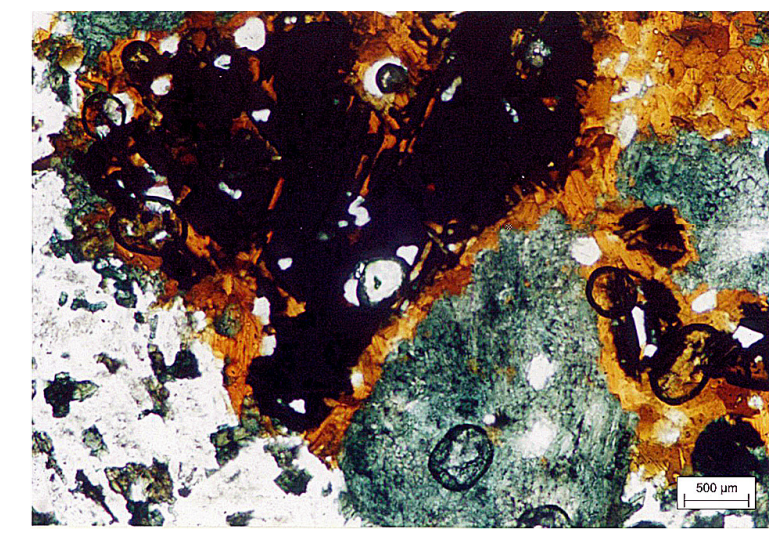

Fotomicrografia 20. Quartzo-álcali feldspato sienito porfirítico: agregado de ilmenita com biotita nas bordas. Polarizadores paralelos. Amostra 50.

Apatita é idiomórfica, prismática e com dimensões não superiores a $0,4 \mathrm{~mm}$. Ocorre na forma de inclusões nos minerais principais, mas também como grãos isolados ao lado dos fenocristais de feldspato alcalino.

Ainda na condição de acessórios, reconhecem-se titanita e zircão. Eles mostram tendência ao idiomorfismo e formam pequenos grãos isolados ou então ocorrem como inclusões nas fases félsicas e máficas acima. 


\subsection{Microssienitos com textura em mosaico}

São rochas de estrutura maciça, granulação fina, hipidiomórfica a alotriomórfica e de coloração cinza claro a escuro. Ao microscópio, exibem textura do tipo mosaico definida pelo arranjo dos cristais de feldspato alcalino, o seu mineral mais abundante (Fotomicrografia 21). É possível também notar que os minerais estão discretamente orientados (Fotomicrografia 22).

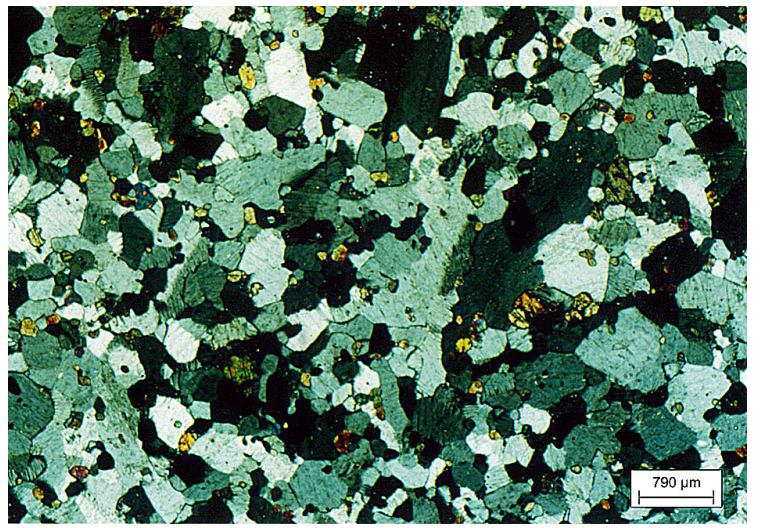

Fotomicrografia 21. Microssienito com textura em mosaico: feldspato alcalino, quartzo e clinopiroxênio representam as principais fases minerais presentes. Polarizadores cruzados. Amostra 19.

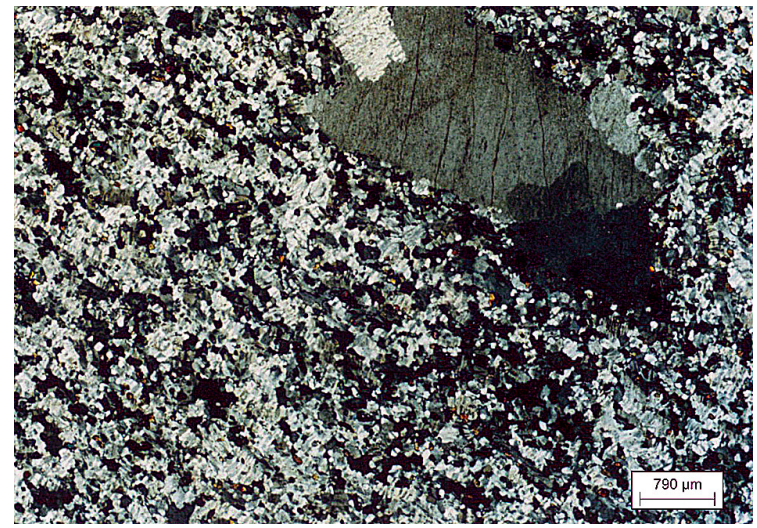

Fotomicrografia 22. Microssienito com textura em mosaico: cristais de feldspato alcalino, clinopiroxênio e quartzo dispostos seguindo discreta orientação; vê-se também raro megacristal de feldspato alcalino. Polarizadores cruzados. Amostra 12

O feldspato alcalino ocorre como cristais hipidiomórficos a xenomórficos e de dimensões variáveis entre 0,1 e 0,4 mm; eventualmente, alguns grãos podem atingir até $0,7 \mathrm{~mm}$ e raros megacristais medir até $3,0 \mathrm{~mm}$. O mineral é encontrado na forma de cristais micropertíticos, embora a ocorrência de fases mesopertíticas, geminadas ou não segundo a lei de Carlsbad, seja mais comum. As bordas do mineral são retilíneas a irregulares quando em contato com os cristais vizinhos (Fotomicrografia 21).

As estruturas de exsolução são bem semelhantes às descritas nos álcali feldspato sienitos e quartzo-álcali feldspato sienitos, sendo possível reconhecer três fases distintas (micropertítica a mesopertítica, sódica e potássica), as duas últimas mais abundantes.

A fase micropertítica a mesopertítica caracteriza-se por mostrar exsoluções que variam de micropertitas, de aparência homogênea e com lamelas muito finas $(<2 \mu \mathrm{m})$, observadas somente com polarizadores cruzados e objetiva de maior aumento, a mesopertitas com lamelas de até $10 \mu \mathrm{m}$.

As fases sódica e potássica, produtos da desmisturação dos componentes alcalinos Ab-Or, constituem as porções mais irregulares da exsolução das pertitas. Elas se distribuem de modo aleatório ou estão concentradas nas margens dos grãos. A fase sódica, de aspecto límpido, ocupa principalmente as porções mais externas do cristal, enquanto que a potássica, de aparência mais turva, situa-se na maioria das vezes no seu interior.

O plagioclásio, presente em pequena concentração, é xenomórfico e de dimensões variando entre 0,1 e 0,2 mm. Contém inclusões de clinopiroxênio e apatita, ao lado de exibir evidências de alteração deutérica (saussuritização e caolinização).

No grupo dos máficos, augita e egirina-augita ocorrem como cristais hipidiomórficos a xenomórficos, com dimensões variáveis entre 0,1 e 0,4 mm. Algumas vezes, estão associados às bordas da olivina (Fotomicrografia 23). O mineral é pleocróico com Z=verde garrafa, $Y=v e r d e-$ 
amarelado claro a verde e $\mathrm{X}=$ verde claro a verde.

A olivina está presente em pequena quantidade, aparecendo como cristais hipidiomórficos de granulação atingindo até 0,4 mm (Fotomicrografia 23).

O quartzo é também xenomórfico, porém mais abundante que o plagioclásio. Forma cristais com dimensões entre 0,1 e 0,7 mm, que preenchem vazios intersticiais (Fotomicrografia 24).

Opacos, apatita e sulfetos são os acessórios mais comuns. Os opacos estão presentes como cristais hipidiomórficos a xenomórficos, isolados ou formando agregados próximos aos grãos de clinopiroxênio, preenchendo vazios intergranulares ou ainda como inclusões das fases principais (Fotomicrografia 24).

A apatita, de hábito acicular, ocorre na forma de inclusões nos grãos de feldspato e de clinopiroxênio, enquanto que a pirita é xenomórfica e preenche espaços intersticiais podendo englobar parcialmente os cristais de feldspato alcalino.

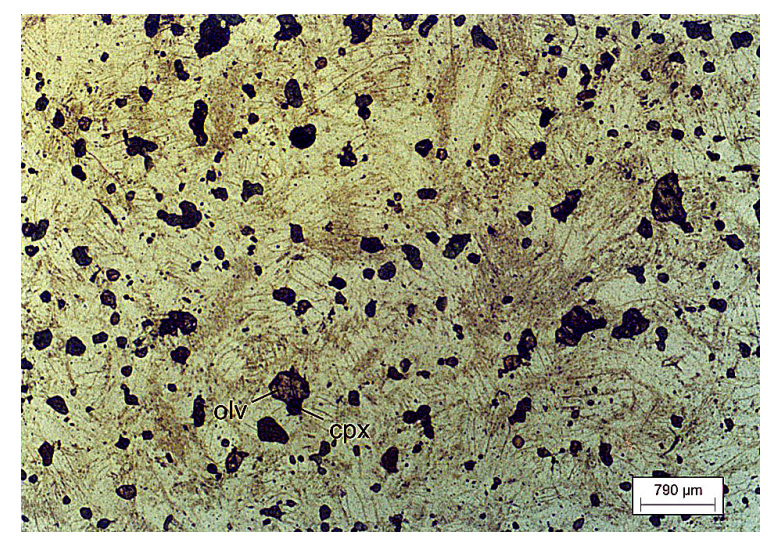

Fotomicrografia 23. Microssienito com textura em mosaico: feldspato alcalino com microestrutura de exsolução (cristais mais claros da fase sódica), clinopiroxênio (cpx) como grãos hipidiomórficos isolados e presentes na borda de cristal de olivina (olv). O quartzo é intergranular e apresenta aspecto mais límpido. Polarizadores paralelos. Amostra 18.

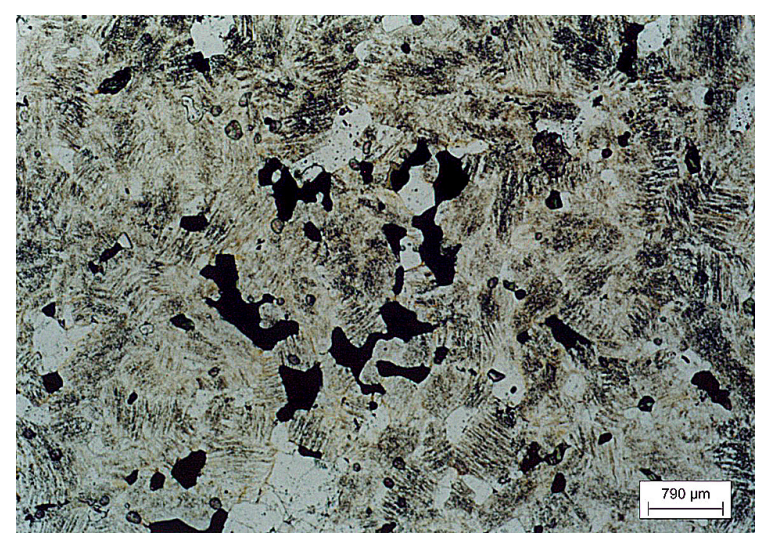

Fotomicrografia 24. Microssienito com textura em mosaico: feldspato alcalino apresentando microestruturas de intercrescimento pertítico (fases pertítica, sódica e potássica), clinopiroxênio hipidiomórfico, além de quartzo e opacos intersticiais. Polarizadores paralelos. Amostra 37.

\subsection{Microssienitos porfiríticos com textura traquítica}

Este litotipo apresenta estrutura maciça e textura porfirítica, com fenocristais de feldspato alcalino de até $1,0 \mathrm{~cm}$ de comprimento imersos em matriz de granulação fina a muito fina. A coloração é comumente cinza-esverdeado escuro. Ao microscópio, essas rochas exibem arranjo traquítico dado pela orientação dos cristais tabulares de feldspato alcalino e dos prismas de clinopiroxênio (Fotomicrografia 25). A matriz pode exibir orientação diferente quando em contato com os fenocristais de feldspato alcalino (Fotomicrografia 26). Ela é composta de feldspato micropertítico e quartzo intergranular, o último em menor quantidade. $O$ feldspato possui hábito tabular, com os cristais se mostrando idiomórficos a xenomórficos e de dimensões variadas $(0,2$ a $0,4 \mathrm{~mm})$, além de geminados segundo a lei de Carlsbad. Contém inclusões de anfibólio, biotita e opacos, bem como evidências de sericitização e caolinização.

Os fenocristais de feldspato alcalino são pertíticos, de hábito tabular e idiomórficos, com o eixo principal atingindo 0,7 a $1,0 \mathrm{~mm}$ de comprimento e eventualmente $13,0 \mathrm{~mm}$; a razão comprimento/largura média é de 6:1. A maioria dos fenocristais possui estrutura mesopertítica que ocupa a quase totalidade do grão ou apenas as suas bordas. Reconhecem-se também núcleos de aspecto pertítico, além de homogêneos (Fotomicrografia 26), mas que são em realidade constituídos 
por finíssimas lamelas regularmente distribuídas. Os fenocristais contêm inclusões de anfibólio, biotita e opacos, bem como exibem evidências de alteração secundária e fraturas preenchidas por sericita, caolinita e carbonatos. Em uma única lâmina foi observado cristal de plagioclásio, xenomórfico, com $1,8 \mathrm{~mm}$ de comprimento, apresentando bordas de reação, inclusões de clinopiroxênio e fraturas preenchidas com carbonatos (Fotomicrografia 27). Pelas suas características morfológicas, o mineral parece ser um xenocristal, resultante seja da contribuição de magma mais básico, seja da assimilação de minerais ou mesmo fragmentos da rocha encaixante.

O clinopiroxênio pertence à série egirina-augita, tem dimensões inferiores às do feldspato e ocorre como cristais prismáticos idiomórficos a xenomórficos (Fotomicrografia 28), ou então na forma de agregados intersticiais. É pleocróico, com coloração verde esmeralda em Z e verde claro em X.

A biotita é rara e, quando presente, está associada às bordas do clinopiroxênio ou aparece como inclusões nos minerais principais. O quartzo é xenomórfico, de tamanho inferior a 0,7 mm, e ocorre preenchendo vazios intersticiais. Opacos idiomórficos e apatita de hábito acicular representam as fases acessórias.

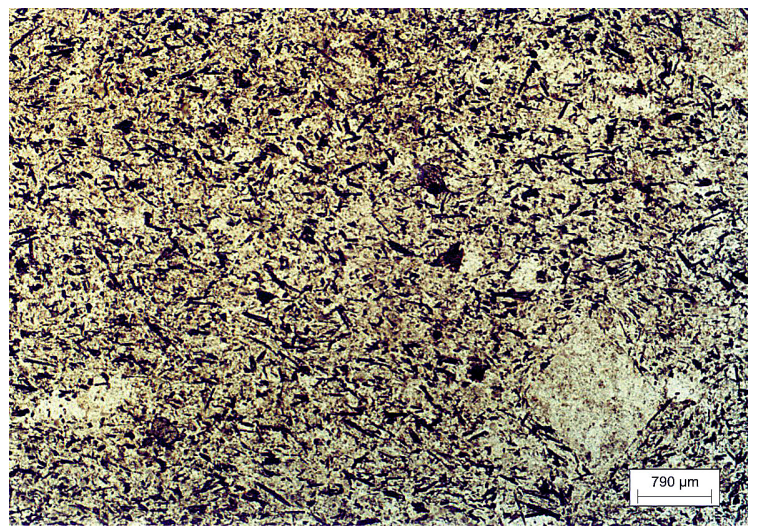

Fotomicrografia 25. Microssienito com textura traquítica porfiritica: matriz formada por cristais de feldspato alcalino e clinopiroxênio prismáticos ligeiramente orientados, caracterizando uma textura de fluxo. Próximo ao fenocristal de feldspato, a matriz apresenta-se pouco orientada. Polarizadores paralelos. Amostra 9B.

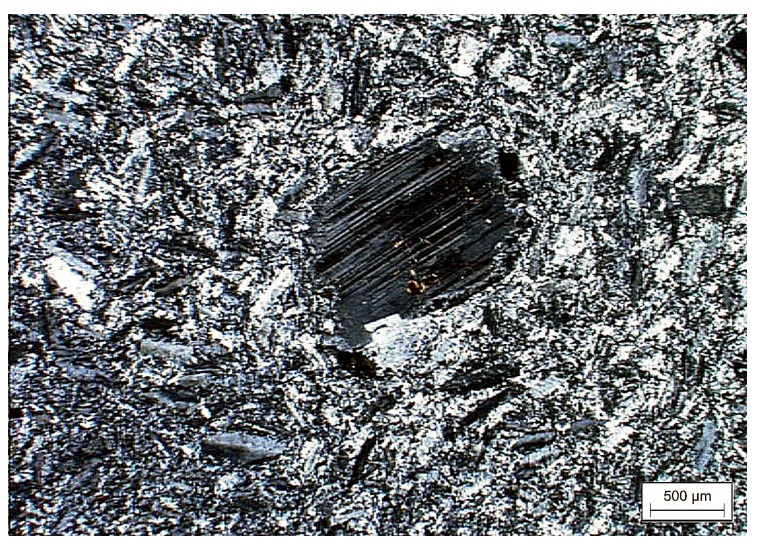

Fotomicrografia 27. Microssienito com textura traquítica porfirítica: feldspato alcalino e clinopiroxênio prismático formando a matriz. No centro, fenocristal de plagioclásio xenomórfico bordejado por albita, inclusão de clinopiroxênio e alterações secundárias. Polarizadores cruzados. Amostra 18.

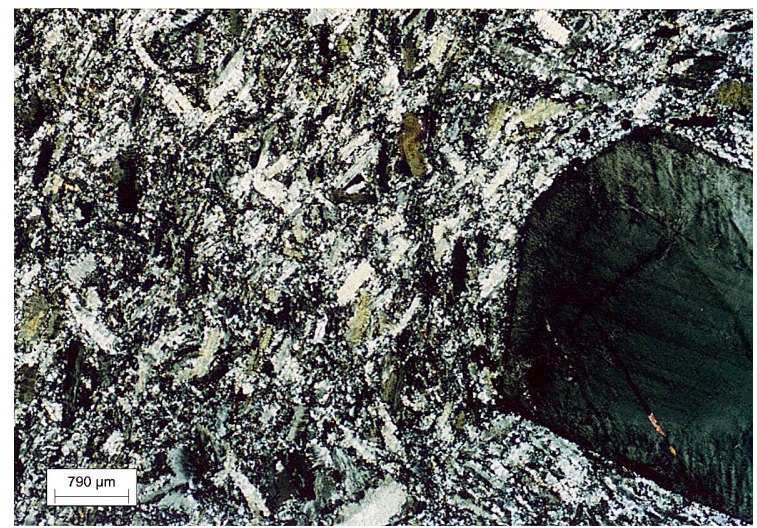

Fotomicrografia 26. Microssienito com textura traquítica porfirítica: matriz composta por cristais de feldspato alcalino e ripas de clinopiroxênio. A matriz assume orientação diversa quando em contato com o fenocristal de feldspato alcalino. Este apresenta borda pertítica e núcleo homogêneo. Polarizadores cruzados. Amostra 9B.

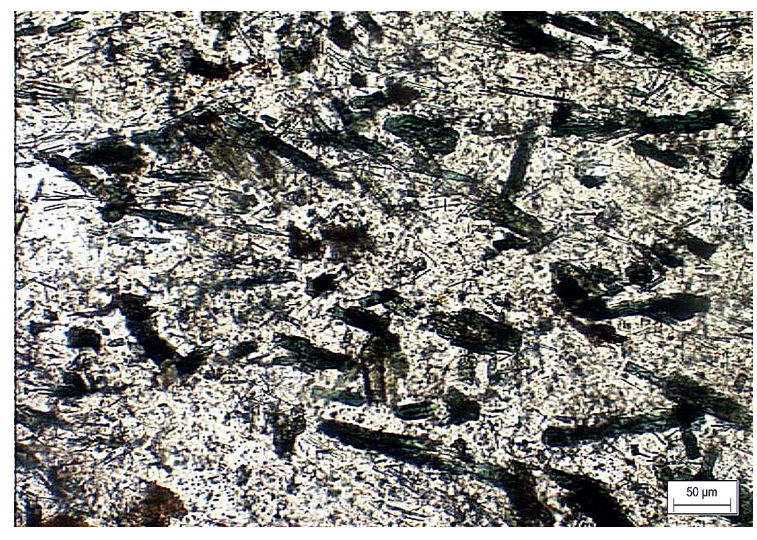

Fotomicrografia 28. Microssienito com textura traquítica porfiritica: cristais prismáticos de clinopiroxênio. À esquerda, observa-se uma porção mais límpida constituída por quartzo com inclusões de clinopiroxênio. Polarizadores paralelos. Amostra 18. 


\subsection{Seqüência de cristalização}

A seqüência de cristalização dos minerais das rochas alcalinas de Cananéia iniciou-se pelos acessórios (apatita, opacos, zircão e titanita) e, em seguida, pelos máficos. As relações texturais indicam que a cristalização da biotita foi posterior à do anfibólio e, sem qualquer sombra de dúvida, à do clinopiroxênio. Uma segunda geração de opacos é visivelmente posterior à formação da biotita e dispõe-se em especial ao longo dos seus planos de clivagem. Por outro lado, não é possível concluir se a cristalização da olivina (reliquiar) foi concomitante ou não à do clinopiroxênio.

Já a cristalização dos félsicos (feldspato alcalino e plagioclásio) se deu logo depois dos máficos. Nas rochas caracteristicamente porfiríticas, contudo, os fenocristais de feldspato alcalino são de cristalização precoce, antecedendo, assim, a formação dos ferromagnesianos. Por último, segregouse o quartzo, ocupando invariavelmente os interstícios dos demais minerais da rocha.

Os processos de alteração tardi e pós-magmática poderiam explicar as texturas de substituição encontradas nos principais minerais primários, assim como as estruturas de exsolução presentes no feldspato e a transformação por "oxi-redução" da titanomagnetita em ilmenita. 


\section{QUÍMICA MINERAL}

\subsection{Feldspatos}

As 160 análises químicas de feldspato alcalino e de plagioclásio das rochas de Cananéia estão reunidas nas Tabelas 2 a 5, juntamente com a fórmula estrutural desses minerais e as proporções moleculares dos componentes Ab (albita), An (anortita) e Or (ortoclásio). As análises foram projetadas em diagramas ternários com os componentes moleculares expressos como $\mathrm{Ab}\left(\mathrm{NaAlSi}_{3} \mathrm{O}_{8}\right)$, $\mathrm{An}$ $\left(\mathrm{CaAl}_{2} \mathrm{Si}_{2} \mathrm{O}_{8}\right)$ e $\mathrm{Or}\left(\mathrm{KAISi}_{3} \mathrm{O}_{8}\right)$.

Os feldspatos alcalinos apresentam lamelas de exsolução com formas as mais variadas e são compostos, em sua maioria, de três fases opticamente distintas: micropertítica a mesopertítica, sódica e potássica. A primeira é caracterizada pela presença de micropertitas com lamelas sódicas, quase imperceptíveis (braind pertitas) a muito finas $(<2 \mu \mathrm{m})$, a mesopertitas com lamelas de até $10 \mu \mathrm{m}$ de largura. As fases sódica e potássica representam produtos de dissolução dos componentes Ab-Or e formam porções irregulares e lamelas interpenetradas, originadas a partir de processos deutéricos. A disposição dessas lamelas é aleatória, ocupando preferencialmente as bordas dos minerais; nos casos em que a exsolução se deu por completo elas são pouco notadas.

Com base na natureza do feldspato, tem-se que a maioria das litologias sieníticas de Cananéia é interpretada como sendo do tipo hipersolvus, pois apresenta apenas a fase pertítica; contudo, algumas delas contêm duas fases, a pertítica e a sódica, enquadrando-se, assim, no tipo subsolvus.

Os feldspatos alcalinos dos diversos litotipos exibem ampla variação composicional, passando de ortoclásio puro até albita pura (Figs. 8A, C-F). Os cristais hospedeiros da pertita têm composição $\mathrm{Or}_{96-}$ ${ }_{60}$ enquanto os hóspedes $A b_{95-74}$. Algumas análises da fase exsolvida mostram teores de Or e $A b$ inferiores a esse intervalo (até $\mathrm{Or}_{55}$ e $A b_{56}$ ), fato aparentemente devido a problemas de interação do feixe eletrônico com as duas fases, levando à análise simultânea do hóspede e hospedeiro. Problema semelhante é observado nas análises das fases sódica e potássica, onde as lamelas de exsolução estão presentes em dimensões submicroscópicas.

Variação composicional do centro para a borda dos cristais é pouco significativa; quando presente, registra-se em geral um aumento do componente Or junto às porções periféricas do mineral. Zoneamento inverso, com as bordas mais enriquecidas em Ab, é também reconhecido, como no caso de fenocristais dos quartzo-álcali feldspato sienitos do Morrete.

Quimicamente, os feldspatos alcalinos contêm Ca (até 0,805 a.f.u.), além de traços de Mn (até 0,011 a.f.u.) e $\mathrm{Ba}$ (até 0,045 a.f.u.). $\mathrm{Fe}^{3+}$ (até 0,550 a.f.u.) e $\mathrm{Ti}$ (até 0,025 a.f.u.) substituem o $\mathrm{Al}$ completando o sítio tetraédrico. Em geral, esses minerais contêm baixo teor de $\mathrm{Sr}$, não detectado pela microssonda.

Os plagioclásios estão presentes nos álcali feldspato sienitos e menos comumente nos quartzoálcali feldspato sienitos (Fig. 8B); em geral, exibem geminação albita, combinada com a das leis do periclínio e Carlsbad. São pouco zonados e têm composição dominantemente sódica, ainda que por vezes se mostrem mais cálcicos. 

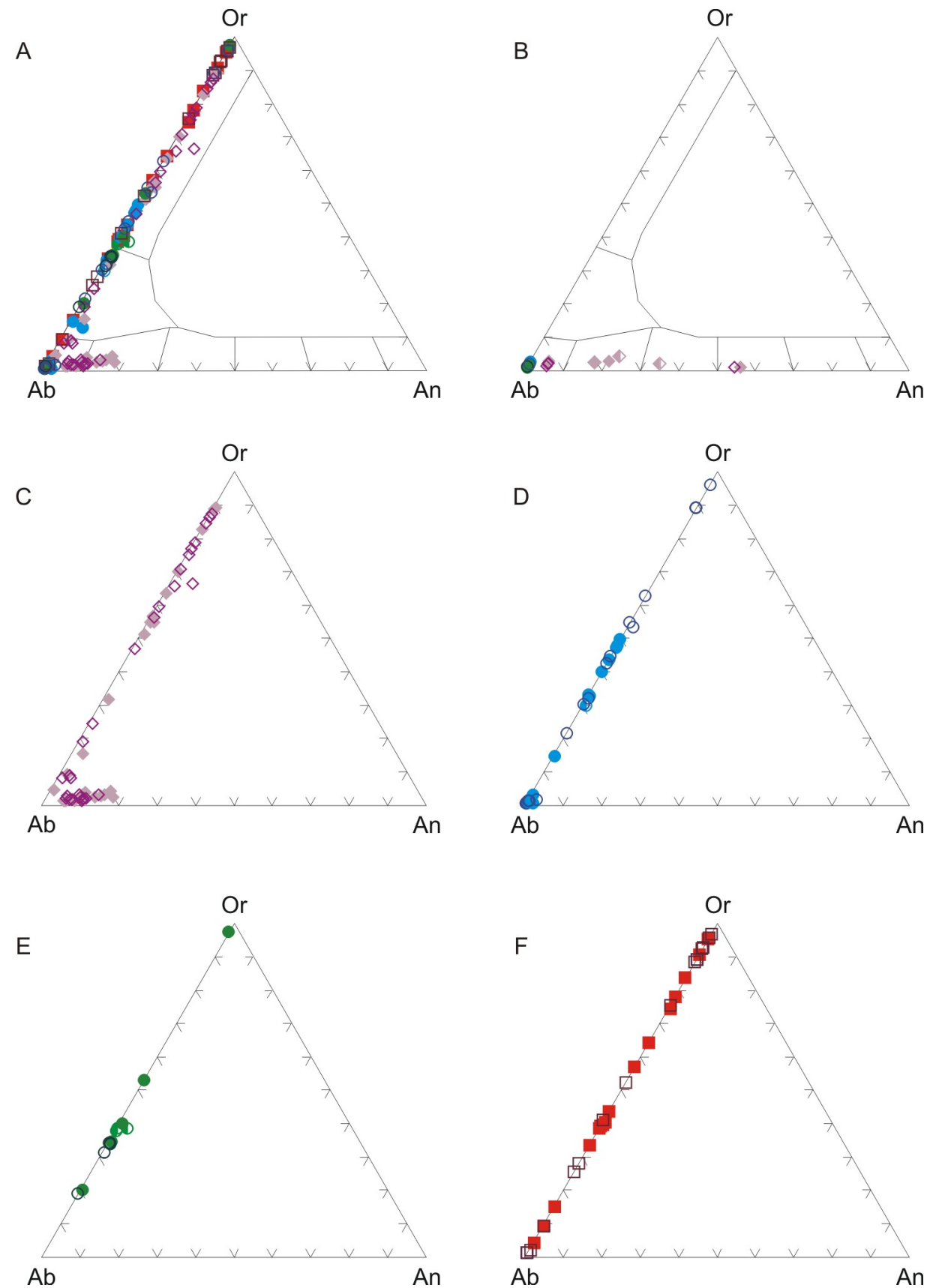

Figura 8. Variação composicional dos feldspatos alcalinos (A, C, D, E, F) e plagioclásios (B), expressa em proporções moleculares de Ab-Or-An para as rochas de Cananéia. Legenda: lilás, azul e vermelho: Morro de São João; verde: Morrete; álcali feldspato sienitos: $(\diamond)$ centro, $(\diamond)$ borda, $(\diamond)$ região intermediária; quartzo-álcali feldspato sienitos: $(\bigcirc)$ centro, $(0)$ borda, (D) região intermediária; quartzo-álcali feldspato sienitos porfiríticos: $(0)$ centro, $(0)$ borda, $(\mathbb{O})$ região intermediária;

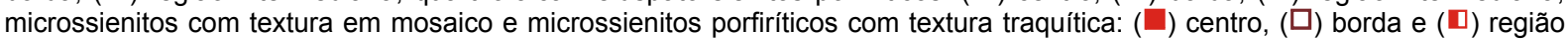
intermediária. 
Tabela 2. Composição química de feldspatos alcalinos e plagioclásios dos álcali feldspato sienitos do Morro de São João. Abreviações: c, b, i, respectivamente, centro, borda e região intermediária dos cristais; p, pertita; h, hospedeiro; lam, lamela hóspede; incl, inclusão; pl, plagioclásio; f, fenocristal; m, matriz; v, veio. n.d., não detectado.

\begin{tabular}{|c|c|c|c|c|c|c|c|c|c|c|c|c|c|c|c|c|c|}
\hline \multirow{4}{*}{\multicolumn{2}{|c|}{\begin{tabular}{l|} 
Amostra \\
Cristal-Análise \\
Localização \\
Mineral
\end{tabular}}} & $28 B$ & $28 B$ & $28 B$ & $28 B$ & $28 B$ & $28 B$ & $28 B$ & $28 B$ & $33 B$ & $33 B$ & $33 B$ & $33 B$ & $33 B$ & $33 B$ & $33 B$ & $33 B$ \\
\hline & & 1-01 & 1-02 & $2-03$ & 2-04 & 3-05 & 3-06 & 4-07 & $4-08$ & 5-09 & $5-10$ & $6-11$ & $6-12$ & $7-13$ & 7-14 & $8-15$ & 8-16 \\
\hline & & b & c & b & c & b & c & b & C & b & $\mathrm{c}$ & $\mathrm{b}$ & $\mathrm{c}$ & b & $\mathrm{c}$ & $\mathrm{b}$ & c \\
\hline & & p & $\mathrm{p}$ & $\mathrm{pl}$ & $\mathrm{pl}$ & $\mathrm{p}$ & $\mathrm{p}$ & lam & $\mathrm{h}$ & $\mathrm{p}$ & $\mathrm{p}$ & $\mathrm{p}$ & $\mathrm{p}$ & lam & $\mathrm{h}$ & lam & h \\
\hline \multirow{2}{*}{\multicolumn{2}{|c|}{$\begin{array}{l}\mathrm{SiO}_{2} \\
\mathrm{TiO}_{2}\end{array}$}} & 67,30 & 65,17 & 54,20 & 54,69 & 64,02 & 63,44 & 63,77 & 65,30 & 68,38 & 65,52 & 62,94 & 66,21 & 67,50 & 65,89 & 66,81 & 66,23 \\
\hline & & n.d. & 0,05 & 0,08 & 0,05 & 0,05 & 0,05 & n.d. & 0,04 & 0,02 & n.d. & 0,18 & n.d. & 0,04 & n.d. & 0,04 & n.d. \\
\hline \multicolumn{2}{|l|}{$\mathrm{Al}_{2} \mathrm{O}_{3}$} & 20,55 & 22,10 & 28,89 & 29,27 & 18,21 & 18,26 & 23,06 & 19,03 & 18,94 & 20,98 & 17,31 & 18,66 & 20,62 & 18,37 & 18,61 & 18,42 \\
\hline \multirow{2}{*}{\multicolumn{2}{|c|}{$\begin{array}{l}\mathrm{Fe}_{2} \mathrm{O}_{3} \\
\mathrm{MnO}\end{array}$}} & 0,16 & 0,15 & 0,02 & 0,08 & 0,77 & 1,50 & 0,11 & 0,08 & 0,18 & 0,13 & 3,94 & 0,17 & 0,09 & 0,39 & 0,45 & 0,23 \\
\hline & & 0,02 & n.d. & n.d. & 0,02 & n.d. & 0,88 & 0,03 & 0,06 & n.d. & n.d. & 0,09 & 0,01 & 0,04 & n.d. & n.d. & n.d. \\
\hline \multicolumn{2}{|l|}{$\mathrm{CaO}$} & 1,44 & 3,05 & 11,03 & 11,48 & 0,08 & 0,44 & 4,27 & 0,29 & 0,13 & 0,19 & 1,11 & 0,06 & 1,59 & 0,03 & 0,13 & 0,03 \\
\hline \multicolumn{2}{|l|}{$\mathrm{BaO}$} & n.d. & 0,12 & n.d. & 0,02 & 0,25 & 0,23 & 0,24 & 0,63 & 0,19 & 0,20 & 0,33 & 0,14 & 0,07 & 0,21 & 0,20 & 0,10 \\
\hline \multicolumn{2}{|l|}{$\mathrm{Na}_{2} \mathrm{O}$} & 10,73 & 9,66 & 5,10 & 4,97 & 2,56 & 3,31 & 8,81 & 3,69 & 9,30 & 7,40 & 2,96 & 4,93 & 10,41 & 1,37 & 4,93 & 3,33 \\
\hline \multicolumn{2}{|l|}{$\mathrm{K}_{2} \mathrm{O}$} & 0,29 & 0,57 & 0,14 & 0,17 & 13,08 & 10,91 & 0,46 & 11,28 & 3,39 & 5,29 & 10,74 & 9,85 & 0,23 & 14,75 & 9,78 & 11,91 \\
\hline \multirow{2}{*}{\multicolumn{2}{|c|}{ Total }} & 100,50 & 100,86 & 99,47 & 100,75 & 99,02 & 99,02 & 100,75 & 100,40 & 100,54 & 99,70 & 99,60 & 100,02 & 100,57 & 101,00 & 100,95 & 100,25 \\
\hline & & \multicolumn{16}{|c|}{ Fórmula estrutural calculada na base de 32 oxigênios } \\
\hline \multirow[t]{5}{*}{$\mathrm{T}$} & & 11,751 & 11,415 & 9,828 & 9,801 & 11,898 & 11,775 & 11,213 & 11,888 & 12,031 & 11,705 & 11,688 & 11,984 & 11,764 & 12,011 & 11,989 & 12,029 \\
\hline & $\mathrm{Ti}$ & 0,000 & 0,006 & 0,011 & 0,007 & 0,007 & 0,007 & 0,000 & 0,005 & 0,003 & 0,000 & 0,025 & 0,000 & 0,005 & 0,000 & 0,005 & 0,000 \\
\hline & Al & 4,226 & 4,559 & 6,168 & 6,178 & 3,985 & 3,991 & 4,776 & 4,079 & 3,923 & 4,415 & 3,786 & 3,977 & 4,232 & 3,944 & 3,932 & 3,940 \\
\hline & $\mathrm{Fe}^{3+}$ & 0,021 & 0,019 & 0,003 & 0,011 & 0,108 & 0,210 & 0,015 & 0,011 & 0,024 & 0,017 & 0,550 & 0,023 & 0,011 & 0,053 & 0,060 & 0,031 \\
\hline & $\Sigma_{\mathrm{T}}$ & 15,998 & 15,999 & 16,010 & 15,997 & 15,998 & 15,983 & 16,004 & 15,983 & 15,981 & 16,137 & 16,049 & 15,984 & 16,012 & 16,008 & 15,986 & 16,000 \\
\hline \multirow[t]{6}{*}{ M1 } & $\mathrm{Mn}$ & 0,003 & 0,000 & 0,001 & 0,003 & 0,000 & 0,139 & 0,004 & 0,010 & 0,000 & 0,000 & 0,014 & 0,002 & 0,006 & 0,000 & 0,000 & 0,000 \\
\hline & $\mathrm{Ca}$ & 270 & 572 & 2,143 & 2,205 & 015 & 0,088 & 0,805 & & 0,025 & 36 & 222 & 12 & & & 0,0 & 0,007 \\
\hline & $\mathrm{Ba}$ & 0,000 & 008 & 0,000 & 0,002 & 0,018 & 0,017 & 0,016 & 0,045 & 0,013 & 0,014 & 0,024 & 0,010 & 0,005 & 0,015 & 0,014 & 0,007 \\
\hline & $\mathrm{Na}$ & 3,633 & 3,281 & 1,794 & 1,728 & 0,923 & & 3,004 & & 3,174 & 2,565 & & & & & & 1,171 \\
\hline & $\mathrm{K}$ & 0,065 & 0,128 & 0,033 & 0,039 & 3,102 & 2,582 & 0,104 & 2,619 & 0,761 & 1,205 & 2,545 & 2,274 & 0,051 & 3,43 & 2,239 & 2,760 \\
\hline & $\Sigma_{\mathrm{M} 1}$ & 3,971 & 3,989 & 3,971 & 3,977 & 4,058 & 4,016 & 3,933 & 4,033 & 3,973 & 3,820 & 3,871 & 4,029 & 3,875 & 3,935 & 3,993 & 3,945 \\
\hline \multicolumn{2}{|c|}{ Total de cátions } & 19,969 & 19,988 & 19,981 & 19,974 & 20,056 & 19,999 & 19,937 & 20,016 & 19,954 & 19,957 & 19,920 & 20,013 & 19,887 & 19,943 & 19,979 & 19,945 \\
\hline \multicolumn{18}{|c|}{ Componentes moleculares } \\
\hline \multirow{2}{*}{\multicolumn{2}{|c|}{$\begin{array}{l}A b \\
A n\end{array}$}} & 91,56 & & & & 22,85 & 30,83 & 76,77 & & 80,15 & 67,39 & 27,81 & 43,09 & 91,02 & 12,35 & 43,13 & 29,74 \\
\hline & & 6,80 & 14,37 & 53,98 & 55,51 & 0,37 & 2,28 & 20,57 & 1,41 & 0,63 & 0,95 & 5,79 & 0,30 & 7,66 & 0,13 & 0,60 & 0,18 \\
\hline \multicolumn{2}{|l|}{ Or } & 1,64 & 3,22 & 0,83 & 0,98 & 76,78 & 66,89 & 2,66 & 65,84 & 19,22 & 31,66 & 66,40 & 56,61 & 1,32 & 87,53 & 56,27 & 70,09 \\
\hline
\end{tabular}

\begin{tabular}{|c|c|c|c|c|c|c|c|c|c|c|c|c|c|c|c|c|c|}
\hline \multirow{4}{*}{\multicolumn{2}{|c|}{$\begin{array}{l}\text { Amostra } \\
\text { Cristal-Análise } \\
\text { Localização } \\
\text { Mineral } \\
\end{array}$}} & $33 B$ & $33 B$ & $33 B$ & $33 B$ & 33B & $33 B$ & $33 B$ & $33 B$ & $33 B$ & $33 B$ & $33 B$ & $33 B$ & 33B & $33 B$ & $33 B$ & $\begin{array}{r}32 B \\
\end{array}$ \\
\hline & & $9-17$ & $9-18$ & $10-19$ & $10-20$ & $11-21$ & $11-22$ & $12-23$ & $12-24$ & 13-25 & $13-26$ & $14-27$ & $14-28$ & $15-29$ & $15-30$ & $15-31$ & $16-32$ \\
\hline & & b & c & b & c & b & C & b & C & b & C & b & c & b & $\mathrm{i}$ & c & b \\
\hline & & $p$ & $p$ & $p$ & $p$ & $p$ & $p$ & lam & $\mathrm{h}$ & lam & $\mathrm{h}$ & $p$ & $p$ & $\mathrm{pl}$ & $\mathrm{pl}$ & $\mathrm{pl}$ & $p$ \\
\hline \multirow{2}{*}{\multicolumn{2}{|c|}{$\begin{array}{l}\mathrm{SiO}_{2} \\
\mathrm{TiO}_{2}\end{array}$}} & 65,50 & 65,49 & 66,21 & 68,10 & 66,69 & 68,30 & 67,63 & 66,07 & 66,48 & 65,04 & 67,38 & 67,37 & 67,80 & 67,05 & 66,79 & 66,22 \\
\hline & & n.d. & n.d. & 0,01 & n.d. & 0,05 & n.d. & n.d. & 0,07 & 0,03 & n.d. & n.d. & 0,04 & 0,12 & 0,06 & 0,01 & 0,03 \\
\hline \multicolumn{2}{|l|}{$\mathrm{Al}_{2} \mathrm{O}_{3}$} & 18,61 & 18,46 & 21,59 & 20,19 & 19,93 & 19,44 & 18,85 & 19,15 & 20,43 & 18,17 & 19,76 & 19,83 & 19,92 & 19,70 & 19,87 & 20,66 \\
\hline \multirow{2}{*}{\multicolumn{2}{|c|}{$\begin{array}{l}\mathrm{Fe}_{2} \mathrm{O}_{3} \\
\mathrm{MnO}\end{array}$}} & 0,64 & 0,19 & 0,38 & 0,38 & 0,99 & 0,11 & 0,10 & 0,12 & 0,17 & 0,05 & 0,11 & 0,08 & n.d. & 0,13 & 0,11 & 0,51 \\
\hline & & 0,02 & 0,02 & n.d. & n.d. & 0,02 & 0,03 & n.d. & n.d. & n.d. & 0,01 & n.d. & 0,03 & n.d. & n.d. & 0,28 & 0,01 \\
\hline \multicolumn{2}{|l|}{$\mathrm{CaO}$} & 0,06 & n.d. & 0,65 & 1,08 & 1,30 & 0,58 & 0,16 & 0,09 & 1,01 & 0,01 & 0,92 & 1,12 & 1,07 & 1,02 & 1,03 & 1,85 \\
\hline \multirow{2}{*}{\multicolumn{2}{|c|}{$\begin{array}{l}\mathrm{BaO} \\
\mathrm{Na}_{2} \mathrm{O}\end{array}$}} & 0,35 & 0,35 & n.d. & 0,11 & n.d. & 0,17 & 0,04 & 0,14 & n.d. & 0,25 & n.d. & 0,13 & n.d. & n.d. & 0,06 & 0,03 \\
\hline & & 2,35 & 1,25 & 10,25 & 10,73 & 10,57 & 9,42 & 5,34 & 3,20 & 10,46 & 1,21 & 11,03 & 10,65 & 10,68 & 10,88 & 10,99 & 10,11 \\
\hline \multicolumn{2}{|l|}{$\mathrm{K}_{2} \mathrm{O}$} & 13,29 & 15,13 & 0,64 & 0,26 & 0,29 & 2,69 & 8,74 & 11,99 & 0,48 & 15,28 & 0,20 & 0,71 & 0,33 & 0,26 & 0,25 & 0,42 \\
\hline \multicolumn{2}{|l|}{ Total } & 100,81 & 100,89 & 99,72 & 00,85 & 99,83 & 100,74 & 100,85 & 100,83 & 99,06 & 100,02 & 99,39 & 99,96 & 99,92 & 99,10 & 99,39 & 99,85 \\
\hline \multirow{6}{*}{$\mathrm{T}$} & & & & & & Fórmula & estrutura & calculad & na base & de 32 ox & yênios & & & & & & \\
\hline & $\mathrm{Si}$ & 11,936 & 11,986 & 11,636 & 11,837 & 11,749 & 11,964 & 12,048 & & 11,763 & 12,009 & 11,872 & 11,845 & 11,866 & 11,856 & 11,806 & 11,664 \\
\hline & $\mathrm{Ti}$ & 0,001 & 0,000 & 0,001 & 000 & 0,006 & 0,000 & & 010 & 0,003 & 0,000 & 0,000 & 005 & 0,016 & 0,008 & 0,001 & 0,005 \\
\hline & $\mathrm{Al}$ & 3,993 & 3,979 & 4,470 & 4,132 & 4,134 & 4,012 & 3,954 & 4,074 & 4,256 & 3,951 & 4,100 & 4,105 & 4,106 & 4,102 & 4,137 & 4,286 \\
\hline & $\mathrm{Fe}^{3+}$ & 0,087 & 0,026 & 0,050 & 0,050 & 0,131 & 0,015 & 0,013 & 0,017 & 0,023 & 0,007 & 0,014 & 0,011 & 0,013 & 0,018 & 0,015 & 0,067 \\
\hline & $\Sigma_{T}$ & 16,017 & 15,991 & 16,157 & 16,019 & 16,020 & 15,991 & 16,015 & 16,036 & 16,045 & 15,967 & 15,986 & 15,966 & 16,001 & 15,984 & 15,959 & 16,022 \\
\hline \multirow[t]{6}{*}{ M1 } & $\mathrm{Mn}$ & 003 & 003 & 000 & 000 & 0,003 & 0,005 &, 000 & 000 & 0,000 & 0,002 & 0,000 & 04 & 0,000 &, 000 & 0,042 & 0,002 \\
\hline & $\mathrm{Ca}$ & 011 & 000 & 0,122 & 201 & 0,244 & 0,109 & 0,030 & 0,017 & 0,192 & 0,002 & 0,174 & 0,210 & 0,201 & 0,192 & 195 & 0,349 \\
\hline & $\mathrm{Ba}$ & 025 & 025 & 0,000 & 007 & 0,000 & 0,011 & 0,003 & & 0,000 & ,018 & & & ,000 & & & 0,002 \\
\hline & $\mathrm{Na}$ & 830 & 442 & 3,493 & 618 & 3,611 & 3,201 & 1,846 & 1,122 & 3,590 & 0,433 & 3,767 & 3,632 & 3,625 & 3,731 & ,767 & 3,453 \\
\hline & $\mathrm{K}$ & & & & & & & & & & & & & & & & 0,094 \\
\hline & $\Sigma_{\mathrm{M} 1}$ & 958 & 4,002 & 3,759 & 3,883 & 3,923 & 3,927 & 3,865 & 3,912 & 3,891 & 4,055 & 3,986 & 4,014 & 3,900 & 3,982 & 4,064 & 3,900 \\
\hline \multicolumn{2}{|c|}{ Total de cátions } & 19,975 & 19,993 & 19,916 & 19,902 & 19,943 & 19,918 & 19,880 & 19,948 & 19,936 & 20,022 & 19,972 & 19,980 & 19,901 & 19,966 & 20,023 & 19,922 \\
\hline \multicolumn{18}{|c|}{ Componentes moleculares } \\
\hline$A b$ & & & & & & 92,12 & 81,85 & 47,80 & 28,75 & 92,26 & 10,73 & 94,5 & & 92,95 & 93,70 & 93,75 & 88,63 \\
\hline An & & & & & 5,19 & 6,22 & & & & $4, \varsigma$ & 0,05 & 4,37 & 5,25 & 5,15 & 4,82 & 4,85 & 8,96 \\
\hline Or & & 78,60 & 88,88 & 3,83 & 1,47 & 1,66 & 15,37 & 51,42 & 70,81 & 2,80 & 89,22 & 1,13 & 3,97 & 1,90 & 1,48 & 1,39 & 2,41 \\
\hline
\end{tabular}


Tabela 2. Continuação.

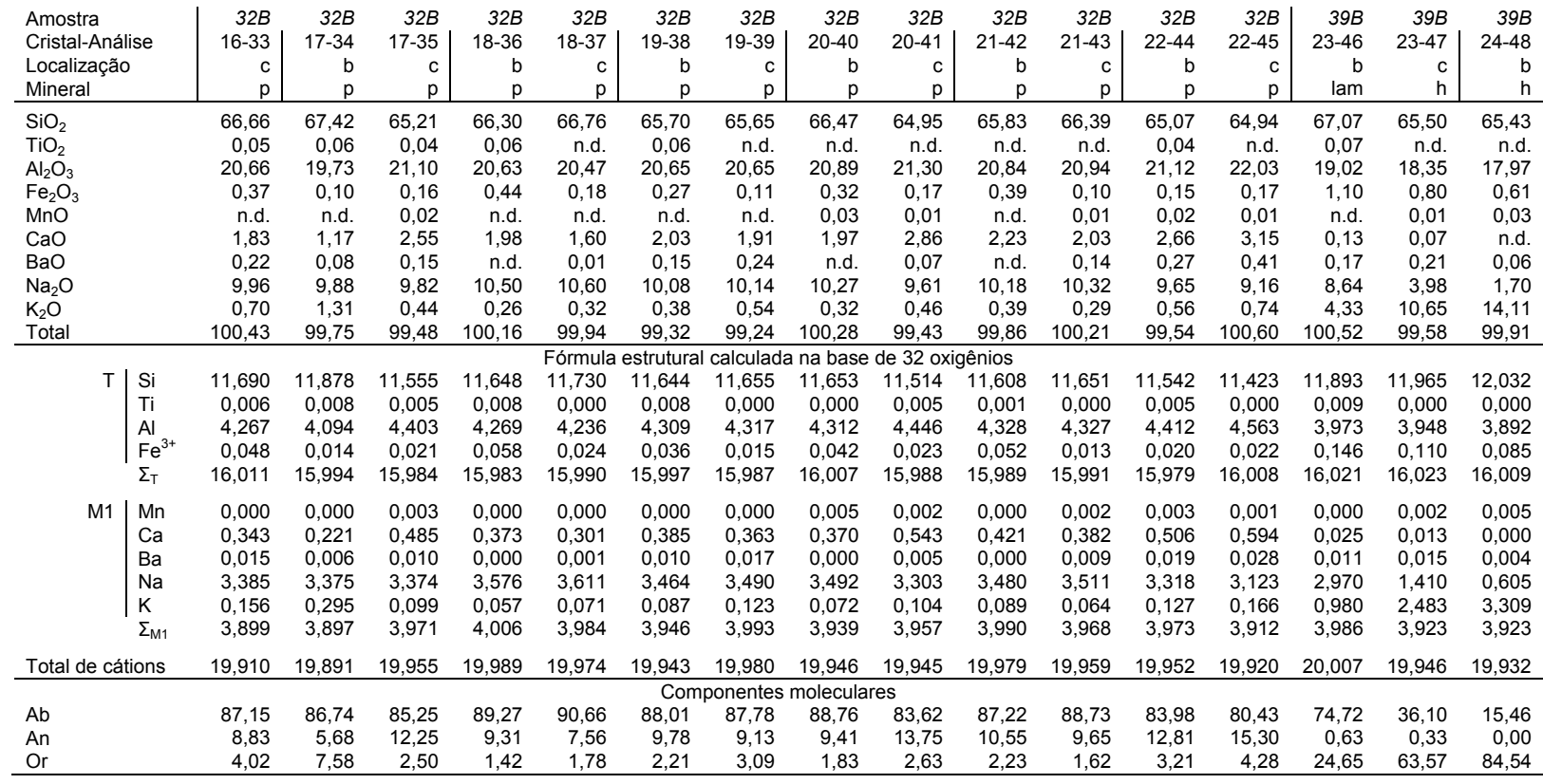

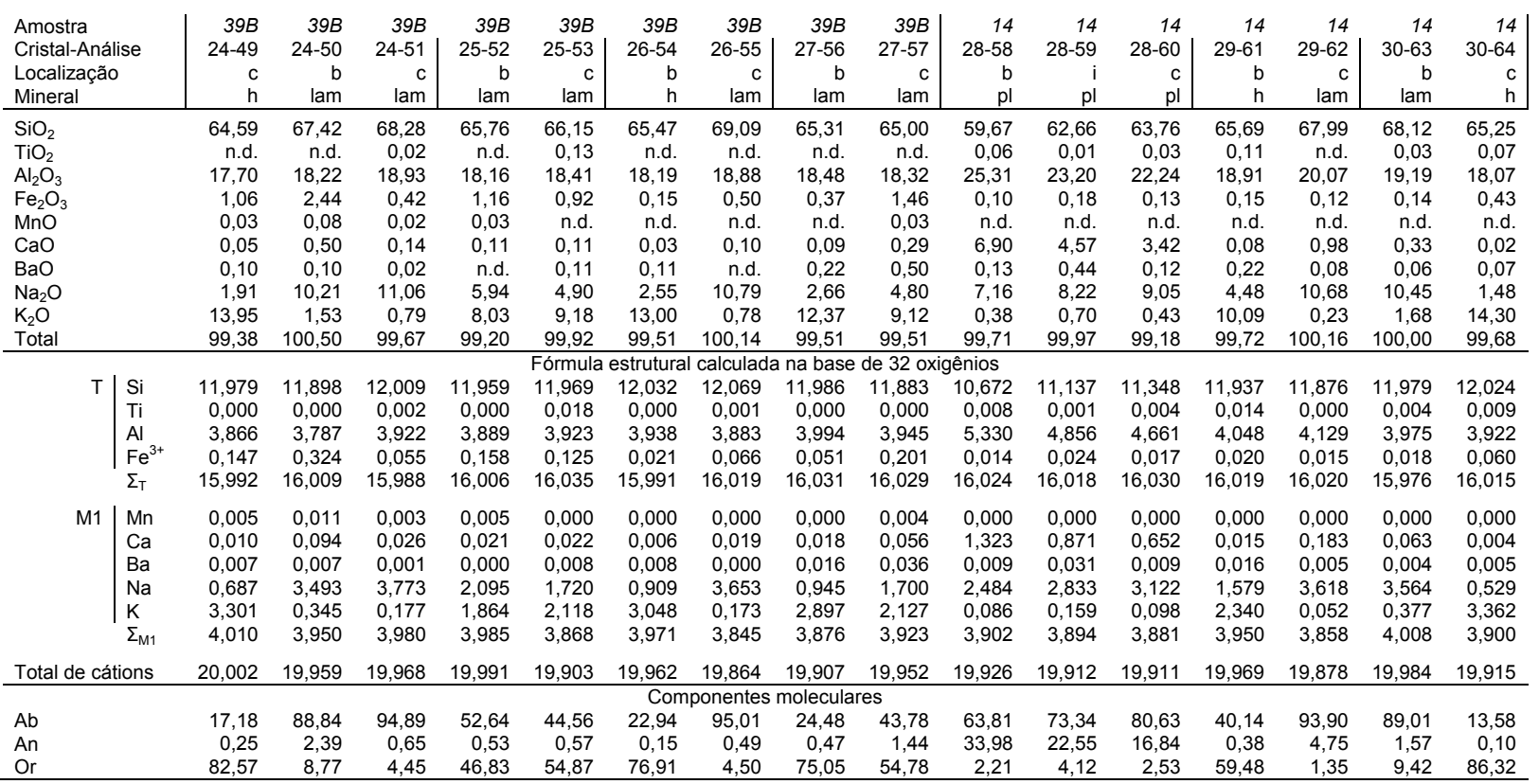


Tabela 3. Composição química de feldspatos alcalinos e plagioclásios dos quartzo-álcali feldspato sienitos do Morro de São João. Abreviações como na Tabela 2.

\begin{tabular}{|c|c|c|c|c|c|c|c|c|c|c|c|c|c|c|c|c|c|}
\hline \multirow{4}{*}{\multicolumn{2}{|c|}{$\begin{array}{l}\text { Amostra } \\
\text { Cristal-Análise } \\
\text { Localização } \\
\text { Mineral }\end{array}$}} & $1 A$ & $1 A$ & $1 A$ & $1 A$ & $1 A$ & $1 A$ & $1 A$ & $1 A$ & $1 A$ & $1 A$ & $1 A$ & $1 A$ & $1 A$ & $1 A$ & $1 A$ & $1 A$ \\
\hline & & $1-01$ & $1-02$ & $2-03$ & $2-04$ & 3-05 & 3-06 & $4-07$ & $4-08$ & $5-09$ & $5-10$ & $6-11$ & $6-12$ & $7-13$ & $7-14$ & $8-15$ & $8-16$ \\
\hline & & b & c & b & c & b & C & b & C & b & C & b & c & b & c & b & c \\
\hline & & $\mathrm{p}$ & $p$ & $p$ & $p$ & lam & $\mathrm{h}$ & lam & lam & incl & incl & $p$ & $p$ & lam & Iam & $p$ & $p$ \\
\hline \multirow{2}{*}{\multicolumn{2}{|c|}{$\begin{array}{l}\mathrm{SiO}_{2} \\
\mathrm{TiO}_{2}\end{array}$}} & 65,13 & 66,75 & 69,36 & 66,43 & 67,41 & 64,76 & 69,28 & 67,37 & 65,94 & 68,54 & 68,49 & 66,74 & 66,76 & 67,00 & 68,15 & 65,94 \\
\hline & & 0,03 & n.d. & 0,02 & n.d. & 0,03 & 0,04 & n.d. & n.d. & n.d. & n.d. & n.d. & 0,06 & 0,07 & n.d. & n.d. & 0,13 \\
\hline \multicolumn{2}{|l|}{$\mathrm{Al}_{2} \mathrm{O}_{3}$} & 17,73 & 18,47 & 19,00 & 18,14 & 18,56 & 18,21 & 18,87 & 18,61 & 18,59 & 19,47 & 19,84 & 20,03 & 18,47 & 18,21 & 18,83 & 18,14 \\
\hline \multirow{2}{*}{\multicolumn{2}{|c|}{$\begin{array}{l}\mathrm{Fe}_{2} \mathrm{O}_{3} \\
\mathrm{MnO}\end{array}$}} & 0,05 & 0,40 & 0,50 & 0,71 & 0,40 & 0,13 & 0,47 & 0,42 & 0,48 & 0,23 & 0,03 & 0,10 & 0,41 & 0,56 & 0,51 & 1,11 \\
\hline & & n.d. & 0,02 & n.d. & 0,02 & n.d. & n.d. & 0,01 & n.d. & n.d. & n.d. & n.d. & 0,03 & 0,03 & n.d. & n.d. & 0,02 \\
\hline \multicolumn{2}{|l|}{$\mathrm{CaO}$} & n.d. & 0,01 & n.d. & n.d. & n.d. & n.d. & n.d. & n.d. & 0,03 & 0,10 & 0,50 & 0,80 & n.d. & 0,02 & 0,03 & 0,01 \\
\hline \multicolumn{2}{|l|}{$\mathrm{BaO}$} & 0,13 & n.d. & 0,01 & 0,07 & n.d. & n.d. & n.d. & 0,05 & 0,05 & 0,13 & n.d. & 0,12 & 0,61 & 0,10 & 0,04 & 0,06 \\
\hline \multicolumn{2}{|l|}{$\mathrm{Na}_{2} \mathrm{O}$} & 1,18 & 5,65 & 11,26 & 5,04 & 6,29 & n.d. & 11,51 & 6,33 & 4,20 & 9,98 & 11,17 & 9,56 & 6,30 & 5,91 & 9,05 & 5,74 \\
\hline \multirow{2}{*}{\multicolumn{2}{|c|}{$\mathrm{K}_{2} \mathrm{O}$}} & 14,78 & 8,50 & 0,19 & 9,32 & 7,42 & 16,38 & 0,14 & 7,49 & 10,78 & 2,63 & 0,30 & 2,28 & 7,79 & 8,26 & 3,77 & 7,87 \\
\hline & & 99,01 & 99,79 & 100,34 & 99,72 & 100,10 & 99,52 & 100,27 & 100,26 & 100,07 & 101,08 & 100,32 & 99,72 & 100,44 & 100,05 & 100,39 & 99,02 \\
\hline \multicolumn{2}{|l|}{ Total } & & & & & Fórmula & estrutura & calculad & na base & de 32 oxi & gênios & & & & & & \\
\hline \multirow[t]{5}{*}{$\mathrm{T}$} & $\mathrm{Si}$ & 12,095 & 12,032 & 12,066 & 12,036 & 12,054 & 11,993 & 12,068 & 12,041 & 11,968 & 11,967 & 11,935 & 11,815 & 11,996 & 12,052 & 12,022 & 11,987 \\
\hline & $\mathrm{Ti}$ & 0,004 & 0,000 & 0,002 & 0,000 & 0,003 & 0,006 & 0,000 & 0,001 & 0,001 & 0,000 & 0,000 & 0,009 & 0,009 & 0,000 & 0,000 & 0,018 \\
\hline & $\mathrm{Al}$ & 3,877 & 3,920 & 3,893 & 3,871 & 3,908 & 3,972 & 3,872 & 3,916 & 3,974 & 4,003 & 4,070 & 4,176 & 3,908 & 3,859 & 3,911 & 3,883 \\
\hline & $\mathrm{Fe}^{3+}$ & 0,007 & 0,055 & 0,065 & 0,097 & 0,053 & 0,018 & 0,061 & 0,056 & 0,065 & 0,030 & 0,004 & 0,013 & 0,056 & 0,075 & 0,068 & 0,152 \\
\hline & $\Sigma_{T}$ & 15,983 & 16,007 & 16,026 & 16,004 & 16,018 & 15,989 & 16,001 & 16,014 & 16,008 & 16,000 & 16,009 & 16,013 & 15,969 & 15,986 & 16,001 & 16,040 \\
\hline \multirow[t]{6}{*}{ M1 } & $\mathrm{Mn}$ & 0,000 & 0,003 & 0,000 & 0,003 & 0,000 & 0,000 & 0,001 & 0,000 & 0,000 & 0,000 & 0,000 & 0,004 & 0,005 & 0,000 & 0,000 & 0,002 \\
\hline & $\mathrm{Ca}$ & 0,000 & 0,001 & 0,000 & 0,000 & 0,000 & 0,000 & 0,000 & 0,000 & 0,006 & 0,019 & 0,093 & 0,151 & 0,000 & 0,004 & 0,006 & 0,002 \\
\hline & $\mathrm{Ba}$ & 0,009 & 0,000 & 0,001 & 0,005 & 0,000 & 0,000 & 0,000 & 0,004 & 0,003 & 0,009 & 0,000 & 0,008 & 0,043 & 0,007 & 0,003 & 0,004 \\
\hline & $\mathrm{Na}$ & 0,424 & 1,975 & 3,798 & 1,771 & 2,181 & 0,150 & 3,886 & 2,192 & 1,479 & 3,379 & 3,773 & 3,283 & 2,196 & 2,061 & 3,097 & 2,023 \\
\hline & $\mathrm{K}$ & 3,500 & 1,954 & 0,042 & 2,154 & 1,692 & 3,870 & 0,030 & 1,707 & 2,497 & 0,587 & 0,066 & 0,515 & 1,785 & 1,895 & 0,848 & 1,825 \\
\hline & $\Sigma_{\mathrm{M} 1}$ & 3,933 & 3,933 & 3,843 & 3,933 & 3,873 & 4,024 & 3,919 & 3,906 & 3,987 & 3,994 & 3,935 & 3,964 & 4,029 & 3,967 & 3,954 & 3,856 \\
\hline \multicolumn{2}{|c|}{ Total de cátions } & 19,916 & 19,940 & 19,869 & 19,937 & 19,891 & 20,013 & 19,920 & 19,920 & 19,995 & 19,994 & 19,944 & 19,977 & 19,998 & 19,953 & 19,955 & 19,896 \\
\hline \multicolumn{18}{|c|}{ Componentes moleculares } \\
\hline $\mathrm{Ab}$ & & 10,81 & 50,25 & 98,91 & 45,12 & 56,31 & 3,73 & 99,23 & 56,22 & 37,14 & 84,79 & 95,96 & 83,13 & 55,16 & 52,05 & 78,39 & 52,55 \\
\hline An & & 0,00 & 0,03 & 0,00 & 0,00 & 0,00 & 0,00 & 0,00 & 0,00 & 0,15 & 0,48 & 2,37 & 3,82 & 0,00 & 0,10 & 0,15 & 0,05 \\
\hline Or & & 89,19 & 49,72 & 1,09 & 54,88 & 43,69 & 96,27 & 0,77 & 43,78 & 62,71 & 14,73 & 1,68 & 13,04 & 44,84 & 47,85 & 21,46 & 47,40 \\
\hline
\end{tabular}

\begin{tabular}{|c|c|c|c|c|c|c|c|c|c|c|c|c|c|c|c|c|c|}
\hline \multicolumn{2}{|c|}{ Amostra } & $22 B$ & $22 B$ & $22 B$ & $22 B$ & $22 B$ & $22 B$ & $\begin{array}{r}15 A \\
1253\end{array}$ & $\begin{array}{r}15 A \\
1254\end{array}$ & $\begin{array}{r}15 A \\
12-25\end{array}$ & $\begin{array}{r}15 A \\
1326\end{array}$ & $\begin{array}{r}15 A \\
1327\end{array}$ & $\begin{array}{r}15 A \\
148\end{array}$ & $15 A$ & $\begin{array}{r}15 A \\
15-30\end{array}$ & $\begin{array}{r}15 A \\
16-31\end{array}$ & $\begin{array}{r}15 A \\
15-32\end{array}$ \\
\hline \multicolumn{2}{|c|}{ Cristal-Análise } & $9-17$ & $9-18$ & $10-19$ & $10-20$ & $11-21$ & $11-22$ & $12-23$ & $12-24$ & $12-25$ & $13-26$ & $13-27$ & $14-28$ & $14-29$ & $15-30$ & $16-31$ & $16-32$ \\
\hline \multicolumn{2}{|c|}{ Localização } & b & & b & & b & c & b & $\mathrm{i}$ & c & b & c & b & c & b & b & c \\
\hline \multicolumn{2}{|c|}{ Mineral } & & lam & incl & incl & $\mathrm{p}$ & $\mathrm{p}$ & $\mathrm{p}$ & $\mathrm{p}$ & $\mathrm{p}$ & $p$ & $\mathrm{p}$ & $\mathrm{pl}$ & $\mathrm{pl}$ & $p$ & lam & h \\
\hline \multirow{2}{*}{\multicolumn{2}{|c|}{$\begin{array}{l}\mathrm{SiO}_{2} \\
\mathrm{TiO}_{2}\end{array}$}} & 68,26 & 67,73 & 67,92 & 68,26 & 67,59 & 67,38 & 67,74 & 67,53 & 67,22 & 67,14 & 68,69 & 68,96 & 68,56 & 66,59 & 68,39 & 68,68 \\
\hline & & n.d. & n.d. & n.d. & n.d. & n.d. & n.d. & n.d. & n.d. & n.d. & n.d. & n.d. & n.d. & n.d. & n.d. & n.d. & n.d. \\
\hline \multicolumn{2}{|l|}{$\mathrm{Al}_{2} \mathrm{O}_{3}$} & 19,28 & 19,81 & 19,13 & 19,40 & 19,18 & 19,10 & 18,99 & 19,36 & 19,39 & 19,04 & 19,68 & 19,36 & 19,38 & 19,06 & 19,47 & 19,35 \\
\hline \multirow{2}{*}{\multicolumn{2}{|c|}{$\begin{array}{l}\mathrm{Fe}_{2} \mathrm{O}_{3} \\
\mathrm{MnO}\end{array}$}} & 0,20 & 0,03 & 0,44 & 0,27 & 0,15 & 0,15 & 0,31 & 0,27 & 0,25 & 0,46 & 0,19 & 0,36 & 0,43 & 0,27 & 0,28 & 0,23 \\
\hline & & n.d. & n.d. & n.d. & 0,03 & n.d. & 0,01 & n.d. & n.d. & n.d. & 0,01 & 0,02 & n.d. & 0,02 & n.d. & n.d. & 0,04 \\
\hline \multicolumn{2}{|l|}{$\mathrm{CaO}$} & 0,06 & 0,40 & 0,04 & 0,14 & 0,08 & 0,06 & 0,03 & 0,08 & 0,25 & 0,04 & 0,30 & 0,04 & 0,12 & 0,04 & 0,12 & 0,09 \\
\hline \multirow{2}{*}{\multicolumn{2}{|c|}{$\begin{array}{l}\mathrm{BaO} \\
\mathrm{Na}_{2} \mathrm{O}\end{array}$}} & n.d. & n.d. & n.d. & 0,11 & n.d. & 0,08 & 0,05 & n.d. & 0,07 & n.d. & 0,08 & 0,02 & n.d. & n.d. & n.d. & n.d. \\
\hline & & 11,49 & 11,19 & 11,37 & 11,08 & 11,33 & 10,99 & 7,59 & 7,72 & 7,95 & 7,90 & 11,63 & 11,45 & 11,43 & 6,63 & 11,38 & 11,26 \\
\hline \multicolumn{2}{|l|}{$\mathrm{K}_{2} \mathrm{O}$} & 0,16 & 0,13 & 0,18 & 0,52 & 0,11 & 0,17 & 5,72 & 5,78 & 5,25 & 5,22 & 0,20 & 0,26 & 0,17 & 7,48 & 0,23 & 0,32 \\
\hline \multicolumn{2}{|l|}{ Total } & 99,45 & 99,29 & 99,07 & 99,82 & 98,43 & 97,94 & 100,42 & 100,75 & 100,36 & 99,80 & 100,80 & 100,44 & 00,12 & 00,06 & 99,87 & 99,97 \\
\hline \multicolumn{18}{|c|}{ Fórmula estrutural calculada na base de 32 oxigênios } \\
\hline \multirow[t]{5}{*}{$\mathrm{T}$} & $\mathrm{Si}$ & 1,992 & 11,915 & 11,986 & 11,974 & 11,989 & 12,008 & 12,012 & 11,948 & 11,927 & 11,969 & 11,935 & 12,002 & 11,975 & 11,942 & 11,970 & 12,004 \\
\hline & $\mathrm{Ti}$ & 0,000 & 0,000 & 0,000 & 0,000 & 0,000 & 0,000 & 0,000 & 0,000 & 0,000 & 0,000 & 0,000 & 0,000 & 0,000 & 0,000 & 0,000 & 0,000 \\
\hline & $\mathrm{Al}$ & 3,990 & 4,105 & 3,975 & 4,008 & 4,006 & 4,008 & 3,965 & 4,034 & 4,052 & 3,997 & 4,027 & 3,967 & 3,987 & 4,026 & 4,013 & 3,984 \\
\hline & $\mathrm{Fe}^{3+}$ & 0,026 & 0,003 & 0,058 & 0,036 & 0,019 & 0,020 & 0,042 & 0,036 & 0,033 & 0,062 & 0,025 & 0,047 & 0,057 & 0,036 & 0,037 & 0,030 \\
\hline & $\Sigma_{T}$ & 16,008 & 16,023 & 16,019 & 16,018 & 16,014 & 16,036 & 16,019 & 16,018 & 16,012 & 16,028 & 15,987 & 16,016 & 16,019 & 16,004 & 16,020 & 16,018 \\
\hline \multirow[t]{6}{*}{ M1 } & $\mathrm{Mn}$ & 000 & ,000 & 000 & ,005 & 0,000 & 001 & 0,000 & 0,000 & 0,000 & ,001 & 0,004 & 0,000 & ,003 &, 000 & 0,000 & 0,006 \\
\hline & $\mathrm{Ca}$ & 012 & 076 & 0,007 & 0,026 & 0,015 & 0,011 & 0,005 & 0,016 & 0,047 & 0,008 & 0,055 & 0,007 & 0,022 & 0,008 & 0,022 & 0,017 \\
\hline & $\mathrm{Ba}$ & 000 &, 000 & 0,000 & 0,007 & 0,000 & 006 & 0,003 & 0,000 & 0,005 & & 0,005 & 0,001 & 0,000 & 0,000 & 0,000 & 0,000 \\
\hline & $\mathrm{Na}$ & 915 & 3,818 & 3,890 & 3,767 & 3,898 & 3,799 & 2,608 & 2,649 & 2,734 & 2,732 & 3,918 & 3,863 & 3,870 & 2,304 & 3,862 & 3,814 \\
\hline & $\mathrm{K}$ & & & 0,041 & & 0,026 & & 1,294 & 1,304 & & & & 0,057 & & & 0,051 & 0,072 \\
\hline & $\Sigma_{\mathrm{M} 1}$ & 964 & 3,923 & 3,938 & 3,922 & 3,939 & 3,855 & 3,910 & 3,969 & 3,974 & 3,927 & 4,026 & 3,928 & 3,933 & 4,023 & 3,935 & 3,909 \\
\hline \multicolumn{2}{|c|}{ Total de cátions } & 19,972 & 19,946 & 19,957 & 19,940 & 19,953 & 19,891 & 19,929 & 19,987 & 19,986 & 19,955 & 20,013 & 19,944 & 19,952 & 20,027 & 19,955 & 19,927 \\
\hline \multicolumn{18}{|c|}{ Componentes moleculares } \\
\hline \multirow{2}{*}{\multicolumn{2}{|c|}{ An }} & 81 & & 98,78 & 96 & 98,96 & 98,73 & 66,75 & 66,74 & 68,88 & 69,5 & 97,54 & 98,37 & 98,47 & 57,27 & 98,14 & 97,72 \\
\hline & & 0,30 & 1,94 & 0,18 & 0,66 & 0,38 & 0,29 & 0,13 & 0,40 & 1,18 & 0,20 & 1,37 & 0,18 & 0,56 & 0,20 & 0,56 & 0,44 \\
\hline \multicolumn{2}{|l|}{ Or } & 0,88 & 0,74 & 1,04 & 2,99 & 0,66 & 0,99 & 33,12 & 32,85 & 29,93 & 30,21 & 1,10 & 1,45 & 0,97 & 42,53 & 1,30 & 1,84 \\
\hline
\end{tabular}


Tabela 4. Composição química de feldspatos alcalinos e plagioclásios dos quartzo-álcali feldspato sienitos porfiríticos do Morrete. Abreviações como na Tabela 2.

\begin{tabular}{|c|c|c|c|c|c|c|c|c|c|c|c|c|c|c|c|c|c|}
\hline \multirow{4}{*}{\multicolumn{2}{|c|}{$\begin{array}{l}\text { Amostra } \\
\text { Cristal-Análise } \\
\text { Localização } \\
\text { Mineral } \\
\end{array}$}} & 50 & 50 & 50 & 50 & 50 & 50 & 50 & 50 & 53 & 53 & 53 & 53 & 53 & 40 & 40 & 40 \\
\hline & & $1-01$ & $1-02$ & $1-03$ & $2-04$ & $2-05$ & 2-06 & 3-07 & $4-08$ & 5-09 & $5-10$ & $5-11$ & $6-12$ & $6-13$ & 7-14 & $7-15$ & $8-16$ \\
\hline & & b & $\mathrm{i}$ & c & b & i & c & b & c & b & $\mathrm{i}$ & c & b & c & c & b & b \\
\hline & & $\mathrm{f}$ & f & $\mathrm{f}$ & $f$ & $f$ & $\mathrm{f}$ & $\mathrm{m}$ & $\mathrm{m}$ & $\mathrm{f}$ & $\mathrm{f}$ & $\mathrm{f}$ & $\mathrm{m}$ & $\mathrm{m}$ & $p$ & $p$ & $p$ \\
\hline \multirow{2}{*}{\multicolumn{2}{|c|}{$\begin{array}{l}\mathrm{SiO}_{2} \\
\mathrm{TiO}_{2}\end{array}$}} & 67,41 & 65,96 & 66,18 & 66,30 & 66,21 & 65,95 & 68,78 & 67,25 & 66,90 & 66,65 & 65,63 & 62,58 & 64,77 & 66,50 & 67,26 & 66,58 \\
\hline & & & $\begin{array}{r}\text { n.d. } \\
18.84\end{array}$ & n.d. & n.d. & $\begin{array}{r}\text { n.d. } \\
1880\end{array}$ & n.d. & n.d. & n.d. & n.d. & $\begin{array}{r}\text { n.d. } \\
1873\end{array}$ & n.d. & n.d. & n.d. & n.d. & n.d. & n.d. \\
\hline $\mathrm{Al}_{2} \mathrm{O}_{3}$ & & $\begin{array}{r}18,87 \\
0,32\end{array}$ & $\begin{array}{r}18,84 \\
0,23\end{array}$ & $\begin{array}{r}18,99 \\
0,19\end{array}$ & $\begin{array}{r}18,90 \\
0,28\end{array}$ & $\begin{array}{r}18,80 \\
0,22\end{array}$ & $\begin{array}{r}18,95 \\
0,20\end{array}$ & $\begin{array}{r}18,81 \\
0,79\end{array}$ & $\begin{array}{r}19,64 \\
0,51\end{array}$ & $\begin{array}{r}18,58 \\
0,37\end{array}$ & $\begin{array}{r}18,73 \\
0,19\end{array}$ & $\begin{array}{r}19,22 \\
0,22\end{array}$ & $\begin{array}{r}17,62 \\
0,28\end{array}$ & $\begin{array}{r}18,02 \\
0,62\end{array}$ & $\begin{array}{r}19,02 \\
0,26\end{array}$ & $\begin{array}{r}19,04 \\
0,26\end{array}$ & $\begin{array}{r}18,60 \\
0,49\end{array}$ \\
\hline \multicolumn{2}{|l|}{$\begin{array}{l}\mathrm{Fe}_{2} \mathrm{O}_{3} \\
\mathrm{MnO}\end{array}$} & 0,04 & 0,01 & 0,01 & n.d. & n.d. & 0,03 & n.d. & n.d. & n.d. & n.d. & 0,01 & 0,02 & 0,01 & 0,02 & n.d. & 0,02 \\
\hline \multicolumn{2}{|l|}{$\mathrm{CaO}$} & 0,19 & 0,53 & 0,20 & 0,15 & 0,22 & 0,08 & 0,01 & 0,10 & 0,20 & 0,17 & 0,61 & n.d. & n.d. & 0,12 & 0,11 & 0,01 \\
\hline \multicolumn{2}{|l|}{$\mathrm{BaO}$} & 0,07 & n.d. & n.d. & 0,07 & 0,04 & 0,13 & n.d. & n.d. & 0,03 & 0,01 & 0,23 & 0,02 & n.d. & 0,08 & n.d. & 0,08 \\
\hline \multicolumn{2}{|l|}{$\mathrm{Na}_{2} \mathrm{O}$} & 7,45 & 6,74 & 6,79 & 7,40 & 7,08 & 7,12 & 11,41 & 11,53 & 7,44 & 6,89 & 6,47 & 0,29 & 5,21 & 7,06 & 7,68 & 9,25 \\
\hline \multicolumn{2}{|l|}{$\mathrm{K}_{2} \mathrm{O}$} & 6,04 & 6,72 & 6,98 & 5,92 & 6,48 & 6,64 & 0,19 & 0,23 & 5,93 & 6,40 & 6,47 & 16,55 & 9,01 & 6,81 & 6,08 & 3,29 \\
\hline \multirow{2}{*}{\multicolumn{2}{|c|}{ Total }} & 100,40 & 99,03 & 99,35 & 99,02 & 99,04 & 99,10 & 99,99 & 99,25 & 99,44 & 99,04 & 98,86 & 97,35 & 97,64 & 99,86 & 100,43 & 98,32 \\
\hline & & \multicolumn{16}{|c|}{ Fórmula estrutural calculada na base de 32 oxigênios } \\
\hline \multirow[t]{5}{*}{$\mathrm{T}$} & $\mathrm{Si}$ & 11,991 & 11,932 & 11,936 & 11,955 & 11,960 & 11,928 & 12,033 & 11,874 & 12,008 & 12,010 & 11,889 & 11,956 & 11,987 & 11,936 & 11,962 & 11,987 \\
\hline & $\mathrm{Ti}$ & 0,000 & 0,000 & 0,000 & 0,000 & 0,000 & 0,000 & 0,000 & 0,000 & 0,000 & 0,000 & 0,000 & 0,000 & 0,000 & 0,000 & 0,000 & 0,000 \\
\hline & $\mathrm{Al}$ & 3,953 & 4,013 & 4,034 & 4,013 & 3,999 & 4,036 & 3,876 & 4,084 & 3,926 & 3,975 & 4,100 & 3,964 & 3,927 & 4,020 & 3,988 & 3,944 \\
\hline & $\mathrm{Fe}^{3+}$ & 0,043 & 0,031 & 0,026 & 0,038 & 0,029 & 0,027 & 0,104 & 0,067 & 0,050 & 0,025 & 0,030 & 0,040 & 0,086 & 0,035 & 0,035 & 0,066 \\
\hline & $\Sigma_{T}$ & 15,987 & 15,976 & 15,996 & 16,006 & 15,988 & 15,991 & 16,013 & 16,025 & 15,984 & 16,010 & 16,019 & 15,960 & 16,000 & 15,991 & 15,985 & 15,997 \\
\hline \multirow[t]{6}{*}{ M1 } & $\mathrm{Mn}$ & 0,006 & 0,001 & 0,002 & 0,000 & 0,000 & 0,004 & 0,000 & 0,000 & 0,000 & 0,000 & 0,002 & 0,004 & 0,002 & 0,003 & 0,000 & 0,003 \\
\hline & $\mathrm{Ca}$ & 0,037 & 0,104 & 0,039 & 0,028 & 0,042 & 0,016 & 0,001 & 0,019 & 0,038 & 0,033 & 0,118 & 0,000 & 0,000 & 0,023 & 0,021 & 0,003 \\
\hline & $\mathrm{Ba}$ & 0,005 & 0,000 & 0,000 & 0,005 & 0,003 & 0,009 & 0,000 & 0,000 & 0,002 & 0,000 & 0,016 & 0,001 & 0,000 & 0,005 & 0,000 & 0,006 \\
\hline & $\mathrm{Na}$ & 2,570 & 2,365 & 2,375 & 2,588 & 2,480 & 2,495 & 3,869 & 3,947 & 2,589 & 2,407 & 2,274 & 0,107 & 1,868 & 2,456 & 2,647 & 3,229 \\
\hline & $\mathrm{K}$ & 1,371 & 1,551 & 1,606 & 1,363 & 1,494 & 1,532 & 0,043 & 0,052 & 1,357 & 1,472 & 1,496 & 4,035 & 2,128 & 1,560 & 1,380 & 0,755 \\
\hline & $\Sigma_{\mathrm{M} 1}$ & 3,989 & 4,021 & 4,022 & 3,984 & 4,019 & 4,056 & 3,913 & 4,018 & 3,986 & 3,912 & 3,906 & 4,147 & 3,998 & 4,047 & 4,048 & 3,996 \\
\hline \multicolumn{2}{|c|}{ Total de cátions } & 19,976 & 19,997 & 20,018 & 19,990 & 20,007 & 20,047 & 19,926 & 20,043 & 19,970 & 19,922 & 19,925 & 20,107 & 19,998 & 20,038 & 20,033 & 19,993 \\
\hline \multicolumn{18}{|c|}{ Componentes moleculares } \\
\hline \multicolumn{2}{|l|}{$\begin{array}{l}A b \\
A n\end{array}$} & 64,61 & 58,83 & 59,08 & 65,04 & 61,75 & 61,71 & 98,88 & 98,23 & 64,98 & 61,53 & 58,49 & 2,58 & 46,75 & 60,81 & 65,39 & 80,99 \\
\hline An & & 0,93 & 2,59 & 0,97 & 0,70 & 1,05 & 0,40 & 0,03 & 0,47 & 0,95 & 0,84 & 3,03 & 0,00 & 0,00 & 0,57 & 0,52 & 0,08 \\
\hline \multicolumn{2}{|l|}{ Or } & 34,46 & 38,58 & 39,95 & 34,25 & 37,20 & 37,89 & 1,10 & 1,29 & 34,06 & 37,63 & 38,48 & 97,42 & 53,25 & 38,62 & 34,09 & 18,94 \\
\hline
\end{tabular}

\begin{tabular}{|c|c|c|c|c|c|c|c|}
\hline \multicolumn{2}{|l|}{ Amostra } & 40 & 40 & 40 & 40 & 40 & \\
\hline \multicolumn{2}{|c|}{ Cristal-Análise } & $8-17$ & $9-18$ & $9-19$ & $10-20$ & $10-21$ & $10-22$ \\
\hline \multicolumn{2}{|c|}{ Localização } & c & b & c & b & $\mathrm{i}$ & c \\
\hline \multicolumn{2}{|l|}{ Mineral } & & $\mathrm{pl}$ & $\mathrm{pl}$ & $\mathrm{p}$ & $\mathrm{p}$ & $\mathrm{p}$ \\
\hline \multirow{2}{*}{\multicolumn{2}{|c|}{$\begin{array}{l}\mathrm{SiO}_{2} \\
\mathrm{TiO}_{2}\end{array}$}} & 67,46 & 68,88 & 68,56 & 67,24 & 67,43 & 66,79 \\
\hline & & n.d. & n.d. & n.d. & n.d. & n.d. & n.d \\
\hline & 19,10 & 19,13 & 19,57 & 18,84 & 19,12 & 18,92 \\
\hline \multirow{2}{*}{\multicolumn{2}{|c|}{$\begin{array}{l}\mathrm{Fe}_{2} \mathrm{O}_{3} \\
\mathrm{MnO}\end{array}$}} & 0,32 & 0,42 & 0,08 & 0,32 & 0,24 & 0,34 \\
\hline & & 0,01 & 0,03 & 0,01 & 0,01 & n.d. & n.d \\
\hline \multicolumn{2}{|l|}{$\mathrm{CaO}$} & 0,11 & 0,02 & 0,05 & 0,11 & 0,28 & 0,05 \\
\hline \multicolumn{2}{|l|}{$\mathrm{BaO}$} & 0,03 & 0,03 & n.d. & 0,08 & n.d. & n.d \\
\hline \multicolumn{2}{|l|}{$\mathrm{Na}_{2} \mathrm{O}$} & 9,22 & 11,59 & 11,35 & 7,77 & 9,14 & 6,79 \\
\hline \multicolumn{2}{|l|}{$\mathrm{K}_{2} \mathrm{O}$} & 3,54 & 0,22 & 0,32 & 5,43 & 3,58 & 6,90 \\
\hline \multirow[t]{2}{*}{ Total } & & 99,79 & 100,32 & 99,94 & 99,80 & 99,78 & 99,78 \\
\hline & \multicolumn{7}{|c|}{ Fórmula estrutural calculada na base de 32 oxigênios } \\
\hline \multirow[t]{5}{*}{$\mathrm{T}$} & $\mathrm{Si}$ & 11,968 & 12,012 & 11,983 & 11,999 & 11,963 & 11,978 \\
\hline & $\mathrm{Ti}$ & 0,000 & 0,000 & 0,000 & 0,000 & 0,000 & 0,000 \\
\hline & $\mathrm{Al}$ & 3,990 & 3,928 & 4,028 & 3,960 & 3,994 & 3,995 \\
\hline & $\mathrm{Fe}^{3+}$ & 0,042 & 0,055 & 0,011 & 0,043 & 0,032 & 0,045 \\
\hline & $\Sigma_{\mathrm{T}}$ & 16,000 & 15,995 & 16,022 & 16,002 & 15,989 & 16,018 \\
\hline \multirow[t]{6}{*}{ M1 } & $\mathrm{Mn}$ & 0,002 & 0,004 & 0,002 & 0,002 & 0,000 & 0,000 \\
\hline & $\mathrm{Ca}$ & 0,021 & 0,004 & 0,008 & 0,020 & 0,052 & 0,009 \\
\hline & $\mathrm{Ba}$ & 0,002 & 0,002 & 0,000 & 0,006 & 0,000 & 0,000 \\
\hline & $\mathrm{Na}$ & 3,172 & 3,920 & 3,847 & 2,687 & 3,143 & 2,361 \\
\hline & $\mathrm{K}$ & 0,801 & 0,049 & 0,071 & 1,237 & 0,810 & 1,578 \\
\hline & $\Sigma_{\mathrm{M} 1}$ & 3,998 & 3,979 & 3,928 & 3,952 & 4,005 & 3,948 \\
\hline \multicolumn{2}{|c|}{ Total de cátions } & 19,998 & 19,974 & 19,950 & 19,954 & 19,994 & 19,966 \\
\hline \multirow{2}{*}{\multicolumn{2}{|c|}{$\mathrm{Ab}$}} & & onen & molecular & & & \\
\hline & & 79,42 & 98,67 & 97,99 & 68,13 & 78,48 & 59,80 \\
\hline \multicolumn{2}{|l|}{ An } & 0,53 & 0,10 & 0,20 & 0,51 & 1,30 & 0,23 \\
\hline \multicolumn{2}{|l|}{ Or } & 20,06 & 1,23 & 1,81 & 31,36 & 20,22 & 39,97 \\
\hline
\end{tabular}


Tabela 5. Composição química de feldspatos alcalinos dos microssienitos com textura em mosaico $(37,19)$ e dos microssienitos porfiríticos com textura traquítica (30) do Morro de São João. Abreviações como na Tabela 2.

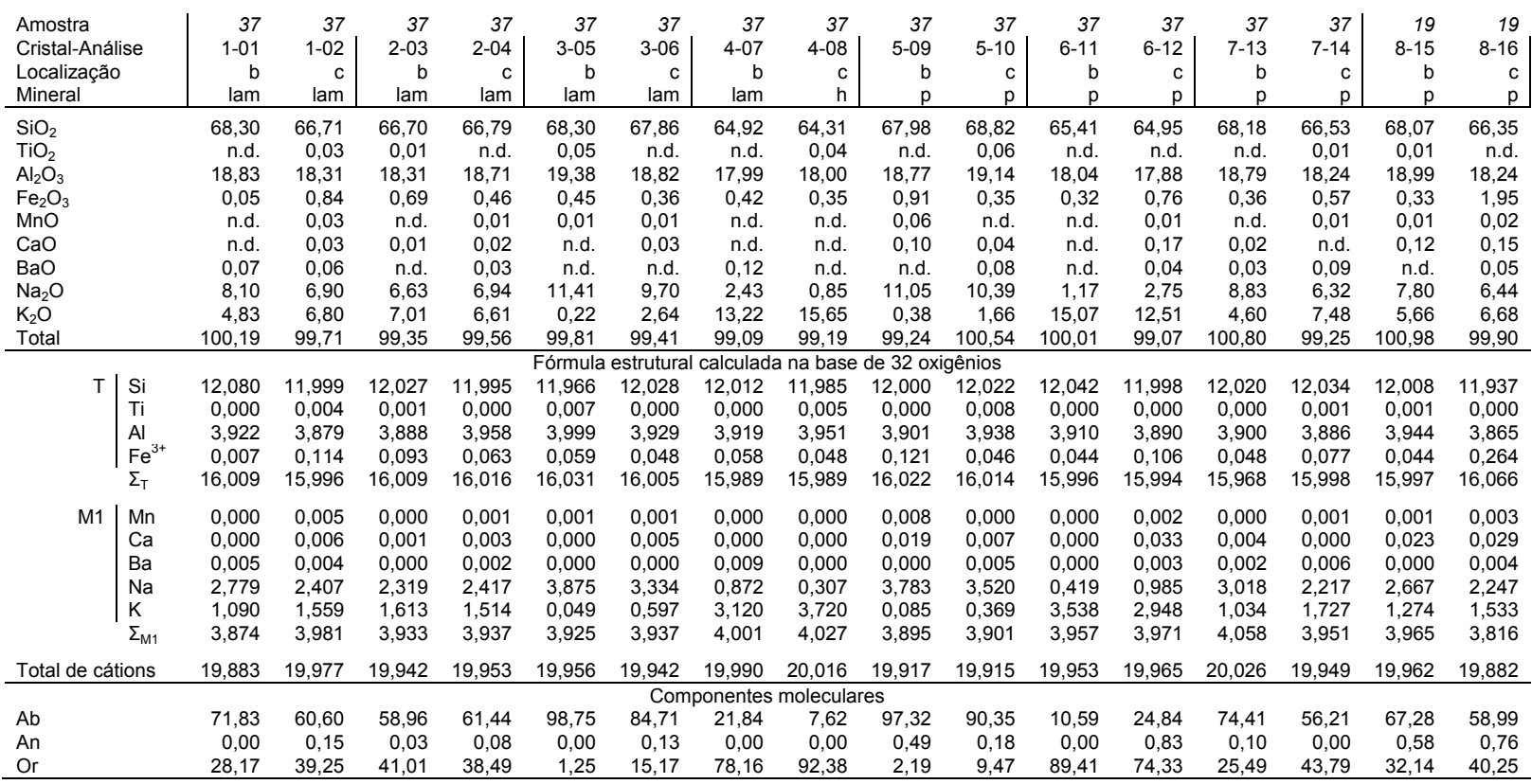

\begin{tabular}{|c|c|c|c|c|c|c|c|c|c|c|c|c|c|c|c|c|c|}
\hline \multicolumn{2}{|c|}{$\begin{array}{l}\text { Amostra } \\
\text { Cristal-Análise } \\
\text { Localização } \\
\text { Mineral } \\
\end{array}$} & $\begin{array}{r}19 \\
9-17 \\
b \\
p \\
\end{array}$ & $\begin{array}{r}19 \\
9-18 \\
c \\
p \\
\end{array}$ & $\begin{array}{r}19 \\
10-19 \\
b \\
p\end{array}$ & $\begin{array}{r}19 \\
10-20 \\
\mathrm{c} \\
\mathrm{p} \\
\end{array}$ & $\begin{array}{r}19 \\
10-21 \\
b \\
p\end{array}$ & \begin{tabular}{r|}
19 \\
$10-22$ \\
$c$ \\
$p$ \\
\end{tabular} & $\begin{array}{r}30 \\
1-01 \\
b-v \\
p \\
\end{array}$ & $\begin{array}{r}30 \\
1-02 \\
c-v \\
p \\
\end{array}$ & $\begin{array}{r}30 \\
2-03 \\
b-v \\
p \\
\end{array}$ & $\begin{array}{r}30 \\
2-04 \\
c-v \\
p \\
\end{array}$ & $\begin{array}{r}30 \\
3-05 \\
v \\
\text { lam } \\
\end{array}$ & $\begin{array}{r}30 \\
3-06 \\
\mathrm{v} \\
\text { lam } \\
\end{array}$ & $\begin{array}{r}30 \\
4-07 \\
b-v \\
\text { lam } \\
\end{array}$ & $\begin{array}{r}30 \\
4-08 \\
c-v \\
\text { lam } \\
\end{array}$ & $\begin{array}{r}30 \\
5-09 \\
b \\
p \\
\end{array}$ & $\begin{array}{r}30 \\
5-10 \\
\mathrm{c} \\
\mathrm{p} \\
\end{array}$ \\
\hline \multirow{4}{*}{\multicolumn{2}{|c|}{$\begin{array}{l}\mathrm{SiO}_{2} \\
\mathrm{TiO}_{2} \\
\mathrm{Al}_{2} \mathrm{O}_{3} \\
\mathrm{Fe}_{2} \mathrm{O}_{3} \\
\mathrm{MnO}\end{array}$}} & $\begin{array}{r}68,72 \\
\text { n.d. }\end{array}$ & $\begin{array}{r}67,13 \\
0,12\end{array}$ & $\begin{array}{r}69,43 \\
\text { n.d. }\end{array}$ & $\begin{array}{r}69,16 \\
0,08\end{array}$ & $\begin{array}{r}64,47 \\
0,02\end{array}$ & $\begin{array}{r}66,06 \\
0,04\end{array}$ & $\begin{array}{r}64,27 \\
\text { n.d. }\end{array}$ & $\begin{array}{r}65,47 \\
\text { n.d. }\end{array}$ & $\begin{array}{r}64,66 \\
\text { n.d. }\end{array}$ & $\begin{array}{r}64,65 \\
\text { n.d. }\end{array}$ & $\begin{array}{r}66,45 \\
\text { n.d. }\end{array}$ & $\begin{array}{r}65,71 \\
\text { n.d. }\end{array}$ & $\begin{array}{r}64,44 \\
\text { n.d. }\end{array}$ & $\begin{array}{r}67,53 \\
\text { n.d. }\end{array}$ & $\begin{array}{r}68,86 \\
0,05\end{array}$ & $\begin{array}{r}68,73 \\
\text { n.d. }\end{array}$ \\
\hline & & 19,12 & 18,61 & 19,24 & 19,46 & 17,94 & 18,34 & 17,81 & 18,22 & 17,51 & 17,41 & 17,88 & 17,84 & 17,63 & 18,53 & 18,72 & 18,64 \\
\hline & & 0,38 & 0,61 & 0,42 & 0,28 & 2,20 & 0,58 & 0,35 & 0,31 & 0,73 & 0,66 & 0,70 & 0,73 & 0,79 & 0,61 & 1,10 & 0,61 \\
\hline & & n.d. & n.d. & 0,01 & 0,01 & 0,02 & 0,01 & n.d. & n.d. & 0,04 & 0,03 & n.d. & n.d. & 0,02 & n.d. & n.d. & 0,01 \\
\hline \multicolumn{2}{|l|}{$\mathrm{CaO}$} & 0,08 & 0,10 & 0,09 & 0,05 & 0,06 & 0,04 & n.d. & n.d. & n.d. & n.d. & n.d. & n.d. & n.d. & 0,01 & 0,01 & n.d. \\
\hline \multirow{2}{*}{\multicolumn{2}{|c|}{$\begin{array}{l}\mathrm{BaO} \\
\mathrm{Na}_{2} \mathrm{O}\end{array}$}} & 0,03 & n.d. & n.d. & 0,10 & n.d. & n.d. & 0,01 & 0,05 & n.d. & n.d. & 0,09 & 0,03 & n.d. & 0,14 & n.d. & n.d. \\
\hline & & 10,75 & 6,64 & 11,60 & 11,02 & 2,64 & 3,94 & 0,35 & 1,86 & 1,27 & 1,04 & 5,39 & 4,89 & 0,76 & 7,67 & 11,35 & 11,53 \\
\hline \multicolumn{2}{|l|}{$\mathrm{K}_{2} \mathrm{O}$} & 1,69 & 6,66 & 0,23 & 0,77 & 12,52 & 10,91 & 16,79 & 14,49 & 14,97 & 15,32 & 9,03 & 9,91 & 15,42 & 5,88 & 0,15 & 0,16 \\
\hline \multicolumn{2}{|l|}{ Total } & 100,77 & 99,87 & 101,04 & 00,92 & 99,87 & 99,91 & 99,57 & 100,39 & 99,17 & 99,10 & 99,55 & 99,10 & 9,06 & 00,37 & 100,24 & 99,69 \\
\hline \multicolumn{18}{|c|}{ Fórmula estrutural calculada na base de 32 oxigênios } \\
\hline \multirow[t]{5}{*}{$\mathrm{T}$} & $\mathrm{Si}$ & 11,998 & 12,012 & 12,018 & 12,000 & 11,871 & 12,005 & 11,994 & 12,001 & 12,035 & 12,053 & 12,057 & 12,018 & 12,021 & 12,021 & 12,025 & 12,057 \\
\hline & $\mathrm{Ti}$ & 0,000 & 0,016 & 0,000 & 0,010 & 0,003 & 0,006 & 0,000 & 0,000 & 0,000 & 0,000 & 0,002 & 0,009 & 0,000 & 0,000 & 0,006 & 0,000 \\
\hline & Al & 3,932 & 3,922 & 3,922 & 3,976 & 3,889 & 3,924 & 3,914 & 3,933 & 3,839 & 3,824 & 3,821 & 3,843 & 3,873 & 3,884 & 3,850 & 3,852 \\
\hline & $\mathrm{Fe}^{3+}$ & 0,050 & 0,082 & 0,055 & 0,037 & 0,304 & 0,080 & 0,049 & 0,043 & 0,103 & 0,092 & 0,095 & 0,100 & 0,111 & 0,081 & 0,145 & 0,081 \\
\hline & $\Sigma_{T}$ & 15,980 & 16,032 & 15,995 & 16,023 & 16,067 & 16,015 & 15,957 & 15,977 & 15,977 & 15,969 & 15,975 & 15,970 & 16,005 & 15,986 & 16,026 & 15,990 \\
\hline \multirow[t]{6}{*}{ M1 } & $\mathrm{Mn}$ & 00 & 0 & 002 & & 0,003 & 0,002 & 0 & & 006 & & & 0,000 & 0,003 & & 0,000 & 0,001 \\
\hline & $\mathrm{Ca}$ & 15 & 019 & 0,017 & 009 & 0,011 & 0,007 & 000 & 0,000 & 000 & 000 & & 0,000 & 000 & 0,002 & & 0,000 \\
\hline & $\mathrm{Ba}$ & 02 & 000 & 0,000 & 007 & 0,000 & 0,000 & 0,001 & 0,004 & 0,000 & 0,000 & 0,007 & 0,002 & 0,000 & 0,010 & 0,000 & 0,000 \\
\hline & $\mathrm{Na}$ & 639 & 2,305 & 3,894 & 3,707 & 0,944 & 1,388 & 0,127 & 0,662 & 0,457 & 0,375 & 1,8 & 1,735 & 0,276 & 2,646 & 3,842 & 3,923 \\
\hline & & & 520 & 0,052 & & & 2,528 & & & 3,554 & & & & & & & 0,035 \\
\hline & $\Sigma_{\mathrm{M} 1}$ & 4,032 & 3,844 & 3,965 & 3,893 & 3,899 & 3,925 & 4,124 & 4,055 & 4,017 & 4,023 & 3,995 & 4,049 & 3,949 & 3,994 & 3,876 & 3,959 \\
\hline \multicolumn{2}{|c|}{ Total de cátions } & & 19,876 & 19,960 & 19,916 & 19,966 & 19,940 & 20,081 & 20,032 & 19,994 & 19,992 & 19,970 & 20,019 & 19,954 & 19,980 & 19,902 & 19,949 \\
\hline \multicolumn{18}{|c|}{ Componentes moleculares } \\
\hline$A b$ & & & & 98,26 & & & & 3,08 & & 11,39 & 9,3 & & & 6,99 & & & 99,12 \\
\hline An & & & & 0,43 & & & 18 & 0,00 & & 0,00 & 0,00 & & 0,00 & 0,00 & 0,05 & 0,03 & 0,00 \\
\hline Or & & & 39,54 & 1,31 & 4,35 & 75,49 & 64,44 & 96,92 & 83,66 & 88,61 & 90,67 & 52,43 & 57,13 & 93,01 & 33,53 & 0,85 & 0,88 \\
\hline
\end{tabular}


Tabela 5. Continuação.

\begin{tabular}{|c|c|c|c|c|c|c|c|c|c|c|c|}
\hline \multicolumn{2}{|c|}{ Amostra } & 30 & 30 & 30 & 30 & 30 & 30 & 30 & 30 & 30 & \\
\hline \multirow{2}{*}{\multicolumn{2}{|c|}{ Cristal-Análise }} & $6-11$ & $6-12$ & $7-13$ & $7-14$ & $8-15$ & $8-16$ & $9-17$ & $9-18$ & $10-19$ & $10-20$ \\
\hline & & b & c & b & c & b & c & b & c & b & \\
\hline \multicolumn{2}{|l|}{ Mineral } & $\mathrm{p}$ & $\mathrm{p}$ & $\mathrm{p}$ & $\mathrm{p}$ & $\mathrm{p}$ & $\mathrm{p}$ & $\mathrm{p}$ & $\mathrm{p}$ & $\mathrm{p}$ & \\
\hline \multirow{2}{*}{\multicolumn{2}{|c|}{$\begin{array}{l}\mathrm{SiO}_{2} \\
\mathrm{TiO}_{2}\end{array}$}} & 69,03 & 69,17 & 69,31 & 69,03 & 64,33 & 64,67 & 69,01 & 69,23 & 65,11 & 68,61 \\
\hline & & & 0,08 & n.d. & n.d. & 0,03 & n.d. & n.d. & 0,08 & 0,07 & $\begin{array}{r}0,02 \\
1886\end{array}$ \\
\hline \multirow{2}{*}{\multicolumn{2}{|c|}{$\begin{array}{l}\mathrm{Al}_{2} \mathrm{O}_{3} \\
\mathrm{Fe}_{2} \mathrm{O}_{3}\end{array}$}} & 18,72 & 18,63 & 18,80 & 18,86 & 18,08 & 18,01 & 18,64 & 19,05 & 17,78 & 18,86 \\
\hline & & 0,82 & 0,85 & 0,85 & 0,62 & 0,21 & 0,21 & 1,12 & 0,80 & 0,48 & 0,59 \\
\hline \multirow{2}{*}{\multicolumn{2}{|c|}{$\begin{array}{l}\mathrm{MnO} \\
\mathrm{CaO}\end{array}$}} & n.d. & 0,02 & 0,02 & n.d. & 0,01 & n.d. & n.d. & n.d. & 0,01 & n.d. \\
\hline & & 0,01 & n.d. & n.d. & n.d. & n.d. & n.d. & n.d. & n.d. & n.d. & 0,01 \\
\hline \multicolumn{2}{|l|}{$\mathrm{BaO}$} & n.d. & 0,01 & n.d. & n.d. & 0,01 & 0,02 & n.d. & 0,01 & 0,03 & n.d. \\
\hline \multicolumn{2}{|l|}{$\mathrm{Na}_{2} \mathrm{O}$} & 11,65 & 11,50 & 11,47 & 11,27 & 0,47 & 0,52 & 11,46 & 11,48 & 1,17 & 11,25 \\
\hline \multicolumn{2}{|l|}{$\mathrm{K}_{2} \mathrm{O}$} & 22 & 0,20 & 0,14 & 0,43 & 16,36 & 16,34 & 0,21 & 0,15 & 14,95 & 0,18 \\
\hline \multirow{2}{*}{\multicolumn{2}{|c|}{ Total }} & 100,45 & 100,48 & 100,58 & 100,21 & 99,50 & 99,78 & 100,44 & 100,79 & 99,61 & 99,51 \\
\hline & & & Fórmula & estrutura & calculad & na base & de 32 ox & yênios & & & \\
\hline \multirow[t]{5}{*}{ T } & $\mathrm{Si}$ & 12,036 & 12,051 & 12,051 & 12,051 & 11,982 & 12,006 & 12,035 & 12,014 & 12,043 & 12,044 \\
\hline & $\mathrm{Ti}$ & 0,000 & 0,011 & 0,000 & 0,000 & 0,004 & 0,000 & 0,000 & 0,010 & 0,010 & 0,003 \\
\hline & $\mathrm{Al}$ & 3,844 & 3,823 & 3,849 & 3,878 & 3,966 & 3,938 & 3,828 & 3,893 & 3,873 & 3,900 \\
\hline & $\mathrm{Fe}^{3+}$ & 0,107 & 0,111 & 0,111 & 0,081 & 0,030 & 0,030 & 0,147 & 0,104 & 0,067 & 0,077 \\
\hline & $\Sigma_{T}$ & 15,987 & 15,996 & 16,011 & 16,010 & 15,982 & 15,974 & 16,010 & 16,021 & 15,993 & 16,024 \\
\hline \multirow[t]{6}{*}{ M1 } & $\mathrm{Mn}$ & 0,000 & & 0,003 & 0,000 & 0001 & 0,000 & 0,000 & 0,000 & 0,002 & 0,000 \\
\hline & $\mathrm{Ca}$ & & & & & & & & & & 0,001 \\
\hline & $\mathrm{Ba}$ & 00 & 001 & 0 & 000 & 000 & 0,001 & 0,000 & 000 & 2 & 0,000 \\
\hline & $\mathrm{Na}$ & & 3,885 & & & & & & & & 3,828 \\
\hline & $\mathrm{K}$ & 050 & 0,044 & 0,03 & $0,0 \mathrm{~s}$ & 3,8 & 3,87 & 0,046 & 34 & 3,5 & 0,040 \\
\hline & $\Sigma_{\mathrm{M} 1}$ & 3,990 & 3,933 & 3,900 & 3,910 & 4,057 & 4,059 & 3,921 & 3,898 & 3,951 & 3,869 \\
\hline \multicolumn{2}{|c|}{ Total de cátions } &, 977 & 19,929 & 19,911 & 19,920 & 20,039 & 20,033 & 19,931 & 19,919 & 19,944 & 19,893 \\
\hline \multicolumn{12}{|c|}{ Componentes moleculares } \\
\hline \multicolumn{2}{|l|}{$A b$} & 98,72 & 98,88 & 99,23 & & & 4,63 & 98,83 & 99,13 & 10,62 & 98,94 \\
\hline An & & 0,03 & 0,00 & 0,00 & 0,00 & 0,00 & 0,00 & 0,00 & 0,00 & 0,00 & 0,03 \\
\hline \multicolumn{2}{|l|}{ Or } & 1,25 & 1,12 & 0,77 & 2,43 & 95,83 & 95,37 & 1,17 & 0,87 & 89,38 & 1,03 \\
\hline
\end{tabular}

\subsection{Clinopiroxênios}

Os dados relativos às 82 análises pontuais de clinopiroxênios das rochas de Cananéia são fornecidos nas Tabelas 6 a 8 , ao lado da sua fórmula estrutural e da porcentagem dos componentes moleculares. Não se dispõem de informações para a intrusão do Morrete, uma vez que nessas rochas o mineral é encontrado apenas residualmente, como resultado da sua transformação para anfibólio.

$\mathrm{Na}$ Figura 9 observa-se que a maioria das análises de clinopiroxênio acha-se projetada no campo referente ao Quad (piroxênios cálcicos) de Morimoto (1990), com leve tendência para o Ca-Na; apenas três análises situam-se próximas ao limite do campo $\mathrm{Na}$.

Quando mostrados no diagrama ternário Wo-En-Fs (Fig. 10A), os clinopiroxênios Quad são em sua maior parte de composição cálcica (diopsídio, subordinado; hedenbergita, fase dominante, que passa a augita). Ainda no diagrama WEF-Jd-Ae de Morimoto (1990) (Fig. 10B) é possível distinguir-se a presença de composições mais sódico-cálcicas (egirina-augita) junto às rochas mais evoluídas da intrusão, as hipoabissais.

No geral, pode-se dizer que os clinopiroxênios dos álcali feldspato sienitos e também dos microssienitos com textura em mosaico são dominantemente mais cálcicos, enquanto os dos quartzoálcali feldspato sienitos e microssienitos porfiríticos com textura traquítica apresentam maior variação composicional (cálcica, de natureza hedenbergítica, até sódico-cálcica, de natureza egirina-augítica).

As rochas alcalinas menos evoluídas de Cananéia podem conter cristais de hedenbergita com núcleos de diopsídio, além de bordas mais enriquecidas em ferro. Já nas mais evoluídas, o clinopiroxênio tem a composição de uma hedenbergita rica em ferro e, mais raramente, de uma egirina-augita. 


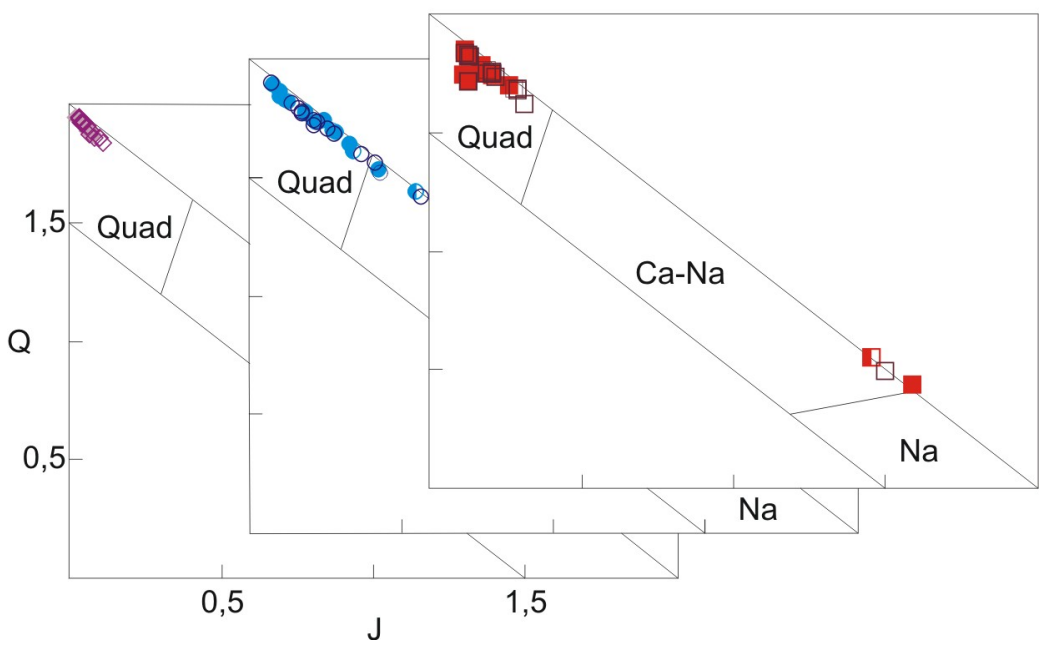

Figura 9. Diagrama de classificação para clinopiroxênios segundo Morimoto (1990), onde $Q=C a+M g+F e^{2+}$ e J=2Na. Símbolos como na Figura 8.

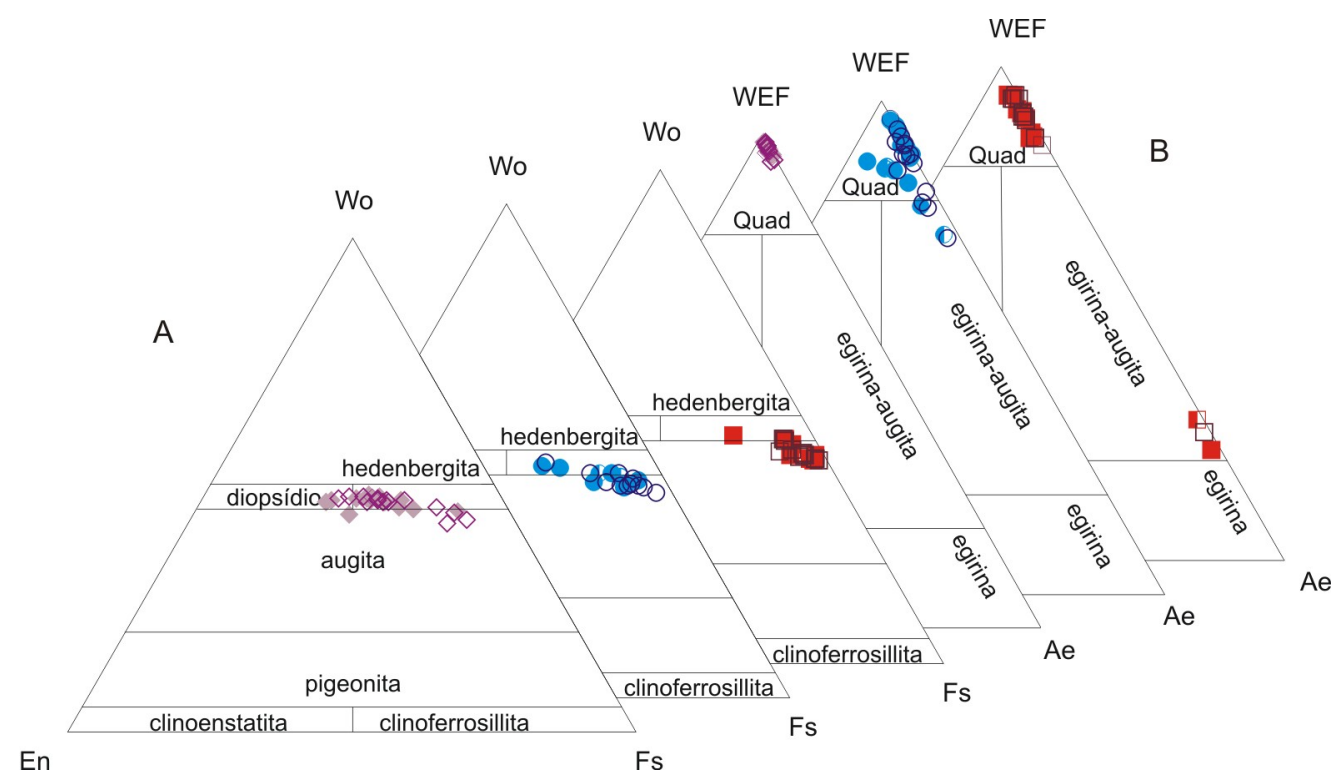

Figura 10. A) Diagrama ternário de classificação Wo-En-Fs (Morimoto, 1990), onde $\mathrm{Wo}=100 \mathrm{Ca} /\left(\mathrm{Ca}+\mathrm{Mg}+\mathrm{Fe}^{2+}+\mathrm{Fe}^{3+}+\mathrm{Mn}+\mathrm{Na}\right.$ ), $\mathrm{En}=100 \mathrm{Mg} /\left(\mathrm{Ca}+\mathrm{Mg}+\mathrm{Fe}^{2+}+\mathrm{Fe}^{3+}+\mathrm{Mn}+\mathrm{Na}\right)$ e $\mathrm{Fs}=100\left(\mathrm{Fe}^{2+}+\mathrm{Fe}^{3+}+\mathrm{Mn}\right) /\left(\mathrm{Ca}+\mathrm{Mg}+\mathrm{Fe}^{2+}+\mathrm{Fe}^{3+}+\mathrm{Mn}+\mathrm{Na}\right)$. B) Diagrama ternário de classificação WEF-Jd-Ae (Morimoto, 1990), onde WEF=(wollastonita, enstatita e ferrossilita), Jd=( $\left.\mathrm{NaAlSi}_{2} \mathrm{O}_{6}\right)$ e $\mathrm{Ae}=\left(\mathrm{NaFe}^{3+} \mathrm{Si}_{2} \mathrm{O}_{6}\right)$. Símbolos como na Figura 8.

A evolução composicional dos clinopiroxênios é mostrada no diagrama triangular $\mathrm{Na}-\mathrm{Mg}-\mathrm{Fe}$ * [onde $\mathrm{Fe}^{*}=\mathrm{Fe}^{2+}+\mathrm{Mn}+\left(\mathrm{Fe}^{2+}-\mathrm{Na}\right)$ ] (Fig. 11A). Observa-se um trend regular caracterizado por progressivo empobrecimento em $\mathrm{Mg}$ e concomitante aumento dos teores de (Fe+Mn); uma pequena inflexão à esquerda da curva é provocada pelo crescimento da proporção em $\mathrm{Na}$ junto às rochas mais evoluídas. Segundo Bonin e Giret (1985), a substituição de Mg por Fe é típica de rochas alcalinas metaluminosas saturadas em sílica.

No diagrama ternário da Figura 11B, nota-se que a evolução composicional dos minerais de Cananéia é, em linhas gerais, concordante com aquela comum a outras associações alcalinas da literatura e se assemelha muito com a mostrada para as fases iniciais de cristalização dos clinopiroxênios da ocorrência de llímaussaq, na Groenlândia (Larsen, 1976) e, particularmente, com a exibida pelos clinopiroxênios da intrusão de Ponta do Morro, no Brasil (Sousa, 1997). Essas semelhanças parecem sugerir que, junto às rochas menos evoluídas dessas ocorrências, a formação de augita em substituição à hedenbergita (ou mesmo diopsídio) foi a principal mudança química 
ocorrida na história evolutiva desses clinopiroxênios.
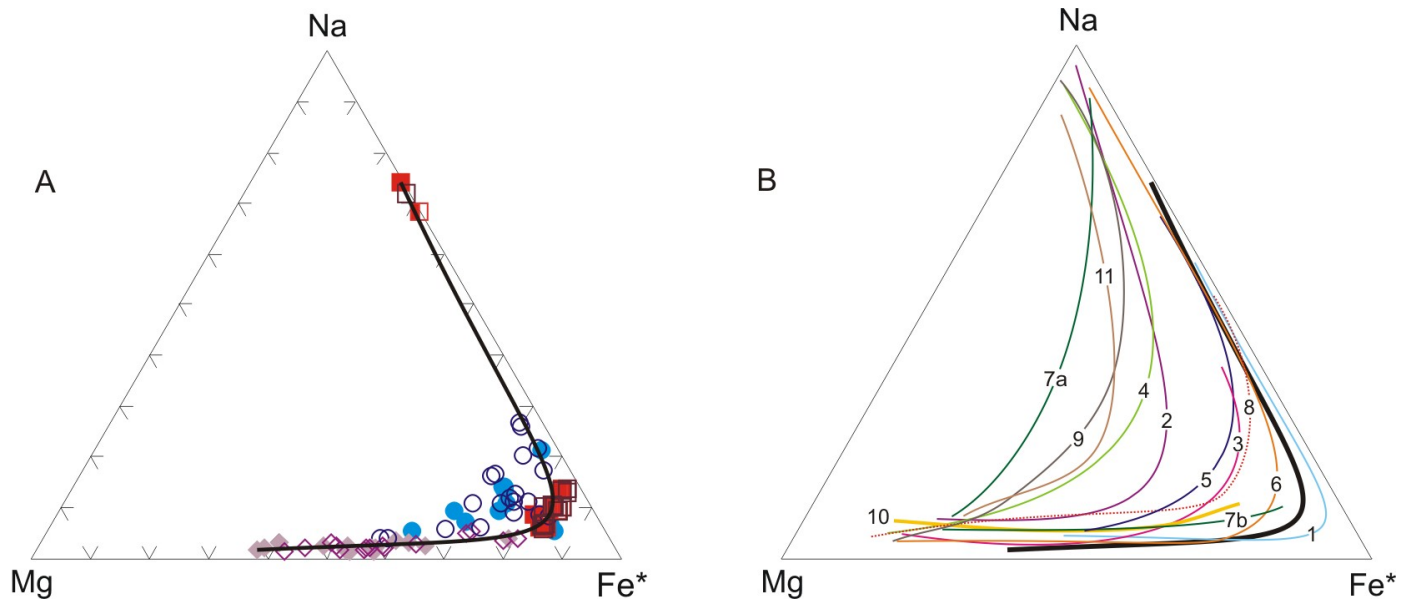

Figura 11. A) Distribuição dos clinopiroxênios das rochas de Cananéia no diagrama ternário Na-Mg-Fe* $\left[o n d e ~ F e^{*}=\mathrm{Fe}^{2+}+\mathrm{Mn}+\left(\mathrm{Fe}^{3+}-\mathrm{Na}\right)\right]$. B) Tendências composicionais de clinopiroxênios em diversos complexos alcalinos: 1. llimaussaq, Groenlândia (Larsen, 1976); 2. South Qôroq, Groenlândia (Stephenson, 1972); 3. Tunas (Gomes et al., 1987); 4. Tanguá-Rio Bonito-ltaúna-Morro de São João (Valença, 1980); 5. Iha de Vitória (Motoki, 1986); 6. Ponta do Morro (Sousa, 1997); 7. Iha de Búzios a) área central e b) área periférica (Alves, 1996); 8. Ilha Monte de Trigo (Enrich, 2000); 9. Itatiaia; 10. São Sebastião; 11. Passa Quatro (Enrich et al., 2005). Símbolos como na Figura 8.

Estruturalmente, o sítio tetraédrico é ocupado por Si (1,953 a 2,024 a.f.u.), substituído parcialmente por $\mathrm{Al}^{\mathrm{IV}}$ (até 0,058 a.f.u.) e $\mathrm{Fe}^{3+}$ (até 0,024 a.f.u.). Na Figura 12, nota-se que grande parte das rochas evoluídas conta, em seus sítios tetraédricos, com pequena proporção de $\mathrm{Al}$ substituindo o Si. Apesar da grande dispersão dos pontos, verifica-se nos diagramas, que reúnem o

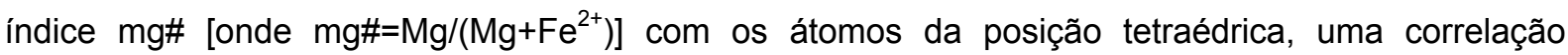
negativa para o Si e positiva para o $\mathrm{Al}$; já para o $\mathrm{Fe}^{3+}$, presente também nesse sítio ainda que em menor concentração, não se observa qualquer tendência. Os sítios tetraédricos, irregulares (M1) e regulares (M2), são preenchidos, respectivamente, por $\mathrm{Al}, \mathrm{Ti}_{1} \mathrm{Fe}^{3+}, \mathrm{Fe}^{2+}$ e $\mathrm{Mg}$ e por $\mathrm{Fe}^{2+}, \mathrm{Mn}, \mathrm{Ca}, \mathrm{Na}$ e K. Embora o $\mathrm{Fe}^{2+}$ esteja representado nessas duas posições, ele ocupa de preferência a posição M1. Os gráficos relacionam ainda o $\mathrm{mg \#} \mathrm{com} \mathrm{os} \mathrm{elementos} \mathrm{que} \mathrm{preenchem} \mathrm{os} \mathrm{sítios} \mathrm{octaédricos,}$ verificando-se, neste caso, correlação positiva para o $\mathrm{Ca}_{\mathrm{M} 1}$ e negativa para os demais, o $\mathrm{Mn}_{\mathrm{M} 2} \mathrm{em}$ particular. $\mathrm{Al}_{\mathrm{M} 1}, \mathrm{Fe}^{3+}{ }_{\mathrm{M} 1}$ e $\mathrm{Na}_{\mathrm{M} 2}$ possuem comportamento muito semelhante, exibindo valores quase nulos para os clinopiroxênios das litologias menos evoluídas e teores crescentes a partir de valores de mg\# próximos a 0,20, o que parece indicar a presença de egirina-augita nas rochas mais evoluídas. Comportamento oposto é indicado pelo $\mathrm{Ca}_{\mathrm{M} 2}$, com queda abrupta de valores nas rochas mais evoluídas, associada ao aumento concomitante de $\mathrm{Na}$ e $\mathrm{Fe}^{3+}$.

Zoneamentos composicionais foram reconhecidos em alguns cristais de clinopiroxênio, sendo o padrão caracterizado pelo empobrecimento de $\mathrm{Ca}$, ao lado do aumento de $\mathrm{Na}$ e $\mathrm{Fe}^{3+}$, do núcleo para as margens dos grãos. Do ponto de vista composicional, têm-se então núcleos de natureza mais diopsídica e bordas mais hedenbergíticas, ou ainda núcleos mais hedenbergíticos circundados por bordas enriquecidas em ferro, ou seja, de natureza mais augítica. 

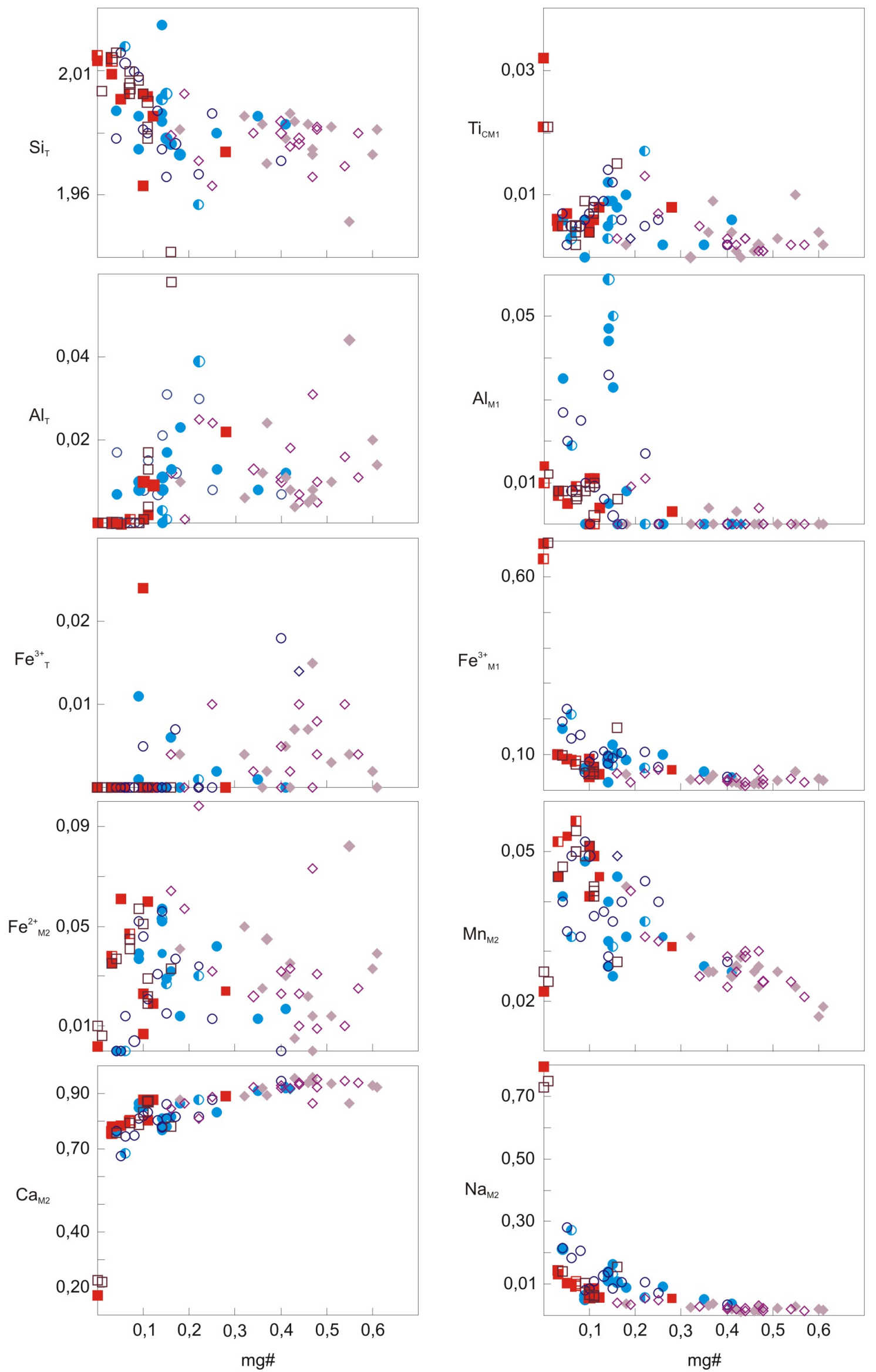

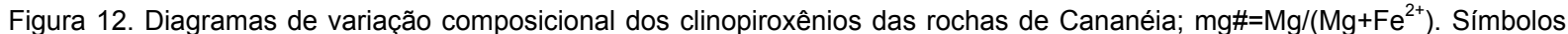
como na Figura 8. 
Tabela 6. Composição química de clinopiroxênios dos álcali feldspato sienitos do Morro de São João. Abreviações: c, b, i, respectivamente, centro, borda e região intermediária dos cristais. Classificação: Di, diopsídio; Hd, hedenbergita; Au, augita; Ea, egirina-augita; $\mathrm{mg} \#=\mathrm{Mg} /(\mathrm{Mg}+\mathrm{Fe})$; n.d., não detectado.

\begin{tabular}{|c|c|c|c|c|c|c|c|c|c|c|c|c|c|c|c|c|c|}
\hline \multicolumn{2}{|c|}{$\begin{array}{l}\text { Amostra } \\
\text { Cristal-Análise }\end{array}$} & $\begin{array}{r}28 B \\
1-01\end{array}$ & $\begin{array}{l}28 B \\
1-02\end{array}$ & $\begin{array}{r}32 B \\
2-03\end{array}$ & $\begin{array}{r}32 B \\
2-04\end{array}$ & $\begin{array}{r}32 B \\
3-05\end{array}$ & $\begin{array}{r}32 B \\
3-06\end{array}$ & $\begin{array}{r}32 B \\
4-07\end{array}$ & $\begin{array}{r}32 B \\
4-08\end{array}$ & $\begin{array}{r}39 B \\
5-09\end{array}$ & $\begin{array}{r}39 B \\
5-10\end{array}$ & $\begin{array}{l}39 B \\
6-11\end{array}$ & $\begin{array}{r}39 B \\
6-12\end{array}$ & $\begin{array}{r}39 B \\
7-13\end{array}$ & $\begin{array}{r}39 B \\
7-14\end{array}$ & $\begin{array}{r}39 B \\
8-15\end{array}$ & $\begin{array}{r}39 B \\
8-16\end{array}$ \\
\hline \multicolumn{2}{|c|}{ Localização } & b & c & $\mathrm{b}$ & c & b & C & b & $\mathrm{C}$ & b & $\mathrm{c}$ & b & C & $\mathrm{b}$ & $\mathrm{C}$ & b & C \\
\hline \multicolumn{2}{|l|}{$\mathrm{SiO}_{2}$} & 51,22 & 51,38 & 50,27 & 50,35 & 50,49 & 50,67 & 51,41 & 51,09 & 50,14 & 49,68 & 49,76 & 50,44 & 50,55 & 50,80 & 48,85 & 49,84 \\
\hline \multirow{2}{*}{\multicolumn{2}{|c|}{$\mathrm{TiO}_{2}$}} & 0,11 & n.d. & 0,05 & 0,33 & 0,09 & 0,07 & 0,12 & 0,08 & 0,10 & n.d. & 0,18 & 0,13 & 0,06 & 0,03 & 0,24 & 0,30 \\
\hline & & 0,11 & 0,09 & 0,77 & 0,96 & 0,14 & 0,18 & 0,22 & 0,36 & 0,22 & 0,12 & 0,28 & 0,35 & 0,39 & 0,23 & 0,51 & 0,51 \\
\hline \multicolumn{2}{|l|}{$\mathrm{Fe}_{2} \mathrm{O}_{3}$} & 1,43 & 1,07 & 1,98 & 2,14 & 1,52 & 1,95 & 1,16 & 1,84 & 1,13 & 1,27 & 1,21 & 1,04 & 1,36 & 0,82 & 2,58 & 1,58 \\
\hline \multicolumn{2}{|l|}{$\mathrm{FeO}$} & 17,09 & 17,18 & 16,28 & 14,01 & 16,48 & 15,04 & 14,78 & 13,44 & 18,09 & 20,45 & 19,31 & 19,21 & 17,46 & 17,85 & 21,22 & 18,79 \\
\hline \multicolumn{2}{|l|}{$\mathrm{MnO}$} & 0,88 & 0,89 & 0,92 & 0,70 & 0,91 & 0,82 & 0,80 & 0,74 & 0,86 & 0,98 & 0,75 & 0,79 & 0,78 & 0,81 & 0,94 & 0,77 \\
\hline \multicolumn{2}{|l|}{$\mathrm{MgO}$} & 7,60 & 7,35 & 8,16 & 9,67 & 7,37 & 7,86 & 8,73 & 9,22 & 6,80 & 5,50 & 5,68 & 5,99 & 7,21 & 7,20 & 4,05 & 6,25 \\
\hline $\mathrm{CaO}$ & & 22,49 & 23,00 & 20,56 & 20,82 & 22,26 & 22,92 & 22,60 & 22,82 & 21,67 & 20,71 & 21,60 & 21,72 & 21,90 & 21,83 & 20,57 & 21,03 \\
\hline \multicolumn{2}{|l|}{$\mathrm{Na}_{2} \mathrm{O}$} & 0,22 & 0,16 & 0,44 & 0,41 & 0,30 & 0,30 & 0,32 & 0,28 & 0,26 & 0,34 & 0,39 & 0,41 & 0,28 & 0,28 & 0,62 & 0,48 \\
\hline \multicolumn{2}{|l|}{$\mathrm{K}_{2} \mathrm{O}$} & n.d. & 0,02 & 0,01 & n.d. & n.d. & 0,01 & n.d. & 0,01 & n.d. & 0,02 & 0,01 & 0,01 & 0,02 & 0,01 & n.d. & n.d. \\
\hline \multicolumn{2}{|l|}{ Total } & 101,17 & 101,14 & 99,43 & 99,38 & 99,57 & 99,81 & 100,13 & 99,86 & 99,27 & 99,13 & 99,18 & 100,08 & 100,02 & 99,87 & 99,59 & 99,54 \\
\hline \multirow{5}{*}{$\mathrm{T}$} & & & & & & órmula & strutural & calculada & com bas & em 6 ox & ênios & & & & & & \\
\hline & $\mathrm{Si}$ & 1,981 & 1,989 & 1,969 & 1,953 & 1,983 & 1,977 & 1,987 & 1,973 & 1,985 & 1,991 & 1,985 & 1,988 & 1,980 & 1,992 & 1,966 & 1,974 \\
\hline & $\mathrm{Al}$ & 0,005 & 0,004 & 0,031 & 0,044 & 0,007 & 0,008 & 0,010 & 0,016 & 0,010 & 0,006 & 0,013 & 0,012 & 0,018 & 0,008 & 0,024 & 0,024 \\
\hline & $\mathrm{Fe}^{3+}$ & 0,014 & 0,007 & 0,000 & 0,004 & 0,010 & 0,015 & 0,003 & 0,010 & 0,005 & 0,004 & 0,002 & 0,000 & 0,002 & 0,000 & 0,010 & 0,002 \\
\hline & $\Sigma_{\mathrm{T}}$ & 2,000 & 2,000 & 2,000 & 2,001 & 2,000 & 2,000 & 2,000 & 1,999 & 2,000 & 2,001 & 2,000 & 2,000 & 2,000 & 2,000 & 2,000 & 2,000 \\
\hline \multirow[t]{6}{*}{ M1 } & $\mathrm{Al}$ & 0,000 & 0,000 & 0,004 & 0,000 & 0,000 & 0,000 & 0,000 & 0,000 & 0,000 & 0,000 & 0,000 & 0,004 & 0,000 & 0,003 & 0,000 & 0,000 \\
\hline & $\mathrm{Ti}$ & 0,003 & 0,000 & 0,001 & 0,010 & 0,003 & 0,002 & 0,003 & 0,002 & 0,003 & 0,000 & 0,005 & 0,004 & 0,002 & 0,001 & 0,007 & 0,009 \\
\hline & $\mathrm{Fe}^{3+}$ & 0,014 & 0,016 & 0,058 & 0,054 & 0,024 & 0,027 & 0,027 & 0,033 & 0,025 & 0,031 & 0,031 & 0,031 & 0,036 & 0,024 & 0,058 & 0,043 \\
\hline & $\mathrm{Fe}^{2+}$ & 0,543 & 0,559 & 0,460 & 0,377 & 0,542 & 0,506 & 0,467 & 0,434 & 0,571 & 0,639 & 0,625 & 0,609 & 0,541 & 0,551 & 0,692 & 0,579 \\
\hline & $\mathrm{Mg}$ & 0,438 & 0,424 & 0,476 & 0,559 & 0,432 & 0,457 & 0,503 & 0,531 & 0,401 & 0,329 & 0,337 & 0,352 & 0,421 & 0,421 & 0,243 & 0,369 \\
\hline & $\Sigma_{\mathrm{M} 1}$ & 0,998 & 0,999 & 0,999 & 1,000 & 1,001 & 0,992 & 1,000 & 1,000 & 1,000 & 0,999 & 0,998 & 1,000 & 1,000 & 1,000 & 1,000 & 1,000 \\
\hline \multirow[t]{6}{*}{ M2 } & $\mathrm{Fe}^{2+}$ & 0,023 & 0,005 & 0,073 & 0,082 & 0,010 & 0,000 & 0,014 & 0,010 & 0,032 & 0,050 & 0,022 & 0,025 & 0,033 & 0,034 & 0,033 & 0,045 \\
\hline & $\mathrm{Mn}$ & 029 & & 030 & 023 & & & & & & & & & & & & 0,026 \\
\hline & $\mathrm{Ca}$ & 0,932 & 0,954 & 0,863 & 0,865 & 0,937 & 0,958 & 0,936 & 0,944 & 0,919 & 0,889 & 0,923 & 0,918 & 0,919 & 0,917 & 0,887 & 0,892 \\
\hline & $\mathrm{Na}$ & 0,016 & 0,012 & 0,033 & 0,030 & 0,023 & 0,023 & 0,024 & 0,021 & 0,020 & 0,026 & 0,030 & 0,031 & 0,021 & 0,021 & 0,049 & 0,037 \\
\hline & $\mathrm{K}$ & 0,000 & 0,001 & 0,001 & 0,000 & 0,000 & 0,000 & 0,000 & 0,001 & 0,000 & 0,001 & 0,000 & 0,0 & & 0,000 & 0,000 & 0,000 \\
\hline & $\Sigma_{\mathrm{M} 2}$ & 1,000 & 1,001 & 1,000 & 1,000 & 1,000 & 1,008 & 1,000 & 1,000 & 1,000 & 0,999 & 1,000 & 1,001 & 1,000 & 0,999 & 1,001 & 1,000 \\
\hline \multicolumn{2}{|c|}{ Total de cátions } & 3,998 & 4,000 & 3,999 & 4,001 & 4,001 & 4,000 & 4,000 & 3,999 & 4,000 & 3,999 & 3,998 & 4,001 & 4,000 & 3,999 & 4,001 & 4,000 \\
\hline \multicolumn{18}{|c|}{ Componentes moleculares } \\
\hline \multicolumn{2}{|l|}{$\mathrm{Jd}$} & & 0,00 &, 21 & 0,00 & 0,00 & 0,00 & & & 0,00 & 0,00 & 0,00 & 0,23 & 0,00 & 0,13 & 0,00 & 0,00 \\
\hline \multirow{2}{*}{\multicolumn{2}{|c|}{$\mathrm{Ae}$}} & 83 & 0,65 & & & 1,18 & 1, & 1,23 & $1, \mathrm{C}$ & 1,04 & 1,41 & 1,56 & 1,40 & 1,14 & 0,97 & 2,56 & 1,93 \\
\hline & & 0,00 & 0,20 & 1,48 & 1,26 & 0,05 & 0,20 & 0,17 & 0,60 & 0,23 & 0,28 & 0,11 & 0,20 & 0,74 & 0,31 & 0,48 & 0,32 \\
\hline \multicolumn{2}{|l|}{$\begin{array}{l}\text { Es } \\
\text { CaTiTs }\end{array}$} & & & & & & & & & & 0,00 & & 0,20 & 0,09 & 0,04 & 0,39 & 0,46 \\
\hline CaTS & & 0,00 & 0,00 & 0,00 & 0,00 & 0,00 & 0,00 & 0,00 & 0,00 & 0,00 & 0,00 & 0,00 & 0,00 & 0,00 & 0,00 & 0,00 & 0,00 \\
\hline Wo & & 47,56 & 48,60 & 43,70 & 43,46 & 48,02 & 48,97 & 47,82 & 47,94 & 46,91 & 45,69 & 47,26 & 47,04 & 46,64 & 46,81 & 45,74 & 45,64 \\
\hline En & & 22,45 & 21,71 & 24,98 & 29,22 & 22,22 & 23,53 & 25,87 & 27,34 & 20,64 & 17,00 & 17,42 & 18,21 & 21,74 & 21,64 & 12,78 & 19,18 \\
\hline Fs & & 29,00 & 28,84 & 27,97 & 23,97 & 28,39 & 26,01 & 24,75 & 22,91 & 31,04 & 35,62 & 33,37 & 32,74 & 29,64 & 30,09 & 38,06 & 32,48 \\
\hline mg\# & & 0,44 & 0,43 & 0,47 & 0,55 & 0,44 & 0,47 & 0,51 & 0,54 & 0,40 & 0,32 & 0,34 & 0,36 & 0,42 & 0,42 & 0,25 & 0,37 \\
\hline & & $\mathrm{Hd}$ & $\mathrm{Hd}$ & $\mathrm{Au}$ & $\mathrm{Au}$ & $\mathrm{Hd}$ & $\mathrm{Hd}$ & $\mathrm{Hd}$ & $\mathrm{Di}$ & $\mathrm{Hd}$ & $\mathrm{Hd}$ & $\mathrm{Hd}$ & $\mathrm{Hd}$ & $\mathrm{Hd}$ & $\mathrm{Hd}$ & $\mathrm{Hd}$ & $\mathrm{Hd}$ \\
\hline
\end{tabular}

\begin{tabular}{|c|c|c|c|c|c|c|c|c|c|c|c|c|c|c|}
\hline \multicolumn{2}{|c|}{$\begin{array}{l}\text { Amostra } \\
\text { Cristal-Análise } \\
\text { Localização }\end{array}$} & $\begin{array}{r}39 B \\
9-17 \\
\mathrm{~b} \\
\end{array}$ & $\begin{array}{r}39 B \\
9-18 \\
C\end{array}$ & $\begin{array}{r}39 B \\
10-19 \\
\mathrm{~b}\end{array}$ & $\begin{array}{r}39 B \\
10-20 \\
\mathrm{~b}\end{array}$ & $\begin{array}{r}39 B \\
10-21 \\
C\end{array}$ & $\begin{array}{r}39 B \\
11-22 \\
\mathrm{~b}\end{array}$ & $\begin{array}{r}39 B \\
11-23 \\
c\end{array}$ & $\begin{array}{r}14 \\
12-24 \\
\mathrm{~b}\end{array}$ & $\begin{array}{r}14 \\
12-25 \\
\mathrm{C}\end{array}$ & $\begin{array}{r}14 \\
13-26 \\
\mathrm{~b}\end{array}$ & $\begin{array}{r}14 \\
13-27 \\
\mathrm{C}\end{array}$ & $\begin{array}{r}14 \\
14-28 \\
\mathrm{~b}\end{array}$ & $\begin{array}{r}14 \\
14-29 \\
\mathrm{C}\end{array}$ \\
\hline \multirow{2}{*}{\multicolumn{2}{|c|}{$\mathrm{SiO}_{2}$}} & 48,86 & 51,06 & 48,65 & 49,13 & 49,17 & 50,47 & 50,57 & 51,56 & 51,36 & 51,58 & 51,78 & 50,79 & 51,61 \\
\hline & & 0,42 & 0,06 & 0,10 & 0,09 & 0,07 & 0,08 & 0,12 & 0,04 & 0,04 & 0,06 & 0,85 & 0,04 & 0,13 \\
\hline \multicolumn{2}{|l|}{$\mathrm{Al}_{2} \mathrm{O}_{3}$} & 0,76 & 0,14 & 0,25 & 0,21 & 0,21 & 0,25 & 0,24 & 0,10 & 0,11 & 0,23 & 0,31 & 0,22 & 0,45 \\
\hline \multirow{2}{*}{\multicolumn{2}{|c|}{$\begin{array}{l}\mathrm{Fe}_{2} \mathrm{O}_{3} \\
\mathrm{FeO}\end{array}$}} & 1,54 & 1,70 & 1,84 & 0,80 & 1,79 & 1,05 & 1,18 & 1,20 & 1,07 & 1,07 & 0,96 & 1,31 & 1,31 \\
\hline & & 23,58 & 15,69 & 24,82 & 24,41 & 24,02 & 17,93 & 17,79 & 15,62 & 16,47 & 13,30 & 12,18 & 15,83 & 12,42 \\
\hline \multicolumn{2}{|l|}{$\mathrm{MnO}$} & 0,96 & 0,70 & 1,42 & 1,23 & 1,26 & 0,69 & 0,74 & 0,74 & 0,80 & 0,66 & 0,60 & 0,73 & 0,53 \\
\hline \multicolumn{2}{|l|}{$\mathrm{MgO}$} & 3,81 & 8,11 & 2,69 & 3,14 & 2,95 & 6,78 & 7,07 & 8,32 & 8,03 & 9,91 & 10,82 & 8,19 & 10,42 \\
\hline \multicolumn{2}{|l|}{$\mathrm{CaO}$} & 18,71 & 22,79 & 19,34 & 19,79 & 20,24 & 21,98 & 22,02 & 23,03 & 22,60 & 22,76 & 22,47 & 21,97 & 22,63 \\
\hline \multicolumn{2}{|l|}{$\mathrm{Na}_{2} \mathrm{O}$} & 0,69 & 0,23 & 0,52 & 0,46 & 0,50 & 0,34 & 0,26 & 0,21 & 0,20 & 0,20 & 0,24 & 0,32 & 0,28 \\
\hline \multicolumn{2}{|l|}{$\mathrm{K}_{2} \mathrm{O}$} & 0,10 & n.d. & 0,01 & 0,03 & 0,02 & n.d. & 0,01 & 0,01 & n.d. & n.d. & n.d. & n.d. & n.d. \\
\hline \multirow{2}{*}{\multicolumn{2}{|c|}{ Total }} & 99,41 & 100,48 & 99,63 & 99,28 & 100,24 & 99,56 & 100,01 & 100,81 & 100,68 & 99,77 & 100,21 & 99,38 & 99,83 \\
\hline & & \multicolumn{13}{|c|}{ Fórmula estrutural calculada com base em 6 oxigênios } \\
\hline \multirow[t]{4}{*}{$\mathrm{T}$} & $\mathrm{Si}$ & 1,975 & 1,979 & 1,984 & 1,999 & 1,986 & 1,989 & 1,983 & 1,987 & 1,988 & 1,985 & 1,975 & 1,986 & 1,977 \\
\hline & $\mathrm{Al}$ & 0,025 & 0,006 & 0,012 & 0,001 & 0,010 & 0,011 & 0,011 & 0,005 & 0,005 & 0,011 & 0,014 & 0,010 & 0,020 \\
\hline & $\mathrm{Fe}^{3+}$ & 0,000 & 0,015 & 0,004 & 0,000 & 0,004 & 0,000 & 0,005 & 0,008 & 0,007 & 0,004 & 0,000 & 0,004 & 0,002 \\
\hline & $\Sigma_{\mathrm{T}}$ & 2,000 & 2,000 & 2,000 & 2,000 & 2,000 & 2,000 & 1,999 & 2,000 & 2,000 & 2,000 & 1,989 & 2,000 & 1,999 \\
\hline \multirow[t]{6}{*}{ M1 } & $\mathrm{Al}$ & 0,011 & 0,000 & 0,000 & 0,009 & 0,000 & 0,000 & 0,000 & 0,000 & 0,000 & 0,000 & 0,000 & 0,000 & 0,000 \\
\hline & $\mathrm{Ti}$ & 0,013 & 0,002 & 0,003 & 0,003 & 0,002 & 0,002 & 0,004 & 0,001 & 0,001 & 0,002 & 0,024 & 0,001 & 0,004 \\
\hline & $\mathrm{Fe}^{3+}$ & 0,047 & 0,020 & 0,048 & 0,024 & 0,045 & 0,031 & 0,024 & 0,018 & 0,017 & 0,022 & 0,000 & 0,031 & 0,033 \\
\hline & $\mathrm{Fe}^{2+}$ & 0,700 & 0,510 & 0,786 & 0,773 & 0,775 & 0,568 & 0,559 & 0,503 & 0,518 & 0,407 & 0,360 & 0,490 & 0,368 \\
\hline & $\mathrm{Mg}$ & 0,230 & 0,469 & 0,163 & 0,191 & 0,178 & 0,398 & 0,413 & 0,478 & 0,464 & 0,569 & 0,615 & 0,477 & 0,595 \\
\hline & $\Sigma_{\mathrm{M} 1}$ & 1,001 & 1,001 & 1,000 & 1,000 & 1,000 & 0,999 & 1,000 & 1,000 & 1,000 & 1,000 & 0,999 & 0,999 & 1,000 \\
\hline \multirow[t]{6}{*}{ M2 } & $\mathrm{Fe}^{2+}$ & 0,098 & 0,014 & 0,064 & 0,057 & 0,041 & 0,023 & 0,030 & 0,009 & 0,022 & 0,025 & 0,056 & 0,031 & 0,033 \\
\hline & $\mathrm{Mn}$ & 0,033 & 0,023 & 0,049 & 0,042 & 0,043 & 0,023 & 0,025 & 0,024 & 0,026 & 0,021 & 0,019 & 0,024 & 0,017 \\
\hline & $\mathrm{Ca}$ & 0,811 & 0,946 & 0,845 & 0,863 & 0,876 & 0,928 & 0,925 & 0,951 & 0,937 & 0,938 & 0,918 & 0,921 & 0,929 \\
\hline & $\mathrm{Na}$ & 0,054 & 0,017 & 0,041 & 0,036 & 0,039 & 0,026 & 0,020 & 0,016 & 0,015 & 0,015 & 0,018 & 0,024 & 0,021 \\
\hline & $\mathrm{K}$ & 0,005 & 0,000 & 0,001 & 0,001 & 0,001 & 0,000 & 0,000 & 0,000 & 0,000 & 0,000 & 0,000 & 0,000 & 0,000 \\
\hline & $\Sigma_{\mathrm{M} 2}$ & 1,001 & 1,000 & 1,000 & 0,999 & 1,000 & 1,000 & 1,000 & 1,000 & 1,000 & 0,999 & 1,011 & 1,000 & 1,000 \\
\hline \multicolumn{2}{|c|}{ Total de cátions } & 4,002 & 4,001 & 4,000 & 3,999 & 4,000 & 3,999 & 3,999 & 4,000 & 4,000 & 3,999 & 3,999 & 3,999 & 3,999 \\
\hline \multicolumn{15}{|c|}{ Componentes moleculares } \\
\hline \multirow{2}{*}{\multicolumn{2}{|c|}{$\begin{array}{l}\mathrm{Jd} \\
\mathrm{Ae}\end{array}$}} & 0,60 & 0,00 & 0,00 & 0,47 & 0,00 & 0,02 & 0,00 & 0,00 & 0,00 & 0,00 & 0,00 & 0,00 & 0,00 \\
\hline & & 2,51 & 0,88 & 2,20 & 1,50 & 2,11 & 1,30 & 1,04 & 0,82 & 0,76 & 0,77 & 0,92 & 1,23 & 1,08 \\
\hline \multicolumn{2}{|l|}{ Es } & 0,00 & 0,13 & 0,31 & 0,00 & 0,30 & 0,30 & 0,20 & 0,12 & 0,12 & 0,37 & 0,00 & 0,38 & 0,67 \\
\hline \multirow{2}{*}{\multicolumn{2}{|c|}{$\begin{array}{l}\text { CaTiTs } \\
\text { CaTs }\end{array}$}} & 0,67 & 0,09 & 0,15 & 0,05 & 0,11 & 0,13 & 0,19 & 0,06 & 0,07 & 0,08 & 0,71 & 0,06 & 0,19 \\
\hline & & 0,00 & 0,00 & 0,00 & 0,00 & 0,00 & 0,00 & 0,00 & 0,00 & 0,00 & 0,00 & 0,00 & 0,00 & 0,00 \\
\hline \multicolumn{2}{|l|}{ Wo } & 42,08 & 48,17 & 44,00 & 44,84 & 45,47 & 47,33 & 47,13 & 48,43 & 47,74 & 47,56 & 45,95 & 46,93 & 46,89 \\
\hline \multicolumn{2}{|l|}{ En } & 12,12 & 23,97 & 8,59 & 9,92 & 9,30 & 20,50 & 21,22 & 24,43 & 23,71 & 29,10 & 31,27 & 24,56 & 30,58 \\
\hline Fs & & 42,03 & 26,76 & 44,76 & 43,22 & 42,72 & 30,42 & 30,24 & 26,15 & 27,62 & 22,12 & 21,15 & 26,82 & 20,59 \\
\hline $\mathrm{mg \#}$ & & 0,22 & 0,47 & 0,16 & 0,19 & 0,18 & 0,40 & 0,41 & 0,48 & 0,46 & 0,57 & 0,60 & 0,48 & 0,60 \\
\hline & & $\mathrm{Au}$ & $\mathrm{Hd}$ & $\mathrm{Au}$ & $\mathrm{Au}$ & $\mathrm{Hd}$ & $\mathrm{Hd}$ & $\mathrm{Hd}$ & $\mathrm{Hd}$ & $\mathrm{Hd}$ & $\mathrm{Di}$ & $\mathrm{Di}$ & $\mathrm{Hd}$ & $\mathrm{Di}$ \\
\hline
\end{tabular}


Tabela 7. Composição química de clinopiroxênios dos quartzo-álcali feldspato sienitos do Morro de São João. Abreviações e classificação como na Tabela 6.

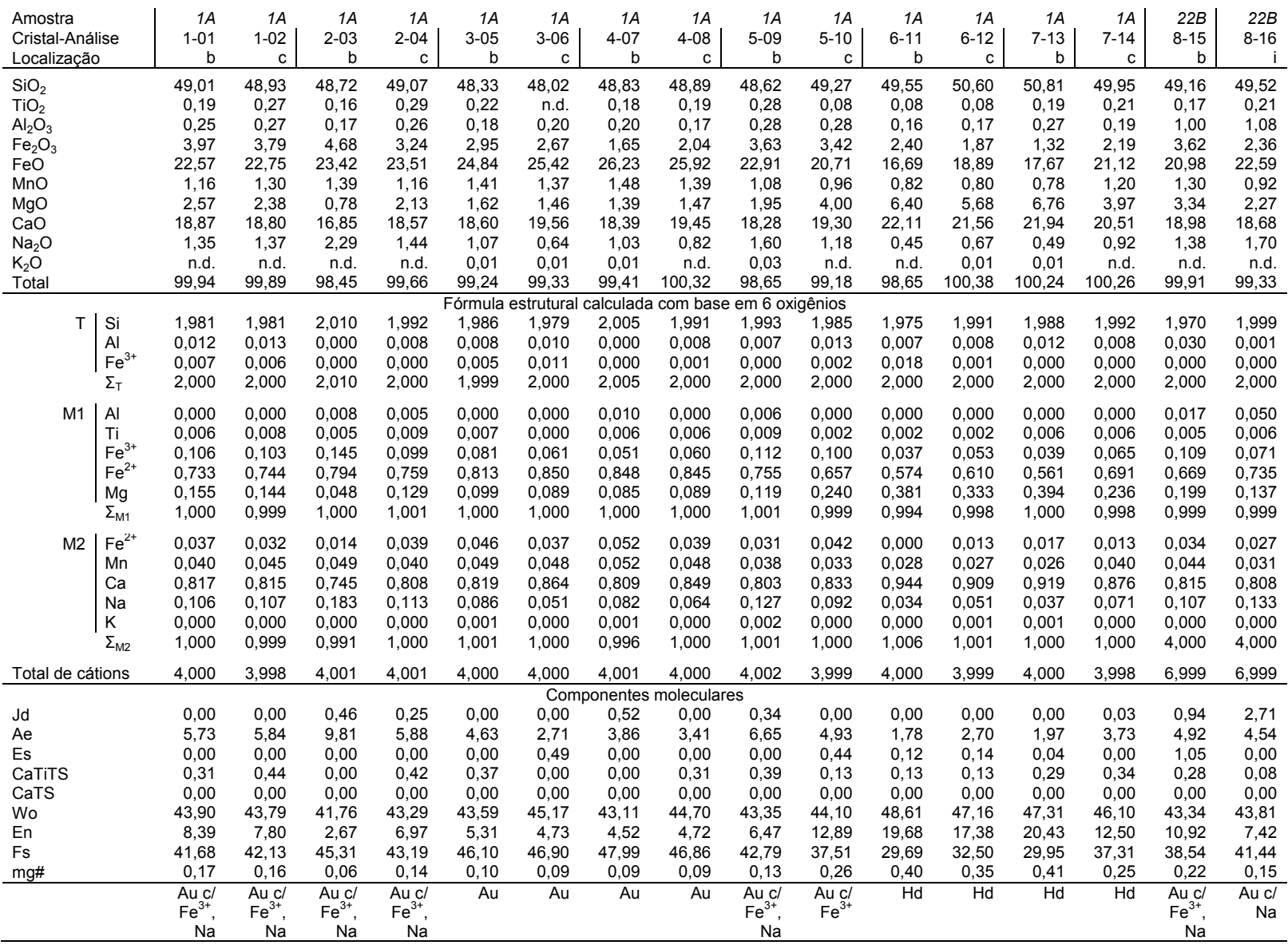

\begin{tabular}{|c|c|c|c|c|c|c|c|c|c|c|c|c|c|c|c|c|}
\hline \multicolumn{2}{|c|}{ Amostra } & $22 B$ & $22 B$ & $22 B$ & $22 B$ & $22 B$ & $22 B$ & $15 A$ & $15 A$ & $15 A$ & $15 A$ & $15 A$ & $15 A$ & $15 A$ & $15 A$ & $15 A$ \\
\hline \multirow{2}{*}{\multicolumn{2}{|c|}{$\begin{array}{l}\text { Cristal-Análise } \\
\text { Localização }\end{array}$}} & $8-17$ & $9-18$ & $9-19$ & $10-20$ & $10-21$ & $10-22$ & $11-23$ & $11-24$ & $11-25$ & $11-26$ & $12-27$ & $12-28$ & $12-29$ & $13-30$ & $13-31$ \\
\hline & & c & b & c & b & $\mathrm{i}$ & c & b & b & $\mathrm{i}$ & $\mathrm{c}$ & b & $\mathrm{i}$ & b & & \\
\hline & 49,79 & 49,54 & 49,97 & 47,79 & 49,88 & 49,95 & 48,13 & 47,96 & 48,36 & 48,36 & 48,96 & 48,93 & 49,19 & 48,03 & 48,29 \\
\hline \multicolumn{2}{|l|}{$\begin{array}{ll}\mathrm{HiO}_{2} \\
\mathrm{TiO}_{2}\end{array}$} & 0,16 & 0,47 & 0,40 & 0,49 & 0,10 & 0,32 & 0,28 & 0,38 & 0,56 & 0,33 & 0,16 & 0,11 & 0,07 & 0,22 & 0,20 \\
\hline $\mathrm{Al}_{2} \mathrm{O}_{3}$ & & 3,16 & 3,16 & 2,85 & 5,80 & 2,44 & 4,28 & 3,21 & 2,95 & 2,12 & 2,76 & 5,08 & 6,90 & 7,45 & 6,23 & 5,57 \\
\hline \multicolumn{2}{|l|}{$\mathrm{FeO}$} & 22,50 & 23,32 & 23,55 & 20,58 & 23,47 & 21,87 & 23,27 & 22,44 & 21,86 & 21,90 & 21,78 & 20,78 & 20,65 & 20,87 & 21,36 \\
\hline \multicolumn{2}{|l|}{$\mathrm{MnO}$} & 0,92 & 0,84 & 0,80 & 0,82 & 0,81 & 0,76 & 1,06 & 1,04 & 1,06 & 0,94 & 0,95 & 0,95 & 0,97 & 1,14 & 1,19 \\
\hline \multicolumn{2}{|l|}{$\mathrm{MgO}$} & 2,28 & 2,20 & 2,23 & 2,23 & 2,21 & 2,25 & 1,65 & 2,27 & 3,46 & 2,66 & 1,14 & 0,68 & 0,64 & 0,53 & 0,47 \\
\hline \multicolumn{2}{|l|}{$\mathrm{K}_{2} \mathrm{O}$} & 0,06 & 0,01 & 0,02 & n.d. & 0,02 & n.d. & 0,01 & n.d. & n.d. & n.d. & n.d. & n.d. & 0,02 & 0,03 & 0,02 \\
\hline \multicolumn{2}{|l|}{ Total } & 99,03 & 100,69 & 100,96 & 99,02 & 100,23 & 100,99 & 98,30 & 98,44 & 99,16 & 98,46 & 98,26 & 97,64 & 98,29 & 97,91 & 97,91 \\
\hline \multicolumn{17}{|c|}{ Fórmula estrutural calculada com base em 6 oxigênios } \\
\hline $\mathrm{T}$ & $\mathrm{Si}$ & 2,024 & 1,979 & 1,989 & 1,942 & 1,997 & 1,983 & 1,985 & 1,969 & 1,959 & 1,977 & 2,007 & 2,016 & 2,014 & 1,983 & 1,993 \\
\hline & $\mathrm{Al}$ & 0,000 & 0,021 & 0,011 & 0,058 & 0,003 & 0,017 & 0,015 & 0,031 & 0,039 & 0,023 & 0,000 & 0,000 & 0,000 & 0,017 & 0,007 \\
\hline & $\mathrm{Fe}^{3+}$ & 0,000 & 0,000 & 0,000 & 0,000 & 0,000 & 0,000 & 0,000 & 0,000 & 0,001 & 0,000 & 0,000 & 0,000 & 0,000 & 0,000 & 0,000 \\
\hline & $\Sigma_{\mathrm{T}}$ & 2,024 & 2,000 & 2,000 & 2,000 & 2,000 & 2,000 & 2,000 & 2,000 & 1,999 & 2,000 & 2,007 & 2,016 & 2,014 & 2,000 & 2,000 \\
\hline & $\Sigma_{\mathrm{M} 1}$ & 1,000 & 1,000 & 1,000 & 1,000 & 1,000 & 1,000 & 1,000 & 0,999 & 1,000 & 1,000 & 0,998 & 0,993 & 0,997 & 0,980 & 0,981 \\
\hline M2 & $\mathrm{Fe}^{2+}$ & 0,052 & 0,056 & 0,057 & 0,033 & 0,053 & 0,029 & 0,021 & 0,015 & 0,030 & 0,014 & 0,004 & 0,000 & 0,000 & 0,000 & 0,000 \\
\hline & $\mathrm{Mn}$ & 0,032 & 0,029 & 0,027 & 0,028 & 0,027 & 0,025 & 0,037 & 0,036 & 0,036 & 0,033 & 0,033 & 0,033 & 0,034 & 0,040 & 0,041 \\
\hline & $\mathrm{Ca}$ & 0,767 & 0,776 & 0,774 & 0,782 & 0,782 & 0,782 & 0,831 & 0,861 & 0,876 & 0,863 & 0,748 & 0,684 & 0,673 & 0,763 & 0,765 \\
\hline & $\mathrm{Na}$ & 0,123 & 0,139 & 0,141 & 0,156 & 0,137 & 0,163 & 0,110 & 0,087 & 0,057 & 0,090 & 0,208 & 0,272 & 0,281 & 0,216 & 0,213 \\
\hline & $\mathrm{K}$ & 0,003 & 0,001 & 0,001 & 0,000 & 0,001 & 0,000 & 0,001 & 0,000 & 0,000 & 0,000 & 0,000 & 0,000 & 0,001 & 0,001 & 0,001 \\
\hline & $\Sigma_{\mathrm{M} 2}$ & 3,997 & 3,999 & 3,999 & 4,000 & 3,999 & 4,000 & 1,000 & 0,999 & 0,999 & 1,000 & 0,993 & 0,989 & 0,989 & 1,020 & 1,020 \\
\hline Total de cát & tions & 7,021 & 3,999 & 3,999 & 4,000 & 3,999 & 4,000 & 4,000 & 3,998 & 3,998 & 4,000 & 3,998 & 3,998 & 4,000 & 4,000 & 4,001 \\
\hline & & & & & & & Compon & tes $\mathrm{mol}$ & culares & & & & & & & \\
\hline Jd & & 2,51 & 1,97 & 2,41 & 0,33 & 3,21 & 1,82 & 0,49 & 0,12 & 0,00 & 0,45 & 1,42 & 1,14 & 1,20 & 1,58 & 2,00 \\
\hline $\mathrm{Ae}$ & & 4,22 & 5,65 & 5,35 & 8,47 & 4,28 & 7,22 & 5,51 & 4,57 & 3,05 & 4,40 & 10,30 & 14,76 & 15,36 & 10,95 & 10,25 \\
\hline Es & & 0,00 & 0,00 & 0,00 & 1,54 & 0,00 & 0,00 & 0,00 & 0,38 & 0,25 & 0,14 & 0,00 & 0,00 & 0,00 & 0,17 & 0,00 \\
\hline CaTiTs & & 0,00 & 0,77 & 0,62 & 0,85 & 0,17 & 0,52 & 0,47 & 0,64 & 0,91 & 0,55 & 0,00 & 0,00 & 0,00 & 0,40 & 0,36 \\
\hline
\end{tabular}


Tabela 8. Composição química de clinopiroxênios dos microssienitos com textura em mosaico $(37,19)$ e dos microssienitos porfiríticos com textura traquítica (30) do Morro de São João. Abreviações e classificação como na Tabela 6.

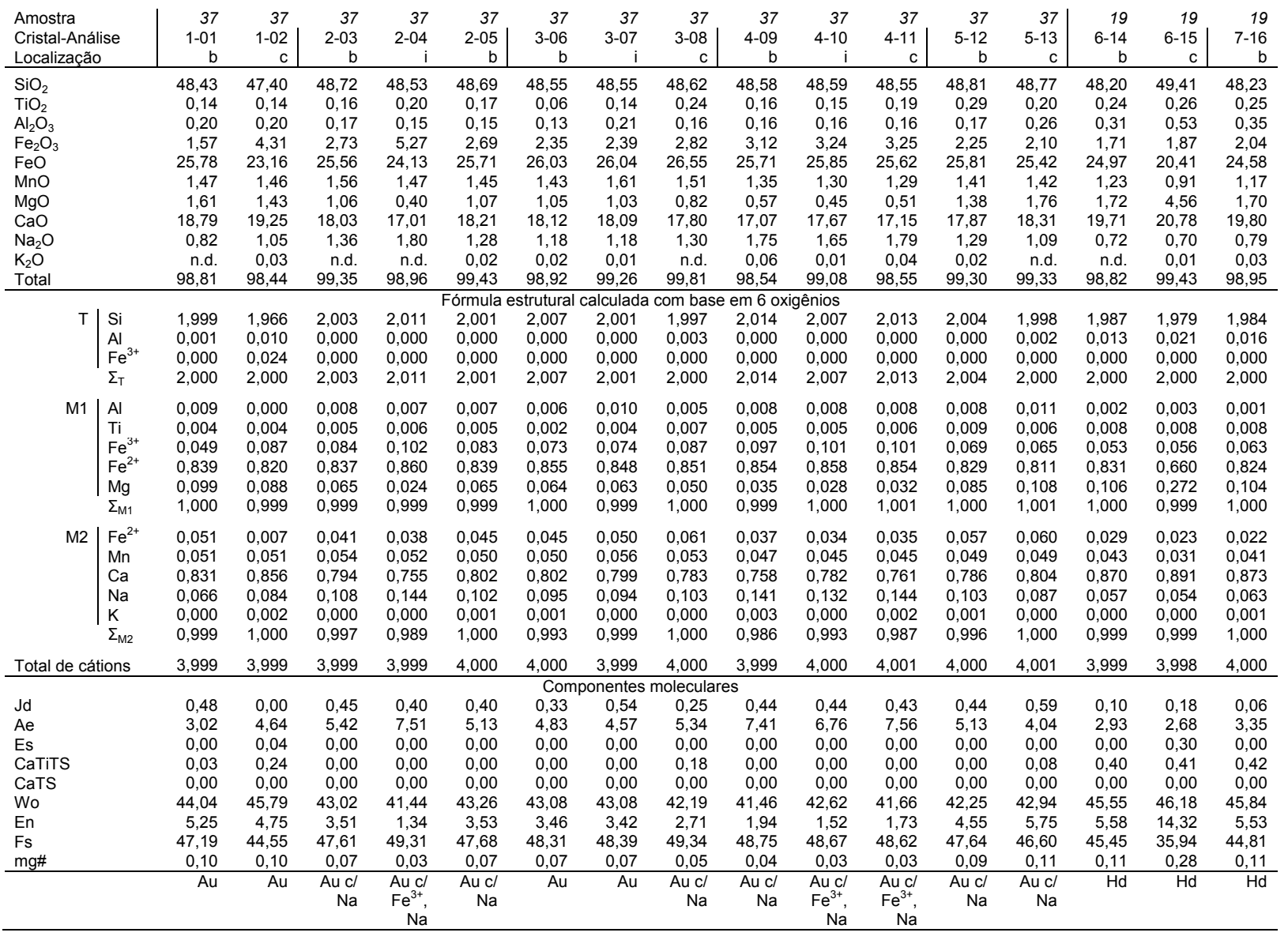

\begin{tabular}{|c|c|c|c|c|c|c|c|}
\hline \multirow{2}{*}{\multicolumn{2}{|c|}{$\begin{array}{l}\text { Amostra } \\
\text { Cristal-Análise } \\
\text { Localização }\end{array}$}} & $\begin{array}{r}19 \\
\end{array}$ & $\begin{array}{r}19 \\
8-18\end{array}$ & $\begin{array}{r}19 \\
819\end{array}$ & $\begin{array}{r}30 \\
\end{array}$ & $\begin{array}{r}30 \\
0-21\end{array}$ & $\begin{array}{r}30 \\
0\end{array}$ \\
\hline & & $\begin{array}{r}7-17 \\
\mathrm{C}\end{array}$ & $\begin{array}{r}8-18 \\
b\end{array}$ & $\begin{array}{r}8-19 \\
\mathrm{C}\end{array}$ & $\begin{array}{r}9-20 \\
b\end{array}$ & $\begin{array}{r}9-21 \\
i\end{array}$ & $\begin{array}{r}9-22 \\
\mathrm{c}\end{array}$ \\
\hline \multicolumn{2}{|l|}{$\mathrm{SiO}_{2}$} & 48,38 & 48,46 & 48,39 & 49,61 & 50,11 & 50,54 \\
\hline \multicolumn{2}{|l|}{$\mathrm{TiO}_{2}$} & 0,27 & 0,22 & 0,17 & 0,77 & 0,68 & 1,07 \\
\hline \multicolumn{2}{|l|}{$\mathrm{Al}_{2} \mathrm{O}_{3}$} & 0,27 & 0,28 & 0,25 & 0,27 & 0,22 & 0,31 \\
\hline $\mathrm{Fe}_{2} \mathrm{O}_{3}$ & & 1,50 & 1,46 & 1,39 & 8,28 & 9,74 & 7,85 \\
\hline \multicolumn{2}{|l|}{$\mathrm{FeO}$} & 24,60 & 24,83 & 25,18 & 21,38 & 20,33 & 21,63 \\
\hline \multicolumn{2}{|l|}{$\mathrm{MnO}$} & 1,30 & 1,22 & 1,16 & 0,72 & 0,76 & 0,65 \\
\hline \multicolumn{2}{|l|}{$\mathrm{MgO}$} & 1,84 & 1,67 & 1,62 & 0,03 & 0,02 & 0,01 \\
\hline \multicolumn{2}{|l|}{$\mathrm{CaO}$} & 19,88 & 19,79 & 19,83 & 5,11 & 5,22 & 4,05 \\
\hline \multicolumn{2}{|l|}{$\begin{array}{l}\mathrm{Na}_{2} \mathrm{O} \\
\mathrm{K}_{2} \mathrm{O}\end{array}$} & 0,73 & 0,79 & 0,73 & 9,58 & 9,33 & 10,28 \\
\hline \multirow{2}{*}{\multicolumn{2}{|c|}{$\begin{array}{l}\mathrm{K}_{2} \mathrm{O} \\
\text { Total }\end{array}$}} & 0,02 & 0,03 & n.d. & 0,01 & 0,01 & n.d. \\
\hline & & 98,78 & 98,74 & 98,74 & 95,74 & 96,49 & 96,42 \\
\hline \multicolumn{2}{|l|}{ Total } & Fórmula & trutural & alculada & ênios & & \\
\hline \multirow[t]{4}{*}{$\mathrm{T}$} & $\mathrm{Si}$ & 1,991 & 1,996 & 1,996 & 1,998 & 2,012 & 2,010 \\
\hline & $\mathrm{Al}$ & 0,009 & 0,004 & 0,004 & 0,002 & 0,000 & 0,000 \\
\hline & $\mathrm{Fe}^{3+}$ & 0,000 & 0,000 & 0,000 & 0,000 & 0,000 & 0,000 \\
\hline & $\Sigma_{\mathrm{T}}$ & 2,000 & 2,000 & 2,000 & 2,000 & 2,012 & 2,010 \\
\hline \multirow[t]{6}{*}{ M1 } & $\mathrm{Al}$ & 0,004 & 0,010 & 0,008 & 0,011 & 0,010 & 0,014 \\
\hline & $\mathrm{Ti}$ & 0,008 & 0,007 & 0,005 & 0,023 & 0,021 & 0,032 \\
\hline & $\mathrm{Fe}^{3+}$ & 0,046 & 0,045 & 0,043 & 0,692 & 0,649 & 0,693 \\
\hline & $\mathrm{Fe}^{2+}$ & 0,828 & 0,836 & 0,843 & 0,272 & 0,317 & 0,259 \\
\hline & Mg & 0,113 & 0,102 & 0,100 & 0,002 & 0,001 & 0,001 \\
\hline & $\Sigma_{\mathrm{M} 1}$ & 0,999 & 1,000 & 0,999 & 1,000 & 0,998 & 0,999 \\
\hline \multirow[t]{6}{*}{ M2 } & $\mathrm{Fe}^{2+}$ & 0,019 & 0,019 & 0,025 & 0,007 & 0,011 & 0,002 \\
\hline & $\mathrm{Mn}$ & 0,045 & 0,042 & 0,041 & 0,024 & 0,026 & 0,022 \\
\hline & $\mathrm{Ca}$ & 0,877 & 0,873 & 0,876 & 0,220 & 0,225 & 0,173 \\
\hline & $\mathrm{Na}$ & 0,059 & 0,063 & 0,058 & 0,748 & 0,726 & 0,793 \\
\hline & $\mathrm{K}$ & 0,001 & 0,002 & 0,000 & 0,001 & 0,000 & 0,000 \\
\hline & $\Sigma_{\mathrm{M} 2}$ & 1,001 & 0,999 & 1,000 & 1,000 & 0,988 & 0,990 \\
\hline \multicolumn{2}{|c|}{ Total de cátions } & 4,000 & 3,999 & 3,999 & 4,000 & 3,998 & 3,999 \\
\hline \multicolumn{8}{|c|}{ Componentes moleculares } \\
\hline \multicolumn{2}{|l|}{$\mathrm{Jd}$} & 0,23 & 0,50 & 0,42 & 0,87 & 0,82 & 1,17 \\
\hline \multicolumn{2}{|l|}{$\mathrm{Ae}$} & 2,90 & 2,92 & 2,64 & 59,05 & 55,94 & 63,40 \\
\hline \multicolumn{2}{|l|}{ Es } & 0,00 & 0,00 & 0,00 & 0,00 & 0,00 & 0,00 \\
\hline \multirow{2}{*}{\multicolumn{2}{|c|}{$\begin{array}{l}\text { CaTiTs } \\
\text { CaTs }\end{array}$}} & 0,45 & 0,20 & 0,23 & 0,14 & 0,00 & 0,00 \\
\hline & & 0,00 & 0,00 & 0,00 & 0,00 & 0,00 & 0,00 \\
\hline \multicolumn{2}{|l|}{ Wo } & 45,80 & 45,86 & 45,84 & 17,49 & 17,55 & 14,06 \\
\hline \multicolumn{2}{|l|}{ En } & 5,96 & 5,40 & 5,23 & 0,13 & 0,11 & 0,06 \\
\hline \multirow{2}{*}{\multicolumn{2}{|c|}{$\begin{array}{l}\text { Fs } \\
\text { mg\# }\end{array}$}} & 44,67 & 45,12 & 45,65 & 22,32 & 25,58 & 21,31 \\
\hline & & 0,12 & 0,11 & 0,10 & 0,01 & 0,00 & 0,00 \\
\hline & $\mathrm{Hd}$ & $\mathrm{Hd}$ & $\mathrm{Hd}$ & $\begin{array}{c}\mathrm{Ea} \mathrm{cl} \\
\mathrm{Fe}^{3+}\end{array}$ & $\begin{array}{c}\mathrm{Ea} \mathrm{cl} \\
\mathrm{Fe}^{3+}\end{array}$ & $\begin{array}{c}\mathrm{Ea} \mathrm{cl} \\
\mathrm{Fe}^{3+}\end{array}$ \\
\hline
\end{tabular}




\subsection{Anfibólios}

Foram efetuadas 121 análises em anfibólios das rochas de Cananéia, estando os dados reunidos nas Tabelas 9 a 12, juntamente com a sua fórmula estrutural e classificação. Como mencionado na parte metodológica, as composições desses minerais foram calculadas seguindo as recomendações de Leake (1997) e obedecendo aos limites dos campos estabelecidos para cada diagrama classificatório. Os prefixos e adjetivos modificadores foram utilizados para expressar quantidades incomuns dos cátions presentes na estrutura do mineral. Foram ainda empregados como parâmetros de distinção: $(\mathrm{Ca}+\mathrm{Na})_{B} \geq 1,00$ e $\mathrm{Na}_{B}<0,50$ para anfibólios cálcicos; $(\mathrm{Ca}+\mathrm{Na})_{B} \geq 1,00$ e $0,50<\mathrm{Na}_{B}<1,50$ para anfibólios sódico-cálcicos; e $\mathrm{Na}_{\mathrm{B}} \geq 1,50$ para anfibólios sódicos.

Os anfibólios estudados pertencem aos três grupos acima, reconhecendo-se ainda importantes mudanças composicionais, com os anfibólios cálcicos passando para termos mais sódico-cálcicos e estes últimos para termos mais sódicos. Os anfibólios dos álcali feldspato sienitos são essencialmente cálcicos (Figs. 13A, B), enquanto que os dos quartzo-álcali feldspato sienitos são dominantemente sódico-cálcicos (Figs. 13C, D); já os dos microssienitos porfiríticos com textura traquítica mostram-se mais sódicos (Fig.14).

A

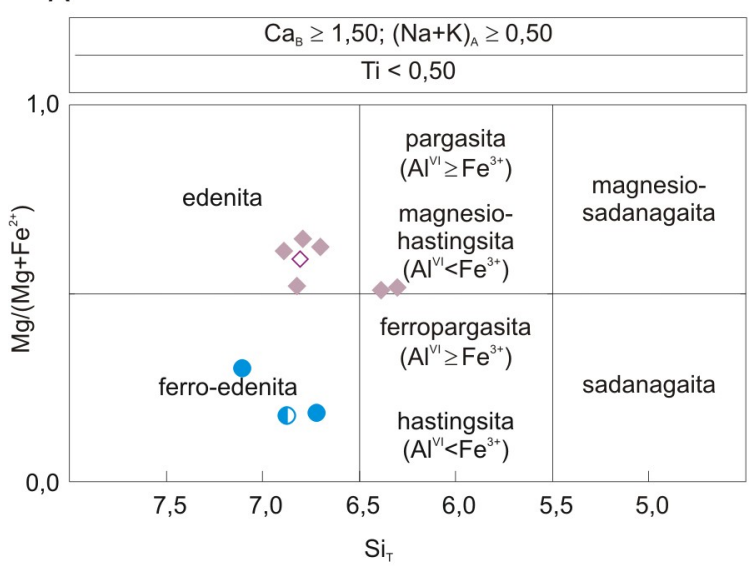

C

$(\mathrm{Na}+\mathrm{K})_{A} \geq 0,50 ;\left(\mathrm{Ca}+\mathrm{Na}_{B}\right) \geq 1,00 ; 0,50<\mathrm{Na}_{B}<1,50$

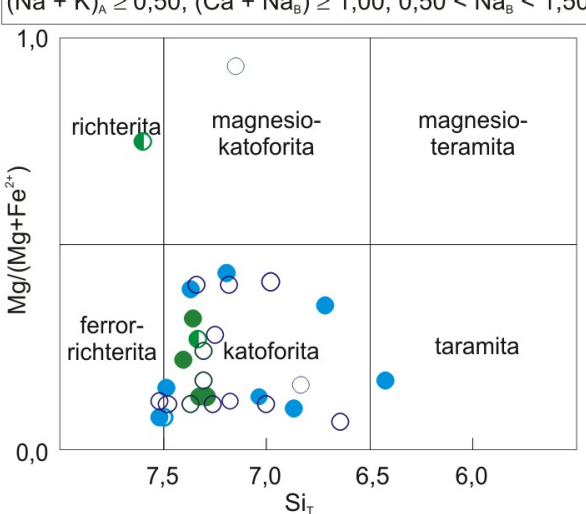

B

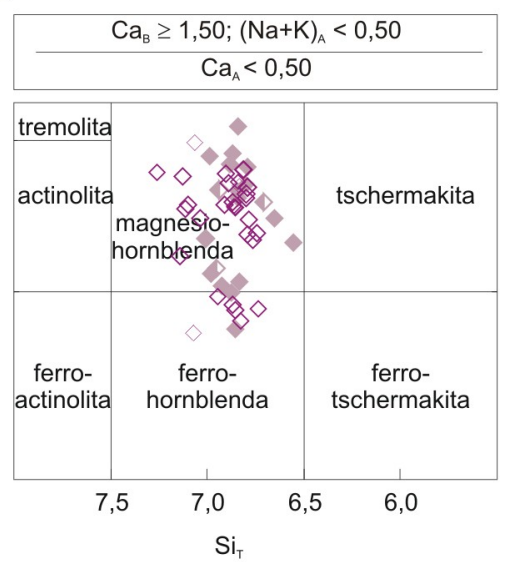

D

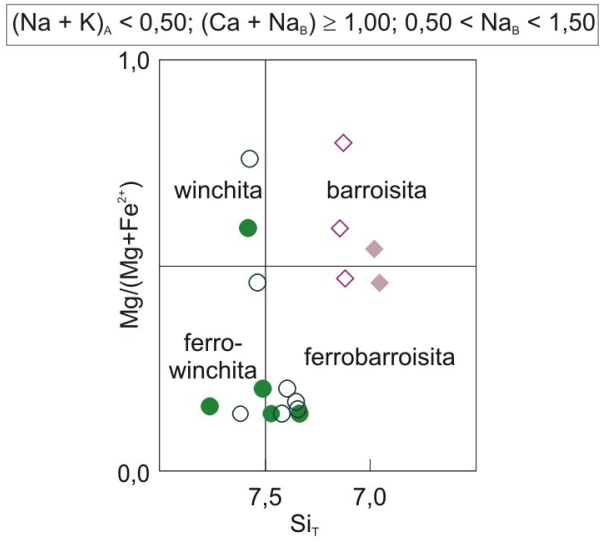

Figura 13. Diagramas classificatórios segundo Leake (1997) para anfibólios cálcicos (A e B) e cálcico-sódicos (C e D) das rochas de Cananéia. Símbolos como na Figura 8.

Com base na grade de Leake (1997), os anfibólios cálcicos estão situados nos campos da magnesiohornblenda (38 análises), fase dominante, ferrohornblenda (6 análises), edenita (5 análises), ferrobarroisita (5 análises) e magnesiohastingsita (2 análises); esses minerais são também enriquecidos em $\mathrm{Fe}^{3+}$ e $\mathrm{F}$, e contêm ou não Ti (Figs. 13A, B); os sódico-cálcicos estão representados principalmente por katoforita (23 análises), ferrobarroisita (6 análises), ferrorrichterita (3 análises), 
ferrowinchita (3 análises), magnesiokatoforita (2 análises), winchita (2 análises) e richterita (1 análise); além disso, possuem $\mathrm{Fe}^{3+}, \mathrm{F}$ e K, o último elemento nem sempre presente (Figs. 13C, D); já os sódicos correspondem a arfvedsonitas ricas em $\mathrm{Fe}^{3+}, \mathrm{K}$ e $\mathrm{F}$ (17 análises) (Fig.14).

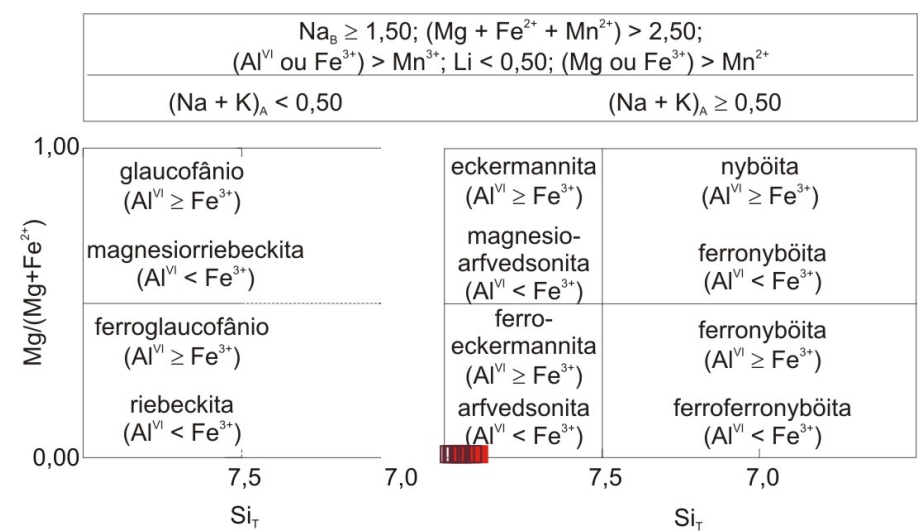

Figura 14. Diagrama classificatório segundo Leake (1997) para anfibólios sódicos das rochas de Cananéia. Símbolos como na Figura 8.

Nas rochas menos evoluídas (os álcali feldspato sienitos), os anfibólios presentes são essencialmente cálcicos, uma magnesiohornblenda, com os núcleos dos grãos compostos de edenita e as bordas mais ricas em magnésio formando magnesiohornblenda (Figs. 13A, B); ocorrem ainda grãos de magnesiohornblenda, com os núcleos e bordas constituídos por ferrobarroisita e barroisita (Fig.13D). Os anfibólios dos quartzo-álcali feldspato sienitos consistem em katoforita (Fig.13C), podendo ter núcleos de ferro-edenita, ferrorrichterita e taramita, ou ainda, no caso das rochas do Morrete, de magnesiokatoforita, com núcleos de ferrowinchita e bordas constituídas por ferrobarroisita (Fig.13D). Já as mais evoluídas, como os microssienitos porfiríticos com textura traquítica, contêm anfibólios sódicos de composição arfvedsonítica, trazendo também $\mathrm{Fe}^{3+}, \mathrm{K}$ e $\mathrm{F}$ (Fig.14).

Como mostrado nas Tabelas 9 a 12, o sítio T é ocupado por $\mathrm{Si}, \mathrm{Al}, \mathrm{Ti}$ (até 0,187 a.f.u.) e Fe ${ }^{3+}$ (até 0,110 a.f.u.) e o sítio $\mathrm{C}$ por $\mathrm{Fe}^{3+}$ e $\mathrm{Fe}^{2+}$, com contribuições de $\mathrm{Mg}$ (até 2,287 a.f.u.), Ti (até 0,312 a.f.u.), Mn (até 0,260 a.f.u.), Al (até 0,191 a.f.u.) e Ca (até 0,100 a.f.u.). Ca (até 1,756 a.f.u.) e Na (até 1,861 a.f.u.) preenchem completamente o sítio $\mathrm{B}$, enquanto o $\mathrm{A}$ é ocupado por $\mathrm{Na}$ e $\mathrm{K}$.

A diversidade composicional dos anfibólios acha-se também evidenciada no gráfico ternário Ca$\mathrm{Mg}-\mathrm{Fe}^{*}$ (onde $\mathrm{Fe}^{*}=\mathrm{Fe}^{3+}+\mathrm{Fe}^{2+}+\mathrm{Mn}$ ) (Fig. 15A), onde se nota um trend evolutivo com o aumento de $\mathrm{Fe}$, mantida a razão $\mathrm{Ca} / \mathrm{Mg}$ praticamente constante, a partir dos álcali feldspato sienitos para os quartzoálcali feldspato sienitos e microssienitos. O diagrama Ca-Na-K (Fig. 15B) mostra o enriquecimento de $\mathrm{Na}$ em relação a Ca para baixos teores de K. Essa variação é também comum em anfibólios de outras províncias alcalinas, como as de Ponta do Morro, no Brasil (Sousa, 1997), Ras ed Dom, no Sudão (O’Halloran, 1985) e Oslo, na Noruega (Neumann, 1976).

O diagrama ternário (Fig. 16) demonstra que os anfibólios comportam-se de modo similar aos clinopiroxênios, com os quartzo-álcali feldspato sienitos exibindo enriquecimento em $(\mathrm{Na}+\mathrm{K})$ e $\left(\mathrm{Fe}^{2+}+\mathrm{Mn}\right)$ e empobrecimento em $\mathrm{Mg}$ quando comparados aos álcali feldspato sienitos.

A Figura 17 ilustra a relação $\mathrm{Si}+\mathrm{Na}+\mathrm{K}$ vs. $\mathrm{Al}_{\mathrm{T}}+\mathrm{Ca}$, indicativa da substituição $\mathrm{Al}_{\mathrm{T}}+\mathrm{Ca} \leftrightarrow \mathrm{Si}+\mathrm{Na}$. Nesse gráfico, são reconhecidos dois trends distintos: o comum às rochas menos evoluídas - os álcali feldspato sienitos - apresentando maior enriquecimento em $\mathrm{Al}_{\mathrm{T}}$ e $\mathrm{Ca}$, e o característico das rochas mais evoluídas - os quartzo-álcali feldspato sienitos, microssienitos com textura em mosaico e microssienitos porfiríticos com textura traquítica exibindo maior riqueza em $\mathrm{SiO}_{2}$ e álcalis. 


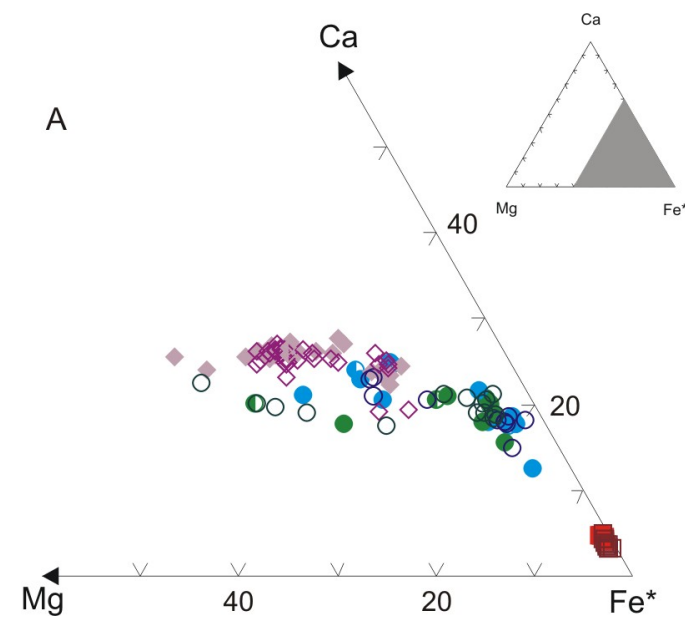

B
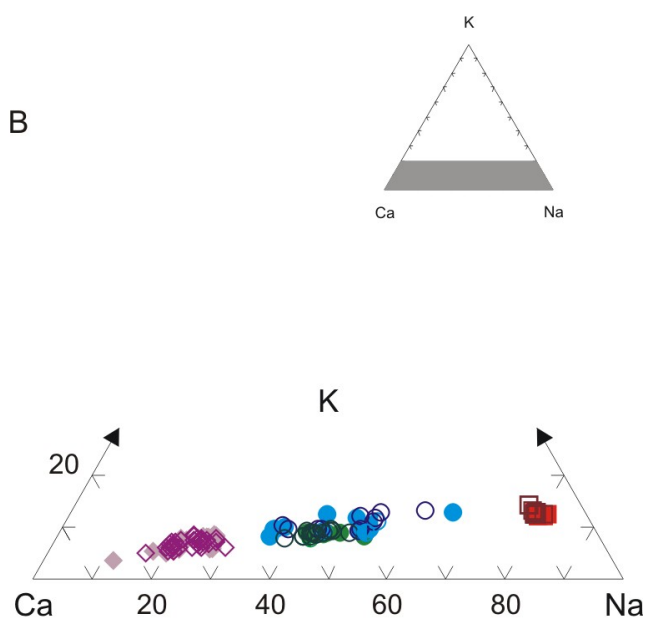

Figura 15. A) Diagrama ternário Ca-Mg-Fe ${ }^{*}$ (onde $\mathrm{Fe}^{*}=\mathrm{Fe}^{3+}+\mathrm{Fe}^{2+}+\mathrm{Mn}$ ); B) Corte do diagrama triangular K-Ca-Na mostrando a evolução composicional dos anfibólios das rochas de Cananéia. Símbolos como na Figura 8

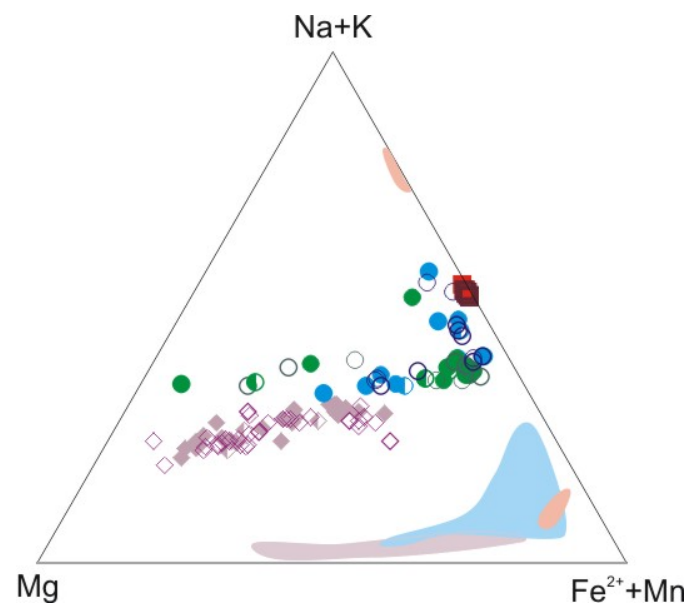

Figura 16. Diagrama ternário $(\mathrm{Na}+\mathrm{K})-\mathrm{Mg}-\left(\mathrm{Fe}^{2+}+\mathrm{Mn}\right)$ comparando as variações composicionais de anfibólios e clinopiroxênios das rochas de Cananéia. Campos para os clinopiroxênios do Morro de São João: lilás - álcali feldspato sienitos; azul - quartzoálcali feldspato sienitos; rosa: - microssienitos. Símbolos como na Figura 8.

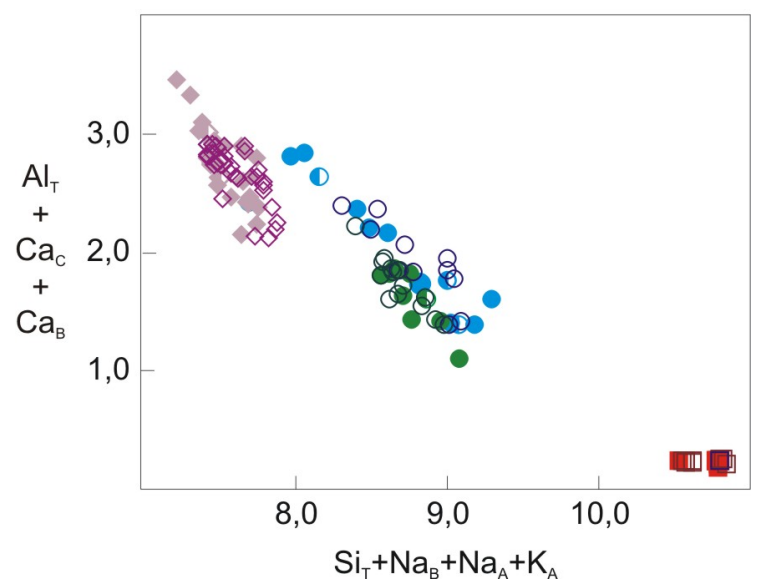

Figura 17. Diagrama $\mathrm{Si}_{T}+\mathrm{Na}_{\mathrm{B}}+\mathrm{Na}_{\mathrm{A}}+\mathrm{K}_{\mathrm{A}}$ vs. $\mathrm{Al}_{\mathrm{T}}+\mathrm{Ca}_{\mathrm{C}}+\mathrm{Ca}_{\mathrm{B}}$ mostrando a variação composicional dos anfibólios das rochas de Cananéia. Símbolos como na Figura 8.

Essas tendências são similares às encontradas nas associações alcalinas ricas em sílica, mesozóicas ou mais antigas, da região de Oslo, na Noruega (Neumann, 1976), de complexos anelares (Giret et al., 1980), de Itiúba, na Bahia (Conceição et al., 1991), e de Ponta do Morro, no Mato Grosso (Sousa, 1997).

Segundo Giret et al. (1980), o fracionamento das fases ricas em Ca e pobres em Si induz ao aumento do último elemento no magma, contribuindo, assim, para a produção de líquidos 
diferenciados ricos em sílica. Petrograficamente, isto é confirmado em Cananéia pela presença de quartzo em contato com o anfibólio preenchendo vazios intergranulares.

O comportamento dos elementos presentes nos anfibólios é mostrado nos diagramas binários que relacionam $\mathrm{mg \#}$ (onde $\mathrm{mg}=\mathrm{Mg} / \mathrm{Mg}+\mathrm{Fe}^{2+}$ ) com diversos cátions, os últimos reunidos em conformidade com as posições estruturais por ele ocupadas (Fig. 18). O sítio tetraédrico (T) é preenchido essencialmente por $\mathrm{Si}$ e $\mathrm{Al}$, sendo, no entanto, a dispersão dos pontos muito grande. Contudo, $\mathrm{Ti}$ e $\mathrm{Fe}^{3+}$ podem estar também ocupando essa posição, além de participar do preenchimento do sítio octaédrico. Os demais cátions, quando relacionados com mg\#, apresentam, tanto para as rochas menos evoluídas como para as mais, correlação positiva para $\mathrm{Fe}^{3+}{ }_{\mathrm{C}}+\mathrm{Fe}^{3+}{ }_{\mathrm{T}} \mathrm{e}$ $\mathrm{Ca}_{B}+\mathrm{Ca}_{\mathrm{A}}$ e negativa para $\mathrm{Ti}_{\mathrm{C}}, \mathrm{Mn}_{\mathrm{C}}, \mathrm{Fe}^{2+}{ }_{\mathrm{C}}$ e $\mathrm{Na}_{\mathrm{B}}+\mathrm{Na}_{\mathrm{A}}$. Os diagramas da Figura 18 sugerem ainda que os álcali feldspato sienitos são mais ricos em $\mathrm{Ca}$ e mais pobres em $\mathrm{Mn}, \mathrm{Fe}^{2+}$, Na e K relativamente às litologias mais evoluídas do maciço. 

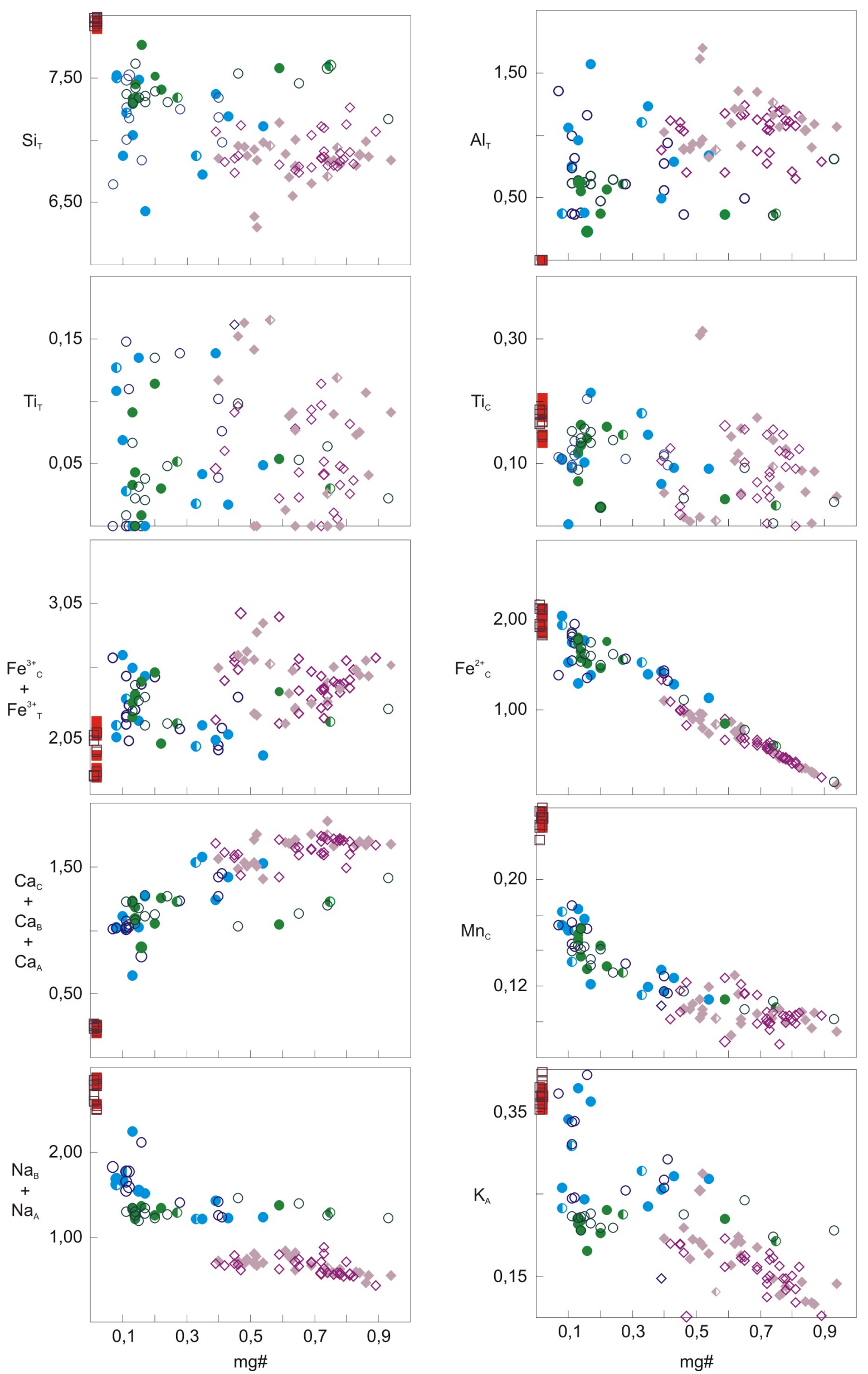

Figura 18. Diagramas de variação composicional dos anfibólios das rochas de Cananéia. Símbolos como na Figura 8. 
6. Quimica Mineral

Tabela 9. Composição química de anfibólios dos álcali feldspato sienitos do Morro de São João. Abreviações: c, b, i, respectivamente, centro, borda e região intermediária dos cristais. Classificação: Ed, edenita; FEd, ferro-edenita; MHas, magnesiohastingsita; MHbl, magnesiohornblenda; $\mathrm{FHbl}$, ferrohornblenda; Rct, richterita; FRct, ferrorrichterita; Ktf, katoforita; MKtf, magnesiokatoforita; Tmt, taramita; Win, winchita; FWin, ferrowinchita; fBar, ferribarroisita; FBar, ferrobarroisita; fFBar, ferri-ferrobarroisita; Avd, arfvedsonita. Fórmula estrutural calculada assumindo (OH, $\mathrm{F}, \mathrm{Cl})=2,00$ a.f.u.; $\mathrm{mg \#}=\mathrm{Mg} /(\mathrm{Mg}+\mathrm{Fe})$.

\begin{tabular}{|c|c|c|c|c|c|c|c|c|c|c|c|c|c|c|c|c|c|}
\hline \multicolumn{2}{|c|}{$\begin{array}{l}\text { Amostra } \\
\text { Cristal-Análise } \\
\text { Localização }\end{array}$} & $\begin{array}{r}28 B \\
1-01 \\
\mathrm{C} \\
\end{array}$ & $\begin{array}{r}28 B \\
1-02 \\
\mathrm{~b} \\
\end{array}$ & $\begin{array}{r}28 B \\
2-03 \\
\mathrm{C} \\
\end{array}$ & $\begin{array}{r}28 B \\
2-04 \\
\mathrm{~b} \\
\end{array}$ & $\begin{array}{r}28 B \\
3-05 \\
C \\
\end{array}$ & $\begin{array}{r}28 B \\
3-06 \\
b \\
\end{array}$ & $\begin{array}{r}28 B \\
4-07 \\
C \\
\end{array}$ & $\begin{array}{r}28 B \\
4-08 \\
b \\
\end{array}$ & $\begin{array}{r}28 B \\
5-09 \\
\mathrm{~b} \\
\end{array}$ & $\begin{array}{r}28 B \\
5-10 \\
\mathrm{i} \\
\end{array}$ & $\begin{array}{r}28 B \\
5-11 \\
C \\
\end{array}$ & $\begin{array}{r}33 B \\
6-12 \\
b \\
\end{array}$ & $\begin{array}{r}33 B \\
6-13 \\
C \\
\end{array}$ & $\begin{array}{r}33 B \\
7-14 \\
\mathrm{~b} \\
\end{array}$ & $\begin{array}{r}33 B \\
7-15 \\
C \\
\end{array}$ & $\begin{array}{r}33 B \\
8-16 \\
\quad b \\
\end{array}$ \\
\hline & 45,91 & 44,13 & 44,55 & 46,50 & 44,98 & 44,69 & 48,66 & 44,07 & 44,38 & 43,27 & 44,97 & 43,26 & 40,28 & 43,20 & 39,81 & 43,30 \\
\hline $\mathrm{TiO}_{2}$ & & 0,97 & 1,13 & 1,33 & 0,92 & 1,21 & 1,39 & 0,68 & 1,32 & 1,33 & 1,04 & 1,07 & 1,39 & 2,56 & 1,10 & 2,62 & 1,23 \\
\hline \multicolumn{2}{|l|}{$\mathrm{Al}_{2} \mathrm{O}_{3}$} & 5,04 & 6,58 & 5,92 & 4,40 & 5,98 & 6,16 & 3,23 & 6,62 & 5,75 & 6,92 & 5,21 & 6,08 & 8,71 & 6,28 & 9,20 & 6,31 \\
\hline \multirow{2}{*}{\multicolumn{2}{|c|}{$\begin{array}{l}\mathrm{FeO} \\
\mathrm{MnO}\end{array}$}} & 26,07 & 26,05 & 26,76 & 25,78 & 24,67 & 25,63 & 23,63 & 25,60 & 26,87 & 26,13 & 26,60 & 27,04 & 27,09 & 27,99 & 26,92 & 28,01 \\
\hline & & 0,65 & 0,54 & 0,76 & 0,73 & 0,63 & 0,72 & 0,69 & 0,72 & 0,68 & 0,72 & 0,82 & 0,83 & 0,68 & 0,90 & 0,71 & 0,85 \\
\hline \multicolumn{2}{|l|}{$\mathrm{MgO}$} & 7,01 & 6,33 & 6,12 & 7,37 & 7,65 & 6,61 & 9,22 & 6,36 & 6,00 & 6,16 & 6,33 & 5,45 & 4,21 & 4,99 & 4,28 & 4,76 \\
\hline \multicolumn{2}{|l|}{$\mathrm{CaO}$} & 10,23 & 10,42 & 10,12 & 10,24 & 10,30 & 10,41 & 9,86 & 10,31 & 10,24 & 10,50 & 10,21 & 9,74 & 10,07 & 9,81 & 10,35 & 9,45 \\
\hline \multirow{2}{*}{\multicolumn{2}{|c|}{$\begin{array}{l}\mathrm{Na}_{2} \mathrm{O} \\
\mathrm{K}_{2} \mathrm{O}\end{array}$}} & 1,30 & 1,55 & 1,61 & 1,22 & 1,57 & 1,52 & 1,09 & 1,63 & 1,61 & 1,77 & 1,46 & 1,91 & 2,18 & 1,97 & 2,11 & 1,80 \\
\hline & & 0,61 & 0,83 & 0,65 & 0,53 & 0,73 & 0,71 & 0,35 & 0,75 & 0,63 & 0,90 & 0,66 & 0,81 & 1,26 & 0,86 & 1,36 & 0,85 \\
\hline \multirow{2}{*}{\multicolumn{2}{|c|}{$\mathrm{F}$}} & 0,57 & 0,57 & 0,47 & 0,28 & 0,35 & 0,57 & 0,46 & 0,42 & 0,42 & 0,71 & 0,44 & 0,65 & 0,65 & 0,67 & 0,61 & 0,46 \\
\hline & & 0,26 & 0,32 & 0,32 & 0,08 & 0,23 & 0,11 & 0,18 & 0,19 & 0,26 & 0,27 & 0,25 & 0,18 & 0,27 & 0,12 & 0,14 & 0,43 \\
\hline Cl & & 98,62 & 98,46 & 98,61 & 98,05 & 98,28 & 98,52 & 98,05 & 97,98 & 98,17 & 98,37 & 98,03 & 97,33 & 97,95 & 97,88 & 98,10 & 97,45 \\
\hline \multicolumn{2}{|l|}{$\mathrm{O}=\mathrm{F}, \mathrm{Cl}$} & 0,30 & 0,31 & 0,27 & 0,13 & 0,20 & 0,26 & 0,24 & 0,22 & 0,23 & 0,36 & 0,24 & 0,31 & 0,33 & 0,31 & 0,29 & 0,29 \\
\hline \multirow{2}{*}{\multicolumn{2}{|c|}{$\mathrm{C}_{\text {Total }}$}} & 98,32 & 98,15 & 98,34 & 97,92 & 98,08 & 98,26 & 97,81 & 97,76 & 97,94 & 98,01 & 97,79 & 97,02 & 97,62 & 97,57 & 97,81 & 97,16 \\
\hline \multirow{2}{*}{\multicolumn{2}{|c|}{$\begin{array}{l}\mathrm{H}_{2} \mathrm{O}_{\text {calc }} \\
\text { Total }\end{array}$}} & 1,59 & 1,56 & 1,61 & 1,78 & 1,71 & 1,62 & 1,69 & 1,66 & 1,64 & 1,49 & 1,63 & 1,52 & 1,49 & 1,53 & 1,55 & 1,54 \\
\hline & & 99,91 & 99,71 & 99,95 & 99,70 & 99,79 & 99,88 & 99,50 & 99,42 & 99,58 & 99,50 & 99,42 & 98,54 & 99,11 & 99,10 & 99,36 & 98,70 \\
\hline \multirow{2}{*}{\multicolumn{18}{|c|}{ 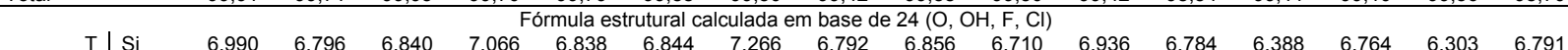 }} \\
\hline & & & & & & & & & & & & & & & & & \\
\hline \multirow{4}{*}{1} & Al & 0,903 & 1,193 & 1,070 & 0,787 & 1,071 & 1,110 & 0,569 & 1,202 & 1,047 & 1,264 & 0,946 & 1,123 & 1,612 & 1,158 & 1,697 & 1,166 \\
\hline & $\mathrm{Ti}$ & 0,107 & 0,011 & 0,090 & 0,105 & 0,091 & 0,046 & 0,076 & 0,006 & 0,097 & 0,026 & 0,118 & 0,093 & 0,000 & 0,078 & 0,000 & 0,043 \\
\hline & $\mathrm{Fe}^{3+}$ & 0,000 & 0,000 & 0,000 & 0,042 & 0,000 & 0,000 & 0,089 & 0,000 & 0,000 & 0,000 & 0,000 & 0,000 & 0,000 & 0,000 & 0,000 & 0,000 \\
\hline & $\Sigma_{\mathrm{T}}$ & 8,000 & 8,000 & 8,000 & 8,000 & 8,000 & 8,000 & 8,000 & 8,000 & 8,000 & 8,000 & 8,000 & 8,000 & 8,000 & 8,000 & 8,000 & 8,000 \\
\hline \multirow[t]{8}{*}{ C } & Al & 0,000 & 0,000 & 0,000 & 0,000 & 0,000 & 0,000 & 0,000 & 0,000 & 0,000 & 0,000 & 0,000 & 0,000 & 0,015 & 0,000 & 0,019 & 0,000 \\
\hline & $\mathrm{Ti}$ & 0,004 & 0,120 & 0,063 & 0,000 & 0,047 & 0,114 & 0,000 & 0,146 & 0,058 & 0,095 & 0,006 & 0,071 & 0,306 & 0,051 & 0,312 & 0,102 \\
\hline & $\mathrm{Mg}$ & 1,592 & 1,454 & 1,401 & 1,670 & 1,734 & 1,509 & 2,052 & 1,460 & 1,382 & 1,423 & 1,455 & 1,274 & 0,994 & 1,165 & 1,010 & 1,112 \\
\hline & $\mathrm{Fe}^{2+}$ & 0,266 & 0,469 & 0,433 & 0,203 & 0,118 & 0,408 & 0,000 & 0,429 & 0,539 & 0,511 & 0,440 & 0,577 & 0,956 & 0,669 & 0,942 & 0,604 \\
\hline & $\mathrm{Fe}^{3+}$ & 3,055 & 2,886 & 3,004 & 3,033 & 3,019 & 2,875 & 2,861 & 2,870 & 2,933 & 2,877 & 2,992 & 2,968 & 2,637 & 2,996 & 2,622 & 3,070 \\
\hline & $\mathrm{Mn}$ & 0,084 & 0,071 & 0,099 & 0,094 & 0,081 & 0,094 & 0,087 & 0,094 & 0,089 & 0,095 & 0,108 & 0,110 &, 092 & 0,119 & 0,095 & 0,112 \\
\hline & $\mathrm{Ca}$ & 0,000 & 0,000 & 0,000 & 0,000 & 0,000 & 0,000 & 0,000 & 0,000 & 0,000 & 0,000 & 0,000 & 0,000 & 0,000 & 0,000 & 0,000 & 0,000 \\
\hline & $\Sigma_{\mathrm{C}}$ & 5,001 & 5,000 & 5,000 & 5,000 & 4,999 & 5,000 & 5,000 & 4,999 & 5,001 & 5,001 & 5,001 & 5,000 & 5,000 & 5,000 & 5,000 & 5,000 \\
\hline \multirow{6}{*}{ 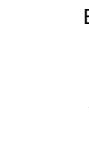 } & $\mathrm{Ca}$ & 1,669 & 1,720 & 1,665 & 1,668 & 1,678 & 1,709 & 1,578 & 1,703 & 1,695 & 1,745 & 1,687 & 1,636 & 1,711 & 1,645 & 1,755 & 1,588 \\
\hline & $\mathrm{Na}$ & 0,331 & 0,280 & 0,335 & 0,332 & 0,322 & 0,291 & 0,314 & 0,297 & 0,305 & 0,255 & 0,313 & 0,364 & $0,2 \varepsilon$ & 0,355 & 0,245 & 0,412 \\
\hline & $\Sigma_{\mathrm{B}}$ & 2,000 & 2,000 & 2,000 & 2,000 & 2,000 & 2,000 & 1,892 & 2,000 & 2,000 & 2,000 & 2,000 & 2,000 & 2,000 & 2,000 & 2,000 & 2,000 \\
\hline & $\mathrm{Na}$ & 0,054 & 0,184 & 0,146 & 0,026 & 0,140 & 0,159 & 0,000 & 0,189 & 0,178 & 0,276 & 0,124 & 0,217 & 0,382 & 0,242 & 0,403 & 0,135 \\
\hline & & 0,118 & & 0,127 & & 0,141 & 0,139 & & & 0,125 & & & & & & & 0,169 \\
\hline & & 0,172 & 0,347 & 0,273 & 0,128 & 0,281 & 0,298 & 0,067 & 0,336 & 0,303 & 0,453 & 0,254 & 0,378 & 0,636 & 0,414 & 0,677 & 0,304 \\
\hline \multicolumn{2}{|c|}{ Total de cátions } & 15,173 & 15,347 & 15,273 & 15,128 & 15,280 & 15,298 & 14,959 & 15,335 & 15,304 & 15,454 & 15,255 & 15,378 & 15,636 & 15,414 & 15,677 & 15,304 \\
\hline \multirow{2}{*}{\multicolumn{2}{|c|}{$\begin{array}{l}\mathrm{Cl} \\
\mathrm{F}\end{array}$}} & 0,067 & 0,084 & 0,083 & 0,021 & 0,058 & 0,028 & 0,046 & 0,048 & 0,067 & 0,072 & 0,065 & 0,048 & 0,072 & 0,031 & 0,037 & 0,115 \\
\hline & & & & & & & & & & 0,206 & & 0,216 & 0,320 & 0,328 & 0,329 & 0,305 & 0,230 \\
\hline $\mathrm{OH}$ & & 1,651 & 1,633 & 1,684 & 1,842 & 1,769 & 1,690 & 1,729 & 1,740 & 1,722 & 1,573 & 1,713 & 1,624 & 1,595 & 1,631 & 1,654 & 1,647 \\
\hline $\mathrm{mg \#}$ & & 0,86 & 0,76 & 0,76 & 0,89 & 0,94 & 0,79 & 1,00 & 0,77 & 0,72 & 0,74 & 0,77 & 0,69 & 0,51 & 0,64 & 0,52 & 0,65 \\
\hline
\end{tabular}

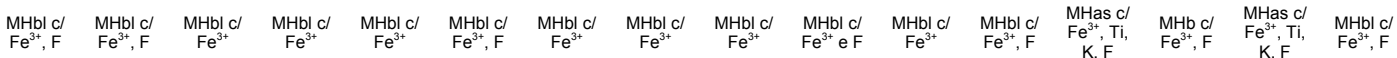

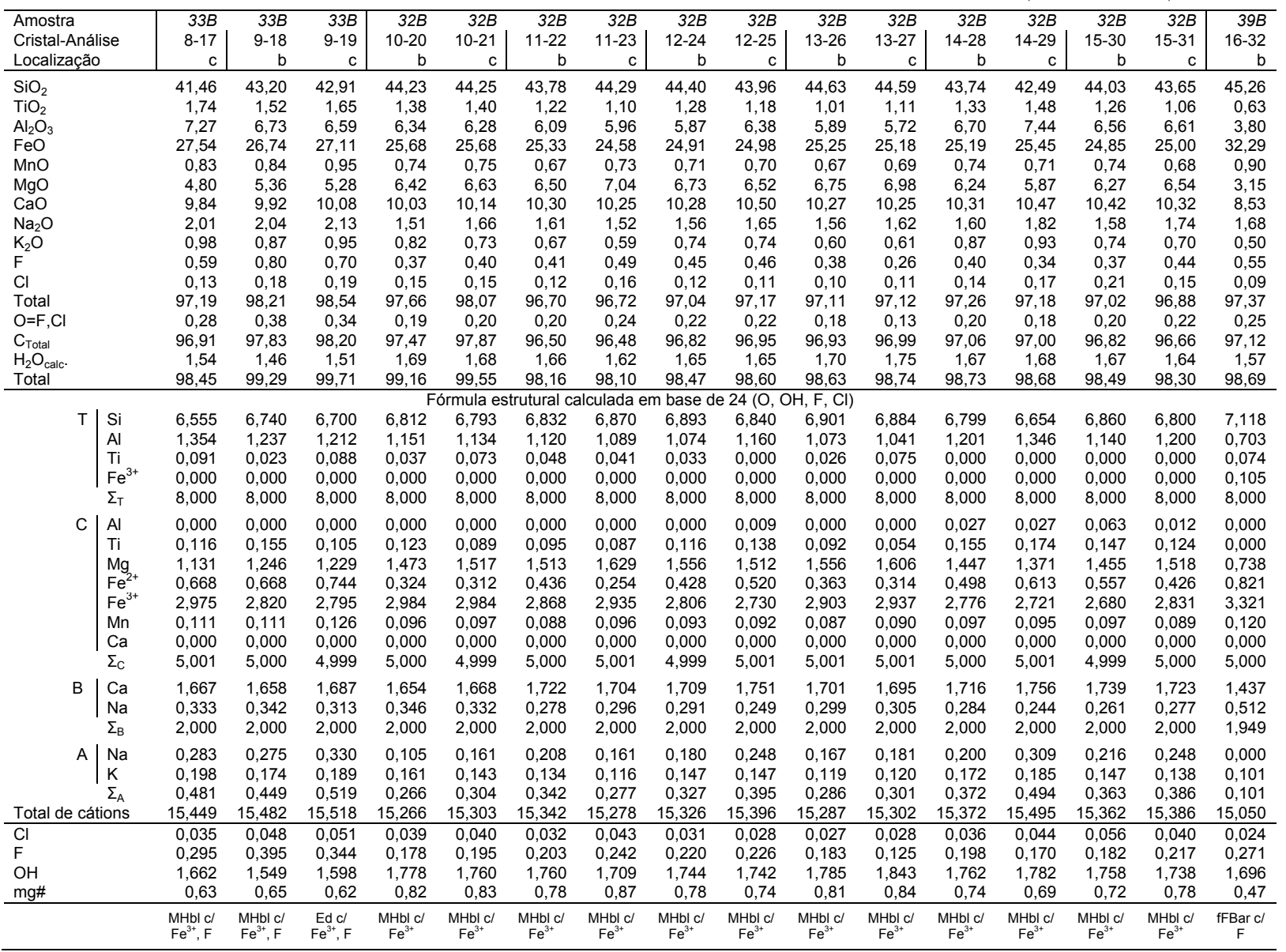


Tabela 9. Continuação.

\begin{tabular}{|c|c|c|c|c|c|c|c|c|c|c|c|c|c|c|c|c|c|}
\hline $\begin{array}{l}\text { Amostra } \\
\text { Cristal-Anális } \\
\text { Localização }\end{array}$ & & $\begin{array}{r}39 B \\
16-33 \\
c \\
\end{array}$ & $\begin{array}{r}39 B \\
17-34 \\
\mathrm{~b} \\
\end{array}$ & $\begin{array}{r}39 B \\
17-35 \\
C \\
\end{array}$ & $\begin{array}{r}39 B \\
18-36 \\
b\end{array}$ & $\begin{array}{r}39 B \\
18-37 \\
\mathrm{C} \\
\end{array}$ & $\begin{array}{r}39 B \\
19-38 \\
\mathrm{~b}\end{array}$ & $\begin{array}{r}39 B \\
19-39 \\
\mathrm{i}\end{array}$ & $\begin{array}{r}39 B \\
19-40 \\
\mathrm{C}\end{array}$ & $\begin{array}{r}39 B \\
20-41 \\
\mathrm{~b}\end{array}$ & $\begin{array}{r}39 B \\
20-42 \\
C\end{array}$ & $\begin{array}{r}39 B \\
21-43 \\
\mathrm{~b} \\
\end{array}$ & $\begin{array}{r}39 B \\
21-44 \\
C\end{array}$ & $\begin{array}{r}39 B \\
22-45 \\
\mathrm{~b} \\
\end{array}$ & $\begin{array}{r}39 B \\
22-46 \\
\mathrm{C} \\
\end{array}$ & $\begin{array}{r}14 \\
23-47 \\
b\end{array}$ & $\begin{array}{r}14 \\
23-48 \\
\mathrm{C} \\
\end{array}$ \\
\hline $\mathrm{SiO}_{2}$ & & 43,25 & 45,52 & 43,78 & 42,58 & 42,99 & 42,31 & 44,09 & 43,97 & 43,30 & 43,49 & 44,40 & 44,15 & 42,99 & 43,89 & 42,77 & 43,60 \\
\hline $\mathrm{TiO}_{2}$ & & 1,43 & 0,40 & 1,43 & 1,53 & 1,40 & 1,51 & 1,46 & 1,41 & 1,28 & 1,57 & 1,26 & 1,21 & 1,03 & 1,31 & 1,52 & 1,32 \\
\hline $\mathrm{Al}_{2} \mathrm{O}_{3}$ & & 5,51 & 3,79 & 4,77 & 5,91 & 5,16 & 5,88 & 4,73 & 4,78 & 5,52 & 5,00 & 4,72 & 4,43 & 5,61 & 5,03 & 6,27 & 5,91 \\
\hline $\mathrm{FeO}$ & & 30,96 & 30,85 & 30,18 & 29,78 & 30,55 & 30,56 & 29,20 & 30,67 & 30,01 & 30,46 & 29,61 & 30,78 & 30,32 & 29,89 & 26,02 & 25,90 \\
\hline $\mathrm{MnO}$ & & 0,84 & 0,94 & 0,74 & 0,67 & 0,73 & 0,72 & 0,69 & 0,74 & 0,74 & 0,77 & 0,76 & 0,87 & 0,84 & 0,80 & 0,54 & 0,58 \\
\hline $\mathrm{MgO}$ & & 3,09 & 4,01 & 3,76 & 3,32 & 3,67 & 3,43 & 4,45 & 3,50 & 3,64 & 3,72 & 3,59 & 3,66 & 3,41 & 3,98 & 5,51 & 5,77 \\
\hline $\mathrm{CaO}$ & & 9,19 & 8,45 & 9,03 & 9,38 & 8,84 & 9,20 & 9,13 & 8,75 & 9,38 & 8,87 & 9,86 & 8,31 & 9,31 & 9,08 & 10,07 & 10,01 \\
\hline $\mathrm{Na}_{2} \mathrm{O}$ & & 1,97 & 1,71 & 1,88 & 1,81 & 1,80 & 2,12 & 2,03 & 1,92 & 1,85 & 2,01 & 1,85 & 1,91 & 1,86 & 1,92 & 2,16 & 2,28 \\
\hline $\mathrm{K}_{2} \mathrm{O}$ & & 0,97 & 0,80 & 0,85 & 0,93 & 0,92 & 0,93 & 0,65 & 1,03 & 0,88 & 0,97 & 0,73 & 0,88 & 0,92 & 0,96 & 0,97 & 0,81 \\
\hline $\mathrm{F}$ & & 0,45 & 0,78 & 0,57 & 0,74 & 0,78 & 0,96 & 0,65 & 0,62 & 0,61 & 0,61 & 0,58 & 0,81 & 0,65 & 0,88 & 1,09 & 1,09 \\
\hline $\mathrm{Cl}$ & & 0,07 & 0,06 & 0,15 & 0,38 & 0,20 & 0,27 & 0,08 & 0,10 & 0,25 & 0,06 & 0,19 & 0,05 & 0,34 & 0,06 & 0,24 & 0,16 \\
\hline Total & & 97,74 & 97,30 & 97,12 & 97,01 & 97,03 & 97,89 & 97,17 & 97,49 & 97,46 & 97,52 & 97,54 & 97,06 & 97,27 & 97,79 & 97,16 & 97,43 \\
\hline $\mathrm{O}=\mathrm{F}, \mathrm{Cl}$ & & 0,21 & 0,34 & 0,27 & 0,40 & 0,37 & 0,46 & 0,29 & 0,28 & 0,31 & 0,27 & 0,29 & 0,35 & 0,35 & 0,38 & 0,51 & 0,49 \\
\hline $\mathrm{C}_{\text {Total }}$ & & 97,53 & 96,96 & 96,85 & 96,61 & 96,66 & 97,43 & 96,88 & 97,21 & 97,15 & 97,25 & 97,25 & 96,71 & 96,92 & 97,41 & 96,65 & 96,94 \\
\hline $\mathrm{H}_{2} \mathrm{O}_{\text {calc. }}$ & & 1,62 & 1,47 & 1,54 & 1,39 & 1,41 & 1,32 & 1,53 & 1,53 & 1,50 & 1,55 & 1,54 & 1,44 & 1,45 & 1,43 & 1,28 & 1,32 \\
\hline Total & & 99,15 & 98,43 & 98,39 & 98,00 & 98,07 & 98,75 & 98,41 & 98,74 & 98,65 & 98,80 & 98,79 & 98,15 & & 98,84 & 97,93 & 98,26 \\
\hline & & & & & & rmula e & trutural c & Iculada & $\mathrm{n}$ base $\mathrm{d}$ & $24(\mathrm{O}$, & $\mathrm{H}, \mathrm{F}, \mathrm{Cl})$ & & & & & & \\
\hline $\mathrm{T}$ & $\mathrm{Si}$ & 6,855 & 7,143 & 6,946 & 6,824 & 6,836 & 6,736 & 6,956 & 6,957 & 6,872 & 6,875 & 7,069 & 6,982 & 6,855 & 6,924 & 6,803 & 6,887 \\
\hline & Al & 028 & 0,700 & 0,891 & 1,116 & 0,966 & 1,103 & 0,879 & 0,891 & 1,032 & 931 & 0,885 & 0,824 & 054 & 0,935 & 1,175 & 1,100 \\
\hline & $\mathrm{Ti}$ & 0,117 & 0,047 & 0,163 & 0,060 & 0,167 & 0,161 & 0,165 & 0,152 & 0,096 & 0,187 & 0,046 & 0,143 & 0,091 & 0,141 & 0,022 & 0,013 \\
\hline & $\mathrm{Fe}^{3+}$ & 000 & 0,110 & 0,000 & 0,000 & 0,031 & 0,000 & 0,000 & 0,000 & 0,000 & 0,007 & 0,000 & 0,051 & 0,000 & 0,000 & 0,000 &, 000 \\
\hline & $\Sigma_{T}$ & 8,000 & 8,000 & 8,000 & 8,000 & 8,000 & 8,000 & 8,000 & 8,000 & 8,000 & 8,000 & 8,000 & 8,000 & 8,000 & 8,000 & 8,000 & 8,000 \\
\hline C & $\mathrm{Al}$ & 0,000 & 0,000 & 0,000 & 0,000 & 0,000 & 0,000 & 0,000 & 0,000 & 0,000 & 0,000 & 0,000 & 0,000 & 0,000 & 0,000 & 0,000 & 0,000 \\
\hline & $\mathrm{Ti}$ & 053 & 0,000 & 0,007 & 0,125 & 0,000 & 0,019 & 0,009 & 0,015 & 0,057 & 000 & 0,105 & 00 & 032 & 0,014 & 160 & 144 \\
\hline & $\mathrm{Mg}$ & 0,729 & 0,938 & 0,888 & 0,793 & 0,869 & 0,814 & 1,047 & 0,826 & 0,860 & 0,876 & 0,851 & 0,864 &, 811 & 0,936 & 1,307 & 1,357 \\
\hline & $\mathrm{Fe}^{2+}$ & 1,105 & 0,649 & 0,949 & 1,096 & 0,790 & 0,988 & 0,827 & 0,964 & 1,005 & 0,899 & 1,351 & 0,725 & 0,998 & 0,885 & 0,899 & 0,857 \\
\hline & $\mathrm{Fe}^{3+}$ & 2,999 & 3,288 & 3,057 & 2,895 & 3,242 & 3,082 & 3,026 & 3,096 & 2,980 & 3,122 & 2,591 & 3,294 & 3,046 & 3,058 & 2,562 & 2,563 \\
\hline & $\mathrm{Mn}$ & 0,113 & 0,124 & 0,099 & 0,091 & & 0,097 & 0,092 & 0,099 & & & & & & & & 0,078 \\
\hline & $\mathrm{Ca}$ & 000 & 0,000 & 0,000 & 0,000 & 0,000 & 000 & 000 & 0,000 & 0,000 & 000 & 000 & 00 & & 00 & 0,000 &, 000 \\
\hline & $\Sigma_{C}$ & 4,999 & 4,999 & 5,000 & 5,000 & 5,000 & 5,000 & 5,001 & 5,000 & 5,001 & 5,000 & 5,000 & 5,000 & 5,001 & 5,000 & 5,001 & 4,999 \\
\hline B & $\mathrm{Ca}$ & 1,561 & 1,421 & 1,535 & 1,611 & 1,506 & 1,570 & 1,542 & 1,483 & 1,595 & 1,502 & 1,682 & 1,408 & 1,591 & 1,534 & 1,716 & 1,694 \\
\hline & $\mathrm{Na}$ & & & 0,465 & 0,389 & 0,494 & 0,430 & 0,458 & 0,517 & 0,405 & 0,498 & & & & 0,466 & 0,284 & 0,306 \\
\hline & $\Sigma_{B}$ & 2,000 & 1,940 & 2,000 & 2,000 & 2,000 & 2,000 & 2,000 & 2,000 & 2,000 & 2,000 & 2,000 & 1,994 & 2,000 & 2,000 & 2,000 & 2,000 \\
\hline A & & 0,166 & 0,000 & 0,113 & 0,172 & 0,061 & 0,225 & 0,162 & 0,073 & 0,165 & 0,119 & 0,253 & 0,000 & 0,166 & 0,122 & 0,382 & 0,392 \\
\hline & $\mathrm{K}$ & & & ,171 & & & 0,189 & 0,131 & & 0,179 & & & & & & & 0,164 \\
\hline & & & & & & & & & & & & & & & & & 0,556 \\
\hline Total de cátio & ions & 15,361 & 15,100 & 15,284 & 15,361 & 15,248 & 15,414 & 15,294 & 15,282 & 15,345 & 15,314 & 15,401 & 15,172 & 15,355 & 15,314 & 15,579 & 15,555 \\
\hline $\mathrm{Cl}$ & & 0,020 & 0,015 & 0,039 & & & 0,072 & & 0,026 & 0,067 & & & & & & 0,065 & 0,043 \\
\hline $\mathrm{F}$ & & & & & & & & & & & & & & & & & 0,543 \\
\hline $\mathrm{OH}$ & & 1,749 & 1,588 & 1,667 & 1,5 & 1,542 & 1,43 & 1,645 & 1,655 & 1,619 & 1,673 & 1,6 & 1,570 & 1,574 & 1,535 & 1,378 & 1,406 \\
\hline $\mathrm{mg} \#$ & & 0,40 & 0,59 & 0,48 & 0,42 & 0,52 & 0,45 & 0,56 & 0,46 & 0,46 & 0,49 & 0,39 & 0,54 & 0,45 & 0,51 & 0,59 & 0,61 \\
\hline & & $\underset{\mathrm{FHel}^{3+} \mathrm{cl}}{\mathrm{Fe}^{3+}}$ & $\begin{array}{c}\mathrm{fBar} \mathrm{c} / \\
\mathrm{F}\end{array}$ & 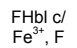 & $\begin{array}{l}\mathrm{FHbl} \mathrm{cl} \\
\mathrm{Fe}^{3+}, \mathrm{F}\end{array}$ & $\begin{array}{l}\mathrm{MHbl} / \mathrm{Cl} \\
\mathrm{Fe}^{3+}, \mathrm{F}\end{array}$ & $\begin{array}{l}\mathrm{MHbl} / \mathrm{c} / \\
\mathrm{Fe}^{3+}, \mathrm{F}\end{array}$ & $\begin{array}{l}\mathrm{MHbl} \mathrm{Cl} / \\
\mathrm{Fe}^{3+}, \mathrm{F}\end{array}$ & $\begin{array}{l}\mathrm{FBar} \mathrm{cl} \\
\mathrm{Fe}^{3+}, \mathrm{F}\end{array}$ & $\begin{array}{l}\mathrm{FHbl}_{\mathrm{CH}} \\
\mathrm{Fe}^{3+}, \mathrm{F}\end{array}$ & $\begin{array}{l}\mathrm{FHbl} \mathrm{Cl} \\
\mathrm{Fe}^{3+}, \mathrm{F}\end{array}$ & $\begin{array}{l}\mathrm{FHbl} \mathrm{Cl} \\
\mathrm{Fe}^{3+}, \mathrm{F}\end{array}$ & $\begin{array}{c}\mathrm{fBar} \mathrm{Cl} \\
\mathrm{F}\end{array}$ & $\begin{array}{l}\mathrm{FHbl} \mathrm{Cl} \\
\mathrm{Fe}^{3+}, \mathrm{F}\end{array}$ & $\begin{array}{l}\mathrm{MHbl} \mathrm{c} / \\
\mathrm{Fe}^{3+}, \mathrm{F}\end{array}$ & $\begin{array}{l}\mathrm{Ed} \mathrm{d} / \\
\mathrm{Fe}^{3+}, \mathrm{F}\end{array}$ & $\begin{array}{l}\mathrm{Ed} \mathrm{cl} \\
\mathrm{Fe}^{3+}, \mathrm{F}\end{array}$ \\
\hline
\end{tabular}

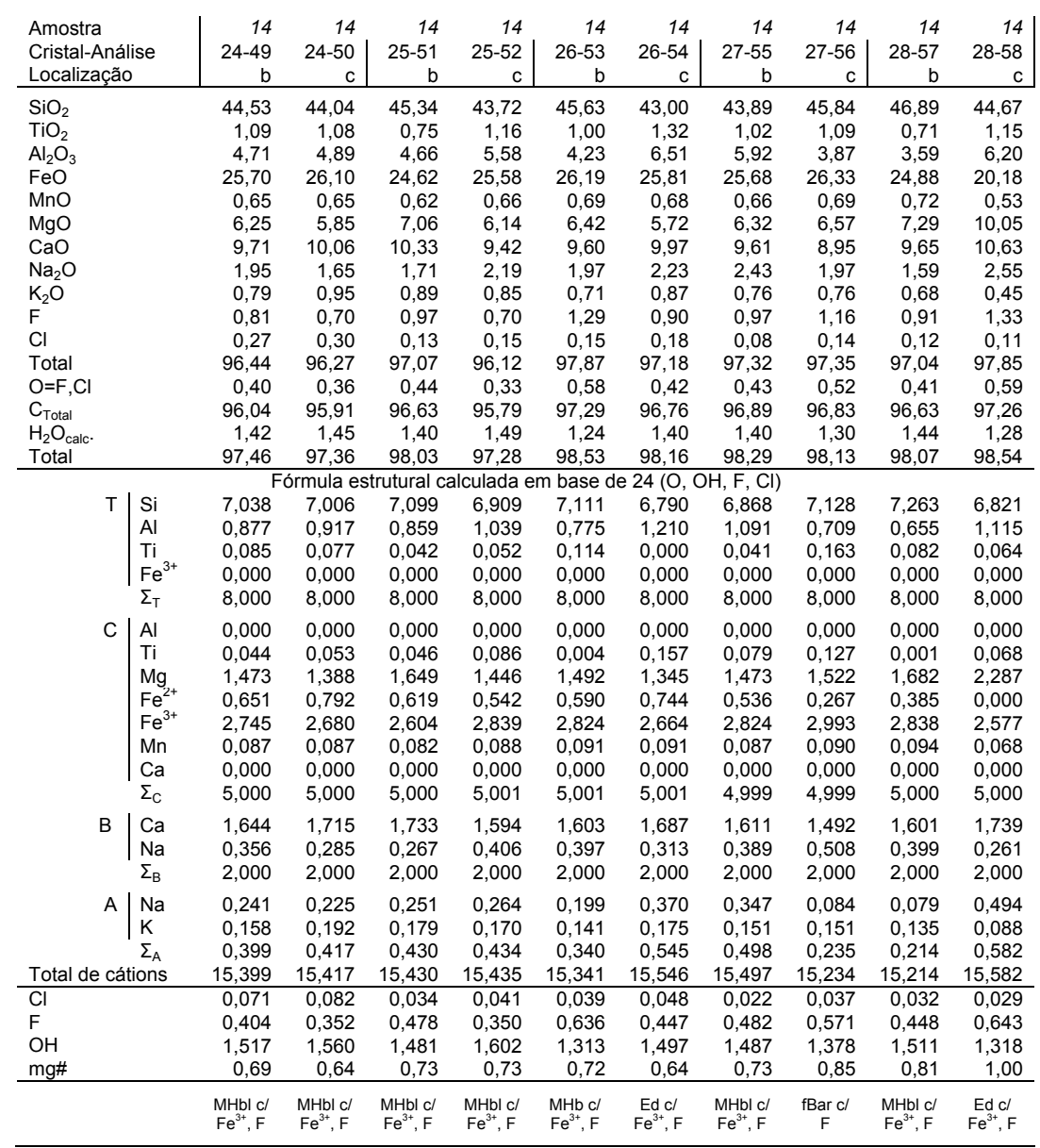


6. Química Mineral

Tabela 10. Composição química de anfibólios dos quartzo-álcali feldspato sienitos do Morro de São João. Abreviações e classificação como na Tabela 9.

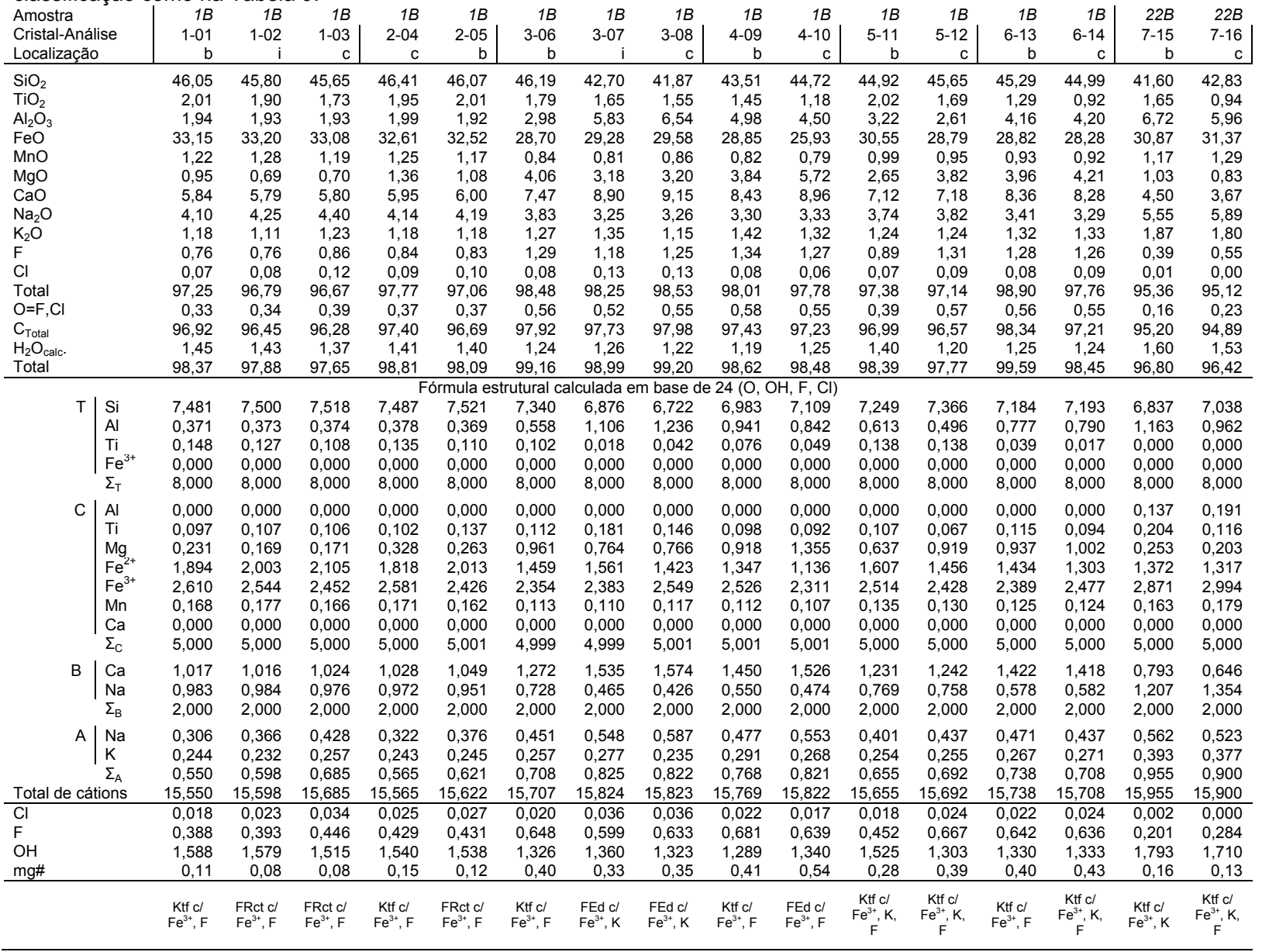

\begin{tabular}{|c|c|c|c|c|c|c|c|c|}
\hline \multirow{2}{*}{\multicolumn{2}{|c|}{$\begin{array}{l}\text { Amostra } \\
\text { Cristal-Análise } \\
\text { Localização }\end{array}$}} & $\begin{array}{r}22 B \\
8-17\end{array}$ & $\begin{array}{r}22 B \\
8-18\end{array}$ & $\begin{array}{r}15 A \\
9-19\end{array}$ & $\begin{array}{r}15 A \\
9-20\end{array}$ & $\begin{array}{r}15 A \\
10-21\end{array}$ & $\begin{array}{r}15 A \\
10-22\end{array}$ & $\begin{array}{r}15 A \\
10-23\end{array}$ \\
\hline & & $\begin{array}{r}8-11 \\
\mathrm{C}\end{array}$ & $\begin{array}{r}8-18 \\
b \\
\end{array}$ & $\begin{array}{r}9-19 \\
b\end{array}$ & $\begin{array}{r}9-20 \\
c\end{array}$ & $\begin{array}{r}10-21 \\
b\end{array}$ & $\begin{array}{r}10-22 \\
\mathrm{i}\end{array}$ & $\begin{aligned} 10-23 \\
b\end{aligned}$ \\
\hline & 39,58 & 40,23 & 42,87 & 42,05 & 44,12 & 44,12 & 43,46 \\
\hline $\mathrm{TiO}_{2}$ & & 1,75 & 0,89 & 0,78 & 0,59 & 0,99 & 0,99 & 0,92 \\
\hline \multicolumn{2}{|l|}{$\mathrm{Al}_{2} \mathrm{O}_{3}$} & 8,39 & 7,63 & 5,21 & 5,50 & 3,89 & 3,89 & 4,30 \\
\hline \multicolumn{2}{|l|}{$\mathrm{FeO}$} & 31,93 & 32,51 & 33,06 & 34,10 & 32,55 & 33,22 & 32,48 \\
\hline \multicolumn{2}{|l|}{$\mathrm{MnO}$} & 0,86 & 1,19 & 1,31 & 1,17 & 1,09 & 0,99 & 1,06 \\
\hline \multicolumn{2}{|l|}{$\mathrm{MgO}$} & 1,20 & 0,42 & 0,82 & 0,72 & 0,95 & 0,91 & 0,95 \\
\hline \multicolumn{2}{|l|}{$\mathrm{CaO}$} & 7,30 & 5,73 & 6,13 & 6,35 & 5,87 & 5,78 & 5,81 \\
\hline \multicolumn{2}{|l|}{$\mathrm{Na}_{2} \mathrm{O}$} & 4,02 & 4,76 & 4,37 & 4,39 & 4,62 & 4,65 & 4,63 \\
\hline \multirow{2}{*}{\multicolumn{2}{|c|}{$\begin{array}{l}\mathrm{K}_{2} \mathrm{O} \\
\mathrm{F}\end{array}$}} & 1,74 & 1,76 & 1,62 & 1,63 & 1,48 & 1,47 & 1,61 \\
\hline & & 0,54 & 0,47 & 0,78 & 0,68 & 0,59 & 0,44 & 0,75 \\
\hline \multicolumn{2}{|l|}{$\mathrm{Cl}$} & 0,02 & 0,01 & 0,04 & 0,04 & 0,02 & 0,02 & 0,02 \\
\hline \multicolumn{2}{|l|}{ Total } & 97,33 & 95,61 & 96,99 & 97,21 & 96,16 & 96,48 & 95,98 \\
\hline \multicolumn{2}{|l|}{$\mathrm{O}=\mathrm{F}, \mathrm{Cl}$} & 0,23 & 0,20 & 0,34 & 0,29 & 0,25 & 0,19 & 0,32 \\
\hline \multirow{2}{*}{\multicolumn{2}{|c|}{$\begin{array}{l}\mathrm{C}_{\text {Total }} \\
\mathrm{H}_{2} \mathrm{O}_{\text {calc. }} .\end{array}$}} & 97,10 & 95,41 & 96,65 & 96,92 & 95,91 & 96,29 & 95,66 \\
\hline & & 1,55 & 1,55 & 1,42 & 1,46 & 1,51 & 1,59 & 1,43 \\
\hline \multicolumn{2}{|l|}{$\begin{array}{l}\mathrm{H}_{2} \mathrm{O}_{\text {calc. }} \\
\text { Total }\end{array}$} & 98,65 & 96,96 & 98,07 & 98,38 & 97,42 & 97,88 & 97,09 \\
\hline \multicolumn{9}{|c|}{ Fórmula estrutural calculada em base de $24(\mathrm{O}, \mathrm{OH}, \mathrm{F}, \mathrm{Cl})$} \\
\hline \multirow[t]{5}{*}{$\mathrm{T}$} & $\mathrm{Si}$ & 6,432 & 6,645 & 7,004 & 6,873 & 7,260 & 7,222 & 7,179 \\
\hline & $\mathrm{Al}$ & 1,568 & 1,355 & 0,996 & 1,058 & 0,740 & 0,750 & 0,821 \\
\hline & $\mathrm{Ti}$ & 0,000 & 0,000 & 0,000 & 0,069 & 0,000 & 0,028 & 0,000 \\
\hline & $\mathrm{Fe}^{3+}$ & 0,000 & 0,000 & 0,000 & 0,000 & 0,000 & 0,000 & 0,000 \\
\hline & $\Sigma_{\mathrm{T}}$ & 8,000 & 8,000 & 8,000 & 8,000 & 8,000 & 8,000 & 8,000 \\
\hline \multirow[t]{8}{*}{6} & Al & 0,038 & 0,130 & 0,007 & 0,000 & 0,014 & 0,000 & 0,016 \\
\hline & $\mathrm{Ti}$ & 0,214 & 0,111 & 0,095 & 0,003 & 0,122 & 0,094 & 0,114 \\
\hline & $\mathrm{Mg}$ & 0,290 & 0,103 & 0,199 & 0,175 & 0,232 & 0,223 & 0,234 \\
\hline & $\mathrm{Fe}^{2+}$ & 1,407 & 1,412 & 1,585 & 1,564 & 1,855 & 1,793 & 1,786 \\
\hline & $\mathrm{Fe}^{3+}$ & 2,933 & 3,078 & 2,932 & 3,096 & 2,625 & 2,754 & 2,701 \\
\hline & $\mathrm{Mn}$ & 0,119 & 0,166 & 0,182 & 0,162 & 0,151 & 0,137 & 0,149 \\
\hline & $\mathrm{Ca}$ & 0,000 & 0,000 & 0,000 & 0,000 & 0,000 & 0,000 & 0,000 \\
\hline & $\Sigma_{c}$ & 5,001 & 5,000 & 5,000 & 5,000 & 4,999 & 5,001 & 5,000 \\
\hline \multirow[t]{3}{*}{ B } & $\mathrm{Ca}$ & 1,271 & 1,014 & 1,073 & 1,111 & 1,035 & 1,013 & 1,028 \\
\hline & $\mathrm{Na}$ & 0,729 & 0,986 & 0,927 & 0,889 & 0,965 & 0,987 & 0,972 \\
\hline & $\Sigma_{\mathrm{B}}$ & 2,000 & 2,000 & 2,000 & 2,000 & 2,000 & 2,000 & 2,000 \\
\hline \multirow[t]{3}{*}{ A } & $\mathrm{Na}$ & 0,538 & 0,540 & 0,457 & 0,504 & 0,510 & 0,488 & 0,510 \\
\hline & $\mathrm{K}$ & 0,361 & 0,371 & 0,337 & 0,340 & 0,310 & 0,308 & 0,338 \\
\hline & & 0,899 & 0,911 & 0,794 & 0,844 & 0,820 & 0,796 & 0,848 \\
\hline \multicolumn{2}{|c|}{ Total de cátions } & 15,900 & 15,911 & 15,794 & 15,844 & 15,819 & 15,797 & 15,848 \\
\hline \multirow{2}{*}{\multicolumn{2}{|c|}{$\begin{array}{l}\mathrm{Cl} \\
\mathrm{F}\end{array}$}} & 0,005 & 0,002 & 0,010 & 0,010 & 0,005 & 0,006 & 0,005 \\
\hline & & 0,279 & 0,248 & 0,405 & 0,351 & 0,309 & 0,229 & 0,391 \\
\hline \multirow{2}{*}{\multicolumn{2}{|c|}{$\begin{array}{l}\mathrm{OH} \\
\mathrm{mg \#}\end{array}$}} & 1,711 & 1,745 & 1,577 & 1,629 & 1,682 & 1,762 & 1,598 \\
\hline & & 0,17 & 0,07 & 0,11 & 0,10 & 0,11 & 0,11 & 0,12 \\
\hline & & $\begin{array}{c}\mathrm{Tmt} \mathrm{c} / \\
\mathrm{Fe}^{3+}, \mathrm{K}, \\
\mathrm{F}\end{array}$ & $\begin{array}{c}\mathrm{Ktf} \mathrm{cl} \\
\mathrm{Fe}^{3+}, \mathrm{K}, \\
\mathrm{F}^{2}\end{array}$ & $\begin{array}{c}\mathrm{Ktf} \mathrm{Cl} \\
\mathrm{Fe}^{3+}, \mathrm{K}, \\
\mathrm{F}^{2}\end{array}$ & $\begin{array}{c}\mathrm{Ktf} \mathrm{Cl} \\
\mathrm{Fe}^{3+}, \mathrm{K}, \\
\mathrm{F}^{2}\end{array}$ & $\begin{array}{c}\mathrm{Ktf}+ \\
\mathrm{Fe}^{3+}, \mathrm{K}, \\
\mathrm{F}^{2}\end{array}$ & $\begin{array}{c}\mathrm{Ktf} \mathrm{Cl} \\
\mathrm{Fe}^{3+}, \mathrm{K}, \\
\mathrm{F}^{2}\end{array}$ & $\begin{array}{c}\mathrm{Kff} \mathrm{cl} \\
\mathrm{Fe}^{3+}, \mathrm{K}, \\
\mathrm{F}^{2}\end{array}$ \\
\hline
\end{tabular}


6. Química Mineral

Tabela 11. Composição química de anfibólios dos quartzo-álcali feldspato sienitos porfiríticos do Morrete. Abreviações e classificação como na Tabela 9.

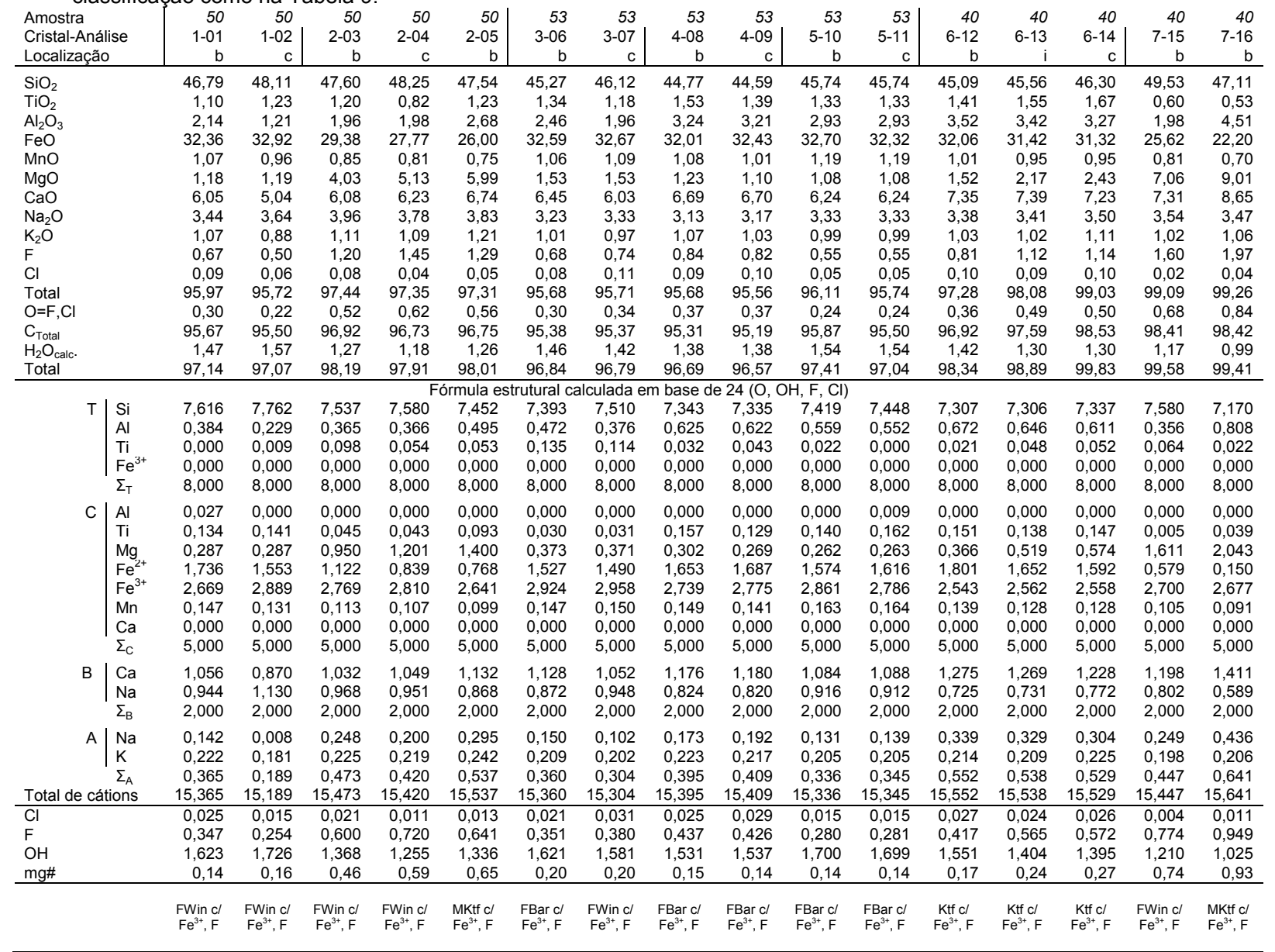

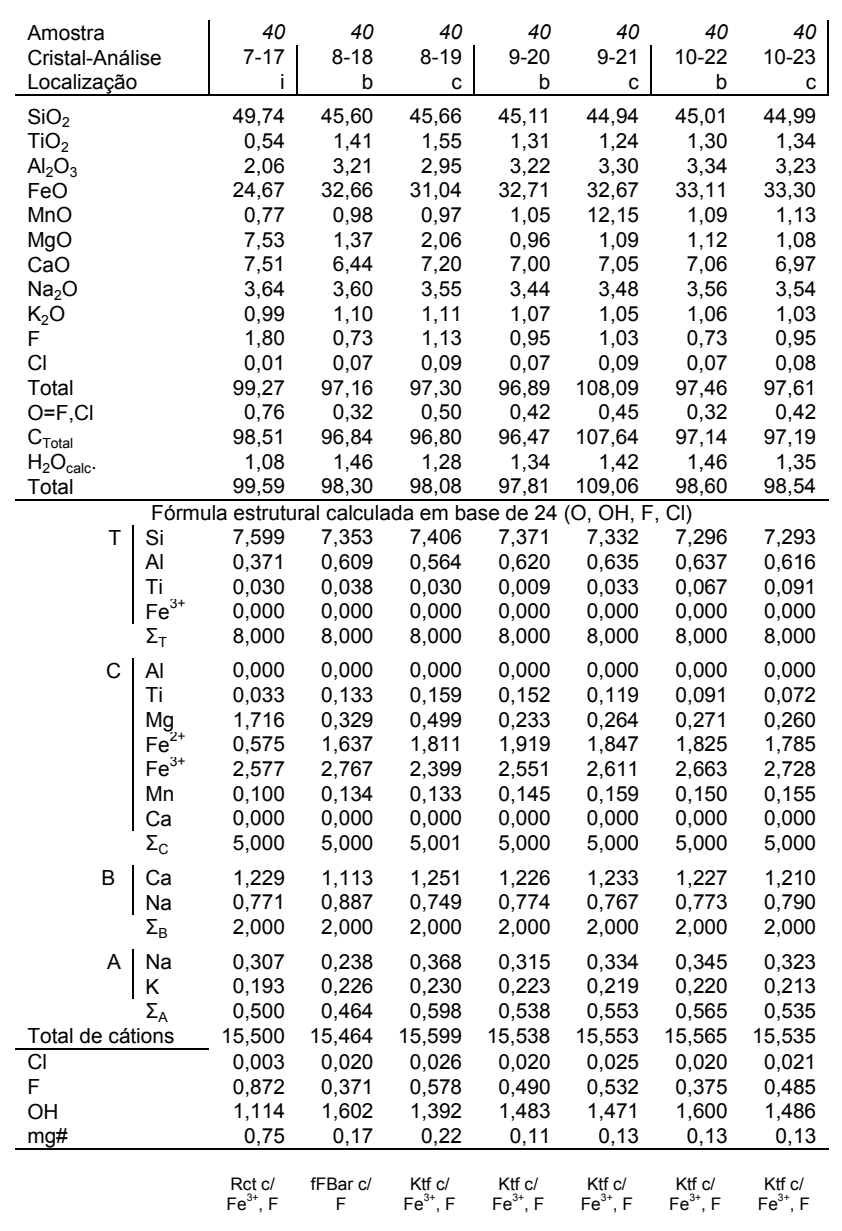


Tabela 12. Composição química de anfibólios dos microssienitos porfiríticos com textura traquítica do Morro de São João. Abreviações e classificação como na Tabela 9.

\begin{tabular}{|c|c|c|c|c|c|c|c|c|c|c|}
\hline \multirow{2}{*}{\multicolumn{2}{|c|}{$\begin{array}{l}\text { Amostra } \\
\text { Cristal-Análise } \\
\text { Localização }\end{array}$}} & $\begin{array}{r}30 \\
1-01\end{array}$ & $\begin{array}{r}30 \\
1-02\end{array}$ & $\begin{array}{r}30 \\
2-03\end{array}$ & $\begin{array}{r}30 \\
2-04\end{array}$ & $\begin{array}{r}30 \\
3-05\end{array}$ & $\begin{array}{r}30 \\
3-06\end{array}$ & $\begin{array}{r}30 \\
4-17\end{array}$ & $\begin{array}{r}30 \\
4-08\end{array}$ & $\begin{array}{r}30 \\
5-09\end{array}$ \\
\hline & & b & $\mathrm{c}$ & b & $\mathrm{c}$ & b & $\mathrm{c}$ & b & C & b \\
\hline \multirow{2}{*}{\multicolumn{2}{|c|}{$\begin{array}{l}\mathrm{SiO}_{2} \\
\mathrm{TiO}_{2}\end{array}$}} & 49,89 & 49,27 & 49,04 & 49,17 & 49,08 & 48,81 & 49,47 & 48,65 & 49,20 \\
\hline & & 1,54 & 1,67 & 1,33 & 1,55 & 1,49 & 1,15 & 1,36 & 1,07 & 1,47 \\
\hline \multirow{2}{*}{\multicolumn{2}{|c|}{$\begin{array}{l}\mathrm{Al}_{2} \mathrm{O}_{3} \\
\mathrm{FeO}\end{array}$}} & 0,56 & 0,58 & 0,69 & 0,75 & 0,58 & 0,82 & 0,54 & 0,60 & 0,54 \\
\hline & & 31,98 & 31,62 & 31,71 & 31,82 & 31,57 & 31,83 & 31,67 & 32,11 & 32,29 \\
\hline \multicolumn{2}{|l|}{$\mathrm{MnO}$} & 1,79 & 1,82 & 1,75 & 1,77 & 1,76 & 1,82 & 1,82 & 1,82 & 1,86 \\
\hline \multicolumn{2}{|l|}{$\begin{array}{l}\mathrm{MgO} \\
\mathrm{CaO}\end{array}$} & 0,13 & 0,15 & 0,11 & 0,15 & 0,16 & 0,16 & 0,16 & 0,18 & 0,13 \\
\hline \multirow{2}{*}{\multicolumn{2}{|c|}{$\mathrm{CaO}$}} & 1,43 & 1,43 & 1,49 & 1,43 & 1,39 & 1,41 & 1,47 & 1,41 & 1,44 \\
\hline & & 7,42 & 7,35 & 7,43 & 7,44 & 7,33 & 7,50 & 7,30 & 7,43 & 7,05 \\
\hline \multicolumn{2}{|l|}{$\mathrm{K}_{2} \mathrm{O}$} & 1,78 & 1,81 & 1,80 & 1,78 & 1,82 & 1,77 & 1,76 & 1,74 & 1,73 \\
\hline \multirow{2}{*}{\multicolumn{2}{|c|}{$\mathrm{F}$}} & 1,56 & 1,29 & 1,35 & 0,92 & 1,12 & 1,14 & 1,21 & 1,23 & 1,22 \\
\hline & & 0,02 & 0,04 & 0,02 & 0,03 & 0,02 & 0,04 & 0,02 & 0,04 & 0,00 \\
\hline \multicolumn{2}{|l|}{ Total } & 98,10 & 97,01 & 96,73 & 96,80 & 96,31 & 96,44 & 96,77 & 96,27 & 96,91 \\
\hline \multicolumn{2}{|l|}{$\mathrm{O}=\mathrm{F}, \mathrm{Cl}$} & 0,66 & 0,55 & 0,57 & 0,40 & 0,48 & 0,49 & 0,51 & 0,53 & 0,51 \\
\hline & 97,44 & 96,46 & 96,16 & 96,40 & 95,83 & 95,95 & 96,26 & 95,74 & 96,40 \\
\hline & & 1,10 & 1,20 & 1,17 & 1,38 & 1,28 & 1,26 & 1,25 & 1,21 & 1,24 \\
\hline \multicolumn{2}{|l|}{$\begin{array}{l}\mathrm{H}_{2} \mathrm{O}_{\text {calc }} \\
\text { Total }\end{array}$} & 98,54 & 97,66 & 97,33 & 97,78 & 97,11 & 97,21 & 97,51 & 96,95 & 97,64 \\
\hline \multicolumn{11}{|c|}{ Fórmula estrutural calculada em base de $24(\mathrm{O}, \mathrm{OH}, \mathrm{F}, \mathrm{Cl})$} \\
\hline \multirow[t]{6}{*}{$\mathrm{T}$} & $\mathrm{Si}$ & 7,976 & 7,951 & 7,952 & 7,922 & 7,959 & 7,915 & 7,985 & 7,910 & 7,911 \\
\hline & Al & 0,024 & 0,049 & 0,048 & 0,078 & 0,041 & 0,085 & 0,015 & 0,090 & 0,089 \\
\hline & $\mathrm{Ti}$ & 0,000 & 0,000 & 0,000 & 0,000 & 0,000 & 0,000 & 0,000 & 0,000 & 0,000 \\
\hline & $\mathrm{Fe}^{3+}$ & 0,000 & 0,000 & 0,000 & 0,000 & 0,000 & 0,000 & 0,000 & 0,000 & 0,000 \\
\hline & $\Sigma_{\mathrm{T}}$ & 8,000 & 8,000 & 8,000 & 8,000 & 8,000 & 8,000 & 8,000 & 8,000 & 8,000 \\
\hline & $\mathrm{Al}$ & 0,085 & 0,065 & 0,086 & 0,067 & 0,071 & 0,073 & 0,089 & 0,026 & 0,015 \\
\hline & $\mathrm{Ti}$ & 0,187 & 0,205 & 0,164 & 0,191 & 0,185 & 0,142 & 0,168 & 0,133 & 0,180 \\
\hline & $\mathrm{Mg}$ & 0,032 & 0,036 & 0,028 & 0,036 & 0,040 & 0,039 & 0,039 & 0,044 & 0,030 \\
\hline & $\mathrm{Fe}^{2+}$ & 2,137 & 2,194 & 2,235 & 2,173 & 2,181 & 2,138 & 2,179 & 2,097 & 2,008 \\
\hline & $\mathrm{Fe}^{3+}$ & 2,222 & 2,183 & 2,175 & 2,253 & 2,204 & 2,326 & 2,173 & 2,422 & 2,485 \\
\hline & $\mathrm{Mn}$ & 0,246 & 0,252 & 0,244 & 0,244 & 0,246 & 0,254 & 0,252 & 0,254 & 0,257 \\
\hline & $\mathrm{Ca}$ & 0,091 & 0,066 & 0,067 & 0,036 & 0,074 & 0,029 & 0,100 & 0,024 & 0,025 \\
\hline & $\Sigma_{\mathrm{c}}$ & 5,000 & 5,001 & 4,999 & 5,000 & 5,001 & 5,001 & 5,000 & 5,000 & 5,000 \\
\hline & $\mathrm{Ca}$ & 0,158 & 0,185 & 0,196 & 0,213 & 0,171 & 0,219 & 0,158 & 0,225 & 0,227 \\
\hline & $\mathrm{Na}$ & 1,842 & 1,815 & 1,804 & 1,787 & 1,829 & 1,781 & 1,842 & 1,775 & 1,773 \\
\hline & $\Sigma_{B}$ & 2,000 & 2,000 & 2,000 & 2,000 & 2,000 & 2,000 & 2,000 & 2,000 & 2,000 \\
\hline & $\mathrm{Na}$ & 0,490 & 0,517 & 0,567 & 0,570 & 0,508 & 0,612 & 0,476 & 0,602 & 0,455 \\
\hline & K & 0,368 & 0,377 & 0,378 & 0,371 & 0,381 & 0,371 & 0,367 & 0,365 & 0,359 \\
\hline & $\Sigma_{A}$ & 0,858 & 0,894 & 0,945 & 0,941 & 0,889 & 0,983 & 0,843 & 0,967 & 0,814 \\
\hline \multicolumn{2}{|c|}{ Total de cátions } & 15,858 & 15,895 & 15,944 & 15,941 & 15,890 & 15,984 & 15,843 & 15,967 & 15,814 \\
\hline \multirow{2}{*}{\multicolumn{2}{|c|}{$\begin{array}{l}\mathrm{Cl} \\
\mathrm{F}\end{array}$}} & 0,005 & 0,011 & 0,007 & 0,009 & 0,005 & 0,011 & 0,004 & 0,011 & 0,001 \\
\hline & & 0,798 & 0,668 & 0,700 & 0,478 & 0,583 & 0,592 & 0,626 & 0,641 & 0,629 \\
\hline \multicolumn{2}{|l|}{$\mathrm{OH}$} & 1,194 & 1,319 & 1,291 & 1,512 & 1,409 & 1,394 & 1,367 & 1,343 & 1,365 \\
\hline \multicolumn{2}{|l|}{$\mathrm{mg \#}$} & 0,01 & 0,02 & 0,01 & 0,02 & 0,02 & 0,02 & 0,02 & 0,02 & 0,01 \\
\hline
\end{tabular}

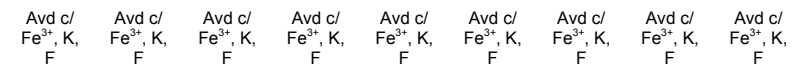

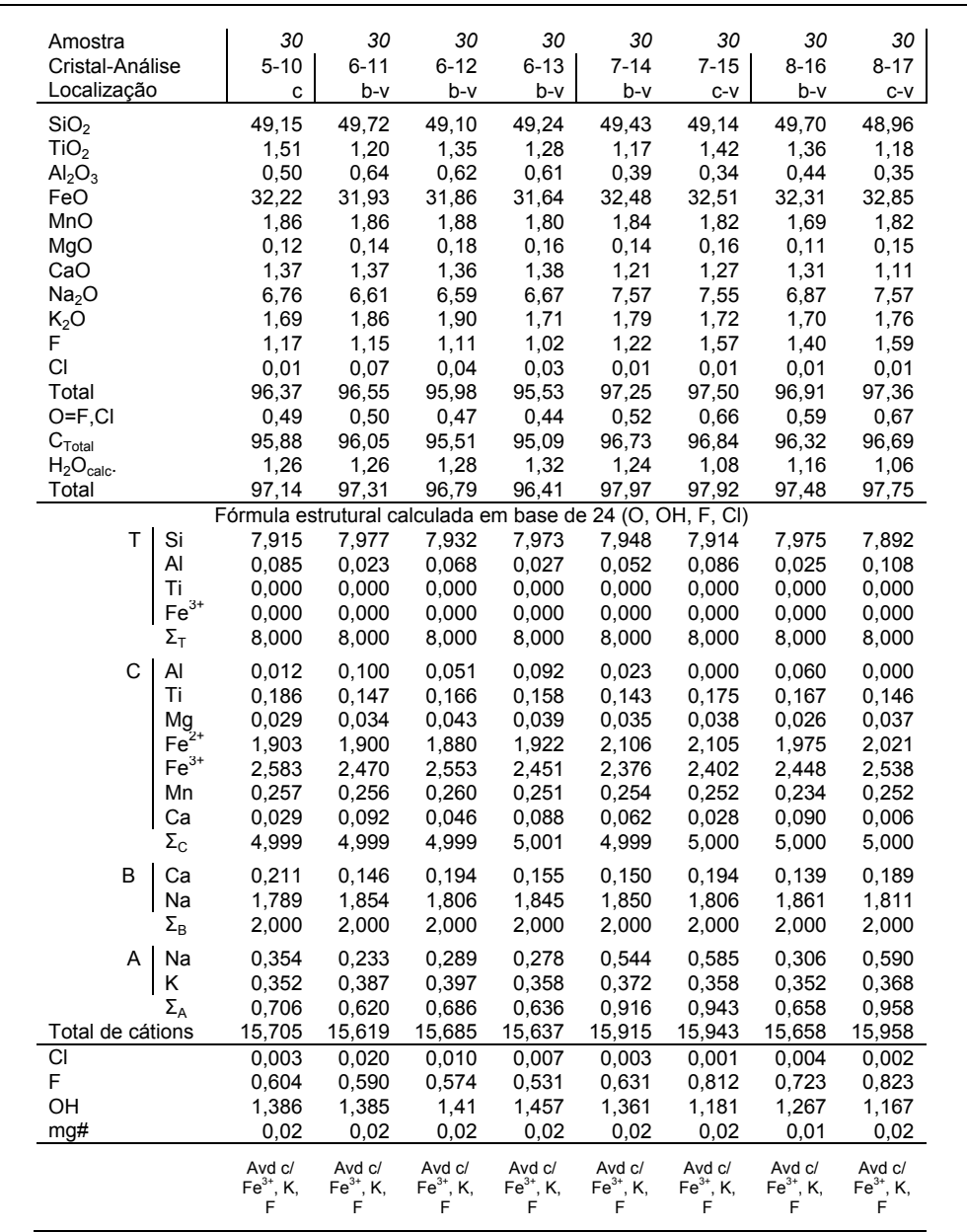




\subsection{Biotitas}

Foram efetuadas 55 análises químicas em biotitas das rochas de Cananéia, sendo os resultados fornecidos nas Tabelas 13 e 14, juntamente com a sua fórmula estrutural.

Os minerais analisados correspondem a micas trioctaédricas pertencentes à série das biotitas (Rieder, 1999), com os dados obtidos caindo no campo comum à maioria das composições de biotitas naturais (Deer et al., 1992). O diagrama ternário da Figura 19 permite verificar que a sua composição se aproxima mais do campo do membro final annita, representado pela fórmula $\mathrm{KFe}^{3+}{ }_{2} \mathrm{AlSi}_{3} \mathrm{O}_{10}(\mathrm{OH})_{2}$.

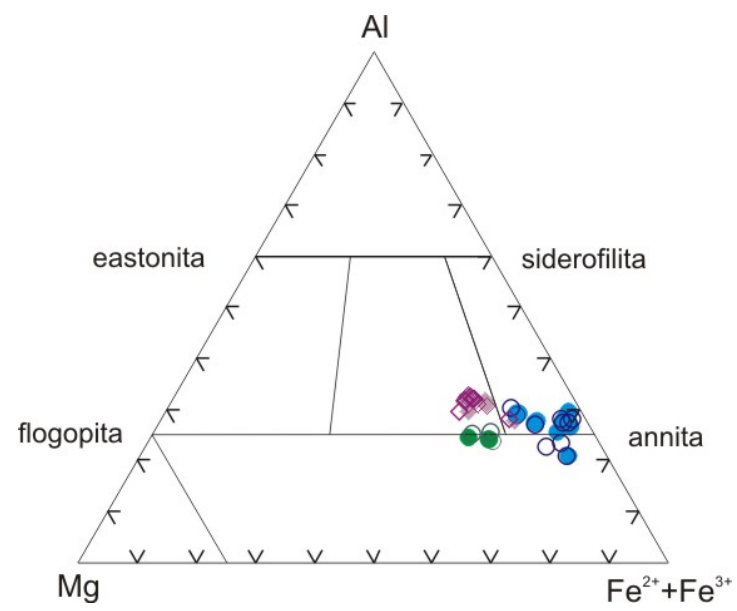

Figura 19. Diagrama Al-Mg- $\left(\mathrm{Fe}^{2+}+\mathrm{Fe}^{3+}\right)$ de classificação de biotitas para as rochas de Cananéia. Símbolos como na Figura 8.

A exemplo do que ocorre com os clinopiroxênios e anfibólios, o índice mg\# das biotitas apresenta também valores decrescentes das rochas menos evoluídas para as mais evoluídas. Ainda que a dispersão dos pontos seja muito grande, nota-se que o comportamento dos elementos $\mathrm{Si}, \mathrm{Fe}^{3+}, \mathrm{Mn} \mathrm{e}$ $\mathrm{K}$, quando relacionados com os valores de mg\#, é negativo, a indicar que as suas concentrações são mais elevadas nos minerais das rochas sieníticas mais evoluídas; já o comportamento positivo do $\mathrm{Al}^{\mathrm{IV}}$ e Ti parece apontar no sentido contrário (Fig. 20). No diagrama ternário da Figura 21 vê-se claramente que as biotitas das rochas sieníticas mais evoluídas são menos magnesianas ao lado de mais ferrosas, enquanto no da Figura 22 nota-se que as proporções de Al (Fig. 22A) e de K (Fig. 22B) se mantêm aproximadamente constantes com o aumento da razão $\mathrm{Fe} / \mathrm{Mg}$.

$\mathrm{Na}$ fórmula estrutural (Tabelas 13 e 14), observa-se que todo o Si e grande parte do Al disponível ocupam o sítio tetraédrico, que pode ainda completar-se com a entrada de $\mathrm{Fe}^{3+}$ (até 0,573 a.f.u.). $\mathrm{O}$ sítio tetraédrico é preenchido por Fe e Mg com quantidade significativa de Ti (até 0,671 a.f.u.) e $\square^{\mathrm{VI}}$ (até 0,843 a.f.u.), além de traços de $\mathrm{Al}$ (até 0,151 a.f.u.) e de Mn (0,150 a.f.u.). Os sítios intercamadas são ocupados por $\mathrm{K}$ e $\mathrm{Na}$ (até 0,522 a.f.u.), juntamente com Ca (até 0,685 a.f.u.) e Ba (até 0,040 a.f.u.).

As maiores variações catiônicas estão presentes nos sítios octaédricos, onde se menciona principalmente a substituição de $\mathrm{Mg}$ por $\mathrm{Fe}^{2+}$, como sugerido atrás (Figs. 21 e 22) e evidenciado na Figura 23.

A presença de Ti no sítio octaédrico implica em mecanismo de substituição visando a balancear as diferenças de cargas. Dymek (1983) propõe para esse processo três tipos de substituição: $\mathrm{Ti}^{\mathrm{IV}}+2\left(\mathrm{Al}, \mathrm{Fe}^{3+}\right)^{\mathrm{IV}}=\left(\mathrm{Mg}, \mathrm{Fe}^{2+}\right)^{\mathrm{VI}}+2 \mathrm{Si}^{\mathrm{IV}}$ (tipo tschermak), $\mathrm{Ti}+\square^{\mathrm{VI}}=2\left(\mathrm{Mg}, \mathrm{Fe}^{2+}\right)^{\mathrm{VI}}$ (tipo sítio octaédrico vago) e $\left(\mathrm{R}^{2+}\right)+2(\mathrm{OH})=\left(\mathrm{T}^{\mathrm{i} 4+}\right)^{\mathrm{V} \mathrm{l}}+2 \mathrm{O}_{2^{-}}$(tipo desidratação). 

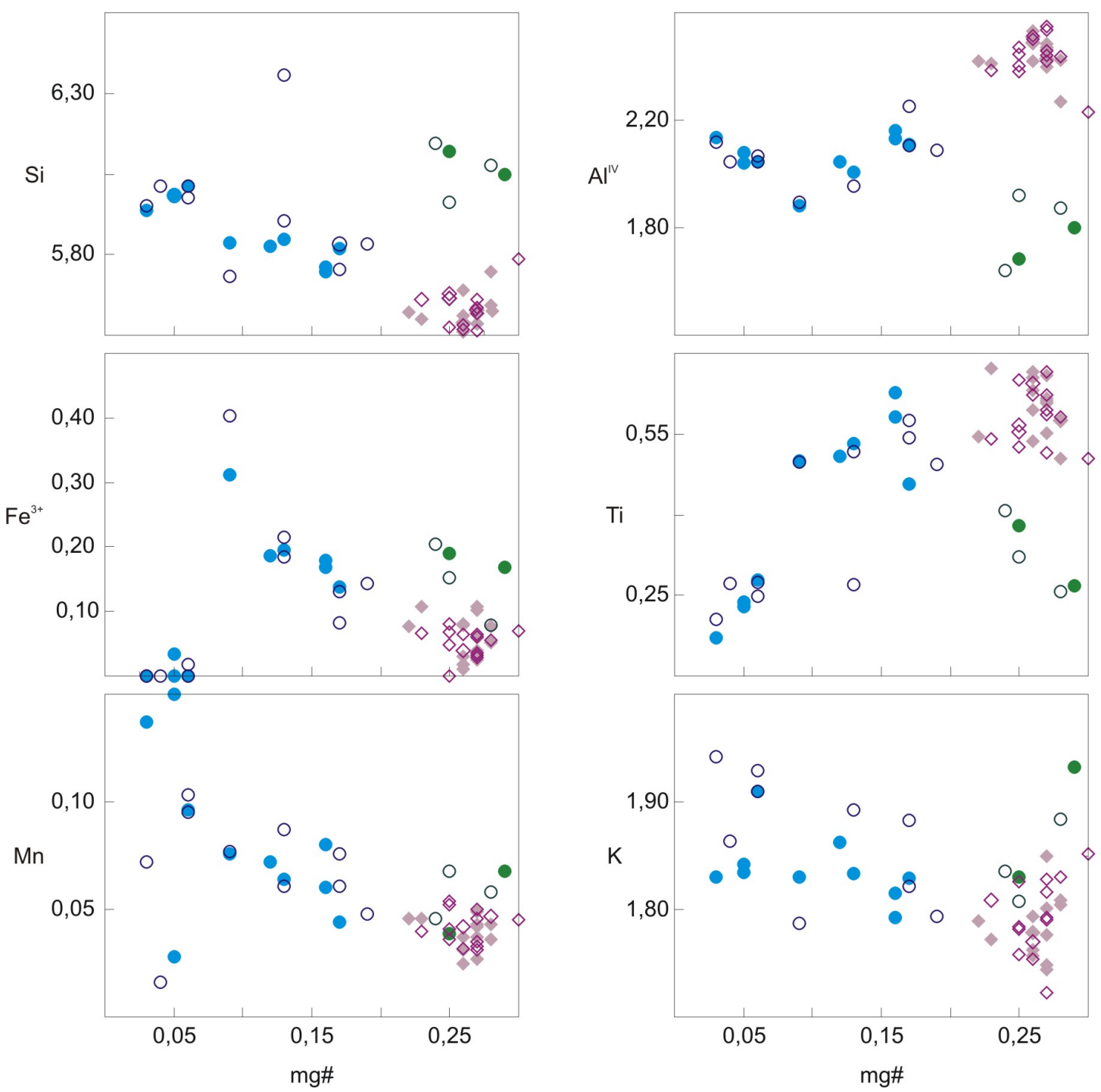

Figura 20. Diagramas de variação relacionando o índice $\mathrm{mg \#}\left(\mathrm{Mg} / \mathrm{Mg}+\mathrm{Fe}^{2+}\right)$ das biotitas com os diferentes cátions presentes na estrutura desses minerais. Símbolos como na Figura 8.

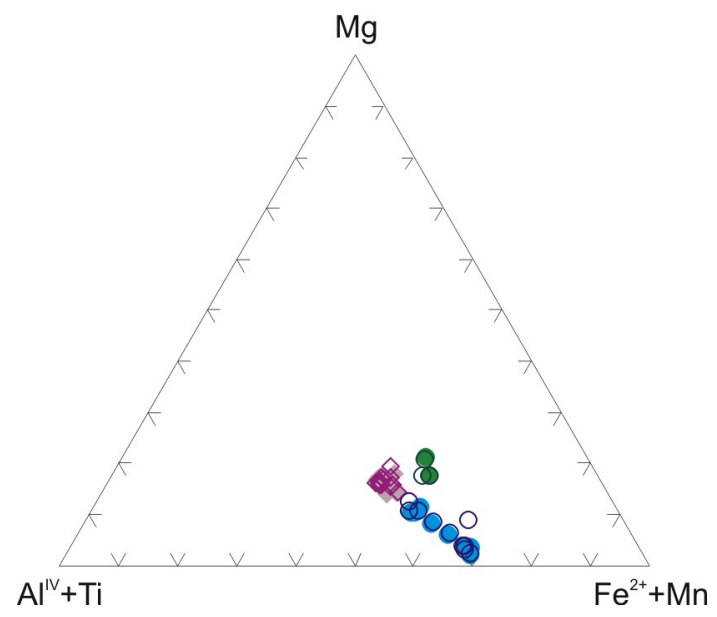

Figura 21. Projeção das biotitas das rochas de Cananéia no diagrama ternário $\mathrm{Mg}-\left(\mathrm{A}^{\mathrm{IV}}+\mathrm{Ti}\right)-\left(\mathrm{Fe}^{2+}+\mathrm{Mn}\right)$. Símbolos como na Figura 8. 


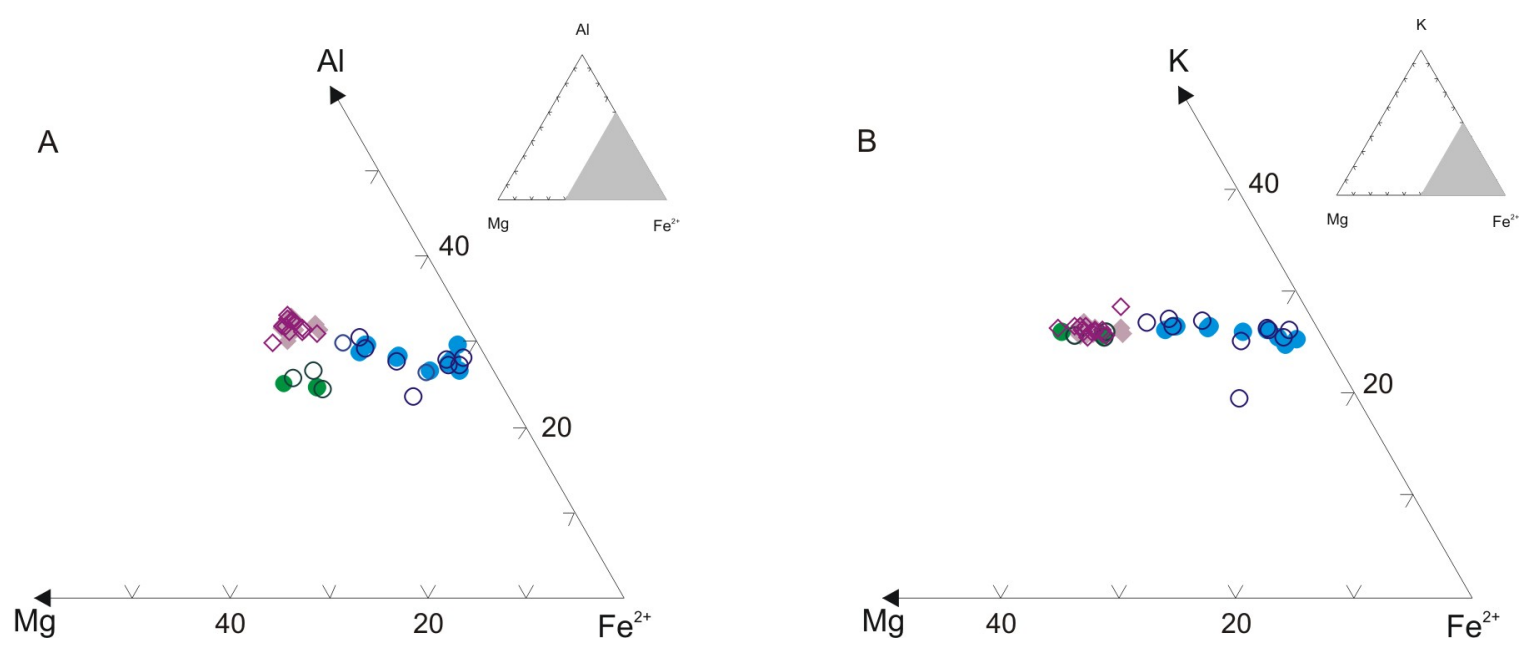

Figura 22. Projeção das biotitas das rochas de Cananéia nos diagramas ternários Al-Mg-Fe ${ }^{2+}(\mathrm{A})$ e K-Mg-Fe ${ }^{2+}(\mathrm{B})$. Símbolos como na Figura 8.

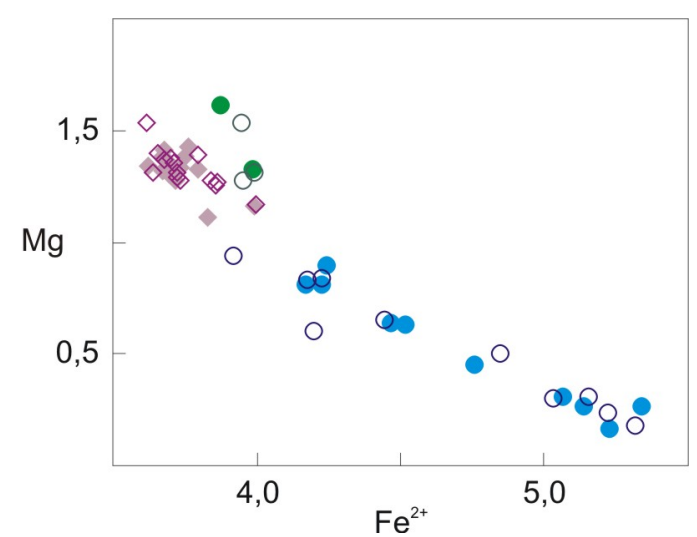

Figura 23. Diagrama $\mathrm{Fe}^{2+}$ vs. Mg indicativa da principal substituição do sítio octaédrico nas biotitas das rochas de Cananéia. Símbolos como na Figura 8.

Os gráficos reunindo, respectivamente, as relações catiônicas entre Ti vs. $\square^{\mathrm{VI}}$ (Fig. 24A) e Ti vs. $\left(\mathrm{Al}+\mathrm{Fe}^{3+}\right)^{\mathrm{IV}}$ (Fig. 24B) indicam que dois tipos de substituição estão presentes. Na do tipo tschermak, Ti e as vacâncias estruturais ocorrem numa proporção de 2:1, sendo que as rochas mais evoluídas exibem menor proporção de vacâncias em relação a Ti. Por outro lado, $\mathrm{Ti}$ e $\left(\mathrm{Al}+\mathrm{Fe}^{3+}\right)^{\mathrm{IV}}$ aparecem em proporções de 1:2, a sugerir um mecanismo resultante da soma das duas equações, que pode ser expresso por: $\mathrm{Ti}^{\mathrm{Vl}}+\left(\mathrm{Al}, \mathrm{Fe}^{3+}\right)^{\mathrm{Vl}}+0,5^{\mathrm{Vl}}=1,5\left(\mathrm{Mg}, \mathrm{Fe}^{2+}\right)^{\mathrm{Vl}}+\mathrm{Si}^{\mathrm{lV}}$. Caso o sítio tetraédrico priorizasse a entrada de $\mathrm{Ti}^{\mathrm{iV}}$ ao invés de $\left(\mathrm{Al}, \mathrm{Fe}^{3+}\right)^{\mathrm{IV}}$, o mecanismo do tipo sítio octaédrico vago teria pequena vantagem em relação ao tipo tschermak.

O mecanismo de substituição do tipo desidratação pode estar também presente, porém, devido à opção de cálculo para a fórmula estrutural das micas, com a quantidade de $(\mathrm{OH}, \mathrm{F}, \mathrm{Cl})$ estimada, ele não se mostra evidente. 

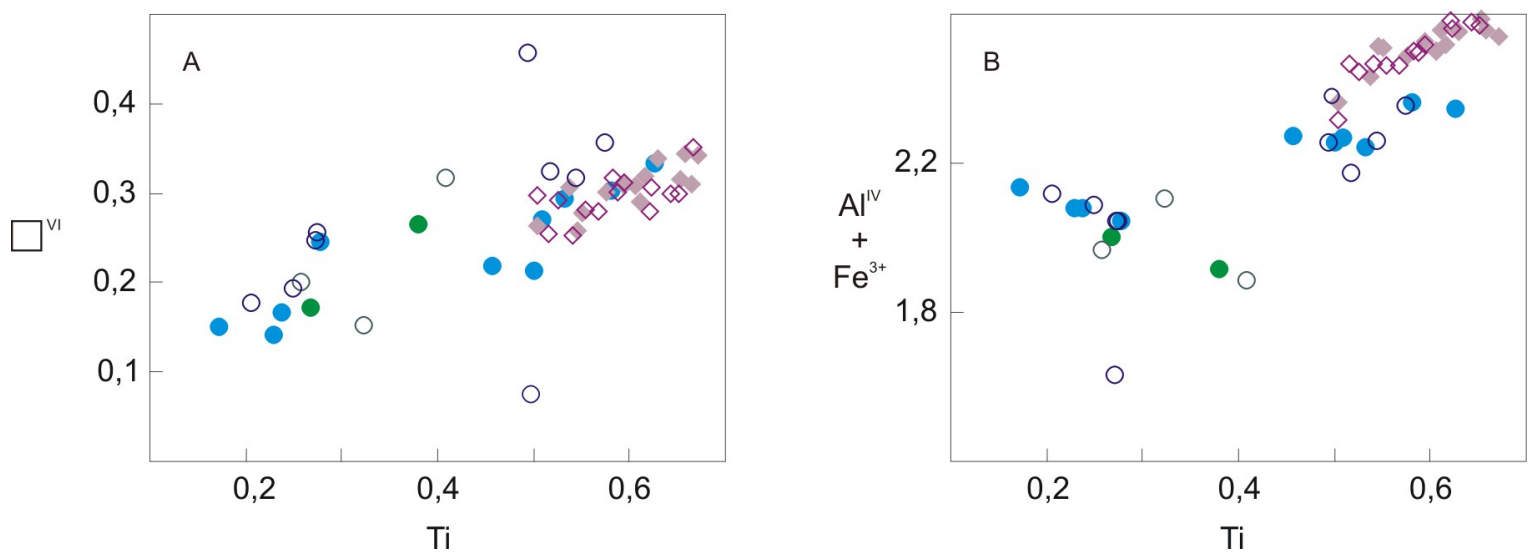

Figura 24. A) Diagrama Ti vs. $\square^{\mathrm{V} /}$ mostrando as substituições acopladas com a entrada de Ti no sítio octaédrico. B) Diagrama Ti vs. $\mathrm{Al}^{\mathrm{lv}}+\mathrm{Fe}^{3+}$ evidenciando as substituições causadas pela entrada de Ti no sítio octaédrico. Símbolos como na Figura 8.

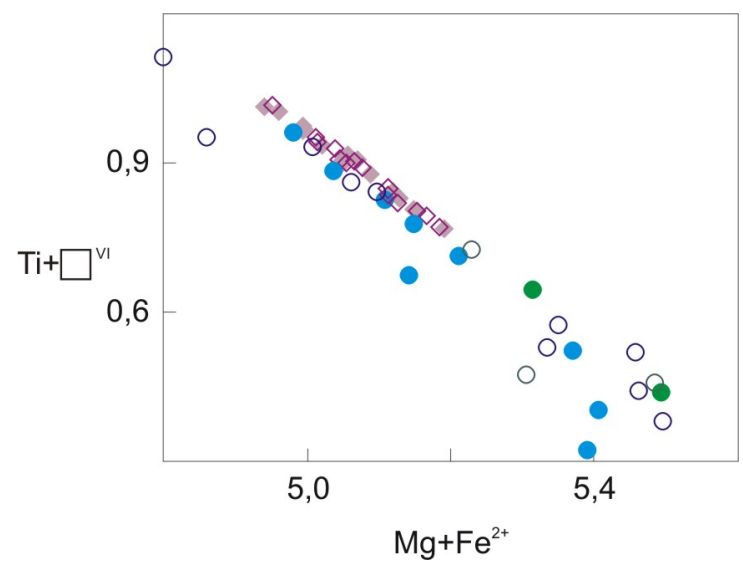

Figura 25. Diagrama $\left(\mathrm{Mg}+\mathrm{Fe}^{2+}\right)$ vs. $\left(\mathrm{Ti}+\square^{\mathrm{Vl}}\right)$ mostrando as substituições dos cátions no sítio octaédrico. Símbolos como na Figura 8.

A Figura 25 demonstra que as biotitas dos álcali feldspato sienitos são mais enriquecidas em Ti e $\square^{\mathrm{V} 1}$ relativamente às micas dos quartzo-álcali feldspato sienitos.

O sítio intercamada, preenchido principalmente por $\mathrm{K}$, não apresenta qualquer mecanismo de substituição dos cátions presentes. $\mathrm{Cl}$ (até 0,318 a.f.u.) e $\mathrm{F}$ (até 0,936 a.f.u.) aparecem substituindo o ânion $(\mathrm{OH})^{-}$. 
Tabela 13. Composição química de biotitas dos álcali feldspato sienitos do Morro de São João. Abreviações: c, b, i, respectivamente, centro, borda e região intermediária dos cristais. Proporção de $\mathrm{H}_{2} \mathrm{O}$ na fórmula estrutural estimada em 4,00 a.f.u.; $\mathrm{mg} \#=\mathrm{Mg} /(\mathrm{Mg}+\mathrm{Fe})$; n.d., não detectado.

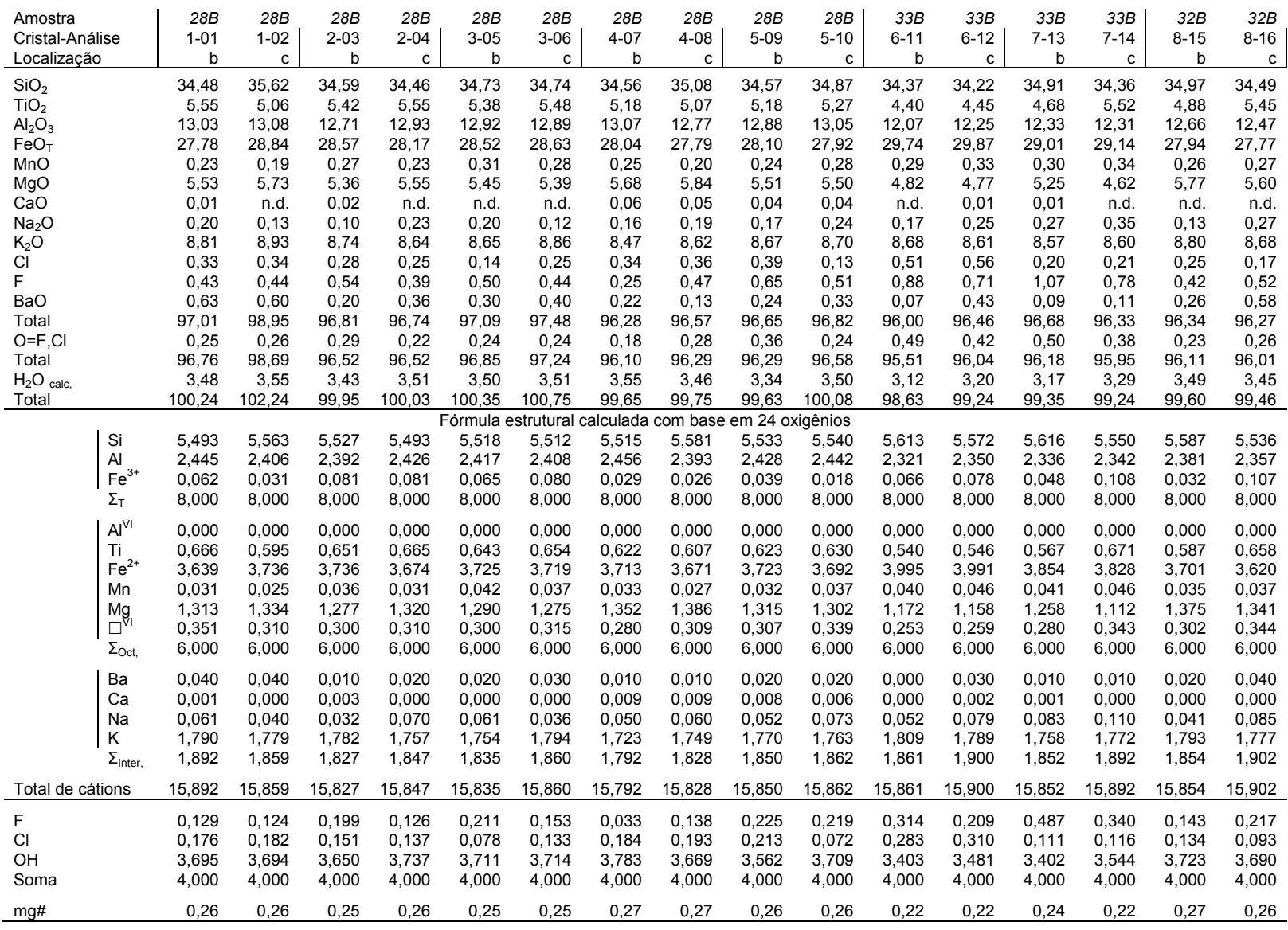

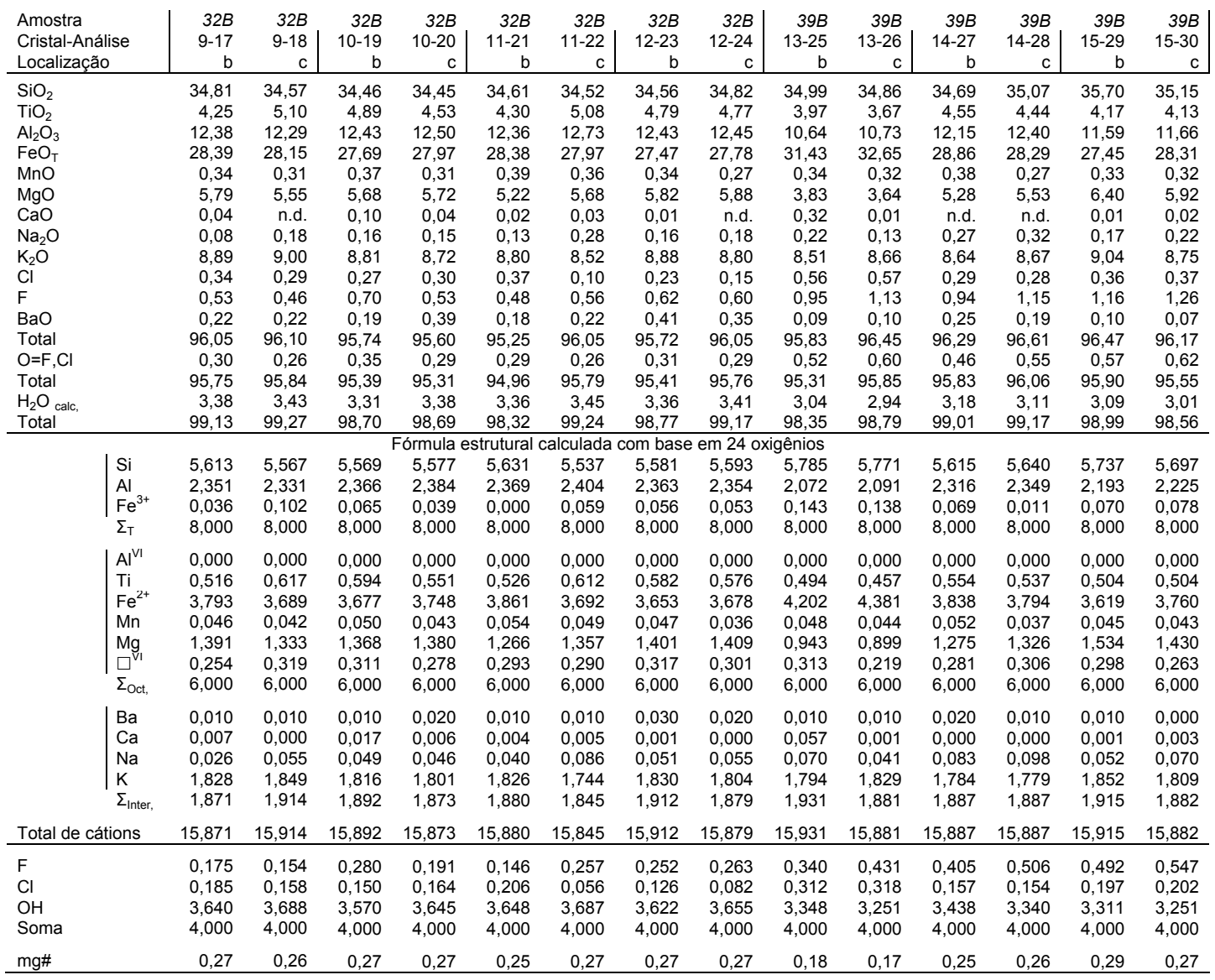


Tabela 14. Composição química de biotitas dos quartzo-álcali feldspato sienitos do Morro de São João (1A, 22B, 15A) e dos quartzo-álcali feldspato sienitos porfiríticos do Morrete $(50,40)$. Abreviações como na Tabela 13.

\begin{tabular}{|c|c|c|c|c|c|c|c|c|c|c|c|c|c|c|c|c|c|}
\hline \multirow{3}{*}{\multicolumn{2}{|c|}{$\begin{array}{l}\text { Amostra } \\
\text { Cristal-Análise } \\
\text { Localização }\end{array}$}} & $1 A$ & $1 A$ & $1 A$ & $1 A$ & $1 A$ & $1 A$ & $1 A$ & $1 A$ & $22 B$ & $22 B$ & $22 B$ & $22 B$ & $22 B$ & $22 B$ & $22 B$ & $22 B$ \\
\hline & & $1-01$ & $1-02$ & $2-03$ & 2-04 & 3-05 & 3-06 & $4-07$ & $4-08$ & $5-09$ & $5-10$ & $6-11$ & $6-12$ & $7-13$ & 7-14 & $8-15$ & 8-16 \\
\hline & & & C & $\mathrm{b}$ & C & $\mathrm{b}$ & C & b & C & $\mathrm{b}$ & C & b & c & b & c & b & \\
\hline & 35,49 & 34,81 & 35,42 & 34,84 & 35,00 & 35,25 & 38,70 & 35,10 & 34,70 & 34,56 & 34,28 & 34,45 & 34,33 & 33,85 & 33,82 & 33,53 \\
\hline \multirow{2}{*}{\multicolumn{2}{|c|}{$\begin{array}{l}\mathrm{TiO}_{2} \\
\mathrm{Al}_{2} \mathrm{O}_{3}\end{array}$}} & 4,44 & 4,72 & 4,16 & 4,08 & 4,69 & 5,14 & 2,20 & 4,29 & 2,12 & 2,14 & 1,92 & 1,84 & 2,09 & 1,74 & 1,56 & 1,30 \\
\hline & & 10,88 & 11,07 & 10,07 & 10,43 & 11,52 & 11,05 & 7,70 & 10,31 & 10,23 & 10,07 & 10,09 & 10,39 & 9,99 & 9,86 & 10,45 & 10,96 \\
\hline \multicolumn{2}{|l|}{$\mathrm{FeO}_{\mathrm{T}}$} & 31,97 & 32,12 & 33,48 & 33,92 & 31,25 & 32,10 & 32,38 & 33,76 & 35,01 & 35,08 & 35,76 & 35,69 & 35,93 & 36,66 & 36,44 & 35,60 \\
\hline & 0,55 & 0,58 & 0,44 & 0,51 & 0,44 & 0,44 & 0,63 & 0,45 & 0,71 & 0,66 & 0,65 & 1,03 & 0,11 & 0,19 & 0,49 & 0,92 \\
\hline \multicolumn{2}{|l|}{$\mathrm{MgO}$} & 3,45 & 3,31 & 2,66 & 2,56 & 3,42 & 3,35 & 2,48 & 2,60 & 1,17 & 1,20 & 1,20 & 1,04 & 0,92 & 1,01 & 0,69 & 0,63 \\
\hline \multicolumn{2}{|l|}{$\mathrm{CaO}$} & n.d. & n.d. & 0,05 & n.d. & n.d. & n.d. & 3,92 & n.d. & 0,06 & 0,02 & 0,04 & 0,02 & 0,08 & 0,11 & 0,01 & 0,06 \\
\hline \multicolumn{2}{|l|}{$\mathrm{Na}_{2} \mathrm{O}$} & 0,18 & 0,28 & 0,06 & 0,20 & 0,16 & 0,25 & 1,65 & 0,23 & 0,07 & 0,11 & 0,10 & 0,05 & 0,24 & 0,13 & 0,08 & 0,19 \\
\hline \multicolumn{2}{|l|}{$\begin{array}{l}\mathrm{K}_{2} \mathrm{O} \\
\mathrm{Cl}\end{array}$} & 8,77 & 8,69 & 8,98 & 8,80 & 9,05 & 8,67 & 5,57 & 8,70 & 8,71 & 8,67 & 8,75 & 8,39 & 8,41 & 8,20 & 8,73 & 8,17 \\
\hline \multicolumn{2}{|l|}{$\mathrm{Cl}$} & 0,15 & 0,17 & 0,25 & 0,22 & 0,15 & 0,16 & 0,23 & 0,20 & n.d. & n.d. & n.d. & 0,01 & 0,02 & 0,01 & n.d. & n.d. \\
\hline \multirow{2}{*}{\multicolumn{2}{|c|}{$\begin{array}{l}\mathrm{F} \\
\mathrm{BaO}\end{array}$}} & 1,38 & 1,07 & 0,86 & 0,97 & 1,25 & 1,65 & 0,78 & 0,60 & 0,80 & 0,76 & 1,00 & 0,57 & 0,55 & 0,74 & 0,43 & 0,73 \\
\hline & & 0,10 & 0,03 & 0,06 & 0,02 & 0,02 & 0,03 & 0,01 & 0,07 & 0,09 & n.d. & n.d. & 0,07 & 0,04 & n.d. & 0,11 & n.d. \\
\hline \multicolumn{2}{|l|}{$\begin{array}{l}\mathrm{BaO} \\
\text { Total }\end{array}$} & 97,36 & 96,84 & 96,48 & 96,56 & 96,94 & 98,09 & 96,25 & 96,31 & 93,66 & 93,27 & 93,79 & 93,54 & 92,70 & 92,48 & 92,80 & 92,08 \\
\hline \multicolumn{2}{|l|}{$\mathrm{O}=\mathrm{F}, \mathrm{Cl}$} & 0,62 & 0,49 &, 42 & 0,46 & 0,56 & 0,73 & 0,38 & 0,30 & 0,34 & 0,32 & 0,42 & 0,24 & 0,24 & 0,31 & 0,18 & 0,31 \\
\hline \multicolumn{2}{|l|}{ Total } & 96,74 & 96,35 & 96,06 & 96,10 & 96,38 & 97,36 & 95,87 & 96,01 & 93,32 & 92,95 & 93,37 & 93,30 & 92,46 & 92,17 & 92,62 & 91,77 \\
\hline \multicolumn{2}{|l|}{$\mathrm{H}_{2} \mathrm{O}$ calc, } & 2,99 & 3,11 & 3,16 & 3,10 & 3,05 & 2,88 & 3,25 & 3,30 & 3,11 & 3,12 & 2,99 & 3,21 & 3,19 & 3,07 & 3,23 & 3,07 \\
\hline \multirow{2}{*}{\multicolumn{2}{|c|}{ Total }} & 99,73 & 99,46 & 99,22 & 99,20 & 99,43 & 100,24 & 99,12 & 99,31 & 96,43 & 96,07 & 96,36 & 96,51 & 95,65 & 95,24 & 95,85 & 94,84 \\
\hline & & \multicolumn{16}{|c|}{ Fórmula estrutural calculada com base em 24 oxigênios } \\
\hline & $\mathrm{Si}$ & 5,782 & 5,697 & 5,854 & 5,776 & 5,706 & 5,712 & 6,307 & 5,798 & 5,963 & 5,964 & 5,927 & 5,933 & 5,962 & 5,932 & 5,902 & 5,886 \\
\hline & $\mathrm{Al}$ & 2,087 & 2,134 & 1,961 & 2,037 & 2,211 & 2,109 & 1,477 & 2,006 & 2,037 & 2,036 & 2,055 & 2,067 & 2,038 & 2,034 & 2,098 & 2,114 \\
\hline & $\mathrm{Fe}^{3+}$ & 0,131 & 0,169 & 0,185 & 0,187 & 0,083 & 0,179 & 0,216 & 0,196 & 0,000 & 0,000 & 0,018 & 0,000 & 0,000 & 0,034 & 0,000 & 0,000 \\
\hline & $\Sigma_{T}$ & 8,000 & 8,000 & 8,000 & 8,000 & 8,000 & 8,000 & 8,000 & 8,000 & 8,000 & 8,000 & 8,000 & 8,000 & 8,000 & 8,000 & 8,000 & 8,000 \\
\hline & $\mathrm{Al}^{\mathrm{VI}}$ & 0,000 & 0,000 & 0,000 & 0,000 & 0,000 & 0,000 & 0,000 & 0,000 & 0,033 & 0,011 & 0,000 & 0,040 & 0,005 & 0,000 & 0,050 & 0,151 \\
\hline & $\mathrm{Ti}$ & 0,544 & 0,581 & 0,518 & 0,509 & 0,575 & 0,626 & 0,270 & 0,533 & 0,274 & 0,278 & 0,249 & 0,238 & 0,273 & 0,229 & 0,205 & 0,172 \\
\hline & $\mathrm{Fe}^{2+}$ & 4,224 & 4,228 & 4,442 & 4,515 & 4,176 & 4,171 & 4,198 & 4,468 & 5,032 & 5,062 & 5,152 & 5,139 & 5,219 & 5,338 & 5,318 & 5,226 \\
\hline & $\mathrm{Mn}$ & 0,076 & 0,080 & 0,061 & 0,072 & 0,061 & 0,060 & 0,087 & 0,064 & 0,103 & 0,096 & 0,095 & 0,150 & & & 72 & 0,137 \\
\hline & $\mathrm{Mg}$ & 0,838 & 0,808 & 0,655 & 0,634 & 0,832 & 0,809 & 0,602 & 0,641 & 0,301 & 0,308 & 0,310 & 0,267 & 0,239 & 0,264 & 0,178 & 0,164 \\
\hline & $\square^{\sqrt{11}}$ & 0,318 & 0,303 & 0,324 & 0,270 & 0,356 & 0,334 & 0,843 & 0,294 & 0,257 & 0,245 & 0,194 & 0,166 & 0,248 & 0,141 & 0,177 & 0,150 \\
\hline & $\Sigma_{\text {Oct, }}$ & 5,682 & 5,697 & 5,676 & 5,730 & 5,644 & 5,666 & 5,157 & 5,706 & 5,743 & 5,755 & 5,806 & 5,834 & 5,752 & 5,859 & 5,823 & 5,850 \\
\hline & $\mathrm{Ba}$ & 0,010 & 0,000 & 0,000 & 0,000 & 0,000 & 0,000 & 0,000 & 0,000 & 0,010 & 0,000 & 0,000 & 0,000 & 0,000 & 0,000 & 0,010 & 0,000 \\
\hline & $\mathrm{Ca}$ & 000 & 0 & 010 & 000 & 0,000 & 0,000 & 0,685 & 0,000 & 0,011 & 0,004 & 0,007 & 34 &, 014 & 0,0 & 0,001 & 0,011 \\
\hline & $\mathrm{Na}$ & 0,058 & 0,088 & 0,020 & 0,064 & 0,051 & 0,077 & 0,522 & 0,074 & 0,024 & 0,037 & & & & & & 0,066 \\
\hline & & 1,822 & 1,815 & 1,893 & 1,862 & 1,883 & 1,793 & 1,158 & 1,833 & 1,910 & 1,910 & 1,929 & 1,842 & 1,863 & 1,834 & 1,9 & 1,830 \\
\hline & $\Sigma_{\text {Inter, }}$ & 1,890 & 1,903 & 1,923 & 1,926 & 1,934 & 1,870 & 2,365 & 1,907 & 1,955 & 1,951 & 1,969 & 1,861 & 1,958 & 1,899 & 1,979 & 1,907 \\
\hline \multicolumn{2}{|c|}{ Total de cátions } & 15,572 & 15,600 & 15,599 & 15,656 & 15,578 & 15,536 & 15,522 & 15,613 & 15,698 & 15,706 & 15,775 & 15,695 & 15,710 & 15,758 & 15,802 & 15,757 \\
\hline \multicolumn{2}{|l|}{$\mathrm{F}$} & 0 & 0 & & 0 & & 0,801 & 336 & 0,259 & 0,432 & 0,414 & 0,546 & 0,307 & 0,299 & 0,406 & 0,234 & 0,402 \\
\hline $\mathrm{Cl}$ & & 083 & & & & & & & & & & & & & & & 0,002 \\
\hline $\mathrm{OH}$ & & & & & & & & & & 3,566 & & & & 690 & 3,590 & 3,765 & 3,596 \\
\hline Soma & & 4,000 & 4,000 & 4,000 & 4,000 & 4,000 & 4,000 & 4,000 & 4,000 & 4,000 & 4,000 & 4,000 & 4,000 & 4,000 & 4,000 & 4,000 & 4,000 \\
\hline mg\# & & 0,16 & 0,16 & 0,12 & 0,12 & 0,16 & 0,16 & 0,12 & 0,12 & 0,06 & 0,06 & 0,06 & 0,05 & 0,04 & 0,05 & 0,03 & 0,03 \\
\hline
\end{tabular}

\begin{tabular}{|c|c|c|c|c|c|c|c|c|c|}
\hline $\begin{array}{l}\text { Amostra } \\
\text { Cristal-Análise } \\
\text { Localização }\end{array}$ & $\begin{array}{r}15 A \\
9-17 \\
b \\
\end{array}$ & $\begin{array}{r}15 A \\
9-18 \\
C \\
\end{array}$ & $\begin{array}{r}15 A \\
10-19 \\
\mathrm{C} \\
\end{array}$ & $\begin{array}{r}15 A \\
10-20 \\
b \\
\end{array}$ & $\begin{array}{r}50 \\
1-01 \\
\mathrm{~b} \\
\end{array}$ & $\begin{array}{r}50 \\
1-02 \\
\mathrm{C} \\
\end{array}$ & $\begin{array}{r}40 \\
2-03 \\
\mathrm{~b} \\
\end{array}$ & $\begin{array}{r}40 \\
2-04 \\
\quad \mathrm{i} \\
\end{array}$ & $\begin{array}{r}40 \\
2-05 \\
\mathrm{C} \\
\end{array}$ \\
\hline & 33,68 & 34,43 & 34,04 & 33,92 & 37,03 & 36,90 & 36,24 & 36,95 & 37,12 \\
\hline \multirow{2}{*}{$\begin{array}{l}\mathrm{TiO}_{2} \\
\mathrm{Al}_{2} \mathrm{O}_{3}\end{array}$} & 3,92 & 3,97 & 3,01 & 3,08 & 3,29 & 3,07 & 2,62 & 2,10 & 2,20 \\
\hline & 9,62 & 9,60 & 8,18 & 8,20 & 8,78 & 8,97 & 10,06 & 9,86 & 9,63 \\
\hline $\begin{array}{l}\mathrm{FeO}_{T} \\
\mathrm{MnO}\end{array}$ & 37,20 & 36,07 & 39,93 & 39,64 & 30,21 & 30,37 & 31,48 & 29,53 & 29,94 \\
\hline $\mathrm{MnO}$ & 0,54 & 0,53 & 0,58 & 0,63 & 0,33 & 0,28 & 0,49 & 0,42 & 0,50 \\
\hline MgO & 2,00 & 1,81 & 2,02 & 2,08 & 5,20 & 5,41 & 5,40 & 6,31 & 6,71 \\
\hline $\mathrm{CaO}$ & 0,03 & n.d. & 0,21 & 0,22 & 0,02 & n.d. & 0,02 & n.d. & n.d. \\
\hline $\mathrm{Na}_{2} \mathrm{O}$ & 0,23 & 0,32 & 0,30 & 0,28 & 0,21 & 0,18 & 0,18 & 0,15 & 0,12 \\
\hline $\mathrm{K}_{2} \mathrm{O}$ & 8,30 & 8,53 & 7,26 & 7,52 & 8,75 & 8,72 & 8,69 & 9,06 & 9,37 \\
\hline $\mathrm{Cl}$ & 0,04 & 0,06 & 0,06 & 0,08 & 0,13 & 0,13 & 0,15 & 0,11 & 0,08 \\
\hline$F$ & 0,52 & 0,59 & 0,41 & 0,60 & 1,87 & 1,64 & 1,62 & 1,81 & 1,89 \\
\hline $\mathrm{BaO}$ & n.d. & 0,07 & n.d. & 0,03 & 0,13 & n.d. & 0,20 & 0,01 & 0,05 \\
\hline \multirow{2}{*}{$\begin{array}{l}\text { Total } \\
\mathrm{O}=\mathrm{F}, \mathrm{Cl}\end{array}$} & 96,07 & 95,98 & 96,00 & 96,27 & 95,93 & 95,67 & 97,14 & 96,30 & 97,62 \\
\hline & 0,23 & 0,26 & 0,18 & 0,27 & 0,82 & 0,72 & 0,71 & 0,78 & 0,82 \\
\hline Total & 95,84 & 95,72 & 95,82 & 96,00 & 95,11 & 94,95 & 96,43 & 95,52 & 96,80 \\
\hline $\mathrm{H}_{2} \mathrm{O}$ calc, & 3,30 & 3,27 & 3,31 & 3,21 & 2,73 & 2,84 & 2,87 & 2,79 & 2,79 \\
\hline $\begin{array}{l}\text { Total } \\
\text { Tol, } \\
\end{array}$ & 99,14 & 98,99 & 99,13 & 99,21 & 97,84 & 97,79 & 99,30 & 98,31 & 99,59 \\
\hline \multicolumn{10}{|c|}{ Fórmula estrutural calculada com base em 24 oxigênios } \\
\hline $\mathrm{Si}$ & 5,683 & 5,787 & 5,801 & 5,781 & 6,094 & 6,071 & 5,913 & 6,026 & 5,998 \\
\hline Al & 1,913 & 1,901 & 1,641 & 1,646 & 1,702 & 1,738 & 1,934 & 1,894 & 1,833 \\
\hline $\mathrm{Fe}^{3+}$ & 0,404 & 0,312 & 0,558 & 0,573 & 0,204 & 0,191 & 0,153 & 0,080 & 0,169 \\
\hline$\Sigma_{T}$ & 8,000 & 8,000 & 8,000 & 8,000 & 8,000 & 8,000 & 8,000 & 8,000 & 8,000 \\
\hline $\mathrm{Al}^{\mathrm{vI}}$ & 0,000 & 0,000 & 0,000 & 0,000 & 0,000 & 0,000 & 0,000 & 0,000 & 0,000 \\
\hline $\mathrm{Ti}$ & 0,497 & 0,501 & 0,558 & 0,573 & 0,408 & 0,380 & 0,322 & 0,258 & 0,268 \\
\hline $\mathrm{Fe}^{2+}$ & 4,846 & 4,757 & 5,132 & 5,079 & 3,953 & 3,987 & 4,143 & 3,948 & 3,876 \\
\hline $\mathrm{Mn}$ & 0,077 & 0,076 & 0,083 & 0,090 & 0,046 & 0,039 & 0,068 & 0,058 & 0,068 \\
\hline $\mathrm{Mg}$ & 0,504 & 0,453 & 0,513 & 0,529 & 1,276 & 1,328 & 1,314 & 1,535 & 1,616 \\
\hline$\square^{v^{11}}$ & 0,076 & 0,213 & 0,000 & 0,000 & 0,317 & 0,266 & 0,153 & 0,201 & 0,172 \\
\hline$\Sigma_{\text {Oct, }}$ & 5,924 & 5,787 & 6,286 & 6,271 & 6,000 & 6,000 & 6,000 & 6,000 & 6,000 \\
\hline $\mathrm{Ba}$ & 0,000 & 0,000 & 0,000 & 0,000 & 0,010 & 0,000 & 0,010 & 0,000 & 0,000 \\
\hline $\mathrm{Ca}$ & 0,005 & 0,000 & 0,038 & 0,039 & 0,003 & 0,001 & 0,003 & 0,000 & 0,000 \\
\hline $\mathrm{Na}$ & 0,074 & 0,104 & 0,099 & 0,093 & 0,066 & 0,057 & 0,057 & 0,048 & 0,036 \\
\hline K & 1,787 & 1,830 & 1,579 & 1,635 & 1,836 & 1,830 & 1,808 & 1,884 & 1,932 \\
\hline$\Sigma_{\text {Inter, }}$ & 1,866 & 1,934 & 1,716 & 1,767 & 1,915 & 1,888 & 1,878 & 1,932 & 1,968 \\
\hline Total de cátions & 15,790 & 15,721 & 16,002 & 16,038 & 15,915 & 15,888 & 15,878 & 15,932 & 15,968 \\
\hline $\mathrm{F}$ & 0,263 & 0,299 & 0,200 & 0,302 & 0,936 & 0,816 & 0,793 & 0,901 & 0,946 \\
\hline $\mathrm{Cl}$ & 0,023 & 0,031 & 0,036 & 0,044 & 0,072 & 0,072 & 0,083 & 0,060 & 0,044 \\
\hline \multirow{2}{*}{$\begin{array}{l}\mathrm{OH} \\
\text { Soma }\end{array}$} & 3,714 & 3,670 & 3,764 & 3,654 & 2,992 & 3,112 & 3,124 & 3,039 & 3,010 \\
\hline & 4,000 & 4,000 & 4,000 & 4,000 & 4,000 & 4,000 & 4,000 & 4,000 & 4,000 \\
\hline $\mathrm{mg} \#$ & 0,09 & 0,08 & 0,08 & 0,09 & 0,23 & 0,24 & 0,23 & 0,28 & 0,29 \\
\hline
\end{tabular}




\subsection{Olivinas}

As olivinas, de presença rara nas rochas de Cananéia, são encontradas na forma de grãos reliquiares no interior do clinopiroxênio, com as suas bordas e fraturas associadas a anfibólio e biotita. Elas são substituídas pseudomorficamente por mineral de cor amarelo pálido (iddingsita?). Somente nos quartzo-álcali feldspato sienitos e microssienitos com textura em mosaico os cristais estão mais preservados, possibilitando, assim, a determinação do seu quimismo. Os dados obtidos referem-se a 9 análises feitas em cristais de uma amostra de quartzo-álcali feldspato sienito (15A) e estão reunidos na Tabela 15, juntamente com a fórmula estrutural do mineral e os valores dos componentes moleculares.

Os resultados indicam que o mineral é uma faialita (Fag8-97) (Fig. 26), com a troca catiônica mais importante na estrutura representada pela substituição de Mg por Fe e Mn. Ca aparece em pequena quantidade (0,009 a 0,018 a.f.u.). Quimicamente, ele é homogêneo, não se registrando qualquer variação do centro para as bordas dos grãos.

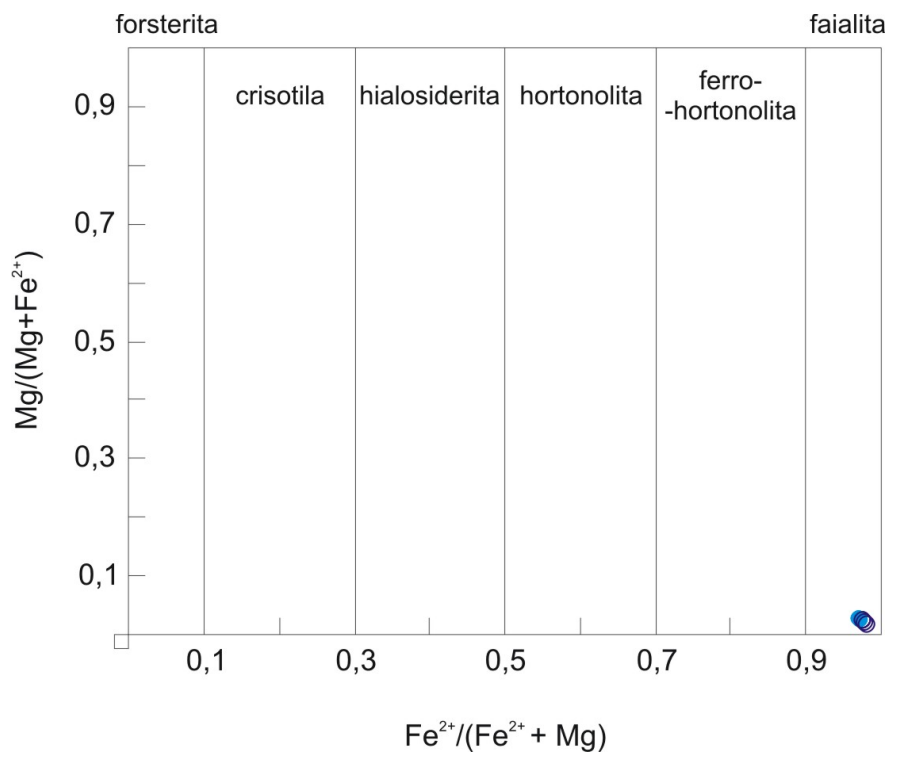

Figura 26. Diagrama de classificação de olivinas para as rochas de Cananéia. Símbolos como na Figura 8.

Tabela 15. Composição química de olivinas dos quartzo-álcali feldspato sienitos do Morro de São João. Abreviações: c, b, i, respectivamente, centro, borda e região intermediária dos cristais; n.d., não determinado.

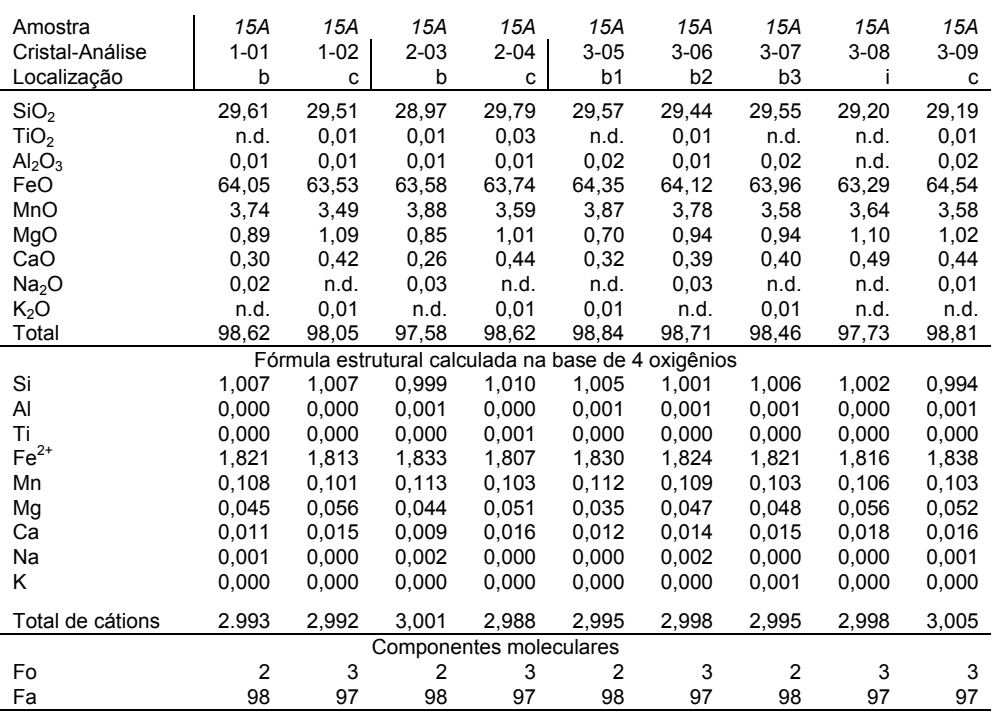




\subsection{Apatitas}

Foram realizadas 64 análises de apatitas, sendo os dados fornecidos nas Tabelas 16 a 18, juntamente com a fórmula estrutural do mineral. Para melhor compreensão do seu comportamento geoquímico, foram também analisadas algumas Terras Raras ( $\mathrm{La}, \mathrm{Ce}, \mathrm{Sm}$ e Y), em adição aos elementos principais.

As apatitas das rochas de Cananéia possuem teor variável de flúor (1,03-1,73\%) seja entre os vários tipos petrográficos, seja entre cristais de um mesmo litotipo. Face à grande dispersão dos pontos, a sua correlação com os elementos Terras Raras é pouco conclusiva. Uma correlação negativa para os álcali feldspato sienitos e positiva para os quartzo-álcali feldspato sienitos é sugerida na Figura 27.

Flúor apatitas presentes nos álcali feldspato sienitos contêm teor de $\mathrm{SrO}$ variando de 0 a $0,12 \%$, enquanto nos quartzo-álcali feldspato sienitos ele é inferior a $0,05 \%$. A concentração total dos elementos Terras Raras $(\mathrm{La}+\mathrm{Ce}+\mathrm{Sm}+\mathrm{Y})$ passa de 0,50 a $2,25 \%$ nas primeiras rochas para 2,25 a $3,60 \%$ nas segundas. Essas variações parecem sugestivas da existência de discreto zoneamento composicional nesses minerais (Figs. 28A, B).

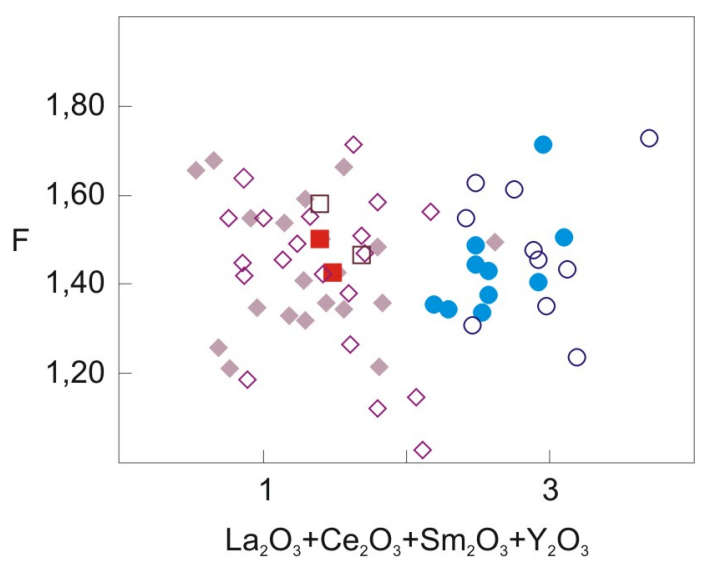

Figura 27. Diagrama $\mathrm{La}_{2} \mathrm{O}_{3}+\mathrm{Ce}_{2} \mathrm{O}_{3}+\mathrm{Sm}_{2} \mathrm{O}_{3}+\mathrm{Y}_{2} \mathrm{O}_{3}$ vs. $\mathrm{F}$ mostrando a variação composicional das apatitas das rochas de Cananéia. Símbolos como na Figura 8.
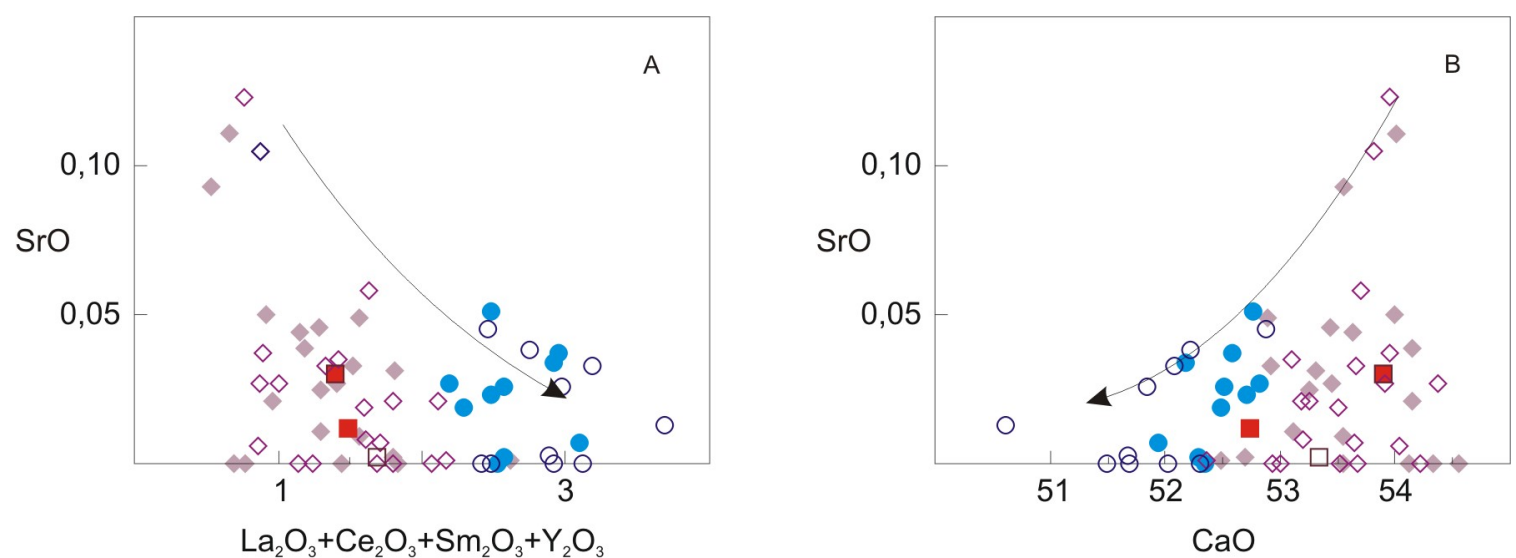

Figura 28. Diagramas de variação composicional de apatitas das rochas de Cananéia. Símbolos como na Figura 8.

As principais alterações químicas registradas nas apatitas envolvem trocas catiônicas entre $\mathrm{Sr}$, ETR, Ca e certamente $P$, bem como outros elementos não investigados neste estudo. Segundo Hogarth (1989), o equilíbrio das cargas iônicas na estrutura desses minerais pode ser demonstrado pela seguinte substituição: $\mathrm{Ca}+\mathrm{Ca} \Rightarrow \mathrm{Na}+\mathrm{TR}^{3+}$ e $\mathrm{Ca}+\mathrm{P} \Rightarrow \mathrm{Na}+\mathrm{S}^{6+}$. 
Nas apatitas de Cananéia, Sr e ETR substituem Ca e P em proporções distintas, variando, no entanto, o comportamento relativo desses elementos, como indicado nas Figuras 28A, B.

Em geral, os resultados analíticos revelam variações nos teores de $\mathrm{CaO}(50,62-54,56 \%), \mathrm{P}_{2} \mathrm{O}_{5}$ $(39,53-43,32 \%)$, além de baixos teores de $\mathrm{FeO}(<0,60 \%)$, $\mathrm{MnO}(<0,90 \%)$ e $\mathrm{Na}_{2} \mathrm{O}(<, 048 \%)$. Nos diversos diagramas de variação elaborados (Figs. 27, 28A, B e 29), apenas o último, que reúne CaO e os ETR, mostra-se conclusivo, com evidente correlação negativa para as apatitas dos dois tipos litológicos principais do Morro de São João. As apatitas dos álcali feldspato sienitos se mostram caracteristicamente mais ricas em $\mathrm{CaO}$ e pobres em ETR, quando comparadas com as das rochas mais evoluídas da intrusão, os quartzo-álcali feldspato sienitos.

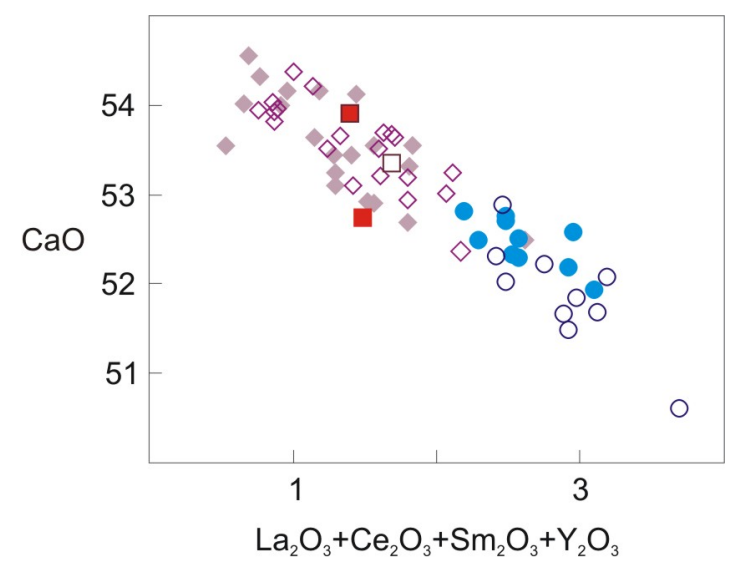

Figura 29. Diagramas de variação composicional de apatitas das rochas de Cananéia. Símbolos como na Figura 8.

Tabela 16. Composição química de apatitas dos álcali feldspato sienitos do Morro de São João. Abreviações: c, b, respectivamente, centro e borda dos cristais; n.d., não determinado.

\begin{tabular}{|c|c|c|c|c|c|c|c|c|c|c|c|c|c|c|c|c|}
\hline $\begin{array}{l}\text { Amostra } \\
\text { Cristal-Análise } \\
\text { Localização }\end{array}$ & $\begin{array}{r}28 B \\
1-01 \\
b \\
\end{array}$ & $\begin{array}{r}28 B \\
1-02 \\
C \\
\end{array}$ & $\begin{array}{r}28 B \\
2-03 \\
b \\
\end{array}$ & $\begin{array}{r}28 B \\
2-04 \\
C \\
\end{array}$ & $\begin{array}{r}28 B \\
3-05 \\
b\end{array}$ & $\begin{array}{r}28 B \\
3-06 \\
C \\
\end{array}$ & $\begin{array}{r}33 B \\
4-07 \\
\mathrm{~b} \\
\end{array}$ & $\begin{array}{r}33 B \\
4-08 \\
\mathrm{C} \\
\end{array}$ & $\begin{array}{r}33 B \\
5-09 \\
\mathrm{~b} \\
\end{array}$ & $\begin{array}{r}33 B \\
5-10 \\
C \\
\end{array}$ & $\begin{array}{r}33 B \\
6-11 \\
b \\
\end{array}$ & $\begin{array}{r}33 B \\
6-12 \\
C \\
\end{array}$ & $\begin{array}{r}33 B \\
7-13 \\
\mathrm{~b} \\
\end{array}$ & $\begin{array}{r}33 B \\
7-14 \\
C \\
\end{array}$ & $\begin{array}{r}32 B \\
8-15 \\
b \\
\end{array}$ & $\begin{array}{r}32 B \\
8-16 \\
\mathrm{C} \\
\end{array}$ \\
\hline $\mathrm{P}_{2} \mathrm{O}_{5}$ & 41,48 & 42,04 & 42,57 & 42,70 & 42,67 & 43,47 & 41,49 & 41,29 & 42,20 & 40,32 & 41,72 & 42,06 & 41,65 & 42,41 & 42,67 & 42,88 \\
\hline $\mathrm{FeO}$ & 0,36 & 0,26 & 0,17 & 0,15 & 0,27 & 0,19 & 0,27 & 0,26 & 0,10 & 0,06 & 0,43 & 0,31 & 0,31 & 0,33 & 0,32 & 0,19 \\
\hline $\mathrm{MnO}$ & 0,90 & 0,05 & 0,07 & 0,08 & 0,11 & 0,06 & 0,05 & 0,07 & 0,04 & 0,12 & 0,12 & 0,12 & 0,10 & 0,16 & 0,11 & 0,09 \\
\hline $\mathrm{MgO}$ & 0,00 & 0,01 & 0,00 & 0,01 & 0,00 & 0,01 & 0,01 & 0,00 & 0,00 & 0,01 & 0,08 & 0,10 & 0,06 & 0,08 & 0,00 & 0,00 \\
\hline $\mathrm{CaO}$ & 54,04 & 54,15 & 53,52 & 53,45 & 54,21 & 54,56 & 53,67 & 53,64 & 53,65 & 52,49 & 53,82 & 53,55 & 53,95 & 54,02 & 53,20 & 53,31 \\
\hline SrO & 0,01 & 0,02 & 0,00 & 0,03 & 0,00 & 0,00 & 0,00 & 0,04 & 0,01 & 0,00 & 0,11 & 0,09 & 0,12 & 0,11 & 0,01 & 0,03 \\
\hline $\mathrm{Na}_{2} \mathrm{O}$ & 0,12 & 0,10 & 0,11 & 0,10 & 0,10 & 0,10 & 0,11 & 0,12 & 0,20 & 0,10 & 0,05 & 0,06 & 0,08 & 0,08 & 0,13 & 0,16 \\
\hline $\mathrm{Sm}_{2} \mathrm{O}_{3}$ & 0,00 & 0,13 & 0,11 & 0,05 & 0,11 & 0,05 & 0,05 & 0,12 & 0,00 & 0,07 & 0,14 & 0,00 & 0,00 & 0,04 & 0,00 & 0,12 \\
\hline $\mathrm{Ce}_{2} \mathrm{O}_{3}$ & 0,45 & 0,57 & 0,64 & 0,63 & 0,60 & 0,42 & 0,91 & 0,58 & 0,98 & 1,45 & 0,28 & 0,16 & 0,35 & 0,24 & 0,94 & 0,85 \\
\hline $\mathrm{La}_{2} \mathrm{O}_{3}$ & 0,20 & 0,05 & 0,20 & 0,49 & 0,29 & 0,07 & 0,40 & 0,29 & 0,49 & 0,69 & 0,13 & 0,07 & 0,09 & 0,02 & 0,36 & 0,60 \\
\hline $\mathrm{Y}_{2} \mathrm{O}_{3}$ & 0,21 & 0,21 & 0,29 & 0,24 & 0,14 & 0,16 & 0,33 & 0,16 & 0,24 & 0,41 & 0,31 & 0,31 & 0,33 & 0,35 & 0,31 & 0,24 \\
\hline $\mathrm{SiO}_{2}$ & 0,38 & 0,33 & 0,55 & 0,50 & 0,36 & 0,17 & 0,66 & 0,34 & 0,63 & 1,06 & 0,02 & 0,08 & 0,13 & 0,21 & 0,61 & 0,61 \\
\hline $\mathrm{F}$ & 1,45 & 1,35 & 1,49 & 1,50 & 1,46 & 1,26 & 1,51 & 1,54 & 1,47 & 1,49 & 1,64 & 1,66 & 1,55 & 1,68 & 1,27 & 1,21 \\
\hline $\mathrm{Cl}$ & 0,06 & 0,05 & 0,13 & 0,12 & 0,10 & 0,12 & 0,03 & 0,05 & 0,05 & 0,07 & 0,01 & 0,02 & 0,03 & 0,01 & 0,04 & 0,09 \\
\hline Total & 99,66 & 99,30 & 99,86 & 100,04 & 100,41 & 100,62 & 99,48 & 98,50 & 100,05 & 98,33 & 98,86 & 98,58 & 98,73 & 99,74 & 99,96 & 100,37 \\
\hline $\mathrm{O}=\mathrm{F}, \mathrm{Cl}$ & 0,66 & 0,62 & 0,70 & 0,70 & 0,67 & 0,59 & 0,68 & 0,70 & 0,67 & 0,69 & 0,73 & 0,74 & 0,70 & 0,75 & 0,58 & 0,56 \\
\hline Total & 98,99 & 98,68 & 99,16 & 99,34 & 99,73 & 100,02 & 98,80 & 97,80 & 99,38 & 97,64 & 98,12 & 97,83 & 98,03 & 98,99 & 99,38 & 99,80 \\
\hline \multicolumn{17}{|c|}{ Fórmula estrutural calculada na base de $26(\mathrm{O}, \mathrm{OH}, \mathrm{F}, \mathrm{Cl})$} \\
\hline $\mathrm{P}$ & 6,066 & 6,137 & 6,162 & 6,172 & 6,156 & 6,229 & 6,071 & 6,095 & 6,122 & 6,000 & 6,129 & 6,165 & 6,122 & 6,148 & 6,179 & 6,188 \\
\hline $\mathrm{Fe}^{2+}$ & 0,052 & 0,037 & 0,025 & 0,021 & 0,038 & 0,026 & 0,038 & 0,038 & 0,014 & 0,009 & 0,063 & 0,044 & 0,044 & 0,047 & 0,046 & 0,027 \\
\hline $\mathrm{Mn}$ & 0,132 & 0,007 & 0,011 & 0,011 & 0,016 & 0,009 & 0,008 & 0,010 & 0,006 & 0,017 & 0,017 & 0,018 & 0,014 & 0,023 & 0,016 & 0,012 \\
\hline Mg & 0,000 & 0,002 & 0,000 & 0,003 & 0,000 & 0,002 & 0,002 & 0,000 & 0,000 & 0,003 & 0,021 & 0,026 & 0,017 & 0,021 & 0,000 & 0,000 \\
\hline $\mathrm{Ca}$ & 10,002 & 10,005 & 9,804 & 9,778 & 9,899 & 9,893 & 9,938 & 10,021 & 9,849 & 9,886 & 10,005 & 9,933 & 10,035 & 9,910 & 9,749 & 9,735 \\
\hline $\mathrm{Sr}$ & 0,001 & 0,002 & 0,000 & 0,003 & 0,000 & 0,000 & 0,000 & 0,004 & 0,001 & 0,000 & 0,011 & 0,009 & 0,012 & 0,011 & 0,001 & 0,003 \\
\hline $\mathrm{Na}$ & 0,041 & 0,032 & 0,037 & 0,034 & 0,034 & 0,032 & 0,036 & 0,042 & 0,066 & 0,035 & 0,016 & 0,020 & 0,027 & 0,027 & 0,044 & 0,052 \\
\hline $\mathrm{Sm}$ & 0,000 & 0,008 & 0,007 & 0,003 & 0,006 & 0,003 & 0,003 & 0,007 & 0,000 & 0,004 & 0,008 & 0,000 & 0,000 & 0,003 & 0,000 & 0,007 \\
\hline $\mathrm{Ce}$ & 0,028 & 0,036 & 0,040 & 0,039 & 0,037 & 0,026 & 0,058 & 0,037 & 0,061 & 0,093 & 0,018 & 0,010 & 0,022 & 0,015 & 0,059 & 0,053 \\
\hline La & 0,013 & 0,003 & 0,013 & 0,031 & 0,018 & 0,004 & 0,026 & 0,019 & 0,031 & 0,045 & 0,009 & 0,004 & 0,006 & 0,001 & 0,023 & 0,038 \\
\hline Y & 0,019 & 0,019 & 0,026 & 0,022 & 0,012 & 0,014 & 0,030 & 0,015 & 0,022 & 0,038 & 0,028 & 0,029 & 0,030 & 0,032 & 0,028 & 0,022 \\
\hline $\mathrm{Si}$ & 0,066 & 0,056 & 0,094 & 0,086 & 0,061 & 0,029 & 0,113 & 0,060 & 0,108 & 0,185 & 0,003 & 0,014 & 0,022 & 0,036 & 0,103 & 0,104 \\
\hline $\mathrm{F}$ & 0,791 & 0,736 & 0,807 & 0,811 & 0,784 & 0,674 & 0,824 & 0,848 & 0,795 & 0,831 & 0,899 & 0,906 & 0,849 & 0,908 & 0,685 & 0,654 \\
\hline $\mathrm{Cl}$ & 0,019 & 0,015 & 0,038 & 0,036 & 0,028 & 0,034 & 0,009 & 0,014 & 0,016 & 0,021 & 0,002 & 0,005 & 0,007 & 0,003 & 0,012 & 0,025 \\
\hline $\mathrm{OH}$ & 0,190 & 0,249 & 0,155 & 0,153 & 0,188 & 0,291 & 0,167 & 0,138 & 0,189 & 0,148 & 0,099 & 0,089 & 0,143 & 0,089 & 0,303 & 0,321 \\
\hline Total de cátions & 17,420 & 17,345 & 17,217 & 17,202 & 17,278 & 17,266 & 17,323 & 17,349 & 17,280 & 17,315 & 17,329 & 17,273 & 17,351 & 17,274 & 17,247 & 17,241 \\
\hline
\end{tabular}


Tabela 16. Continuação.

\begin{tabular}{|c|c|c|c|c|c|c|c|c|c|c|c|c|c|c|c|c|}
\hline Amostra & $32 B$ & $32 B$ & $32 B$ & $32 B$ & $39 B$ & $39 B$ & $39 B$ & $39 B$ & 7 & 7 & 7 & 7 & 29 & 29 & 29 & 29 \\
\hline Cristal-Análise & $9-17$ & $9-18$ & $10-19$ & $10-20$ & $11-21$ & $11-22$ & $12-23$ & $12-24$ & $13-25$ & $13-26$ & $14-27$ & $14-28$ & $15-29$ & $15-30$ & $16-31$ & $16-32$ \\
\hline Localização & $\mathrm{b}$ & & $\mathrm{b}$ & $\mathrm{c}$ & $\mathrm{b}$ & c & $\mathrm{b}$ & c & $\mathrm{b}$ & c & $\mathrm{b}$ & c & $\mathrm{b}$ & c & $\mathrm{b}$ & \\
\hline $\mathrm{P}_{2} \mathrm{O}_{5}$ & 42,82 & 42,32 & 41,80 & 42,56 & 40,89 & 42,26 & 41,11 & 41,28 & 42,06 & 42,15 & 42,24 & 43,32 & 41,94 & 41,58 & 42,17 & 41,26 \\
\hline $\mathrm{FeO}$ & 0,28 & 0,15 & 0,08 & 0,07 & 0,19 & 0,35 & 0,32 & 0,18 & 0,47 & 0,19 & 0,32 & 0,23 & 0,46 & 0,60 & 0,09 & 0,18 \\
\hline $\mathrm{MnO}$ & 0,09 & 0,12 & 0,10 & 0,06 & 0,06 & 0,07 & 0,08 & 0,09 & 0,09 & 0,06 & 0,06 & 0,10 & 0,05 & 0,08 & 0,13 & 0,10 \\
\hline $\mathrm{MgO}$ & 0,00 & 0,03 & 0,00 & 0,00 & 0,00 & 0,00 & 0,00 & 0,01 & 0,00 & 0,00 & 0,02 & 0,01 & 0,01 & 0,00 & 0,02 & 0,00 \\
\hline $\mathrm{CaO}$ & 53,92 & 53,55 & 53,65 & 54,32 & 53,18 & 53,11 & 52,36 & 52,90 & 54,37 & 53,99 & 53,96 & 54,15 & 53,70 & 53,55 & 53,01 & 52,92 \\
\hline $\mathrm{SrO}$ & 0,03 & 0,00 & 0,03 & 0,00 & 0,02 & 0,01 & 0,00 & 0,05 & 0,03 & 0,05 & 0,04 & 0,04 & 0,06 & 0,01 & 0,00 & 0,03 \\
\hline $\mathrm{Na}_{2} \mathrm{O}$ & 0,09 & 0,10 & 0,13 & 0,13 & 0,14 & 0,13 & 0,18 & 0,13 & 0,10 & 0,15 & 0,10 & 0,14 & 0,09 & 0,11 & 0,10 & 0,09 \\
\hline $\mathrm{Sm}_{2} \mathrm{O}_{3}$ & 0,06 & 0,24 & 0,16 & 0,00 & 0,06 & 0,00 & 0,12 & 0,04 & 0,02 & 0,06 & 0,03 & 0,21 & 0,01 & 0,10 & 0,06 & 0,11 \\
\hline $\mathrm{Ce}_{2} \mathrm{O}_{3}$ & 0,49 & 0,95 & 0,70 & 0,50 & 0,87 & 0,77 & 1,23 & 0,85 & 0,58 & 0,60 & 0,63 & 0,56 & 0,86 & 0,80 & 1,00 & 0,90 \\
\hline $\mathrm{La}_{2} \mathrm{O}_{3}$ & 0,07 & 0,38 & 0,29 & 0,05 & 0,56 & 0,31 & 0,49 & 0,40 & 0,27 & 0,05 & 0,07 & 0,20 & 0,49 & 0,38 & 0,67 & 0,29 \\
\hline $\mathrm{Y}_{2} \mathrm{O}_{3}$ & 0,25 & 0,28 & 0,18 & 0,22 & 0,31 & 0,21 & 0,32 & 0,28 & 0,14 & 0,20 & 0,17 & 0,21 & 0,26 & 0,28 & 0,34 & 0,22 \\
\hline $\mathrm{SiO}_{2}$ & 0,44 & 0,46 & 0,40 & 0,23 & 0,66 & 0,59 & 0,81 & 0,71 & 0,28 & 0,18 & 0,28 & 0,34 & 0,54 & 0,60 & 0,74 & 0,53 \\
\hline $\mathrm{F}$ & 1,42 & 1,36 & 1,55 & 1,21 & 1,59 & 1,59 & 1,56 & 1,35 & 1,55 & 1,55 & 1,19 & 1,33 & 1,72 & 1,66 & 1,15 & 1,43 \\
\hline $\mathrm{Cl}$ & 0,14 & 0,17 & 0,19 & 0,23 & 0,04 & 0,05 & 0,07 & 0,03 & 0,10 & 0,16 & 0,08 & 0,08 & 0,06 & 0,04 & 0,05 & 0,05 \\
\hline Total & 100,10 & 100,09 & 99,26 & 99,58 & 98,59 & 99,44 & 98,65 & 98,28 & 100,05 & 99,38 & 99,19 & 100,92 & 100,24 & 99,80 & 99,53 & 98,12 \\
\hline $\mathrm{O}=\mathrm{F}, \mathrm{Cl}$ & 0,67 & 0,65 & 0,74 & 0,60 & 0,72 & 0,72 & 0,71 & 0,61 & 0,72 & 0,73 & 0,55 & 0,61 & 0,78 & 0,75 & 0,53 & 0,65 \\
\hline Total & 99,43 & 99,44 & 98,52 & 98,98 & 97,87 & 98,72 & 97,94 & 97,67 & 99,33 & 98,65 & 98,64 & 100,31 & 99,46 & 99,04 & 99,00 & 97,47 \\
\hline \multicolumn{17}{|c|}{ Fórmula estrutural calculada na base de $26(\mathrm{O}, \mathrm{OH}, \mathrm{F}, \mathrm{Cl})$} \\
\hline $\mathrm{P}$ & 6,177 & 6,145 & 6,117 & 6,181 & 6,048 & 6,147 & 6,072 & 6,100 & 6,110 & 6,148 & 6,169 & 6,204 & 6,086 & 6,067 & 6,150 & 6,111 \\
\hline $\mathrm{Fe}^{2+}$ & 0,040 & 0,021 & 0,011 & 0,009 & 0,028 & 0,050 & 0,046 & 0,026 & 0,068 & 0,028 & 0,047 & 0,033 & 0,066 & 0,086 & 0,012 & 0,026 \\
\hline $\mathrm{Mn}$ & 0,013 & 0,017 & 0,014 & 0,009 & 0,009 & 0,010 & 0,011 & 0,013 & 0,013 & 0,008 & 0,009 & 0,015 & 0,007 & 0,012 & 0,019 & 0,015 \\
\hline $\mathrm{Mg}$ & 0,000 & 0,007 & 0,000 & 0,000 & 0,001 & 0,000 & 0,000 & 0,002 & 0,000 & 0,000 & 0,006 & 0,004 & 0,004 & 0,000 & 0,006 & 0,001 \\
\hline $\mathrm{Ca}$ & 9,843 & 9,840 & 9,935 & 9,985 & 9,954 & 9,777 & 9,787 & 9,894 & 9,996 & 9,965 & 9,972 & 9,814 & 9,863 & 9,889 & 9,783 & 9,918 \\
\hline $\mathrm{Sr}$ & 0,003 & 0,000 & 0,003 & 0,000 & 0,002 & 0,001 & 0,000 & 0,005 & 0,003 & 0,005 & 0,004 & 0,004 & 0,006 & 0,001 & 0,000 & 0,003 \\
\hline $\mathrm{Na}$ & 0,030 & 0,033 & 0,042 & 0,043 & 0,049 & 0,042 & 0,062 & 0,045 & 0,034 & 0,049 & 0,034 & 0,045 & 0,029 & 0,038 & 0,035 & 0,031 \\
\hline $\mathrm{Sm}$ & 0,003 & 0,014 & 0,010 & 0,000 & 0,004 & 0,000 & 0,007 & 0,002 & 0,001 & 0,004 & 0,002 & 0,012 & 0,001 & 0,006 & 0,004 & 0,007 \\
\hline $\mathrm{Ce}$ & 0,031 & 0,059 & 0,044 & 0,031 & 0,056 & 0,048 & 0,079 & 0,054 & 0,036 & 0,038 & 0,039 & 0,034 & 0,054 & 0,051 & 0,063 & 0,058 \\
\hline La & 0,004 & 0,024 & 0,019 & 0,003 & 0,036 & 0,020 & 0,032 & 0,026 & 0,017 & 0,003 & 0,004 & 0,013 & 0,031 & 0,024 & 0,042 & 0,019 \\
\hline Y & 0,023 & 0,025 & 0,016 & 0,020 & 0,029 & 0,019 & 0,030 & 0,026 & 0,013 & 0,019 & 0,016 & 0,019 & 0,024 & 0,025 & 0,031 & 0,020 \\
\hline $\mathrm{Si}$ & 0,074 & 0,079 & 0,069 & 0,039 & 0,116 & 0,101 & 0,142 & 0,124 & 0,047 & 0,030 & 0,049 & 0,057 & 0,093 & 0,104 & 0,128 & 0,093 \\
\hline $\mathrm{F}$ & 0,765 & 0,738 & 0,849 & 0,657 & 0,876 & 0,864 & 0,862 & 0,743 & 0,839 & 0,844 & 0,647 & 0,712 & 0,930 & 0,906 & 0,626 & 0,790 \\
\hline $\mathrm{Cl}$ & 0,041 & 0,049 & 0,057 & 0,067 & 0,012 & 0,015 & 0,020 & 0,010 & 0,030 & 0,045 & 0,023 & 0,022 & 0,016 & 0,012 & 0,014 & 0,015 \\
\hline $\mathrm{OH}$ & 0,194 & 0,213 & 0,094 & 0,275 & 0,112 & 0,121 & 0,119 & 0,248 & 0,131 & 0,110 & 0,329 & 0,266 & 0,054 & 0,081 & 0,360 & 0,196 \\
\hline Total de cátions & 17,241 & 17,265 & 17,280 & 17,321 & 17,331 & 17,216 & 17,267 & 17,317 & 17,337 & 17,296 & 17,349 & 17,253 & 17,264 & 17,303 & 17,274 & 17,302 \\
\hline
\end{tabular}

\begin{tabular}{|c|c|c|c|c|c|c|c|c|}
\hline $\begin{array}{l}\text { Amostra } \\
\text { Cristal-Análise }\end{array}$ & $\begin{array}{r}29 \\
17-33 \\
b\end{array}$ & $\begin{array}{r}29 \\
17-34 \\
c\end{array}$ & $\begin{array}{r}29 \\
18-35 \\
b\end{array}$ & $\begin{array}{r}29 \\
18-36 \\
c\end{array}$ & $\begin{array}{r}36 \\
19-37 \\
b\end{array}$ & $\begin{array}{r}36 \\
19-38 \\
\end{array}$ & $\begin{array}{r}36 \\
20-39 \\
b\end{array}$ & $\begin{array}{r}36 \\
20-40 \\
\end{array}$ \\
\hline $\mathrm{P}_{2} \mathrm{O}_{5}$ & 41,98 & 41,78 & 42,36 & 42,76 & 41,28 & 41,10 & 42,61 & 41,93 \\
\hline $\mathrm{FeO}$ & 0,32 & 0,27 & 0,32 & 0,29 & 0,36 & 0,24 & 0,07 & 0,13 \\
\hline $\mathrm{MnO}$ & 0,07 & 0,10 & 0,10 & 0,02 & 0,07 & 0,06 & 0,10 & 0,09 \\
\hline $\mathrm{MgO}$ & 0,00 & 0,00 & 0,00 & 0,00 & 0,00 & 0,00 & 0,05 & 0,00 \\
\hline $\mathrm{CaO}$ & 52,93 & 53,25 & 53,10 & 53,44 & 53,51 & 52,69 & 53,25 & 54,13 \\
\hline SrO & 0,00 & 0,03 & 0,04 & 0,05 & 0,02 & 0,00 & 0,02 & 0,00 \\
\hline $\mathrm{Na}_{2} \mathrm{O}$ & 0,15 & 0,14 & 0,14 & 0,12 & 0,13 & 0,14 & 0,14 & 0,17 \\
\hline $\mathrm{Sm}_{2} \mathrm{O}_{3}$ & 0,06 & 0,09 & 0,05 & 0,18 & 0,08 & 0,18 & 0,10 & 0,06 \\
\hline $\mathrm{Ce}_{2} \mathrm{O}_{3}$ & 0,91 & 0,73 & 0,60 & 0,66 & 0,94 & 0,93 & 0,91 & 0,75 \\
\hline $\mathrm{La}_{2} \mathrm{O}_{3}$ & 0,47 & 0,27 & 0,54 & 0,25 & 0,34 & 0,36 & 0,74 & 0,43 \\
\hline $\mathrm{Y}_{2} \mathrm{O}_{3}$ & 0,36 & 0,21 & 0,24 & 0,20 & 0,24 & 0,32 & 0,38 & 0,21 \\
\hline $\mathrm{SiO}_{2}$ & 0,55 & 0,40 & 0,42 & 0,25 & 0,53 & 0,54 & 0,53 & 0,30 \\
\hline $\mathrm{F}$ & 1,12 & 1,32 & 1,42 & 1,41 & 1,38 & 1,48 & 1,03 & 1,36 \\
\hline $\mathrm{Cl}$ & 0,12 & 0,12 & 0,13 & 0,18 & 0,13 & 0,16 & 0,14 & 0,15 \\
\hline Total & 99,03 & 98,69 & 99,44 & 99,80 & 99,00 & 98,21 & 100,05 & 99,69 \\
\hline $\mathrm{O}=\mathrm{F}, \mathrm{Cl}$ & 0,53 & 0,62 & 0,67 & 0,67 & 0,65 & 0,70 & 0,49 & 0,64 \\
\hline Total & 98,50 & 98,08 & 98,78 & 99,12 & 98,35 & 97,51 & 99,55 & 99,04 \\
\hline \multicolumn{9}{|c|}{ Fórmula estrutural calculada na base de $26(\mathrm{O}, \mathrm{OH}, \mathrm{F}, \mathrm{Cl})$} \\
\hline $\mathrm{P}$ & 6,157 & 6,144 & 6,172 & 6,201 & 6,0788 & 6,094 & 6,184 & 6,120 \\
\hline $\mathrm{Fe}^{2+}$ & 0,046 & 0,039 & 0,046 & 0,041 & 0,0519 & 0,035 & 0,009 & 0,019 \\
\hline $\mathrm{Mn}$ & 0,010 & 0,015 & 0,014 & 0,002 & 0,0102 & 0,009 & 0,015 & 0,013 \\
\hline $\mathrm{Mg}$ & 0,000 & 0,000 & 0,000 & 0,000 & 0,0000 & 0,000 & 0,013 & 0,000 \\
\hline $\mathrm{Ca}$ & 9,825 & 9,910 & 9,791 & 9,806 & 9,9718 & 9,888 & 9,781 & 9,999 \\
\hline $\mathrm{Sr}$ & 0,000 & 0,003 & 0,003 & 0,005 & 0,0019 & 0,000 & 0,002 & 0,000 \\
\hline $\mathrm{Na}$ & 0,049 & 0,048 & 0,046 & 0,041 & 0,0449 & 0,047 & 0,046 & 0,057 \\
\hline $\mathrm{Sm}$ & 0,003 & 0,005 & 0,003 & 0,011 & 0,0047 & 0,011 & 0,006 & 0,003 \\
\hline $\mathrm{Ce}$ & 0,058 & 0,046 & 0,038 & 0,041 & 0,0598 & 0,060 & 0,057 & 0,047 \\
\hline $\mathrm{La}$ & 0,030 & 0,017 & 0,034 & 0,016 & 0,0215 & 0,023 & 0,047 & 0,027 \\
\hline $\mathrm{Y}$ & 0,033 & 0,020 & 0,022 & 0,018 & 0,0224 & 0,030 & 0,034 & 0,019 \\
\hline $\mathrm{Si}$ & 0,094 & 0,069 & 0,071 & 0,044 & 0,0913 & 0,094 & 0,091 & 0,051 \\
\hline $\mathrm{F}$ & 0,615 & 0,725 & 0,774 & 0,764 & 0,7596 & 0,822 & 0,557 & 0,742 \\
\hline $\mathrm{Cl}$ & 0,036 & 0,034 & 0,038 & 0,052 & 0,0395 & 0,048 & 0,041 & 0,043 \\
\hline $\mathrm{OH}$ & 0,349 & 0,241 & 0,188 & 0,184 & 0,2009 & 0,130 & 0,402 & 0,215 \\
\hline Total de cátions & 17,307 & 17,316 & 17,240 & 17,225 & 17,359 & 17,291 & 17,285 & 17,356 \\
\hline
\end{tabular}


Tabela 17. Composição química de apatitas dos quartzo-álcali feldspato sienitos do Morro de São João. Abreviações como na Tabela 16.

\begin{tabular}{|c|c|c|c|c|c|c|c|c|c|c|c|c|c|c|c|c|}
\hline $\begin{array}{l}\text { Amostra } \\
\text { Cristal-Análise } \\
\text { Localização }\end{array}$ & $\begin{array}{r}1 A \\
1-01 \\
b \\
\end{array}$ & $\begin{array}{r}1 A \\
1-02 \\
\mathrm{C} \\
\end{array}$ & $\begin{array}{r}1 A \\
2-03 \\
b\end{array}$ & $\begin{array}{r}1 A \\
2-04 \\
\mathrm{C}\end{array}$ & $\begin{array}{r}1 A \\
3-05 \\
\mathrm{~b} \\
\end{array}$ & $\begin{array}{r}1 A \\
3-06 \\
\mathrm{C}\end{array}$ & $\begin{array}{r}15 A \\
4-07 \\
b \\
\end{array}$ & $\begin{array}{r}15 A \\
4-08 \\
\mathrm{C}\end{array}$ & $\begin{array}{r}15 A \\
5-09 \\
\mathrm{~b} \\
\end{array}$ & $\begin{array}{r}15 A \\
5-10 \\
\mathrm{C}\end{array}$ & $\begin{array}{r}15 A \\
6-11 \\
b \\
\end{array}$ & $\begin{array}{r}15 A \\
6-12 \\
\mathrm{C} \\
\end{array}$ & $\begin{array}{r}9 A \\
7-13 \\
b\end{array}$ & $\begin{array}{r}9 A \\
7-14 \\
\mathrm{C} \\
\end{array}$ & $\begin{array}{r}9 A \\
8-15 \\
b\end{array}$ & $\begin{array}{r}9 A \\
8-16 \\
C \\
\end{array}$ \\
\hline P2O5 & 41,73 & 41,48 & 41,00 & 40,88 & 40,36 & 40,42 & 40,48 & 40,74 & 41,20 & 41,19 & 40,83 & 40,84 & 39,95 & 40,13 & 40,40 & 41,47 \\
\hline $\mathrm{FeO}$ & 0,34 & 0,40 & 0,04 & 0,00 & 0,10 & 0,09 & 0,16 & 0,08 & 0,14 & 0,12 & 0,08 & 0,25 & 0,31 & 0,26 & 0,17 & 0,04 \\
\hline $\mathrm{MnO}$ & 0,08 & 0,06 & 0,01 & 0,04 & 0,02 & 0,10 & 0,05 & 0,07 & 0,05 & 0,04 & 0,07 & 0,08 & 0,06 & 0,05 & 0,06 & 0,04 \\
\hline $\mathrm{MgO}$ & 0,00 & 0,01 & 0,00 & 0,00 & 0,00 & 0,00 & 0,00 & 0,00 & 0,00 & 0,00 & 0,00 & 0,00 & 0,00 & 0,01 & 0,00 & 0,00 \\
\hline $\mathrm{CaO}$ & 52,88 & 52,77 & 52,22 & 52,71 & 52,08 & 52,29 & 51,70 & 52,59 & 52,31 & 52,51 & 51,67 & 52,82 & 51,50 & 51,94 & 51,85 & 52,34 \\
\hline SrO & 0,05 & 0,05 & 0,04 & 0,02 & 0,03 & 0,00 & 0,00 & 0,04 & 0,00 & 0,03 & 0,00 & 0,03 & 0,00 & 0,01 & 0,03 & 0,00 \\
\hline $\mathrm{Na}_{2} \mathrm{O}$ & 0,22 & 0,23 & 0,15 & 0,15 & 0,21 & 0,14 & 0,19 & 0,10 & 0,13 & 0,13 & 0,15 & 0,13 & 0,14 & 0,14 & 0,17 & 0,16 \\
\hline $\mathrm{Sm}_{2} \mathrm{O}_{3}$ & 0,17 & 0,21 & 0,07 & 0,13 & 0,12 & 0,18 & 0,31 & 0,14 & 0,05 & 0,09 & 0,17 & 0,12 & 0,09 & 0,26 & 0,05 & 0,00 \\
\hline $\mathrm{Ce}_{2} \mathrm{O}_{3}$ & 1,38 & 1,21 & 1,52 & 1,31 & 1,89 & 1,59 & 1,66 & 1,46 & 1,55 & 1,42 & 1,58 & 1,14 & 1,99 & 1,64 & 1,69 & 1,54 \\
\hline $\mathrm{La}_{2} \mathrm{O}_{3}$ & 0,38 & 0,51 & 0,38 & 0,63 & 0,82 & 0,51 & 0,78 & 1,02 & 0,53 & 0,74 & 0,80 & 0,60 & 0,42 & 0,82 & 0,65 & 0,58 \\
\hline $\mathrm{Y}_{2} \mathrm{O}_{3}$ & 0,53 & 0,55 & 0,78 & 0,41 & 0,35 & 0,29 & 0,37 & 0,33 & 0,28 & 0,32 & 0,34 & 0,33 & 0,41 & 0,38 & 0,58 & 0,41 \\
\hline $\mathrm{SiO}_{2}$ & 0,79 & 0,78 & 1,07 & 0,85 & 0,99 & 1,12 & 1,17 & 1,05 & 1,07 & 1,03 & 1,25 & 1,03 & 1,48 & 1,21 & 1,30 & 1,02 \\
\hline $\mathrm{F}$ & 1,31 & 1,44 & 1,61 & 1,49 & 1,24 & 1,43 & 1,44 & 1,71 & 1,55 & 1,38 & 1,48 & 1,36 & 1,46 & 1,51 & 1,35 & 1,34 \\
\hline $\mathrm{Cl}$ & 0,01 & 0,01 & 0,00 & 0,01 & 0,00 & 0,00 & 0,01 & 0,01 & 0,00 & 0,02 & 0,00 & 0,00 & 0,02 & 0,03 & 0,02 & 0,01 \\
\hline Total & 99,87 & 99,70 & 98,88 & 98,64 & 98,22 & 98,16 & 98,28 & 99,33 & 98,85 & 99,00 & 98,41 & 98,72 & 97,83 & 98,38 & 98,33 & 98,93 \\
\hline $\mathrm{O}=\mathrm{F}, \mathrm{Cl}$ & 0,59 & 0,65 & 0,72 & 0,67 & 0,55 & 0,64 & 0,64 & 0,77 & 0,69 & 0,62 & 0,66 & 0,61 & 0,66 & 0,68 & 0,61 & 0,60 \\
\hline Total & 99,28 & 99,05 & 98,16 & 97,97 & 97,66 & 97,52 & 97,64 & 98,56 & 98,16 & 98,38 & 97,75 & 98,12 & 97,17 & 97,70 & 97,71 & 98,33 \\
\hline \multicolumn{17}{|c|}{ Fórmula estrutural calculada na base de $26(\mathrm{O}, \mathrm{OH}, \mathrm{F}, \mathrm{Cl})$} \\
\hline$P$ & 6,095 & 6,074 & 6,044 & 6,051 & 6,030 & 6,018 & 6,028 & 6,005 & 6,066 & 6,067 & 6,050 & 6,037 & 5,975 & 5,984 & 6,010 & 6,097 \\
\hline $\mathrm{Fe}^{2+}$ & 0,050 & 0,058 & 0,005 & 0,000 & 0,015 & 0,013 & 0,023 & 0,012 & 0,020 & 0,017 & 0,012 & 0,037 & 0,045 & 0,039 & 0,025 & 0,005 \\
\hline $\mathrm{Mn}$ & 0,012 & 0,008 & 0,002 & 0,006 & 0,003 & 0,015 & 0,008 & 0,010 & 0,008 & 0,005 & 0,010 & 0,011 & 0,010 & 0,008 & 0,009 & 0,006 \\
\hline $\mathrm{Mg}$ & 0,000 & 0,003 & 0,000 & 0,000 & 0,000 & 0,000 & 0,000 & 0,000 & 0,000 & 0,000 & 0,000 & 0,000 & 0,000 & 0,002 & 0,000 & 0,000 \\
\hline $\mathrm{Ca}$ & 9,774 & 9,778 & 9,741 & 9,873 & 9,848 & 9,852 & 9,743 & 9,810 & 9,746 & 9,787 & 9,690 & 9,879 & 9,748 & 9,802 & 9,761 & 9,739 \\
\hline $\mathrm{Sr}$ & 0,005 & 0,005 & 0,004 & 0,002 & 0,003 & 0,000 & 0,000 & 0,004 & 0,000 & 0,003 & 0,000 & 0,003 & 0,000 & 0,001 & 0,003 & 0,000 \\
\hline $\mathrm{Na}$ & 0,074 & 0,076 & 0,050 & 0,051 & 0,071 & 0,047 & 0,063 & 0,035 & 0,044 & 0,044 & 0,050 & 0,045 & 0,047 & 0,048 & 0,059 & 0,052 \\
\hline $\mathrm{Sm}$ & 0,010 & 0,012 & 0,004 & 0,008 & 0,008 & 0,011 & 0,019 & 0,008 & 0,003 & 0,006 & 0,010 & 0,007 & 0,006 & 0,016 & 0,003 & 0,000 \\
\hline $\mathrm{Ce}$ & 0,087 & 0,076 & 0,097 & 0,084 & 0,122 & 0,102 & 0,107 & 0,093 & 0,099 & 0,091 & 0,101 & 0,073 & 0,129 & 0,106 & 0,109 & 0,098 \\
\hline La & 0,024 & 0,033 & 0,024 & 0,040 & 0,053 & 0,033 & 0,050 & 0,066 & 0,034 & 0,047 & 0,052 & 0,039 & 0,028 & 0,053 & 0,042 & 0,037 \\
\hline Y & 0,048 & 0,051 & 0,072 & 0,038 & 0,033 & 0,027 & 0,035 & 0,030 & 0,026 & 0,030 & 0,031 & 0,031 & 0,039 & 0,035 & 0,054 & 0,038 \\
\hline $\mathrm{Si}$ & 0,136 & 0,135 & 0,186 & 0,149 & 0,175 & 0,197 & 0,205 & 0,183 & 0,186 & 0,179 & 0,218 & 0,179 & 0,262 & 0,214 & 0,228 & 0,177 \\
\hline $\mathrm{F}$ & 0,715 & 0,789 & 0,888 & 0,823 & 0,691 & 0,796 & 0,798 & 0,943 & 0,851 & 0,758 & 0,818 & 0,748 & 0,813 & 0,839 & 0,752 & 0,734 \\
\hline $\mathrm{Cl}$ & 0,002 & 0,001 & 0,001 & 0,003 & 0,000 & 0,000 & 0,002 & 0,002 & 0,000 & 0,005 & 0,000 & 0,001 & 0,006 & 0,009 & 0,007 & 0,002 \\
\hline $\mathrm{OH}$ & 0,283 & 0,209 & 0,111 & 0,174 & 0,309 & 0,204 & 0,199 & 0,054 & 0,149 & 0,238 & 0,182 & 0,251 & 0,181 & 0,153 & 0,241 & 0,264 \\
\hline Total de cátions & 17,315 & 17,310 & 17,230 & 17,303 & 17,362 & 17,315 & 17,280 & 17,255 & 17,232 & 17,275 & 17,225 & 17,339 & 17,289 & 17,306 & 17,303 & 17,249 \\
\hline
\end{tabular}

Tabela 18. Composição química de apatitas dos quartzo-álcali feldspato sienitos $(9 A)$ e dos microssienitos com textura em mosaico (37) do Morro de São João. Abreviações como na Tabela 16.

\begin{tabular}{|c|c|c|c|c|c|c|c|c|}
\hline $\begin{array}{l}\text { Amostra } \\
\text { Cristal-Análise } \\
\text { Localização }\end{array}$ & $\begin{array}{r}9 A \\
9-17 \\
b \\
\end{array}$ & $\begin{array}{r}9 A \\
9-18 \\
C \\
\end{array}$ & $\begin{array}{r}9 A \\
10-19 \\
b \\
\end{array}$ & $\begin{array}{r}9 A \\
10-20 \\
\mathrm{C} \\
\end{array}$ & $\begin{array}{r}37 \\
1-01 \\
b \\
\end{array}$ & $\begin{array}{r}37 \\
1-02 \\
\mathrm{C} \\
\end{array}$ & $\begin{array}{r}37 \\
2-03 \\
b \\
\end{array}$ & $\begin{array}{r}37 \\
2-04 \\
\mathrm{C} \\
\end{array}$ \\
\hline P2O5 & 40,43 & 40,38 & 39,53 & 41,09 & 40,98 & 41,44 & 41,57 & 41,57 \\
\hline $\mathrm{FeO}$ & 0,23 & 0,17 & 0,13 & 0,09 & 0,37 & 0,35 & 0,44 & 0,44 \\
\hline $\mathrm{MnO}$ & 0,02 & 0,07 & 0,03 & 0,04 & 0,06 & 0,09 & 0,08 & 0,08 \\
\hline $\mathrm{MgO}$ & 0,00 & 0,00 & 0,00 & 0,01 & 0,00 & 0,00 & 0,00 & 0,00 \\
\hline $\mathrm{CaO}$ & 52,03 & 52,18 & 50,62 & 52,49 & 53,34 & 52,74 & 53,90 & 53,90 \\
\hline $\mathrm{SrO}$ & 0,00 & 0,03 & 0,01 & 0,02 & 0,00 & 0,01 & 0,03 & 0,03 \\
\hline $\mathrm{Na}_{2} \mathrm{O}$ & 0,20 & 0,13 & 0,23 & 0,13 & 0,13 & 0,48 & 0,12 & 0,12 \\
\hline $\mathrm{Sm}_{2} \mathrm{O}_{3}$ & 0,17 & 0,18 & 0,16 & 0,10 & 0,17 & 0,06 & 0,22 & 0,22 \\
\hline $\mathrm{Ce}_{2} \mathrm{O}_{3}$ & 1,59 & 1,66 & 2,23 & 1,19 & 0,84 & 0,89 & 0,65 & 0,65 \\
\hline $\mathrm{La}_{2} \mathrm{O}_{3}$ & 0,49 & 0,69 & 0,86 & 0,71 & 0,38 & 0,33 & 0,22 & 0,22 \\
\hline $\mathrm{Y}_{2} \mathrm{O}_{3}$ & 0,23 & 0,39 & 0,44 & 0,29 & 0,30 & 0,20 & 0,31 & 0,31 \\
\hline $\mathrm{SiO}_{2}$ & 0,91 & 1,30 & 1,63 & 0,89 & 0,48 & 0,49 & 0,52 & 0,52 \\
\hline $\mathrm{F}$ & 1,63 & 1,41 & 1,73 & 1,34 & 1,47 & 1,43 & 1,58 & 1,50 \\
\hline $\mathrm{Cl}$ & 0,00 & 0,01 & 0,00 & 0,00 & 0,05 & 0,04 & 0,04 & 0,04 \\
\hline Total & 97,93 & 98,59 & 97,59 & 98,38 & 98,57 & 98,56 & 99,68 & 99,60 \\
\hline $\mathrm{O}=\mathrm{F}, \mathrm{Cl}$ & 0,73 & 0,63 & 0,77 & 0,60 & 0,67 & 0,65 & 0,72 & 0,68 \\
\hline Total & 97,20 & 97,96 & 96,82 & 97,78 & 97,90 & 97,91 & 98,96 & 98,92 \\
\hline \multicolumn{9}{|c|}{ Fórmula estrutural calculada na base de $26(\mathrm{O}, \mathrm{OH}, \mathrm{F}, \mathrm{Cl})$} \\
\hline $\bar{P}$ & 6,033 & 5,995 & 5,945 & 6,083 & 6,066 & 6,114 & 6,072 & 6,076 \\
\hline $\mathrm{Fe}^{2+}$ & 0,034 & 0,024 & 0,020 & 0,012 & 0,054 & 0,051 & 0,063 & 0,063 \\
\hline $\mathrm{Mn}$ & 0,003 & 0,010 & 0,005 & 0,006 & 0,009 & 0,013 & 0,011 & 0,011 \\
\hline $\mathrm{Mg}$ & 0,000 & 0,000 & 0,000 & 0,002 & 0,000 & 0,000 & 0,000 & 0,000 \\
\hline $\mathrm{Ca}$ & 9,824 & 9,806 & 9,632 & 9,835 & 9,994 & 9,848 & 9,963 & 9,971 \\
\hline $\mathrm{Sr}$ & 0,000 & 0,003 & 0,001 & 0,002 & 0,000 & 0,001 & 0,003 & 0,003 \\
\hline $\mathrm{Na}$ & 0,069 & 0,045 & 0,079 & 0,044 & 0,045 & 0,162 & 0,041 & 0,041 \\
\hline $\mathrm{Sm}$ & 0,010 & 0,011 & 0,010 & 0,006 & 0,010 & 0,004 & 0,013 & 0,013 \\
\hline $\mathrm{Ce}$ & 0,102 & 0,106 & 0,145 & 0,076 & 0,054 & 0,057 & 0,041 & 0,041 \\
\hline $\mathrm{La}$ & 0,032 & 0,045 & 0,057 & 0,046 & 0,024 & 0,021 & 0,014 & 0,014 \\
\hline Y & 0,022 & 0,036 & 0,041 & 0,027 & 0,028 & 0,018 & 0,028 & 0,028 \\
\hline $\mathrm{Si}$ & 0,160 & 0,229 & 0,289 & 0,155 & 0,084 & 0,085 & 0,090 & 0,090 \\
\hline $\mathrm{F}$ & 0,907 & 0,780 & 0,970 & 0,743 & 0,810 & 0,785 & 0,861 & 0,821 \\
\hline $\mathrm{Cl}$ & 0,001 & 0,002 & 0,001 & 0,000 & 0,015 & 0,012 & 0,012 & 0,012 \\
\hline $\mathrm{OH}$ & 0,092 & 0,218 & 0,029 & 0,257 & 0,175 & 0,203 & 0,127 & 0,168 \\
\hline Total de cátions & 17,288 & 17,311 & 17,222 & 17,294 & 17,368 & 17,376 & 17,339 & 17,352 \\
\hline
\end{tabular}




\subsection{IImenitas e magnetitas}

Foram realizadas 144 análises em minerais opacos, sendo 98 em ilmenitas e 46 em magnetitas. Os dados estão reunidos nas Tabelas 19 a 22, juntamente com a fórmula estrutural desses minerais.

Os opacos constituem a fase acessória mais comum da maioria das rochas de Cananéia. Estão representados por ilmenitas e magnetitas, que ocorrem seja como pequenos cristais da mesóstase, como inclusões em feldspatos e máficos (clinopiroxênios, anfibólios, olivinas e biotitas), ou ainda como produto de reação desses últimos, quando aparecem geralmente associados às bordas e planos de clivagem de anfibólios e biotitas. Apresentam-se quer na forma de cristais homogêneos, quer de produtos de exsolução.

No diagrama $\mathrm{FeO}-\mathrm{TiO}_{2}-\mathrm{Fe}_{2} \mathrm{O}_{3}$ (Fig. 30), proposto por Buddington e Lindsley (1964) e adaptado por Haggerty (1976), os pontos analisados de magnetita formam um trend paralelo ao eixo $\mathrm{Fe}_{3} \mathrm{O}_{4^{-}}$ $\mathrm{Fe}_{2} \mathrm{TiO}_{4}$ (série magnetita-ulvöespinélio), enquanto os relativos às ilmenitas concentram-se próximos ao pólo $\mathrm{FeTiO}_{3}$. A posição dos pontos no diagrama indica para os óxidos da série magnetitaulvöespinélio temperaturas de cristalização em torno de $600^{\circ} \mathrm{C}$, com baixa fugacidade de oxigênio; já para as ilmenitas, aponta para temperaturas de $800^{\circ} \mathrm{C}$ e fugacidade de oxigênio mais alta.

Tanto as rochas menos como as mais evoluídas de Cananéia contêm magnetita e ilmenita, sendo, no entanto, o primeiro mineral mais freqüente nos quartzo-álcali feldspato sienitos do Morro de São João e do Morrete. Por sua vez, o segundo é mais comum nos álcali feldspato sienitos e nas rochas hipoabissais (microssienitos com textura em mosaico e microssienitos com textura traquítica).

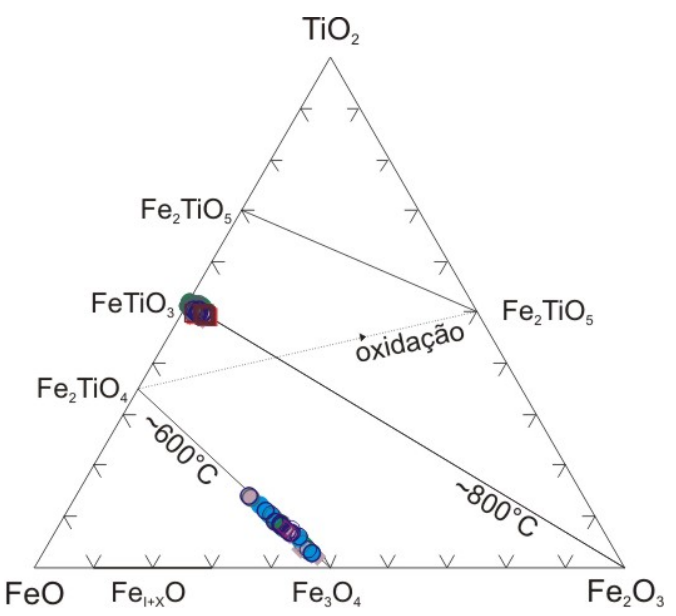

Figura 30. Diagrama $\mathrm{FeO}-\mathrm{TiO}_{2}-\mathrm{Fe}_{2} \mathrm{O}_{3}$ de Buddington e Lindsley (1964), modificado por Haggerty (1976), para ilmenitas e magnetitas das rochas de Cananéia. Símbolos como na Figura 8.

As Figuras 31A-D mostram as variações de $\mathrm{TiO}_{2}, \mathrm{Al}_{2} \mathrm{O}_{3}, \mathrm{MnO}$, e $\mathrm{MgO}$ em função de $\mathrm{FeO}_{\mathrm{T}}$ das ilmenitas e das magnetitas, com as análises formando dois grupos separados, respectivamente, com teores de $\mathrm{FeO}_{\mathrm{T}}$ inferiores a $50 \%$ e superiores a $80 \%$. As ilmenitas apresentam proporções de $\mathrm{TiO}_{2}$ variando de 46,70 a $51,00 \%, \mathrm{Al}_{2} \mathrm{O}_{3}$ inferior a $0,07 \%$, uma ampla variação dos teores de $\mathrm{MnO}(1,34-$ $3,70 \%)$, baixos conteúdos de $\mathrm{MgO}(0-0,16 \%)$, além também de $\mathrm{CaO}$ menor que $0,41 \%, \mathrm{Nb}_{2} \mathrm{O}_{5}$ indo de 0 a $1,90 \%$ e $\mathrm{Cr}_{2} \mathrm{O}_{3}$ abaixo de $0,10 \%$. Já as magnetitas possuem teor de $\mathrm{MnO}$ variando de 0,01 a $1,22 \%, \mathrm{MgO}$ inferior a $0,09 \%$ e baixos valores de $\mathrm{CaO}(<0,19 \%), \mathrm{Nb}_{2} \mathrm{O}_{5}(<0,11 \%)$ e $\mathrm{Cr}_{2} \mathrm{O}_{3}(<0,13 \%)$ (Tabelas 19 a 22). Os teores elevados de $\mathrm{TiO}_{2}$ permitem classificar o mineral mais apropriadamente como uma titanomagnetita, sendo os valores mais altos encontrados junto aos quartzo-álcali feldspato sienitos. Uma correlação negativa entre $\mathrm{TiO}_{2}$ e $\mathrm{FeO}_{\mathrm{T}}$ acha-se evidenciada na Figura 31A, o mesmo 
sucedendo para $\mathrm{MnO}$ e $\mathrm{FeO}_{\mathrm{T}}$ e $\mathrm{MgO}$ e $\mathrm{FeO}_{\mathrm{T}}(\mathrm{Figs}$. 31C, D). A despeito da grande variabilidade, o teor de $\mathrm{Al}_{2} \mathrm{O}_{3}$ das magnetitas é muito baixo e mantém-se, à exceção de uma amostra de álcali feldspato sienito com $0,71 \%$, inferior a $0,6 \%$ (Fig. 31B).
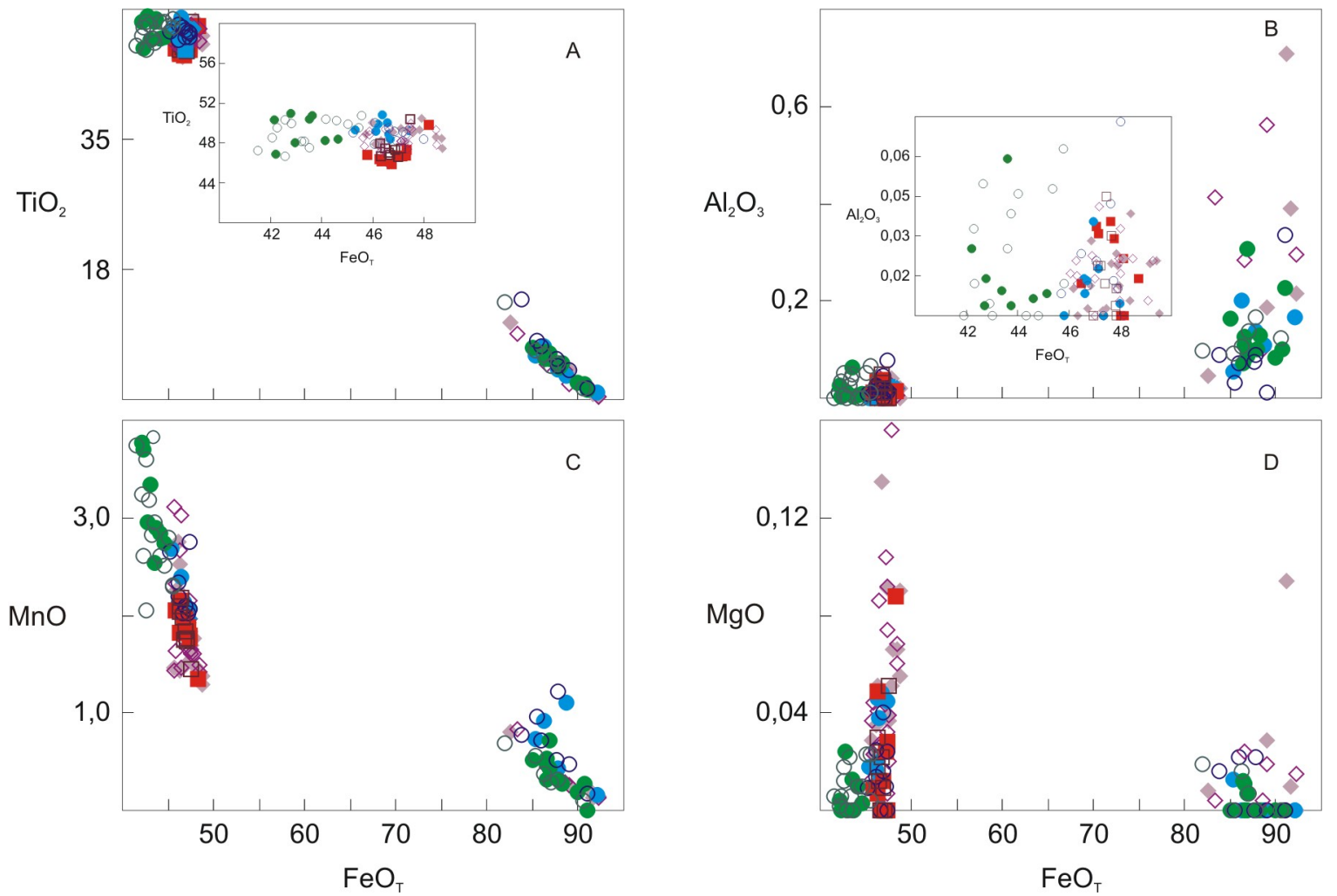

Figura 31. Diagramas relacionando $\mathrm{FeO}_{\mathrm{T}}$ vs. $\mathrm{TiO}_{2}, \mathrm{Al}_{2} \mathrm{O}_{3}, \mathrm{MnO}$ e $\mathrm{MgO}$ para ilmenitas e magnetitas. Em A e $\mathrm{B}$, o campo ocupado pelas análises de ilmenitas encontra-se expandido para facilitar a visualização. Símbolos como na Figura 8.

Tabela 19. Composição química de ilmenitas (ilm) e magnetitas $(\mathrm{mt})$ dos álcali feldspato sienitos do Morro de São João. Abreviações: c, b, respectivamente, centro e borda dos cristais; lam: lamela. Classificação: Gkl, geikielita; IIm, ilmenita; Hem, hematita; Crm, cromita; Her, hercinita; Mt, magnetita; Spi, espinélio; Usp, ulvöespinélio; n.d., não determinado. Cálculo de $\mathrm{fO}_{2} \mathrm{e}$ $\mathrm{T}^{\circ} \mathrm{C}$.

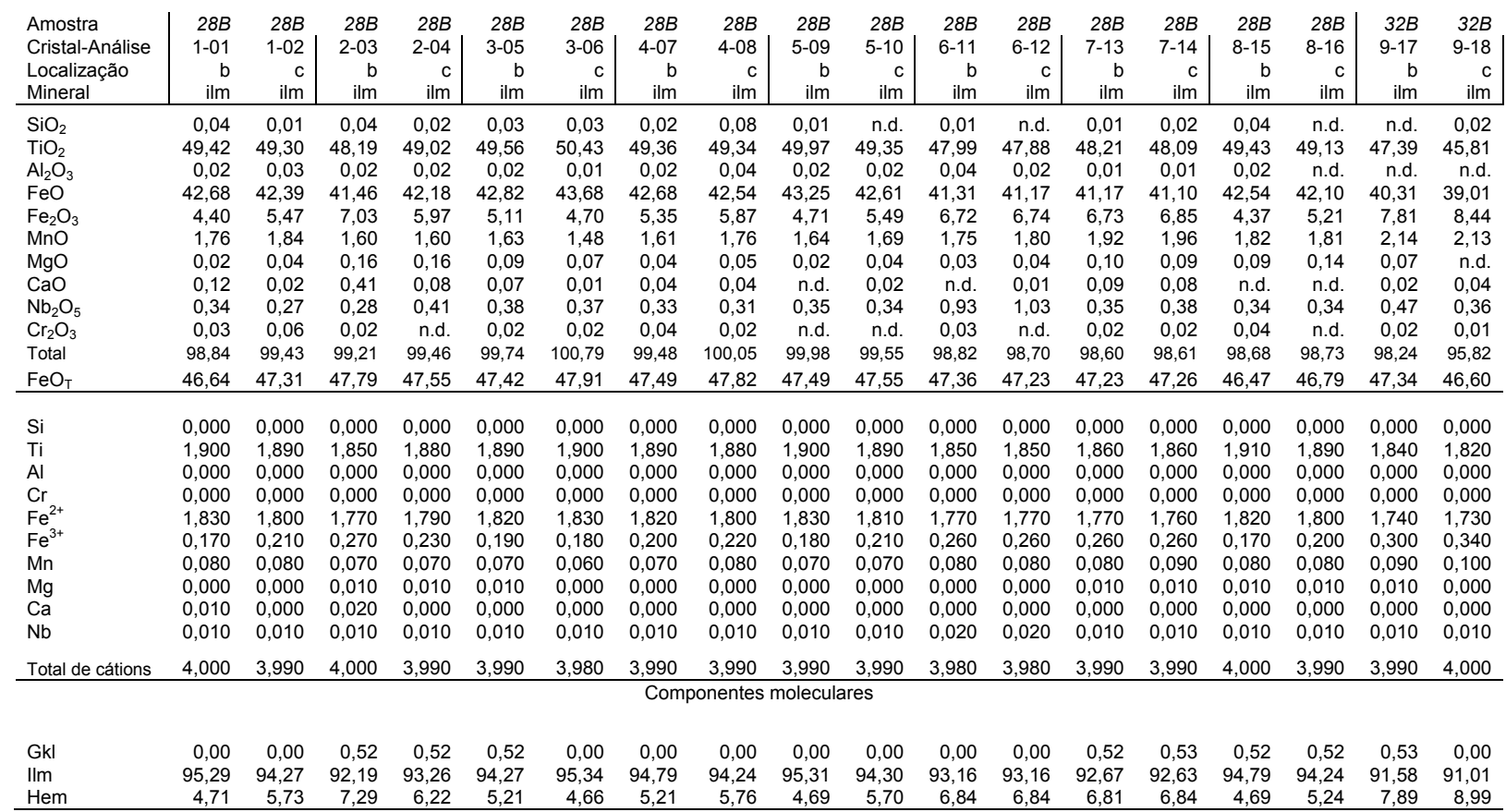


Tabela 19. Continuação.

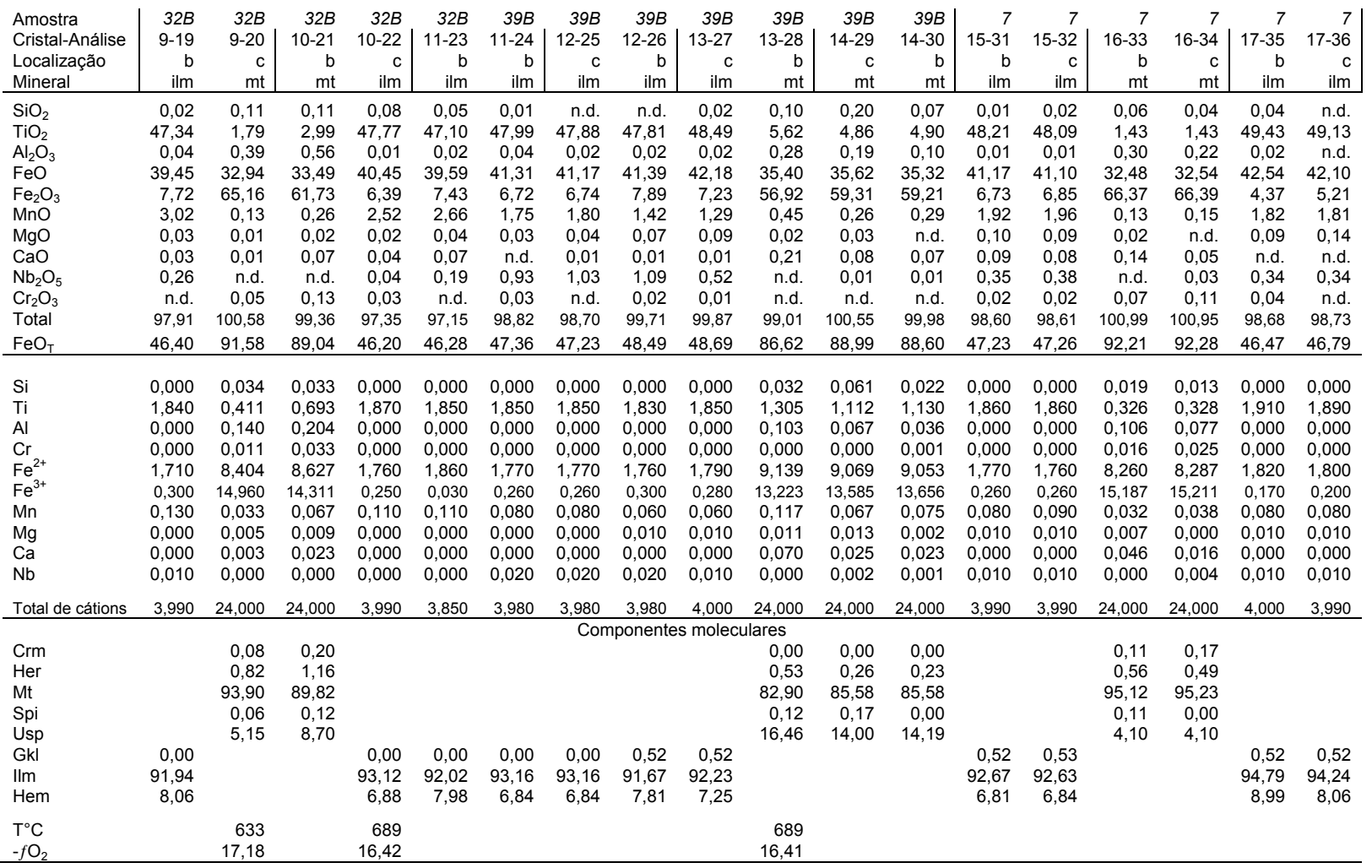

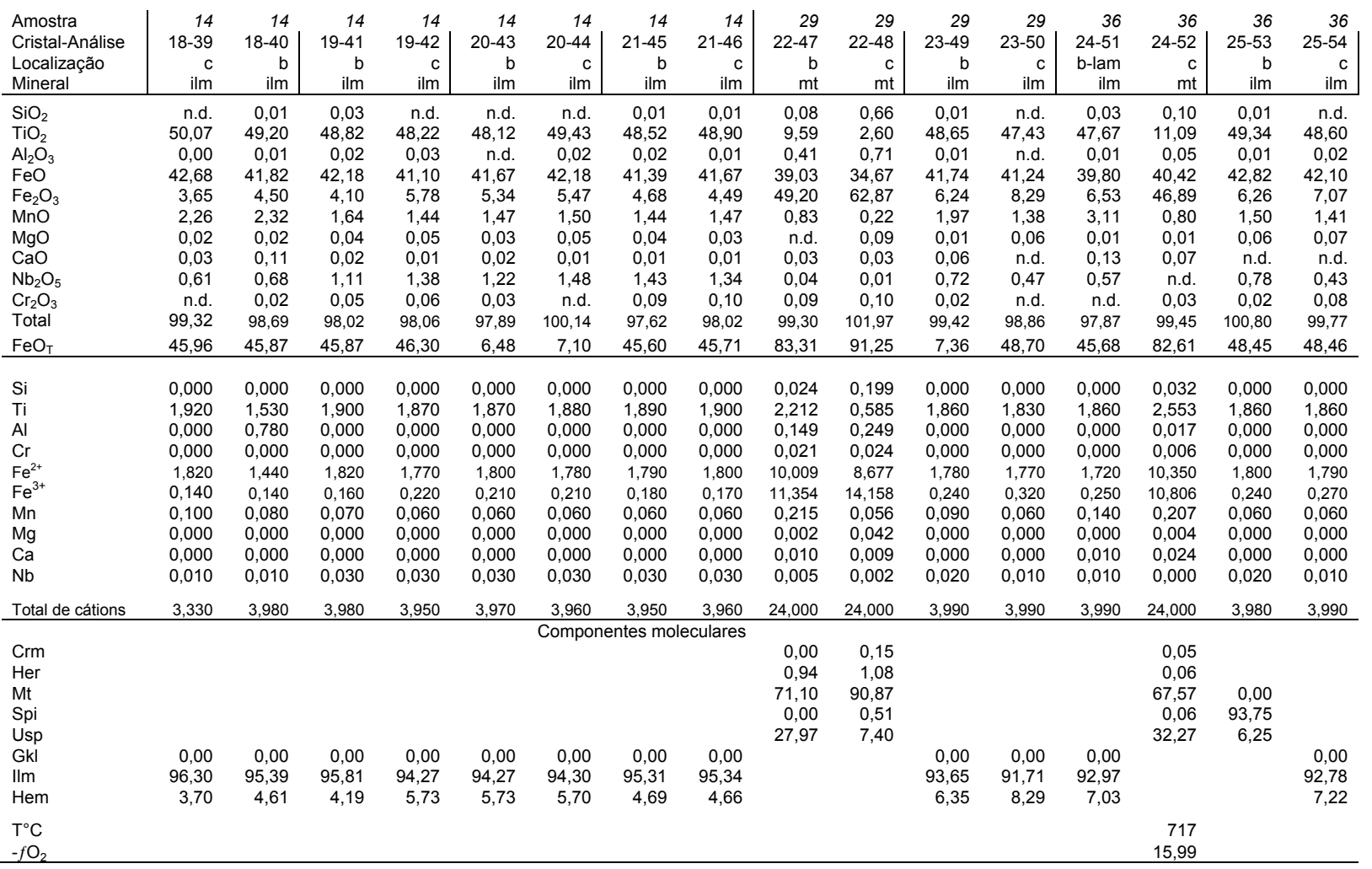


Tabela 20. Composição química de ilmenitas (ilm) e magnetitas (mt) dos quartzo-álcali feldspato sienitos do Morro de São João. Abreviações e classificação como na Tabela 19.

\begin{tabular}{|c|c|c|c|c|c|c|c|c|c|c|c|c|c|c|c|c|c|c|}
\hline $\begin{array}{l}\text { Amostra } \\
\text { Cristal-Análise } \\
\text { Localização } \\
\text { Mineral }\end{array}$ & $\begin{array}{r}1 A \\
1-01 \\
b \\
\text { ilm } \\
\end{array}$ & $\begin{array}{r}1 A \\
1-02 \\
\mathrm{C} \\
\mathrm{ilm} \\
\end{array}$ & $\begin{array}{r}1 A \\
2-03 \\
b \\
\text { blm }\end{array}$ & $\begin{array}{r}1 A \\
2-04 \\
\mathrm{C} \\
\mathrm{ilm} \\
\end{array}$ & $\begin{array}{r}1 A \\
3-05 \\
\text { b } \\
\text { ilm }\end{array}$ & $\begin{array}{r}1 A \\
3-06 \\
\mathrm{C} \\
\mathrm{ilm} \\
\end{array}$ & $\begin{array}{r}1 A \\
4-07 \\
b \\
i l m\end{array}$ & $\begin{array}{r}1 A \\
4-08 \\
\mathrm{C} \\
\mathrm{ilm} \\
\end{array}$ & $\begin{array}{r}1 A \\
5-09 \\
b \\
\text { ilm }\end{array}$ & $\begin{array}{r}1 A \\
5-10 \\
\mathrm{C} \\
\mathrm{ilm} \\
\end{array}$ & $\begin{array}{r}15 A \\
6-11 \\
b \\
\mathrm{mt} \\
\end{array}$ & $\begin{array}{r}15 A \\
6-12 \\
\mathrm{c} \\
\mathrm{mt} \\
\end{array}$ & $\begin{array}{r}15 A \\
7-13 \\
b \\
\mathrm{mt} \\
\end{array}$ & $\begin{array}{r}15 A \\
7-14 \\
\mathrm{c} \\
\mathrm{mt} \\
\end{array}$ & $\begin{array}{r}15 A \\
8-15 \\
b \\
\mathrm{mt} \\
\end{array}$ & $\begin{array}{r}15 A \\
8-16 \\
\mathrm{i} \\
\mathrm{mt} \\
\end{array}$ & $\begin{array}{r}15 A \\
8-17 \\
\mathrm{c} \\
\mathrm{mt} \\
\end{array}$ & $\begin{array}{r}15 A \\
9-18 \\
\text { b-lam } \\
\text { ilm } \\
\end{array}$ \\
\hline $\mathrm{SiO}_{2}$ & n.d. & n.d. & 0,03 & 0,04 & $\begin{array}{r}0,01 \\
\end{array}$ & 0,03 & n.d. & n.d. & $\begin{array}{r}0,02 \\
\end{array}$ & n.d. & 0,05 & 0,08 & 0,09 & 0,15 & 0,05 & 0,07 & 0,07 & 0,03 \\
\hline $\mathrm{TiO}_{2}$ & 48,27 & 48,42 & 49,54 & 48,90 & 48,92 & 49,89 & 49,17 & 49,23 & 47,88 & 49,15 & 5,43 & 4,11 & 8,75 & 8,04 & 7,89 & 2,55 & 1,96 & 48,42 \\
\hline $\mathrm{Al}_{2} \mathrm{O}_{3}$ & 0,05 & n.d. & 0,02 & 0,02 & 0,01 & 0,02 & n.d. & 0,01 & 0,01 & 0,01 & 0,09 & 0,11 & 0,03 & 0,20 & 0,07 & 0,34 & 0,17 & 0,08 \\
\hline $\mathrm{FeO}$ & 40,52 & 40,60 & 42,46 & 41,89 & 41,82 & 42,68 & 42,03 & 42,10 & 40,02 & 41,31 & 34,97 & 33,95 & 38,46 & 38,10 & 37,69 & 33,56 & 33,13 & 40,74 \\
\hline $\mathrm{Fe}_{2} \mathrm{O}_{3}$ & 7,12 & 6,76 & 4,62 & 5,26 & 6,08 & 3,92 & 5,33 & 5,89 & 6,72 & 5,32 & 58,64 & 60,87 & 52,17 & 53,50 & 53,58 & 63,88 & 65,52 & 7,28 \\
\hline $\mathrm{MnO}$ & 2,10 & 2,14 & 2,03 & 2,11 & 2,06 & 2,05 & 2,09 & 2,07 & 2,20 & 2,13 & 1,22 & 1,10 & 0,96 & 0,92 & 0,72 & 0,17 & 0,16 & 2,75 \\
\hline $\mathrm{MgO}$ & 0,02 & 0,05 & n.d. & n.d. & 0,02 & 0,05 & 0,04 & 0,05 & 0,03 & 0,02 & 0,02 & n.d. & n.d. & n.d. & 0,02 & n.d. & n.d. & n.d. \\
\hline $\mathrm{CaO}$ & 0,18 & 0,02 & 0,04 & 0,02 & 0,14 & n.d. & 0,08 & 0,01 & 0,01 & 0,01 & 0,10 & 0,01 & 0,03 & 0,01 & n.d. & n.d. & 0,01 & n.d. \\
\hline $\mathrm{Nb}_{2} \mathrm{O}_{5}$ & 1,36 & 1,38 & 0,55 & 0,48 & 0,51 & 0,23 & 0,50 & 0,52 & 1,90 & 1,35 & 0,11 & n.d. & 0,07 & 0,04 & n.d. & n.d. & 0,01 & 0,12 \\
\hline $\mathrm{Cr}_{2} \mathrm{O}_{3}$ & 0,02 & 0,02 & n.d. & 0,02 & 0,02 & 0,01 & 0,03 & 0,01 & 0,01 & 0,02 & 0,01 & 0,08 & n.d. & n.d. & n.d. & 0,02 & 0,01 & n.d. \\
\hline Total & 99,63 & 99,39 & 99,28 & 98,74 & 99,58 & 98,87 & 99,27 & 99,88 & 98,80 & 99,32 & 100,66 & 100,32 & 100,57 & 100,95 & 100,01 & 100,59 & 101,03 & 99,42 \\
\hline $\mathrm{FeO}_{\mathrm{T}}$ & 6,93 & 46,68 & 46,62 & 46,62 & 47,29 & 6,21 & 46,83 & 47,40 & 46,07 & 46,10 & 87,74 & 88,73 & 85,41 & 86,24 & 85,90 & 91,05 & 92,09 & 47,29 \\
\hline $\mathrm{Si}$ & 0,000 & 0,000 & 0,000 & 0,000 & 0,000 & 0,000 & 0,000 & 0,000 & 0,000 & 0,000 & 0,016 & 0,024 & 0,027 & 0,044 & 0,014 & 0,022 & 0,020 & 0,000 \\
\hline $\mathrm{Ti}$ & 1,840 & 1,850 & 1,900 & 1,890 & 1,870 & 1,920 & 1,890 & 1,880 & 1,840 & 1,880 & 1,243 & 0,944 & 2,000 & 1,830 & 1,813 & 0,584 & 0,449 & 1,860 \\
\hline Al & 0,000 & 0,000 & 0,000 & 0,000 & 0,000 & 0,000 & 0,000 & 0,000 & 0,000 & 0,000 & 0,032 & 0,039 & 0,011 & 0,072 & 0,026 & 0,121 & 0,060 & 0,000 \\
\hline $\mathrm{Cr}$ & 0,000 & 0,000 & 0,000 & 0,000 & 0,000 & 0,000 & 0,000 & 0,000 & 0,000 & 0,000 & 0,003 & 0,020 & 0,000 & 0,000 & 0,000 & 0,005 & 0,003 & 0,000 \\
\hline $\mathrm{Fe}^{2+}$ & 1,720 & 1,730 & 1,810 & 1,800 & 1,780 & 1,830 & 1,790 & 1,780 & 1,710 & 1,760 & 8,901 & 8,680 & 9,771 & 9,636 & 9,631 & 8,562 & 8,426 & 1,740 \\
\hline $\mathrm{Fe}^{3+}$ & 0,270 & 0,260 & 0,180 & 0,200 & 0,230 & 0,150 & 0,200 & 0,220 & 0,260 & 0,200 & 13,432 & 14,003 & 11,924 & 12,176 & 12,321 & 14,663 & 14,998 & 0,280 \\
\hline $\mathrm{Mn}$ & 0,090 & 0,090 & 0,090 & 0,090 & 0,090 & 0,090 & 0,090 & 0,090 & 0,100 & 0,090 & 0,315 & 0,285 & 0,247 & 0,236 & 0,186 & 0,044 & 0,041 & 0,120 \\
\hline $\mathrm{Mg}$ & 0,000 & 0,000 & 0,000 & 0,000 & 0,000 & 0,000 & 0,000 & 0,000 & 0,000 & 0,000 & 0,010 & 0,000 & 0,000 & 0,000 & 0,010 & 0,000 & 0,000 & 0,000 \\
\hline $\mathrm{Ca}$ & 0,010 & 0,000 & 0,000 & 0,000 & 0,010 & 0,000 & 0,000 & 0,000 & 0,000 & 0,000 & 0,033 & 0,004 & 0,009 & 0,002 & 0,000 & 0,000 & 0,002 & 0,000 \\
\hline $\mathrm{Nb}$ & 0,030 & 0,030 & 0,010 & 0,010 & 0,010 & 0,010 & 0,010 & 0,010 & 0,040 & 0,030 & 0,015 & 0,000 & 0,010 & 0,005 & 0,000 & 0,000 & 0,001 & 0,000 \\
\hline Total de cátions & 3,960 & 3,960 & 3,990 & 3,990 & 3,990 & 4,000 & 3,980 & 3,980 & 3,950 & 3,960 & 24,000 & 24,000 & 24,000 & 24,000 & 24,000 & 24,000 & 24,000 & 4,000 \\
\hline \multicolumn{19}{|c|}{ Componentes moleculares } \\
\hline Crm & & & & & & & & & & & 0,02 & 0,12 & 0,00 & 0,00 & 0,00 & 0,03 & 0,02 & \\
\hline Her & & & & & & & & & & & 0,09 & 0,25 & 0,07 & 0,39 & 0,16 & 0,77 & 0,38 & \\
\hline Mt & & & & & & & & & & & 83,99 & 87,66 & 74,64 & 76,42 & 76,98 & 91,87 & 93,98 & \\
\hline Spi & & & & & & & & & & & 0,12 & 0,00 & 0,00 & 0,06 & 0,00 & 0,00 & 0,00 & \\
\hline Usp & & & & & & & & & & & 15,79 & 11,97 & 25,30 & 23,13 & 22,86 & 7,33 & 5,62 & \\
\hline Gkl & 0,00 & 0,00 & 0,00 & 0,00 & 0,00 & 0,00 & 0,00 & 0,00 & 0,00 & 0,00 & & & & & & & & 0,00 \\
\hline $\mathrm{Ilm}$ & 92,59 & 93,12 & 95,26 & 94,74 & 93,68 & 95,81 & 94,74 & 94,21 & 93,05 & 94,71 & & & & & & & & 92,55 \\
\hline Hem & 7,41 & 6,88 & 4,74 & 5,26 & 6,32 & 4,19 & 5,26 & 5,79 & 6,95 & 5,29 & & & & & & & & 7,45 \\
\hline
\end{tabular}

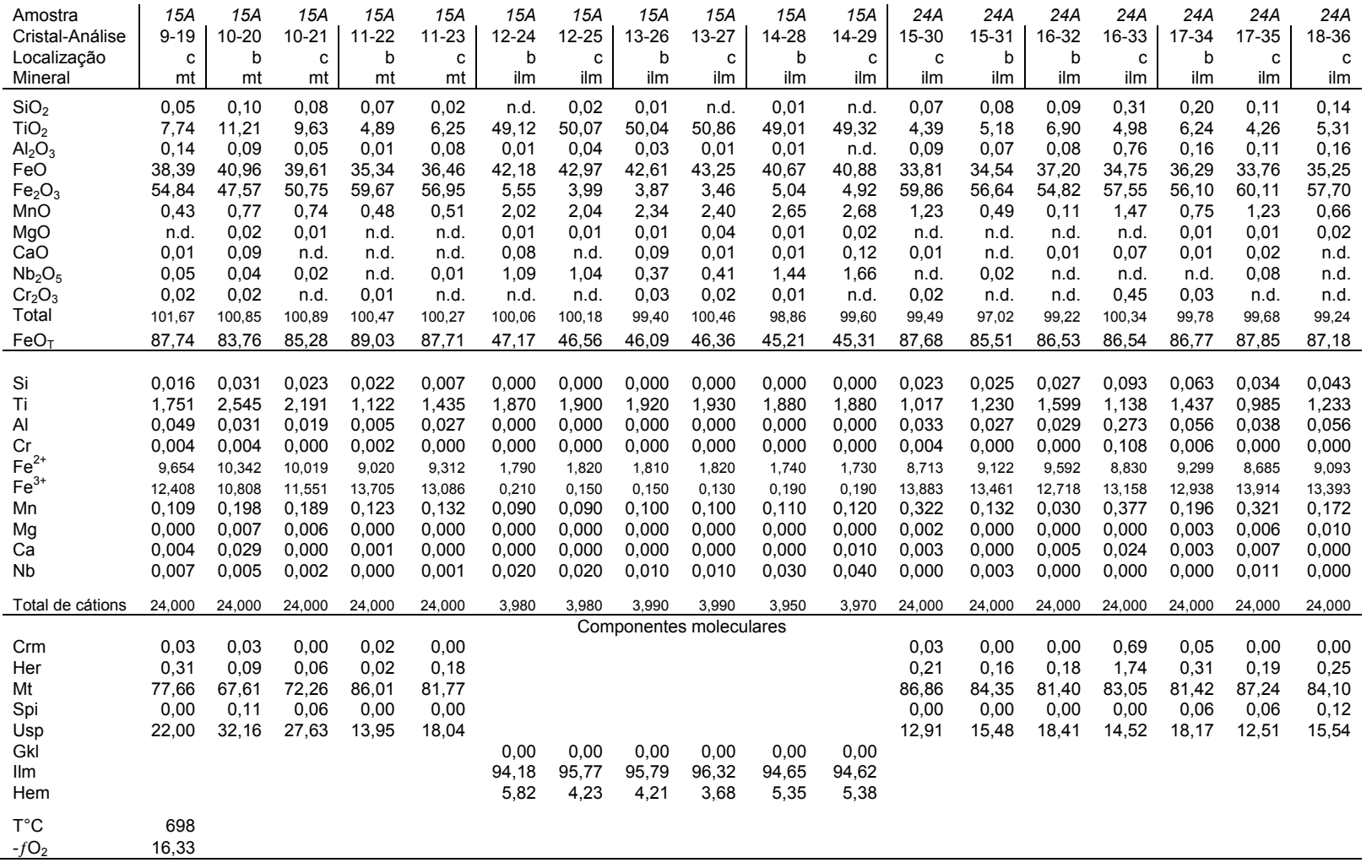


Tabela 21. Composição química de ilmenitas (ilm) e magnetitas (mt) dos quartzo-álcali feldspato sienitos do Morrete. Abreviações e classificação como na Tabela 19.

\begin{tabular}{|c|c|c|c|c|c|c|c|c|c|c|c|c|c|c|c|c|c|c|}
\hline $\begin{array}{l}\text { Amostra } \\
\text { Cristal-Análise } \\
\text { Localização } \\
\text { Mineral }\end{array}$ & $\begin{array}{r}50 \\
1-01 \\
\mathrm{~b} \\
\mathrm{ilm}\end{array}$ & $\begin{array}{r}50 \\
1-02 \\
\mathrm{c} \\
\mathrm{ilm}\end{array}$ & $\begin{array}{r}50 \\
2-03 \\
b \\
\text { blm }\end{array}$ & $\begin{array}{r}50 \\
2-04 \\
\mathrm{c} \\
\mathrm{ilm}\end{array}$ & $\begin{array}{r}50 \\
3-05 \\
b \\
\text { ilm }\end{array}$ & $\begin{array}{r}50 \\
3-06 \\
\mathrm{c} \\
\mathrm{ilm}\end{array}$ & $\begin{array}{r}50 \\
4-07 \\
\text { b-lam } \\
\text { ilm }\end{array}$ & $\begin{array}{r}50 \\
4-08 \\
i \\
\mathrm{ilm}\end{array}$ & $\begin{array}{r}50 \\
4-09 \\
\mathrm{c} \\
\mathrm{mt}\end{array}$ & $\begin{array}{r}50 \\
5-10 \\
b \\
\mathrm{mt}\end{array}$ & $\begin{array}{r}50 \\
5-11 \\
\mathrm{c} \\
\mathrm{mt}\end{array}$ & $\begin{array}{r}50 \\
6-12 \\
b \\
\mathrm{ilm}\end{array}$ & $\begin{array}{r}50 \\
6-13 \\
\mathrm{c} \\
\mathrm{mt}\end{array}$ & $\begin{array}{r}50 \\
7-14 \\
\mathrm{~b} \\
\mathrm{mt}\end{array}$ & $\begin{array}{r}50 \\
7-15 \\
\mathrm{i} \\
\mathrm{mt}\end{array}$ & $\begin{array}{r}50 \\
7-16 \\
\mathrm{c} \\
\mathrm{mt}\end{array}$ & $\begin{array}{r}50 \\
8-17 \\
\text { b-lam } \\
\text { ilm }\end{array}$ & $\begin{array}{r}50 \\
8-18 \\
\mathrm{c} \\
\mathrm{mt}\end{array}$ \\
\hline $\mathrm{SiO}_{2}$ & 0,02 & 0,05 & n.d. & 0,04 & n.d. & n.d. & n.d. & 0,14 & 0,11 & 0,10 & 0,11 & 0,16 & 0,23 & 0,11 & 0,14 & 0,08 & 0,02 & 0,10 \\
\hline $\mathrm{TiO}_{2}$ & 50,28 & 50,41 & 50,37 & 51,00 & 50,76 & 48,23 & 47,55 & 49,87 & 7,32 & 5,72 & 5,86 & 49,56 & 5,44 & 6,83 & 6,47 & 3,05 & 48,18 & 5,28 \\
\hline $\mathrm{Al}_{2} \mathrm{O}_{3}$ & n.d. & 0,06 & n.d. & 0,02 & 0,01 & 0,01 & 0,05 & 0,05 & 0,11 & 0,17 & 0,13 & 0,07 & 0,14 & 0,11 & 0,13 & 0,10 & 0,04 & 0,10 \\
\hline $\mathrm{FeO}$ & 42,68 & 42,82 & 42,61 & 42,82 & 43,25 & 39,80 & 39,01 & 42,10 & 37,48 & 36,16 & 36,50 & 42,32 & 35,77 & 36,89 & 36,71 & 33,90 & 39,45 & 35,64 \\
\hline $\mathrm{Fe}_{2} \mathrm{O}_{3}$ & 2,11 & 0,79 & 1,71 & n.d. & 2,56 & 4,82 & 5,02 & 3,25 & 54,49 & 57,44 & 57,51 & 3,47 & 56,97 & 54,81 & 55,47 & 63,21 & 4,29 & 58,11 \\
\hline $\mathrm{MnO}$ & 2,51 & 2,54 & 2,61 & 2,95 & 2,30 & 2,83 & 2,95 & 2,80 & 0,54 & 0,32 & 0,27 & 2,31 & 0,30 & 0,38 & 0,31 & 0,27 & 3,83 & 0,31 \\
\hline $\mathrm{MgO}$ & 0,01 & 0,01 & 0,01 & 0,02 & n.d. & 0,01 & n.d. & 0,02 & 0,01 & n.d. & n.d. & 0,02 & 0,01 & 0,02 & n.d. & n.d. & 0,01 & n.d. \\
\hline $\mathrm{CaO}$ & 0,06 & n.d. & 0,16 & 0,21 & 0,01 & 0,02 & 0,06 & 0,09 & n.d. & 0,01 & n.d. & n.d. & 0,01 & n.d. & n.d. & 0,02 & 0,01 & 0,01 \\
\hline $\mathrm{Nb}_{2} \mathrm{O}_{5}$ & 0,33 & 0,72 & 0,58 & 0,34 & 0,38 & 3,46 & 3,48 & 1,27 & n.d. & n.d. & n.d. & 0,26 & 0,04 & n.d. & n.d. & 0,03 & 0,64 & n.d. \\
\hline $\mathrm{Cr}_{2} \mathrm{O}_{3}$ & n.d. & n.d. & n.d. & n.d. & 0,02 & 0,03 & 0,02 & 0,04 & n.d. & n.d. & 0,02 & 0,04 & 0,03 & 0,05 & 0,01 & n.d. & 0,02 & 0,03 \\
\hline Total & 98,00 & 97,40 & 98,05 & 97,41 & 99,29 & 99,22 & 98,13 & 99,63 & 100,07 & 99,92 & 100,40 & 98,21 & 98,93 & 99,19 & 99,24 & 100,67 & 96,47 & 99,58 \\
\hline $\mathrm{FeO}_{\mathrm{T}}$ & 44,58 & 43,53 & 44,15 & 42,82 & 45,55 & 44,14 & 43,53 & 45,02 & 86,51 & 87,85 & 88,25 & 45,44 & 87,03 & 86,21 & 86,62 & 90,78 & 43,31 & 87,93 \\
\hline $\mathrm{Si}$ & 0,000 & 0,000 & 0,000 & 0,000 & 0,000 & 0,000 & 0,000 & 0,010 & 0,035 & 0,030 & 0,033 & 0,010 & 0,071 & 0,033 & 0,044 & 0,024 & 0,000 & 0,030 \\
\hline $\mathrm{Ti}$ & 1,950 & 1,970 & 1,950 & 1,990 & 1,940 & 1,850 & 1,840 & 1,900 & 1,683 & 1,319 & 1,345 & 1,920 & 1,266 & 1,585 & 1,500 & 0,701 & 1,900 & 1,222 \\
\hline Al & 0,000 & 0,000 & 0,000 & 0,000 & 0,000 & 0,000 & 0,000 & 0,000 & 0,040 & 0,061 & 0,046 & 0,000 & 0,050 & 0,039 & 0,046 & 0,036 & 0,000 & 0,036 \\
\hline $\mathrm{Cr}$ & 0,000 & 0,000 & 0,000 & 0,000 & 0,000 & 0,000 & 0,000 & 0,000 & 0,000 & 0,000 & 0,004 & 0,000 & 0,007 & 0,011 & 0,001 & 0,000 & 0,000 & 0,007 \\
\hline $\mathrm{Fe}^{2+}$ & 1,840 & 1,860 & 1,840 & 1,860 & 1,840 & 1,700 & 1,680 & 1,790 & 9,573 & 9,262 & 9,308 & 1,820 & 9,253 & 9,512 & 9,461 & 8,648 & 1,730 & 9,169 \\
\hline $\mathrm{Fe}^{3+}$ & 0,080 & 0,030 & 0,070 & 0,000 & 0,100 & 0,180 & 0,190 & 0,120 & 12,526 & 13,242 & 13,194 & 0,130 & 13,263 & 12,715 & 12,864 & 14,510 & 0,170 & 13,452 \\
\hline $\mathrm{Mn}$ & 0,110 & 0,110 & 0,110 & 0,130 & 0,100 & 0,120 & 0,130 & 0,120 & 0,139 & 0,082 & 0,070 & 0,100 & 0,078 & 0,098 & 0,082 & 0,070 & 0,170 & 0,080 \\
\hline $\mathrm{Mg}$ & 0,000 & 0,000 & 0,000 & 0,000 & 0,000 & 0,000 & 0,000 & 0,000 & 0,005 & 0,000 & 0,000 & 0,000 & 0,003 & 0,007 & 0,000 & 0,000 & 0,000 & 0,000 \\
\hline $\mathrm{Ca}$ & 000 & 0,000 & 0,010 & 0,010 & 0,000 & 0,000 & 0,000 & 0,000 & 0,000 & 0,004 & 0,000 & 0,000 & 0,003 & 0,001 & 0,001 & 0,006 & 0,000 & 0,003 \\
\hline $\mathrm{Nb}$ & 0,010 & 0,020 & 0,010 & 0,010 & 0,010 & 0,080 & 0,080 & 0,030 & 0,000 & 0,000 & 0,000 & 0,010 & 0,006 & 0,000 & 0,000 & 0,004 & 0,020 & 0,000 \\
\hline Total de cátions & 3,990 & 3,990 & 3,990 & 4,000 & 3,990 & 3,930 & 3,920 & 3,970 & 24,000 & 24,000 & 24,000 & 3,990 & 24,000 & 24,000 & 24,000 & 24,000 & 3,990 & 24,000 \\
\hline \multicolumn{19}{|c|}{ Componentes moleculares } \\
\hline Crm & & & & & & & & & 0,00 & 0,00 & 0,30 & & 0,05 & 0,08 & 0,02 & 0,00 & & 0,05 \\
\hline Her & & & & & & & & & 1,92 & 3,86 & 2,93 & & 0,26 & 0,14 & 0,30 & 0,23 & & 0,23 \\
\hline Mt & & & & & & & & & 78,58 & 83,06 & 82,81 & & 83,71 & 79,77 & 80,85 & 90,99 & & 84,39 \\
\hline Spi & & & & & & & & & 0,57 & 0,00 & 0,00 & & 0,06 & 0,12 & 0,00 & 0,00 & & 0,00 \\
\hline Usp & & & & & & & & & 21,17 & 16,55 & 16,87 & & 15,92 & 19,90 & 18,84 & 8,78 & & 15,34 \\
\hline Gkl & 0,00 & 0,00 & 0,00 & 0,00 & 0,00 & 0,00 & 0,00 & 0,00 & & & & 0,00 & & & & & 0,00 & \\
\hline IIm & 97,87 & 98,94 & 97,87 & 100,00 & 97,35 & 95,05 & 94,48 & 96,74 & & & & 96,30 & & & & & 95,05 & \\
\hline Hem & 2,13 & 1,06 & 2,13 & 0,00 & 2,65 & 4,95 & 5,52 & 3,28 & & & & 3,70 & & & & & 4,95 & \\
\hline $\mathrm{T}^{\circ} \mathrm{C}$ & & & & & & & & & 657 & & & & 596 & & & & & 629 \\
\hline$-f \mathrm{O}_{2}$ & & & & & & & & & 18,25 & & & & 21,10 & & & & & 19,22 \\
\hline
\end{tabular}

\begin{tabular}{|c|c|c|c|c|c|c|c|c|c|c|c|c|c|c|c|c|c|c|}
\hline $\begin{array}{l}\text { Amostra } \\
\text { Cristal-Análise } \\
\text { Localização } \\
\text { Mineral }\end{array}$ & $\begin{array}{r}50 \\
9-19 \\
\mathrm{~b} \\
\mathrm{mt} \\
\end{array}$ & $\begin{array}{r}50 \\
9-20 \\
\mathrm{c} \\
\mathrm{mt} \\
\end{array}$ & $\begin{array}{r}50 \\
10-21 \\
b \\
\mathrm{mt} \\
\end{array}$ & $\begin{array}{r}50 \\
10-22 \\
\mathrm{c} \\
\mathrm{mt} \\
\end{array}$ & $\begin{array}{r}50 \\
11-23 \\
\mathrm{~b} \\
\mathrm{mt} \\
\end{array}$ & $\begin{array}{r}50 \\
11-24 \\
\mathrm{c} \\
\mathrm{mt} \\
\end{array}$ & $\begin{array}{r}53 \\
12-25 \\
b \\
m t \\
\end{array}$ & $\begin{array}{r}53 \\
12-26 \\
\mathrm{c} \\
\mathrm{mt} \\
\end{array}$ & $\begin{array}{r}53 \\
13-27 \\
\text { b-lam } \\
\text { ilm } \\
\end{array}$ & $\begin{array}{r}53 \\
13-28 \\
\mathrm{c} \\
\mathrm{mt} \\
\end{array}$ & $\begin{array}{r}53 \\
14-29 \\
\text { b-lam } \\
\text { ilm } \\
\end{array}$ & $\begin{array}{r}53 \\
14-30 \\
\mathrm{c} \\
\mathrm{ilm} \\
\end{array}$ & $\begin{array}{r}53 \\
15-31 \\
b \\
\text { ilm } \\
\end{array}$ & $\begin{array}{r}53 \\
15-32 \\
\mathrm{c} \\
\mathrm{ilm} \\
\end{array}$ & $\begin{array}{r}40 \\
16-33 \\
\mathrm{~b} \\
\mathrm{ilm} \\
\end{array}$ & $\begin{array}{r}40 \\
16-34 \\
c \\
\text { ilm } \\
\end{array}$ & $\begin{array}{r}40 \\
17-35 \\
\mathrm{~b} \\
\mathrm{ilm} \\
\end{array}$ & $\begin{array}{r}40 \\
17-36 \\
\mathrm{c} \\
\mathrm{ilm} \\
\end{array}$ \\
\hline $\mathrm{SiO}_{2}$ & 0,10 & 0,16 & 0,12 & 0,10 & 0,13 & 0,08 & 0,11 & 0,11 & 0,32 & 0,08 & 0,03 & 0,01 & 0,04 & n.d. & 0,04 & n.d. & 0,04 & n.d. \\
\hline $\mathrm{TiO}_{2}$ & 10,84 & 7,77 & 2,44 & 2,33 & 6,39 & 3,27 & 7,49 & 6,99 & 46,70 & 6,31 & 49,54 & 46,87 & 47,24 & 48,00 & 48,54 & 48,40 & 48,54 & 48,00 \\
\hline $\mathrm{Al}_{2} \mathrm{O}_{3}$ & 0,10 & 0,16 & 0,13 & 0,23 & 0,07 & 0,09 & 0,09 & 0,31 & 0,01 & 0,09 & 0,04 & n.d. & n.d. & 0,01 & 0,01 & 0,01 & 0,01 & 0,01 \\
\hline $\mathrm{FeO}$ & 39,90 & 37,63 & 33,29 & 33,40 & 36,37 & 34,00 & 37,15 & 37,42 & 39,52 & 36,21 & 41,96 & 37,72 & 38,01 & 39,09 & 39,73 & 40,02 & 39,73 & 39,09 \\
\hline $\mathrm{Fe}_{2} \mathrm{O}_{3}$ & 46,69 & 52,63 & 63,65 & 64,06 & 55,68 & 62,25 & 53,54 & 54,97 & 3,37 & 56,29 & 0,34 & 4,98 & 3,88 & 4,30 & 2,58 & 5,12 & 2,58 & 4,30 \\
\hline $\mathrm{MnO}$ & 0,69 & 0,52 & 0,10 & 0,01 & 0,50 & 0,18 & 0,56 & 0,44 & 2,05 & 0,72 & 2,61 & 3,70 & 3,74 & 3,34 & 3,24 & 2,74 & 3,24 & 3,34 \\
\hline $\mathrm{MgO}$ & 0,02 & n.d. & n.d. & n.d. & 0,01 & n.d. & n.d. & n.d. & 0,01 & 0,01 & 0,01 & n.d. & 0,01 & n.d. & n.d. & n.d. & n.d. & n.d. \\
\hline $\mathrm{CaO}$ & 0,19 & n.d. & 0,02 & 0,01 & 0,01 & n.d. & 0,17 & 0,03 & 0,02 & 0,01 & 0,02 & 0,02 & n.d. & 0,02 & 0,15 & 0,03 & 0,15 & 0,02 \\
\hline $\mathrm{Nb}_{2} \mathrm{O}_{5}$ & 0,01 & 0,04 & 0,03 & 0,04 & n.d. & 0,06 & 0,02 & n.d. & 2,40 & 0,02 & 0,87 & 2,39 & 2,15 & 1,65 & 1,59 & 1,55 & 1,59 & 1,65 \\
\hline $\mathrm{Cr}_{2} \mathrm{O}_{3}$ & 0,01 & n.d. & 0,02 & n.d. & n.d. & 0,02 & n.d. & n.d. & n.d. & 0,06 & n.d. & 0,01 & n.d. & 0,04 & n.d. & n.d. & n.d. & 0,04 \\
\hline Total & 98,54 & 98,91 & 99,80 & 100,17 & 99,17 & 99,95 & 99,13 & 100,26 & 94,39 & 99,79 & 95,41 & 95,70 & 95,07 & 96,44 & 95,89 & 97,87 & 95,89 & 96,44 \\
\hline $\mathrm{FeO}_{\mathrm{T}}$ & 81,91 & 84,99 & 90,57 & 91,05 & 86,48 & 90,02 & 85,33 & 86,89 & 42,55 & 86,87 & 42,27 & 42,20 & 41,50 & 42,96 & 42,05 & 44,63 & 42,05 & 42,96 \\
\hline $\mathrm{Si}$ & 0,029 & 0,048 & 0,036 & 0,032 & 0,040 & 0,025 & 0,034 & 0,034 & 0,020 & 0,025 & 0,000 & 0,000 & 0,000 & 0,000 & 0,000 & 0,000 & 0,000 & 0,000 \\
\hline $\mathrm{Ti}$ & 2,520 & 1,804 & 0,565 & 0,536 & 1,483 & 0,756 & 1,737 & 1,602 & 1,880 & 1,455 & 1,970 & 1,860 & 1,890 & 1,890 & 1,920 & 1,880 & 1,920 & 1,890 \\
\hline $\mathrm{Al}$ & 0,036 & 0,060 & 0,045 & 0,082 & 0,026 & 0,031 & 0,034 & 0,110 & 0,000 & 0,031 & 0,000 & 0,000 & 0,000 & 0,000 & 0,000 & 0,000 & 0,000 & 0,000 \\
\hline $\mathrm{Cr}$ & 0,002 & 0,000 & 0,006 & 0,000 & 0,001 & 0,006 & 0,000 & 0,000 & 0,000 & 0,014 & 0,000 & 0,000 & 0,000 & 0,000 & 0,000 & 0,000 & 0,000 & 0,000 \\
\hline $\mathrm{Fe}^{2+}$ & 10,307 & 9,716 & 8,569 & 8,564 & 9,384 & 8,734 & 9,575 & 9,532 & 1,770 & 9,288 & 1,860 & 1,670 & 1,690 & 1,710 & 1,750 & 1,730 & 1,750 & 1,710 \\
\hline $\mathrm{Fe}^{3+}$ & 10,853 & 12,230 & 14,743 & 14,777 & 12,925 & 14,392 & 12,416 & 12,601 & 0,140 & 12,992 & 0,010 & 0,200 & 0,150 & 0,170 & 0,100 & 0,200 & 0,100 & 0,170 \\
\hline $\mathrm{Mn}$ & 0,181 & 0,136 & 0,027 & 0,002 & 0,132 & 0,048 & 0,147 & 0,113 & 0,090 & 0,187 & 0,120 & 0,170 & 0,170 & 0,150 & 0,140 & 0,120 & 0,140 & 0,150 \\
\hline $\mathrm{Mg}$ & 0,009 & 0,000 & 0,000 & 0,000 & 0,006 & 0,000 & 0,000 & 0,000 & 0,000 & 0,003 & 0,000 & 0,000 & 0,000 & 0,000 & 0,000 & 0,000 & 0,000 & 0,000 \\
\hline $\mathrm{Ca}$ & 0,063 & 0,000 & 0,005 & 0,002 & 0,002 & 0,000 & 0,055 & 0,009 & 0,000 & 0,002 & 0,000 & 0,000 & 0,000 & 0,000 & 0,010 & 0,000 & 0,010 & 0,000 \\
\hline $\mathrm{Nb}$ & 0,001 & 0,006 & 0,004 & 0,006 & 0,000 & 0,008 & 0,002 & 0,000 & 0,060 & 0,002 & 0,020 & 0,060 & 0,050 & 0,040 & 0,040 & 0,040 & 0,040 & 0,040 \\
\hline Total de cátions & 24,000 & 24,000 & 24,000 & 24,000 & 24,000 & 24,000 & 24,000 & 24,000 & 3,960 & 24,000 & 3,980 & 3,960 & 3,950 & 3,960 & 3,960 & 3,970 & 3,960 & 3,960 \\
\hline \multicolumn{19}{|c|}{ Componentes moleculares } \\
\hline Crm & 0,02 & 0,00 & 0,03 & 0,00 & 0,00 & 0,03 & 0,00 & 0,00 & & 0,92 & & & & & & & & \\
\hline Her & 0,11 & 0,37 & 0,30 & 0,52 & 0,17 & 0,20 & 0,21 & 0,70 & & 0,15 & & & & & & & & \\
\hline Mt & 67,92 & 76,90 & 92,59 & 92,75 & 80,54 & 90,29 & 77,88 & 79,16 & & 81,35 & & & & & & & & \\
\hline Spi & 0,12 & 0,00 & 0,00 & 0,00 & 0,00 & 0,00 & 0,00 & 0,00 & & 0,06 & & & & & & & & \\
\hline Usp & 31,84 & 22,73 & 7,08 & 6,73 & 19,29 & 9,48 & 21,92 & 20,14 & & 18,36 & & & & & & & & \\
\hline $\mathrm{Gkl}$ & & & & & & & & & 0,00 & & 0,00 & 0,00 & 0,00 & 0,00 & 0,00 & 0,00 & 0,00 & 0,00 \\
\hline IIm & & & & & & & & & 96,24 & & 99,46 & 94,41 & 95,56 & 95,08 & 97,27 & 94,62 & 97,27 & 95,08 \\
\hline Hem & & & & & & & & & 3,76 & & 0,54 & 5,59 & 4,44 & 4,92 & 2,73 & 5,38 & 2,73 & 4,92 \\
\hline $\begin{array}{l}\mathrm{T}^{\circ} \mathrm{C} \\
-f \mathrm{O}_{2}\end{array}$ & & & & & & & & & & $\begin{array}{r}602 \\
20,91\end{array}$ & & & & & & & & \\
\hline
\end{tabular}


Tabela 22. Composição química de ilmenitas (ilm) e magnetitas (mt) dos microssienitos com textura em mosaico do Morro de São João. Abreviações e classificação como na Tabela 19.

\begin{tabular}{|c|c|c|c|c|c|c|c|c|c|}
\hline $\begin{array}{l}\text { Amostra } \\
\text { Cristal-Análise } \\
\text { Localização } \\
\text { Mineral }\end{array}$ & $\begin{array}{r}37 \\
1-01 \\
b \\
i l m \\
\end{array}$ & $\begin{array}{r}37 \\
1-02 \\
\mathrm{c} \\
\mathrm{ilm} \\
\end{array}$ & $\begin{array}{r}37 \\
2-03 \\
b \\
\text { ilm } \\
\end{array}$ & $\begin{array}{r}37 \\
2-04 \\
\mathrm{c} \\
\mathrm{ilm} \\
\end{array}$ & $\begin{array}{r}37 \\
3-05 \\
b \\
\text { ilm } \\
\end{array}$ & $\begin{array}{r}37 \\
3-06 \\
\mathrm{c} \\
\mathrm{ilm} \\
\end{array}$ & $\begin{array}{r}37 \\
4-07 \\
b \\
\text { ilm } \\
\end{array}$ & $\begin{array}{r}37 \\
4-08 \\
\mathrm{C} \\
\mathrm{ilm} \\
\end{array}$ & $\begin{array}{r}37 \\
5-09 \\
b \\
\text { ilm }\end{array}$ \\
\hline $\begin{array}{l}\mathrm{SiO}_{2} \\
\mathrm{TiO}_{2} \\
\mathrm{Al}_{2} \mathrm{O}_{3} \\
\mathrm{FeO} \\
\mathrm{Fe}_{2} \mathrm{O}_{3} \\
\mathrm{MnO} \\
\mathrm{MgO} \\
\mathrm{CaO} \\
\mathrm{Nb}_{2} \mathrm{O}_{5} \\
\mathrm{Cr}_{2} \mathrm{O}_{3} \\
\text { Total }\end{array}$ & $\begin{array}{r}\text { n.d. } \\
47,01 \\
0,01 \\
39,52 \\
7,87 \\
1,98 \\
\text { n.d. } \\
0,11 \\
3,18 \\
0,03 \\
99,72\end{array}$ & $\begin{array}{r}0,02 \\
45,91 \\
0,04 \\
38,51 \\
9,12 \\
1,96 \\
\text { n.d. } \\
0,26 \\
3,13 \\
\text { n.d. } \\
98,94\end{array}$ & $\begin{array}{r}\text { n.d. } \\
47,97 \\
\text { n.d. } \\
40,24 \\
6,72 \\
2,10 \\
0,02 \\
0,02 \\
3,39 \\
\text { n.d. } \\
100,45\end{array}$ & $\begin{array}{r}\text { n.d. } \\
46,83 \\
0,01 \\
39,30 \\
7,19 \\
2,06 \\
0,01 \\
0,06 \\
3,37 \\
0,01 \\
98,85\end{array}$ & $\begin{array}{r}\text { n.d. } \\
46,64 \\
0,02 \\
39,01 \\
8,10 \\
2,03 \\
0,03 \\
0,06 \\
3,31 \\
0,03 \\
99,25\end{array}$ & $\begin{array}{r}0,03 \\
4,76 \\
0,03 \\
39,37 \\
8,39 \\
1,97 \\
0,01 \\
0,15 \\
3,23 \\
\text { n.d. } \\
99,95\end{array}$ & $\begin{array}{r}\text { n.d. } \\
47,49 \\
0,02 \\
39,73 \\
7,50 \\
2,18 \\
0,01 \\
0,02 \\
3,24 \\
0,01 \\
100,20\end{array}$ & $\begin{array}{r}0,04 \\
46,38 \\
0,04 \\
38,87 \\
8,21 \\
2,15 \\
0,05 \\
0,01 \\
3,37 \\
0,04 \\
99,16\end{array}$ & $\begin{array}{r}0,03 \\
50,36 \\
\text { n.d. } \\
43,83 \\
4,02 \\
1,45 \\
0,05 \\
0,04 \\
0,36 \\
\text { n.d. } \\
100,15\end{array}$ \\
\hline $\mathrm{FeO}_{\mathrm{T}}$ & 46,60 & 46,72 & 46,29 & 45,77 & 46,30 & 46,92 & 46,48 & 46,26 & 47,45 \\
\hline $\begin{array}{l}\mathrm{Si} \\
\mathrm{Ti} \\
\mathrm{Al} \\
\mathrm{Cr} \\
\mathrm{Fe}^{2+} \\
\mathrm{Fe}^{3+} \\
\mathrm{Mn} \\
\mathrm{Mg} \\
\mathrm{Ca} \\
\mathrm{Nb}\end{array}$ & $\begin{array}{l}0,000 \\
1,800 \\
0,000 \\
0,000 \\
1,680 \\
0,300 \\
0,090 \\
0,000 \\
0,010 \\
0,070\end{array}$ & $\begin{array}{l}0,000 \\
1,770 \\
0,000 \\
0,000 \\
1,650 \\
0,350 \\
0,080 \\
0,000 \\
0,010 \\
0,070\end{array}$ & $\begin{array}{l}0,000 \\
1,820 \\
0,000 \\
0,000 \\
1,700 \\
0,250 \\
0,090 \\
0,000 \\
0,000 \\
0,080\end{array}$ & $\begin{array}{l}0,000 \\
1,800 \\
0,000 \\
0,000 \\
1,680 \\
0,280 \\
0,090 \\
0,000 \\
0,000 \\
0,080\end{array}$ & $\begin{array}{l}0,000 \\
1,790 \\
0,000 \\
0,000 \\
1,660 \\
0,310 \\
0,090 \\
0,000 \\
0,000 \\
0,080\end{array}$ & $\begin{array}{l}0,000 \\
1,780 \\
0,000 \\
0,000 \\
1,670 \\
0,320 \\
0,080 \\
0,000 \\
0,010 \\
0,070\end{array}$ & $\begin{array}{l}0,000 \\
1,810 \\
0,000 \\
0,000 \\
1,680 \\
0,280 \\
0,090 \\
0,000 \\
0,000 \\
0,070\end{array}$ & $\begin{array}{l}0,000 \\
1,780 \\
0,000 \\
0,000 \\
1,660 \\
0,320 \\
0,090 \\
0,000 \\
0,000 \\
0,080\end{array}$ & $\begin{array}{l}0,000 \\
1,910 \\
0,000 \\
0,000 \\
1,850 \\
0,150 \\
0,060 \\
0,000 \\
0,000 \\
0,010\end{array}$ \\
\hline \multicolumn{10}{|c|}{ Componentes moleculares } \\
\hline $\begin{array}{l}\text { Gkl } \\
\text { Ilm } \\
\text { Hem }\end{array}$ & $\begin{array}{r}0,00 \\
91,94 \\
8,06 \\
\end{array}$ & $\begin{array}{r}0,00 \\
90,37 \\
9,63 \\
\end{array}$ & $\begin{array}{r}0,00 \\
93,01 \\
6,99 \\
\end{array}$ & $\begin{array}{r}0,00 \\
92,43 \\
7,57 \\
\end{array}$ & $\begin{array}{r}0,00 \\
91,40 \\
8,60 \\
\end{array}$ & $\begin{array}{r}0,00 \\
91,40 \\
8,60 \\
\end{array}$ & $\begin{array}{r}0,00 \\
92,47 \\
7,53 \\
\end{array}$ & $\begin{array}{r}0,00 \\
91,35 \\
8,65 \\
\end{array}$ & $\begin{array}{r}0,00 \\
95,85 \\
4,15 \\
\end{array}$ \\
\hline
\end{tabular}

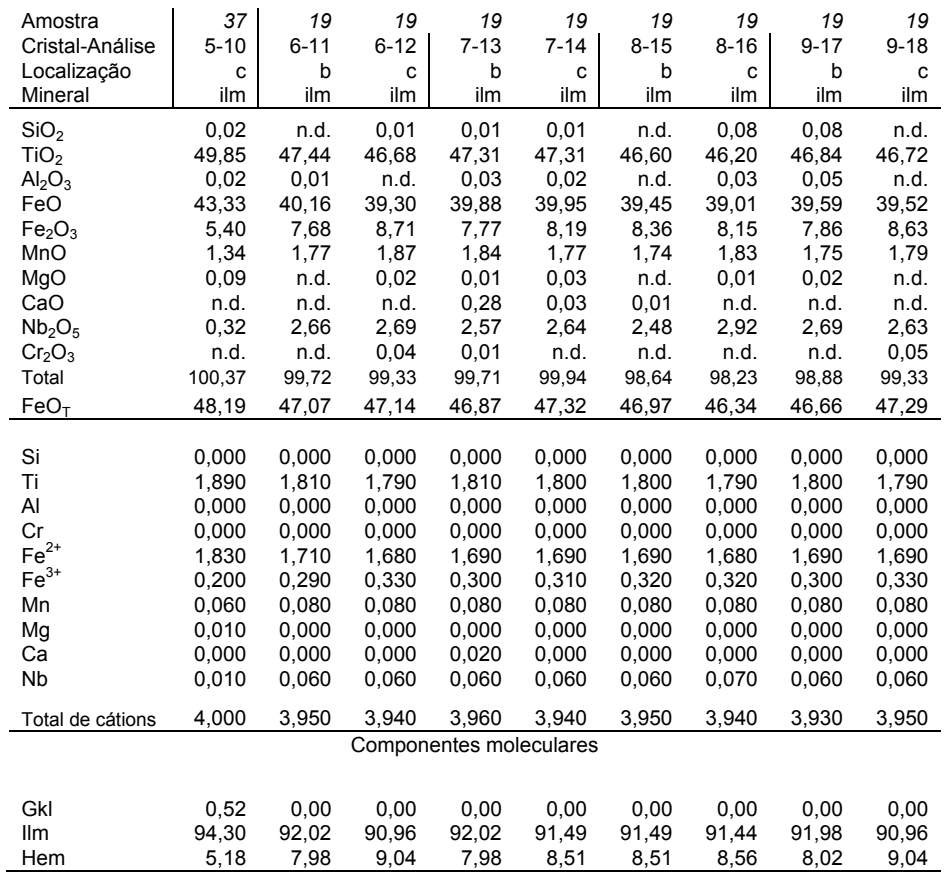




\section{GEOQUÍMICA}

Amostras representativas dos tipos litológicos de Cananéia, sem evidências de alteração intempérica, foram analisadas do ponto de vista geoquímico. Os dados obtidos (36 análises, sendo 32 relativas à intrusão do Morro de São João e 4 à ocorrência satélite do Morrete) para elementos maiores, menores e Terras Raras acham-se reunidos na Tabela 23, com os primeiros expressos em $\%$ e os demais em ppm, e foram trabalhados segundo diversos diagramas de variação com o objetivo de caracterizar geoquimicamente essas rochas e melhor entender a sua origem e evolução.

A Tabela 23 demonstra que as rochas de Cananéia são pobres em $\mathrm{Mg}, \mathrm{Mn}, \mathrm{Cr}$ e Ni, contêm altos teores em Al e álcalis, além de concentrações variadas em $\mathrm{Ti}$, Fe e outros elementos. $\mathrm{O}$ exame dos dados normativos permite realçar a sua natureza dominantemente saturada a supersaturada, com o teor de quartzo normativo oscilando de 0 a $20 \%$. A afinidade alcalina se manifesta principalmente na presença normativa de ortoclásio e do componente albítico do plagioclásio, alcançando valores máximos, respectivamente, de $32,73 \%$ e $61,56 \%$. Uma única amostra (15A) apresenta caráter ligeiramente insaturado, ou seja, ausência de quartzo normativo e presença de nefelina em pequena quantidade $(2,21 \%)$.

Adotado o esquema classificatório empregado por Comin-Chiaramonti e Gomes (1996) para as rochas alcalinas mesozóicas da porção centro-oriental do Paraguai - onde se distinguem, com base nos teores de $\mathrm{K}_{2} \mathrm{O}$ e $\mathrm{Na}_{2} \mathrm{O}$, os tipos fortemente potássicos $\left(\mathrm{K}_{2} \mathrm{O} / \mathrm{Na}_{2} \mathrm{O}>2\right)$, potássicos $\left(1<\mathrm{K}_{2} \mathrm{O} / \mathrm{Na}_{2} \mathrm{O} \leq 2\right)$, transicionais $\left(\mathrm{Na}_{2} \mathrm{O}-2<\mathrm{K}_{2} \mathrm{O}, \mathrm{K}_{2} \mathrm{O} / \mathrm{Na}_{2} \mathrm{O} \leq 1\right)$ e sódicos $\left(\mathrm{Na}_{2} \mathrm{O}-2 \geq \mathrm{K}_{2} \mathrm{O}\right)$-, verifica-se que a quase totalidade das rochas de Cananéia está concentrada no campo correspondente às variedades transicionais (Fig. 32). Cinco amostras (12, 37, 19, 9B e 22B) situam-se próximas ao limite dos campos transicional e sódico, com apenas uma amostra (30) caindo nitidamente no campo das sódicas.

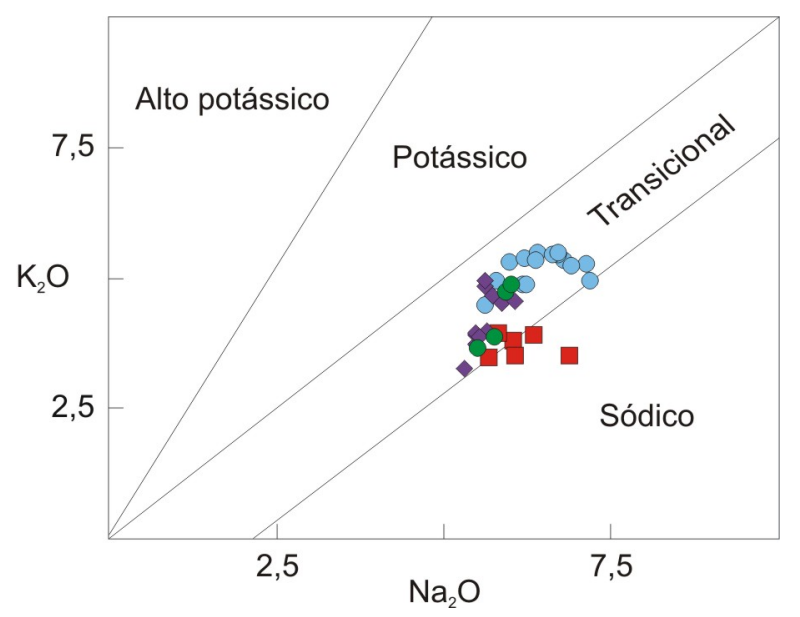

Figura 32. Diagrama classificatório para o índice de alcalinidade das rochas de Cananéia segundo os campos definidos por Comin-Chiaramonti e Gomes (1996). Símbolos como na Figura 7.

Os valores listados na Tabela 23 para o índice agpaítico $\left(\mathrm{K}_{2} \mathrm{O}+\mathrm{Na}_{2} \mathrm{O} / \mathrm{Al}_{2} \mathrm{O}_{3}\right.$, proporção molecular) são sempre inferiores a $1(0,74-1,00)$, o que possibilita incluir essas rochas, segundo Gerasimovskii (1956) e Sørensen (1960), na série miaskítica, fato também confirmado por outras características químicas e também pela assembléia mineralógica, onde não se registra a presença de minerais ecêntricos (p.e. eudialita, catapleíta, sinkita, låvenita, enigmatita) típicos de associações agpaíticas (cf. Sørensen, 1960). 
Tabela 23. Análises químicas de elementos maiores (\%) e traços (ppm), juntamente com os valores para a norma CIPW, R1-R2 (cf. De La Roche, 1986; De La Roche et al., 1980); mg\# [(Mg/Mg+Fe) assumindo $\left.\mathrm{Fe}^{3+} / \mathrm{Fe}^{2+}=0,18\right]$; índice agpaítico (I.A. $=\mathrm{Na}_{2} \mathrm{O}+\mathrm{K}_{2} \mathrm{O} / \mathrm{Al}_{2} \mathrm{O}_{3}$; proporção molecular, cf. Sørensen, 1960); índice de cor (I.C.); índice de diferenciação (I.D.=Q+Or+Ab+Ne+Ks+Lc; cf. Thornton e Tuttle, 1960) e razões entre elementos incompatíveis e Terras Raras para as rochas de Cananéia. Outras abreviações: n.d., não detectado; não analisado, em branco.

\begin{tabular}{|c|c|c|c|c|c|c|c|c|c|c|c|c|c|}
\hline & 1 & 2 & 3 & 4 & 5 & 6 & 7 & 8 & 9 & 10 & 11 & 12 & 13 \\
\hline Amostra & 12 & 18 & 30 & 37 & 19 & $9 B$ & 2 & $16 B$ & $22 A$ & 36 & $9 A$ & $22 C$ & $24 A$ \\
\hline & $T q$ & $T q$ & $T q$ & $m S$ & $m S$ & $T q$ & Qs & Qs & Qs & Qs & Qs & Qs & Qs \\
\hline $\mathrm{SiO}_{2}$ & 69,83 & 68,92 & 68,76 & 68,52 & 66,31 & 66,16 & 67,43 & 66,65 & 66,46 & 66,22 & 66,12 & 66,02 & 65,23 \\
\hline $\mathrm{TiO}_{2}$ & 0,15 & 0,09 & 0,11 & 0,17 & 0,23 & 0,23 & 0,18 & 0,21 & 0,25 & 0,33 & 0,33 & 0,09 & 0,19 \\
\hline $\mathrm{Al}_{2} \mathrm{O}_{3}$ & 16,16 & 16,56 & 16,87 & 16,20 & 17,57 & 16,78 & 17,71 & 17,80 & 17,74 & 15,91 & 15,76 & 18,24 & 17,55 \\
\hline $\mathrm{FeO}_{\mathrm{T}}$ & 3,24 & 3,16 & 2,77 & 3,56 & 3,93 & 4,99 & 2,85 & 2,10 & 2,25 & 3,66 & 4,43 & 2,26 & 3,58 \\
\hline $\mathrm{MnO}$ & 0,08 & 0,15 & 0,10 & 0,05 & 0,12 & 0,18 & 0,10 & 0,03 & 0,03 & 0,08 & 0,16 & 0,04 & 0,03 \\
\hline $\mathrm{MgO}$ & n.d. & n.d. & n.d. & n.d. & 0,06 & 0,06 & 0,10 & 0,01 & 0,03 & 0,13 & 0,18 & n.d. & 0,04 \\
\hline $\mathrm{CaO}$ & 0,76 & 0,57 & 0,46 & 0,59 & 0,97 & 0,98 & 0,76 & 0,26 & 0,28 & 0,81 & 0,91 & 0,05 & 0,38 \\
\hline $\mathrm{Na}_{2} \mathrm{O}$ & 5,68 & 5,81 & 6,86 & 6,05 & 6,34 & 6,02 & 5,61 & 6,69 & 6,61 & 6,23 & 6,18 & 7,11 & 6,70 \\
\hline $\mathrm{K}_{2} \mathrm{O}$ & 3,48 & 3,95 & 3,51 & 3,53 & 3,90 & 3,80 & 4,47 & 5,45 & 5,46 & 4,89 & 4,89 & 5,28 & 5,47 \\
\hline $\mathrm{P}_{2} \mathrm{O}_{5}$ & n.d. & n.d. & n.d. & n.d. & 0,03 & 0,02 & 0,01 & 0,01 & 0,01 & 0,07 & 0,07 & 0,01 & 0,01 \\
\hline P.F. & 0,61 & 0,79 & 0,58 & 1,33 & 0,54 & 0,77 & 0,79 & 0,81 & 0,88 & 0,37 & 0,51 & 0,89 & 0,82 \\
\hline Total & 99,99 & 100,00 & 100,02 & 100,00 & 100,00 & 99,99 & 100,01 & 100,02 & 100,00 & 98,70 & 99,54 & 99,99 & 100,00 \\
\hline $\mathrm{Cr}$ & 6,70 & 4,00 & 26,18 & 1,00 & 16,10 & 5,00 & 0,00 & 1,00 & 2,00 & 10,00 & 10,35 & 0,00 & 2,00 \\
\hline $\mathrm{Ni}$ & 7,65 & 0,00 & 14,01 & 5,00 & 12,01 & 4,00 & 2,00 & 2,00 & 3,00 & 10,00 & 10,84 & 7,00 & 3,00 \\
\hline $\mathrm{Rb}$ & 126,53 & 146,00 & 71,83 & 117,00 & 113,28 & 101,00 & 109,00 & 138,00 & 141,00 & 126,00 & 131,00 & 156,00 & 97,00 \\
\hline $\mathrm{Sr}$ & 703,58 & 9,00 & 358,87 & 14,00 & 257,20 & 16,00 & 29,00 & 13,00 & 13,00 & 69,00 & 76,00 & 13,00 & 10,00 \\
\hline $\mathrm{Zr}$ & 1048,0 & 698,00 & 866,00 & 1037,00 & 851,00 & 784,00 & 726,00 & 766,00 & 730,00 & 692,00 & 727,00 & 540,00 & 181,00 \\
\hline Y & 89,00 & 71,00 & 89,00 & 110,00 & 52,00 & 65,00 & 29,00 & 66,00 & 73,00 & 76,00 & 79,00 & 47,00 & 34,00 \\
\hline $\mathrm{Nb}$ & 91,08 & 120,00 & 44,75 & 119,00 & 79,88 & 102,00 & 32,00 & 122,00 & 138,00 & 49,00 & 59,00 & 66,00 & 34,00 \\
\hline $\mathrm{Ba}$ & 89,00 & 66,00 & 43,00 & 77,00 & 306,00 & 203,00 & 315,00 & 138,00 & 141,00 & 552,90 & 503,10 & 176,00 & 289,00 \\
\hline La & 118,65 & 114,00 & 43,36 & 194,00 & 84,30 & 146,00 & 54,00 & 120,00 & 136,00 & 173,11 & 135,59 & 121,00 & 63,00 \\
\hline $\mathrm{Ce}$ & 224,37 & 201,00 & 82,00 & 326,00 & 167,21 & 258,00 & 95,00 & 216,00 & 239,00 & 281,57 & 245,47 & 151,00 & 62,00 \\
\hline $\mathrm{Nd}$ & 193,76 & 95,00 & 49,79 & 143,00 & 113,44 & 120,00 & 45,00 & 81,00 & 92,00 & 102,87 & 86,14 & 74,00 & 45,00 \\
\hline Sm & 18,26 & & 9,01 & & 14,55 & & & & & 8,69 & 16,02 & & \\
\hline $\mathrm{Eu}$ & 2,03 & & 2,79 & & 1,64 & & & & & 2,00 & 2,04 & & \\
\hline Gd & 19,95 & & 10,10 & & 15,09 & & & & & 5,98 & 13,24 & & \\
\hline $\mathrm{Tb}$ & 3,18 & & 1,50 & & 2,18 & & & & & 0,83 & 2,39 & & \\
\hline Dy & 18,97 & & 6,71 & & 11,93 & & & & & 3,90 & 11,64 & & \\
\hline Ho & 3,42 & & 1,69 & & 2,27 & & & & & 0,63 & 2,56 & & \\
\hline $\mathrm{Er}$ & 9,92 & & 3,82 & & 5,84 & & & & & 1,84 & 6,53 & & \\
\hline $\mathrm{Tm}$ & 2,09 & & 0,79 & & 1,16 & & & & & 0,33 & 1,27 & & \\
\hline $\mathrm{Yb}$ & 10,70 & & 3,76 & & 6,12 & & & & & 2,00 & 5,87 & & \\
\hline Lu & 1,49 & & 0,50 & & 0,99 & & & & & 0,30 & 1,17 & & \\
\hline $\mathrm{Pb}$ & 32,55 & & 171,47 & & 324,81 & & & & & & & & \\
\hline Th & 30,35 & & 7,46 & & 11,55 & & & & & 11,47 & 13,44 & & \\
\hline U & 7,85 & & 2,19 & & 2,85 & & & & & 1,65 & 1,73 & & \\
\hline $\mathrm{Sc}$ & 1,70 & & 11,33 & & 3,72 & & & & & & & & \\
\hline V & 11,65 & & 56,64 & & 24,47 & & & & & 8,96 & 8,11 & & \\
\hline Co & 1,70 & & 8,50 & & 5,01 & & & & & & & & \\
\hline $\mathrm{Cu}$ & 28,26 & & 72,08 & & 152,50 & & & & & 50,09 & 32,44 & & \\
\hline $\mathrm{Zn}$ & 40,27 & & 179,92 & & 1043,72 & & & & & 121,24 & 227,34 & & \\
\hline $\mathrm{Pr}$ & 22,51 & & 9,82 & & 18,38 & & & & & 19,68 & 25,39 & & \\
\hline Q & 19,87 & 16,78 & 12,68 & 16,50 & 9,95 & 11,28 & 14,22 & 5,12 & 5,22 & 7,98 & 7,40 & 2,94 & 2,28 \\
\hline C & 1,67 & 1,70 & 0,95 & 1,37 & 1,23 & 1,03 & 2,30 & 0,44 & 0,47 & - & - & 0,76 & - \\
\hline or & 20,68 & 23,52 & 20,85 & 21,13 & 23,16 & 22,62 & 26,61 & 32,46 & 32,54 & 29,37 & 29,16 & 31,48 & 32,58 \\
\hline$a b$ & 48,34 & 49,53 & 58,35 & 51,86 & 53,91 & 51,30 & 47,83 & 57,05 & 56,41 & 53,58 & 52,77 & 60,69 & 57,13 \\
\hline an & 3,79 & 2,85 & 2,29 & 2,97 & 4,64 & 4,77 & 3,73 & 1,23 & 1,34 & 1,00 & 0,81 & 0,18 & 1,65 \\
\hline ne & - & - & - & - & - & - & - & - & - & - & - & - & - \\
\hline di (Wo) & - & - & - & - & - & - & - & - & - & 1,09 & 1,37 & - & 0,08 \\
\hline di (En) & - & - & - & - & - & - & - & - & - & 0,08 & 0,10 & - & 0,00 \\
\hline di (Fs) & - & - & - & - & - & - & - & - & - & 1,14 & 1,42 & - & 0,08 \\
\hline hi (En) & - & - & - & - & 0,15 & 0,15 & 0,25 & 0,02 & 0,08 & 0,25 & 0,35 & - & 0,10 \\
\hline hi (Fs) & 4,62 & 4,71 & 4,02 & 5,05 & 5,55 & 7,21 & 4,03 & 2,78 & 2,93 & 3,85 & 4,78 & 3,23 & 4,90 \\
\hline ol (Fo) & - & - & - & - & - & - & - & - & - & - & - & - & - \\
\hline ol (Fa) & - & - & - & - & - & - & - & - & - & - & - & - & - \\
\hline $\mathrm{mt}$ & 0,73 & 0,72 & 0,63 & 0,80 & 0,89 & 1,14 & 0,64 & 0,46 & 0,50 & 0,83 & 1,01 & 0,50 & 0,79 \\
\hline ilm & 0,29 & 0,17 & 0,21 & 0,33 & 0,44 & 0,44 & 0,34 & 0,40 & 0,48 & 0,64 & 0,63 & 0,17 & 0,36 \\
\hline ap & - & - & - & - & 0,07 & 0,04 & 0,02 & 0,02 & 0,02 & 0,16 & 0,15 & 0,02 & 0,02 \\
\hline R1 & 1726 & 1513 & 1243 & 1486 & 1138 & 1241 & 1370 & 726 & 734 & 945 & 939 & 578 & 587 \\
\hline $\mathrm{R} 2$ & 398 & 386 & 380 & 381 & 451 & 437 & 434 & 377 & 379 & 405 & 416 & 363 & 387 \\
\hline mg\# & 0,00 & 0,00 & 0,00 & 0,00 & 0,03 & 0,02 & 0,07 & 0,01 & 0,03 & 0,07 & 0,08 & 0,00 & 0,02 \\
\hline I.A. & 0,81 & 0,84 & 0,89 & 0,85 & 0,83 & 0,84 & 0,79 & 0,95 & 0,95 & 0,98 & 0,98 & 0,95 & 0,97 \\
\hline I.C. & 5,63 & 5,61 & 4,86 & 6,17 & 7,03 & 8,96 & 5,27 & 3,67 & 3,98 & 7,87 & 9,67 & 3,90 & 6,34 \\
\hline I.D. & 88,89 & 89,83 & 91,89 & 89,49 & 87,02 & 85,16 & 88,66 & 94,62 & 94,17 & 90,93 & 89,33 & 95,11 & 92,02 \\
\hline $\mathrm{Eu} / \mathrm{Eu}^{*}$ & 0,32 & & 0,89 & & 0,34 & & & & & 0,85 & 0,43 & & \\
\hline$(\mathrm{La} / \mathrm{Sm})_{\mathrm{N}}$ & 4,06 & & 3,00 & & 3,62 & & & & & 12,44 & 9,57 & & \\
\hline$(G d / Y b)_{N}$ & 1,51 & & 2,18 & & 1,99 & & & & & 2,42 & 1,82 & & \\
\hline$(\mathrm{La} / \mathrm{Yb})_{\mathrm{N}}$ & 7,53 & & 7,84 & & 9,36 & & & & & 58,80 & 28,41 & & \\
\hline
\end{tabular}


Tabela 23. Continuação.

\begin{tabular}{|c|c|c|c|c|c|c|c|c|c|c|c|c|c|}
\hline & 14 & 15 & 16 & 17 & 18 & 19 & 20 & 21 & 22 & 23 & 24 & 25 & 26 \\
\hline Amostra & $22 D$ & $22 B$ & $16 A$ & $15 B$ & $1 B$ & $24 B$ & 14 & $39 B$ & $33 B$ & $1 A$ & $33 A$ & $39 A$ & 7 \\
\hline & Qs & Qs & Qs & Qs & Qs & Qs & As & As & As & Qs & As & As & As \\
\hline $\mathrm{SiO}_{2}$ & 65,00 & 64,90 & 64,75 & 64,55 & 64,50 & 64,42 & 63,71 & 63,59 & 63,46 & 63,21 & 62,77 & 62,45 & 61,46 \\
\hline $\mathrm{TiO}_{2}$ & 0,15 & 0,13 & 0,14 & 0,26 & 0,37 & 0,28 & 0,71 & 0,43 & 0,65 & 0,49 & 0,67 & 0,69 & 0,90 \\
\hline $\mathrm{Al}_{2} \mathrm{O}_{3}$ & 17,93 & 17,55 & 17,47 & 16,96 & 17,16 & 16,91 & 16,48 & 17,10 & 16,60 & 16,26 & 16,42 & 19,37 & 16,92 \\
\hline $\mathrm{FeO}_{\mathrm{T}}$ & 3,52 & 3,44 & 3,71 & 4,14 & 4,07 & 5,07 & 5,79 & 5,10 & 5,07 & 5,68 & 5,68 & 6,29 & 6,47 \\
\hline $\mathrm{MnO}$ & 0,07 & 0,13 & 0,12 & 0,22 & 0,10 & 0,07 & 0,14 & 0,18 & 0,10 & 0,19 & 0,16 & 0,22 & 0,15 \\
\hline $\mathrm{MgO}$ & 0,04 & 0,03 & 0,05 & 0,11 & 0,30 & 0,06 & 1,28 & 0,36 & 0,90 & 0,52 & 0,90 & 0,50 & 1,27 \\
\hline $\mathrm{CaO}$ & 0,13 & 0,33 & 0,19 & 1,08 & 1,20 & 0,50 & 2,45 & 2,05 & 1,94 & 1,53 & 2,10 & 2,22 & 2,48 \\
\hline $\mathrm{Na}_{2} \mathrm{O}$ & 6,89 & 7,18 & 6,78 & 6,40 & 6,21 & 6,36 & 5,31 & 6,05 & 5,61 & 5,97 & 5,61 & 5,73 & 5,87 \\
\hline $\mathrm{K}_{2} \mathrm{O}$ & 5,23 & 4,95 & 5,33 & 5,50 & 5,37 & 5,35 & 3,27 & 4,55 & 4,95 & 5,31 & 4,85 & 4,66 & 4,51 \\
\hline $\mathrm{P}_{2} \mathrm{O}_{5}$ & 0,02 & 0,01 & 0,02 & 0,03 & 0,06 & 0,03 & 0,14 & 0,12 & 0,15 & 0,07 & 0,13 & 0,17 & 0,23 \\
\hline P.F. & 1,01 & 1,33 & 1,44 & 0,76 & 0,66 & 0,95 & 0,71 & 0,49 & 0,58 & 0,78 & 0,69 & 0,71 & 0,44 \\
\hline Total & 99,99 & 99,98 & 100,00 & 100,01 & 100,00 & 100,00 & 99,99 & 100,02 & 100,01 & 100,01 & 99,98 & 103,01 & 100,70 \\
\hline $\mathrm{Cr}$ & 0,00 & 13,30 & 3,00 & 7,58 & 11,28 & 0,00 & 7,00 & 12,93 & 7,00 & 5,00 & 4,00 & 10,00 & 11,00 \\
\hline $\mathrm{Ni}$ & 6,00 & 12,04 & 2,00 & 6,66 & 6,48 & 5,00 & 5,00 & 16,53 & 5,00 & 1,00 & 9,00 & 9,00 & 10,00 \\
\hline $\mathrm{Rb}$ & 150,00 & 170,25 & 170,00 & 100,94 & 116,82 & 133,00 & 100,00 & 78,58 & 115,00 & 114,00 & 115,00 & 72,00 & 106,00 \\
\hline $\mathrm{Sr}$ & 14,00 & 395,28 & 25,00 & 388,16 & 208,79 & 10,00 & 165,00 & 297,13 & 124,00 & 58,00 & 144,00 & 156,00 & 174,00 \\
\hline $\mathrm{Zr}$ & 577,00 & 717,00 & 708,00 & 210,00 & 1343,00 & 557,00 & 383,00 & 207,00 & 504,00 & 1165,00 & 472,00 & 330,00 & 391,00 \\
\hline Y & 59,00 & 77,00 & 69,00 & 28,00 & 193,00 & 62,00 & 38,00 & 26,00 & 39,00 & 79,00 & 53,00 & 42,00 & 53,00 \\
\hline $\mathrm{Nb}$ & 67,00 & 91,94 & 96,00 & 34,34 & 114,78 & 92,00 & 52,00 & 27,76 & 42,00 & 77,00 & 65,00 & 56,00 & 48,00 \\
\hline $\mathrm{Ba}$ & 202,00 & 198,00 & 268,00 & 59,00 & 637,00 & 263,00 & 1155,00 & 2242,00 & 1179,00 & 666,00 & 1310,00 & 1995,00 & 605,40 \\
\hline La & 207,00 & 133,17 & 169,00 & 31,27 & 162,93 & 162,00 & 54,00 & 21,50 & 45,00 & 120,00 & 46,00 & 39,00 & 96,35 \\
\hline $\mathrm{Ce}$ & 358,00 & 237,70 & 270,00 & 60,22 & 254,63 & 215,00 & 105,00 & 44,73 & 78,00 & 194,00 & 92,00 & 68,00 & 130,41 \\
\hline $\mathrm{Nd}$ & 133,00 & 132,57 & 103,00 & 34,75 & 97,34 & 120,00 & 53,00 & 39,19 & 33,00 & 70,00 & 45,00 & 31,00 & 47,70 \\
\hline $\mathrm{Sm}$ & & 16,22 & & 6,66 & 21,79 & & & 5,81 & & & & & 9,12 \\
\hline $\mathrm{Eu}$ & & 1,00 & & 1,03 & 2,73 & & & 0,72 & & & & & 1,92 \\
\hline $\mathrm{Gd}$ & & 14,77 & & 8,30 & 26,15 & & & 7,25 & & & & & 8,65 \\
\hline $\mathrm{Tb}$ & & 2,33 & & 1,12 & 4,16 & & & 1,10 & & & & & 1,43 \\
\hline Dy & & 10,18 & & 4,49 & 21,87 & & & 4,52 & & & & & 7,91 \\
\hline $\mathrm{Ho}$ & & 2,36 & & 0,68 & 5,30 & & & 1,28 & & & & & 1,66 \\
\hline $\mathrm{Er}$ & & 5,32 & & 2,30 & 13,72 & & & 2,34 & & & & & 4,67 \\
\hline $\mathrm{Tm}$ & & 0,96 & & 0,47 & 2,92 & & & 0,51 & & & & & 0,73 \\
\hline $\mathrm{Yb}$ & & 4,85 & & 2,79 & 14,02 & & & 2,77 & & & & & 4,21 \\
\hline Lu & & 0,63 & & 0,50 & 2,19 & & & 0,39 & & & & & 0,47 \\
\hline $\mathrm{Pb}$ & & 270,22 & & 67,10 & 125,89 & & & 129,96 & & & & & \\
\hline Th & & 16,74 & & 4,71 & 13,81 & & & 5,97 & & & & & 7,98 \\
\hline$U$ & & 5,23 & & 3,22 & 3,86 & & & 1,63 & & & & & 0,82 \\
\hline $\mathrm{Sc}$ & & 1,73 & & 4,07 & 4,98 & & & 7,81 & & & & & \\
\hline V & & 18,67 & & 18,00 & 17,03 & & & 25,58 & & & & & 49,23 \\
\hline Co & & 1,25 & & 2,12 & 2,05 & & & 1,62 & & & & & \\
\hline $\mathrm{Cu}$ & & 46,30 & & 8,45 & 8,66 & & & 60,93 & & & & & 68,36 \\
\hline$Z n$ & & 299,19 & & 205,27 & 133,23 & & & 50,81 & & & & & 199,93 \\
\hline $\operatorname{Pr}$ & & 23,71 & & 7,50 & 27,01 & & & 5,78 & & & & & 12,69 \\
\hline Q & 2,37 & 1,33 & 2,08 & 2,03 & 3,04 & 2,80 & 10,20 & 3,95 & 4,57 & 1,92 & 3,67 & 3,50 & 0,70 \\
\hline C & 0,75 & - & 0,25 & - & - & - & 0,08 & - & - & - & - & - & - \\
\hline or & 31,21 & 29,64 & 31,94 & 32,73 & 31,93 & 31,90 & 19,45 & 27,00 & 29,40 & 31,60 & 28,84 & 27,71 & 26,56 \\
\hline$a b$ & 58,87 & 61,56 & 58,18 & 54,53 & 52,87 & 54,29 & 45,22 & 51,40 & 47,71 & 50,87 & 47,77 & 48,78 & 49,50 \\
\hline an & 0,52 & 1,03 & 0,82 & 1,30 & 3,09 & 1,79 & 11,31 & 6,07 & 5,50 & 1,88 & 5,31 & 5,20 & 6,46 \\
\hline ne & - & - & - & - & - & - & - & - & - & - & - & - & - \\
\hline di (Wo) & - & 0,23 & - & 1,63 & 1,05 & 0,21 & - & 1,40 & 1,33 & 2,21 & 1,80 & 1,99 & 1,80 \\
\hline di (En) & - & 0,00 & - & 0,08 & 0,14 & 0,01 & - & 0,17 & 0,36 & 0,34 & 0,44 & 0,28 & 0,52 \\
\hline di (Fs) & - & 0,26 & - & 1,75 & 1,01 & 0,24 & - & 1,36 & 1,04 & 2,06 & 1,47 & 1,89 & 1,35 \\
\hline hi (En) & 0,10 & 0,07 & 0,13 & 0,19 & 0,61 & 0,15 & 3,20 & 0,72 & 1,89 & 0,96 & 1,81 & 0,97 & 2,62 \\
\hline hi (Fs) & 5,04 & 4,80 & 5,43 & 4,23 & 4,50 & 6,86 & 7,53 & 5,66 & 5,46 & 5,75 & 5,99 & 6,52 & 6,79 \\
\hline ol (Fo) & - & - & - & - & - & - & - & - & - & - & - & - & - \\
\hline ol (Fa) & - & - & - & - & - & - & - & - & - & - & - & - & - \\
\hline $\mathrm{mt}$ & 0,79 & 0,79 & 0,85 & 0,96 & 0,91 & 1,13 & 1,30 & 1,16 & 1,13 & 1,29 & 1,28 & 1,43 & 1,44 \\
\hline ilm & 0,29 & 0,25 & 0,27 & 0,50 & 0,71 & 0,54 & 1,36 & 0,82 & 1,24 & 0,94 & 1,28 & 1,32 & 1,70 \\
\hline ap & 0,04 & 0,02 & 0,04 & 0,07 & 0,13 & 0,07 & 0,31 & 0,26 & 0,33 & 0,15 & 0,29 & 0,37 & 0,50 \\
\hline $\mathrm{R} 1$ & 563 & 522 & 557 & 624 & 717 & 638 & 1419 & 875 & 924 & 683 & 884 & 847 & 757 \\
\hline $\mathrm{R} 2$ & 367 & 381 & 365 & 454 & 480 & 388 & 650 & 573 & 578 & 509 & 592 & 643 & 661 \\
\hline $\mathrm{mg} \#$ & 0,02 & 0,02 & 0,03 & 0,05 & 0,13 & 0,02 & 0,31 & 0,13 & 0,27 & 0,16 & 0,25 & 0,14 & 0,29 \\
\hline I.A. & 0,95 & 0,98 & 0,97 & 0,97 & 0,93 & 0,96 & 0,74 & 0,87 & 0,88 & 0,96 & 0,88 & 0,75 & 0,86 \\
\hline I.C. & 6,22 & 6,45 & 6,69 & 9,45 & 9,11 & 9,23 & 13,74 & 11,68 & 12,91 & 13,80 & 14,48 & 14,93 & 16,22 \\
\hline I.D. & 92,44 & 92,54 & 92,18 & 89,28 & 87,82 & 89,01 & 74,73 & 82,28 & 81,60 & 84,35 & 80,21 & 79,88 & 76,76 \\
\hline $\mathrm{Eu} / \mathrm{Eu}^{*}$ & & 0,20 & & 0,42 & 0,35 & & & 0,34 & & & & & 0,66 \\
\hline$(\mathrm{La} / \mathrm{Sm})_{\mathrm{N}}$ & & 5,13 & & 2,93 & 4,67 & & & 2,31 & & & & & 6,60 \\
\hline$(G d / Y b)_{N}$ & & 2,46 & & 2,40 & 1,51 & & & 2,12 & & & & & 1,66 \\
\hline$(\mathrm{La} / \mathrm{Yb})_{\mathrm{N}}$ & & 18,64 & & 7,61 & 7,90 & & & 5,27 & & & & & 15,55 \\
\hline
\end{tabular}


Tabela 23. Continuação.

\begin{tabular}{|c|c|c|c|c|c|c|c|c|c|c|}
\hline \multirow{3}{*}{ Amostra } & 27 & 28 & 29 & 30 & 31 & 32 & 33 & 34 & 35 & 36 \\
\hline & $32 A$ & $28 B$ & $32 B$ & $28 A$ & $15 A$ & 29 & 40 & 50 & $51 B$ & $51 A$ \\
\hline & As & As & As & As & Qs & As & Qs & Qs & Qs & Qs \\
\hline $\mathrm{SiO}_{2}$ & 60,71 & 60,55 & 60,54 & 60,25 & 59,07 & 58,98 & 68,73 & 68,54 & 67,04 & 66,22 \\
\hline $\mathrm{TiO}_{2}$ & 0,92 & 0,92 & 0,96 & 0,93 & 0,32 & 0,08 & 0,28 & 0,30 & 0,29 & 0,33 \\
\hline $\mathrm{Al}_{2} \mathrm{O}_{3}$ & 16,41 & 16,50 & 16,39 & 16,41 & 14,91 & 16,80 & 16,60 & 16,73 & 15,91 & 16,09 \\
\hline $\mathrm{FeO}_{\mathrm{T}}$ & 6,83 & 6,80 & 7,01 & 6,95 & 12,61 & 7,32 & 3,64 & 3,45 & 4,14 & 4,78 \\
\hline $\mathrm{MnO}$ & 0,16 & 0,15 & 0,16 & 0,15 & 0,47 & 0,15 & 0,09 & 0,08 & 0,08 & 0,08 \\
\hline $\mathrm{MgO}$ & 1,54 & 1,47 & 1,56 & 1,55 & 0,23 & 1,72 & 0,17 & 0,15 & 0,15 & 0,21 \\
\hline $\mathrm{CaO}$ & 3,11 & 3,26 & 3,33 & 3,54 & 1,45 & 3,06 & 0,64 & 0,71 & 0,82 & 0,78 \\
\hline $\mathrm{Na}_{2} \mathrm{O}$ & 5,65 & 5,48 & 5,54 & 5,46 & 5,77 & 5,46 & 5,51 & 5,76 & 6,00 & 5,92 \\
\hline $\mathrm{K}_{2} \mathrm{O}$ & 3,99 & 3,91 & 3,87 & 3,74 & 4,96 & 3,96 & 3,65 & 3,86 & 4,88 & 4,74 \\
\hline $\mathrm{P}_{2} \mathrm{O}_{5}$ & 0,24 & 0,20 & 0,24 & 0,24 & 0,09 & 0,29 & 0,04 & 0,04 & 0,05 & 0,07 \\
\hline P.F. & 0,45 & 0,75 & 0,40 & 0,78 & 0,11 & 0,38 & 0,67 & 0,38 & 0,63 & 0,78 \\
\hline Total & 100,01 & 99,99 & 100,00 & 100,00 & 99,99 & 98,20 & 100,02 & 100,00 & 99,99 & 100,00 \\
\hline $\mathrm{Cr}$ & 16,00 & 8,00 & 15,86 & 6,38 & 9,42 & 12,93 & 3,00 & 2,00 & 5,00 & 8,00 \\
\hline $\mathrm{Ni}$ & 10,00 & 13,00 & 12,02 & 5,36 & 27,17 & 16,53 & 6,00 & 1,00 & 4,00 & 3,00 \\
\hline $\mathrm{Rb}$ & 104,00 & 87,00 & 88,03 & 235,52 & 111,55 & 78,58 & 120,00 & 124,00 & 149,00 & 140,00 \\
\hline $\mathrm{Sr}$ & 222,00 & 245,00 & 309,18 & 202,13 & 173,95 & 297,13 & 74,00 & 73,00 & 83,00 & 89,00 \\
\hline $\mathrm{Zr}$ & 581,00 & 358,00 & 337,00 & 322,00 & 269,00 & 291,00 & 627,00 & 756,00 & 912,00 & 820,00 \\
\hline Y & 73,00 & 147,00 & 53,00 & 46,00 & 39,00 & 42,00 & 62,00 & 56,00 & 76,00 & 83,00 \\
\hline $\mathrm{Nb}$ & 70,00 & 45,00 & 43,63 & 88,40 & 51,80 & 27,76 & 77,00 & 87,00 & 100,00 & 96,00 \\
\hline $\mathrm{Ba}$ & 1334,00 & 1461,00 & 1429,00 & 1434,00 & 64,00 & 474,30 & 1019,00 & 825,00 & 897,00 & 980,00 \\
\hline La & 59,00 & 63,00 & 47,35 & 95,37 & 44,83 & 21,50 & 168,00 & 114,00 & 119,00 & 132,00 \\
\hline $\mathrm{Ce}$ & 94,00 & 87,00 & 82,84 & 170,69 & 90,94 & 44,73 & 256,00 & 206,00 & 214,00 & 203,00 \\
\hline $\mathrm{Nd}$ & 45,00 & 46,00 & 71,16 & 185,87 & 56,66 & 39,19 & 144,00 & 99,00 & 92,00 & 106,00 \\
\hline $\mathrm{Sm}$ & & & 8,95 & 16,77 & 9,47 & 8,48 & & & & \\
\hline $\mathrm{Eu}$ & & & 2,87 & 2,41 & 1,86 & 2,03 & & & & \\
\hline $\mathrm{Gd}$ & & & 10,77 & 16,64 & 9,71 & 7,43 & & & & \\
\hline $\mathrm{Tb}$ & & & 1,74 & 2,83 & 1,52 & 1,18 & & & & \\
\hline Dy & & & 8,94 & 14,52 & 4,43 & 6,28 & & & & \\
\hline Ho & & & 1,56 & 2,84 & 1,37 & 1,25 & & & & \\
\hline $\mathrm{Er}$ & & & 4,72 & 8,60 & 3,47 & 3,38 & & & & \\
\hline $\mathrm{Tm}$ & & & 0,98 & 1,79 & 0,84 & 0,50 & & & & \\
\hline $\mathrm{Yb}$ & & & 4,86 & 9,36 & 4,97 & 2,92 & & & & \\
\hline Lu & & & 0,61 & 1,36 & 0,80 & 0,67 & & & & \\
\hline $\mathrm{Pb}$ & & & 115,32 & 122,40 & 84,97 & & & & & \\
\hline Th & & & 9,99 & 18,55 & 6,13 & 7,57 & & & & \\
\hline U & & & 2,41 & 5,24 & 43,00 & 0,85 & & & & \\
\hline Sc & & & 9,67 & 1,34 & 4,73 & & & & & \\
\hline $\mathrm{V}$ & & & 50,27 & 18,05 & 21,34 & 69,99 & & & & \\
\hline Co & & & 7,36 & 5,47 & 0,69 & & & & & \\
\hline $\mathrm{Cu}$ & & & 30,54 & 42,66 & 86,52 & 77,15 & & & & \\
\hline $\mathrm{Zn}$ & & & 83,02 & 140,29 & 137,02 & 186,86 & & & & \\
\hline $\mathrm{Pr}$ & & & 10,34 & 21,39 & 11,38 & 11,83 & & & & \\
\hline$Q$ & 1,69 & 2,48 & 2,10 & 2,42 & - & 0,41 & 19,05 & 16,57 & 9,46 & 8,96 \\
\hline C & - & - & - & - & - & - & 2,53 & 1,88 & - & - \\
\hline or & 23,66 & 23,26 & 22,94 & 22,25 & 29,29 & 23,66 & 21,70 & 22,89 & 29,01 & 28,21 \\
\hline$a b$ & 47,97 & 46,68 & 47,02 & 46,52 & 44,70 & 46,70 & 46,91 & 48,90 & 51,07 & 50,45 \\
\hline an & 7,64 & 8,92 & 8,43 & 9,27 & 0,12 & 9,72 & 2,93 & 3,27 & 2,06 & 3,34 \\
\hline ne & - & - & - & - & 2,21 & - & - & - & - & - \\
\hline di (Wo) & 2,61 & 2,52 & 2,74 & 2,85 & 2,70 & 1,55 & - & - & 0,71 & 0,04 \\
\hline di (En) & 0,83 & 0,78 & 0,86 & 0,90 & 0,09 & 0,51 & - & - & 0,05 & 0,00 \\
\hline di (Fs) & 1,88 & 1,84 & 1,98 & 2,06 & 2,96 & 1,09 & - & - & 0,74 & 0,04 \\
\hline hi (En) & 3,00 & 2,89 & 3,02 & 2,97 & - & 3,80 & 0,42 & 0,37 & 0,33 & 0,52 \\
\hline hi (Fs) & 6,83 & 6,84 & 6,92 & 6,82 & - & 8,13 & 5,01 & 4,67 & 4,97 & 6,55 \\
\hline ol (Fo) & - & - & - & - & 0,34 & - & - & - & - & - \\
\hline ol (Fa) & - & - & - & - & 12,05 & - & - & - & - & - \\
\hline $\mathrm{mt}$ & 1,54 & 1,53 & 1,57 & 1,56 & 2,87 & 1,65 & 0,82 & 0,77 & 0,92 & 1,07 \\
\hline ilm & 1,75 & 1,76 & 1,83 & 1,78 & 0,61 & 2,07 & 0,54 & 0,57 & 0,55 & 0,63 \\
\hline ap & 0,53 & 0,44 & 0,53 & 0,53 & 0,20 & 0,64 & 0,09 & 0,09 & 0,11 & 0,15 \\
\hline $\mathrm{R} 1$ & 896 & 965 & 946 & 988 & 371 & 862 & 1659 & 1513 & 1071 & 1058 \\
\hline $\mathrm{R} 2$ & 732 & 746 & 756 & 779 & 459 & 743 & 403 & 412 & 407 & 409 \\
\hline $\mathrm{mg} \#$ & 0,32 & 0,31 & 0,32 & 0,32 & 0,04 & 0,33 & 0,09 & 0,08 & 0,07 & 0,08 \\
\hline I.A. & 0,83 & 0,80 & 0,81 & 0,79 & 1,00 & 0,79 & 0,78 & 0,82 & 0,95 & 0,92 \\
\hline I.C. & 19,21 & 18,80 & 19,68 & 19,71 & 21,97 & 18,80 & 6,78 & 6,38 & 8,27 & 9,06 \\
\hline I.D. & 73,17 & 72,28 & 71,89 & 71,02 & 77,94 & 70,77 & 87,65 & 88,36 & 89,53 & 87,61 \\
\hline $\mathrm{Eu} / \mathrm{Eu}^{*}$ & & & 0,89 & 0,44 & 0,59 & 0,78 & & & & \\
\hline$(\mathrm{La} / \mathrm{Sm})$ & & & 3,30 & 3,55 & 2,96 & 1,58 & & & & \\
\hline$(\mathrm{Gd} / \mathrm{Yb})_{\mathrm{N}}$ & & & 1,80 & 1,44 & 1,58 & 2,06 & & & & \\
\hline$(\mathrm{La} / \mathrm{Yb})_{\mathrm{N}}$ & & & 6,62 & 6,92 & 6,13 & 5,00 & & & & \\
\hline
\end{tabular}

Legenda: Morro de São João - hipoabissais: 1 (12), 2 (18), 3 (30), 4 (37), 5 (19) e 6 (9B); intrusivas: 7 (2) a 32 (29); Morrete: 33 (40), 34 (50), 35 $(51 B)$ e $36(51 A)$. Abreviações: As, álcali feldspato sienito; $Q s$, quartzo-álcali feldspato sienito; $m S$, microssienito com textura em mosaico; Tq, microssienito porfirítico com textura traquítica; classificação petrográfica com base em dados modais, cf. Streckeisen (1976). 
O gráfico classificatório R1-R2 segundo De La Roche et al. (1980) e De La Roche (1986) (Fig. 33) situa as amostras estudadas dominantemente no campo dos sienitos, com pequena incursão no campo dos quartzo sienitos, notadamente para as variedades hipoabissais. Três amostras intrusivas do Morrete caem no campo dos quartzo sienitos e uma no dos granitos alcalinos.

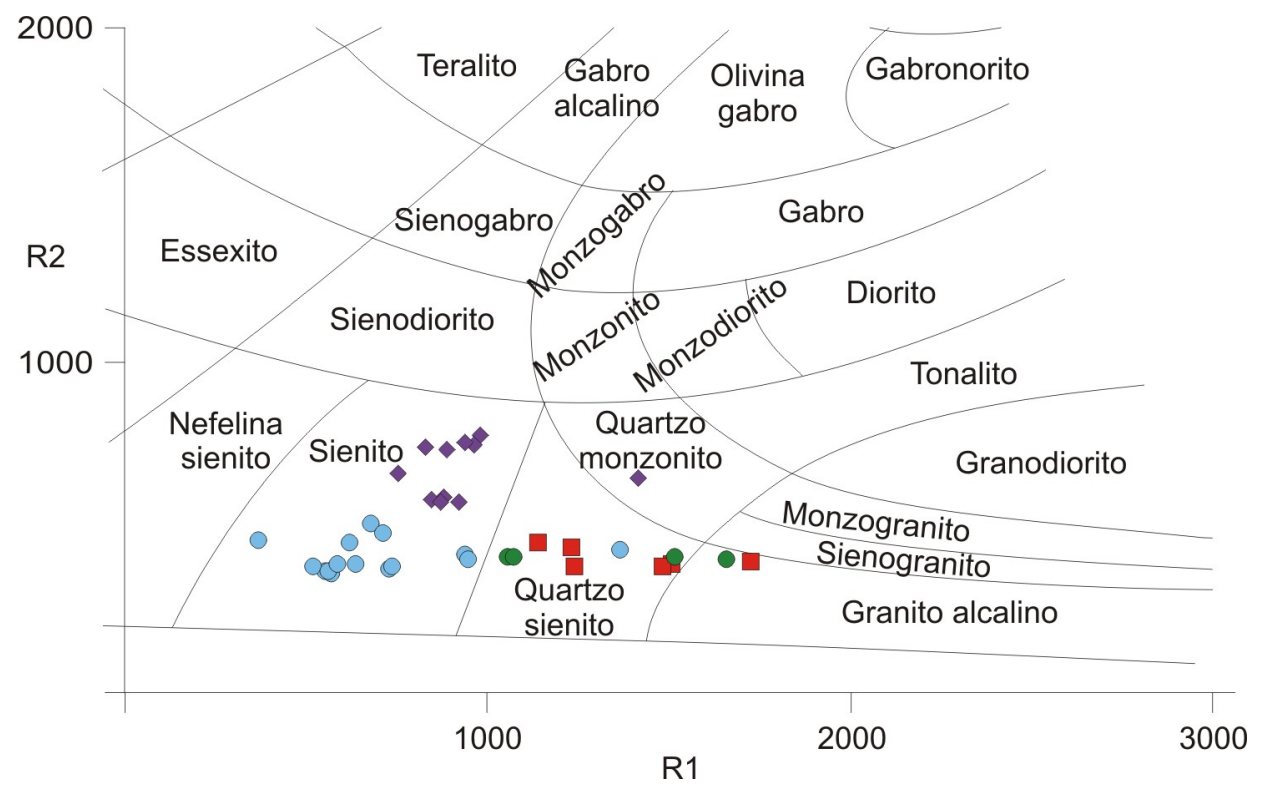

Figura 33. Diagrama R1-R2 (R1=4Si-11(Na+K)-2(Fe+Ti); R2=6Ca-2Mg+Al; cf. De La Roche et al., 1980; De La Roche, 1986) para as rochas de Cananéia. Símbolos como na Figura 7.

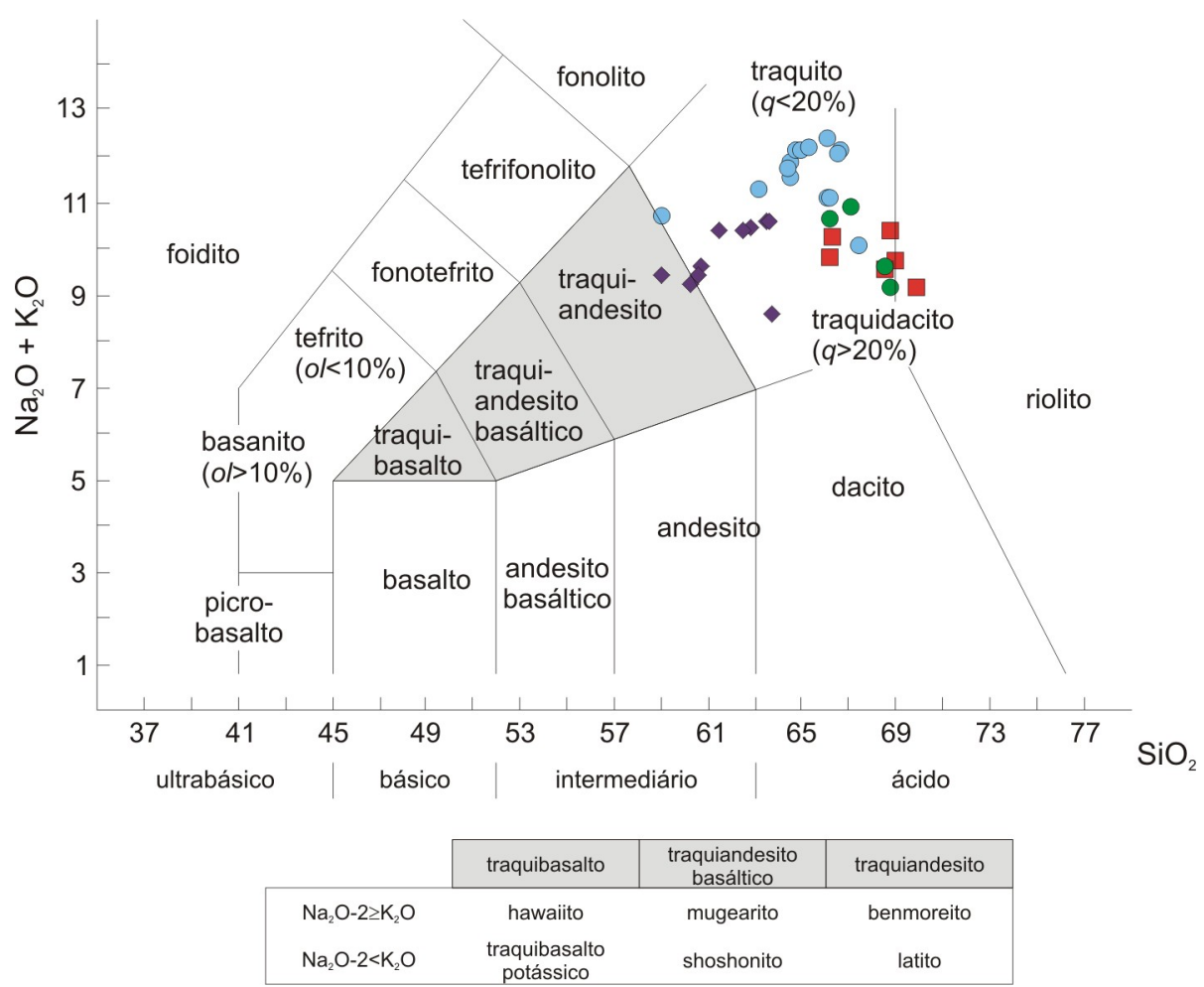

Figura 34. Diagrama TAS (cf. LeMaitre et al., 2003). para as rochas de Cananéia. O campo de cor cinza no diagrama está subdividido conforme a tabela. Abreviações: ol=olivina normativa e $q=Q /(Q+o r+a b+a n)$ normativos X100. Símbolos como na Figura 7.

Quando projetadas no diagrama TAS (Fig. 34, cf. LeMaitre et al., 2003), nota-se que a quase totalidade das rochas de Cananéia ocupa os campos dos traquitos e traquidacitos evidenciando, a exemplo da figura anterior, a sua natureza fortemente alcalina e a riqueza em sílica. 
A Figura 33 e a Tabela 23 demonstram que as rochas de Cananéia têm grau de saturação em sílica variado, sendo no geral saturadas (sienitos) a ligeiramente supersaturadas (quartzo sienitos).

As análises químicas indicam também o seu alto grau de evolução, com os valores para o índice de diferenciação (I.D. $=\mathrm{Q}+\mathrm{Or}+\mathrm{Ab}+\mathrm{Ne}+\mathrm{Ks}+\mathrm{Lc}$ ) de Thornton e Tuttle (1960) compreendidos no intervalo de $72-95 \%$ (Tabela 23). O pronunciado enriquecimento em álcalis e o concomitante empobrecimento em ferro e magnésio dessas rochas é também sugerido por sua mineralogia, onde os feldspatos aparecem como fase dominante. Adicionalmente, esse caráter evoluído é demonstrado pelos teores muito baixos da razão $\mathrm{Mg} / \mathrm{Mg}+\mathrm{Fe}$ (mg\# inferior a 0,33, mas em 27 das 36 análises abaixo de 0,25 ) e pelas baixas concentrações em $\mathrm{Cr}$ e Ni. No conjunto, as rochas de Cananéia exibem uma variação química contínua dominada pelos álcalis, a sugerir que cristalização fracionada foi um mecanismo atuante na sua formação.

Diagramas de Harker para elementos maiores e menores foram empregados para mostrar as variações químicas presentes (Figs. 35 a 37). No geral, as intrusivas sieníticas apresentam correlações positivas para $\mathrm{Al}_{2} \mathrm{O}_{3}, \mathrm{Na}_{2} \mathrm{O}$ e $\mathrm{K}_{2} \mathrm{O}$ em relação à concentração de $\mathrm{SiO}_{2}$, a despeito da dispersão dos teores de álcalis em algumas análises, e negativas para $\mathrm{TiO}_{2}, \mathrm{FeO}_{\mathrm{T}}, \mathrm{MnO}, \mathrm{MgO}, \mathrm{CaO}$ e $\mathrm{P}_{2} \mathrm{O}_{5}$ (Fig. 35). As variedades hipoabissais mostram comportamento variável, ora similar ao dos tipos intrusivos, ora formando agrupamento à parte, como indicado para $\circ \mathrm{Al}_{2} \mathrm{O}_{3}, \mathrm{Na}_{2} \mathrm{O}, \mathrm{K}_{2} \mathrm{O}$ e mesmo $\mathrm{MnO}$. Essa última tendência é também notada para alguns óxidos (p.e. $\mathrm{Al}_{2} \mathrm{O}_{3}$ e $\mathrm{Na}_{2} \mathrm{O}$ ) nas amostras do corpo do Morrete.

A análise conjunta dos dados para as rochas intrusivas e hipoabissais indica maior dispersão dos elementos traços quando comparados com os maiores, ainda que correlações negativas com o teor de $\mathrm{SiO}_{2}$ possam ser sugeridas para os elementos $\mathrm{Cr}$, Ni, $\mathrm{Sr}$ e $\mathrm{Ba}$ (Figs. 36 e 37) e positivas para Rb, $\mathrm{Nb}$ e Zr (Fig. 36).

Em todas essas figuras merece registro a posição isolada da amostra $15 \mathrm{~A}$, um sienito do Morro de São João (modalmente um quartzo-álcali feldspato sienito, ver Fig. 7 e Tabela 23), contendo nefelina e olivina faialítica em sua composição normativa, e exibindo teores muito discrepantes seja para os elementos maiores, como também para os traços comparativamente às demais rochas.

No geral, as composições modais e normativas das rochas de Cananéia são semelhantes. As diferenças notadas resultam principalmente das concentrações de quartzo e da presença de coríndon normativo em algumas amostras. A maior discrepância aparece na amostra $15 \mathrm{~A}$, que contém $6,5 \%$ de quartzo na moda e, por outro lado, traz $2,21 \%$ de nefelina e $12,05 \%$ de olivina na norma. Esta última grande discordância poderia ser explicada pelo fato de a amostra encaminhada para a análise de química global apresentar uma variação mineralógica localizada, que se reflete na sua maior concentração de $\mathrm{FeO}_{\mathrm{T}}$ e menor de $\mathrm{Al}_{2} \mathrm{O}_{3}$ em relação às demais rochas sieníticas, levando à formação de olivina normativa e, conseqüentemente, à ausência de quartzo.

Vistas no seu todo, as variações químicas observadas são indicativas de que processos de cristalização fracionada tiveram papel marcante na formação das rochas sieníticas, como sugerido pela mineralogia presente, notadamente a grande riqueza em feldspatos. Contudo, o fato de os microssienitos e também algumas amostras de quartzo-álcali feldspato sienitos situarem-se fora da curva de tendência geral para as rochas da intrusão, parecendo mesmo integrar outro agrupamento, como visível nos gráficos envolvendo principalmente $\mathrm{Al}_{2} \mathrm{O}_{3}, \mathrm{CaO}$ e os álcalis, é sugestivo de que outros processos tenham também interferido na geração dessas litologias. 

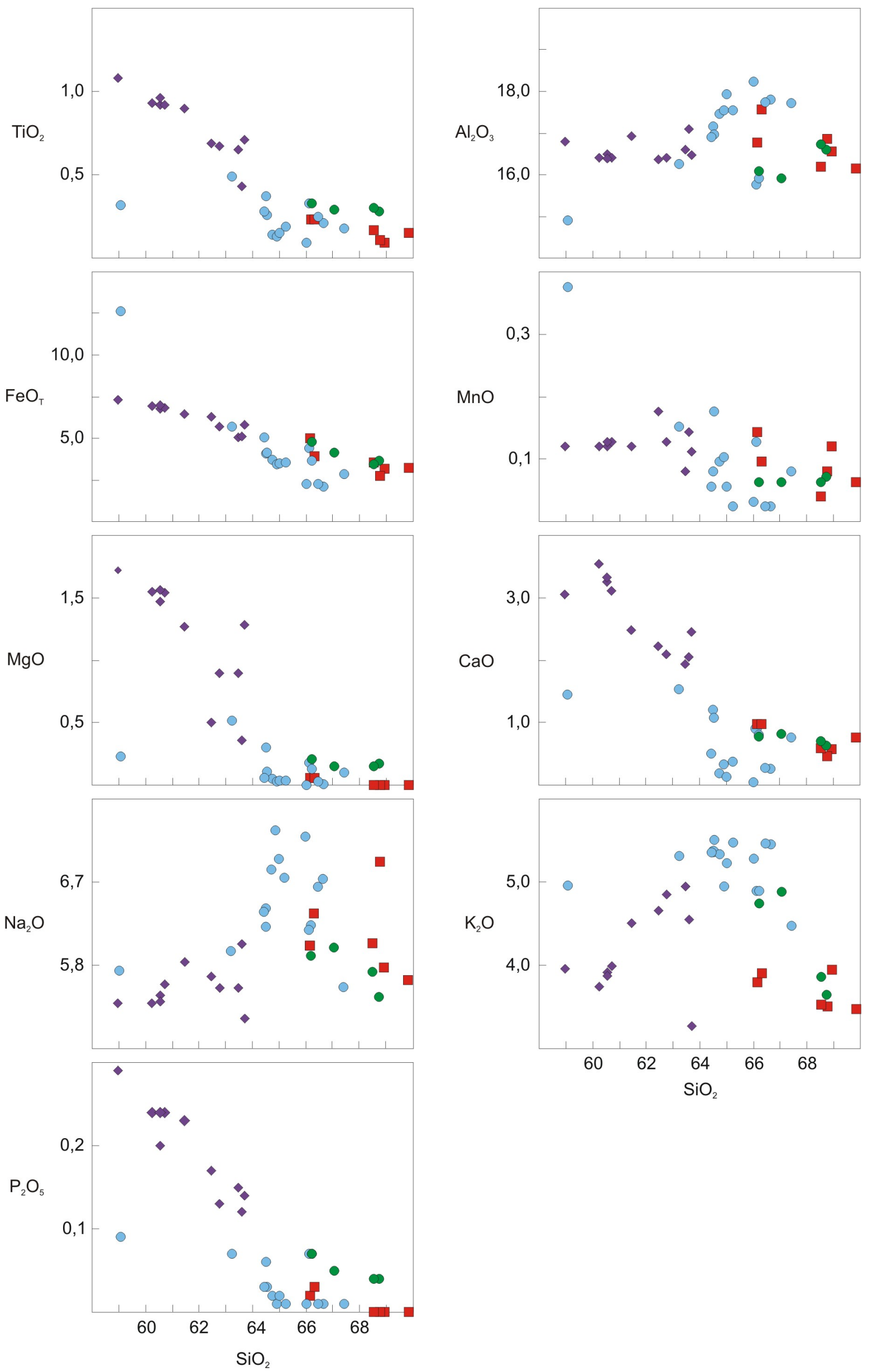

Figura 35. Diagramas relacionando os elementos maiores com a concentração de sílica para as rochas de Cananéia. Símbolos como na Figura 7. 

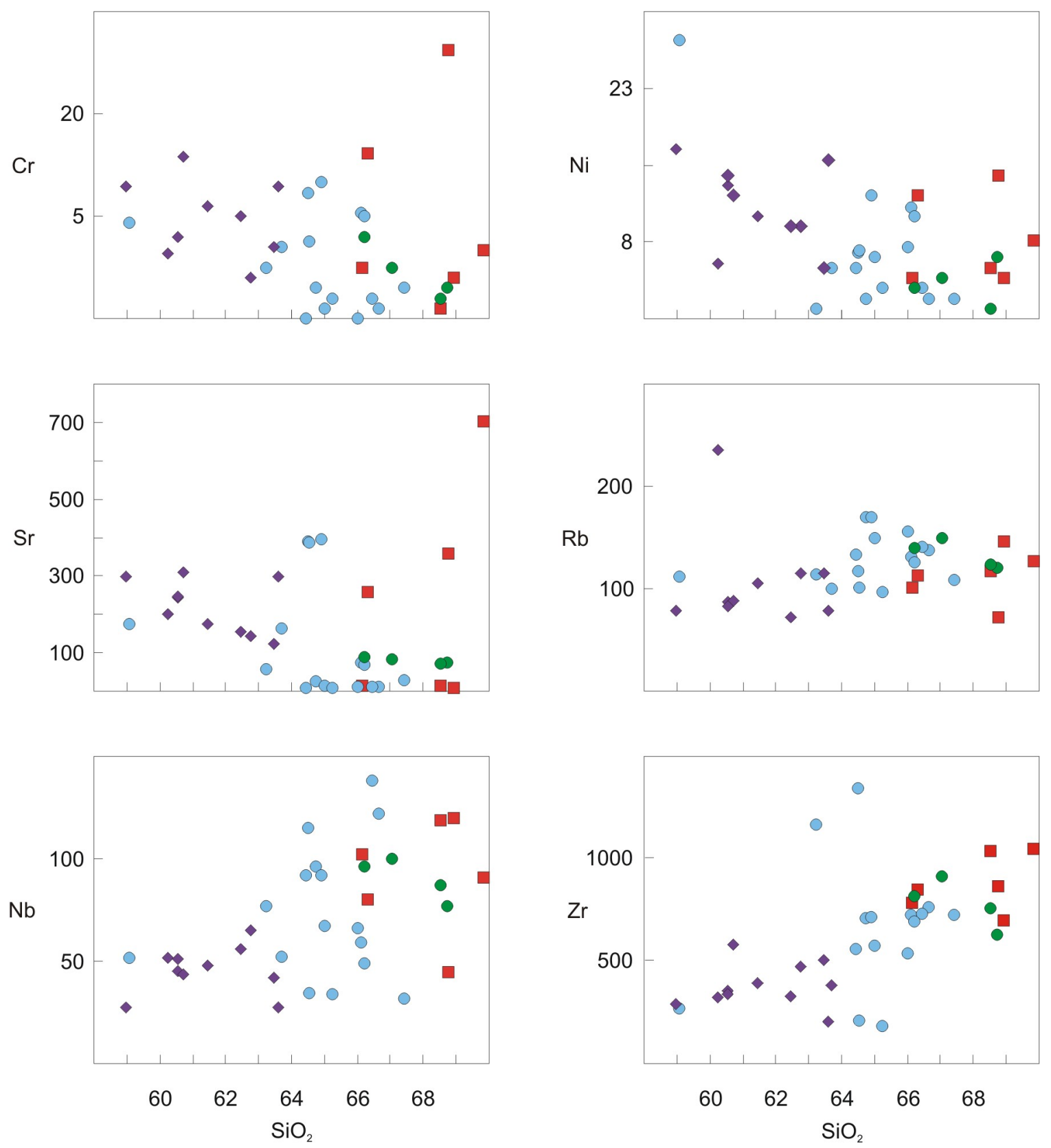

Figura 36. Diagramas relacionando os elementos menores com a concentração de sílica para as rochas de Cananéia. Símbolos como na Figura 7.

O comportamento dos elementos incompatíveis (EI) normalizados para o manto primitivo (McDonough e Sun, 1995), como ilustrado nas Figuras 38A e B, mostra pronunciada anomalia negativa em Sr, $\mathrm{P}$ e Ti. Zr e Nd exibem visível anomalia positiva, enquanto no $\mathrm{La}$ e $\mathrm{Y}$ ela é mais discreta. Ba apresenta anomalia positiva e negativa, respectivamente, para as rochas menos e mais evoluídas. A leitura dos dados da Tabela 23 demonstra que o teor de Ba é extremamente variável (43 a $2242 \mathrm{ppm}$ ), tendendo a ser maior nos álcali feldspato sienitos, menor nos quartzo-álcali feldspato sienitos e consideravelmente menor junto às rochas de diques. A existência de duas suítes principais, uma mais rica em Ba (>500 ppm) e outra mais pobre (200 $\pm 84 \mathrm{ppm})$, como já apontado por Ruberti et al. (2005), é também sugerida na Figura 38A.

No geral, a distribuição dos elementos incompatíveis em Cananéia apresenta grandes similaridades com aquela observada em distritos alcalinos brasileiros, sem carbonatitos, reunindo rochas evoluídas (Morbidelli et al., 1995). 

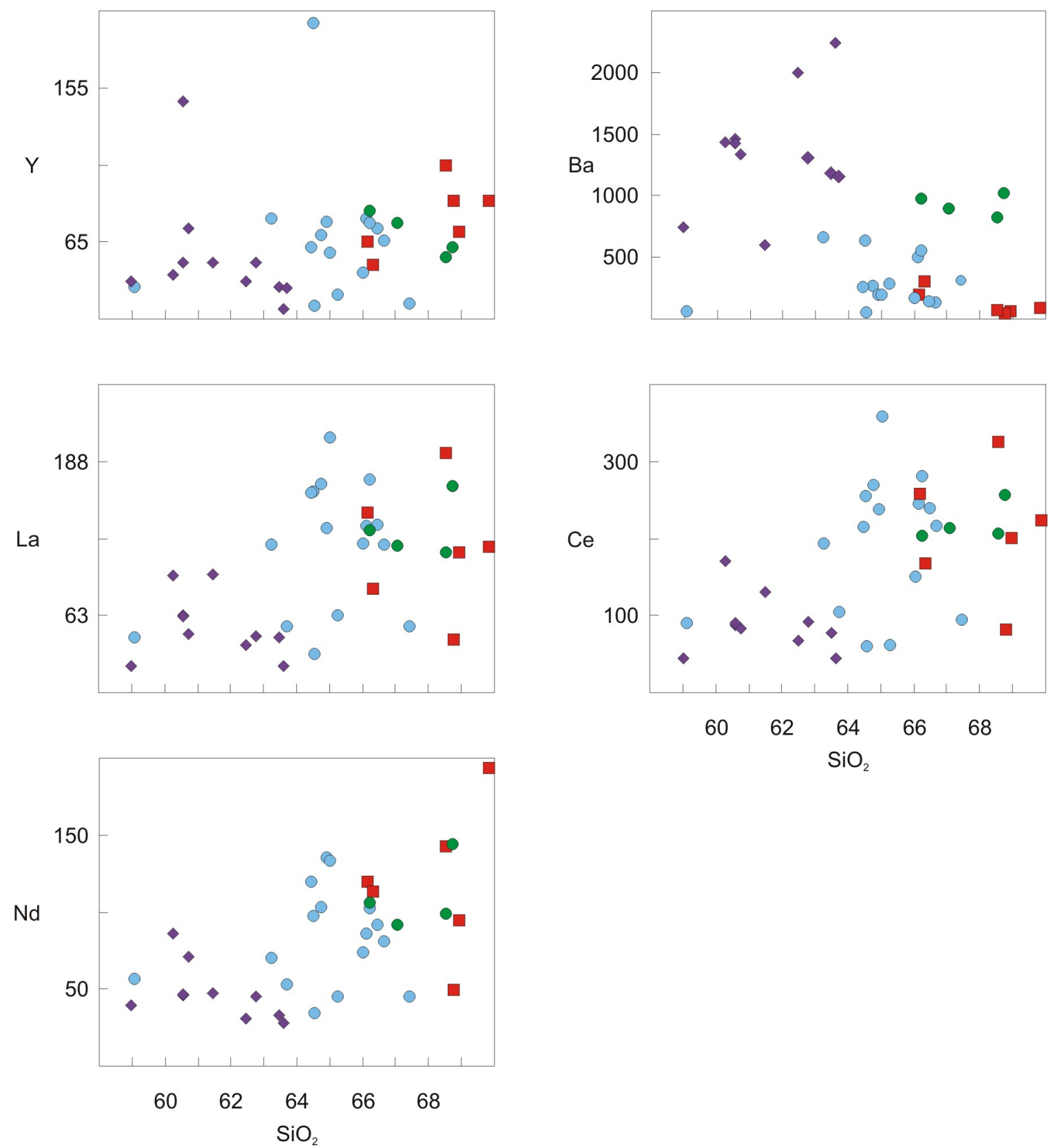

Figura 37. Diagramas relacionando os elementos menores com a concentração de sílica para as rochas de Cananéia. Símbolos como na Figura 7.

A distribuição dos elementos Terras Raras (ETR) normalizados para os condritos (McDonough e Sun, 1995), é caracterizada pela alta concentração em TRP e fracionamento das TRL em relação às TRP, típico de séries alcalinas em geral (Fig. 39). A salientar ainda a mudança de comportamento das TRM e TRP, que se torna mais uniforme, muito provavelmente devido à remoção do líquido de uma ou mais fases com alto coeficiente de partição cristal/líquido, como apatita e titanita, durante o processo de diferenciação magmática (Gomes et al., 1987). Esse último padrão de distribuição, onde a curva de distribuição assume por vezes para as TRM e TRP forma caracteristicamente mais côncava, é também comum às rochas de natureza "sienítica" presentes em muitas ocorrências alcalinas brasileiras (p.e. Piratini, Barbieri et al., 1987; Tunas, Gomes et al., 1987; Morro Redondo, Brotzu et al., 1989; Lages, Traversa et al., 1996; Passa Quatro, Brotzu et al., 1992, entre outras).

A razão $L a_{N} / Y_{b_{N}}$ varia de 5,00 a 9,36 para as rochas intrusivas, podendo excepcionalmente atingir até 58,80 na amostra do quartzo-álcali feldspato sienito $9 \mathrm{~A}$. O enriquecimento em ETR é 
levemente maior nos quartzo-álcali feldspato sienitos $\left(\mathrm{La}_{N} / \mathrm{Sm}_{N}: 1,58-12,44 ; \mathrm{Ga}_{N} / \mathrm{Yb}_{N}: 1,51-2,46\right)$ quando comparado ao dos álcali feldspato sienitos $\left(\operatorname{La}_{N} / \mathrm{Sm}_{N}: 1,58\right.$ a 6,$\left.60 ; \mathrm{Ga}_{N} / \mathrm{Yb}_{N}: 1,44-2,06\right)$, contudo, a curva de distribuição dos ETR para as duas litologias é muito similar entre si, notando-se apenas maior dispersão nos valores das razões $\operatorname{La}_{N} / \mathrm{Yb}_{N}(5,00-28,41)$ e $\mathrm{La}_{N} / \mathrm{Sm}_{N}(1,58-12,44)$ e menor na de $\mathrm{Ga}_{\mathrm{N}} / \mathrm{Yb}_{\mathrm{N}}(1,44-2,46)$ (Fig. 39A).

Já o padrão para as hipoabissais é semelhante ao das intrusivas (Fig. 39B), apresentando as mesmas características gerais e uma razão $L a_{N} / Y b_{N}$ variável de 7,53 a 9,36. Por sua vez, os valores das razões $\mathrm{La}_{N} / \mathrm{Sm}_{N}(3,00$ a 4,06$)$ e $\mathrm{Gd}_{N} / \mathrm{Yb}_{N}(1,51$ a 2,18$)$ situam-se dentro do intervalo definido acima para os álcali feldspato sienitos e quartzo-álcali feldspato sienitos.

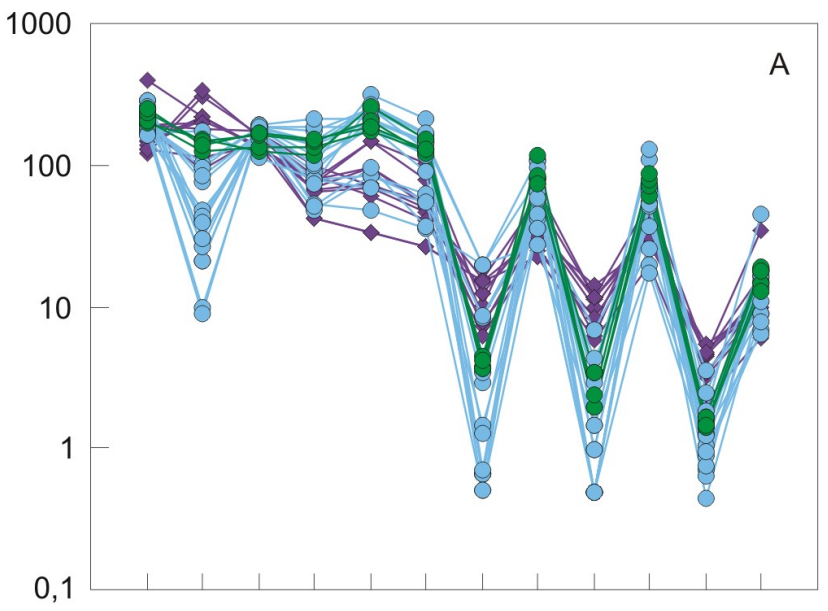

$\mathrm{Rb} B \mathrm{Ba} \mathrm{K}$ Nb La Ce $\mathrm{Sr} N \mathrm{Nd} \quad \mathrm{P} \quad \mathrm{Zr} \quad \mathrm{Ti} \quad \mathrm{Y}$

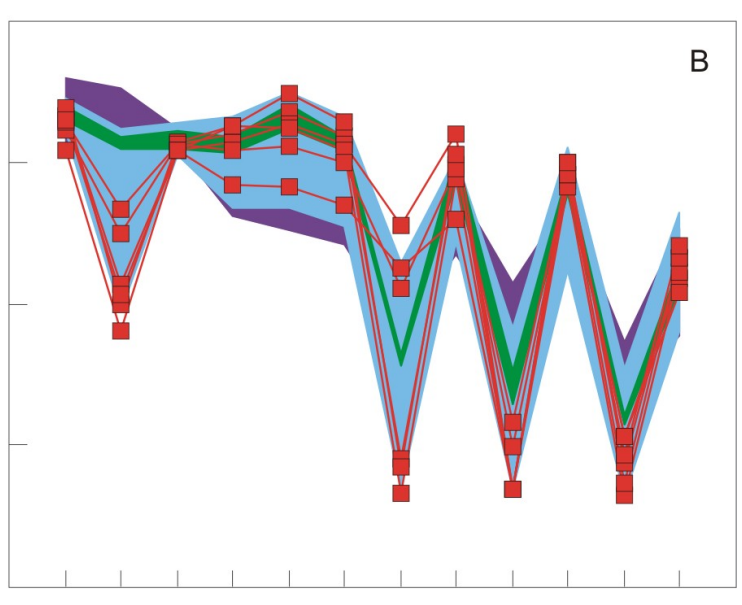

$\mathrm{Rb} \mathrm{Ba} \mathrm{K} \mathrm{Nb}$ La Ce Sr Nd P Zr Ti Y

Figura 38. Diagramas do tipo spider para elementos incompatíveis normalizados para o manto primitivo (McDonough e Sun, 1995). O gráfico A contém os pontos referentes às rochas intrusivas do Morro de São João e do Morrete; já o $B$ reúne os microssienitos do Morro de São João, ao lado dos campos relativos às variedades intrusivas. Símbolos como na Figura 7.

Ainda a ressaltar que as rochas de Cananéia exibem pronunciada anomalia negativa de Eu $\left(E u / E u^{*}=0,20\right.$ a 0,89$)$ (Figs. 39A, B), possivelmente devida a importante processo de remoção de feldspato, como já observado anteriormente por Ruberti et al. (2005).

A grande dispersão dos pontos impede que se tirem conclusões da Figura 40, não obstante uma correlação positiva para as razões $\left.(\mathrm{La} / \mathrm{Sm})_{\mathrm{N}}, \mathrm{Gd} / \mathrm{Yb}\right)_{\mathrm{N}}$ e $(\mathrm{La} / \mathrm{Yb})_{\mathrm{N}}$ com o teor de sílica possa ser sugerida (Figs. 40A-C) e, menos evidente ainda, uma correlação negativa para a razão Eu/Eu* (Fig. 40D).

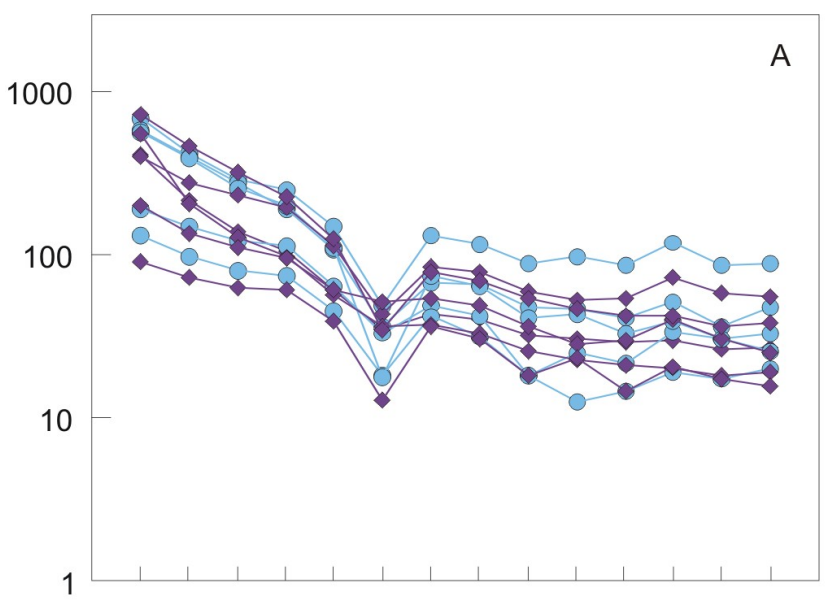

La Ce Pr Nd Sm Eu Gd Tb Dy Ho Er Tm Yb Lu

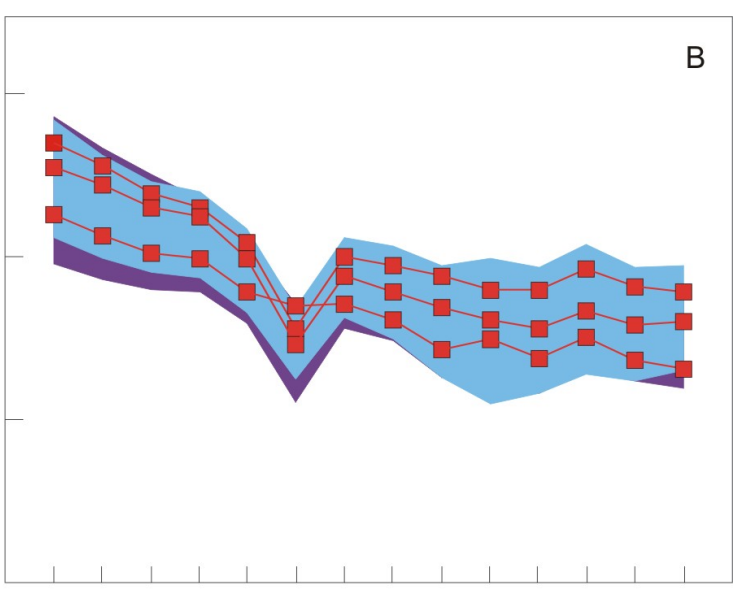

La Ce Pr NdSm Eu Gd Tb Dy Ho Er Tm Yb Lu

Figura 39. Diagramas de elementos Terras Raras normalizados para os condritos (McDonough e Sun, 1995). O gráfico A contém os pontos referentes às variedades intrusivas do Morro de São João; já o B reúne os campos de distribuição dessas rochas e os pontos relativos às hipoabissais do Morro de São João. Símbolos como na Figura 7. 

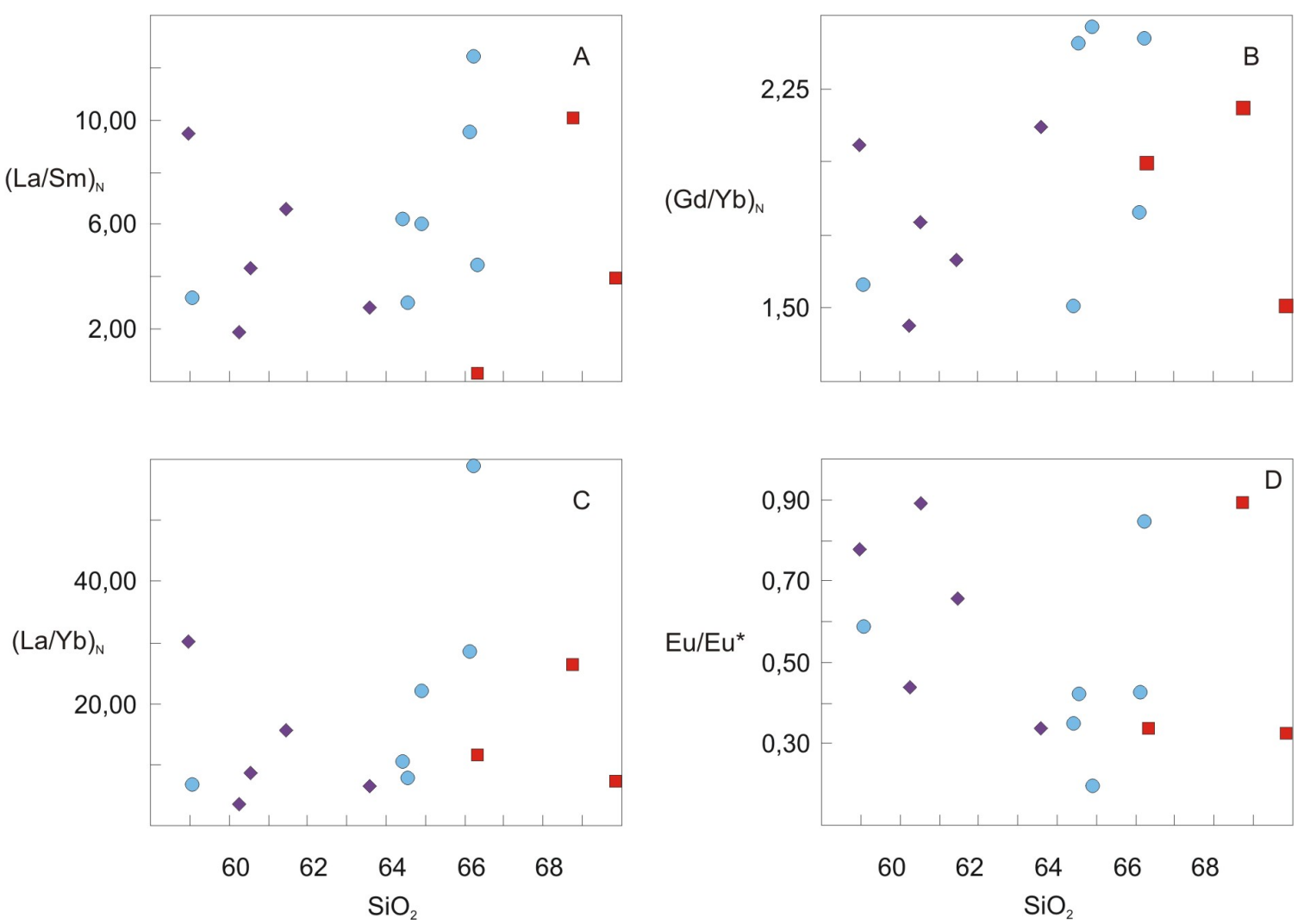

Figura 40. Diagramas $\mathrm{SiO}_{2}$ vs. $(\mathrm{La} / \mathrm{Sm})_{\mathrm{N}},(\mathrm{La} / \mathrm{Yb})_{\mathrm{N}},(\mathrm{Gd} / \mathrm{Yb})_{\mathrm{N}}$ e $\left(\mathrm{Eu}^{\mathrm{E}} \mathrm{Eu}^{*}\right)_{\mathrm{N}}$. Elementos normalizados segundo o Condrito $\mathrm{C} 1 \mathrm{de}$ McDonough e Sun (1995). Símbolos como na Figura 7. 


\section{GEOCRONOLOGIA}

Neste capítulo estão agrupados os resultados geocronológicos obtidos pelos métodos $\mathrm{Rb} / \mathrm{Sr}, \mathrm{K} / \mathrm{Ar}$ e $\mathrm{Ar} / \mathrm{Ar}$ em rocha total e concentrados minerais para as rochas de Cananéia, fornecendo idades convencionais e a correspondente idade magmática.

\subsection{Método $\mathrm{Rb} / \mathrm{Sr}$}

As datações $\mathrm{Rb} / \mathrm{Sr}$ foram efetuadas em rocha total e em concentrados minerais (feldspato alcalino, biotita e clinopiroxênio+anfibólio), com a Tabela 24 reunindo os dados analíticos produzidos. Uma isócrona de referência em rocha total, obtida a partir de onze pontos, indica para as rochas de Cananéia uma idade de $83,5 \pm 2,2 \mathrm{Ma}$, além de razão inicial ${ }^{87} \mathrm{Sr} /{ }^{86} \mathrm{Sr}$ de $0,70686 \pm 0,00070$ e MSWD=52 (Fig. 41A). Já o diagrama da Figura 41B exibe isócrona mineral construída a partir de cinco pontos, apresentando idade de $84,1 \pm 7,5 \mathrm{Ma}$, razão inicial ${ }^{87} \mathrm{Sr} /{ }^{86} \mathrm{Sr}$ de $0,7066 \pm 0,0080$ e $\mathrm{MSWD}=77$.

Um diagrama isocrônico incluindo a totalidade dos dezesseis pontos analíticos sugere para essa rocha uma idade de $84 \pm 2 \mathrm{Ma}$, com razão inicial de 0,7068 $\pm 0,0013$ e MSWD=50 (Fig. 42). Esse resultado confirma os valores fornecidos nas isócronas das Figuras $41 \mathrm{~A}, \mathrm{~B}$, posicionando a intrusão no Cretáceo Superior.

Por outro lado, essas novas idades $\mathrm{Rb} / \mathrm{Sr}$ são um pouco mais antigas que aquelas fornecidas anteriormente por Spinelli (2000) e Spinelli et al. (2001), respectivamente, de 78,0 $\pm 1,9$ Ma e 76,2 $\pm 1,5$ Ma.
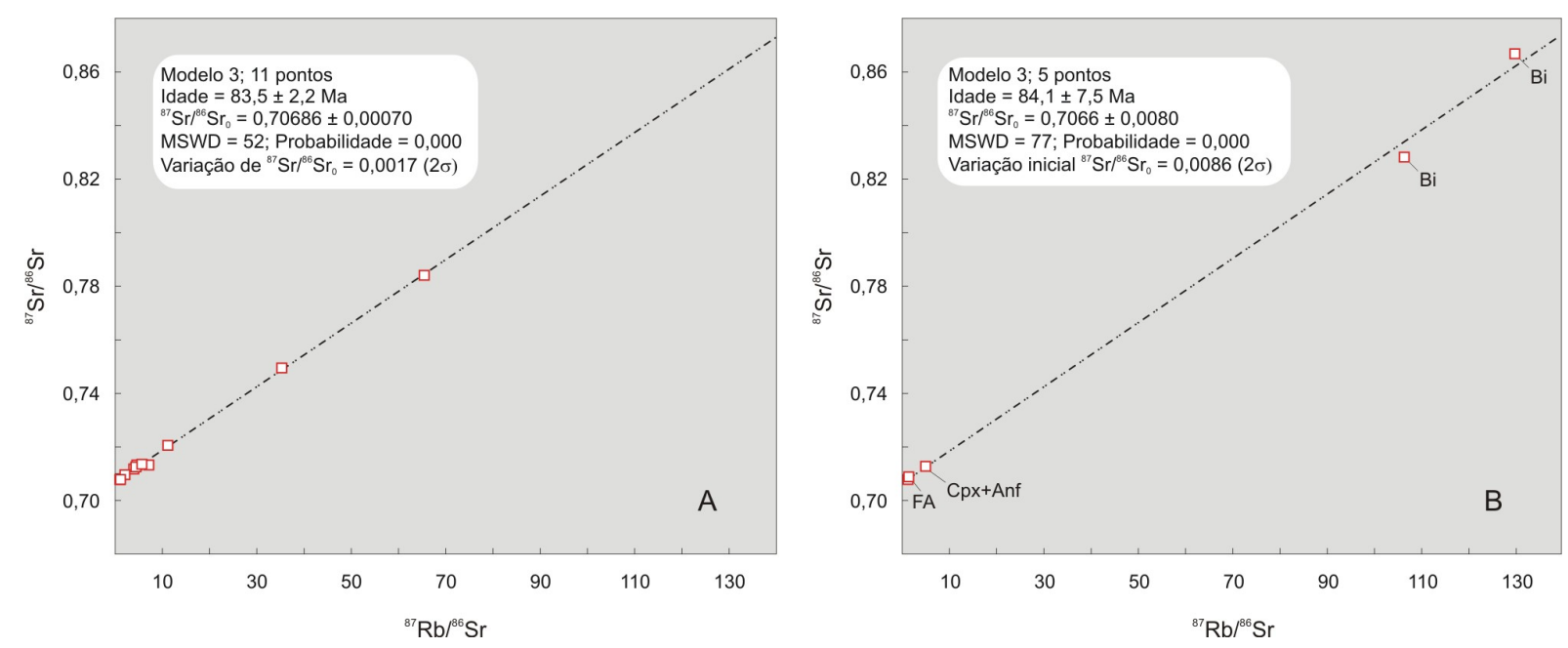

Figura 41. Idades $\mathrm{Rb} / \mathrm{Sr}$ em rocha total $(\mathrm{A})$ e em concentrados minerais (B) para as rochas de Cananéia. 


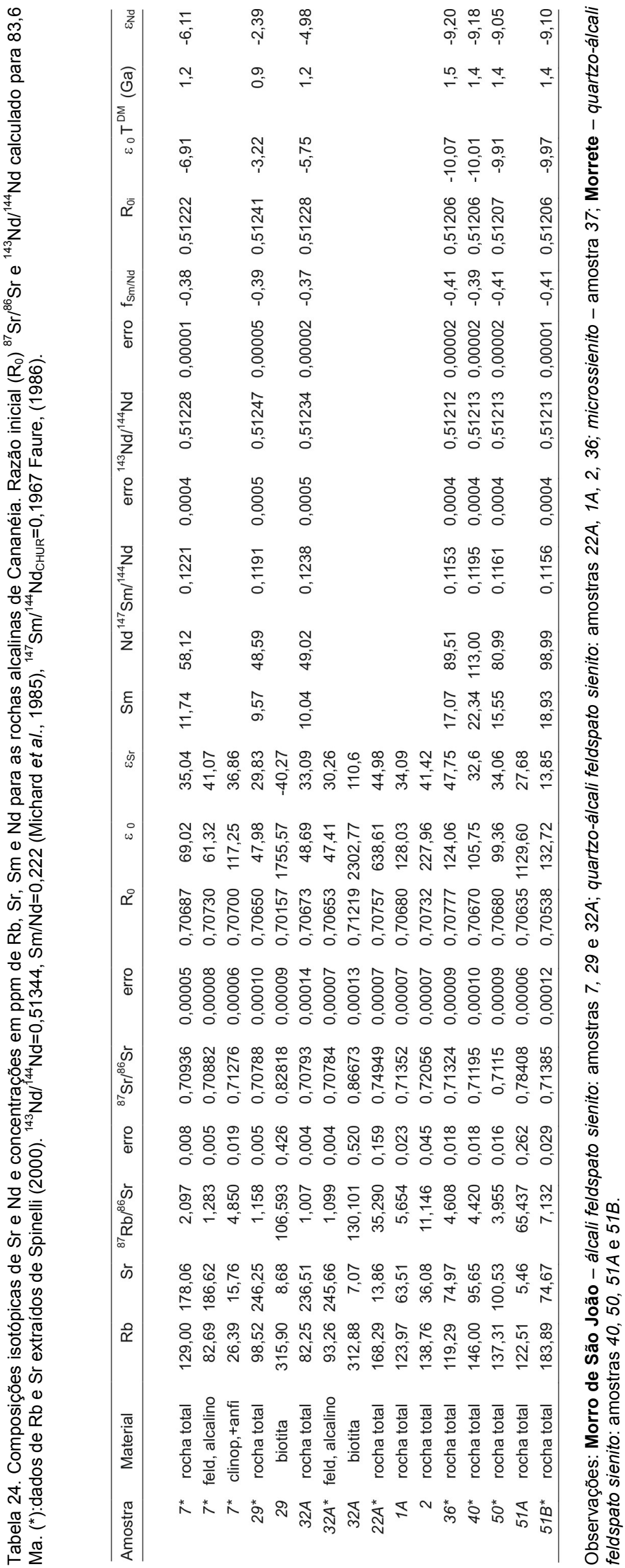




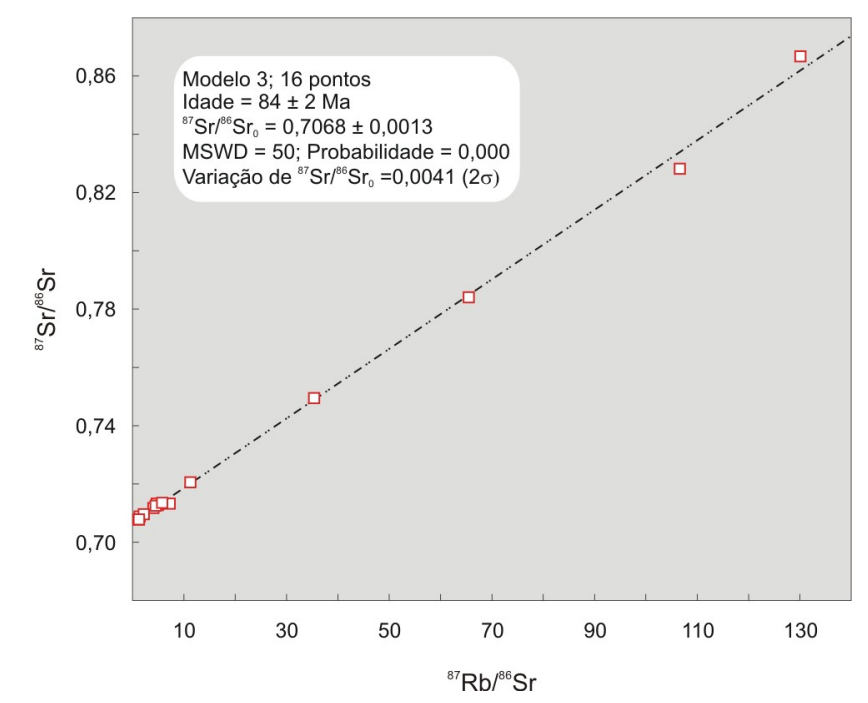

Figura 42. Diagrama ${ }^{87} \mathrm{Rb} /{ }^{86} \mathrm{Sr}$ vs. ${ }^{87} \mathrm{Sr} /{ }^{86} \mathrm{Sr}$ para as rochas de Cananéia.

\subsection{Método $\mathrm{K} / \mathrm{Ar}$}

A primeira referência sobre determinações radiométricas pelo método $\mathrm{K} / \mathrm{Ar}$ em rochas alcalinas da Plataforma Sul-Americana é de Amaral et al. (1967), reunindo um total de 66 idades para 21 ocorrências, datadas seja a partir de rocha total, seja de concentrados minerais (micas, feldspatos e anfibólios). Com base nesses valores, os autores distinguiram dois grupos cronológicos distintos: um do Cretáceo Inferior, com idade variável de 133 a 122 Ma, e o outro, do Cretáceo Superior ao Terciário, com idade compreendida no intervalo de 82 a $51 \mathrm{Ma}$. O primeiro grupo é tido como contemporâneo ao vulcanismo basáltico da Bacia do Paraná.

Muito posteriormente, Sonoki e Garda (1988) compilaram um acervo de dados constando de 295 idades K/Ar de 52 ocorrências alcalinas do Brasil Meridional e Paraguai Oriental. As idades foram recalculadas usando as constantes de decaimento recomendadas por Steiger e Jäeger (1977), sendo a estimativa de erro analítico dada em função das condições experimentais (Cox e Dalrymple, 1967).

Outras publicações também se ocuparam do tema, trazendo inclusive novos dados, como as de Brotzu et al. (1989, 1992, 1997), Bellieni et al. (1990), Garda et al. (1995) e Thompson et al. (1998), enquanto o trabalho de Ulbrich et al. (1991) ofereceu uma reavaliação crítica das idades K/Ar então disponíveis para os maciços alcalinos do Brasil Meridional e Paraguai Oriental.

As primeiras idades K/Ar determinadas para as rochas de Cananéia são de Amaral et al. (1967, dados recalculados por Sonoki e Garda, 1988) e variam de 82,7 a 86,6 Ma, tendo sido obtidas em concentrados minerais (biotita, 82,7 Ma; anfibólio, 84,2 Ma; feldspato alcalino, 86,6 Ma) de uma amostra de quartzo-álcali feldspato sienito.

\subsection{Método $\mathrm{Ar} / \mathrm{Ar}$}

As determinações geocronológicas por este método foram realizadas em concentrados de biotita provenientes de quatro amostras da intrusão principal, duas relativas aos álcali feldspato sienitos $7 \mathrm{e}$ 29, e duas aos quartzo-álcali feldspato sienitos 36 e 9A. Essas novas idades estão representadas nas Figuras 43 a 46, com os dados analíticos constando da Tabela 25.

Os diagramas (Figs. 43A-C) de extração de argônio de três grãos de biotita da amostra 7 apresentam idades platôs de $83,0 \pm 0,3 \mathrm{Ma}, 82,9 \pm 0,1 \mathrm{Ma}$ e $82,9 \pm 0,2 \mathrm{Ma}$, definidas por cinco a nove 
etapas sucessivas de degaseificação da rocha, com mais de $70 \%$ do gás liberado. A extração de argônio gerou platôs demonstrando a quase inexistência de perturbação na amostra, com os valores obtidos refletindo a idade de cristalização da rocha. As idades integradas dessas biotitas (respectivamente, $82,7 \pm 0,2 \mathrm{Ma}, 82,7 \pm 0,1 \mathrm{Ma}$ e $82,8 \pm 0,2 \mathrm{Ma}$ ) são levemente inferiores, porém, muito próximas dos valores sugeridos pelas idades aparentes.

Três cristais de biotita da amostra 29 exibem idades platôs, definidas por cinco a seis etapas de degaseificação com 80 a 95\% do total de gás argônio, com idades de 83,6 $\pm 05 \mathrm{Ma}, 83,0 \pm 0,2 \mathrm{Ma}$ e $84,9 \pm 0,7 \mathrm{Ma}$ (idades integradas, respectivamente, de $85,9 \pm 0,7 \mathrm{Ma}, 82,4 \pm 0,2 \mathrm{Ma}$ e $85,6 \pm 0,4 \mathrm{Ma}$ ) (Figs. $44 \mathrm{~A}-\mathrm{C}$ ). As baixas razões ${ }^{37} \mathrm{Ar} /{ }^{39} \mathrm{Ar}$ (valores não mencionados) indicam que essas biotitas são similares às da amostra anterior, com o espectro não apresentando perturbação e indicando a idade de cristalização da rocha (Fig. 44B).
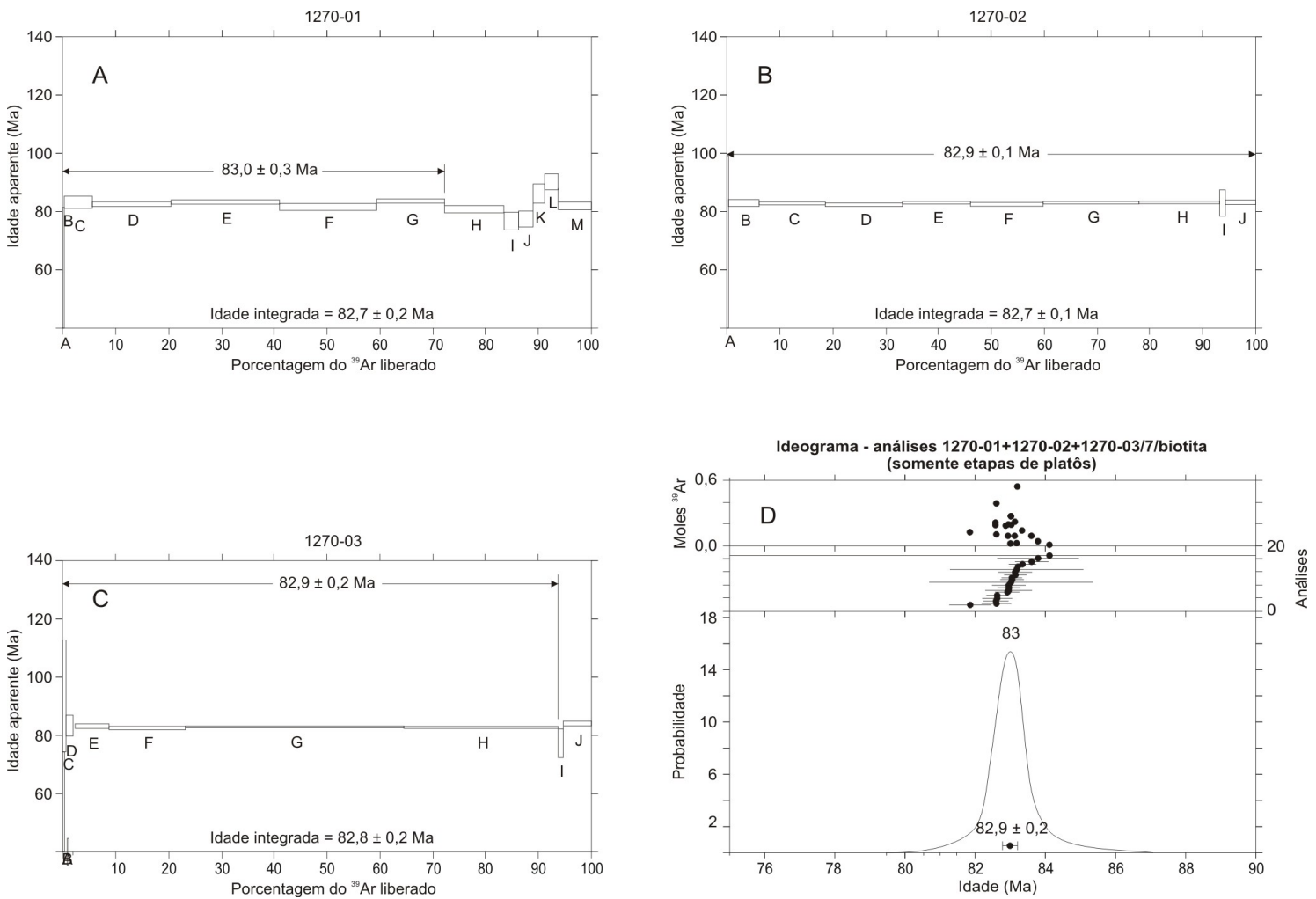

Figura 43. A-C) Diagramas de extração de argônio por aquecimento em etapas de biotitas da amostra 7 mostrando idades platôs e integradas. D) Ideograma de densidade de probabilidade dos resultados dos diagramas A-C define uma boa distribuição.

Tabela 25. Síntese dos dados analíticos de ${ }^{40} \mathrm{Ar} /{ }^{39} \mathrm{Ar}$ para as rochas de Cananéia.

\begin{tabular}{ccccccc} 
Amostra & Litologia & Mineral & N. ${ }^{\circ}$ Lab. & $\begin{array}{c}\text { Idade } \\
\text { platô (Ma) }\end{array}$ & $\begin{array}{c}\text { Idade } \\
\text { integrada (Ma) }\end{array}$ & $\begin{array}{c}\text { Ideograma } \\
(\mathrm{Ma})\end{array}$ \\
\hline 7 & álcali feldspato sienito & biotita & $1270-01$ & $83,0 \pm 0,3$ & $82,7 \pm 0,2$ & \\
7 & álcali feldspato sienito & biotita & $1270-02$ & $82,9 \pm 0,1$ & $82,7 \pm 0,1$ & $82,9 \pm 0,2$ \\
7 & álcali feldspato sienito & biotita & $1270-03$ & $82,9 \pm 0,2$ & $82,8 \pm 0,2$ & \\
\hline 29 & álcali feldspato sienito & biotita & $1269-01$ & $83,6 \pm 0,5$ & $85,9 \pm 0,7$ & \\
29 & álcali feldspato sienito & biotita & $1269-02$ & $83,0 \pm 0,2$ & $82,4 \pm 0,2$ & $83,2 \pm 0,4$ \\
29 & álcali feldspato sienito & biotita & $1269-03$ & $84,9 \pm 0,7$ & $85,6 \pm 0,4$ & \\
\hline 36 & qtz-álcali feldspato sienito & biotita & $1268-01$ & $85,6 \pm 0,4$ & $85,6 \pm 0,2$ & \\
36 & qtz-álcali feldspato sienito & biotita & $1268-02$ & $84,1 \pm 0,2$ & $84,1 \pm 0,2$ & $84,3 \pm 0,5$ \\
36 & qtz-álcali feldspato sienito & biotita & $1268-03$ & $83,9 \pm 0,4$ & $84,8 \pm 0,2$ & \\
\hline $9 A$ & qtz-álcali feldspato sienito & biotita & $1271-01$ & $83,3 \pm 0,5$ & $85,5 \pm 0,4$ & \multirow{2}{*}{$83,6 \pm 0,9$} \\
$9 A$ & qtz-álcali feldspato sienito & biotita & $1271-02$ & $83,8 \pm 0,7$ & $85,1 \pm 0,4$ & \\
\hline
\end{tabular}



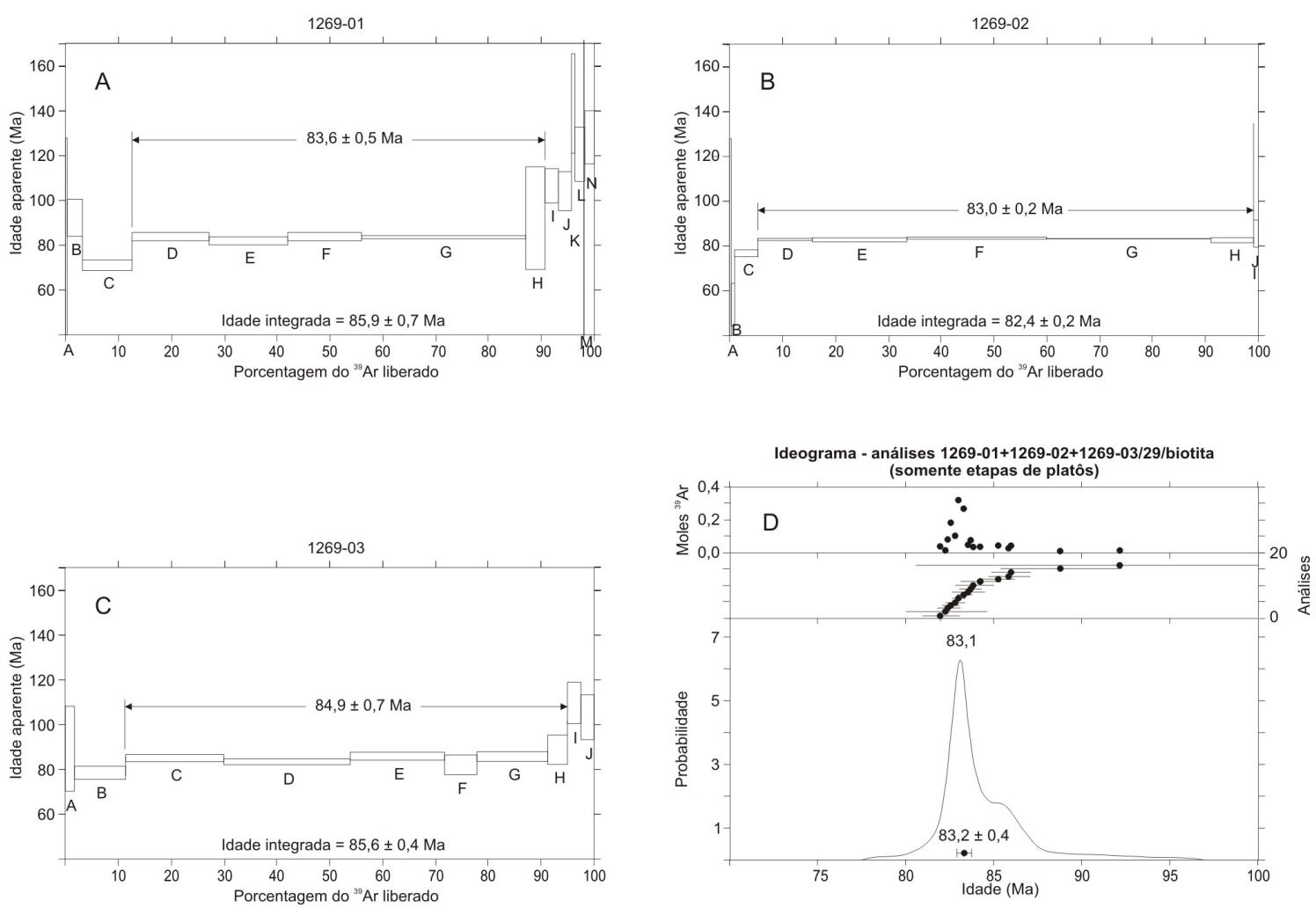

Figura 44. A-C) Diagramas de extração de argônio por aquecimento em etapas de biotitas da amostra 29 mostrando idades platôs e integradas. D) Ideograma de densidade de probabilidade dos resultados dos diagramas A-C define uma boa distribuição.

Assim, a média das idades platôs para as biotitas das amostras 7 e 29 sugere que o magmatismo dos álcali feldspato sienitos ocorreu dentro de um curto intervalo de tempo, entre $82,9 \pm 02$ Ma e $83,2 \pm 0,4 \mathrm{Ma}$ (respectivamente, Figs. 43D e 44D).

Os diagramas para as biotitas da amostra 36 (Figs. 45A-C) revelam que as idades platôs $(85,6 \pm 0,4 \mathrm{Ma}, 84,1 \pm 0,2 \mathrm{Ma}$ e $83,9 \pm 0,4 \mathrm{Ma})$, determinadas pela liberação de 60 a $92 \%$ do total de argônio, com quatro a seis etapas de degaseificação, estão próximas às das idades integradas $(85,6 \pm 0,2 \mathrm{Ma}, 84,1 \pm 0,2 \mathrm{Ma}$ e $84,8 \pm 0,2 \mathrm{Ma})$. A média das idades platôs produz um valor de $84,3 \pm 0,5$ $\mathrm{Ma}$, indicativo da idade do magmatismo dos quartzo-álcali feldspato sienitos (Fig. 45D).

A extração de argônio para dois cristais de biotita da amostra 9A apresenta idades platôs de $83,3 \pm 0,5 \mathrm{Ma}$ e $83,8 \pm 0,7 \mathrm{Ma}$, definidas pela liberação de 70 a $82 \%$ de argônio em cinco a sete etapas de degaseificação da rocha (Figs. 46A, B). O material analisado é similar ao das demais amostras analisadas, como sugerido pela baixa razão ${ }^{37} \mathrm{Ar} /{ }^{39} \mathrm{Ar}$ (valores não fornecidos). A Figura $46 \mathrm{C}$ mostra a interação das etapas de platôs e a definição de uma idade de $83,6 \pm 0,9 \mathrm{Ma}$. As idades integradas (respectivamente, $85,5 \pm 0,4 \mathrm{Ma}$ e 85,1 $\pm 0,4 \mathrm{Ma}$ ) são levemente superiores às das idades platôs.

Os valores propostos para as duas amostras de quartzo-álcali feldspato sienito analisadas são muito próximos (84,3 $\pm 0,5 \mathrm{Ma}$ e $83,6 \pm 0,9 \mathrm{Ma}$, respectivamente, amostras 36 e $9 \mathrm{~A})$, situando-se dentro do erro analítico. 

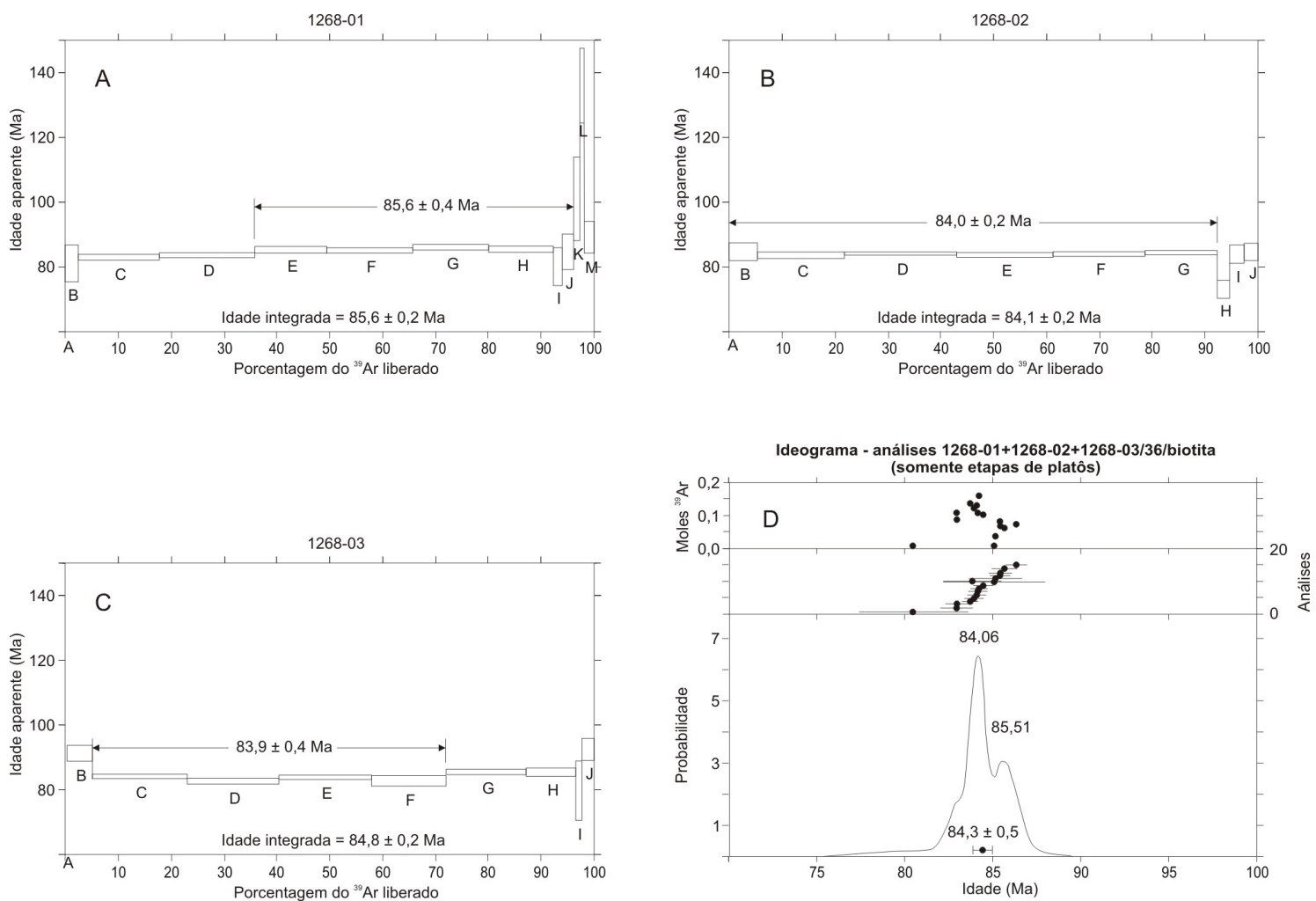

Figura 45. A-C) Diagramas de extração de argônio por aquecimento em etapas de biotitas da amostra 36 mostrando idades platôs e integradas. D) Ideograma de densidade de probabilidade dos resultados dos diagramas A-C define dois picos de distribuição.
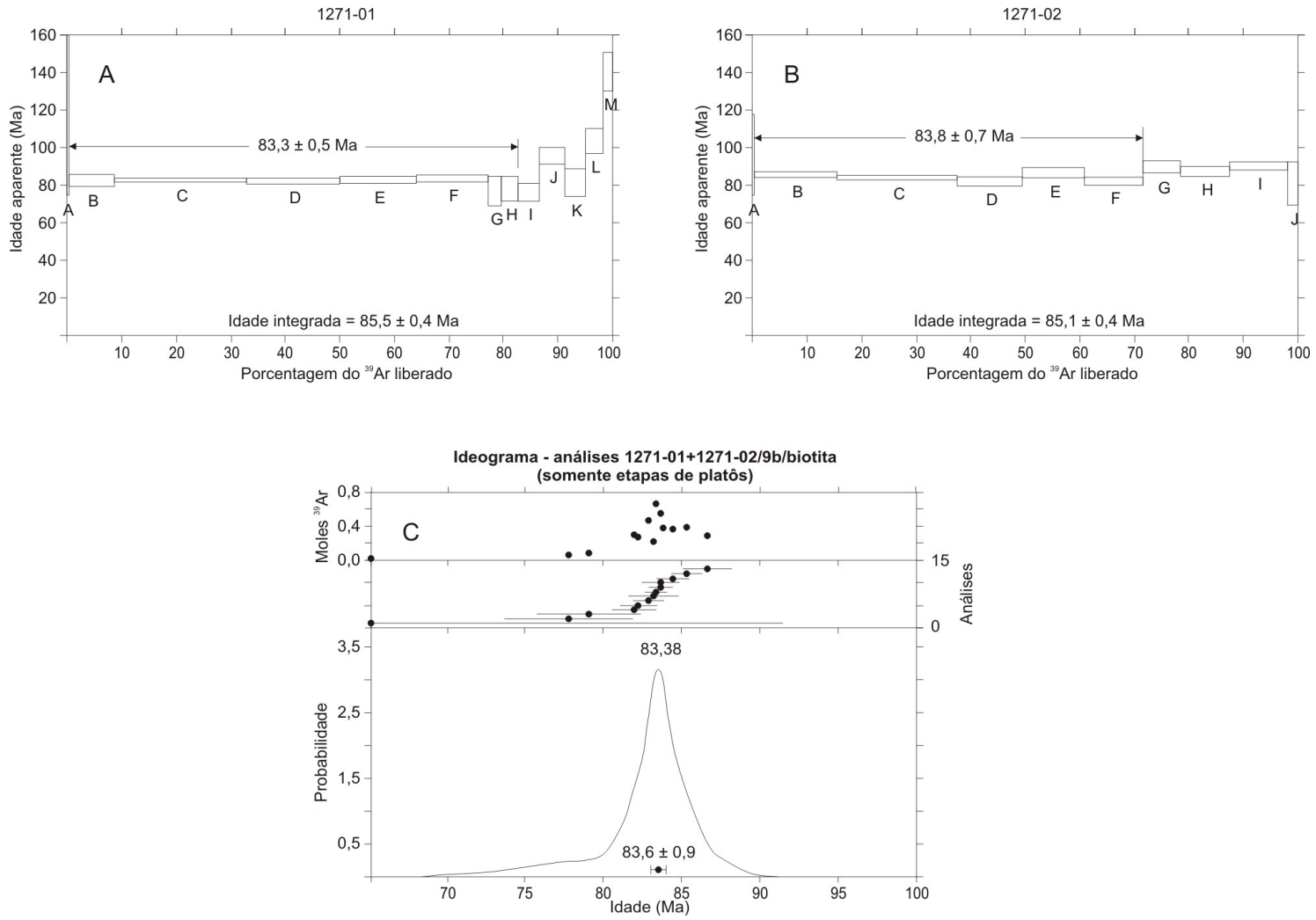

Figura 46. A-C) Diagramas de extração de argônio por aquecimento em etapas de biotitas da amostra $9 A$ mostrando idades platôs e integradas. D) Ideograma de densidade de probabilidade dos resultados dos diagramas A-C define uma boa distribuição. 


\subsection{Outras considerações}

Não obstante as pequenas diferenças encontradas, os dados radiométricos obtidos pelas três metodologias ( $\mathrm{Rb} / \mathrm{Sr}, \mathrm{K} / \mathrm{Ar}$ e $\mathrm{Ar} / \mathrm{Ar}$ ) para as rochas da intrusão principal de Cananéia guardam similaridades e são consistentes com a inclusão desse evento alcalino no Cretáceo Superior. As datações Ar/Ar recentes em concentrados de biotita (Tabela 25) permitem sugerir para amostras de duas das suas unidades litológicas principais, os álcali feldspato sienitos e os quartzo-álcali feldspato sienitos, uma idade de formação de $83,6 \mathrm{Ma}(82,9 \pm 0,2 \mathrm{Ma}$ a $84,3 \pm 0,5 \mathrm{Ma})$, valor esse situado dentro do intervalo do erro analítico admitido para os demais resultados $(\mathrm{Rb} / \mathrm{Sr}, 81 \pm 3 \mathrm{Ma}$; $\mathrm{K} / \mathrm{Ar}, 82,7 \pm 2,5 \mathrm{Ma}$ a $86,6 \pm 2,6 \mathrm{Ma}$ ). Por outro lado, o valor médio de $83,6 \mathrm{Ma}$ é comparável às idades obtidas para o

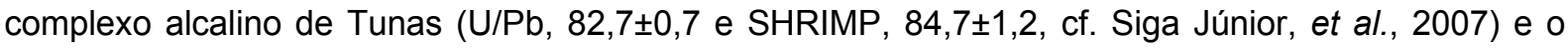
corpo intrusivo de Mato Preto (70-72 Ma, K/Ar, dados antigos de Amaral et al., 1967, recalculados por Sonoki e Garda, 1988), ambos localizados na Província do Arco de Ponta Grossa, e para algumas intrusões do setor norte da Província da Serra do Mar (81,4 Ma, K/Ar, Ilha dos Búzios, cf. Alves, 1996; 86,5 Ma, Ar/Ar, Ilha Monte de Trigo, cf. Enrich, 2005; $84 \mathrm{Ma}, \mathrm{K} / \mathrm{Ar}$, Ilha de São Sebastião, cf. Bellieni et al., 1990; 80-90 Ma, K/Ar, Ilha de Vitória, cf. Motoki, 1986; 72 Ma, K/Ar, Itatiaia, cf. Brotzu et al., 1997; 80,6 Ma, Rb/Sr, Passa Quatro, cf. Montes-Lauar et al., 1995). 


\section{GEOQUÍMICA ISOTÓPICA}

\subsection{Isótopos de $\mathrm{Sr}$ e Nd}

Determinações das razões isotópicas iniciais de ${ }^{87} \mathrm{Sr} /{ }^{86} \mathrm{Sr}$ e de ${ }^{144} \mathrm{Nd} /{ }^{143} \mathrm{Nd}$, calculadas com base no valor de 83,6 Ma para a idade da intrusão de Cananéia, foram efetuadas em amostras de rochas provenientes do corpo principal (Morro de São João: amostras 7, 22A, 29, 32A, 34 e 38) e do corpo satélite (Morrete: amostras 40, 49, 50, 52 e 53) (Tabela 24).

As razões ${ }^{87} \mathrm{Sr}^{86} \mathrm{Sr}_{(83,6 \mathrm{Ma})}$ obtidas para os álcali feldspato sienitos são de 0,7065 a 0,70700 e para os quartzo-álcali feldspato sienitos de 0,70538 a 0,70777. Da tabela constam também os teores variáveis de $\mathrm{Sr}(5,46$ a 246,25 ppm), cujas baixas concentrações poderiam responder por algumas das diferenças encontradas nos valores da razão inicial. Já os valores da razão ${ }^{147} \mathrm{Sm} /{ }^{144} \mathrm{Nd}$ para essas duas litologias são, respectivamente, de 0,51221 a 0,51241 e de 0,51206 a 0,51207, sendo, assim, claramente inferiores na segunda.

Examinando o conjunto de dados isotópicos disponíveis para as ocorrências alcalinas associadas tectonicamente ao Lineamento Guapiara - que incluem os complexos de Jacupiranga, Juquiá e Pariquera-Açu, todos do Cretáceo Inferior, além da intrusão de Cananéia, do Cretáceo Superior Ruberti et al. (2005) obtiveram para o primeiro conjunto valores de ${ }^{87} \mathrm{Sr} /{ }^{86} \mathrm{Sr}\left(\mathrm{R}_{0}\right)$ variando no intervalo de 0,70489 a 0,70452, e de 0,70709 $( \pm 0,00070)$ para os sienitos de Cananéia. À exceção de duas análises mostrando resultados muito discrepantes para a razão inicial $(0,70163$ e 0,71228, ambas com baixo teor de Sr, cf. Tabela 24), as demais forneceram valores inteiramente compatíveis com a média daqueles autores para as rochas de Cananéia, e sugestivos da participação de processos de contaminação crustal na sua formação.

Os valores de $\varepsilon S r$ para os álcali feldspato sienitos situam-se no intervalo de +27 a +32 , porém, as diferenças são maiores nos quartzo-álcali feldspato sienitos, quando passam de +11 a +45 . Em comparação, os valores de $\varepsilon N d$ apresentam menores variações, compreendidas no intervalo de -2 a -6 para os álcali feldspato sienitos, enquanto nos quartzo-álcali feldspato sienitos eles são praticamente constantes, em torno de -9 .

Quando projetados no diagrama $\varepsilon S r$ vs. $\varepsilon N d$ (Fig. 47), os dados caem no quadrante enriquecido, quase todos próximos ao limite do campo definido para o magmatismo toleítico e alcalino do Cretáceo Inferior da Bacia do Paraná. Já os valores elevados de $\varepsilon S r$, praticamente superiores aos encontrados na literatura para as ocorrências alcalinas do Cretáceo Superior (cf. Ruberti et al., 2005), indicam que o campo delineado para essas rochas é, na verdade, bem mais extenso. À exceção de uma amostra (53) apresentando menor enriquecimento em $\varepsilon S r$, as demais estão alinhadas paralelamente à extensão do "low-Nd mantle array" de Hart et al. (1986), no quadrante enriquecido ("Paraguay array" de Comin-Chiaramonti et al., 1995), incluindo material não-contaminado associado ao magmatismo toleítico e alcalino (rochas silicáticas e carbonatíticas) de idade mesozóica (Cretáceo Inferior e Superior) da Província Paraná-Angola-Etendeka (Comin-Chiaramonti et al., 1999). A assinatura isotópica dos elementos $\mathrm{Sr}$ e $\mathrm{Nd}$ sugere ainda que fontes mantélicas do tipo EMI e HIMU (ou EMI e DMM) possam ter contribuído no processo de geração das rochas sieníticas de Cananéia.

O gráfico possibilita também observar que essas rochas parecem constituir um campo à parte daquele representado pelas ocorrências alcalinas relacionadas com Província do Arco de Ponta Grossa, aqui incluídos os complexos alcalino-carbonatíticos de Jacupiranga e Juquiá, do Cretáceo 
Inferior, e os corpos alcalino-carbonatíticos de Barra do Itapirapuã e Mato Preto, o maciço de Tunas, além dos diques e plugs associados, todos eles do Cretáceo Superior.

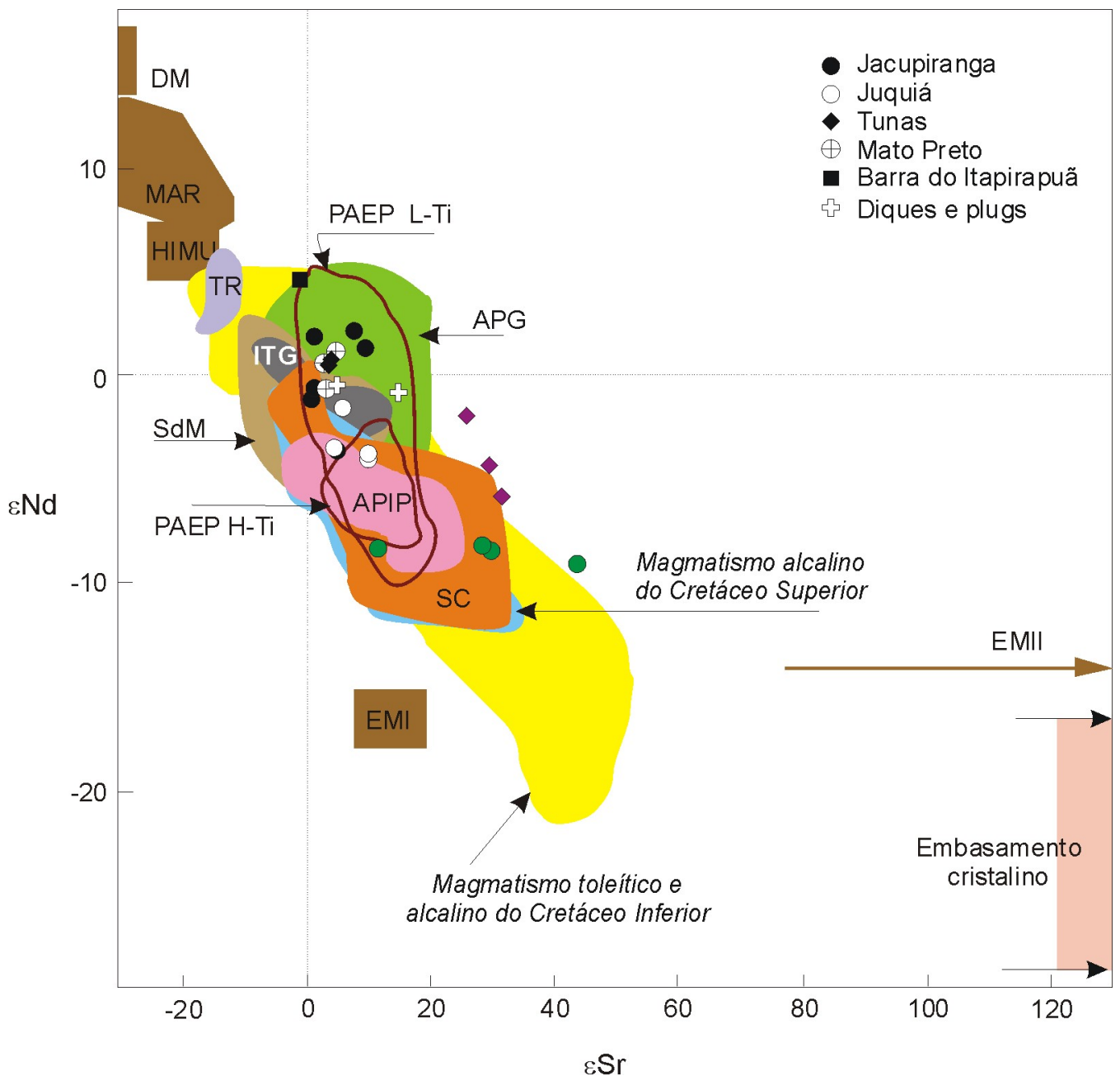

Figura 47. Diagrama $\varepsilon S r$ vs. $\varepsilon N d$ para as rochas de Cananéia. Abreviações: PAEP, Província Paraná-Angola-Etendeka, H-Ti e L-Ti, alto e baixo Ti; APG, Arco de Ponta Grossa; SdM, Serra do Mar; APIP, Alto Paranaíba; SC, Anitápolis e Lages; TR, Ilhas Trindade e Martin Vaz; ITG, Ilhas Inaccessible, Tristan e Gough; MAR, Dorsal Meso-Attântica; DM, EMI, EMII e HIMU, respectivamente, manto empobrecido, mantos enriquecidos e manto de alto $\mu$ (alto ${ }^{238} \mathrm{U} /{ }^{204} \mathrm{~Pb}$ ). Fonte de dados: Ruberti et al. (2005 e referências) e Enrich et al. (2005 e referências). Símbolos como na Figura 7.

Cálculos da idade modelo ( $T_{\mathrm{DM}}$, manto empobrecido) para as rochas de Cananéia, feitos com base na equação de DePaolo (1988), deram números variáveis entre 1000 e 1600 Ma, com valor médio de $1200 \pm 200 \mathrm{Ma}(\approx \approx-4)$ para os álcali feldspato sienitos e de $1500 \pm 100 \mathrm{Ma}(\approx \approx-4)$ para os quartzo-álcali feldspato sienitos (Tabela 24). A idade média ( $\left.T_{D M}\right)$ para a intrusão é de $1400 \pm 200 \mathrm{Ma}$, valor superior ao das idades obtidas por Ruberti et al. (2005) para outras ocorrências alcalinas da Província do Arco de Ponta Grossa - Jacupiranga, 744-979 Ma; Juquiá, 889-1001 Ma; Mato Preto, 668-735 Ma; Tunas, 863 Ma, e 1019 Ma, segundo Siga Júnior et al. (2007), juntamente com os diques e plugs associados (731-742 Ma). Também maior que as idades fornecidas por Enrich et al. (2005) para os grandes maciços sieníticos da Província da Serra do Mar - Ilha de São Sebastião, 619819 Ma; Itatiaia, 838-928 Ma; Passa Quatro, 872-899 Ma - e outras disponíveis para ocorrências

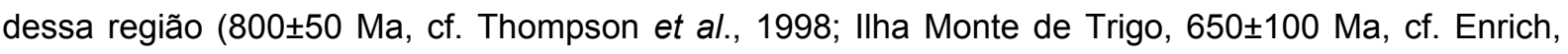
2005; Poços de Caldas, 692 \pm 54 Ma, cf. Ulbrich et al., 2003) (Fig. 48). Ela é ainda superior ao valor médio caracterizando os numerosos corpos alcalinos da adjacente Província do Alto Paranaíba (990 $\pm 100 \mathrm{Ma}$, Gomes e Comin-Chiaramonti, 2005). 
Tratando especificamente do magmatismo alcalino do Arco de Ponta Grossa, Ruberti et al. (2005) distinguiram dois eventos distintos de enriquecimento metassomático, com idades estimadas em 900 Ma e $700 \mathrm{Ma}$, que teriam afetado as ocorrências associadas, respectivamente, ao Lineamento Guapiara e ao Lineamento São Jerônimo-Curiúva.

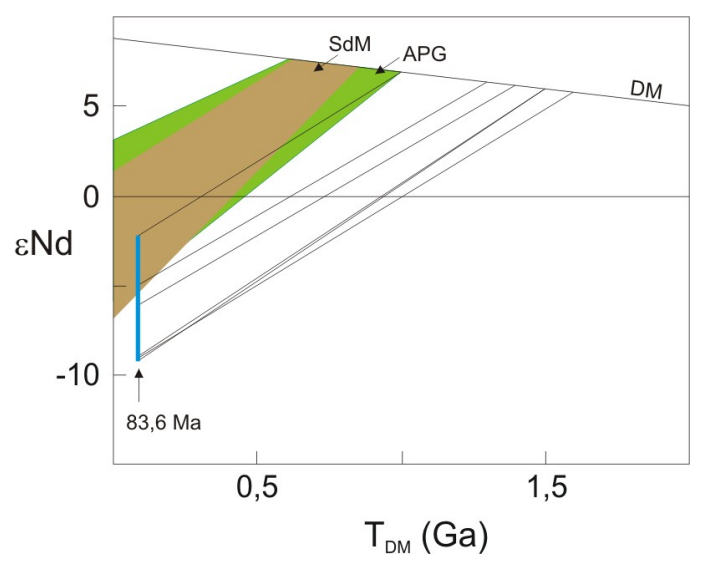

Figura 48. Diagrama $T_{D M}$ vs. $\varepsilon N d$ (DePaolo, 1988) para as rochas de Cananéia (azul). Abreviações: SdM, Serra do Mar; APG, Arco de Ponta Grossa; DM, manto empobrecido Valor de $\mathrm{T}_{\mathrm{DM}}$ : calculado de acordo com a idade modelo relativa ao manto empobrecido (83,6 ma), ${ }^{143} \mathrm{Nd} /{ }^{144} \mathrm{Nd}=0,513114 \mathrm{e}^{147} \mathrm{Sm} /{ }^{144} \mathrm{Nd}=0,222$; (Faure, 1986).

No confronto das idades modelo disponíveis para ocorrências alcalinas da parte sudeste do território brasileiro, cabe assinalar a maior similaridade entre os valores de Cananéia com aqueles relativos aos dois complexos alcalino-carbonatíticos do Estado de Santa Catarina: Anitápolis e Lages, respectivamente, do Cretáceo Inferior e Cretáceo Superior. Scheibe et al. (2005) listam valores de $1300 \pm 100 \mathrm{Ma}$ (intermediários aos dos toleítos de alto e baixo Ti do sistema Paraná-Angola-Etendeka,

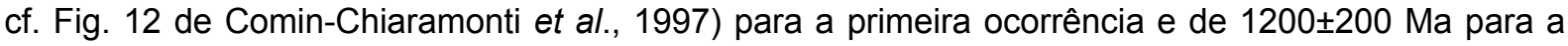
segunda. Contudo, a distribuição de idades para as rochas de Lages, ainda segundo Scheibe et al. (2005), mostra natureza bimodal (rochas máficas: $900 \pm 100 \mathrm{Ma}$; fonolitos peralcalinos+carbonatitos: 1400 $100 \mathrm{Ma}$ ), fato interpretado por Traversa et al. (1996) como indicativo da existência de fontes mantélicas que sofreram metassomatismo em épocas distintas.

Por outro lado, o exame das ocorrências da borda ocidental da Bacia do Paraná possibilita verificar a existência de idades modelo mais antigas, do Proterozóico Médio, variando de 2000 a 1400 Ma, e valor médio de 1500 \pm 200 Ma (Comin-Chiaramonti et al., 1997), para os corpos alcalinos potássicos do Cretáceo Inferior encontrados nas regiões norte-nordeste (Províncias do Rio Apa e de Amambay) e centro-meridional (Província Central) do Paraguai Oriental. Esses corpos contêm rochas silicáticas e carbonatíticas associadas e, do ponto de vista tectônico, estão relacionados, respectivamente, ao bloco do Apa, Gráben de Amambay e Rift de Assunção-Sapucai-Villarrica. Com base ainda naqueles autores, estão também incluídos no intervalo acima alguns representantes do vulcanismo basáltico da Bacia do Paraná: as lavas toleíticas de alto e baixo Ti presentes em território paraguaio, e os enxames de diques toleíticos do Arco de Ponta Grossa e da região litorânea de São Paulo-Rio de Janeiro (Fig. 49).

Esses autores caracterizaram ainda para o magmatismo alcalino da Plataforma Sul-Americana um segundo grupo, do Proterozóico Superior, com valores de idades modelo compreendidos no intervalo 1000-500 Ma, incluídas aí não apenas ocorrências potássicas como sódicas, ao lado também de diques de basaltos toleíticos. É importante observar que as rochas alcalinas de natureza sódica, tanto em território brasileiro quanto paraguaio, estão associadas tão-somente a esse evento mais 
novo ainda que, em três (Província Ígnea do Alto Paranaíba, no Brasil; Províncias do Alto Paraguai e de Misiones, no Paraguai Oriental) das quatro ocorrências investigadas, as idades médias obtidas estejam em torno de $1000 \mathrm{Ma}$ ou se aproximem desse valor (900-800 Ma, caso das rochas de Misiones). Apenas as litologias da Província de Assunção, também no Paraguai Oriental, mostram idades mais baixas, de 800 a 500 Ma (Fig. 49). Já o comportamento dos basaltos toleíticos da Bacia do Paraná é também variável, com as lavas de alto Ti apresentando idade média de $1100 \pm 100$ Ma e as de baixo Ti, como já assinalado, valores consideravelmente mais elevados, de 1500 $\pm 200 \mathrm{Ma}$ (Fig. 49).
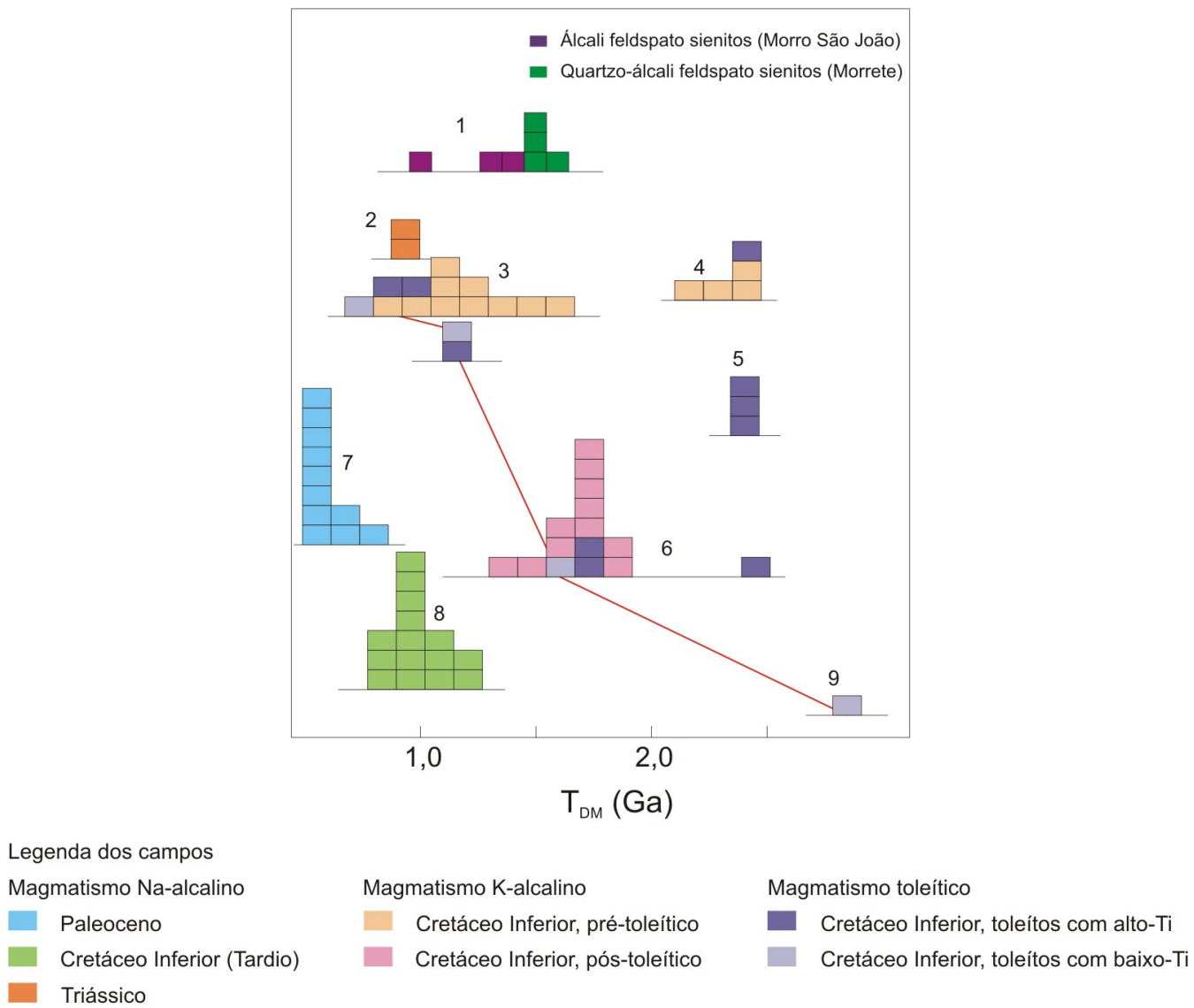

Figura 49. Distribuição de idades $\mathrm{T}_{\mathrm{DM}}(\mathrm{Ga})$ das rochas alcalinas de Cananéia (1) e Paraguai Oriental (2, Província do Alto do Paraguai; 3, Província do Rio Apa; 4, Província de Amambay; 6, Província Central-Sapucai; 7, Província de Assunção; 8, Província de Misiones). Basaltos toleíticos: 5, Carayó; 9, Encarnación. A linha em vermelho representa toleítos com baixo teor em Ti. Dados de Comin-Chiaramonti e Gomes (2005) e Comin-Chiaramonti et al. (2007a).

Assim, com base nos valores de idades modelo, Comin-Chiaramonti et al. (1997) propuseram que dois eventos metassomáticos distintos ocorridos durante o Proterozóico (Paleo: 2000-1400 Ma; Neo: 1000-500 Ma), levando principalmente ao enriquecimento da(s) fonte(s) mantélica(s) em elementos incompatíveis, foram os agentes precursores da gênese do magmatismo toleítico e alcalino na Bacia do Paraná. Esses autores sustentam ainda que esses dois processos de metassomatismo do manto subcontinental litosférico foram quimicamente muito distintos, como demonstram as grandes diferenças existentes nas concentrações dos elementos Ti, LILE e HFSE junto às rochas alcalinas e toleíticas. Segundo Philipp et al. (2005), a existência desses dois eventos é sugestiva que diferentes segmentos do manto litosférico foram variadamente metassomatizados como resultado de efeitos superpostos provocados pelos ciclos Arqueano, Transamazônico e Brasiliano. Ainda, segundo lacumin et al. (2003), essas heterogeneidades da fonte mantélica acham-se bem estabelecidas, no mínimo, desde o Arqueano Superior. 
Heterogeneidades no manto litosférico que originou o magmatismo alcalino e toleítico da Bacia do Paraná são também sugeridas, segundo Comin-Chiaramonti et al. (2007a), pelos dados isotópicos Re-Os obtidos em rochas potássicas de afinidade kimberlítica e kamafugítica da Província do Alto Paranaíba e do complexo alcalino-carbonatítico de Lages (Carlson et al., 1996; Araújo et al., 2001), cobrindo intervalo de variação similar ao mostrado pelas idades de $\mathrm{Nd}$. Elas encontram ainda apoio nas idéias de Meen et al. (1989; ver também discussão em Castorina et al., 1996) que propõe a existência de um manto litosférico laminado, de idade Proterozóica, para a geração do magmatismo da Bacia do Paraná.

\subsection{Contaminação crustal}

Muito longe de ser o mecanismo dominante na gênese das rochas alcalinas presentes nas porções periféricas da Bacia do Paraná, processos de contaminação crustal têm sido apontados na literatura como responsáveis pela formação, principalmente, de alguns tipos litológicos apresentando características geoquímicas especiais (valores altos da razão inicial ${ }^{87} \mathrm{Sr} /{ }^{86} \mathrm{Sr}$ ). Ainda que essas litologias possam ocupar maior área de exposição - como parece ser o caso nas ocorrências de Itatiaia, Ilha de Vitória, Lages, em alguns corpos da Província do Alto Paraguai, na divisa do Brasil (Estado do Mato Grosso do Sul) com o Paraguai, da Província de Velasco, na Bolívia, ou ainda da Província de Misiones, no Paraguai Oriental -, elas estão mais comumente representadas por pequenos corpos cortando as rochas do embasamento cristalino. Situações do gênero foram reconhecidas, por exemplo, em alguns diques associados ao complexo alcalino-carbonatítico de Juquiá ( $R_{0}=0,7060-0,7078$, cf. Beccaluva et al., 1992), ao maciço sienítico de Tunas $\left(R_{0}=0,70718 \pm 0,00087\right.$, cf. Gomes et al., 1987) ou em diques e plugs fonolíticos da região de Cerro Azul $\left(R_{0}>0,706\right.$, cf. Vasconcellos e Gomes, 1998) e da Província Alcalina Terciária de Fortaleza $\left(R_{0}>0,705\right.$, cf. Macciotta et al., 1990), estando todos esses corpos encaixados genericamente em gnaisses, metaígneas e metassedimentares do Pré-cambriano.

Os dados isotópicos ${ }^{87} \mathrm{Sr} /{ }^{86} \mathrm{Sr}$ obtidos sugerem que a quase totalidade das rochas alcalinas e carbonatíticas brasileiras foram originadas a partir de fonte mantélica que sofreu pouca ou nenhuma interação crustal (Morbidelli et al., 1995; Brotzu et al., 1997), conclusão também endossada por Comin-Chiaramonti et al. (1997) para as litologias congêneres paraguaias. Porém, como assinalado por Ruberti et al. (2005) para as ocorrências da Província do Arco de Ponta Grossa, razões de ${ }^{87} \mathrm{Sr}{ }^{86} \mathrm{Sr}$ superiores a 0,706 poderiam estar relacionadas a processos de contaminação crustal ou de assimilação-cristalização fracionada, o que parece ser o caso das rochas de Cananéia, apresentando valores altos para aquele parâmetro.

Uma possível ação de contaminação crustal nessas rochas foi investigada com o auxílio do diagrama Sr vs. ${ }^{87} \mathrm{Sr} /{ }^{86} \mathrm{Sr}$ (Fig. 50A), onde se verifica que os pontos estão concentrados em torno de 0,707 , com os valores mais elevados de Sr presentes nos álcali feldspato sienitos (178,06 a 246,25 ppm, cf. Tabela 23), que mostram também menor variação para as razões iniciais ${ }^{87} \mathrm{Sr} /{ }^{86} \mathrm{Sr}$. Já os quartzo-álcali feldspato sienitos exibem maior dispersão e valores mais altos para as razões ${ }^{87} \mathrm{Sr} /{ }^{86} \mathrm{Sr}$, além de teores menores de $\mathrm{Sr}$ (5,46 a 100,53 ppm, cf. Tabela 24).

A Figura 50A mostra a curva de uma mistura simples envolvendo reservatórios crustais e magma inicial (cf. DePaolo, 1988). Nota-se que as rochas menos evoluídas de Cananéia estão mais próximas da composição do magma inicial, ao contrário das mais evoluídas, que se aproximam mais do 
embasamento cristalino. O gráfico parece indicar uma tendência de correlação negativa entre ${ }^{87} \mathrm{Sr} /{ }^{86} \mathrm{Sr}$ e a concentração de $\mathrm{Sr}$, ao lado de uma positiva entre $10^{3} / \mathrm{Sr}$ e ${ }^{87} \mathrm{Sr} /{ }^{86} \mathrm{Sr}$ (Fig. 50B), que poderiam ser interpretadas como sugestivas de uma possível ação de processos de contaminação crustal e/ou assimilação-cristalização fracionada.

Além disso, chama também a atenção em ambos os gráficos (Fig. 50) a grande dispersão dos valores das razões iniciais obtidos para os quartzo-álcali feldspato sienitos provenientes das duas localidades: corpo principal (Morro de São João, em azul) e satélite (Morrete, em verde). São amostras cogenéticas, da mesma litologia, que deveriam, portanto, exibir pouca variação nos valores da razão inicial. Contudo, convém lembrar que também no diagrama ${ }^{87} \mathrm{Rb} /{ }^{86} \mathrm{Sr}$ vs. ${ }^{87} \mathrm{Sr} /{ }^{86} \mathrm{Sr}$ (Fig. $41 \mathrm{~A}$ ) os pontos projetados não estão alinhados devido a razões provavelmente de natureza genética. Esse não-alinhamento dos onze pontos de análise é sugerido pelo valor do parâmetro MSWD (=52), acima dos níveis de corte (Snelling, 1976), o que poderia indicar uma heterogeneidade inicial ou a abertura parcial do sistema Rb/Sr.
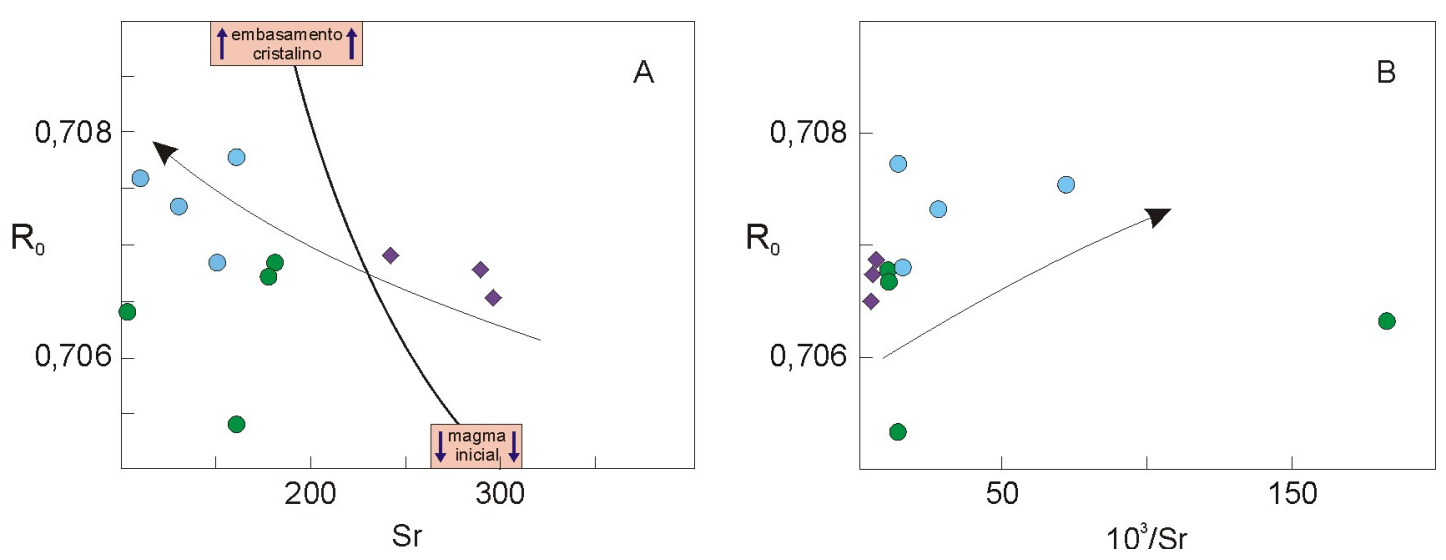

Figura 50. A) Diagrama reunindo razão inicial ${ }^{87} \mathrm{Sr} /{ }^{86} \mathrm{Sr}\left(\mathrm{R}_{0}\right)$ e $\mathrm{Sr}(\mathrm{ppm})$ (cf. DePaolo, 1988). A curva em negrito mostra a linha de mistura simples entre a crosta e o manto; a seta indica um trend negativo para as rochas de Cananéia. B) Diagrama reunindo razão inicial ${ }^{87} \mathrm{Sr} /{ }^{86} \mathrm{Sr}\left(\mathrm{R}_{0}\right)$ e $10^{3} / \mathrm{Sr}$, com a seta sugerindo um trend positivo para as rochas de Cananéia. Símbolos como na Figura 7.

O gráfico reunindo a razão inicial $\mathrm{R}_{0}$ e a concentração de $\mathrm{SiO}_{2}$ (Fig. 51) representa uma tentativa de identificar uma mistura resultante da contaminação de magma alcalino provocada pela assimilação de rochas encaixantes (Faure e Powel, 1972). O diagrama mostra uma correlação positiva para as rochas de Cananéia, com as maiores razões iniciais ${ }^{87} \mathrm{Sr} /{ }^{86} \mathrm{Sr}$ presentes nas rochas mais ricas em $\mathrm{SiO}_{2}$, tendência essa que vem sendo interpretada por alguns autores (Faure e Powel, 1972; Petrini et al., 1987; Landoll e Foland, 1996) como evidência da ação de um agente contaminante enriquecido em sílica. Na Figura 51A, estão também representados os campos correspondentes às rochas dos complexos alcalinos vizinhos de Jacupiranga, Juquiá e Pariquera-Açu, igualmente associados ao Lineamento Guapiara. As altas razões iniciais das rochas de Cananéia poderiam ser explicadas pela sua derivação a partir de processos de cristalização fracionada (FC, seta vermelha tracejada), conjugados com a assimilação de material do embasamento cristalino de composições isotópicas adequadas. Considerando apenas a simples mistura de material, Ruberti et al. (2005) chegaram a resultados de até $30 \%$ para a contribuição do contaminante (embasamento cristalino), valores tidos por eles como pouco realísticos, propondo, dessa forma, a ação conjunta dos dois processos.

Correlações positivas entre $\mathrm{R}_{0}$ vs. $\mathrm{SiO}_{2}$ são também sugeridas para as rochas do complexo de Tunas e de alguns diques e plugs fonolíticos ocorrendo na área de Cerro Azul, no Paraná (Fig. 51B). 
Segundo Ruberti et al. (2005), as variações da razão inicial ${ }^{87} \mathrm{Sr} /{ }^{86} \mathrm{Sr}$ são sugestivas de que processos de assimilação-cristalização fracionada também atuaram na formação dessas rochas. Entretanto, esses autores procuram ressaltar que a correlação entre aqueles dois parâmetros na ocorrência de Tunas, à vista da sua maior complexidade geológica, poderia ter sido afetada considerando a possível existência de múltiplas intrusões provenientes de diferentes fontes, tanto do manto como da crosta inferior.

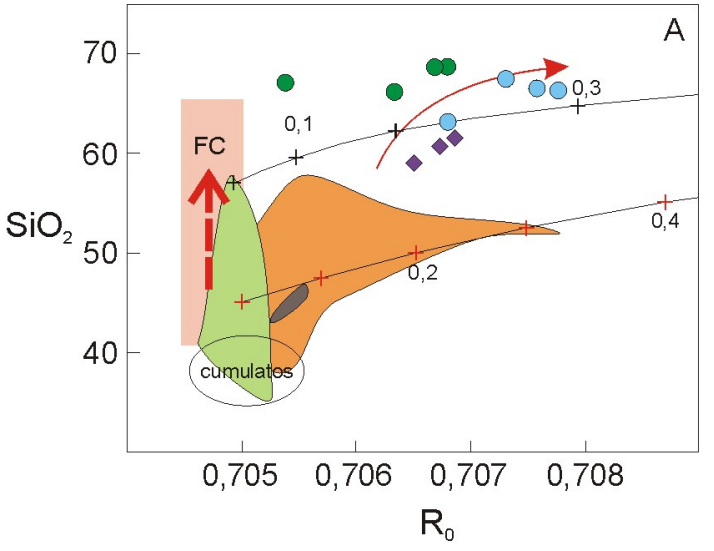

Legenda dos campos

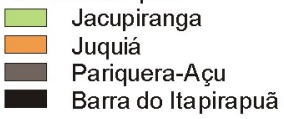

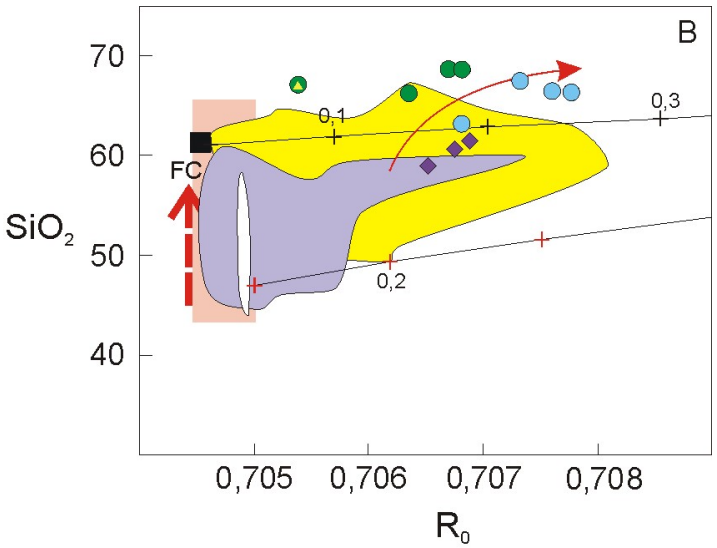

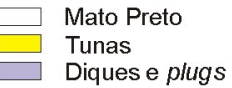

Figura 51. Diagrama de razão inicial ${ }^{87} \mathrm{Sr} /{ }^{86} \mathrm{Sr}\left(\mathrm{R}_{0}\right)$ vs. $\mathrm{SiO}_{2}$ (\% peso) para as rochas de Cananéia e de ocorrências associadas aos Alinhamentos de Guapiara (A) e de São Jerônimo-Curiúva (B) no Arco de Ponta Grossa. Dos diagramas constam também a tendência das rochas de Cananéia e os vetores (setas tracejadas em vermelho) indicativos de cristalização fracionada (FC) em sistema fechado. Extraído de Ruberti et al. (2005). Símbolos como na Figura.

A Figura 52 procura correlacionar as composições isotópicas de $\mathrm{Nd}$ das rochas de Cananéia com as curvas extraídas de Stevenson et al. (1997), indicativas do comportamento dos processos de cristalização fracionada (FC), assimilação-cristalização fracionada (AFC) e de mistura de magmas com as encaixantes da crosta Ketilidiana, para o complexo alcalino de llímaussaq, na Groenlândia. O gráfico mostra que os álcali feldspato sienitos apresentam razões $1 / \mathrm{Nd}$ mais baixas e valores menos negativos de $\varepsilon N d$, fato já evidenciado na Figura 47 , quando comparados aos quartzo-álcali feldspato sienitos. Ele é também sugestivo que os quartzo-álcali feldspato sienitos poderiam ter evoluído, por processos de assimilação-cristalização fracionada e de contaminação crustal, a partir dos álcali feldspato sienitos.

O comportamento das razões entre elementos incompatíveis (p.e. $\mathrm{La} / \mathrm{Sm}, \mathrm{La} / \mathrm{Ce}$ ) tem sido interpretado como indicativo de evidências de heterogeneidade mantélica, além de sensível à atuação de processos petrogenéticos, como fusão parcial e fusão de desequilíbrio (Wagoner e Leybourne, 1991). No diagrama $\mathrm{SiO}_{2}$ vs. La/Ce (Fig. 53A), os dados se mantêm razoavelmente constantes, sendo, assim, pouco conclusivos sobre uma possível ação de contaminação crustal junto às rochas de Cananéia. 


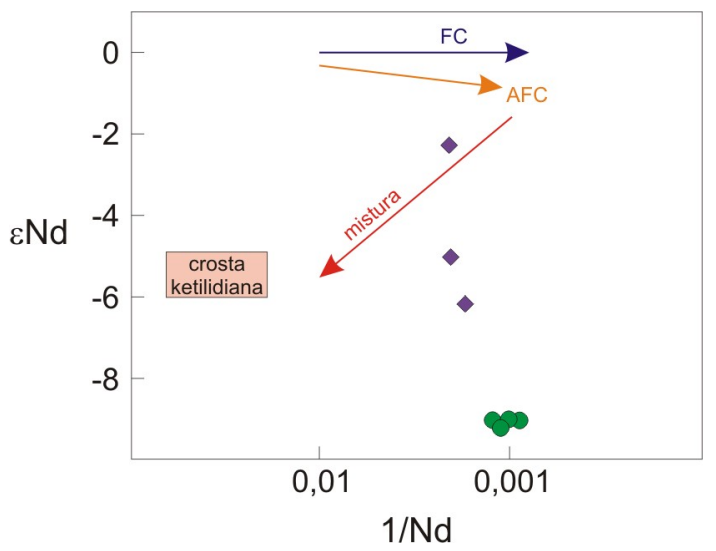

Figura 52. Dados de $\varepsilon N d$ e $1 / \mathrm{Nd}$ para as rochas de Cananéia. Diagrama extraído de Stevenson et al. (1997) mostrando o comportamento dos processos de cristalização fracionada (FC), assimilação-cristalização fracionada (AFC) e de mistura de magmas para as rochas alcalinas do complexo de llímaussaq, na Groenlândia.

Já na Figura 53B, reconhece-se uma correlação negativa para os pontos, com as litologias menos evoluídas, os álcali feldspato sienitos, apresentando razões $\mathrm{Ba} / \mathrm{Rb}$ mais elevadas, fruto da sua maior riqueza em $\mathrm{Ba}$. Por outro lado, os tipos mais evoluídos, os quartzo-álcali feldspato sienitos, mostram razões menores, em virtude principalmente do seu alto teor em $\mathrm{Rb}$. Nas rochas ígneas, $\mathrm{Ba}$ está preferencialmente presente nos feldspatos (plagioclásio e feldspato alcalino), enquanto o Rb na biotita (Harris e Inger 1992). Como mencionado no capítulo referente à geoquímica, as rochas de Cananéia podem ser divididas em dois grupos em função do seu conteúdo alto ou baixo em Ba. Em termos gerais, as litologias mais evoluídas contêm concentrações menores desse elemento e poderiam ter contado na sua formação com a contribuição de um magma crustal empobrecido em $\mathrm{Ba}$, porém, com alto teor em $\mathrm{Rb}$.
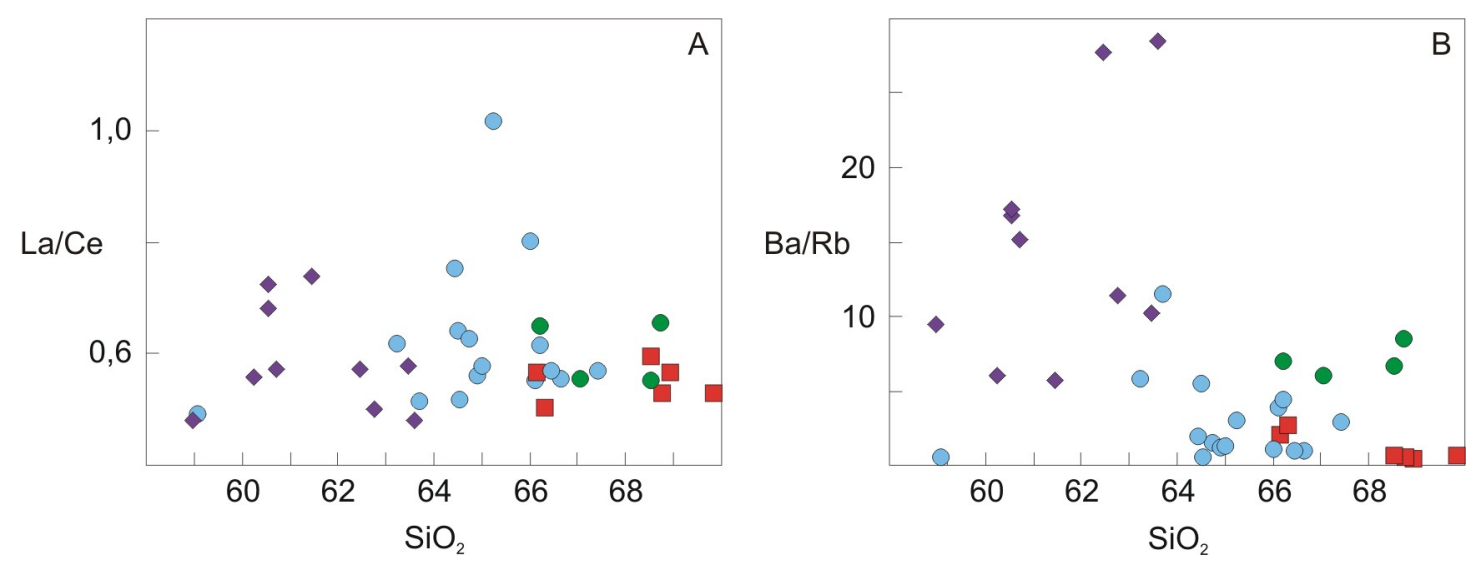

Figura 53. Diagrama $\mathrm{SiO}_{2}$ vs. $\mathrm{La} / \mathrm{Ce}(\mathrm{A})$ e $\mathrm{SiO}_{2}$ vs. $\mathrm{Ba} / \mathrm{Rb}(\mathrm{B})$ para as rochas de Cananéia. 


\section{PETROGÊNESE}

\subsection{Magma parental}

A origem de magmas sieníticos tem sido objeto de muita controvérsia na literatura. Alguns autores interpretam esses magmas como sendo o produto da diferenciação extrema de material fundido de natureza básica alcalina ou traquítica (Coombs e Wilkinson, 1969; Price et al., 1985), da imiscibilidade de líquidos (Ferguson e Currie, 1971) ou ainda da fusão parcial de material básico na crosta inferior-manto superior, quando esses magmas são volumetricamente predominantes em relação às rochas básicas associadas (Bailey e Scheirer, 1966; Bailey, 1987). Ainda segundo Eggler $(1978,1987)$ e Wyllie (1978), algumas questões críticas relacionadas à gênese das rochas alcalinas incluem a identificação dos seus magmas parentais e a definição das características da fonte mantélica, além do melhor entendimento dos processos de fracionamento sofridos pelos magmas durante a subida para níveis mais rasos.

Vários autores têm procurado associar geneticamente magmas sieníticos a processos de diferenciação de magmas basaníticos, instalados em câmaras de níveis profundos na base da crosta (Sørensen, 1986; Eby et al., 1998; Morogan et al., 2000). Contudo, Eby et al. (1998, 2003) admitem também que esses magmas poderiam resultar de fracionamento magmático direto da litosfera. Experimentos de baixas taxas de fusão parcial sob condições próximas do mínimo, em equilíbrio com peridotito mantélico de 1 a $1,5 \mathrm{Ga}$, demonstram que os líquidos resultantes são ricos em sílica e nefelina normativa (Falloon et al., 1999) e apresentam composições similares às das rochas sieníticas alcalinas. Esses resultados são fortemente indicativos da possibilidade de geração de magmas alcalinos por derivação direta do manto.

A investigação de diversas intrusões alcalinas da região sul-sudeste do país tem sugerido que as rochas de natureza "sienítica" aí presentes são resultantes do processo de cristalização fracionada de magmas basaníticos. A apoiar a hipótese está a presença, na forma de pequenos diques, de basanito em algumas delas (Piratini, Barbieri et al., 1987; Ilha de São Sebastião, Bellieni et al., 1990; Juquiá, Beccaluva et al., 1992; Ilha dos Búzios, Alves, 1996; Lages, Traversa et al., 1996), ao lado da possibilidade de, por modelagens geoquímicas com balanço de massas, derivar as demais litologias da suíte dessas ocorrências a partir desse material, supostamente tido como o mais primitivo. Sugestões indicativas de um magma parental de afinidade basanítica foram também feitas por Macciotta et al. (1990) para as rochas alcalinas da Província de Fortaleza, por Brotzu et al. (1989) para a intrusão sienítica de Morro Redondo e, mais recentemente, por Enrich et al. (2006) para a suíte alcalina da llha Monte de Trigo. Por outro lado, magmas parentais de composição gábrica alcalina, teralítica e ankaratrítica foram também propostos, respectivamente, para os complexos de Tunas (Gomes et al., 1987), Pariquera-Açu (Morbidelli et al., 2000) e alcalino-carbonatítico de Jacupiranga (Morbidelli et al., 1995).

Em Cananéia, a ausência de litologias menos diferenciadas (mg\# das rochas da intrusão atinge valor máximo de 0,33 , cf. Tabela 23) e de xenocristais e/ou restitos, bem como de evidências indicativas da presença de material mais primitivo limita em muito qualquer consideração a respeito da natureza do seu magma gerador. Disso resulta que ilações são feitas levando em conta tãosomente as características gerais das rochas, quando comparadas às congêneres de outras ocorrências alcalinas, e o contexto geológico regional em que estão inseridas. Analisando 
conjuntamente os diversos corpos da Província do Arco de Ponta Grossa, Ruberti et al. (2005) concluíram que aqueles associados ao Lineamento de Guapiara, onde também se enquadra o de Cananéia, apresentam maior diversidade composicional, sendo inferidas três possíveis afinidades para os seus magmas geradores: basanítica (Juquiá), teralítica (Pariquera-Açu) e ankaratrítica (Jacupiranga); já os relacionados com o Lineamento São Jerônimo-Curiúva mostram apenas uma tendência, a basanítica (Tunas). Por sua vez, o magmatismo alcalino da Província da Serra do Mar tem basanito como sua única fonte geradora (Morbidelli et al., 1995; Alves, 1996; Brotzu et al., 1997; Enrich, 2005).

A atividade magmática em Cananéia desenvolveu-se em ambiente de baixa pressão, como também sugerido para outras ocorrências sieníticas, igualmente do Cretáceo Superior, da região sudeste do país. Brotzu et al. (1997) interpretaram o complexo de Itatiaia como exemplo notável de manifestação de alto nível crustal, com o magma colocado em profundidade rasa, aproximando-se mesmo de condições subaéreas. Como evidências indicativas dessa conclusão apontaram o caráter quebradiço dos corpos originados nos primeiros pulsos magmáticos e a ocorrência de brechas magmáticas. Estas, por sua vez, estão também presentes na vizinha intrusão sienítica de Morro Redondo (Brotzu et al., 1989), para a qual Valença et al. (1983) propuseram uma formação por diferenciação in situ via cristalização fracionada e/ou acumulação em câmara magmática rasa com pressão de água crescente. Segundo Gomes et al. (1987), a evolução do maciço de Tunas, constituído por cinco estruturas subvulcânicas de forma anelar e apresentando áreas de exposição de brechas magmáticas de formação tardia, se deu também a pequena profundidade.

Ainda que baseados em evidências colhidas principalmente em alguns dos complexos por eles investigados (p.e. Fortaleza, Itatiaia, Jacupiranga, Juquiá, Lages, Morro Redondo, Passa Quatro, Piratini), Morbidelli et al. (1995) generalizaram o entendimento que processos de cristalização foram responsáveis pelas principais tendências evolutivas junto aos distritos alcalinos brasileiros, portadores ou não de carbonatitos, e que a evolução desses magmas se fez em condições de baixa pressão. Mais recentemente, em estudo minucioso sobre o magmatismo alcalino da llha Monte de Trigo, que propiciou a obtenção de informações geológicas sobre o comportamento estrutural dos diques e brechas e, ainda, de dados geobarométricos em minerais de rochas, Enrich (2005) propôs para aquela manifestação, do tipo sienito-gabróide, uma formação em ambiente de baixa pressão (<1 kbar), em concordância também com o modelo de evolução geomorfológica-geotectônica da área apresentado por Almeida e Carneiro (1998).

\subsection{Condições e seqüência de cristalização}

A falta de geotermômetros e geobarômetros mais confiáveis e úteis para a associação petrográfica presente em Cananéia faz com que a determinação de temperaturas de equilíbrio e de pressões apresente grandes incertezas. Não obstante as limitações metodológicas, temperaturas de cristalização e condições de oxidação da intrusão foram calculadas com base na composição química de alguns minerais. Assim, estimativas de temperaturas da cristalização magmática foram determinadas a partir do termômetro proposto por Watson e Harrison (1984), usando a concentração de $\mathrm{P}_{2} \mathrm{O}_{5}$ em rochas granitóides. Esses autores argumentam que, considerando o conteúdo fixo de $\mathrm{P}$ (ou Zr) no mineral cristalizado, a apatita (ou o zircão), a sua concentração no líquido é função apenas do coeficiente de distribuição do elemento, o qual depende diretamente da temperatura. A Figura 54 
demonstra que a temperatura necessária para que todo o $\mathrm{P}_{2} \mathrm{O}_{5}$ dos álcali feldspato sienitos seja dissolvido no magma é em torno de $950^{\circ} \mathrm{C}$. Para os quartzo-álcali feldspato sienitos, a temperatura de dissolução situa-se ao redor de $800^{\circ} \mathrm{C}$, enquanto nos microssienitos ela é inferior a esse valor.

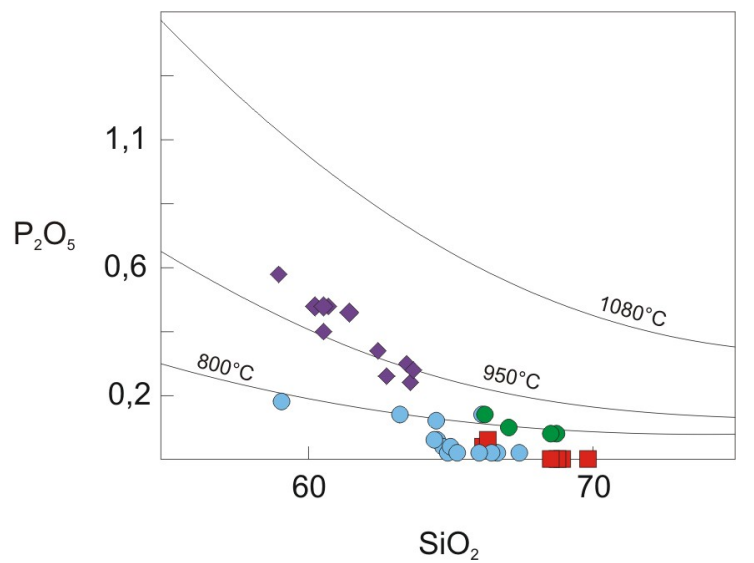

Figura 54. Diagrama $\mathrm{SiO}_{2}$ vs. $\mathrm{P}_{2} \mathrm{O}_{5}$ para as rochas de Cananéia mostrando as curvas de saturação em $\mathrm{P}_{2} \mathrm{O}_{5}$ para temperaturas de $800^{\circ} \mathrm{C}, 950^{\circ} \mathrm{C}$ e $1080^{\circ} \mathrm{C}$ (Watson e Harrison, 1984). Símbolos como na Figura 7.

As condições da fugacidade de oxigênio $\left(\mathrm{fO}_{2}\right)$ para as rochas de Cananéia foram estimadas a partir do quimismo das fases coexistentes magnetita-ilmenita, utilizando para tanto a metodologia de Andersen e Lindsley (1988). A Figura 55 mostra que os dados de fugacidade para o magma que gerou as litologias menos evoluídas da intrusão estão acima ou próximos do buffer NNO, refletindo, assim, um ambiente relativamente oxidado, consistente com ausência de faialita nessas rochas (Brotzu et al., 1997). Por sua vez, aqueles relativos às mais evoluídas situam-se dominantemente entre os buffers NNO e QFM, sugerindo um ambiente menos oxidado que o anterior, a permitir a eventual formação de faialita, como de fato observado em uma amostra do Morro de São João. Dados para a temperatura variam no intervalo de 633 a $717^{\circ}$ para as rochas menos diferenciadas e de 596 a $698^{\circ} \mathrm{C}$ para as mais evoluídas e, em geral, são mais baixos, muito possivelmente, como resultado de reações de reequilíbrio mineral no estado sólido (Brotzu et al., 1997).

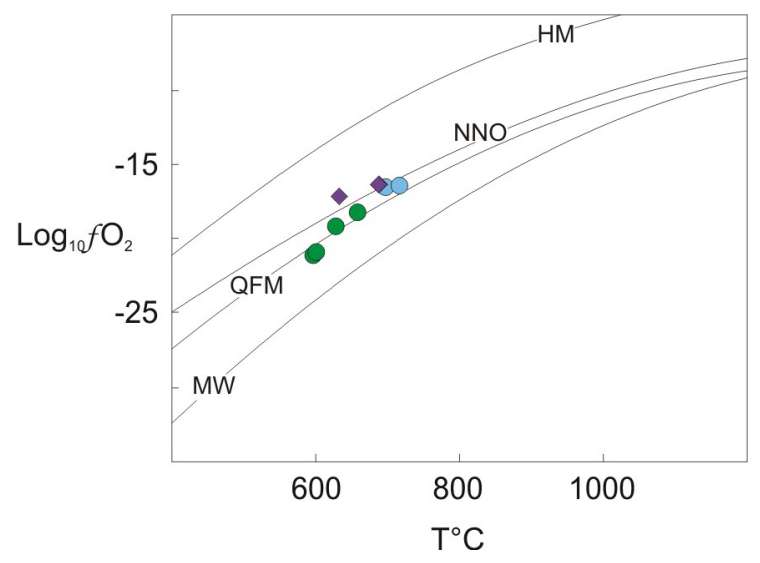

Figura 55. Diagrama $\mathrm{T}^{\circ} \mathrm{C}$ vs. $\log _{10} \mathrm{fO}_{2}$ (Andersen e Lindsley, 1988) para os pares magnetita e ilmenita das rochas de Cananéia. Buffers: HM, hematita-magnetita; NNO, níquel-óxido de níquel; QFM, quartzo-faialita-magnetita; MW, magnetita-wüstita. Valores de $\mathrm{fO}_{2}$ e $\mathrm{T}^{\circ} \mathrm{C}$ obtidos pelo programa ILMAT (Lepage, 2003).

As variações indicadas para a fugacidade são também coerentes com o quimismo dos clinopiroxênios. As rochas menos evoluídas contêm cristais de hedenbergita com núcleos de diopsídio, sendo as bordas dos grãos mais enriquecidas em ferro. Nas mais evoluídas, esses 
minerais têm composição de hedenbergita rica em ferro e, mais raramente, de egirina-augita. Além disso, nessas últimas litologias os anfibólios e as biotitas se mostram mais ricos em $\mathrm{Fe}^{3+}$.

$\mathrm{O}$ conteúdo de $\mathrm{P}_{2} \mathrm{O}_{5}$ e as condições de $\mathrm{fO}_{2}$ sugerem que o início da cristalização das rochas de Cananéia se deu por volta de $950-850^{\circ} \mathrm{C}$, em ambiente apresentando alta atividade de $\mathrm{SiO}_{2}$, valores de $\mathrm{fO}_{2}$ próximos aos dos buffers NNO-QFM e condições oxi-redutoras, como também sugere o baixo valor de $\mathrm{mg \#}(<1,00)$ dos minerais ferromagnesianos primários.

O principal constituinte mineral das rochas de Cananéia é um feldspato alcalino mesopertítico, exibindo estruturas de exsolução bem desenvolvidas e preservadas. Em algumas amostras nota-se que a evolução dos feldspatos teve início com a formação de estruturas de exsolução criptomicroscópicas, passando depois a formas como microtexturas strain-controlled e pertitas do tipo braind (Brown e Parsons, 1988). Nessas condições de resfriamento, as exsoluções evoluíram para pertitas fim e, posteriormente, para pertitas do tipo patch com lamelas grossas e irregulares. $O$ mineral também ocorre como fenocristais idiomórficos a hipidiomórficos, interpretados como sendo de cristalização precoce. Contudo, quando portadores de inclusões, eles parecem ser de formação tardia (cf. Flood e Vernon, 1988).

Plagioclásio é encontrado apenas nas rochas menos evoluídas, mostrando feições sugestivas de cristalização mais precoce, como a presença de cristais idiomórficos a subidiomórficos tabulares, pouco zonados, e composição labradorítica. O mineral ocorre também na forma de manchas no interior dos cristais de feldspato pertítico, sugerindo desmisturação parcial dos componentes Ab-Or. Por sua vez, a presença exclusiva do mineral nos tipos litológicos acima parece indicativa de sua participação nos processos de cristalização fracionada que contribuíram para a formação das rochas de Cananéia.

O diagrama An-Ab-Or (Fig. 56B) mostra a curva do solvus (linha LKS, onde K é o ponto consoluto) e a linha cotética plagioclásio-feldspato alcalino (PAL-C, onde $C$ é o ponto mínimo) para o sistema de feldspatos saturados a uma pressão constante de 2 kbar e pressão de $\mathrm{H}_{2} \mathrm{O}=0,1$ (cálculos segundo Nekvasil,1990, apud Janasi, 1992).

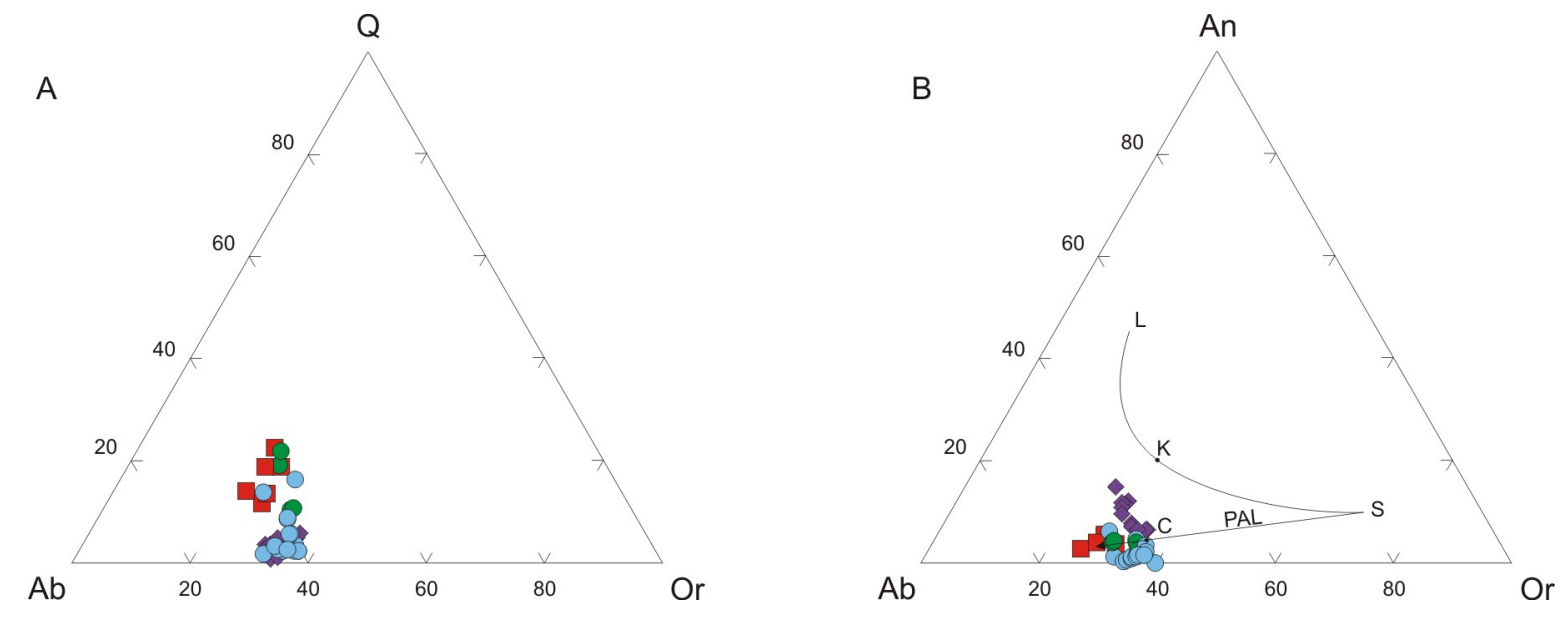

Figura 56. A) Diagrama Q-Ab-Or normativo para as rochas de Cananéia. B) Diagrama An-Ab-Or normativo mostrando as curvas de solvus (linha LSK; K, ponto consoluto) para feldspatos e a linha cotética plagioclásio-feldspato alcalino (PAL; C, ponto mínimo) para o sistema insaturado com pressão de $\mathrm{H}_{2} \mathrm{O}=0,1$ (Nevkvasil, 1990 apud Janasi, 1992). Símbolos como na Figura 7.

Para as rochas menos evoluídas - os álcali feldspato sienitos -, situados acima da linha PAL e próximos ao ponto mínimo $\mathrm{C}$, o plagioclásio é o primeiro feldspato a se cristalizar, sendo, porém, reabsorvido ao final da cristalização magmática, como indica o exame microscópico, onde se 
reconhece tão-somente a sua presença no interior dos cristais de feldspato alcalino. Por outro lado, para as rochas mais diferenciadas, que se situam no campo do feldspato alcalino+líquido, o baixo teor de anortita normativa impede a cristalização de plagioclásio magmático, o que também é confirmado pelo estudo petrográfico. A presença rara de plagioclásio nos microssienitos com textura em mosaico, uma das litologias mais evoluídas da suíte de Cananéia, é, muito possivelmente, devida à rápida cristalização dessas rochas, com o mineral não dispondo de tempo suficiente para reagir totalmente com o magma (Janasi, 1992). Alternativamente, ele poderia estar presente como xenocristal.

A ocorrência simultânea de feldspato alcalino e quartzo, reconhecida tão-somente nas rochas do Morrete, é comum nas bordas de alguns cristais de feldspato apresentando textura eutética a protoeutética. Segundo Flood e Vernon (1988), essa feição é característica do estágio tardio de cristalização de alguns granitóides de alto grau de sub-resfriamento. O quartzo pode ser de origem mais tardia que a do feldspato alcalino, aparecendo quer no preenchimento de espaços intersticiais, quer, ainda que mais raramente, intercrescido com o feldspato alcalino, além de associado às bordas de cristais de anfibólio provenientes da transformação de clinopiroxênio.

Transformações tardias e pós-magmáticas envolvem processos de caolinização e sericitização do feldspato alcalino, ao lado de saussuritização do plagioclásio.

Os principais minerais ferromagnesianos das rochas de Cananéia são os clinopiroxênios e os anfibólios, com o seu quimismo mostrando variações segundo uma linha evolutiva que se inicia pelos termos mais magnesianos, junto aos álcali feldspato sienitos, até os mais ferrosos, ou mesmo férricos, junto aos quartzo-álcali feldspato sienitos e microssienitos. Essa evolução, sugerida principalmente pelo zoneamento químico do mineral, onde os núcleos dos cristais exibem maior riqueza em $\mathrm{Mg}$ e as bordas em Fe, pode ser também visualizada a partir do comportamento da relação $\mathrm{Mg} / \mathrm{Fe}$ das rochas. Variações desse parâmetro permitem acompanhar a seqüência de evolutiva das rochas de Cananéia, primeiramente com a formação dos álcali feldspato sienitos (mg\# 0,33 a 0,13 ), seguida pela dos quartzo-álcali feldspato sienitos (mg\# 0,31 a 0) e, por último, dos microssienitos (mg\# inferior a 0,03).

Os clinopiroxênios e os anfibólios das rochas alcalinas menos evoluídas são dominantemente cálcicos. Já nas mais evoluídas, eles exibem maior variação composicional (cálcica a cálcica-sódica até mesmo sódica), com o empobrecimento em $\mathrm{Mg}$ e $\mathrm{Ca}$ se dando concomitantemente com o enriquecimento em $(\mathrm{Fe}+\mathrm{Mn})$ e $\mathrm{Na}$, típico de rochas alcalinas metaluminosas saturadas em sílica (Bonin e Giret, 1985). A formação de augita em substituição à hedenbergita (ou mesmo diopsídio) nos álcali feldspato sienitos foi a principal mudança química ocorrida na história evolutiva dos clinopiroxênios das rochas de Cananéia.

Os produtos de transformação de temperatura mais baixa dos clinopiroxênios são os anfibólios, as micas (biotita) e os opacos. Algumas vezes observa-se também a presença de quartzo intersticial associado aos anfibólios cálcicos, o que sugere que durante aquele processo de transformação teria ocorrido a liberação de sílica. Segundo Giret et al. (1980), o fracionamento de fases ricas em Ca e pobres em Si junto aos anfibólios induz ao aumento do último elemento no magma, contribuindo, assim, para a produção de líquidos diferenciados ricos em sílica. Nos álcali feldspato sienitos, os cristais de clinopiroxênio de composição cálcica (diopsídio, hedenbergita e augita) encontram-se parcial ou totalmente substituídos por magnesiohornblenda, enquanto nos quartzo-álcali feldspato 
sienitos os anfibólios estão representados por katoforita e richterita. Por último, a biotita secundária, e mesmo os opacos, podem também resultar das reações envolvendo os anfibólios.

Com base em evidências químicas e texturais, a seguinte seqüência de cristalização inicial plagioclásio+clinopiroxênio+anfibólio+opacos+titanita+apatita é sugerida para as rochas de Cananéia; em seguida deu-se a separação de clinopiroxênio+anfibólio (de composição mais cálcica-sódica) e, por último, de feldspato alcalino+quartzo. A cristalização inicial de um clinopiroxênio mais rico em $\mathrm{Mg}$ e Ca levou ao enriquecimento do líquido em Fe, provocando, dessa forma, uma maior saturação em sílica e, ao mesmo tempo, criando condições para a formação de anfibólio cálcico. Já o fracionamento de plagioclásio cálcico foi o fator responsável pelo caráter peralcalino do líquido residual.

\subsection{Cristalização fracionada}

A natureza saturada a supersaturada das rochas de Cananéia é indicada pelo seu teor de quartzo normativo, variando de 0 a $20 \% \cdot \mathrm{K}_{2} \mathrm{O}$ e $\mathrm{Na}_{2} \mathrm{O}$, contribuindo, respectivamente, para a formação de ortoclásio (até 32,73\%) e do componente albítico do plagioclásio (até 61,56\%) (Tabela 23), comprovam a afinidade alcalina dessas rochas, também confirmada pela sua composição modal, que contém mais de $70 \%$ de feldspatos. O alto grau de evolução dessas rochas é demonstrado pelos valores do seu índice de diferenciação (Thorton e Tuttle, 1960), que varia de 71 a 94\% (Tabela 23). Os vários diagramas de variação química e o diagrama ternário Q-Ab-An normativo (Fig. 56A, cf. Tuttle e Bowen, 1958) permitem enquadrá-las em dois grupos litológicos principais: o primeiro, formado pelos álcali feldspato sienitos, e o segundo, reunindo os quartzo-álcali feldspato sienitos, juntamente com os microssienitos de textura em mosaico e os microssienitos porfiríticos de textura traquítica.

Variações sistemáticas na composição química das rochas e nas seqüências paragenéticas (substituição de clinopiroxênio por anfibólio e de plagioclásio por feldspato alcalino, além de outras importantes feições mineralógicas e texturais apontadas no item anterior) são fortemente sugestivas que as rochas de Cananéia foram formadas por processos de cristalização fracionada. A sua seqüência evolutiva é mostrada no sistema petrogenético residual de Hamilton e MacKenzie (1965) (Fig. 57), reunindo as concentrações dos minerais normativos quartzo, nefelina e kalsilita. Nesse diagrama, observa-se que todas as rochas estão projetadas no seu campo superior, o saturado a supersaturado em sílica, e que se dispõem concordantemente à tendência geral no sentido do mínimo riolítico, sugerida para processos de assimilação-cristalização fracionada (ACF). Essa tendência é compatível com o marcante fracionamento de feldspato alcalino, principalmente nos estágios finais da evolução magmática, como indicado pela menor concentração em $\mathrm{K}, \mathrm{Sr}$ e Ba das rochas mais diferenciadas (cf. Figs. 35-37) e, ainda, pela característica e pronunciada anomalia negativa em Eu de todas as litologias da intrusão (cf. Fig. 39). 


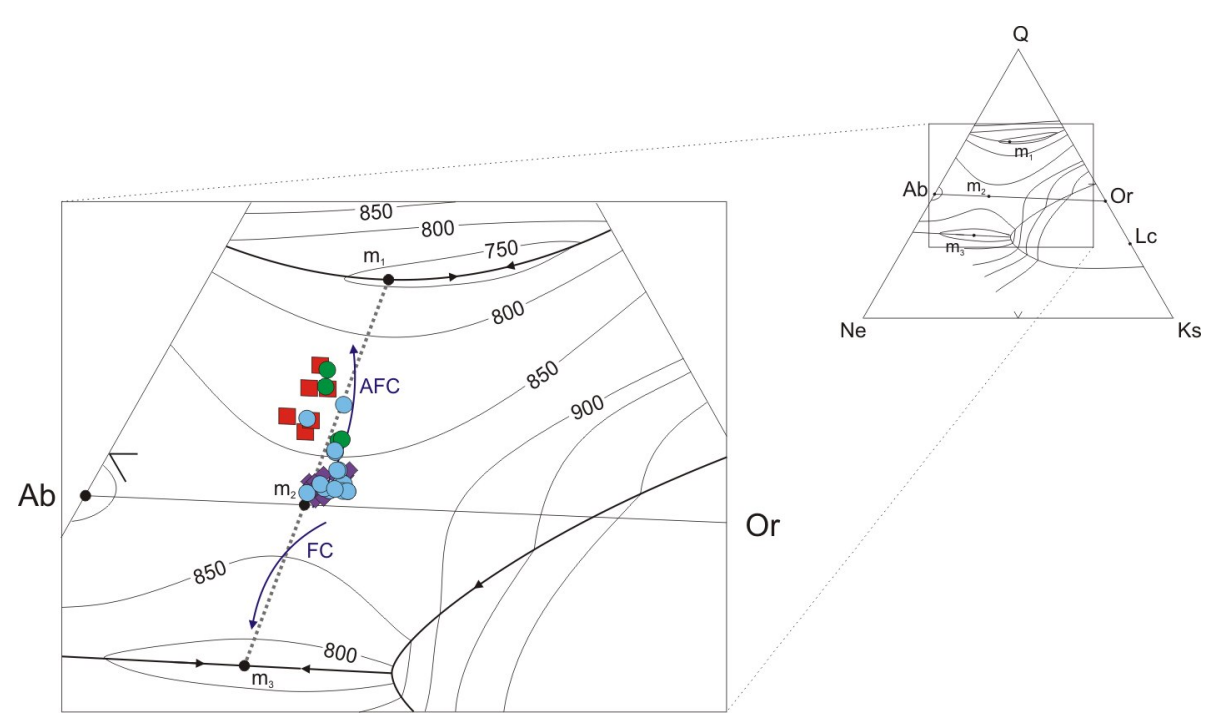

Figura 57. Diagrama normativo nefelina-quartzo-kalsilita para as rochas de Cananéia no sistema petrogenético residual de Hamilton e MacKenzie (1965) para uma pressão de água de 1 kbar. Mínimos: $m_{1}$, riolítico; $m_{2}$, magma inicial; $m_{3}$, fonolítico.

Essa evolução é também consistente com as variações mostradas nos diagramas de Harker (Figs. 35 e 36), onde os teores de $\mathrm{Al}_{2} \mathrm{O}_{3}, \mathrm{Na}_{2} \mathrm{O}, \mathrm{K}_{2} \mathrm{O}, \mathrm{Rb}, \mathrm{Nb}$ e $\mathrm{Zr}$ crescem continuamente, enquanto os de $\mathrm{TiO}_{2}, \mathrm{FeO}_{\mathrm{T}}, \mathrm{MgO}, \mathrm{CaO}, \mathrm{P}_{2} \mathrm{O}_{5}, \mathrm{Cr}$ e $\mathrm{Ni}$ decrescem, com a concentração de sílica, quando passando dos álcali feldspato sienitos para os quartzo-álcali feldspato sienitos e microssienitos.

$\mathrm{Na}$ intrusão de Cananéia, as rochas hipoabissais aparecem como o seu tipo litológico mais evoluído, com valores baixos de mg\# $(<0,03)$, concentrações pequenas de $\mathrm{Sr}$ e $\mathrm{Ba}$ (como mencionado atrás), além de feições mineralógicas muito características, em especial, a natureza mais sódica dos clinopiroxênios e anfibólios e a maior riqueza em $\mathrm{Fe}^{3+}$ das micas.

\subsection{Fonte do magmatismo}

Nos últimos anos, a gênese do magmatismo alcalino e toleítico associado à Província ParanáAngola-Etendeka tem despertado enorme interesse junto à comunidade científica em função da grande quantidade de dados, notadamente geoquímicos e isotópicos, disponibilizados na literatura nacional e internacional. Ao lado do avanço no conhecimento dessas atividades magmáticas, os trabalhos desenvolvidos têm criado condições para uma discussão mais aprofundada e abrangente do tema, proporcionando resultados em número crescente e de maior confiabilidade para a sua melhor compreensão.

Particularmente no tocante ao magmatismo alcalino, dispõe-se no momento de valioso acervo de informações a permitir algumas conclusões petrogenéticas para as rochas presentes em ambas as margens da Bacia do Paraná, que se encontram distribuídas pelo território brasileiro e dos países vizinhos (Paraguai, Bolívia, Uruguai e Argentina) ou mesmo que se estendem pelo continente africano, apresentando variações significativas do ponto de vista geológico, mineralógico-petrográfico, geoquímico e geocronológico.

Considerações genéticas sobre o tema magmatismo alcalino foram feitas em diversos artigos focalizando ocorrências da região sul-sudeste do país (p.e. Piratini, Barbieri et al., 1987; Tunas, Gomes et al., 1987; Morro Redondo, Brotzu et al., 1989; Juquiá, Beccaluva et al., 1992; Passa Quatro, Brotzu et al., 1992; Jacupiranga, Morbidelli et al., 1995; Lages, Traversa et al., 1996; Itatiaia, Brotzu et al., 1997) e da porção central do Paraguai (p.e. Acahay, Comin-Chiaramonti et al., 1990; 
corpos nefeliníticos da região de Assunção, Comin-Chiaramonti et al., 1991; Sapucai, CominChiaramonti et al., 1992), no trabalho de revisão de Morbidelli et al. (1995) e constam também de alguns textos incluídos na obra de Comin-Chiaramonti e Gomes (1996), tratando em geral das alcalinas do Paraguai Oriental. Ainda na década de 1990, um grupo liderado por pesquisadores ingleses forneceu também três importantes contribuições sobre a petrogênese dessas rochas (Gibson et al., 1995, 1997; Thompson et al., 1998).

A partir dos dados coligidos no transcurso do programa de investigação sistemática do magmatismo alcalino da Plataforma Sul-Americana, iniciado primeiramente com as ocorrências brasileiras, em meados da década de 1980, e que envolveu depois os países vizinhos, em especial o Paraguai, Comin-Chiaramonti et al. (1997), analisando conjuntamente o magmatismo toleítico associado, propuseram para a gênese das rochas paraguaias, com ênfase nas variedades potássicas, uma evolução a partir de fonte mantélica litosférica empobrecida, de composição granada peridotito ( \pm flogopita), vertical e lateralmente heterogênea em pequena a grande escala e que foi submetida a baixo grau de fusão parcial, além de variadamente enriquecida em elementos incompatíveis (e também em proporções significativas de $\mathrm{H}_{2} \mathrm{O}, \mathrm{CO}_{2}$ e $\mathrm{F}$, a julgar pela ocorrência de carbonatitos associados).

A heterogeneidade da fonte mantélica em grande escala é sugerida principalmente a partir da idade do magmatismo potássico do Cretáceo Inferior, que decresce do Oeste (Paraguai) para o Leste (Brasil, margem continental SE e Namíbia), e também da idade do magmatismo em geral para as ocorrências do Brasil e Paraguai, variando desde o Cretáceo Inferior até o Terciário (CominChiaramonti et al., 2005). Já os valores para a fusão parcial (4-6\% e 6-11\%, respectivamente, para o magmatismo alcalino sódico e potássico) foram calculados por Comin-Chiaramonti et al. (2007a) constando do trabalho sobre a revisão do magmatismo pós-paleozóico do Paraguai Oriental. Ainda segundo Comin-Chiaramonti et al. (1997), a atividade magmática potássica se caracteriza por apresentar como principais feições geoquímicas o forte fracionamento em Terras Raras, as anomalias negativas em $\mathrm{Ta}-\mathrm{Nb}-\mathrm{Ti}$ e os teores altos em $\mathrm{Sr}$ e baixos em $\mathrm{Nd}$ radiogênicos, enquanto a sódica mostra anomalias positivas para aqueles elementos e está colocada, no diagrama $\varepsilon S r$ vs. $\varepsilon N d$, mais próxima à Terra Global.

Comin-Chiaramonti et al. (1997) argumentaram também que o enriquecimento em elementos incompatíveis estaria associado a processos metassomáticos do manto superior subcontinental, causados seja por fluidos ou por material fundido, relacionados com episódios de subducção (cf. Maury et al., 1992), seja por pequeno volume de material fundido da astenosfera, rico em voláteis, levando à laminação da litosfera sobrejacente em diferentes níveis de profundidade (cf. Foley, 1992a, b) ou, ainda, pela ação de ambos os mecanismos. Adicionalmente, esses processos teriam sido responsáveis pela cristalização de fases ricas em K (p.e. flogopita) no manto peridotítico (pristina), onde se deu também o desenvolvimento de estrutura laminada, diversamente enriquecida em LILE e TRL, em condições "redox". Os veios assim formados (componente enriquecido) e matriz peridotítica (componente empobrecido) foram submetidos a evolução isotópica diferente com o tempo, em função da relação de desintegração radioativa de seus elementos. Por último, considerando as similaridades geoquímicas e, principalmente, isotópicas existentes entre as rochas toleíticas de alto e baixo Ti e as alcalinas e alcalina-carbonatíticas contemporâneas, isto é, do Cretáceo Inferior, aqueles autores estenderam o modelo acima às vulcânicas da Bacia do Paraná, no entendimento que essas duas 
atividades magmáticas estão inseridas no mesmo contexto geodinâmico que promoveu a abertura do Atlântico Sul, sendo, assim, ambas geradas a partir de fontes litosféricas apropriadas durante os estágios iniciais do rifteamento, antes da separação continental.

Esses autores propuseram ainda a existência de dois eventos de metassomatismo no Proterozóico (2,0 a 1,4 Ga e 1,0 a 0,5 Ga), que teriam sido responsáveis pela formação de magmas isotopicamente distintos com marcantes diferenças químicas em termos de concentração de Ti (p.e. alta e baixa), LILE e HFSE, como as encontradas nas rochas alcalinas e toleíticas da Bacia do Paraná. Mais recentemente, investigações conduzidas por esse grupo de pesquisa em ocorrências alcalinas sul-americanas (Comin-Chiaramonti et al., 1999, 2002, 2007b; Ruberti et al., 2002; Velázquez et al., 2006; além de vários outros trabalhos constando do volume de Comin-Chiaramonti e Gomes, 2005) e mesmo africanas (Alberti et al., 1999) confirmam o entendimento para o modelo exposto acima e procuram chamar a atenção para o fato que a assinatura isotópica ( $\mathrm{Sr}-\mathrm{Nd}-\mathrm{Pb}$ ) dessas rochas parece indicativa que os componentes mantélicos HIMU e EMI foram importantes na gênese do magmatismo da Província Paraná-Angola-Etendeka. Essa assinatura isotópica foi também interpretada por Gibson et al. (1995) como indicativa da presença de um manto litosférico subcontinental mostrando diferentes graus de enriquecimento.

Tratando especificamente das rochas do Paraguai Oriental e com base em dados para os isótopos acima, Comin-Chiaramonti et al. (2007a) concluíram que a gênese do magmatismo alcalino nessa região contou com a participação de dois elementos mantélicos principais: um extremo e heterogêneo componente $\mathrm{EMI}$, que prevaleceu junto ao magmatismo potássico do Cretáceo Inferior, e um componente empobrecido, desempenhando papel importante junto ao magmatismo sódico, que se estendeu de meados do Triássico, Cretáceo Inferior (Tardio) até o Paleogeno.

A possível participação de um componente astenosférico na formação de algumas ocorrências alcalinas da Serra do Mar foi primeiramente advogada por Garda et al. (1995), tendo, logo depois, Thompson et al. (1998) desenvolvido a tese que o magmatismo alcalino e alcalino-carbonatítico do Cretáceo Superior, respectivamente, das províncias da Serra do Mar e do Alto Paranaíba refletiria a influência da contribuição variável de componentes do manto astenosférico associado à pluma de Trindade. Discordantemente, vários outros autores têm defendido a idéia que o magmatismo alcalino da Província Paraná-Angola-Etendeka foi originado no manto litosférico e não contou com a participação expressiva de material derivado daquela pluma. Ainda segundo Comin-Chiaramonti et al. (1997), o calor liberado por essa fonte térmica foi responsável pela fusão parcial do manto litosférico sobrejacente, não tendo havido, contudo, contribuição apreciável de componentes da pluma Mesozóica. Com base em dados geoquímicos e geofísicos, Ernesto et al. (2002) propuseram que a gênese dos toleítos da província PAE representaria o produto da fusão de reservatórios do manto subcontinental heterogêneo, com as assinaturas isotópicas dos basaltos de composição variável de Walvis Ridge e Rio Grande Rise sendo explicadas pela contaminação de fragmentos do manto continental litosférico abandonados durante o processo de ruptura dos continentes.

De forma simplificada, pode-se dizer então que, na última década, a discussão sobre a origem do magmatismo alcalino da Plataforma Sul-Americana tem sido centrada, entre outros aspectos, em dois pontos principais: a) a natureza da fonte mantélica e b) a definição da fonte de calor responsável pelo processo de fusão magmática e formação dessas rochas. 
Quanto ao primeiro ponto, como mencionado acima, duas hipóteses de trabalho, manto litosférico versus manto astenosférico, vêm sendo sistematicamente colocadas nos trabalhos que se ocupam da temática. Características geoquímicas e assinaturas isotópicas constituem-se em fortes argumentos a favor de uma origem litosférica para o magmatismo alcalino da Plataforma Sul-Americana, opinião compartilhada por número considerável de pesquisadores (Brotzu et al., 1989, 1992, 1995; 1997; Beccaluva et al., 1992; Gibson et al., 1995, 1997; Traversa et al., 1996; Comin-Chiaramonti et al.,1997, 1999, 2002, 2005, 2007a, b; Castorina et al.,1997; Alberdi et al.,1999; Ulbrich et al., 2003; Riccomini et al., 2005; Bizzi e Araújo, 2005; Velázquez et al.,2006) e também reforçada por Enrich (2005), com base em valores de idade modelo $\left(T_{D M}\right)$ para as rochas da llha Monte de Trigo e demais ocorrências da Província da Serra do Mar. Nesta região, a evolução da crosta continental sobrejacente ao manto litosférico que deu origem ao magmas alcalinos é marcada pela existência de vários eventos tectônicos neoproterozóicos (cf. Heilbron et al., 2004) com idades correlacionáveis aos valores de $\mathrm{T}_{\mathrm{DM}}$ fornecidos por aquele autor.

No tocante ao segundo, o aumento da temperatura no manto poderia ter sido devido ao impacto de plumas mantélicas sob o manto litosférico, como defendido por alguns autores (O'Connor e Duncan, 1990; Wilson, 1992; Gibson et al., 1995, 1997; Thompson et al., 1998; Fodor e Hanan, 2000). Duas plumas principais têm sido sugeridas para o magmatismo alcalino associado geograficamente à Bacia do Paraná: Tristão da Cunha - a maior, responsável pelos eventos do Cretáceo Inferior ( 130 Ma) que atingiram não só a Plataforma Sul-Americana como também o continente africano - e Trindade - a menor, responsável pela atividade do Cretáceo Superior, que se manifesta dominantemente em território brasileiro.

Para o evento do Cretáceo Superior, especificamente o da Província da Serra do Mar, Thompson et al. (1998) propuseram que o desenvolvimento desse magmatismo teria se dado pela migração por distâncias consideráveis da pluma de Trindade para o sul, ao tempo em que a Plataforma Continental se deslocava para o oeste, onde a espessura da litosfera da margem continental era menor quando comparada àquela do norte, sob o Cráton de São Francisco. Como elementos de sustentação da proposta, os autores mencionaram a distribuição espacial e temporal das várias intrusões alcalinas dispostas ao longo do Lineamento Magmático de Cabo Frio (Almeida, 1991; para visualização dessa disposição ver Fig. 3 de Riccomini et al., 2005). Contudo, com base nesse modelo, torna-se difícil justificar a presença de algumas ocorrências alcalinas, também do Cretáceo Superior, muito distantes geograficamente do hipotético centro da pluma por ocasião de sua formação, como as de Lages, em Santa Catarina, ou a de Piratini, no Rio Grande do Sul. Assim, o complexo alcalino-carbonatítico de Lages, situado mais de $1000 \mathrm{~km}$ ao sul do centro de formação da pluma de Trindade, teria a sua origem explicada, segundo Gibson et al. (1999), pela consolidação de material fundido de alta temperatura que teria migrado rumo sul, através de canais, a partir de fonte mantélica localizada sob o Cráton de São Francisco. Essa sugestão, como observado por Comin-Chiaramonti et al. (2005), não leva em consideração, por exemplo, os corpos fonolíticos presentes na área de Piratini, ainda mais distantes daquele centro, bem como as barreiras mecânicas representadas pelo Arco de Ponta Grossa e pelos lineamentos de Piquiri e Uruguai ("limites de placa de segunda ordem").

Outra alternativa para a fonte de calor responsável por aquele magmatismo seria a deixada pela passagem da pluma de Tristão da Cunha, adotado o modelo de VanDercar et al. (1995). Questionando a proposta, Riccomini et al. (2005) argumentaram que a atividade magmática alcalina 
se estendeu por um longo período de tempo (Permo-Triássico ao Cenozóico), tornando, dessa forma, pouco viável a manutenção desse calor remanescente por cerca de mais de $200 \mathrm{Ma}$. Ainda que teoricamente factível, considerando a grande dimensão (diâmetro calculado de cerca de $2000 \mathrm{~km}$ ) estimada para o centro da pluma (cf. White e McKenzie, 1995), aqueles autores observaram ainda que a área coberta pelo magmatismo alcalino é muito extensa, aproximadamente $2000 \mathrm{~km}$ na direção $\mathrm{N}-\mathrm{S}$ e $1700 \mathrm{~km}$ na E-W, ou seja, superior a $2.10^{6} \mathrm{~km}^{2}$.

Levantando sérias restrições ao papel que tem sido atribuído nos últimos anos ao conceito de plumas mantélicas/hotspots, Smith e Lewis (1999) propuseram um novo modelo para explicar a origem do vulcanismo intraplaca. Para o Atlântico Sul, eles defenderam a idéia que forças atuando sobre as placas tectônicas (Sul-Americana e Africana), que se movem a diferentes velocidades angulares, e a presença de fontes mantélicas ricas em voláteis (wetspots) levariam ao desenvolvimento de um sistema de rifteamento paralelo às suturas preexistentes (N-S), correspondente ao Oceano Adamastor, que separou o Cráton do Rio de La Plata, na América do Sul, dos Crátons do Kalahari e Congo, no sudeste da África, a 580-550 Ma (cf. Frimmel e Fölling, 2004). Magmatismo alcalino e alcalino-carbonatítico intraplaca teria ocorrido onde os "limites de placa de segunda ordem" (p.e. Alto Paranaíba, Arcos de Ponta Grossa-Moçâmedes, Lineamento Uruguai, Cinturão Damara) intersectam o eixo principal do rifteamento, indicando uma origem relacionada com a erosão e circulação do manto continental no sentido do eixo da crista por meio de convecção local com o material assumindo a forma de cilindros transversais.

Holbrook e Kelemen (1993) associam a fonte de calor à existência de anomalias térmicas de pequena profundidade. Já Ernesto et al. (2002) procuram relacioná-la com anomalias de alcance regional. No sudeste do Brasil, o magmatismo alcalino e alcalino-carbonatítico está concentrado em regiões mostrando anomalias positivas do geóide (Molina e Ussami, 1999) que, muito possivelmente, guardam ligação com a presença de material denso e quente de grande profundidade. Adicionalmente, as velocidades angulares variáveis, no sentido oeste, de fragmentos litosféricos na Placa Sul-Americana, como definido pelo "limites de placa de segunda ordem", além das distintas tendências rotacionais observadas a $19-20^{\circ}$ de Latitude Sul, poderiam favorecer a descompressão e a fusão de porções variadamente metassomatizadas (wetspots) do manto litosférico com diferentes assinaturas isotópicas e em tempos diferentes. Este cenário explicaria a presença de magmatismo alcalino sódico do Cretáceo Inferior ao Paleogeno na Província Paraná-Angola-Etendeka, até mesmo nas longitudes do Paraguai Oriental, onde existem evidências de estruturas de rifteamento ainda ativas (Comin-Chiaramonti et al., 1992, 1999). Neste caso, as perturbações termais poderiam ter se manifestado ao longo dos "limites de placa de segunda ordem", a exemplo do sucedido com os hipocentros dos terremotos detectados na América do Sul (Berrocal e Fernandes, 1996). 


\section{CORRELAÇÃO GEOLÓGICA}

Considerando o grande número de ocorrências alcalinas existentes na Plataforma Sul-Americana, vários fatores (p.e. condicionamento tectônico, associação petrográfica, características geoquímicas, idade radiométrica entre outros) poderiam ser empregados com o propósito de buscar similaridades e diferenças entre elas, de modo a contribuir para o seu melhor conhecimento e enquadramento no cenário geral dessa atividade magmática.

\subsection{As ocorrências da Província do Arco de Ponta Grossa}

Como observado atrás, a intrusão de Cananéia está associada tectonicamente ao Lineamento de Guapiara, uma das quatro feições estruturais identificadas com ○ Arco de Ponta Grossa. Geograficamente, ela dista apenas algumas dezenas de quilômetros de três outros centros alcalinos da região, os complexos de Pariquera-Açu, Jacupiranga e Juquiá, todos do Cretáceo Inferior, com idade aproximada de $130 \mathrm{Ma}$. Por outro lado, ela encontra-se mais distante de outro conjunto de corpos alcalinos, agora do Cretáceo Superior, mostrando relação tectônica com um segundo lineamento daquele Arco, o de São Jerônimo-Curiúva. Esse agrupamento reúne intrusões maiores (Tunas, Banhadão, Itapirapuã), menores (Mato Preto, Barra do Itapirapuã), além de plugs e pequenos diques distribuídos pelo Vale do Ribeira, que afloram principalmente ao longo da divisa dos Estados do Paraná e São Paulo.

A despeito da proximidade geográfica e do condicionamento tectônico, a intrusão de Cananéia, do Cretáceo Superior, não apresenta qualquer afinidade geológica com os complexos alcalinocarbonatíticos vizinhos de Pariquera-Açu, Jacupiranga e Juquiá, diferindo deles não apenas pela idade mais nova, como também pela sua associação petrográfica, essencialmente sienítica, muito mais simples e sobretudo mais evoluída, quando comparada àquela presente nessas três ocorrências. Petrograficamente, as últimas consistem em rochas cumuláticas de composição variada (piroxenitos, dunitos, peridotitos, ijolitos, melteigitos, gabros alcalinos), com predominância de um ou outro tipo, que ocorrem associadas a variedades sienodioríticas a sieníticas, bem como a carbonatitos, caso de Jacupiranga e Juquiá. $\mathrm{Na}$ forma de pequenos diques estão presentes basanitos, fonotefritos, fonolitos e outras rochas, enquanto fenitos foram também reconhecidos nos dois últimos complexos.

A diversidade petrográfica exibida pelo segundo conjunto é também um fator que dificulta uma correlação mais estreita com as litologias de Cananéia. Rochas cumuláticas (ijolitos, melteigitos, gabros alcalinos) aparecem associadas a nefelina sienitos, carbonatitos, brechas e fenitos em algumas ocorrências, caso, por exemplo, de Banhadão, Itapirapuã e Mato Preto, ao lado de diques de fonolito, tinguaíto e lamprófiro. Já a intrusão de Barra do Itapirapuã é representada dominantemente por um sistema complexo de diques e veios de carbonatitos, de diferentes gerações e composição variável, juntamente com rochas silicáticas de natureza sienítica.

Quanto às variedades hipoabissais e vulcânicas (plugs), dominantemente de composição fonolítica, associadas a esse lineamento, Ruberti et al. (2005) destacam como suas feições mais características nos diagramas multielementares normalizados para o manto primitivo (Sun e McDonough, 1989) e condritos (Boynton, 1984): a) as fortes anomalias positivas em Nb e Zr e negativas em $B a$ e $P, b)$ o grau de enriquecimento muito variável dos elementos Terras Raras (ETR), 
c) o fracionamento das TRL em relação às TRP, que se mostra, contudo, mais complexo junto às TRM e TRP e d) a presença de anomalias positivas e negativas em Eu.

De todos os centros alcalinos intrusivos da região do Arco de Ponta Grossa, o maciço de Tunas, distante cerca de $80 \mathrm{~km}$ da cidade de Curitiba e ocupando área aproximada de $22 \mathrm{~km}^{2}$, é, sem dúvida, aquele que apresenta maiores similaridades com o de Cananéia, considerando principalmente a idade das suas rochas $(82,7 \pm 0,7 \mathrm{Ma}$, U/Pb e $84,7 \pm 1,2 \mathrm{Ma}$, SHRIMP; cf. Siga Júnior et al., 2007) e a sua associação petrográfica. Não obstante a ocorrência de tipos cumuláticos (gabros alcalinos, sienogabros, essexitos) e a presença de brechas magmáticas, a litologia dominante em Tunas é representada por sienitos e álcali sienitos, com os diques tardios, igualmente de afinidade sienítica (microssienitos, traquitos), sendo pouco freqüentes.

Diagramas de elementos incompatíveis e Terras Raras são fornecidos somente para as litologias mais evoluídas de Tunas (Figs. 58A, B), de modo a permitir a sua comparação com as rochas fortemente diferenciadas de Cananéia. As variedades intrusivas de Tunas se caracterizam por exibir anomalia negativa muito pronunciada em $\mathrm{Sr}$ e menos acentuada em P e Ti. Zr apresenta anomalia positiva, que se mostra mais intensa nas rochas de diques. Já Ba comporta-se irregularmente, com picos positivo ou negativo. No geral, o padrão de distribuição dos El é muito similar ao observado nas rochas de Cananéia (Figs. 38A, B), inclusive no tocante ao comportamento do Ba.
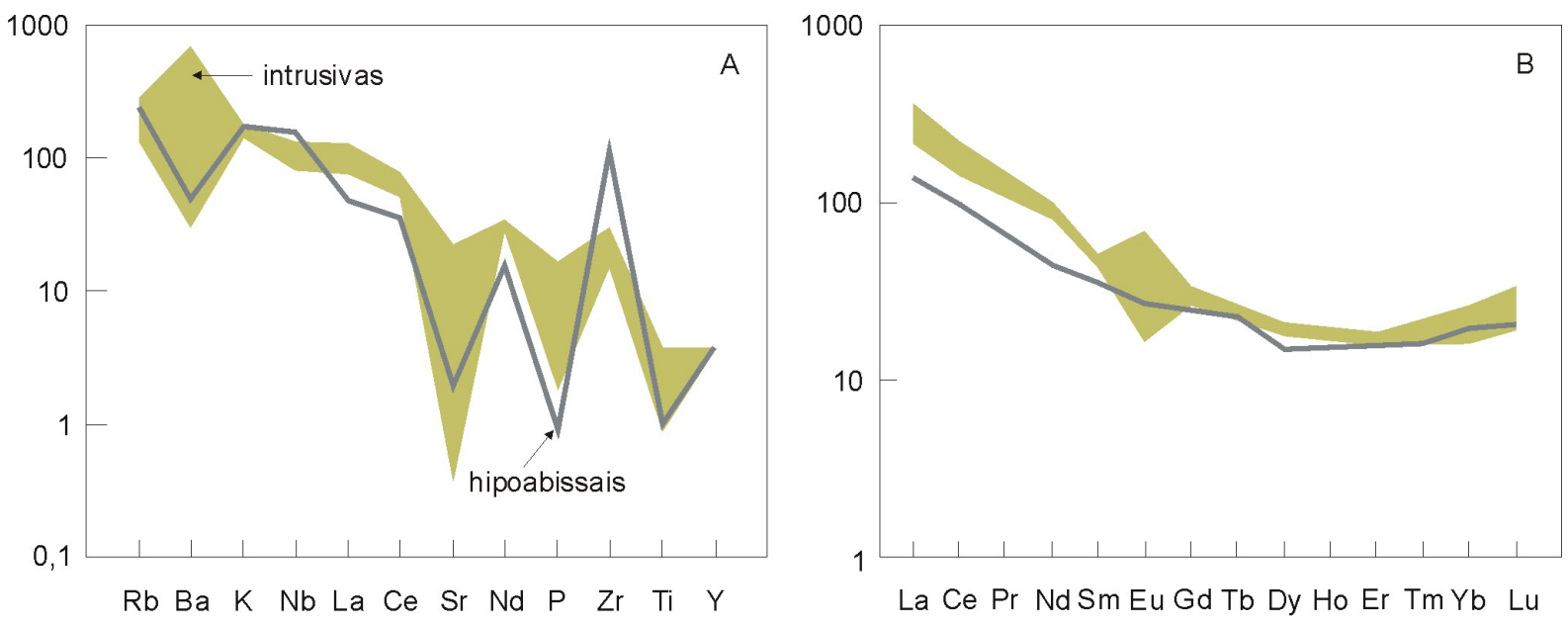

Figura 58. Diagramas de elementos incompatíveis $(A)$ e Terras Raras (B), normalizados, respectivamente, para o manto primitivo (Sun e McDonough, 1989) e condritos (Boynton, 1984), para as rochas alcalinas de Tunas. Dados extraídos de Ruberti et al. (2005).

Segundo Ruberti et al. (2005), a distribuição dos ETR nas rochas de Tunas (Fig. 58B) é marcada pelo fracionamento das TRL em relação às TRP, com a curva assumindo forma ligeiramente côncava junto às TRM e TRP ( $\left.\mathrm{La} / \mathrm{Sm}_{\mathrm{C}}=4,5-7,3 ; \mathrm{La} / \mathrm{Yb}_{\mathrm{C}}=8,7-20,9\right)$. Eu mostra anomalia positiva ( $\mathrm{Eu} / \mathrm{Eu}^{*}=1,81 \mathrm{e}$ $2,01)$ ou negativa $\left(\mathrm{Eu}^{\mathrm{E}} \mathrm{Eu}^{*}=0,41\right)$, comportamento esse interpretado por aqueles autores como indicativo do ambiente complexo de formação dessas rochas, envolvendo, respectiva e localmente, processos de acumulação e remoção de plagioclásio. A análise comparativa com as Figuras 39A, B possibilita realçar a similaridade do padrão de distribuição das Terras Raras nas duas ocorrências, com a diferença mais significativa residindo na anomalia em $\mathrm{Eu}\left(\mathrm{Eu}_{\mathrm{Eu}}^{*}=0,20-0,89\right)$ das rochas intrusivas de Cananéia, exclusivamente negativa e bem mais pronunciada que em Tunas. 


\subsection{As ocorrências da Província da Serra do Mar}

Os corpos alcalinos dessa província, todos do Cretáceo Superior, em geral intrusivos e de natureza eminentemente sienítica, formam dois conjuntos distintos, com o primeiro incluindo as ilhas oceânicas existentes na região litorânea do Estado de São Paulo e o segundo correspondendo aos maciços da Serra da Mantiqueira. Do ponto de vista tectônico, os complexos costeiros estão relacionados ao Rift Continental do SE do Brasil (Riccomini et al., 2005), desenvolvido no cinturão Ribeira segundo sistemas transcorrentes de orientação ENE a EW, reativados durante a separação do Gondwana. Já os complexos do segundo conjunto, que se destacam pela grande área de exposição e topografia elevada (p.e. Itatiaia: 220 km², 2.787 m; Passa Quatro: 165 km², 2.780 m), estão associados ao Lineamento Magmático de Cabo Frio (Almeida,1991; Riccomini et al., 2005), uma importante feição estrutural de direção WNW-ESSE que se estende por centenas de quilômetros e reúne mais de duas dezenas de ocorrências alcalinas, entre elas a de Poços de Caldas, o maior maciço alcalino brasileiro, com área superior a $800 \mathrm{~km}^{2}$.

No primeiro grupo estão incluídas as ocorrências das Ilhas de São Sebastião, esta conhecida geologicamente desde o final da década de 1940, Vitória, Búzios e Monte de Trigo. Por uma coincidência, todas foram investigadas como temas de teses de doutorado, respectivamente, de Freitas (1947), Motoki (1986), Alves (1996) e Enrich (2005). Em geral, são constituídas por rochas sieníticas, que variam de insaturadas a supersaturadas, ainda que os tipos saturados sejam dominantes. Como diques estão presentes rochas de afinidade sienítica (microssienitos, traquitos, fonolitos, traquifonolitos), além de basanitos e lamprófiros. Rochas cumuláticas (teralitos, essexitos) são encontradas nas llhas de São Sebastião e Monte de Trigo, sendo ainda que nesta última ocorrência existem brechas magmáticas.

Diagramas de elementos incompatíveis, normalizados para o manto primitivo (McDonough e Sun, 1995), são mostrados para as rochas sieníticas e diques félsicos das llhas de Vitória, Monte de Trigo, Búzios e São Sebastião (Figs. 59A, B). O padrão de distribuição para essas ocorrências é geralmente muito similar, com anomalias negativas em $\mathrm{Sr}, \mathrm{P}$ e Ti, e positivas em $\mathrm{Nb}$ (à exceção de Vitória), $\mathrm{Nd}$, $\mathrm{Zr}$ e Y. O comportamento do Ba é irregular, com anomalia positiva muito discreta e negativa muito acentuada, principalmente nas variedades intrusivas de São Sebastião (Fig. 59A) e nas hipoabissais de Vitória, Monte de Trigo e Búzios (Fig. 59B). Já as rochas de Monte de Trigo e São Sebastião, ao lado do fracionamento das TRL em relação às TRP, têm como principais características a maior riqueza em Terras Raras e a presença de forte anomalia negativa em Eu dos seus tipos hipoabissais (Figs. 60A, B). A análise comparativa com as rochas de Cananéia (Figs. 38A, B e Figs. 39A, B) aponta grandes semelhanças na tendência geral de distribuição dos ETR e El, sendo as pequenas diferenças devidas a maior ou menor intensidade das anomalias apresentadas por alguns elementos.

Ao segundo, pertencem as ocorrências da região da Serra da Mantiqueira, onde se distinguem três maciços geograficamente muito próximos: Itatiaia, Passa Quatro e Morro Redondo. Eles têm como litologia dominante sienitos, que variam composicionalmente de insaturados a supersaturados. Diques estão também representados por rochas sieníticas (microssienitos, traquitos, fonolitos) e, em Morro Redondo, por pequenos corpos de microessexito e fonotefrito. Uma pequena ocorrência de granito alcalino é encontrada na porção central do complexo de Itatiaia, enquanto brechas magmáticas foram ali também reconhecidas, bem como no maciço vizinho de Morro Redondo. 

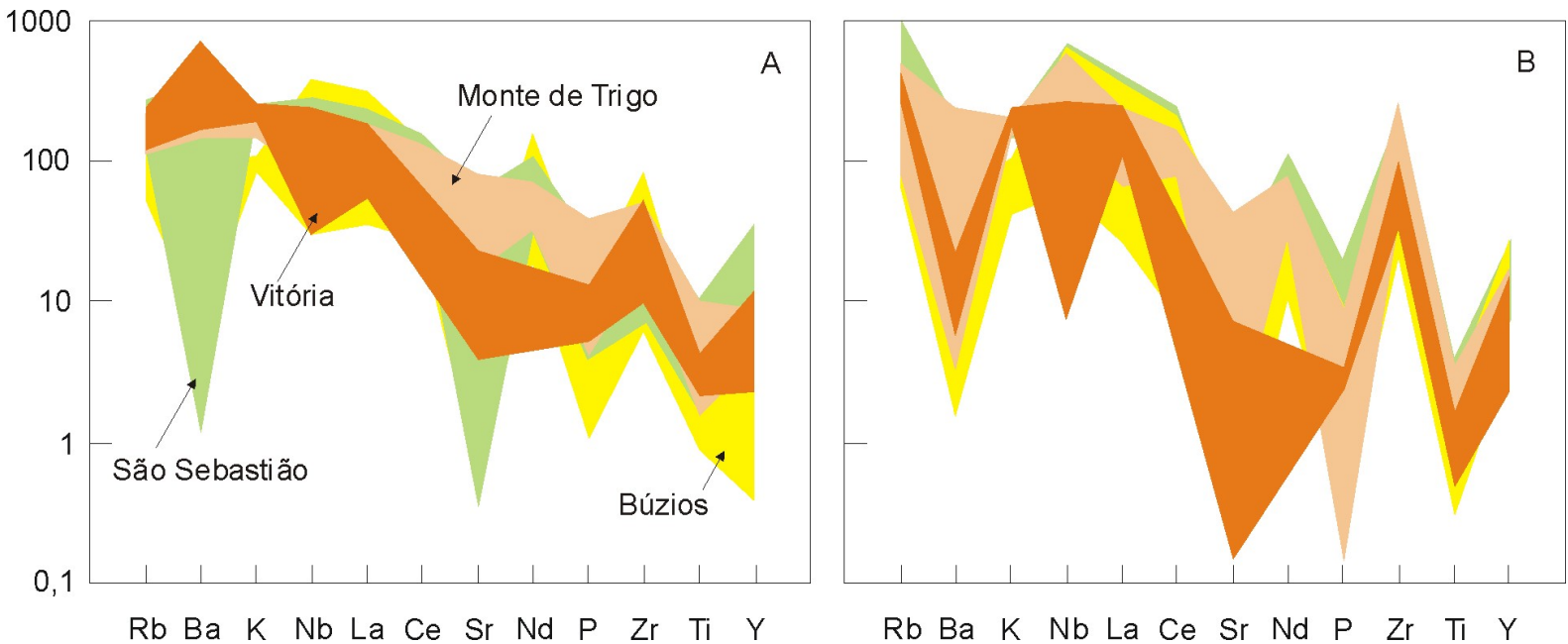

Figura 59. Diagramas de elementos incompatíveis, normalizados para o manto primitivo (McDonough e Sun, 1995) para as rochas alcalinas intrusivas (A) e hipoabissais (B) das llhas de Vitória, Monte de Trigo, Búzios e São Sebastião. Dados extraídos de Motoki (1986) para Vitória, de Alves (1996) para Búzios e de Enrich (2005) e Enrich et al. (2005) para Monte de Trigo e São Sebastião.

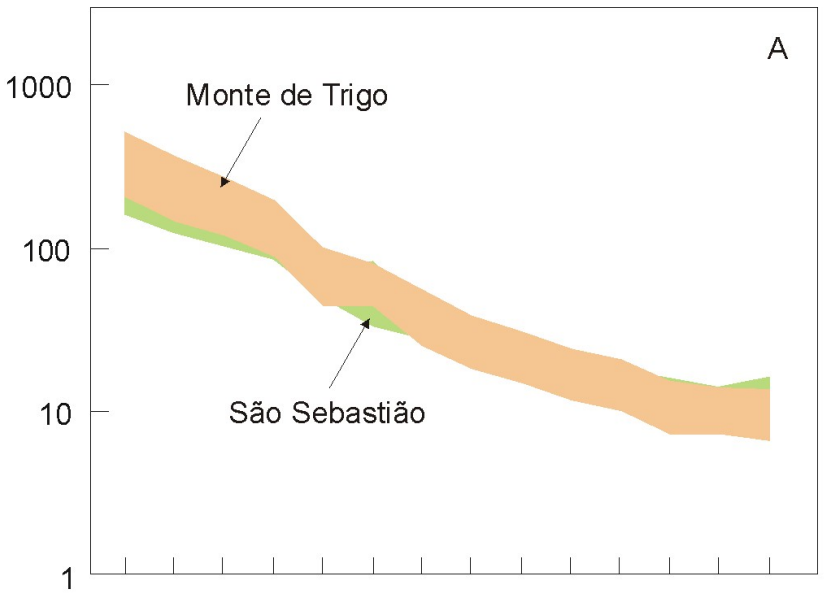

La Ce Pr NdSm Eu Gd Tb Dy Ho Er Tm Yb Lu

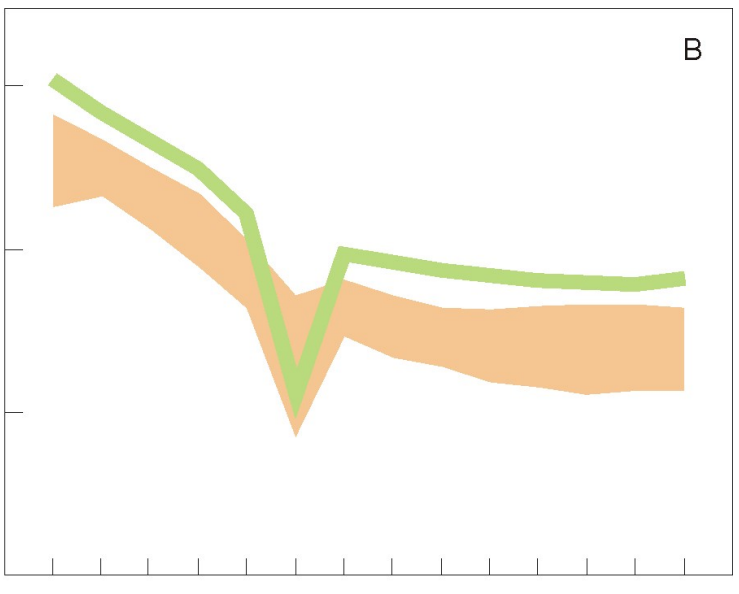

La Ce Pr NdSm Eu Gd Tb Dy Ho Er Tm Yb Lu

Figura 60. Diagramas de elementos Terras Raras, normalizados para os condritos (McDonough e Sun, 1995), para as rochas alcalinas intrusivas (A) e hipoabissais (B) das llhas de Monte de Trigo e São Sebastião. Dados extraídos de Enrich (2005) e Enrich et al. (2005).

As Figuras 61A, B contêm os diagramas de elementos incompatíveis, normalizados para o manto primitivo (McDonough e Sun, 1995), das variedades intrusivas e diques félsicos associados dos maciços de Itatiaia, Passa Quatro e Morro Redondo. As características gerais são consistentes com as apresentadas pelas rochas das ilhas oceânicas (Figs. 59A, B), indicando fortes anomalias negativas em $\mathrm{Sr}, \mathrm{P}$ e $\mathrm{Ti}$, e positivas em $\mathrm{Nb}, \mathrm{Nd}, \mathrm{Zr}$ e $\mathrm{Y}$. Ba comporta-se de forma mais uniforme nessas três ocorrências, exibindo pronunciada anomalia negativa, em particular junto às litologias de Itatiaia e Passa Quatro.

O comportamento das Terras Raras é ilustrado nos diagramas normalizados para condritos (McDonough e Sun, 1995) das Figuras 62A, B. Ao lado do fracionamento das TRL em relação às TRP, observa-se a presença de anomalia negativa em Eu, que se mostra mais acentuada nas variedades intrusivas de Itatiaia e um pouco menos nas de Passa Quatro. Nos tipos intrusivos dessa última ocorrência nota-se também que o elemento exibe uma discreta anomalia positiva. A tendência geral de distribuição das Terras Raras nas rochas dos três maciços não difere significativamente da mostrada pelas rochas de Cananéia. 

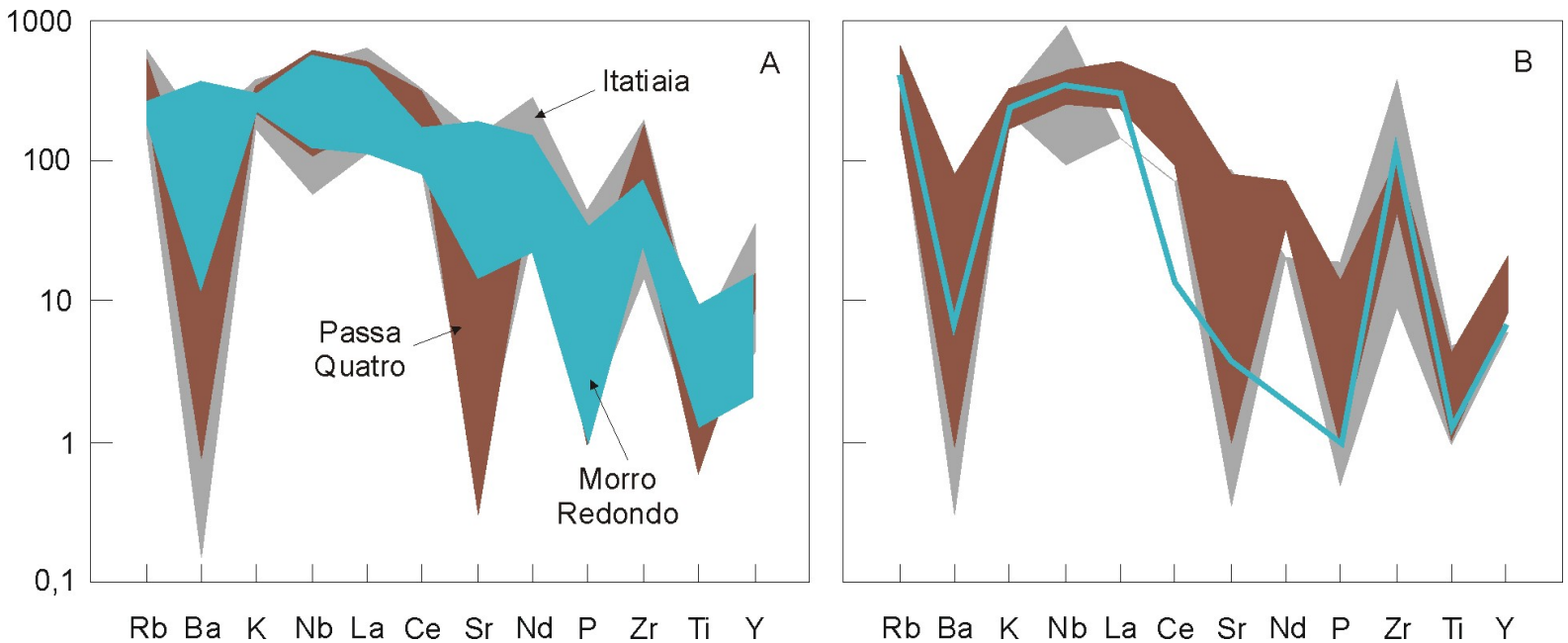

Figura 61. Diagramas de elementos incompatíveis, normalizados para o manto primitivo (McDonough e Sun, 1995), para as rochas alcalinas intrusivas (A) e hipoabissais (B) de Itatiaia, Morro Redondo e Passa Quatro. Dados extraídos de Brotzu et al. (1989) e Enrich et al. (2005)

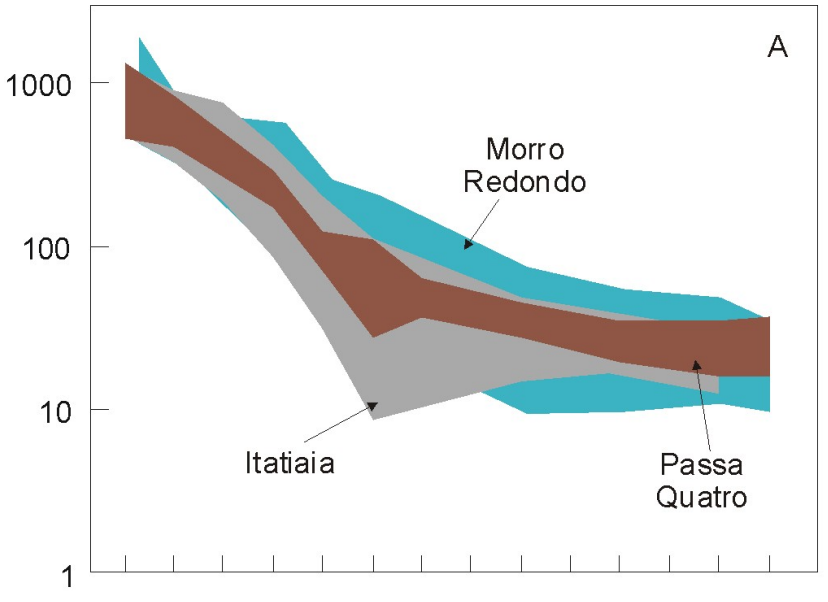

La Ce Pr NdSm Eu Gd Tb Dy Ho Er Tm Yb Lu

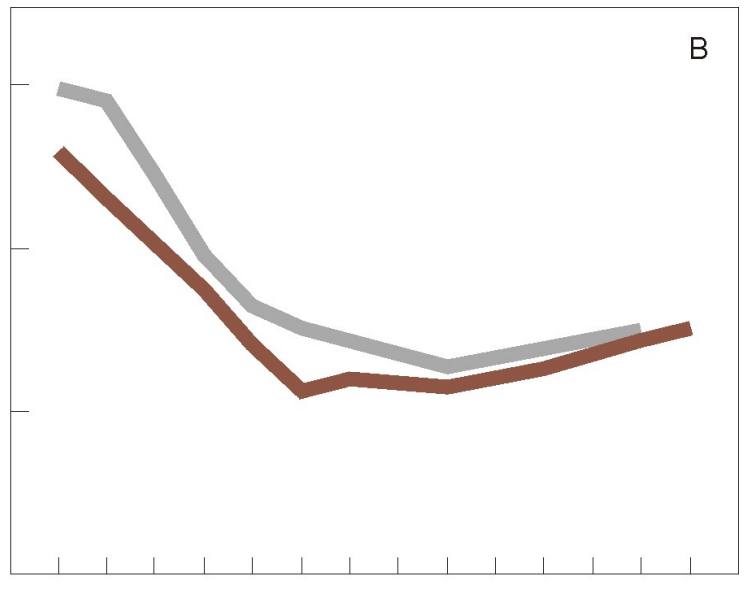

La Ce Pr NdSm Eu Gd Tb Dy Ho Er Tm Yb Lu

Figura 62. Diagramas de elementos Terras Raras, normalizados para condritos (McDonough e Sun, 1995). Para as rochas alcalinas intrusivas (A) e hipoabissais (B) de Itatiaia, Morro Redondo e Passa Quatro. Dados extraídos de Brotzu et al. (1989) e Enrich et al. (2005).

\subsection{A ocorrência de Ponta do Morro, MT}

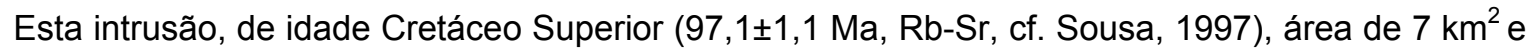
incluída por Riccomini et al. (2005) no grupo das províncias alcalinas adjacentes à Bacia do Bauru, está relacionada tectonicamente à Antéclise de Rondonópolis (Coimbra, 1991), uma feição tectônica positiva de orientação NE-SW reunindo importantes elementos estruturais como os Arcos de São Vicente e Alto Xingu e o Lineamento Transbrasiliano de Schobbenhaus et al. (1981). Ela é constituída principalmente por rochas graníticas e sieníticas subordinadas, cortadas por diques de ocorrência rara de traquitos e riolitos.

Diagramas de elementos incompatíveis, normalizados para o manto primitivo (McDonough e Sun, 1995), das rochas intrusivas (A) e diques (B) de Ponta do Morro são mostrados na Figura 63. O padrão de distribuição dos El reconhecido nas ocorrências do Arco de Ponta Grossa e da Serra do Mar está também presente, com destaque para as anomalias negativas em $\mathrm{Ba}, \mathrm{Sr}, \mathrm{P}$ e Ti, e positivas em Nb, Zr e Y. No geral, esse comportamento é similar ao das rochas de Cananéia (Figs. 38A, B). 


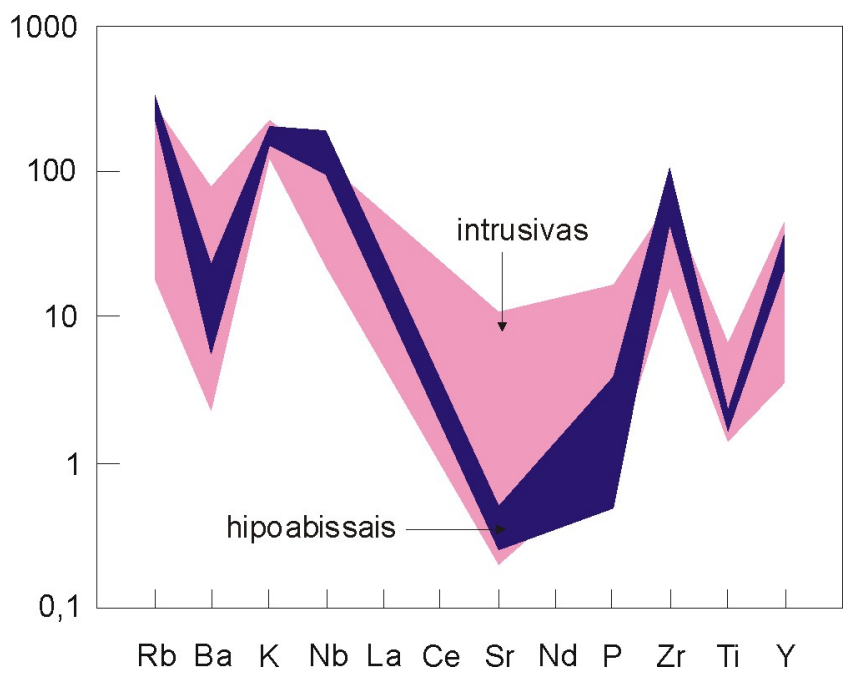

Figura 63. Diagramas de elementos incompatíveis, normalizados para o manto primitivo (McDonough e Sun, 1995), das rochas intrusivas (A) e de diques (B) do Ponta do Morro. Dados extraídos de Sousa (1997). 


\section{CONSIDERAÇÕES FINAIS}

\subsection{Seqüência cronológica}

Devido à limitação dos dados geológicos de campo, as informações disponíveis permitem apenas inferir uma possível seqüência cronológica de formação para as rochas de Cananéia, como idealizada no gráfico esquemático da Figura 64.

- Intrusão do magma sienítico nas rochas encaixantes do Grupo Açungui. As variações texturais (p.e. granulométricas) dos litotipos alcalinos são indicativas de diferentes regimes termais, com a consolidação do magma se dando de forma progressiva e contínua. Com a queda do gradiente termal cristalizaram-se, sucessivamente, desde sienitos de granulação mais grossa até variedades de granulação mais fina como os microssienitos. Durante o alojamento do magma sienítico parece ter havido assimilação parcial das encaixantes graníticas, provocando modificação da composição original do material intrusivo, principalmente da sua concentração em sílica.

- Sincrônica e posteriormente à formação dos sienitos, teve lugar a colocação dos diques de microssienito e de veios pegmatóides, indicando ambiente tectônico de formação de baixa temperatura e profundidade. A intrusão dos microssienitos processou-se em duas fases: na primeira, os corpos apresentam-se orientados para NW-SE (Senoniano) e, na segunda, para NESW (Paleozóico/Eoceno). Pelo fato de estarem parcialmente deformados, alguns diques de microssienito podem também ter origem sin-plutônica.

- Nível atual (Souza et al., 1996) recuo erosivo da Serra do Mar (Almeida e Carneiro, 1998) e formação da Planície Costeira Cananéia-Iguape (Souza et al., 1996).
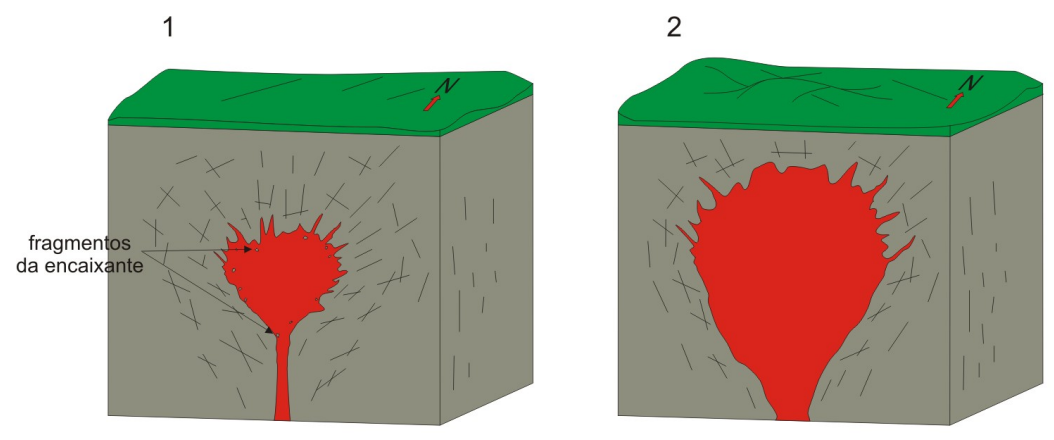

3

4

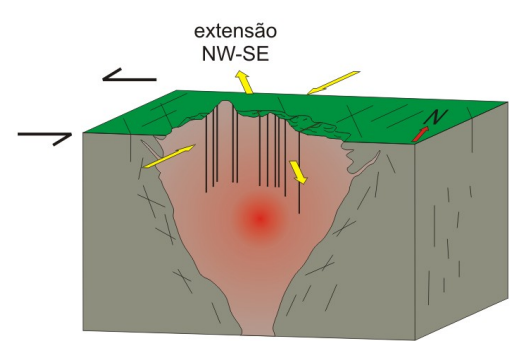

5

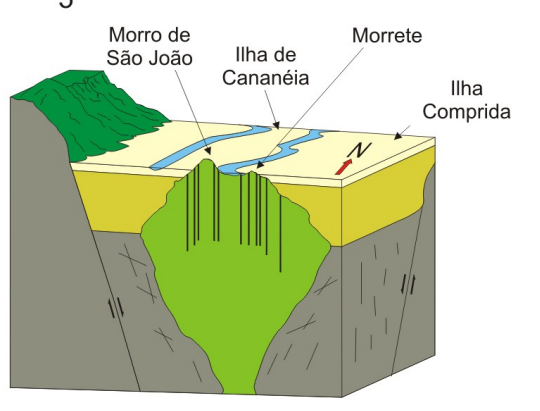

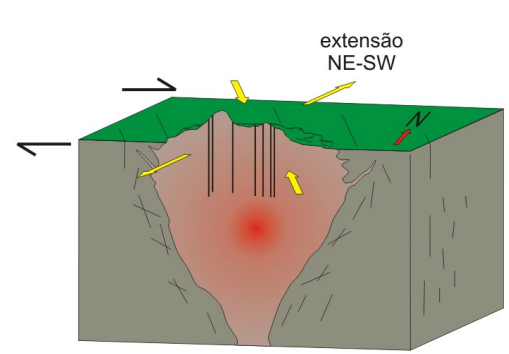

Legenda

- Vegetação

$\square$ Sedimentos quaternários

$\square$ Sedimentos terciários

- Diques e veios de microssienitos

$\square$ Rochas sieníticas

Magma alcalino

Grupo Açungui

$\Rightarrow$ Direção do tectonismo regional

Figura 64. Blocos diagramas esquemáticos da evolução magmática de Cananéia; sem escala. 1 e 2 - início da intrusão do magma alcalino e assimilação de material crustal; 3 - desenvolvimento da Superfície Japi no Senoniano com extensão NE-SW e intrusão dos diques de direção NW-SE; 4 - avanço da erosão na Superfície Japi no Paleozóico/Eoceno com extensão NW-SE e intrusão dos diques de direção NE-SW; 5 - estágio atual da Planície Costeira Cananéia-Iguape. 


\subsection{Conclusões}

Com base em dados modais, as rochas de Cananéia são classificadas como álcali feldspato sienitos, quartzo-álcali feldspato sienitos e quartzo-álcali feldspato sienitos porfiríticos de matriz fina subordinados. Os diques que cortam o maciço estão representados por microssienitos com textura em mosaico e microssienitos porfiríticos com textura traquítica.

Os álcali feldspato sienitos são rochas de estrutura maciça, textura fanerítica inequigranular, granulação variável de média a grossa, compostas por feldspato alcalino, clinopiroxênio, anfibólio, biotita, quartzo e raros pseudomorfos de olivina; opacos, apatita, titanita e zircão constituem os seus principais acessórios. Os quartzo-álcali feldspato sienitos são rochas de estrutura, textura e mineralogia similares às anteriores. Localmente, podem exibir caráter pegmatóide e a sua variação porfirítica reúne rochas de estrutura maciça, fanerítica fina e textura traquítica, sendo a matriz de granulação variável e orientada face à disposição dos cristais tabulares de feldspato, anfibólio e, mais raramente, de biotita.

As variedades hipoabissais (microssienitos de textura em mosaico) são rochas de estrutura maciça, granulação fina e textura do tipo mosaico, definida pelo arranjo dos cristais de feldspato alcalino discretamente orientados, ao lado de clinopiroxênio de composição sódico-cálcica (augita) a sódica (egirina-augita e pequena quantidade de olivina e biotita. Elas podem também evoluir para tipos porfiríticos com arranjo traquítico, este dado pela orientação dos cristais tabulares de feldspato alcalino e dos prismas de clinopiroxênio.

A química mineral das rochas de Cananéia mostra um feldspato alcalino com ampla variação composicional e representado por uma mesopertita exibindo caráter predominantemente hipersolvus. A presença de plagioclásio está restrita aos termos menos evoluídos, caracterizando, assim, os litotipos subsolvus. Intercrescimentos micrográfícos de feldspato alcalino e quartzo são raros, além de reconhecidos somente nos quartzo-álcali feldspato sienitos do Morrete. O clinopiroxênio é de composição cálcica (hedenbergita, augita e diopsídio) com tendência sódico-cálcica (egirina-augita) ou ainda sódica nas rochas mais evoluídas. Outros minerais máficos presentes incluem anfibólio cálcico (magnesiohornblenda, ferrohornblenda, edenita, ferro-edenita, magnesiohastingsita), cálcicosódico (katoforita, barroisita, richterita, winchita) e sódico (arfvedsonita), bem como biotita (ferrobiotita do grupo da annita) e olivina (faialita).

A seqüência de cristalização dos minerais das rochas de Cananéia teve início com os acessórios (apatita, zircão, titanita, opacos), que foram seguidos pelo plagioclásio cálcico e clinopiroxênio. $O$ aumento da pressão de água parece ter levado à formação de anfibólio e biotita em substituição ao clinopiroxênio cálcico, que, por sua vez, se torna cada vez mais cálcico-sódico ou mesmo sódico com o aumento da diferenciação. Na seqüência, tem lugar o aparecimento de feldspato alcalino e quartzo, o último claramente de cristalização mais tardia e ocupando invariavelmente os interstícios dos demais minerais da rocha. Mais raramente, fenocristais de feldspato alcalino estão presentes em variedades porfiríticas, sendo, então, de formação precoce. A presença de opacos de cristalização tardia, de formação posterior à da biotita, é sugerida pelo alojamento desses minerais ao longo dos planos de clivagem dos filossilicatos. Por outro lado, não é possível concluir se a cristalização da olivina foi concomitante ou não à do clinopiroxênio.

A associação mineralógica e o conteúdo de $\mathrm{P}_{2} \mathrm{O}_{5}$ das rochas permitem inferir temperaturas de cristalização em torno de $950^{\circ} \mathrm{C}$ para os álcali feldspato sienitos e próximas ou inferiores a $800^{\circ} \mathrm{C}$ 
para os quartzo-álcali feldspato sienitos e microssienitos. Por outro lado, a distribuição dos minerais opacos mostra que ilmenitas são mais comuns na primeira litologia, enquanto magnetitas são mais abundantes nas rochas mais diferenciadas. Dados obtidos a partir do quimismo das fases coexistentes sugerem temperaturas de cristalização entre $600^{\circ}$ e $800^{\circ} \mathrm{C}$, sendo os valores em geral mais altos para as ilmenitas e mais baixos para as magnetitas; já os valores da fugacidade de oxigênio indicam um ambiente de formação relativamente oxidado e menos oxidado, respectivamente, para esses minerais.

Atividades tardi a pós-magmática e hidrotermal são responsáveis por mudanças mineralógicas que, em geral, não provocaram grandes modificações nas texturas primárias das rochas do maciço. Aqui se distinguem a sericitização dos feldspatos, a uralitização dos piroxênios, o pseudomorfismo parcial ou total da olivina e do clinopiroxênio, além das estruturas de exsolução presentes nos feldspatos e as transformações dos opacos por processos de oxi-redução.

O estudo geoquímico caracteriza os sienitos de Cananéia como sendo rochas altamente evoluídas, com marcante enriquecimento em álcalis e empobrecimento em ferro e magnésio, além de teores muito baixos em mg\#, $\mathrm{Cr}$ e $\mathrm{Ni}$. Com base no índice de diferenciação e na variação do teor de $\mathrm{SiO}_{2}$, têm-se que os álcali feldspato sienitos $\left(\mathrm{SiO}_{2}: 63,6-60,2 \%\right)$ são os tipos petrográficos menos evoluídos; os quartzo-álcali feldspato sienitos $\left(\mathrm{SiO}_{2}: 68,7-63,2 \%\right)$ ocupam posição intermediária; e os microssienitos com textura em mosaico e os microssienitos porfiríticos com textura traquítica $\left(\mathrm{SiO}_{2}\right.$ : $69,8-66,1 \%)$ são as litologias mais diferenciadas.

A seqüência de cristalização dos minerais e o conjunto dos dados geoquímicos parece sugerir que a evolução magmática das rochas de Cananéia processou-se por cristalização fracionada a partir dos álcali feldspato sienitos, que, uma vez em contato com as encaixantes graníticas, vieram a dar origem aos quartzo-álcali feldspato sienitos. Essa evolução é consistente com as variações indicadas no sistema petrogenético residual de Hamilton e MacKenzie (1965), onde se nota uma tendência geral no sentido do mínimo riolítico, sugerida para processos ACF no campo saturado a supersaturado em sílica. Essa evolução é também concordante com o que se observa nos diagramas de variação química reunindo os teores de $\mathrm{SiO}_{2}$ e de elementos maiores, menores e traços. Nesses diagramas, os conteúdos de $\mathrm{Al}_{2} \mathrm{O}_{3}, \mathrm{Na}_{2} \mathrm{O}, \mathrm{K}_{2} \mathrm{O}, \mathrm{Rb}, \mathrm{Nb}$ e $\mathrm{Zr}$ crescem enquanto os de $\mathrm{TiO}_{2}, \mathrm{FeO}_{\mathrm{T}}$, $\mathrm{MgO}, \mathrm{CaO}, \mathrm{P}_{2} \mathrm{O}_{5}, \mathrm{Cr}$ e Ni decrescem relativamente à proporção de sílica, quando passando dos álcali feldspato sienitos para os quartzo-álcali feldspato sienitos e microssienitos.

A distribuição dos elementos incompatíveis mostrada nos diagramas do tipo spider indica pronunciada anomalia negativa em $\mathrm{Sr}, \mathrm{P}$ e $\mathrm{Ti}$, e visível anomalia positiva em $\mathrm{Zr}$ e $\mathrm{Nd}$; ainda que menos evidente, ela é também positiva em La e Y. Ba comporta-se irregularmente, exibindo anomalia negativa ou mesmo positiva. A sua concentração é sensivelmente maior nos tipos menos evoluídos, levando à distinção de duas suítes, uma mais rica e outra mais pobre em Ba.

O comportamento dos elementos Terras Raras, tanto para as rochas intrusivas quanto para as hipoabissais, é caracterizado pela alta concentração em ETR e fracionamento das TRL em relação às TRP. Eu exibe acentuada anomalia negativa, que pode estar associada a importante processo de remoção de feldspato, ou ainda, a provável processo de assimilação da rocha granítica encaixante.

Não obstante as pequenas diferenças, os resultados das determinações radiométricas (Rb-Sr, K$\operatorname{Ar}$ e $\mathrm{Ar}-\mathrm{Ar}$ ) guardam similaridades e permitem incluir o evento alcalino de Cananéia no Cretáceo 
Superior. Datações Ar-Ar recentes em concentrados de biotita indicam uma idade de formação de 83,6 Ma para as rochas da intrusão.

Cálculos da idade modelo $\left(T_{D M}\right)$ para as rochas de Cananéia forneceram idade média de $1400 \pm 200 \mathrm{Ma}$, valor superior ao obtido para outras ocorrências de províncias alcalinas da região Sudeste do Brasil (p.e. Arco de Ponta Grossa, Serra do Mar e Alto Paranaíba). Por outro lado, aquele valor é muito próximo ao encontrado para os dois complexos alcalino-carbonatíticos do Estado de Santa Catarina (Anitápolis, $1300 \pm 100 \mathrm{Ma}$; Lages,1200 $\pm 200 \mathrm{Ma}$ ) e do calculado para as ocorrências

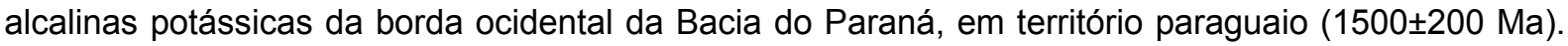
Os altos valores para a idade modelo indicam enriquecimento da fonte mantélica em elementos incompatíveis por eventos metassomáticos precursores da gênese do magmatismo toleítico e alcalino da Bacia do Paraná, que teriam ocorrido durante o Proterozóico (Paleo: 2000-1400 Ma; Neo: 1000$500 \mathrm{Ma})$.

As razões iniciais ${ }^{87} \mathrm{Sr}^{86} \mathrm{Sr}_{(83,6 \mathrm{Ma})}$ são de 0,7065 a 0,70700 para as litologias menos evoluídas e de 0,70538 a 0,70777 para as mais diferenciadas. Os altos valores obtidos para essa razão, superiores a 0,706, e a sua variação em amostras cogenéticas são indicativos de que as rochas de Cananéia foram, juntamente com a cristalização fracionada, submetidas à ação de processos de contaminação crustal. Essa contribuição crustal é sugerida principalmente pela maior concentração em $\mathrm{SiO}_{2}$ dos tipos petrográficos apresentando valores mais elevados para a razão inicial.

Os estudos isotópicos e as comparações com outras ocorrências alcalinas da Plataforma SulAmericana indicam uma assinatura isotópica $(\mathrm{Sr}-\mathrm{Nd})$ ligada à contribuição de fontes mantélicas possivelmente do tipo HIMU e EMI para as rochas de Cananéia. De modo análogo, essas rochas estariam geneticamente associadas à presença de um manto litosférico subcontinental heterogêneo e enriquecido metassomaticamente. Esse magma parental, provavelmente de afinidade basanítica, teria interagido com as encaixantes, provocando a assimilação de material crustal, sob condições de baixa pressão. A fonte de calor responsável pelo magmatismo (toleítico e alcalino) da Província Paraná-Angola-Etendeka é ainda tema de controvérsia, com a literatura trazendo argumentos favoráveis e contrários à hipótese das plumas mantélicas, que encontrou grande número de adeptos nos últimos anos.

A análise comparativa das características petrográficas, mineralógicas, geoquímicas e isotópicas das rochas de Cananéia com as das três ocorrências alcalinas vizinhas (Jacupiranga, Juquiá e Pariquera-Açu) não indica qualquer afinidade geológica, tendo elas em comum apenas o condicionamento tectônico (Arco de Ponta Grossa). Por outro lado, essa mesma análise permite reconhecer similaridades entre as rochas de Cananéia com as do maciço de Tunas, com as das ocorrências da Província da Serra do Mar (Illhas de Vitória, Búzios, São Sebastião e Monte de Trigo, Itatiaia, Passa Quatro e Morro Redondo) e com as da intrusão de Ponta do Morro, principalmente no que diz respeito à idade e às características geoquímicas (comportamento dos elementos incompatíveis e Terras Raras). 


\section{REFERÊNCIAS BIBLIOGRÁFICAS}

Alberti, A.; Castorina, F.; Censi, P.; Comin-Chiaramonti, P.; Gomes, C.B. (1999) Geochemical characteristics of Cretaceous carbonatites from Angola. J. Afr. Earth Sci., 29:735-759.

Almeida, F.F.M. (1991) O alinhamento magmático de Cabo Frio. $2^{\circ}$ Simpósio de Geologia do Sudeste, São Paulo, Atas, pp.423-428.

Almeida, F.F.M. (1983) Relações tectônicas das rochas alcalinas mesozóicas da região meridional da plataforma Sul-Americana. Rev. Brasil. Geoc., 13:139-158.

Almeida, F.F.M. e Carneiro, C.D.R. (1998) Origem e evolução da Serra do Mar. Rev. Brasil. Geoc., 28:135-150.

Almeida, T.I.R. (1982) Arco de Ponta Grossa: uma resposta para a sua configuração e evolução a partir da interpretação de dados de sensoriamento remoto. Dissertação de Mestrado, Instituto de Geociências da USP, 143p.

Alves, F.R. (1996) Contribuição ao conhecimento geológico e petrológico da llha de Búzios, SP. Tese de Doutorado, Instituto de Geociências da USP, 274p.

Amaral, G.; Bushee, J.; Cordani, U.G.; Kawashita, K.; Reynolds, J.H. (1967) Potassium-argon ages of alkaline rocks from southern Brazil. Geochim. Cosmochim. Acta, 31:117-142.

Andersen, D.J. e Lindsley, D.H. (1988) Internally consistent solution models for Fe-Mg-Mn-Ti oxides: Fe-Ti oxides. Amer. Mineral., 73:714-726.

Araújo, A.L.N.; Carlson, R.W.; Gaspar, J.C.; Bizzi, L.A. (2001) Petrology of kamafugites and kimberlites from the Alto Paranaíba Alkaline Province, Minas Gerais, Brazil. Contrib. Mineral. Petrol., 142:163-177.

Bailey, D.K. (1987) Mantle metasomatism: perspective and prospect. In: Fitton, J.G. e Upton, B.G.J. (eds.) Alkaline igneous rocks. Geol. Soc. London, Spec. Publ., 30:1-13.

Bailey, D.K. e Scheirer, J.F. (1966) The system $\mathrm{Na}_{2} \mathrm{O}-\mathrm{Al}_{2} \mathrm{O}_{3}-\mathrm{Fe}_{2} \mathrm{O}_{3}-\mathrm{SiO}_{2}$ at 1 atmosphere and the petrogenesis of alkaline rocks. J. Petrol., 7:144-170.

Barbieri, M.; Beccaluva, L.; Brotzu, P.; Conte, A.; Garbarino, C.; Gomes, C.B.; Loss, E.I.; Macciotta, G.; Morbidelli, L.; Scheibe, L.F.; Tamura, R.M.; Traversa, G. (1987) Petrological and geochemical studies of alkaline rocks from continental Brazil; 1, The phonolite suite from Piratini, RS. Geochim. Brasil., 1:109-138.

Bard, J.P. (1986) Microtextures of igneous and metamorphic rocks. Dordrecht, Boston, 264p.

Beccaluva, L.; Barbieri, M.; Born, H.; Brotzu, P.; Coltorti, M.; Conte, A.; Garbarino, C.; Gomes, C.B.; Macciotta, G.; Morbidelli, L.; Ruberti, E.; Siena, F.; Traversa, G. (1992) Fractional crystallization and liquid immiscibility process in the alkaline carbonatite complex of Juquiá, São Paulo, Brazil. J. Petrol., 33:1371-1404.

Bellieni, G.; Montes-Lauar, C.B.; DeMin, A.; Piccirillo, E.M.; Cavazzini, G.; Melfi, A.J.; Pacca, I.G. (1990) Early and Late Cretaceous magmatism from São Sebastião Island (SE-Brazil): geochemistry and petrology. Geochim. Brasil., 4:59-83.

Bellieni, G.; Brotzu, P.; Comin-Chiaramonti, P.; Ernesto, M.; Melfi, A.J.; Pacca, I.G.; Piccirillo, E.M.; Stolfa, D. (1983) Petrological and paleomagnetic data on the plateau basalt to rhyolite sequences of Southern Paraná Basin (Brazil). An. Acad. Brasil. Ciênc., 55:355-383.

Berrocal, J. e Fernandes, C. (1996) Seismicity in Paraguay and neighboring regions. In: CominChiaramonti, P. e Gomes, C.B. (eds.) Alkaline magmatism in central-eastern Paraguay. Relationships with coeval magmatism in Brazil. Edusp-Fapesp, São Paulo, pp.57-66.

Bigarella, J.J. e Mousinho, M.R. (1965) Contribuição da Formação Pariquera-Açu, Estado de São Paulo. Bol. Paran. Geogr., 16/17:17-41.

Biondi, J.C. (2005) Brazilian mineral deposits associated with alkaline and alkaline-carbonatite complexes. In: Comin-Chiaramonti, P. e Gomes, C.B. (eds.) Mesozoic to Cenozoic alkaline magmatism in the Brazilian Platform. Edusp-Fapesp, São Paulo, pp.707-750.

Bizzi, L.A. e Araújo, A.L.N. (2005) Dynamics of mantle-derived magmatism in the southwestern São Francisco Craton. In: Comin-Chiaramonti, P. e Gomes, C.B. (eds.) Mesozoic to Cenozoic alkaline magmatism in the Brazilian Platform. Edusp-Fapesp, São Paulo, pp.341-366.

Bonin, B. e Giret, A. (1985) Contrasting roles of rock-forming minerals in alkaline ring complexes. J. Afr. Earth Sci., 3:41-49.

Boynton, W.V. (1984) Cosmochemistry of the Rare Earth elements: meteorite studies. In: Henderson, P. (ed.) Rare Elements geochemistry. Elsevier, Amsterdam, pp.63-114. 
Brotzu, P.; Gomes, C.B.; Melluso, L.; Morbidelli, L.; Morra, V.; Ruberti, E. (1997) Petrogenesis of coexisisting $\mathrm{SiO}_{2}$-undersaturated to $\mathrm{SiO}_{2}$-oversaturated felsic igneous rocks: the alkaline complex of Itatiaia, southeastern Brazil. Lithos, 40:133-156.

Brotzu, P.; Gomes, C.B.; Melluso, L.; Morbidelli, L.; Morra, V.; Ruberti, E. (1995) Petrologia do maciço alcalino de Itatiaia, RJ-MG-SP. V Congr. Bras. Geoq., Niterói, Anais (CD-ROM).

Brotzu, P.; Barbieri, M.; Beccaluva, L.; Gargbarino, C.; Gomes, C.B.; Macciota, G.; Melluso, L.; Morbidelli, L.; Ruberti, E.; Sígolo, J.B.; Traversa, G. (1992) Petrology and geochemistry of the Passa Quatro alkaline complex, southern Brazil. J. South Amer. Earth Sci., 6:237-252.

Brotzu, P.; Beccaluva, L.; Conte, A.; Fonseca, M.; Garbarino, C.; Gomes, C.B.; Leong, R.; Macciotta, G.; Mansur, R.L.; Melluso, L.; Morbidelli, L.; Ruberti, E.; Sígolo, J.B.; Traversa, G.; Valença, J.G. (1989) Petrological and geochemical studies of alkaline rocks from continental Brazil. 8. The syenitic intrusion of Morro Redondo, RJ. Geochim. Brasil., 3:63-80.

Brown, W.L. e Parsons, I. (1988) Zoned ternary feldspars in the Kokklen intrusion: exsolution microtextures and mechanisms. Contrib. Mineral. Petrol., 98:444-454.

Buddington, A.F. e Lindsley, D.H. (1964) Iron-titanium oxides minerals of syntetic equivalents. J. Petrol., 5:310-357.

Carlson, R.W; Esperança, S.; Svisero, D.P. (1996) Chemical and Os isotopic study of Cretaceous potassic rocks from southern Brazil. Contrib. Mineral. Petrol., 125:393-405.

Carmichael, I.S.E. (1974) The iron-titanium oxides of salic volcanic rocks and their associated ferromagnesian silicates. Contrib. Mineral. Petrol., 14:36-64.

Casetta, B.; Giaretta, A.; Mezzacasa, G. (1990) Determination of rare earth and other trace elements in rock samples by ICP-mass spectrometry: comparison with other techniques. Atom. Spec., 11:222-228.

Castorina, F.; Censi, P.; Comin-Chiaramonti, P.; Gomes, C.B. Piccirillo, E.M.; Alcover Neto, A.; Almeida, R.T.; Speziale, S.; Toledo, M.C. (1997) Geochemistry of carbonatites from Eastern Paraguay and genetic relationships with potassic magmatism: $\mathrm{C}, \mathrm{O}, \mathrm{Sr}$ and $\mathrm{Nd}$ isotopes. Mineral. Petrol., 61:237-260.

Castorina, F.; Censi, P.; Barbieri, M.; Comin-Chiaramonti, P.; Cundari, A.; Gomes, C.B.; Pardini, G. (1996) Carbonatites from Eastern Paraguay: a comparison with coeval carbonatites from Brazil and Angola. In: Comin-Chiaramonti, P. e Gomes, C.B. (eds.) Alkaline magmatism in central-eastern Paraguay. Relationships with coeval magmatism in Brazil. Edusp-Fapesp, São Paulo, pp.231-248.

Cawthorn, R.G. e Collerson, K.D. (1974) The recalculation of pyroxene end-member parameters and estimation of ferrous and ferric iron content from electron microprobe analyses. Amer. Mineral., 59:1203-1208.

Coimbra, A.M. (1991) Sistematização crítica da obra. Tese de Livre Docência, Instituto de Geociências da USP, 54p.

Comin-Chiramonti, P.; Gomes, C.B.; DeMin, A.; Ernesto, M.; Marzoli, A.; Riccomini, C. (2007b) Eastern Paraguay: an overview of the post-Paleozoic magmatism and geodynamic implications. Rend. Fis. Acc. Licei. (no prelo)

Comin-Chiaramonti, P.; Marzoli, A.; Gomes, C.B.; Milan, A.; Riccomini, C.; Mantovani, M.M.S.; Renne, P.; Tassinari, C.C.G.; Vasconcelos, P.M. (2007a) Origin of Post-Paleozoic magmatism in Eastern Paraguay. In: Fougler, G.R. e Jurdy, D.M. (eds.) The origin of the melting anomalies. Geol. Soc. Amer. Spec. Paper., 430.

Comin-Chiaramonti, P. e Gomes, C.B. (2005) Mesozoic to Cenozoic alkaline magmatism in the Brazilian Platform. Edusp-Fapesp, São Paulo, 752p.

Comin-Chiaramonti, P.; Gomes, C.B.; Censi, P.; Gasparon, M.; Velázquez, V.F. (2005) Alkaline complexes from the Alto Paraguay Province at the border of Brazil (Mato Grosso do Sul State) and Paraguay. In: Comin-Chiaramonti P. e Gomes, C.B. (eds.) Mesozoic to Cenozoic alkaline magmatism in the Brazilian Platform, Edusp-Fapesp, São Paulo, pp.71-148.

Comin-Chiaramonti, P.; Gomes, C.B.; Castorina, F.; Censi, P.; Antonini, P.; Furtado, S.; Ruberti, E.; Scheibe, L.F. (2002) Anitápolis and Lages alkaline-carbonatite complexes, Santa Catarina State, Brazil: geochemistry and geodynamic implications. Rev. Brasil. Geoc., 32:639-653.

Comin-Chiaramonti, P.; Cundari, A.; DeGraff, J.M.; Gomes, C.B.; Piccirillo, E.M. (1999) Early Cretaceous-Paleogene magmatism in Eastern Paraguay (western Paraná Basin): geological, geophysical and geochemical relationships. J. Geodyn., 28:375-391.

Comin-Chiaramonti, P.; Cundari, A.; Piccirillo, E.M.; Gomes, C.B.; Castorina, F.; Censi , P.; DeMin, A.; Marzoli, A.; Speziale, S.; Velázquez, V.F. (1997) Potassic and sodic igneous rocks from 
Eastern Paraguay: their origin from the lithospheric mantle and genetic relationships with the associated Paraná flood tholeiites. J. Petrol., 38:495-528.

Comin-Chiaramonti, P. e Gomes, C.B. (1996) Alkaline magmatism in central-eastern Paraguay Relationships with coeval magmatism in Brazil. Edusp-Fapesp, São Paulo, 464p.

Comin-Chiaramonti, P.; Castorina, F.; Cundari, A.; Petrini, R.; Gomes, C.B. (1995) Dykes and sills from Eastern Paraguay: Sr and Nd isotope systematics. In: Baer, G. e Heimann, A. (eds.) Physics and Chemistry of Dykes. Balkema, Rotterdam, pp.267-278.

Comin-Chiaramonti, P.; Gomes, C.B.; Petrini, R.; DeMin, A.; Velázquez, V.F.; Orué, D. (1992) A new area of alkaline rocks in Eastern Paraguay. Rev. Brasil. Geoc., 22:500-506.

Comin-Chiaramonti, P.; Civetta, L.; Petrini, R.; Piccirillo, E.M.; Bellieni, G.; Censi, P.; Bitschene, P.; Demarchi, G.; DeMin, A.; Gomes, C.B.; Castillo, A.M.C.; Velázquez, J.C. (1991) Paleogene nephelinitic magmatism in Eastern Paraguay: petrology, Sr-Nd isotopes and genetic relationships with associated spinel-peridotite xenoliths. Eur. J. Mineral., 3:507-525.

Comin-Chiaramonti, P.; Gomes, C;B.; Piccirillo, E.M.; Bellieni, G.; Castillo, A.M.C.; Demarchi, G.; Gallo, P.; Velázquez, J.C. (1990) Petrologia do maciço alcalino de Acahay, Paraguai Oriental. Rev. Brasil. Geoc., 20:133-152.

Conceição, H.; Sabaté, P.; Bonin, B. (1991) The Itiúba alkaline syenite massif, Bahia State (Brazil): mineralogical, geochemical and petrological constraints - relation to the genesis of rapakivi magmatism. Prec. Res., 51:283-314.

Coombs, D.S. e Wilkinson, J.F.G. (1969). Lineages and fractionation trends in undersaturated volcanic rocks from the East Otago volcanic province (New Zealand) and related rocks. J. Petrol., 10:440-501.

Cox, K.G. e Dalrymple, G.B. (1967) Potassium-Argon dating: principles techniques and applications to geochronology. Freeman, San Francisco, 258p.

De La Roche, H.C. (1986) Classification et nomenclature des roches ignées: un essai de restauration de la convergence entre systematique quantitative, typologie d'usage et modélisation génétique. Bull. Soc. Géol. France, 2:237-313.

De La Roche, H.C.; Leterrier, J.; Grandclaure, P.; Marchal, M. (1980) A classification of volcanic rocks using R1-R2 diagram and major-element analyses. Its relationships with current nomenclature. Chem. Geol., 29:183-210.

Deer, W.A.; Howie, R.A.; Zussman, J. (1992) An introduction to the rock-forming minerals. 2nd ed. Longman, London, 696p.

DePaolo, D.J. (1988) Neodymium isotope geochemistry: an introduction. Berlin; New York: SpringerVerlag, Mineral and Rocks 20, 187p.

Droop, G.T.R. (1987) A general equation for estimating $\mathrm{Fe}^{3+}$ concentrations in ferromagnesian silicates and oxides from microprobe analyses, using stoichiometric criteria. Mineral. Mag., 51:431-435.

Dymek, R.F. (1983) Titanium, aluminum and interlayer cation substitutions in the biotite from highgrade gneisses, West Greenland. Amer. Mineral., 68:880-899.

Eby, G. N.; Lloyd, F. E.; Woolley, A. R.; Stoppa, F.; Weaver, S. D. (2003) Geochemistry and mantle source(s) for carbonatitic and potassic lavas, western branch of the East-African rift system, SW Uganda. GeoLines 15:15-19.

Eby, G.N.; Woolley, A.R.; Din, V.; Platt, G. (1998) Geochemistry and petrogenesis of nepheline syenites: Kasungu-Chilapa, llomba and Ulindi Nepheline Syenite Intrusions, North Nyasa Alkaline Province, Malawi. J. Petrol., 39:1405-1424.

Eggler, D.H. (1978) The effect of $\mathrm{CO}_{2}$ upon partial melting of peridotite in the system $\mathrm{Na}_{2} \mathrm{O}-\mathrm{CaO}-$ $\mathrm{Al}_{2} \mathrm{O}_{3}-\mathrm{MgO}-\mathrm{SiO}_{2}-\mathrm{CO}_{2}$ to $35 \mathrm{~Kb}$, with analysis of melting in a peridotite- $\mathrm{H}_{2} \mathrm{O}-\mathrm{CO}_{2}$ system. Amer. J. Sci., 278:305-343.

Eggler, D.H., (1987) Discussion of recent papers on carbonated peridotite, bearing on mantle metasomatism and magmatism: an alternative. Earth Plan. Sci. Lett., 82:398-400.

Enrich, G.A.R. (2000) Geologia e química mineral da llha Monte de Trigo, litoral Norte do Estado de São Paulo. Dissertação de Mestrado, Instituto de Geociências da USP, 227p.

Enrich, G.A.R. (2005) Petrogênese da suíte alcalina da llha Monte de Trigo, SP. Tese de Doutorado, Instituto de Geociências da USP, 229p.

Enrich, G.A.R.; Azzone, R.G.; Ruberti, E.; Gomes, C.B.; Comin-Chiaramonti, P. (2005) Itatiaia, Passa Quatro and São Sebastião island, the major alkaline syenitic complex from Serra do Mar 
region. In: Comin-Chiaramonti, P. e Gomes, C.B. (eds.) Mesozoic to Cenozoic alkaline magmatism in the Brazilian Plataform. Edusp-Fapesp, São Paulo, pp.419-441.

Enrich, G.A.R.; Ruberti, E.; Gomes, C.B.; Azzone, R.G. (2006) ${ }^{40} \mathrm{Ar} /{ }^{39} \mathrm{Ar}$ geochronology of Monte de Trigo Island alkaline suite: implications in the regional geodynamic context. In: V South Amer. Symp. Isotope Geology, Punta del Este, Uruguay, Short Papers, 2006.

Ernesto, M.; Marques, L.M.; Piccirillo, E.M.; Molina, E.; Ussami, N.; Comin-Chiaramonti, P.; Bellieni, G. (2002) Paraná Magmatic Province - Tristan da Cunha plume system: fixed versus mobile plume, petrogenetic considerations and alternative heat sources. J. Volcanol. Geother. Res., 118:15-36.

Falloon, T.J.; Green, D.H.; Danyshevsky, L.V.; Faul, U.H. (1999) Peridotite melting at 1.0 and 1.5 GPa: an experimental evaluation of techniques using diamond aggregates and mineral mixes for determination of near-solidus melts. J. Petrol., 84:70-77.

Faure, G. (1986) Principles of isotope geology. 2nd ed. Wiley, New York, 589p.

Faure, G. e Powel, J.L. (1972) Strontium isotope geology. Springer-Verlag, Berlin, 188p.

Ferguson, J. e Currie, K.L (1971) Evidence of liquid immiscibility in alkaline ultrabasic dikes at Callander Bay, Ontario. J. Petrol., 12:561-585.

Ferreira, F.J.F. (1982a) Alinhamentos estruturais-magnéticos da região centro ocidental da Bacia do Paraná e seu significado tectônico. IPT, Publ. n¹217, pp.143-166.

Ferreira, F.J.F. (1982b) Integração de dados aeromagnéticos e geológicos: configuração e evolução tectônica do arco de Ponta Grossa. Dissertação de Mestrado, Instituto de Geociências da USP, 170p.

Flood, R.H. e Vernon, R.H. (1988) Microstructural evidence of orders of crystallization in granitoids rocks. Lithos, 21:237-245.

Fodor, R.V. e Hanan, B.B. (2000) Geochemical evidence for the Trindade hotspot trace; Columbia Seamount ankaramite. Lithos, 51:293-304.

Foley, S.F. (1992a) Petrological characterization of the sources components of potassic magmas: geochemical and experimental constraints. Lithos, 28:187-204.

Foley, S.F. (1992b) Vein plus wall-rock melting mechanism in the lithosphere and the origin potassic alkaline magmas. Lithos, 28:435-453.

Freitas, R.O. (1947) Eruptivas alcalinas de Cananéia, Estado de São Paulo. Bol. Fac. Fil. Ci. Let. USP, Geologia, 3:4-35.

Frimmel, H.E. e Fölling, P.G. (2004) Late Vendian closure of the Adamastor Ocean: timing of tectonic inversion and syn-orogenic sedimentation in the Gariep Basin. Gondw. Res., 7:685-699.

Garda, G.M.; Schorscher, H.D.; Esperança, S.; Carlson, R.W. (1995) The petrology and geochemistry of coastal dikes from São Paulo State, Brazil: implications for variable lithospheric contributions to alkaline magmas from the western margin of the South Atlantic. An. Acad. Brasil. Ciênc., 67:191-216.

Gerasimovskii, V.I. (1956) Geochemistry and mineralogy of nepheline syenite intrusions. Geochem., 5:494-510.

Gibson, S.A.; Thompson, R.N.; Dickin, A.P.; Leonardos, O.H. (1995) The Late Cretaceous impact of the Trindade mantle plume: evidence from large-volume, mafic potassic magmatism in SE Brazil. J. Petrol., 36:189-229.

Gibson, S.A.; Thompson, R.N.; Leonardos, O.H.; Dickin, A.P.; Mitchell, J.G. (1999) The limit extent of plume-lithosphere interactions during continental flood-basalt genesis: geochemical evidence from Cretaceous magmatism in southern Brazil. Contrib. Mineral. Petrol., 137:147-169.

Gibson, S.A.; Thompson, R.N.; Weska, R.K.; Dickin, A.P.; Leonardos, O.H. (1997) Late Cretaceous rift-related upwelling and melting of the Trindade starting mantle plume head beneath western Brazil. Contrib. Mineral. Petrol., 126:303-314.

Gillespie, M.R. e Styles, M.T. (1997) BGS rock classification scheme, volume 1 - Classification of igneous rocks. British Geological Survey Research Report RR97-2, 63p.

Giret, A.; Bonin, B.; Leger, J.M. (1980) Amphibole compositional trends in oversaturated and unsaturated alkaline plutonic ring-composition. Can. Mineral., 18:481-495.

Gomes, C.B. e Comin-Chiaramonti, P. (2005) Some notes on the Alto Paranaíba Igneous Province. In: Comin-Chiaramonti, P. e Gomes, C.B. (eds.) Mesozoic to Cenozoic alkaline magmatism in the Brazilian Platform. Edusp-Fapesp, São Paulo, pp.317-340.

Gomes, C.B.; Barbieri, M.; Beccaluva, L.; Brotzu, P.; Conte, A.; Garbarino, C.; Macciotta, G.; Melluso, L.; Morbidelli, L.; Ruberti, E.; Scheibe, L.F.; Tamura, R.M.; Traversa, G. (1987) Petrological 
and geochemical studies of alkaline rocks from continental Brazil; 2, The Tunas massif, State of Paraná. Geochim. Brasil., 1:201-234.

Gomes, C.B.; Morbidelli, L.; Ruberti, E.; Comin-Chiaramonti, P. (1996) Comparative aspects between pos-paleozoic alkaline rocks from the western and eastern margins of the Paraná Basin. In: Comin-Chiaramonti, P. e Gomes, C.B. (eds.) Alkaline magmatism in central-eastern Paraguay - Relationships with coeval magmatism in Brazil. Edusp-Fapesp, São Paulo, pp.249-274.

Gomes, C.B.; Ruberti, E.; Morbidelli, L. (1990) Carbonatite complexes from Brazil: a review. J. South Amer. Earth Sci., 3:51-63.

Guia 4 Rodas Brasil (2003) Ed Abril, São Paulo, 738p.

Haggerty, S.E. (1976) Opaque mineral oxides in terrestrial igneous rocks. In: Rumbles, D. (ed.) Oxide minerals, reviews in mineralogy., 3:101-300.

Hamilton, D.L. e MacKenzie, W.S. (1965) Phase equilibria studies in the system $\mathrm{NaAlSiO}_{4}-\mathrm{KAISiO}_{4}-$ $\mathrm{SiO}_{2}$. J. Petrol., 1:56-72.

Harris, N.B.W. e Inger, S. (1992) Iron microprobe determination of High Himalayan leucogranites. In: Treolar, P.J e Searle, M.P.(eds.) Himalayan tectonics. Spec. Public. Geol. Soc. London, 74:391-400.

Hart, S.R.; Gerlach, D.C.; White, W.M. (1986) A possible new Sr-Nd-Pb mantle array and consequences for mantle mixing. Geochim. Cosmoch. Acta, 50:1551-1557.

Hasui, Y. e Sadowski, G.R. (1976) Evolução geológica do Pré-Cambriano na região Sudeste do Estado de São Paulo. Rev. Brasil. Geoc., 6:180-200.

Hasui, Y.; Dantas, A.S.L.; Carneiro, C.D.R.; Bistrichi, C.A. (1981) Embasamento Pré-Cambriano em São Paulo. In: Almeida, F.M.F.; Hasui, Y.; Poçano, W.L.; Dantas, A.S.L.; Carneiro, C.D.R.; Melo, M.S.; Bistrichi, C.A. (coords.) Mapa geológico do Estado de São Paulo na escala 1:500.000. Nota explicativa. IPT, Publ. $n^{\circ} 1184,1: 12-45$.

Heilbron, M.; Pedrosa-Soares, A.C.; Campos Neto, M.C.; Silva, L.C.; Trouw, R.A.J.; Janasi, V.A. (2004) Província Mantiqueira. In: Mantesso-Neto, V.; Bartorelli, A.; Carneiro, C.D.R.; Brito Neves, B.B. (eds.) Geologia do Continente Sul-Americano: evolução da obra de Fernando Flávio Marques de Almeida. Beca Produções Culturais Ltda., São Paulo, pp.203-234.

Hogarth, D.D. (1989) Pyrochole, apatite and amphibole: distinctive minerals carbonatite. In: Bell, K. (ed.) Carbonatites, genesis and evolution. Unwin Hyman, London, pp.105-148.

Holbrook, W.S. e Kelemen, P.B. (1993) Large igneous province on the US Atlantic margin and implications for magmatism during continental breakup. Nature, 364:433-436.

lacumin, M.; DeMin, A.; Piccirillo, E.M.; Bellieni, G. (2003) Source mantle heterogeneity and its role in the genesis of Late Archean-Proterozoic (2.7-1.0 Ga) and Mesozoic (200 and $130 \mathrm{Ma}$ ) tholeiitic magmatism in the South American Platform. Earth-Sci. Rev., 62:365-397.

IGC - Instituto Geográfico e Cartográfico do Estado de São Paulo (1989) Ilha de Cananéia II. Governo do Estado de São Paulo, Secretaria de Economia e Planejamento, Coordenadoria de Ação Regional, Instituto Geográfico e Cartográfico. 74 x 99 cm; escala 1:10.000.

IPT - Instituto de Pesquisas Tecnológicas do Estado de São Paulo (1981) Mapa geológico do Estado de São Paulo: Escala 1:500 000. São Paulo: IPT, Divisão de Minas e Geologia Aplicada.

Janasi, V.A. (1992) Rochas sieníticas e mangerito-charnockíticas neoproterozóicas da região entre Caldas e Campestre, MG: aspectos petrológicos. Tese de Doutorado, Instituto de Geociências da USP, 298p.

Kawashita, K.; Sato, K.; Diaz, M.; Tassinari, C.C.G. (1991) Metodologia Sm/Nd no IG-USP: teses e resultados preliminares. III Congr. Bras. Geoq., São Paulo, 2:442-446

Landoll, J. e Foland, K. (1996) The formation of quartz syenite by crustal contamination at Mont Sheford and other Monteregian complexes, Quebec. Can. Mineral., 34:301-324.

Larsen, L.M. (1976) Clinopyroxenes and coexisting mafic minerals from the alkaline llímaussaq Intrusion, South Greenland. J. Petrol., 17:258-290.

Leake, B.E. (1997) Nomenclature of amphiboles. Report of the Subcommittee on Amphiboles of the International Mineralogical Association Commission on New Minerals and Mineral Names. Eur. J. Mineral., 9:623-651.

Leinz, V. (1940) Petrologia das jazidas de apatita de Ipanema, São Paulo. DNPM, Div. Fom. Prod. Min., Bol., 88:1-52.

LeMaitre R.W. (2003) Igneous rock: classification of igneous rock and glossary of terms. 2nd ed. Cambridge University Press, 236p. 
Lepage, L.D. (2003) ILMAT: an Excel worksheet for ilmenite-magnetite geothermometry and geobarometry. Comput. Geosci.,29:673-678.

Ludwig, K.R. (1999) Isoplot/Ex: a geochronological toolkit for Microsoft Excel. Version 2.10. Berkeley Geochronology Center, Special Publication $n^{\circ} 1 a$.

Macciotta, G.; Almeida, A.; Barbieri, M.; Beccaluva, L.; Brotzu, P.; Coltorti, M.; Conte, A.; Garbarino, C.; Gomes, C.B.; Morbidelli, L.; Ruberti, E.; Siena, F.; Traversa, G. (1990) Petrology of the tephrite-phonolite suit and cognate xenolithes of the Fortaleza district (Ceará, Brazil). Eur. J. Mineral., 2:687-709.

Mackenzie, W.S.; Donaldson, C.H.; Gulford, C. (1993) Atlas of igneous rock and their textures. Longman Scientific \& Technical, 148p.

Martin, L. e Suguio, K. (1978) Excursion route along the coastline between the town of Cananéia (State of São Paulo) and Guaratiba outlet (State of Rio de Janeiro). Int. Symp. on Coast Evolution in the Quaternary, São Paulo, Special Publication, 2:1-97.

Maury, R.; Defant, C.; Joron, M.J. (1992) Metasomatism of the sub-arc mantle inferred from trace elements in Philippine xenoliths. Nature, 360:661-663.

McDonough, W.F. e Sun, S. (1995) The composition of Earth. Chem. Geol., 120:223-253.

Meen, J.K.; Ayers, J.C.; Fregeau, E.J. (1989) A model of mantle metasomatism by carbonated alkaline melts: trace element and isotopic compositions of mantle source regions of carbonatite and other continental igneous rocks. In: Bell, K. (ed.) Carbonatites, genesis and evolution. Unwin Hyman, London, pp.464-499.

Melo, M.S. (1990) A Formação Pariquera-Açu e depósitos relacionados: sedimentação tectônica e geomorfogênese. Dissertação de Mestrado, Instituto de Geociências da USP, 211p.

Michard, A.; Gurriet, P.; Soudant, M.; Albared, F. (1985) Nd isotopes in French Phanerozoic shales: external vs. internal aspects of crustal evolution. Geochim. Cosmochim. Acta, 49:601-610.

Molina, E.C. e Ussami, N. (1999) The geiod in the southern Brazil and adjacent regions: new constraints on the density distribution and thermal state of lithosphere. J. Geodyn., 28:321340.

Montes-Lauar, C.R.; Pacca, I.G.; Melfi, A.J.; Kawashita, K. (1995) Late Cretaceous alkaline complexes, southeastern Brazil: paleomagmatism and geochronology. Earth Planet. Sci. Lett., 134:425-440.

Morbidelli, L.; Gomes, C.B.; Beccaluva, L.; Brotzu, P.; Conte, A.M.; Ruberti, E.; Traversa, G. (2000) The Pariquera-Açu K-alkaline complex and Southeastern Brazil lithospheric mantle source characteristics. J. Asian. Earth Sci., 18:129-150.

Morbidelli, L.; Gomes, C.B.; Beccaluva, L.; Brotzu, P.; Conte, A.M.; Ruberti, E.; Traversa, G. (1995) Mineralogical, petrological and geochemical aspects of alkaline and alkaline-carbonatite associations from Brazil. Earth-Sci. Rev., 39:135-168.

Morimoto, N. (1990) Nomenclatura de piroxênios. Tradução do original em Inglês "Nomenclature of pyroxenes" realizada com a permissão da IMA por Garda, M.G. e Atêncio, D. Rev. Brasil. Geoc., 20:318-328.

Morogan, V.; Upton, B.G.J.; Fitton, J.G. (2000) The petrology of the Ditral alkaline complex, Eastern Carpathians. Mineral. Petrol., 69:227-265.

Motoki, A. (1986) Geologia e petrologia do maciço alcalino da llha de Vitória, SP. Tese de Doutorado, Instituto de Geociências da USP, 245p.

Neumann, E.R. (1976) Compositional relations among pyroxenes, amphiboles and other mafic phases in the Oslo region plutonic rocks. Lithos, 9:85-109.

O'Connor, J.M. e Duncan, R.A. (1990) Evolution of the Walvis Ridge-Rio Grande Rise hot spot system: implications for African and South American plate motions over plumes. J. Geophys. Res., 95:17475-17502.

O'Halloran, D.A. (1985) Ras ed Dom migrating ring complex: A-type granites and syenites from the Bayuda Desert, Sudan. J. Afr. Earth Sci., 3:61-75.

Petri, S. e Suguio, K. (1971) Some aspects of the Neocenozoic sedimentation in the Cananéia-Iguape lagoonal region, São Paulo, Brazil. Est. Sedimentol., Universidade Federal do Rio Grande do Norte, 1:25-33.

Petri, S. e Suguio, K. (1973) Stratigraphy of the Iguape-Cananéia lagoonal region sedimentary deposits, São Paulo, Brazil. Part II: heavy mineral studies, microorganisms inventories and stratigraphical interpretations. Bol. IG-USP, Sér. Cient., 4:71-85. 
Petrini, R.; Civetta, L.; Piccirillo, E.M.; Bellieni, G.; Comin-Chiaramonti, P.; Marques, L.S.; Melfi, A.J. (1987) Mantle heterogeneity and crustal contamination in the genesis of low-Ti continental flood basalts from Paraná plateau (Brazil): Sr-Nd isotope and geochemical evidence. J. Petrol., 28:701-726.

Philipp, R.P.; Viero, A.P.; Comin-Chiaramonti, P.; Gomes, C.B, (2005) Mesozoic alkaline rocks of Rio Grande do Sul. In: Comin-Chiaramonti, P. e Gomes, C.B. (eds.) Mesozoic to Cenozoic alkaline magmatism in the Brazilian Plataform. Edusp-Fapesp, São Paulo, pp.573-590.

Piccirillo, E.M. e Melfi, A.J. (1988) The Mesozoic flood volcanism from the Paraná basin (Brazil): petrogenetic and geophysical aspects. IAG-USP, São Paulo, 600p.

Poçano, W.L. (1981) As coberturas cenozóicas. In: Almeida, F.M.F.; Hasui, Y.; Poçano, W.L.; Dantas, A.S.L.; Carneiro, C.D.R.; Melo, M.S.; Bistrichi, C.A. (coords.) Mapa geológico do Estado de São Paulo na escala 1:500.000. Nota explicativa. IPT, Publ. ${ }^{\circ}$ 1184, 1:82-96.

Price, R.C.; Johnson, R.W.; Gray, C.M.; Frey, F.A. (1985) Geochemistry of phonolites and trachytes from summit region of Mt. Kenya. Contrib. Mineral. Petrol., 89:394-409.

Riccomini, C. (1995) Padrão de fraturamento do maciço alcalino de Cananéia, Estado de São Paulo: relações com a tectônica mesozóico-cenozóica do sudeste do Brasil. Rev. Brasil. Geoc., 25:79-84.

Riccomini, C.; Velázquez, V.F.; Gomes, C.B. (2005) Tectonic controls of the Mesozoic and Cenozoic alkaline magmatism in central-southeastern Brazilian platform. In: Comin-Chiaramonti, P. e Gomes, C.B. (eds.) Mesozoic to Cenozoic alkaline magmatism in the Brazilian Plataform. Edusp-Fapesp, São Paulo, pp.31-56.

Richard, L.R. (1995) MinPet: Mineralogical and Petrological Data Processing System. MinPet for Windows, version 2.02. Canada, MinPet Geological Software.

Rieder, M. (1999) Nomenclature of the micas. Mineral. Mag., 63:267-279.

Ruberti, E.; Castorina, F.; Censi, P.; Comin-Chiaramonti, P.; Gomes, C.B.; Antonini P.; Andrade, F.R.D. (2002) The geochemistry of the Barra do Itapirapuã carbonatite (Ponta Grossa Arch, Brazil): a multiple stockwork. J. South Amer. Earth Sci.,15:215-228.

Ruberti, E.; Gomes, C.B.; Comin-Chiaramonti, P. (2005), The alkaline magmatism from the Ponta Grossa Arch. In: Comin-Chiaramonti, P. e Gomes, C.B. (eds.) Mesozoic to Cenozoic alkaline magmatism in the Brazilian Plataform. Edusp-Fapesp, São Paulo, pp.473-522.

Sato, K. (1998) Evolução crustal da Plataforma Sul Americana, com base na geoquímica isotópica $\mathrm{Sm} / \mathrm{Nd}$. Tese de Doutorado, Instituto de Geociências da USP, 297p.

Sato, K.; Tassinari, C.; Kawashita, K.; Petronilho, L. (1995) O método geocronológico Sm/Nd no IGc/USP e suas aplicações. An. Acad. Brasil. Ciênc., 67:313-335.

Scheibe, L.F.; Furtado, S.M.A.; Comin-Chiaramonti, P.; Gomes, C.B. (2005) Cretaceous alkaline magmatism from Santa Catarina, State, southern Brazil. In: Comin-Chiaramonti, P. e Gomes, C.B. (eds.) Mesozoic to Cenozoic alkaline magmatism in the Brazilian Platform. EduspFapesp, São Paulo, pp.523-572.

Schobbenhaus, C.; Campos, D.A.; Derze, G.R.; Asmus, H.E. (1981) Mapa geológico do Brasil e da área oceânica adjacente, incluindo depósitos minerais. Escala 1:2.5000.000. Brasília: Departamento Nacional de Produção Mineral/Ministério das Minas e Energia, 4f.

Schumacher, J.C., (1997) The estimation of ferric iron in electron microprobe analysis of amphiboles. In: Leake, B.E. (1997) Nomenclature of amphiboles. Report of the Subcommittee on Amphiboles of the International Mineralogical Association Commission on New Minerals and Mineral Names. Eur. J. Mineral., 9:623-651.

Siga Júnior, O.; Gomes, C.B.; Sato, K.; Passarelli, C.R. (2007) O maciço alcalino de Tunas, PR: novos dados geocronológicos. Geol. USP, Sér. Cient., 7:71-80.

Silva, A.T.S.F. da; Francesconi, O.; Godoy, A.M.; Chiodi Filho, C.; Takashi, A.T.; Alegri, V.; Ferreira, J.C.G.; Silva, C.R.; Alves, M.J.; Macedo, A.B.; Fernandes, N.A. (1981) Projeto Integração e detalhe geológico no Vale do Ribeira. Relatório Final - Geologia Integrada. DNPM/CPRM. Superintendência Regional de São Paulo, SP, 240p.

Smith, A.D. e Lewis, C. (1999) The planet beyond the plume hypothesis. Earth Sci. Res., 48:135-182.

Snelling, N.J. (1976) Rubidium-strontium systematics. In: UNDP Technical Support for Regional Offshore Prospecting in East Asia (coord.) Proc. Seminar on Isotopic Dating, Bangkok, 204p.

Sonoki, I.K. e Garda, G.M. (1988) Idades K/Ar de rochas alcalinas do Brasil Meridional e Paraguai Oriental: compilação e adaptação às novas constantes de decaimento. Bol. IG-USP, Sér.Cient., 19:63-87. 
Sørensen, H. (1960) On the agpaitic rocks. Rep. Int. Geol. Congr., Norden, XXI Session, Part XIII, pp.319-327.

Sørensen, H. (1986) The alkaline rocks: a review. Fortschr. Miner., 64:63-86.

Sousa, M.Z.A. (1997) Petrologia e geoquímica do complexo alcalino Ponta do Morro - MT. Tese de Doutorado, Instituto de Geociências da USP, 168p.

Souza, L.A.P. (1995) A planície costeira Cananéia-lguape, litoral sul do Estado de São Paulo: um exemplo de utilização de métodos geofísicos no estudo de áreas costeiras. Dissertação de Mestrado, Instituto de Oceanografia da USP, 270p.

Souza, L.A.P.; Tessler, M.G.; Galli, V.L. (1996) O Gráben de Cananéia. Rev. Brasil. Geoc., 26:139150.

Spinelli, F.P. (2000) A intrusão alcalina de Cananéia, SP: características petrográficas e geoquímicas. Monografia de Trabalho de Formatura, Instituto de Geociências da USP, 37p.

Spinelli, F.P.; Gomes, C.B.; Velázquez, V.F.; Riccomini, C.; Comin-Chiaramonti, P. (2001) Considerações petrográficas e geoquímicas sobre a intrusão alcalina de Cananéia, litoral sul de São Paulo. VIII Congr. Brasil. Geoq./ $1^{\circ}$ Simp. Geoq. Países Mercosul, Curitiba, Anais (CD-ROM)

Steiger, R.H. e Jäger, E. (1977) Subcommission on Geochronology: convention on the use of decay constants in geochronology and cosmochronology. Earth Plan. Sci. Lett., 26:359-362.

Stephenson, D. (1972) Alkali clinopyroxenes from nepheline syenites of the South Qôroq Centre, South Greenland. Lithos, 5:187-201.

Steveson, R.; Upton, B.G.J.; Steenfelt, A. (1997) Crust-mantle interaction in the evolution of the llímaussaq Complex, South Greenland: Nd isotopic studies. Lithos, 40:189-202.

Streckeisen, A. (1976) To each plutonic rock its proper name. Earth-Sci. Rev., 12:1-33.

Suguio, K. e Martin, L. (1978) Formações quaternárias marinhas do litoral paulista e sul fluminense. 2: Int. Symp. on Coast Evolution in the Quaternary, São Paulo, Spec. Publ., 1, 55p.

Suguio, K. e Petri, S. (1973) Stratigraphy of the Iguape-Cananéia lagoonal region sedimentary deposits, São Paulo, Brazil. Part I: Field observations and grain size analysis. Bol. IG-USP, Sér. Cient., 4:1-20.

Suguio, K. e Tessler, M.G. (1992) Depósitos quaternários da planície costeira de Cananéia-Iguape (SP). Publicação Especial do Instituto Oceanográfico da USP, 9:1-33.

Suguio, K.; Tessler, M.G.; Furtado, V.V.; Esteves, C.A.; Souza, L.A.P. (1987) Perfilagens geofísicas e sedimentação na área submersa entre Cananéia e Barra de Cananéia. I Simpósio sobre ecossistemas da costa sul e sudeste brasileira, Cananéia. Academia de Ciências do Estado de São Paulo (Publicação ACIESP n 54-II), 2:234-241.

Sun, S.S. e McDonough, W.F. (1989) Chemical and isotopic systematics of oceanic basalts: implications for mantle compositions and process. In: Sauders, A.D. \& Norry, M.J. (eds.) Magmatism in the ocean basins. Geol. Soc. Sp. Publ., 42:313-345.

Sundaram, D. e Suguio, K. (1983) Nota preliminar sobre uma assembléia mioflorística da Formação Pariquera-Açu, Estado de São Paulo. Departamento da Produção Mineral, Coleção de Trabalhos Paleontológicos, Brasília, pp.503-506.

Tessler, M.G. (1982) Sedimentação lagunar na região de Cananéia-Iguape, Estado de São Paulo. Dissertação de Mestrado, Instituto de Geociências da USP, 169p.

Thompson, R.N.; Gibson, S.A.; Mitchell, J.G.; Dickin, A.P.; Leonardos, O.H.; Brod, J.A.; Greenwood, J.C. (1998) Migrating Cretaceous-Eocene magmatism in the Serra do Mar alkaline Province, SE Brazil: melts from the deflected Trindade mantle plume? J. Petrol., 39:1493-1526.

Thornton, C.P. e Tuttle, O.F. (1960) Chemistry of igneous rocks differentiation index. Amer. J. Sci., 258:664-684.

Traversa, G.; Barbieri, M.; Beccaluva, L.; Coltorti, M.; Conte, A.M.; Garbarino, C.; Gomes, C.B.; Macciotta, G.; Morbidelli, L.; Ronca, S.; Scheibe, L.F. (1996) Mantle sources and differentiation of alkaline magmatic suite of Lages, Santa Catarina, Brazil. Eur. J. Mineral., 8:193-208.

Tröger, W.E. (1979) Optical determination of rock-forming minerals. Part 1 - Determinative tables. English Edition of the Fourth German Edition by H.U. Bambuer, F. Taborsky, H.D. Trochim. Transl. by $\mathrm{Chr}$ Hoffmann in conjunction with the authors. E. Schweizerbart'sche verlagsbuchhandlung (Nägele u. Obermiller), Stuttgart, 188p.

Tuttle, O.F. e Bowen, N.L. (1958) Origin of granite in the light of experimental studies in the system $\mathrm{NaSi}_{3} \mathrm{O}_{8}-\mathrm{KAISi}_{3} \mathrm{O}_{8}-\mathrm{SiO}_{2}-\mathrm{H}_{2} \mathrm{O}$. Geol. Soc. Amer. Mem., 74, 153p. 
Ulbrich, H.H.G.J. e Gomes, C.B. (1981) Alkaline rocks from continental Brazil. Earth-Sci. Rev., 17:135154.

Ulbrich, H.H.G.J.; Demaiffe, D.; Vlach, S.R.; Ulbrich, M.N.C. ( 2003) Geochemical and Sr, Nd and Pb isotope signatures of phonolites and nepheline syenites from the Poços de Caldas alkaline massif, southeastern Brazil. In: IV South Amer. Symp. on Isotope Geology, Salvador, pp.698701.

Ulbrich, H.H.G.J.; Garda, G.M.; Ulbrich, M.N.C. (1991) Avaliação das idades K/Ar dos maciços alcalinos do Brasil sul-oriental e do Paraguai oriental. Bol. IG-USP, Sér. Esp., 9:87-92.

Valença, J.G. (1980) Geology, petrography and petrogenesis of some alkaline igneous complexes of Rio de Janeiro State, Brazil. Tese de Doutorado, University of Western Ontario, 248p.

Valença, J.G.; Reis, A.P.; Carvalho Filho, C.A.; Soares Filho, J.R.S.; Braun, P.V.C.B. (1983) Geologia do complexo ígneo alcalino do Morro Redondo (Município de Resende, Estado do Rio de Janeiro). An. Acad. Brasil. Ciênc., 55:135-136.

VanDercar, J.C.; James, D.E.; Assumpção, M. (1995) Seismic evidence for a fossil mantle plume beneath South America and implications for plate driving forces. Nature, 378:25-31.

Vasconcellos, E.M.G. e Gomes, C.B. (1998) Diques e plugs alcalinos da região do Vale do Ribeira, divisa dos Estados do Paraná e São Paulo: características petrográficas e geoquímicas. Geochim. Brasil., 12:123-143.

Vasconcelos, P.M.; Onoe, A.T.; Kawashita, K.; Soares, A.J.; Teixeira, W. (2002) ${ }^{40} \mathrm{Ar} /{ }^{39} \mathrm{Ar}$ geochronology at the Instituto de Geociências, USP: instrumentation, analytical procedures, and calibration. An. Acad. Brasil. Ciênc., 74:297-342.

Velázquez V.F.; Comin-Chiaramonti P.; Cundari, A.; Gomes C.B.; Riccomini C. (2006) Cretaceous Naalkaline magmatism from Misiones province (Paraguay): relationships with the Paleogene $\mathrm{Na}$ alkaline analogue from Asunción and geodynamic significance. J. Geol., 114:593-614.

Velázquez, V.F. (1992) Província Alcalina Central, Paraguai Oriental: aspectos petrográficos, tectônicos e geocronológicos. Dissertação de Mestrado, Instituto de Geociências da USP, $119 \mathrm{p}$.

Velázquez, V.F. (1996) Província Alcalina Alto Paraguai: características petrográficas, geoquímicas e geocronológicas. Tese de Doutorado, Instituto de Geociências da USP, 101p.

Vieira, A.J. (1973) Geologia do centro e nordeste do Paraná e centro-sul de São Paulo. In: XXVII Congr. Brasil. Geol., Aracaju, Anais 3:259-277.

Villa, I. (1998) Isotopic closure. Terra Nova, 10:42-47.

Wagoner, R.H. e Leybourne, R.H. (1991) Evidence for magma mixing and heterogeneous mantle on the West Valley segment of the Juan de Fuca Ridge. J. Geophys. Res., 96:16295-16318.

Watson, E.B. e Harrison, T.M. (1984) Zircon saturation revisited temperature and composition effects in a variety crustal magma types. Earth Planet. Sci. Lett., 64:295-304.

White, R.S. e McKenzie, D.P. (1995) Mantle plumes and fluid basalts. J. Geophys., Res., 100:1754317585.

Williams, H.; Turner, F.J.; Gilbert, C.M. (1982) Petrography - an introduction to the study of rocks in thin sections. 2nd ed. W.H.Freeman and Company, New York, 626p.

Wilson, M. (1992) Magmatism and continental rifting during the opening South Atlantic Ocean: a sequence of Lower Cretaceous super-plume activity? In: Storey, B.C.; Alabaster, T.; Pankhurst, R.J. (eds.) Magmatism and the causers of continental breakup. Geol. Soc. Spec. Publ., 68:241-255.

Wyllie, P.J. (1978) Mantle fluid compositions buffered in peridotite- $\mathrm{CO}_{2}-\mathrm{H}_{2} \mathrm{O}$ by carbonates, amphibole and phlogopite. J. Geol., 86:687-713. 